\title{
ANAIS_TRABALHOS APRESENTADOS_ARTIGOS \\ INFODEMIA E DESINFORMAÇÃO: DISCUSSÕES SOBRE O PAPEL DA CONSCIENTIZAÇÃO CRÍTICA À LUZ DOS ENSINAMENTOS FREIRIANOS
}

Adaci A. O. Rosa e Silva

Mariana Xavier

\section{RESUMO}

Tomados pela experiência da pandemia de Covid-19, a pesquisa trata da importância da consciência crítica e da competência informacional frente à avalanche de informações sobre a doença, disponíveis nos diversos canais de informação. Parte do pressuposto que a compreensão da sua gravidade é difusa, confundida com "construção midiática" e "exageros na prevenção" decorrente da falta de compreensão dos achados da produção científica a respeito da doença e de correntes de desinformação. A pesquisa é exploratória, fundamentada na literatura produzida sobre o entendimento da pandemia e nas reflexões sobre Educação, na perspectiva freiriana de "consciência crítica" em oposição à "opressão do não saber" e do "medo" subjacente, valendo-se da sua contribuição teórico-metodológica para análise do cenário de infodemia e desinformação. Apresenta como resultado a proposta de um projeto-piloto de um curso de formação e aprimoramento de discentes e jovens pesquisadores na pesquisa de informação de qualidade em fontes de informação confiáveis. Em síntese, conclui-se sobre a perfeita adequação do papel nuclear que a "conscientização para a liberdade", proposta por Paulo Freire, ocupa no ambiente social, capaz de produzir mudanças e transformações sociais e salvar vidas.

Palavras-chave: Infodemia. Desinformação. Competência Informacional. Pedagogia. Paulo Freire.

\section{Introdução}

Em uma pesquisa livre feita nos buscadores do Google e Yahoo, em setembro de 2021, com o termo de busca: "pandemia de Covid-19" obteve-se a resposta de 43.600.000 resultados no Google e 38.000.000 resultados no Yahoo'. Ao se pesquisar "quantos artigos sobre a pandemia foram publicados", o site da Revista Piauí traz a informação que, em junho de 2020, se contava 23 mil artigos científicos submetidos para publicação (SANTOS, 2020); semelhante informação foi encontrada no site da BBC Brasil (LÓPEZ-GOÑI, 2021), onde se diz "que já ultrapassa os 100 mil artigos", cálculos feitos em fevereiro de 2021.

\footnotetext{
${ }^{1}$ Pesquisa livre feita em 5/9/2021, nos buscadores https://www.google.com/ e https://br.search.yahoo.com/search.
} 
Avaliando o impacto do tema Covid no cotidiano da população mundial, a necessidade do isolamento social e da prevenção, estudiosos estrangeiros (VALIZADEH-HAGHI, 2021) desenvolveram a pesquisa intitulada: Sites de saúde no COVID-19: eles são legíveis e confiáveis o suficiente para ajudar no autocuidado público? O estudo avaliou a compreensão do texto em diferentes grupos e constatou que a linguagem adotada pelas fontes de informação oficiais sobre saúde é de difícil compreensão para o cidadão comum.

Outro desafio, que já se encontrava na esteira dos estudos dos campos científicos da Educação, Informação e Saúde, é o expressivo aumento da circulação da desinformação, termo que recebeu popularidade mundial ao ser designada como fake news e se traduz por notícias falsas, intencionalmente criadas para serem amplamente divulgadas, criando prejuízos e confusão no senso comum.

Neste período crítico de crise sanitária, viu-se no espaço social o confronto entre a disponibilidade de informação e a capacidade de se apropriar do seu sentido e valor; denotando-se a carência da compreensão da linguagem para a execução de processos mais complexos e profundos para a apreensão da realidade, indo além das aparências das coisas, para uma interpretação dos fatos; especialmente nos temas sobre o entendimento do que é a pandemia, o autocuidado e a reflexo das atitudes individuais no coletivo.

Deste cenário se ressalta a necessidade de voltarmos o olhar à dimensão social da formação humana e à função social dos educadores, profissionais da informação, das escolas, universidades e bibliotecas. Para nos orientar nestas tarefas e responsabilidades, consideramos elementos das reflexões sobre educação de Paulo Freire, numa tentativa de diminuir a dicotomia teoria-prática e criar possibilidade para construção de conhecimento ao invés de alimentar a falácia da transferência de conhecimento.

Na perspectiva acima relatada, foi se desenhando no horizonte a necessidade da proposição de sugestões de estudos que fossem além do que as teorizações sobre as competências informacionais; e, espera-se que esta pesquisa possa sugerir melhorias neste sentido, como uma proposta educativa para iniciação do discente no interesse pela pesquisa, onde se promova a utilização de estratégias de abordagem 
crítica, considerando a interação entre seus interlocutores: alunos, professores e demais sujeitos, valorizando o envolvimento de todos, em busca do enfrentamento da "opressão do não saber", aplacando a desinformação, com o instrumento da "conscientização para a liberdade", como fartamente nos orienta Paulo Freire.

\section{Revisão bibliográfica}

O entrelaçamento dos conceitos "conscientização crítica e emancipação" nos desafios educacionais contemporâneos está consolidado pela proposta do educador e filósofo brasileiro Paulo Freire, cuja trajetória e obras já foram estudadas por competentes autores, encaminhando o reconhecimento do estudioso como patrono dessa teoria da educação orientadora, que é comumente conhecida como Método Paulo Freire, que não se resume em um método de alfabetização, e, ainda que se o fosse não o desmereceria, como o próprio Freire afirmava como é relatado por Mafra (2007).

A fundamentação deste estudo na teoria freiriana encontra sustentação na proposta de Paulo Freire encadeada no estudo da realidade, de acordo com Feitosa (1999) e Mafra (2007), onde "na mediação dialógica, o educando tem papel preponderante na contextualização de seu mundo; e da organização dos dados, em que a ação do educador é primordial no trabalho de sistematização" (MAFRA, 2007, p. 131, grifos do autor).

Nesse processo surgem os Temas Geradores, extraídos da problematização prática de vida dos educandos. Os conteúdos de ensino são resultados de uma metodologia dialógica. Cada pessoa, cada grupo envolvido na ação pedagógica dispõe em si próprio, ainda que de forma rudimentar, dos conteúdos necessários dos quais se parte. O importante não é transmitir conteúdo específico, mas despertar uma nova forma de relação com a experiência vivida. A transmissão de conteúdos estruturados fora do contexto social do educando é considerada "invasão cultural" ou "depósito de informações" porque não emerge do saber popular. Portanto, antes de qualquer coisa, é preciso conhecer o aluno. Conhecê-lo enquanto indivíduo inserido num contexto social de onde deverá sair o "conteúdo" a ser trabalhado (FEITOSA, 2006, grifos nossos).

Assim, a associação discursiva entre a conscientização crítica e emancipação, formam uma articulação que deve promover nos discursos educacionais a descoberta dos sentidos dos objetos apresentados aos educandos, e esses conteúdos devem, 
por sua vez, partir dos debates na realidade vivida, sendo, portanto e necessariamente, um processo político e dialógico.

Nesse contexto, Gadotti (2001, p. 21) analisa e destaca os três pontos que demonstram o encadeamento do processo de significação e o dialogismo:

i) A investigação temática, pela qual aluno e professor buscam, no universo vocabular do aluno e da sociedade onde ele vive, as palavras e temas centrais de sua biografia (...)

ii) A tematização, pela qual professor e aluno codificam e decodificam esses temas (...)

iii) A problematização, na qual eles buscam superar uma primeira visão mágica por meio de uma visão crítica, partindo para a transformação do contexto vivido (2001, p. 21).

Essa problematização da realidade, do universo do vivido, articulada com a interação dos sujeitos está no cerne dos debates educacionais contemporâneos, e deve ser cada vez mais investigada para ser repensada e aplicada sob nova ótica, a da atualidade, como Freire, humilde e solidariamente, instiga seus "seguidores" para a efetividade da sua epistemologia: o desafio teórico de:

Quanto aos outros, os que põem em prática a minha prática, que se esforcem por recriá-la, repensando também meu pensamento. $E$ ao fazêlo, que tenham em mente que nenhuma prática educativa se dá no ar, mas num contexto concreto, histórico, social, cultural, econômico, político, não necessariamente idêntico a outro contexto. (1987, p. 17).

Neste sentido, de acordo com Mafra (2007), esta "ideia de reinvenção, atitude profundamente pedagógica e epistemológica que marcou sua trajetória de intelectual e educador, é uma fala coerente com o que ele já dizia em 1968".

Acrescenta-se que é o fundamento que se aplica neste estudo, seguindo Gadotti (2001, p. 42), “(...) não devemos repetir Freire, mas reinventá-lo (...)". Mas, frise-se, estas autoras humildemente se propõem a reivindicar sua orientação para a pauta do advento da avalanche de informações, a que fomos inundados, porém em muitos casos sem instrumentos para lidar com essa realidade.

Nesta perspectiva da práxis, em outra mão, a Ciência da Informação, como campo de estudo que estuda os fenômenos da informação, sua produção e gestão, reúne as disciplinas da Biblioteconomia, Arquivologia e Museologia, e, na atualidade tem tido um papel cada vez mais central e decisivo na sociedade da informação, agregando conhecimento no ambiente de informatização, seja acompanhando as 
novas formas de preservação e segurança da informação na internet, e sobretudo na circulação e da relevância das fontes de informação.

Essa evolução tecnológica, atualmente com as TICs, encaminhou os desafios de uma Competência Informacional para o campo da Ciência da Informação. Os estudiosos se debruçaram sobre essa capacidade de lidarmos com os elevados volumes de informação, mas observando todo o fluxo informacional, desde a criação de conteúdos até seus estoques, e também o acesso, preservando o usuário do risco da desinformação, pela exposição desnecessária à conteúdos sem relevância ou afastado da abordagem crítica.

A competência informacional, no Brasil, é um termo que está em fase de construção. Caregnato (2000, p. 50), apresenta a temática e sua denominação foi traduzida como "alfabetização informacional" propondo a

expansão do conceito de educação de usuários e ressaltava a
necessidade de que as bibliotecas universitárias se preparassem para
oferecer novas possibilidades de desenvolver nos alunos habilidades
informacionais necessárias para interagir no ambiente digital.
(CAREGNATO, 2000, p. 50).

Entretanto, o que pode beneficiar a todos seja a interdisciplinaridade, ou seja, a interlocução da Educação e da Ciência da Informação, observando a realidade, a vivência dos cidadãos em todos os níveis educacionais.

Assim, os educadores e os profissionais da informação que lidam e compreendem os diferentes tipos de interação nos sistemas, os conteúdos e discursos que circulam na sociedade e se deparam com a "responsabilidade social", objeto que Freire, também defendeu, no capítulo "O Compromisso do profissional com a sociedade", no livro "Educação e Mudança" publicado em 1979, sendo uma referência no campo da educação e dialogando diretamente com o que se discute e propõe neste artigo.

A seguir, nos itens que tratam do método da pesquisa e discussão de resultados, pretende-se configurar a necessidade de se empreender um projeto que exercite a competência informacional, sob a orientação da abordagem crítica. 


\section{Métodos e Discussão de Resultados}

O estudo se caracteriza como exploratório e descritivo e é composto de duas etapas:

1. Elaboração do quadro referencial teórico a partir da matriz freireana, relacionado a Educação e a Competência Informacional;

2. Pesquisa bibliográfica, exploratória e descritiva, que analisa os artigos que tratam do tema "Covid-19", publicados em periódicos e/ou anais de encontros científicos da área de Ciência da Informação.

$\mathrm{Na}$ fase atual da pesquisa, foi realizado um recorte no corpus, a fim de avaliar os métodos empregados, a massa de dados reunida compreendeu 265 trabalhos, retiradas as duplicidades, 6 casos, e aplicado um teste de instrumentos e procedimentos (LAKATOS, 2003).

Neste artigo, são apresentados os resultados parciais obtidos, os dados brutos que caracterizam a emergência do tema. $\mathrm{Na}$ continuidade do projeto de pesquisa serão feitos os mapeamentos nos níveis teórico e metodológico. Entretanto, na pesquisa bibliográfica exploratória empreendida para este estudo, observou-se a alta incidência da temática "Infodemia e Desinformação", objetos que emergiram e delinearam como subsídios para o planejamento de um projeto piloto de "curso de formação e aprimoramento de discentes e jovens pesquisadores na pesquisa de informação de qualidade em fontes de confiáveis".

Inicialmente, a busca foi realizada no Banco de Dados Referencial de Artigos de Periódicos em Ciência da Informação (BRAPCI, 2021), a partir dos termos de busca "Covid-19" e "Pandemia", e foram recuperados e salvos 259 artigos, com 685 autores relacionados. Foi verificado que haviam apenas 2 artigos produzidos até 2018, e os demais 257 foram publicados entre 2019 e 2021. A alta produção na temática suscitou a avaliação dos subtemas a partir das palavras-chave escolhidas pelos autores.

Considera-se nesta amostra um exemplo da relação direta e intrínseca da pandemia $>$ infodemia $>$ desinformação $>$ negacionismo $>$ redes sociais, como se vê no quadro: 
Quadro - Resultados de pesquisa em base de dados com o tema pandemia e informação.

\begin{tabular}{|c|c|c|c|}
\hline Palavias-chave! & 7) Palavasschave? & v Palavias-chave 3 & $\checkmark$ Palavras-chave 4 \\
\hline Infodemia & Comunicacao de risco & Covid 19 & Infodemiologia \\
\hline Desinformacao & Pandemia de covid 19 & Amazonia & Misinformation \\
\hline Infodemia & Covid -19 & Retracted articles & Retracted preprints \\
\hline Infodemia & Desinfodemia & Competencia em informacao & Desinformacao \\
\hline Intodemia & Ciencia & Dimensao da competencia em informacao & Desinformacao \\
\hline Negacionismo & Imunidade de rebanho & Caso & Informalidade \\
\hline Desinformacao & Posverdade & Pratica informacional & Covid:-19 \\
\hline Infodemia & Vacina & Desinformacao & Rede social \\
\hline Informacao tecnica e cientificta & Indexacao & Recuperacao da informacao & Scientific and technical information \\
\hline Uso social da informacao & $\begin{array}{l}\text { Tecnologia da informacao e da } \\
\text { comunicacao }\end{array}$ & Ambiente organizacional & Minoria social \\
\hline Principio trust & Repositorio de dado cientifico & Confiabilidade de repositorio & Avaliacao de repositorio \\
\hline Informacao falsa & Programa checador & Covid 19 & Informacion falsa \\
\hline
\end{tabular}

Fonte: BRAPCI, elaborado pelas autoras.

A alta incidência dos temas "Infodemia e Desinformação" refletem a importância e a convergência de esforços para reprimir ou ao menos controlar os efeitos nocivos da disseminação das fake news, como se vê no Informe da Organização Pan-americana da Saúde (2020):

O que é infodemia?

Conforme declarado pela OMS, o surto de COVID-19 e a resposta a ele têm sido acompanhados por uma enorme infodemia: um excesso de informações, algumas precisas e outras não, que tornam difícil encontrar fontes idôneas e orientações confiáveis quando se precisa. A palavra infodemia se refere a um grande aumento no volume de informações associadas a um assunto específico, que podem se multiplicar exponencialmente em pouco tempo devido a um evento específico, como a pandemia atual. Nessa situação, surgem rumores e desinformação, além da manipulação de informações com intenção duvidosa. Na era da informação, esse fenômeno é amplificado pelas redes sociais e se alastra mais rapidamente, como um vírus (ORGANIZAÇÃO PAN-AMERICANA DA SAÚDE, 2020).

O que é desinformação? 
Desinformação é uma informação falsa ou imprecisa cuja intenção deliberada é enganar. No contexto da pandemia atual, pode afetar profundamente todos os aspectos da vida e, mais especificamente, a saúde mental das pessoas, pois a busca por atualizações sobre a COVID-19 na Internet cresceu de $50 \%$ a $70 \%$ em todas as gerações. Em uma pandemia, a desinformação pode prejudicar a saúde humana. Muitas histórias falsas ou enganosas são inventadas e compartilhadas sem que se verifique a fonte nem a qualidade. Grande parte dessas desinformações se baseia em teorias conspiratórias; algumas inserem elementos dessas teorias em um discurso que parece convencional. Estão circulando informações imprecisas e falsas sobre todos os aspectos da doença: como o vírus se originou, a causa, o tratamento e o mecanismo de propagação. A desinformação pode circular e ser absorvida muito rapidamente, mudando o comportamento das pessoas e possivelmente levando-as a correr riscos maiores. Tudo isso torna a pandemia muito mais grave, afetando mais pessoas e comprometendo o alcance e a sustentabilidade do sistema global de saúde (ORGANIZAÇÃO PAN-AMERICANA DA SAÚDE, 2020).

Observa-se que a humanidade já experienciou a presença massiva de conteúdos enganosos e falsos circulando, tal qual o "vírus [que] se espalha de forma avassaladora ao redor do mundo, informações enganosas sobre origem, prevenção e tratamento sobre a Covid-19 viralizaram com rapidez e abrangências preocupantes no ambiente digital" (CORDEIRO et al., 2021, p. 3).

Conclui-se que há urgência do tratamento desta temática e sua aplicação em cursos de extensão ou atualização, onde ações de conscientização na formação de leitores e pesquisadores sejam uma prática libertadora, sem minimizar ou negar o potencial destrutivo das fakes news e das responsabilidades assumidas por todos com a sua propagação.

Da mesma forma, esta sugestão de capacitação de alunos e jovens pesquisadores poderá se desenvolver e projetar outros estudos sobre propostas curriculares para qualificar outros profissionais educadores e bibliotecários, por exemplo.

A seguir, a partir dos estudos e das recomendações da literatura de elencada, apresentamos uma sugestão de projeto piloto de curso para empreender a tarefa de conscientização sobre as fontes confiáveis de pesquisa científica, as formas de comunicação viáveis aos cidadãos, com o entendimento do seu público, a fim de proporcionar uma informação compreensível e transformadora. 
objetivo é desenvolver projetos de formação continuada em competência informacional, a justificativa é a necessidade de potencializar a informação confiável, espera-se, como resultado, formar novos pesquisadores e cidadãos conscientes.

\section{Metodologia / proposta didática/ princípios pedagógicos}

Carga horária: 24h, divididas em 5 encontros.

Desenvolvimento de atividades práticas e trabalhos em grupo

Quadro 2 - Proposta de atividade

\begin{tabular}{|c|c|c|}
\hline ENCONTRO 1 & ENCONTRO 2 & ENCONTRO 3 \\
\hline $\begin{array}{l}\text { Conhecendo o meu grupo } \\
\text { de trabalho. Quem somos? } \\
\text { Resultado esperado: } \\
\text { equalizar os vocabulários e } \\
\text { estabelecer vínculos de } \\
\text { origens e referências. }\end{array}$ & $\begin{array}{l}\text { Onde se obtêm as } \\
\text { informações de uso no } \\
\text { cotidiano? E seus colegas } \\
\text { e familiares? } \\
\text { O que são Fake-News? } \\
\text { Resultado esperado: } \\
\text { Contextualizar a } \\
\text { comunicação e a } \\
\text { responsabilidade da } \\
\text { produção de notícias falsas } \\
\text { e verdadeiras. } \\
\text { Roda de leitura: listar os } \\
\text { termos associados à } \\
\text { temática da informação em } \\
\text { Saúde ou Educação e } \\
\text { buscar exemplificá-los no } \\
\text { contexto dos participantes. }\end{array}$ & $\begin{array}{l}\text { O que é ciência? O que } \\
\text { são fontes de informação? } \\
\text { Resultado esperado: } \\
\text { Discutir os fundamentos da } \\
\text { ciência, da produção e } \\
\text { comunicação científica e a } \\
\text { avaliação por pares. } \\
\text { Roda de leitura: debater os } \\
\text { conceitos apresentados e } \\
\text { discutidos. }\end{array}$ \\
\hline ENCONTRO 4 & ENCONTRO 5 & Recursos necessários \\
\hline $\begin{array}{l}\text { Conhecendo os vários } \\
\text { meios de comunicação e } \\
\text { disseminação da } \\
\text { informação: rádio, TV, } \\
\text { Jornal impresso, sites, } \\
\text { Blogs, Facebook, } \\
\text { Instagram, Podcast. } \\
\text { Roda de leitura: debate } \\
\text { sobre o consumo, a } \\
\text { circulação de Memes e } \\
\text { maneiras de verificar se as } \\
\text { informações são confiáveis. }\end{array}$ & $\begin{array}{l}\text { Apresentação final do } \\
\text { curso: projeto e execução } \\
\text { de atividade. Resultado } \\
\text { esperado: propor temas e } \\
\text { textos para a Roda de } \\
\text { Leitura. Planejar atividades } \\
\text { de pesquisa e } \\
\text { disseminação da } \\
\text { informação em diferentes } \\
\text { veículos no contexto da } \\
\text { análise crítica por } \\
\text { evidências. }\end{array}$ & \begin{tabular}{|l|} 
Professores-tutores; \\
Sala de aula on-line; \\
Canal de acesso. \\
Disponibilidade de \\
plataforma para a inserção \\
de conteúdos e exercícios.
\end{tabular} \\
\hline
\end{tabular}

\section{Considerações Finais}

Conclui-se que as práticas que envolvem a capacidade de selecionar e interpretar ideias foram celebremente desenvolvidas por Paulo Freire e inspiram 
educadores, todos que mesmo em outras profissões complementares professam o Ensino e a Educação, na tarefa de trazer para a aprendizagem os valores e conhecimentos que auxiliam na formação do cidadão livre, emancipado e crítico. $\mathrm{E}$, citando o filósofo:

O meu respeito de professor à pessoa do educando, à sua curiosidade, à sua timidez, que não devo agravar com procedimentos inibidores, exige de mim o cultivo da humildade e da tolerância. Como posso respeitar a curiosidade do educando se, carente de humildade e da real compreensão do papel da ignorância na busca do saber, temo revelar o meu desconhecimento? (FREIRE, 2009, p. 67).

A pandemia impõe enormes desafios para as Ciências, demandas para os campos da Saúde, Educação e na prática da gestão da informação. Neste estudo abordou-se sobre a Covid-19, a doença e suas consequências, sob a ótica dos estudos da informação. $O$ objetivo foi refletir sobre essa capacidade da educação de emancipar as pessoas para intervirem em sua própria formação, transmutada em competência informacional, na medida em que as sociedades passaram a produzir ou a circular volumes cada vez maiores de conteúdos, amplificados pelas tecnologias de informação.

Para tal, reunimos elementos das reflexões sobre educação de Paulo Freire e a produção e o consumo de informação a respeito da pandemia e a responsabilidade social da comunicação, e sua manifestação na competência informacional. Espera-se que na continuidade do estudo, os resultados possam impulsionar novos projetos de educação e pesquisa.

\section{Referências}

BRAPCI - Base de Dados em Ciência da Informação Acervo de Publicações Brasileiras em Ciência da Informação. Versão 4.3.2021.05.28 beta | 2010-2021 30 ago. 2020. Curitiba: Universidade Federal do Paraná; Porto Alegre: Universidade Federal do Rio Grande do Sul, 2021. Disponível em: https://brapci.inf.br/. Acesso em: 04 set. 2021.

CAREGNATO, Sônia Elisa. O desenvolvimento de habilidades informacionais: o papel das bibliotecas universitárias no contexto da informação digital em rede. Revista de Biblioteconomia \& Comunicação, v. 8, p. 47-55, 2000. Disponível em: https://core.ac.uk/download/pdf/11883861.pdf. Acesso em: 04 set. 2021.

CORDEIRO, J. D. R et al. educação em ciências e saúde e o enfrentamento à desinfodemia: um relato de experiências críticas no ensino online. Liinc em revista, 
v. 17, 2021. Disponível em: http://hdl.handle.net/20.500.11959/brapci/160977. Acesso em: 04 set. 2021.

FEITOSA, Sonia Couto. O Método Paulo Freire: teoria e prática de uma concepção popular de educação. 1999. Dissertação (Mestrado em Educação) - Programa de Pós-Graduação em Educação, USP, São Paulo, 1999. Disponível em: http://acervo.paulofreire.org:8080/xmlui/handle/7891/4274. Acesso em: 05 set. 2021.

FREIRE, Paulo. O compromisso do profissional com a sociedade. In: Freire P. Educação e mudança. Rio de Janeiro: Paz e Terra; 1979. p. 7-13.

FREIRE, Paulo. Pedagogia da autonomia: saberes necessários à prática educativa. 39. ed. São Paulo: Paz e Terra, 2009.

FREIRE, Paulo. Pedagogia do oprimido. 17. ed. Rio de Janeiro: Paz e Terra, 1987.

GADOTTI, Moacir. Um legado de esperança. São Paulo: Cortez, 2001.

IJUIM, J. K. A responsabilidade social do jornalista e o pensamento de Paulo Freire. Em Questão, v. 15, n. 2, p. 31-43, 2009. Disponível em: http://hdl.handle.net/20.500.11959/brapci/9051. Acesso em: 05 set. 2021.

LAKATOS, Eva Maria; MARCONI, Marina de Andrade. Fundamentos de metodologia científica. 5. ed. São Paulo: Atlas, 2003.

LÓPEZ-GOÑI, Ignácio. Coronavírus: 10 boas notícias sobre a pandemia, um ano depois. BBC News Brasil, 24 fev. 2021. Disponível em: https://www.bbc.com/portuguese/geral-56180843. Acesso em: 05 set. 2021.

MAFRA, Jason Ferreira. A conectividade radical como princípio e prática da educação em Paulo Freire. 2007. 2007. Tese de Doutorado. Tese (Doutorado em Educação) - Faculdade de Educação, Universidade de São Paulo, São Paulo. Disponível em: doi:10.11606/T.48.2007.tde-30052007-110510. Acesso em: 05 set. 2021.

ORGANIZAÇÃO PAN-AMERICANA DA SAÚDE. Entenda a infodemia e a desinformação na luta contra a COVID-19. Washington: Departamento de Evidência e Inteligência para Ação em Saúde/OPAS; 2020. (Página informativa, n. 5). Disponível em: https://iris.paho.org/bitstream/handle/10665.2/52054/FactsheetInfodemic_por.pdf. Acesso em: 05 set. 2021.

SANTOS, Yasmin. Pandemia de papers. Revista Piauí, São Paulo, 18 jun. 2020, questões científicas. Disponível em: https://piaui.folha.uol.com.br/pandemia-depapers-preprints/. Acesso em: 05 set. 2021.

SILVA, M. F. A. P.; FREIRE, G. H. A. Socialização da informação: possíveis contribuições de Paulo Freire à ciência da informação. Pesquisa Brasileira em Ciência da Informação e Biblioteconomia, v. 8, n. 2, 2013. Disponível em: http://hdl.handle.net/20.500.11959/brapci/25020. Acesso em: 04 set. 2021.

SOUZA, J. S.; SANTOS, J. C. S. D. Infodemia e desinformação na pandemia da covid19. Revista Fontes Documentais, v. 3, p. 231-238, 2020. Disponível em: http://hdl.handle.net/20.500.11959/brapci/151121. Acesso em: 05 set. 2021. 
VALIZADEH-HAGHI, Saeideh et al. Health websites on COVID-19: are they readable and credible enough to help public self-care? Journal of the Medical Library Association: JMLA, v.109, n. 1, p. 75-83, 2021. Disponível em: doi:10.5195/jmla.2021.1020. Acesso em: 05 set. 2021. 


\section{RESUMO}

O presente texto resulta da discussão dos dados de um levantamento realizado pelo grupo de pesquisa Políticas Públicas em Educação, vinculado ao Mestrado Profissional em "Práticas Docentes no Ensino Fundamental" da Universidade Metropolitana de Santos - UNIMES, junto a profissionais de Educação da Região Metropolitana da Baixada Santista. O trabalho remoto emergencial resultante da pandemia de COVID-19 exigiu a mobilização dos profissionais da Educação a fim de não cessarem as atividades letivas. A forma como esses profissionais avaliam a sua atuação e os sentimentos que demandam dessa ação docente são o foco das discussões dessa investigação. Os dados foram coletados por adesão voluntária de professores e gestores dessa região ao questionário divulgado com uso de recursos digitais, sendo analisados à luz da teoria das representações sociais. A avaliação sobre a própria ação docente, tão necessária à prática pedagógica demonstra fragilidades das ações emergenciais e superação de obstáculos e necessidades que os profissionais da Educação enfrentaram no ano pandêmico de 2020.

Palavras-chave: Avaliação. Profissionais da Educação. Ensino remoto. Sentimentos e Emoções.

\section{Introdução}

A motivação e o estado esperançoso de encontrar caminhos moveram os professores de todos os níveis de ensino no ano de 2020, durante o período de atividades escolares remotas devido à Pandemia de Covid-19.

O presente texto apresenta dados e discussões a partir dos sentimentos expressos em pesquisa realizada junto à profissionais da Educação Básica da Região Metropolitana da Baixada Santista.

A pesquisa aqui apresentada está atrelada a Linha de Pesquisa "Ensino e Aprendizagem no Ensino Fundamental” do Grupo de Pesquisa Políticas Públicas em Educação, vinculada ao Mestrado Profissional em "Práticas Docentes no Ensino Fundamental" da Universidade Metropolitana de Santos - UNIMES.

Inicialmente apresentamos um breve estudo teórico que fundamenta a análise dos dados. A seguir, expomos dados referentes às especificidades dos participantes da pesquisa. Em seguida, trazemos aspectos da avaliação destes participantes sobre sua própria atuação e as demandas alteradas pelas mudanças decorrentes da pandemia de COVID-19 causada pelo novo coronavírus SARS-CoV-2 que atingiu o 
Mundo todo desde o final de 2019. Na discussão desses dados dialogamos com autores que pontuam o cenário educacional e suas perspectivas.

\section{Revisão bibliográfica: da teoria das representações às esperanças}

O cenário Mundial instalado com as exigências de isolamento e controle sanitários para contenção da Pandemia, possibilitou uma vivência inusitada e sem precedentes à Educação. As atividades escolares necessitaram adequar-se ao apoio tecnológico e às características regionais e locais para oferecer aos estudantes algum tipo de interação.

Nossa intenção, neste texto, não recai sobre a avaliação qualitativa das atividades oferecidas e das condições que efetivamente os estudantes tinham para acesso às mudanças e ao uso efetivo dos aparatos tecnológicos. Centramo-nos em compreender como os profissionais da Educação avaliaram a própria atuação nesse cenário.

Para tal reconhecemos que a Teoria das Representações Sociais nos possibilita compreender às construções coletivas e dinâmicas da realidade pelos diferentes sujeitos e sua diversidade nos contextos. A relevância da Teoria das Representações Sociais tem se destacado cada vez mais na análise dos fenômenos complexos, tais como a formação dos profissionais da educação, pois por meio dela podemos compreender melhor a realidade que permeia a vida desses sujeitos que produzem suas próprias histórias, identidades, fazem a diferença na vida de tantos outros indivíduos, e ainda, produzem inferências em suas próprias práticas sociais, conduzindo um processo de condutas e posicionamentos que valorizam as interações sociais.

Neste sentido, Moscovici (2007, p. 21) indica que as representações sociais são:

Um sistema de valores, ideias e práticas, com uma dupla função: primeiro, estabelecer uma ordem que possibilitará às pessoas orientar-se em seu mundo material e social e controlá-los; e, em segundo lugar, possibilitar que a comunicação seja possível entre os membros de uma comunidade, fornecendo-lhes um código para nomear e classificar, sem ambiguidade, os vários aspectos de seu mundo e da sua história individual e social.

Assim, avaliar os próprios sentimentos e emoções, no contexto educacional do ano de 2020 com os impasses gerados pela Covid-19, faz-se essencialmente 
necessário para compreender as necessidades emergentes desse cenário. Além de observar as superações e as frustações de um grupo de profissionais que possibilitam uma amostra da realidade regional.

Nesse sentido nosso olhar engaja-se no pensar esperançoso de Paulo Freire. Pensar para além das condições concretas e efetivas, pautados na esperança como "necessidade ontológica" humana (FREIRE, 2013, p. 14). Nessa necessidade vital que move cada ser humano na prática de alcançar a "concretude histórica" de sua ação (FREIRE, 2013, p. 15). Como sujeitos históricos e sociais que atuam sobre uma determinada ação educativa, os profissionais da Educação têm na ação cotidiana de seu fazer as dimensões de idealizar as esperanças e exercer uma prática que possibilite alcançá-las.

O processo de ensino e aprendizagem envolve grande carga de aspectos afetivos e emocionais. Assim, a ação educativa está intimamente ligada ao emocional dos professores e demais profissionais que atuam sobre ela. Desde a década de 1980, pesquisadores vêm apontando a necessidade de observação e estudo sobre as condições de saúde dos professores (cf. VASCONCELLOS, 1995, p. 28). Em estudos recentes, Barreto e Hissa (2020, p. 88) apontam que "as condições de trabalho e saúde do professor das escolas públicas têm-se constituído num problema crítico para a educação brasileira".

Segundo as autoras

O cenário atual da educação, com o sucateamento das instituições escolares, a violência física e verbal, a sobrecarga de trabalho, a desvalorização da carreira, os baixos salários etc., corroboram o desencadeamento de doenças físicas e o sofrimento psíquico. (BARRETO; HISSA, 2020, p. 88).

Com a pandemia de COVID 19 que assolou o Mundo desde final de 2019, aspectos sobre estresse e sobrecarga vêm sendo discutidos em diversos meios de comunicação. O fato de mudar repentinamente suas rotinas para um estado de isolamento social, por si só já caracteriza uma mudança abrupta bastante significativa para concentrar olhares sobre qualquer pessoa no nosso entorno. Sobre os professores recaiu, também, o uso de novas ferramentas de ensino e a própria organização de formas de ensino jamais pensadas e ousadas desde a educação infantil. 
A educação por meio de ferramentas tecnológicas sem presença e interação física, Educação a Distância, não é algo novo em nossa sociedade, mas foi pensada, estudada e estruturada para jovens e adultos. Para os professores da Educação Infantil e do Ensino Fundamental o uso das tecnologias estava associado a ferramentas motivadoras ou conteúdo específico. De um momento a outro o cenário foi mudado e a ferramenta tecnológica passou a ser a única ferramenta possível ao ensino com o isolamento social que demandou a pandemia.

Todas as mais perenes mudanças que ocorreram no cenário educacional foram expressas por Nóvoa (2020, p. 10):

No início de 2020, o mundo foi surpreendido pela pandemia do Covid-19. De repente, o que era tido como impossível, transformou-se em poucos dias: diferentes espaços de aprendizagem, sobretudo em casa; diferentes horários de estudo e de trabalho; diferentes métodos pedagógicos, sobretudo por meio de ensino remoto; diferentes procedimentos de avaliação, entre outras. A necessidade impôs-se à inércia, ainda que com soluções frágeis e precárias.

Além de todas as mudanças que o cenário educacional sofreu, nossa pesquisa exigia do profissional algo, também, nada fácil: avaliar-se em relação à própria prática pedagógica em elementos tão significativos quanto o planejamento e a preparação das atividades. Hadji (2001) pontua aspectos que se tornam obstáculos no processo avaliativo: 1) O primeiro destaca-se pelo caráter social dominante que impregna ao ato avaliativo "fatores de ordem ideológica e social" (p. 23); 2) destacase pela dificuldade de compreender seus próprios conhecimentos sobre o objeto de ensino e as formas que possibilitam a aprendizagem, que resulta na constante busca por modelos e explicações psicológicas; 3) destaca-se pelo medo de ousar, de "correr o risco de se autolimitar" (p. 24). Todos esses aspectos podem ser pontuados nos sentimentos e emoções apontados pelos profissionais quanto à sua atuação e a reflexão sobre sua ação docente. Essas dimensões possibilitam que o profissional da Educação impregne à fatores externos a ele suas fraquezas e insucessos.

\section{Metodologia: organização da pesquisa e seus participantes}

A pesquisa contou com participantes que atuam na Região Metropolitana da Baixada Santista (RMBS), que compreende as cidades: Bertioga, Cubatão, Guarujá, Itanhaém, Mongaguá, Peruíbe, Santos e São Vicente. 
Gráfico 1 - Porcentagem de participantes atuantes nos municípios da Região Metropolitana da Baixada Santista

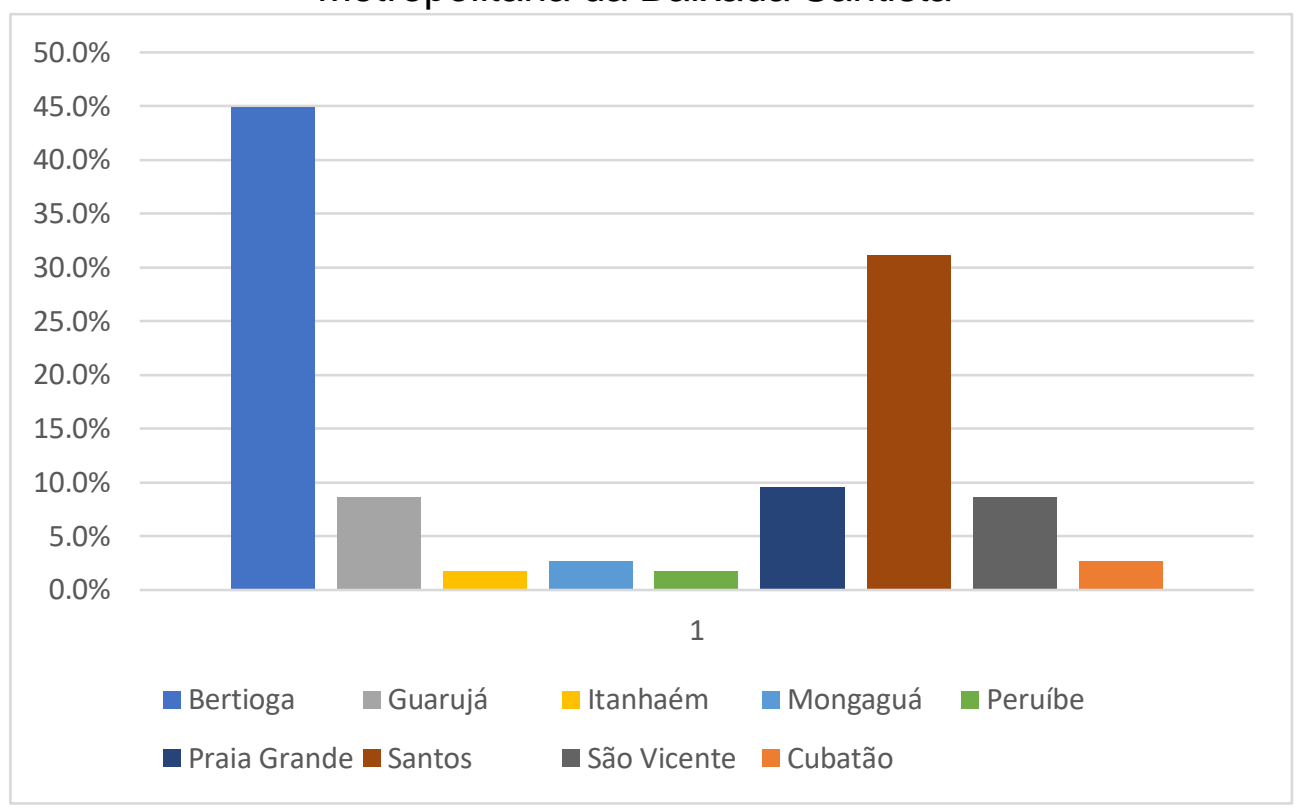

Fonte: Elaborado pelas autoras.

A coleta de dados ocorreu por meio de um questionário elaborado no Google Formulários, pelos pesquisadores e discentes participantes do Grupo de Pesquisa Políticas Públicas em Educação. Os participantes da pesquisa dispuseram-se a responder ao questionário por adesão voluntária de forma colaborativa, uma vez que o link de acesso ao questionário foi disponibilizado via grupos de redes sociais formados por Profissionais da Educação atuantes nas diferentes cidades da RMBS.

A coleta de dados se concretizou por intermédio de dois questionários específicos: um direcionado à alunos dos anos finais Ensino Fundamental (6으 ao 9을 ano) e outro aos profissionais da Educação. Os dados apresentados nesse texto correspondem ao questionário dirigido aos profissionais da Educação com recorte em questões específicas que focavam a avaliação sobre a própria prática docente e os sentimentos desses profissionais. A amostra contou com um total de 116 Profissionais da Educação (Professores e Gestores), que em sua maioria são do gênero feminino e cursaram Pedagogia, conforme os dados apresentados a seguir.

Observemos no Gráfico 1, os municípios de atuação dos Profissionais. Destacam-se nesses dados maior representatividade nas cidades de Bertioga e Santos que somam conjuntamente $75,8 \%$ dos participantes desta pesquisa. É notório, 
ainda, observar que, embora com menor representatividade, obtivemos participantes das nove cidades que compõem a RMBS.

Quanto ao gênero, a maioria dos participantes assinalaram a opção Feminino, como podemos observar na tabela a seguir:

Tabela 1: Gênero dos participantes

\begin{tabular}{ccc}
\hline Orientação & Quantidade de sujeitos & Porcentagem \\
\hline Feminino & 92 & $79,3 \%$ \\
Masculino & 21 & $18,1 \%$ \\
Prefiro não opinar & 2 & $1,7 \%$ \\
Mulher trans & 1 & $0,9 \%$ \\
\hline
\end{tabular}

Fonte: Elaborado pelas autoras.

Quanto à formação inicial, obtivemos participantes com formação em diversas áreas de conhecimento. Destacando-se a Licenciatura em Pedagogia representando $55,2 \%$ dos participantes. Em seguida, Letras com 8,6\%, Matemática com 7,8\%, História com 6,0\%, Educação Física e Ciência Biológicas com 3,4\% cada, Arte e Geografia com 2,6\% cada, Ciências, Ciências Contábeis, Educação Especial, Física e Magistério Superior com 0,9\% cada. No total de participantes 4,3\% declararam ter formação em Magistério em nível Médio. Houve ainda 0,9\% de sujeitos que não compreenderam a questão declarando como formação a expressão "Polivalente".

Outro aspecto importante a ser destacado sobre os participantes desta pesquisa é a relação de disciplinas ministradas. Observamos que 58,6\% dos sujeitos declaram-se polivalentes, ou seja, atuam nos diferentes conteúdos tanto na Educação Infantil, quanto nos anos iniciais do Ensino Fundamental. Observa-se com isso que a maior parte dos Profissionais atuam nesses seguimentos.

Quanto aos atuantes nos anos finais do Ensino Fundamental, as disciplinas como Matemática e Língua Portuguesa representaram 8,6\% dos participantes cada uma, seguidas por História com 7,6\% e Ciências com 5,2\%. As demais disciplinas tiveram representação inferior à 5\%, sendo elas: Artes, Biologia, Educação Especial, Educação Física, Ensino Religioso, Física, Geografia, Investigação e Pesquisa, Língua Inglesa, Química e Projetos. Nessa questão consideramos a escolha pelos participantes em mais de um item nas respostas, dadas as possibilidades de lecionarem mais de uma disciplina conforme a área de formação, sem serem polivalentes. 
Destaca-se, ainda, entre as informações dos participantes o tempo de magistério. A maioria dos participantes da pesquisa têm mais de 15 anos de atuação no Magistério representando 48,3\% e os com menor tempo de magistério representam $25,0 \%$ que declararam ter entre 1 e 5 anos de atuação no magistério.

Todos os participantes da pesquisa realizaram com seus alunos atividades por meios digitais e remotos dada a Pandemia de COVID-19, uma vez que em março de 2020 foi decretado pelo governo estadual paulista a suspensão das atividades presenciais nas escolas. A partir daí cada rede de ensino organizou suas diretrizes para que o ano letivo tivesse sequência. Tal organização foi orientada por diretrizes e pareceres do Ministério da Educação, Secretaria Estadual de Educação e Secretarias Municipais. Especialmente, o Parecer CNE/CP no 5/2020 (BRASIL, 2020) que possibilitou às redes de ensino readequarem seus calendários letivos considerando a carga horaria mínima prevista na Lei de Diretrizes e Bases da Educação Nacional LDB (BRASIL, 1996).

A maioria dos participantes utilizou as redes sociais (WhatsApp e Facebook) e plataformas (Classroom, Google Meet e Zoom Metting) como ferramentas de interação entre docentes e discentes. Algumas redes oficializaram os portais específicos: Portal Educação (SANTOS, 2020) e Centro de Mídias (SÃO PAULO, 2020). Para aquelas famílias que não tinham acesso às redes sociais ou às plataformas de interação, foram providenciadas atividades impressas ou distribuição de materiais didáticos, de forma que não houvesse interrupção do ano letivo.

O uso de dispositivos eletrônicos e o acesso à internet foram indispensáveis para a interação remota dos profissionais com os alunos e suas respectivas famílias. Como ferramentas para a interação remota todos os participantes declararam utilizar dispositivos celulares ou tablets e computadores ou notebooks.

\section{Discussão dos resultados: Sentimentos e impressões na esperançosa lutar do educar}

No processo de transposição do modelo escolar com prédio físico e suas instalações para o modelo remoto em suas mais diversas acepções, os professores passaram por momentos de enfrentamento do novo e desconhecido que poderiam gerar diferentes reações.

Quanto à avaliação de seu desempenho durante o período de atuação remota, o momento de superação no qual se encontravam no final do ano de 2020 
possibilitava uma análise mais positiva e confiante, se observarmos ao somar as avaliações "ótimo" e "bom" obtendo o percentual de $84,5 \%$. Isso demonstra que os participantes se avaliaram com boa prática educativa diante das adversidades enfrentadas.

Essa visão não sempre a mesma. Quando os profissionais analisam suas reações frente as mudanças nos primeiros meses da pandemia há certo equilíbrio nas quanto às visões "otimista" e "pessimista" com 46,0\% cada um e 8,0\% que se declarou "indiferente". A incerteza gerada pelas mudanças abruptas de postura e relacionamento com as ferramentas tecnológicas causaram uma divisão entre os sentimentos e as perspectivas.

O planejamento das atividades de ensino, tão importante ao trabalho docente, foi avaliado pelos participantes sobre algumas óticas: o tempo gasto para tal; seus sentimentos em relação ao mesmo; e os dispositivos tecnológicos utilizados.

Quanto ao tempo gasto no planejamento e preparo das atividades remotas, os participantes demonstraram uma divisão de opiniões bem equilibrada. Considerando as opções "Gasto MUITO MENOS TEMPO que antes" e "Gasto MENOS TEMPO que antes" somadas representaram $43,1 \%$ dos participantes e a soma das opções "Gasto MUITO MAIS TEMPO que antes" e "Gasto MAIS TEMPO que antes", 41,4\%. Houve ainda 15,5\% dos participantes que consideraram que que gastam "aproximadamente O MESMO TEMPO que antes".

Esse equilíbrio aproximado também pode ser observado quando os participantes avaliaram seus sentimentos em relação tempo gasto com 0 planejamento e preparação das atividades remotas: 46,6\% compreenderam como positivos, já 38,8\% compreendem como negativo esse tempo utilizado no planejamento e preparo das aulas remotas. É interessante observarmos que 14,7\% dos participantes declaram neutralidade quanto a seus sentimentos sobre o tempo gasto no planejamento e preparo das aulas nesse período remoto.

Quanto aos dispositivos utilizados no preparo das aulas antes da pandemia, o computador/notebook era o recurso mais pontuado pelos participantes totalizando $79,3 \%$. É notório, também, observarmos que 13,8\% declararam não utilizar dispositivos para o preparo das aulas antes da pandemia.

O uso dos dispositivos durante a preparação das atividades remotas não apenas aumenta, como a não utilização destes recursos não foi sinalizada pelos participantes. O computador/notebook continua na liderança com $81,0 \%$, contra 
$19,0 \%$ que declararam utilizar apenas celular/tablet. É primordial ressaltar que o período de atividades remotas exigiu dos profissionais o uso de dispositivos para o preparo das atividades remotas, de maneira que todos os profissionais passaram a utilizar recursos tecnológicos.

Esses dados são essenciais para compreendermos a avaliação dos profissionais quanto às vantagens e desvantagens do período de atividades escolares remotas. As respostas analisadas a seguir foram obtidas por respostas múltiplas, além da opção "outros" que pode trazer opções redigidas pelo próprio participante. Quando questionados sobre as vantagens do período de aulas remotas mais de $50 \%$ profissionais da Educação reportaram "novos desafios" e a "utilização dos recursos tecnológicos" como as maiores vantagens desse período. Observemos o gráfico 2 :

Gráfico 2: Vantagens do período de aulas remotas

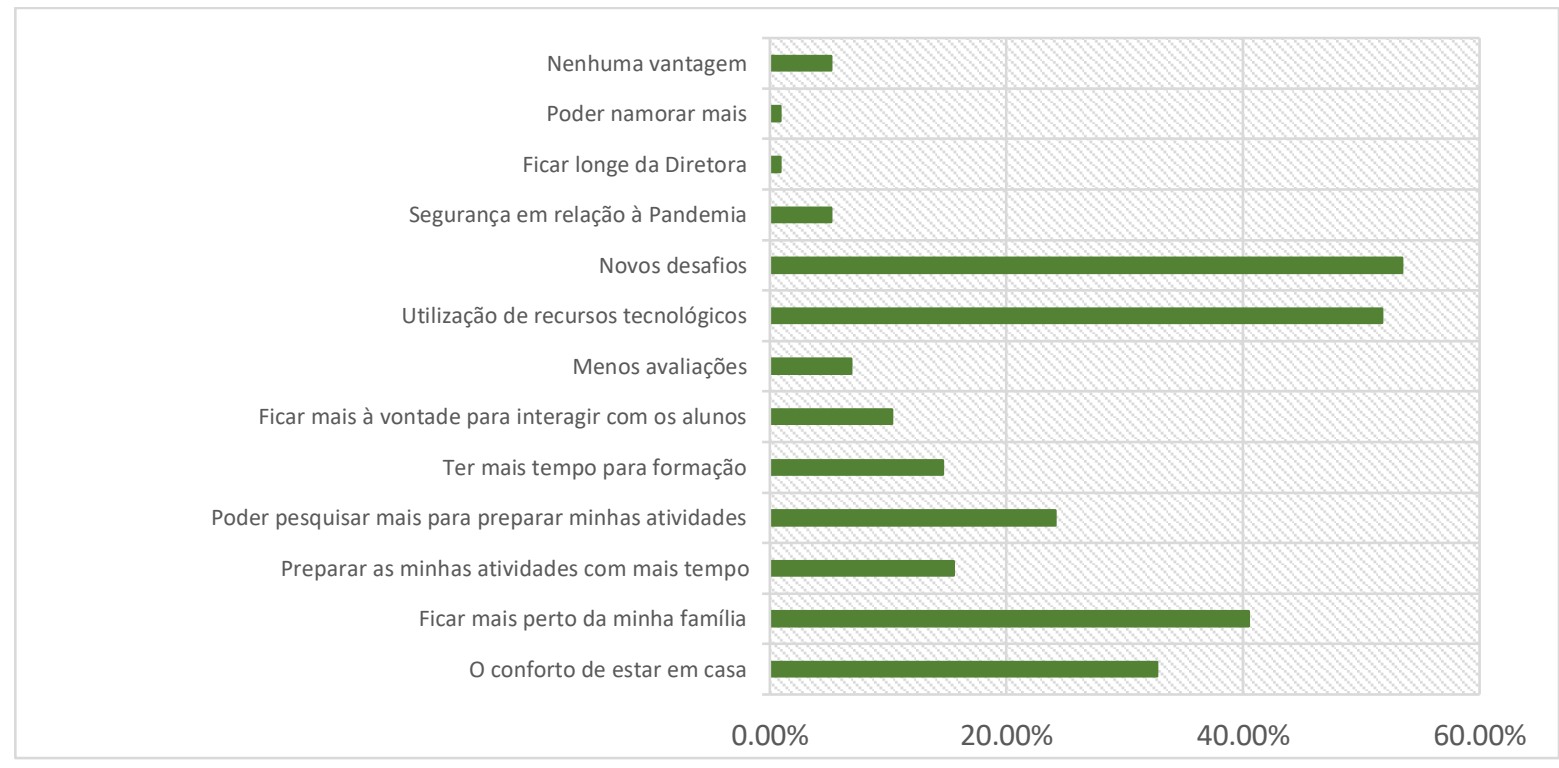

Fonte: Elaborado pelas autoras.

Nesse panorama sobre as vantagens elencadas pelos profissionais destacam-se as opções relacionadas ao ficar no conforto de sua casa e estar mais próximo a sua família, com, respectivamente, $32,8 \%$ e $40,5 \%$ das opções.

Nesse gráfico, é notório observarmos os dados quanto ao planejamento das atividades: $15,5 \%$ declararam ser vantajoso ter mais tempo para preparar as atividades e $24,1 \%$ destacaram poder pesquisar mais para a preparação das atividades. Quanto à formação também foi expressivo: 14,7\% dos profissionais registraram as vantagens de maior tempo para formações. 
Dentre as vantagens elencadas, houve reporte de questões relacionadas aos alunos: $10,3 \%$ registraram ficarem mais à vontade para interagir com os alunos e 6,9\% pontuaram como vantagem haver menos avaliações.

É interessante, e curioso, observar que apenas 5,2\% dos profissionais destacaram como vantagem a segurança frente à pandemia e para a mesma proporção de participantes não haver vantagens nesse período. Parece não haver uma conscientização do afastamento social como mecanismo de proteção contra a contaminação.

Já quando inqueridos sobre as desvantagens desse período os dados mostram outras dimensões e a interação entre os pares como essencial, pois, conforme observamos no gráfico 3 , vemos que $56,1 \%$ dos participantes retrataram estar longe dos colegas e amigos como desvantagens do período e 10,3\% pontuam a dificuldade em tirar dúvidas com o coordenador ou outro gestor.

Gráfico 3: Desvantagens do período de aulas remotas

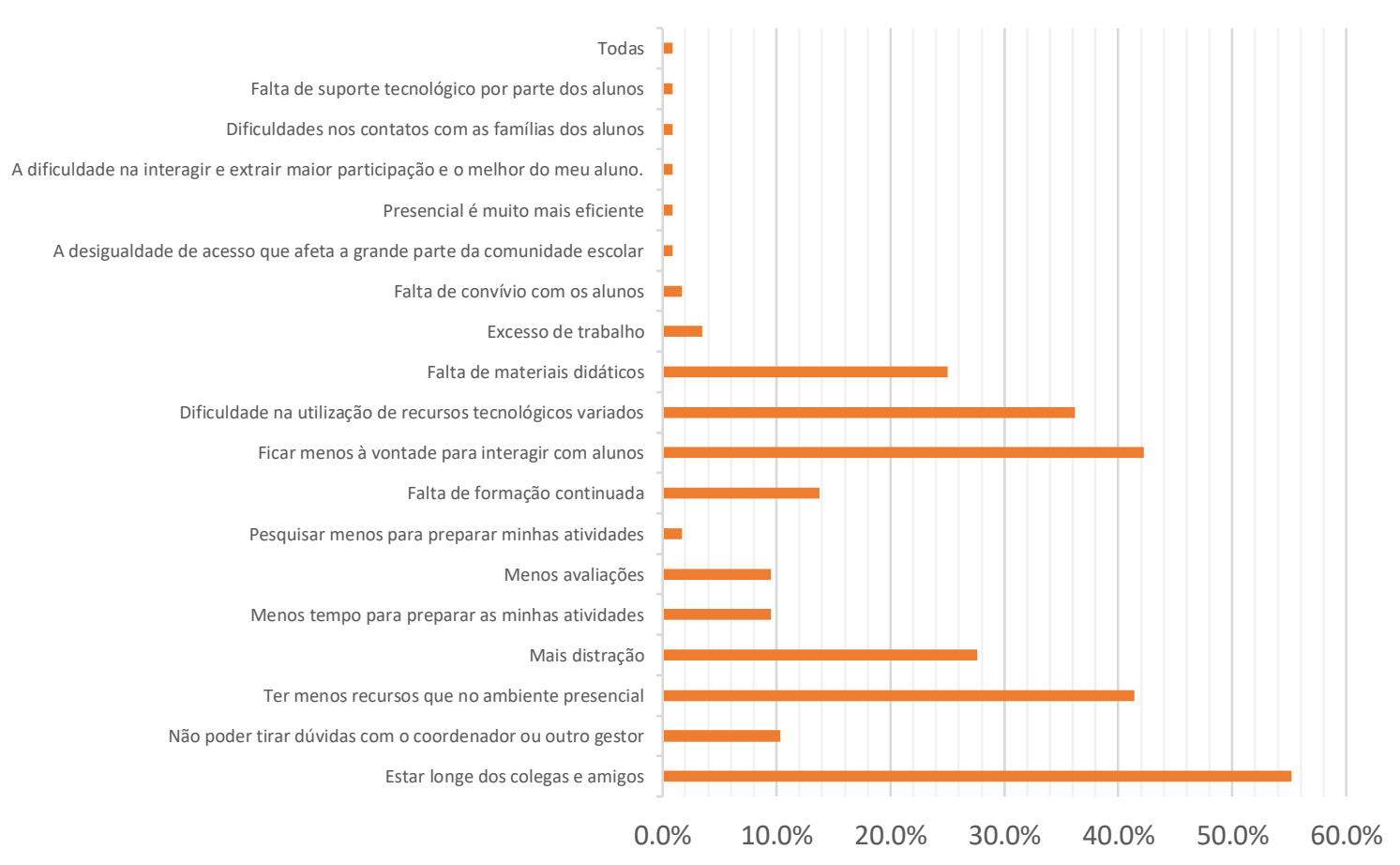

Fonte: Elaborado pelas autoras.

Várias foram as desvantagens pontuadas relacionas aos alunos: mais distração; menos avaliações; falta de convívio e dificuldades de interação; dificuldades 
de acesso; dificuldades de contato com as famílias e falta de suporte tecnológico. Quanto à avaliação observa-se certo impasse entre os profissionais: 9,50\% apontam "menos avaliações" como algo negativo (Gráfico 3), enquanto, 6,90\% apontaram como algo positivo (Gráfico 2).

Entre os dados dos dois gráficos acima outro ponto de divergências entre os profissionais apareceu quanto à interação com os alunos: 10,34\% dos participantes declaram ficar mais à vontade para interagir com os alunos e $42,2 \%$ declaram ficar menos à vontade para interagir com os alunos.

É notório observarmos que $41,4 \%$ dos participantes pontuaram como desvantagens haver menos recursos que no ambiente presencial e $25,0 \%$ a falta de materiais didáticos, o que nos faz refletir sobre a autonomia docente diante dos conteúdos e a dependência destes por materiais de ensino.

Quanto às questões relacionadas a si próprios, os participantes reportaram como desvantagens: excesso de trabalho, falta de formação continuada, pesquisar e ter menos tempo para o preparo das atividades. Destaca-se, ainda, que $36,2 \%$ declararam dificuldade na utilização dos recursos tecnológicos.

Quando questionados sobre as emoções e sentimentos que concebiam ao refletirem sobre o planejar e preparar aulas remotas no período pandêmico, os participantes apresentaram uma vasta gama de respostas que puderam ser agrupadas em sentimentos bons, ruins e neutros.

Dentre os sentimentos, podemos observar que ao refletir sobre a preparação e planejamento das atividades remotas $28,0 \%$ consideraram "bons" por se referirem à superação, esperança, alegria, comprometimento, confiança, entre outros. Já $65 \%$ dos sentimentos apresentados foram considerados "ruins", por estarem ligados à cansaço, insegurança, angústia, frustração, incerteza, ansiedade, tristeza, saudades, desespero, crise, depressão, entre outros. Apenas 7\% foram considerados sentimentos "neutros" por estarem relacionados à adaptação às necessidades da contemporaneidade, como nada a declarar, um misto de sentimentos, oportunidades, participação e pensar no que pode ser atrativo para os alunos. 
Gráfico 4: Sentimentos frente a reflexão sobre a preparação e planejamento das atividades remotas

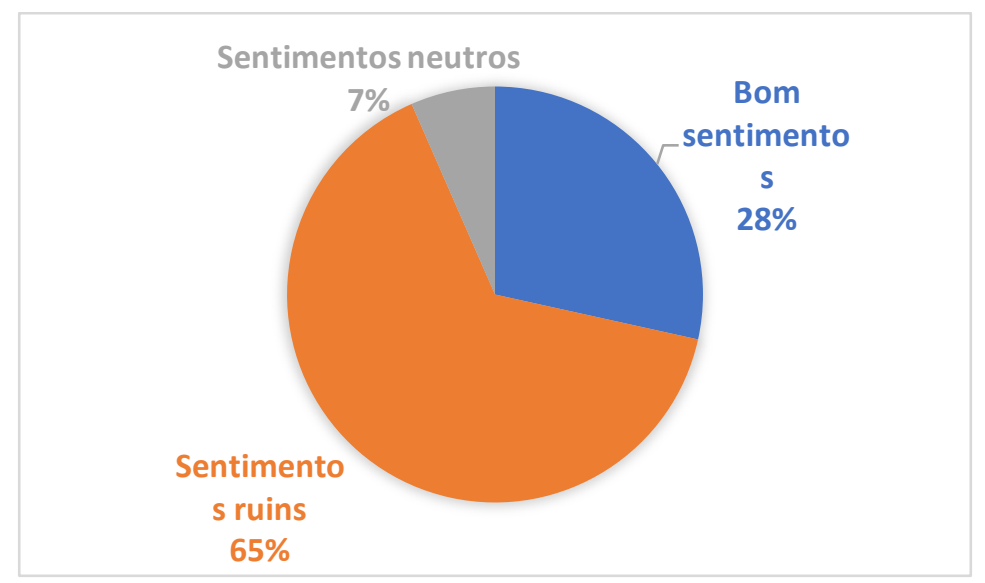

Fonte: Elaborado pelas autoras.

Este último gráfico, revela fortemente uma sobreposição de sentimentos ruins quando refletem sobre a preparação e o planejamento de atividades remotas. Uma das maiores reflexões possíveis entre os dados aqui expostos é notarmos a complexidade de avaliar-se quanto a sentimentos e emoções. Se analisarmos os dados que retratam sentimentos em comparação ao gráfico, observamos uma contradição entre os sentimentos e um maior desprendimento para declarar seus sentimentos.

A experiência de atividades letivas remotas no ano de 2020 constituiu-se para muitos profissionais um período de superação e angústias que oscilaram entre sentimentos positivos e negativos. É necessário resgatar nesses profissionais sentimentos bons relacionados ao gosto por seu trabalho e sua atuação docente. Como nos diz Freinet (2000, p. 126), "[...] seria necessário lembrar aos pais e professores que um educador que já não tem gosto pelo trabalho é um escravo do ganha-pão e que um escravo não poderia preparar homens livres e ousados".

Diante das mais adversas condições, utilizando seus próprios recursos tecnológicos (dispositivos, acesso à internet e impressão) os profissionais da Educação enfrentaram a batalha, superaram desafios e necessidades. A dificuldade em avaliar as emoções e sentimentos consistem exatamente na própria dificuldade de separar suas frustrações e superações que convivem lado a lado. Faz-se necessário pois, compreender que foram chamados a aprender com Freinet (2000, p. 140), 
jardineiro, técnico, chefe e poeta; reaprenda a rir, a viver e a se emocionar. Você será um outro homem.

É pelo brilho dos olhos que se avaliam a porção de liberdade e a profundidade da cultura do bom operário que pudesse vangloriar-se de ser educador.

A esse mesmo respeito, Nóvoa (2020) recentemente nos possibilita refletir e ponderar que o reconhecimento não se fará por meios oficiais e de cunho governamental, mas se pelo apoio às famílias e o vínculo afetivo e cultural que se forma pelas condições e características vivenciadas:

[...] as melhores respostas à pandemia não vieram dos governos ou dos ministérios da educação, mas antes de professores que, trabalhando em conjunto, foram capazes de manter o vínculo com os seus alunos para os apoiar nas aprendizagens. Em muitos casos, as famílias compreenderam melhor a dificuldade e a complexidade do trabalho dos professores. Isso pode trazer uma valorização do trabalho docente e criar as condições para um maior reconhecimento social da profissão. (NÓVOA, 2020. p. 9).

Os profissionais da Educação transpuseram obstáculos, lacunas na própria formação e dificuldades de uma geração que não foi acostumada ao digital para que o ano letivo de 2020 não se perdesse. Mostraram que são capazes de unir-se e apoiarse para além das orientações e das estruturas oferecidas pelos governantes.

\section{Considerações finais}

Embora o texto ora apresentado não tenha objetivado esgotar possibilidades de análise, as reflexões aqui expostas inegavelmente requerem um aprofundamento de duas questões que pontuam aspectos nevrálgicos dos dados apresentados: 1) a necessidade de formação continuada emergente dos profissionais da Educação sobre os usos das tecnologias no processo de ensino e aprendizagem; 2) a necessidade de atenção e acompanhamento das emoções e sentimentos desses profissionais no atual momento.

Que a percepção das necessidades e possibilidades de uma prática educativa mais libertária, sem as pressões imperativas das demandas extra aprendizagem que engessam e burocratizam os sistemas escolares possam ser pilares para verem-se novos e de novo motivados e valorizados todos os profissionais da Educação.

\section{Referências bibliográficas}


BARRETO, R. de M. M.; HISSA, D. L. A. Depressão e o impacto na prática docente em professores do ensino médio da Rede Estadual de Ensino em Fortaleza (CE). Educação em Debate. Fortaleza, ano 42, n. 82 - maio/ago. 2020. Disponível em: http://www.periodicosfaced.ufc.br/index.php/educacaoemdebate/article/view/1080. Acesso em: 19 fev. 2021.

FREINET, C. Pedagogia do Bom Senso.6.ed. Tradução J. Baptista. São Paulo: Martins Fontes, 2000.

FREIRE, Paulo. Pedagogia da esperança [recurso eletrônico]: um reencontro com a pedagogia do oprimido. Rio de Janeiro: Paz e Terra, 2013.

HADJI, C. Avaliação desmistificada. Porto Alegre: Artmed, 2001.

NÓVOA, António. A pandemia de Covid-19 e o futuro da Educação. Revista Com Censo: Estudos Educacionais do Distrito Federal, v. 7, n. 3, p. 8-12, 2020. Disponível em: http://periodicos.se.df.gov.br/index.php/comcenso/article/view/905. Acesso em: 04 mar. 2021.

MOSCOVICl, S. Representações Sociais: investigações em psicologia social. Tradução Pedrinho A. Guareschi. 5. ed. Petrópolis, RJ: Editora Vozes, 2007.

VASCONCELLOS, C. dos S. Construção do conhecimento em sala de aula. São Paulo: Libertad. 1995. 


\title{
DESENVOLVIMENTO DE ATIVIDADES INTERATIVAS COM NMRDB E PUBCHEM: ALFABETIZAÇÃO CIENTÍFICA COM A QUÍMICA ESTRUTURAL
}

\author{
Andressa Ribeiro Pereira \\ Alba Denise de Queiroz Ferreira
}

\section{RESUMO}

A alfabetização científica é apresentada para a leitura do mundo natural, que é formado por átomos e moléculas que se organizam em estruturas específicas, que fazem parte da linguagem química estrutural. Este mundo atômico molecular é visualizado indiretamente via técnicas espectroscópicas. Os recursos digitais interativos PubChem e NMRDB, possuem potencial para a elaboração de atividades na formação de professores e para o Ensino Médio, para mobilizar as competências de argumentação, do pensamento científico, crítico e criativo. O PubChem facilita observação de modelos de moléculas 3D - a visualização mais direta das estruturas, o NMRDB faz a simulação dos espectros de ressonância magnética nuclear de prótons $\left(\mathrm{RMN}-{ }^{1} \mathrm{H}\right)$ - uma visualização indireta. Esses dados simulados são comparados com resultados experimentais do banco de dados SDBS, que contém dados de $\mathrm{RMN}-{ }^{-1} \mathrm{H}$ e de espectrosopia no infravermelho (IV) - uma técnica mais limitada, facilitando a comparação dos potenciais e limitações dessas duas técnicas do cotidiano da prática química, para a identificação de um par de moléculas pequenas, com propriedades diferentes, mas com a mesma composição (são isômeros) e de um par de drogas, com poucas diferenças estruturais, que tornam uma em líicta e outra em ilíicta. Diante desses fatos, o uso desses recursos digitais são apresentados e discutidos como faciltadores para atividades fundamentadas no modelo da prática educativa que exige diálogo, curiosidade, questionamentos, intervenção, exercício da curiosidade e problematização, sobre como as estruturas químicas são identificadas.

Palavras-chave: Alfabetização Científica, Formação de Professores, Técnicas Espectroscópicas, PubChem, NMRDB

\section{INTRODUÇÃO}

A alfabetização científica tem despertado interesse de educadores e pesquisadores em ciências que idealizam o ensino básico para capacitar na compreensão e interação com o mundo natural, nas decisões em sociedade 
fundamentadas em evidências, reconhecendo as linguagens, os métodos, os potenciais e os limites da ciência (PENICK, 1998; LORENZETTI e DELIZOICOV, 2001; AULER e DELIZOICOV, 2001; CHASSOT, 2003; CHASSOT, 2016; SASSERON e CARVALHO, 2011).

Essa proposta requer a formação de professores que inclua a preparação para a pesquisa da sua própria prática educacional (KRASILCHIK, 1992), a vivência com as habilidades necessárias para um indivíduo ser identificado como alfabetizado cientificamente, entre elas, apreciar as ciências e as tecnologias pela estimulação intelectual que elas despertam, extrair da formação científica uma visão mais rica e interessante do mundo natural (PENICK, 1998; SASSERON e CARVALHO, 2011). E este conhecimento deve facilitar o controle e previsões de transformações que ocorrem na natureza (CHASSOT, 2003).

A prática educativa de Paulo Freire marcada pelo diálogo, problematização, inquietação, questionamento e investigação curiosa, continua proporcionando aportes metodológicos para a educação básica no ensino de ciências (FRANCISCO Jr. et al., 2008; AIRES e LAMBACH, 2010; MACHADO, 2015; GUAITA e GONÇALVES, 2015; SILVA, 2019). O pensamento freiriano e o ensino de química se encontram na perspectiva da alfabetização científica, pois se "a leitura do mundo deve anteceder a leitura da palavra" (FREIRE, 2015), a química é uma ciência que facilita a leitura do mundo (CHASSOT, 2016). Ademais, na formação docente há exigências em reconhecer que o ensino envolve o exercício da curiosidade e que ensinar não é transmissão de conhecimentos (FREIRE, 2002). Porém, para que essa construção de saberes supere os mitos de que a ciência é a única a fornecer as soluções únicas e superiores para as questões e os desafios da sociedade, a proposta é reinventar a concepção freiriana para incluir a concepção crítica para essa "leitura do mundo" contemporâneo através da alfabetização científica ampliada (AULER e DELIZOCOV, 2001). Dentro dessa perspectiva, a alfabetização científica pode proporcionar a decodificação das crenças a ela relacionadas, além da compreensão dos fazeres cotidianos da ciência e da linguagem científica (CHASSOT, 2003)

Considerando que a linguagem química está presente no cotidiano e em contextos sociais pluralizados, a sua compreensão é inerente aos eixos estruturantes da alfabetização científica por Sasseron e Carvalho (2011), pois requer o entendimento básico de termos e conceitos científicos fundamentais, da sua natureza, dos fatores éticos e políticos que envolvem a sua prática, bem como das relações 
entre tecnologia, ciência e sociedade. Dentre os fatos básicos da natureza da química está a relação estrutura-atividade das substâncias. A aplicação de um composto químico como fármaco ou droga ilícita, é determinado pelos detalhes nos arranjos específicos dos átomos nas moléculas. E um dos fazeres do cotidiano da química é a determinação das estruturas moleculares das substâncias químicas.

É conhecido que há uma grande dificuldade por parte dos alunos em entender o universo molecular da química apenas em aulas expositivas (AGUIAR, 2016), além disso, a divisão tradicional do currículo de química tem gerado desinteresse por essa ciência devido à dificuldade que apresentam para entendê-la (TALANQUER, 2016). $\mathrm{Na}$ maioria das escolas, o modelo pedagógico utilizado nas aulas de química ainda segue a linha tradicional, ou seja, prioriza a memorização e a reprodução dos conteúdos, desmotivando os alunos. Por isso, torna-se interessante o uso de atividades interativas e experimentais que permitam que eles possam aprender de forma ativa, o que fará com que os alunos consigam relacionar a teoria aprendida na sala de aula com a prática, possibilitando a alfabetização científica e tecnológica, o trabalho em equipe, o desenvolvimento da criatividade, a formação de senso crítico e a construção gradativa de conhecimento.

Nesse sentido, pretende-se introduzir as características essenciais das técnicas espectroscópicas aplicadas no cotidiano da prática da química para determinação de estruturas moleculares, demonstrar os recursos digitais para não especialistas em espectroscopia, que possuem potencial para a elaboração de atividades na formação de professores para o Ensino Médio e que possibilitam o uso das competências de argumentação, do pensamento científico, crítico e criativo. Para isso foram selecionadas moléculas que podem despertar a curiosidade e questionamentos, como as moléculas pequenas, de mesma composição, mas propriedades diferentes e as moléculas polêmicas-drogas ilícitas, que com pequenas alterações se tornam em drogas lícitas. Por tanto, tem-se como objetivos explorar os recursos do PubChem (PUBCHEM, 2021), NMRDB (BANFI e PATINY, 2008) e SDBS (SAITO, et al., 2021) com as moléculas de interesse, a fim de exemplificar a construção de saberes com base em questionamentos, considerando que uma importante contribuição para alfabetização científica é discutir como a química é praticada (TALANQUER, 2016) e exercitar a curiosidade sobre como as estruturas químicas são identificadas.

\section{METODOLOGIA}


A pesquisa-ação foi elaborada durante Seminários Temáticos II do curso Licenciatura em Química da Unimes Virtual. A necessidade identificada foi a da criação de uma proposta de alfabetização científica sobre como as estruturas das substâncias químicas são identificadas, com uma abordagem não focada na teoria das espectroscopias de RMN e IV, mas em como a química é praticada com essas técnicas.

A primeira etapa da pesquisa foi para a construção de saberes com a abordagem da investigação guiada sobre os fundamentos da espectroscopia molecular, para diferenciar os potenciais e as limitações das técnicas UV-VIS, RMN${ }^{1} \mathrm{H}$ e IV com questões elaboradas com o apoio docente. Na segunda etapa o foco esteve na escolha dos pares de isômeros e de drogas (lícita e ilícita). Nessa fase os recursos digitais foram explorados para a coletada de dados com as substâncias escolhidas. A terceira etapa foi dedicada para elaboração da proposta da atividade interativa com os dados coletados.

\section{LEITURA DO MUNDO ATÔMICO-MOLECULAR: A VISUALIZAÇÃO DAS ESTRUTURAS QUÍMICAS}

A identificação das substâncias químicas é uma das ideias centrais da química, como proposto por Talanquer (TALANQUER, 2016), sendo que uma das formas de identificar as substâncias consiste na utilização de métodos espectroscópicos, uma vez que eles permitem, por exemplo, identificar transições eletrônicas nas substâncias, vibrações moleculares que geram sinais característicos nos espectros para alguns grupos funcionais, além de fornecer dados sobre a conectividade das cadeias carbônicas (MCMURRY, 2004). Ao longo dos anos têm sido incluídos no currículo das aulas de química tópicos relacionados a como diferentes porções das moléculas interagem com o espectro eletromagnético. No entanto, tópicos relacionados a esse assunto costumam ser abordados apenas em aulas teóricas, não mostrando aos alunos os experimentos que podem ser realizados em laboratório com instrumentos apropriados (BONJOUR et al., 2017).

Em relação a identificação das estruturas de substâncias orgânicas, as técnicas espectroscópicas mais úteis são a espectroscopia na região do infravermelho (IV) e a espectroscopia de ressonância magnética nuclear de prótons (RMN- $\left.{ }^{1} \mathrm{H}\right)$ 
(MCMURRY, 2004; BRUICE, 2006). Nesse caso, é possível obter detalhes sobre a conexão dos carbonos das moléculas orgânicas, por exemplo. A técnica de RMN permite encontrar a posição dos átomos nas moléculas, uma vez que cada sinal observado no espectro informa sobre o núcleo observado e sobre o seu vizinho (MCMURRY, 2004; BRUICE, 2006). A espectroscopia de IV, por estar relacionada as vibrações das moléculas, fornece um espectro com vários sinais, onde os diferentes grupos funcionais das moléculas apresentam absorções características (MCMURRY, 2004), permitindo a identificação de cada um, o que auxilia a identificação das substâncias, mas que deve ser confirmada com a técnica de RMN.

É importante destacar que com o progresso da internet e da ciência da computação, surgiram novas oportunidades educacionais e novas ferramentas foram desenvolvidas tanto para os professores, quanto para os estudantes, as quais podem ser usadas tanto para o estudo da teoria, quando para a prática de diferentes assuntos como a espectroscopia citada anteriormente (DEBSKA e GUZOWSKA-SWIDER, 2007). Tem sido relatada a importância de incluir experimentos/atividades que mostrem o uso das técnicas de IR e RMN, uma vez que elas estão relacionadas a ideia de "como as coisas são feitas" em relação às estruturas moleculares. E para o caso das escolas de Ensino Médio nas quais não são possíveis a realização dos experimentos em laboratórios convencionais, os professores podem explorar os recursos da química informática.

\section{INTERAÇÃO COM AS DIFERENTES FORMAS DE VISUALIZAÇÃO COM O PUBCHEM}

O isoburitato de metila e o propionato de etila são compostos classificados como ésteres, de acordo com sua função orgânica. Ambos têm fórmula molecular $\mathrm{C}_{5} \mathrm{H}_{10} \mathrm{O}_{2}$ e massa molecular igual a $102,13 \mathrm{~g} / \mathrm{mol}$, no entanto, o primeiro é usado como solvente, além de ser um dos possíveis compostos orgânicos oxigenados presentes em formulações de produtos de consumo (WAYTT et al., 1999), enquanto que o segundo é conhecido por seu odor de abacaxi, por ser utilizado como agente aromatizante e de fragrância e também por ser considerado um modelo para ésteres etílicos de ácidos graxos que são utilizados como biodiesel de primeira geração (ANDERSEN et al., 2012). 
Assim, o primeiro questionamento que surge a partir dessas características é: porque esses compostos têm propriedades e aplicações diferentes se apresentam a mesma fórmula molecular? $\mathrm{E}$ a resposta está relacionada justamente a um dos temas centrais da química que é a importância da identificação das substâncias e de suas estruturas. $\mathrm{O}$ isobutirato de metila e o propionato de etila são considerados isômeros estruturais, sendo isômeros, aqueles compostos que contêm o mesmo número de átomos, mas com arranjos diferentes (ATKINS e JONES, 2006), o que confere a eles propriedades diferentes.

Utilizando os recursos disponíveis no PubChem é possível verificar a estrutura 3D dessas moléculas, analisar suas ligações e sua disposição no espaço, além de ser possível observar diferentes tipos de representação da molécula, como mostrado na Figura 1. Ou seja, esses recursos permitem analisar os modelos de maneira interativa: é possível girá-los para analisar as ligações, observar como é a disposição da molécula no espaço, além de ser possível analisar a estrutura em diferentes formas, que não somente a tradicional representação em bolas e varetas (Figura 1, itens II), mas também a representação de preenchimento espaço (space-filling) (Figura 1, itens III).

Figura 1. (a) Isoburitato de metila: (I) estrutura química; (II) representação de bolas e varetas; (III) representação de preenchimento-espaço; (b) Propionato de etila: (I) estrutura química; (II) representação de bolas e varetas; (III) representação de preenchimentoespaço. Nos modelos 3D, cor cinza representa o carbono, a vermelha representa o oxigênio e a branca representa o hidrogênio.

(a)

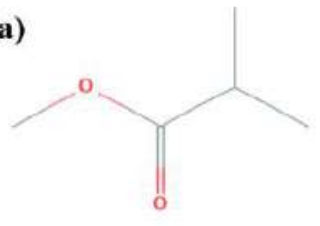

I

(b)

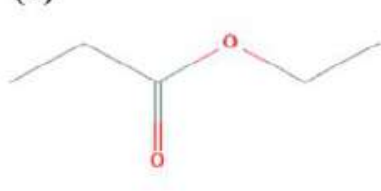

I

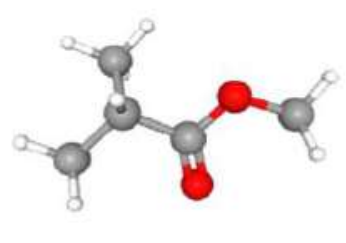

II

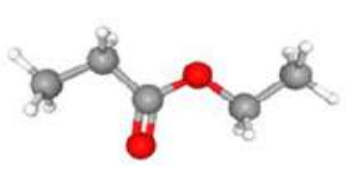

II

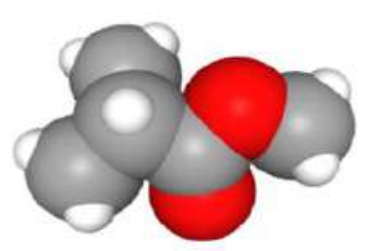

III

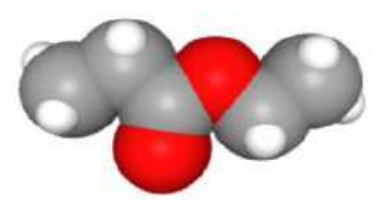

III

Fonte: PubChem, 2021. 
Como observado na Figura 1, ambos os compostos contêm a mesma quantidade de carbonos, hidrogênios e oxigênios na estrutura e possuem a mesma função orgânica, que é a função éster, a diferença entre essas moléculas é estrutural, o que permite que as técnicas citadas anteriormente auxiliem na identificação desses compostos.

\section{INTERAÇÃO COM O BANCO DE DADOS SDBS}

Para a análise da estrutura desses compostos utilizou-se primeiramente 0 banco de dados SDBS Spectra, o qual permite a visualização de espectros de IV e de RMN- ${ }^{1} \mathrm{H}$ obtidos de maneira experimental. Para tanto, é necessário inserir o nome do composto de interesse ou então sua fórmula molecular e então escolher o espectro relativo ao isômero de interesse. Assim, a Figura 2 contém os espectros de IV obtidos do banco de dados SDBS Spectra para o isobutirato de metila (Figura 2a) e para o propionato de etila (Figura $2 b)$.

Figura 2. Espectro de IV do (a) isobutirato de metila e (b) propionato de etila.
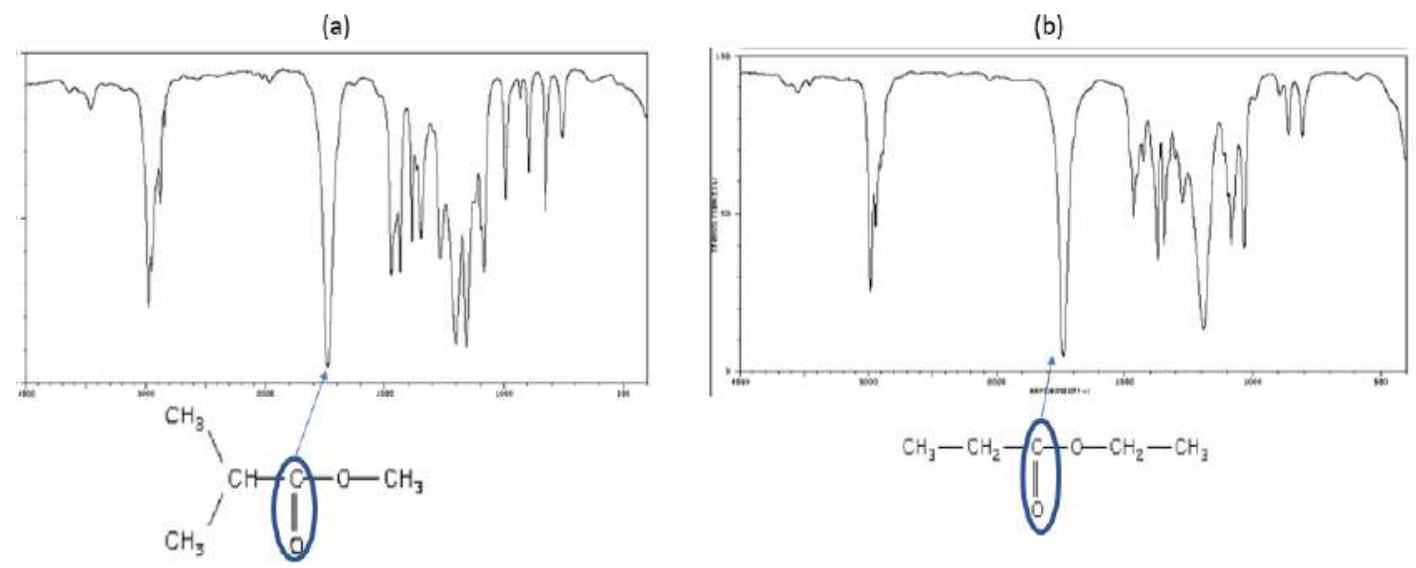

Fonte: adaptados do banco de dados SDBS Spectra.

Analisando os dados dos espectros, observa-se que por serem compostos com o mesmo grupo funcional (éster), não há grandes diferenças nos espectros de IV, embora seja possível utilizar esses dados para confirmar a presença do éster na estrutura de ambos, uma vez que é observada a presença do pico relativo à ligação $\mathrm{C}=\mathrm{O}$ em $1740 \mathrm{~cm}^{-1}$ nos dois casos, sendo esse pico referente ao grupamento carbonila de ésteres (CONSTANTINO, 2008). Nesse ponto da atividade interativa fica evidenciado que a técnica de IV não fornece uma identificação inequívoca das duas 
estruturas para não especialistas, sendo uma oportunidade para despertar questionamentos e introduzir a próxima técnica que resolve esse problema.

\section{INTERAÇÃO COM O NMRDB}

A espectroscopia de $\mathrm{RMN}-{ }^{1} \mathrm{H}$ permite observar como os hidrogênios estão ligados ao longo da cadeia carbônica, fazendo com que sejam obtidos mais detalhes sobre a estrutura que está sendo analisada, a fim delas serem identificadas e diferenciadas. Para tanto, foi utilizado o simulador NMRDB, o qual a partir do desenho da estrutura da molécula fornece dados como o espectro de RMN- ${ }^{1} \mathrm{H}$ simulado, dados de deslocamento químico e a correlação dos hidrogênios com os deslocamentos. Observando a Figura 3, notam-se as diferenças nos espectros que foram obtidos de forma simulada para o isobutirato de metila (Figura 3a) e para o propionato de etila (Figura 3b). Nesse caso, observou-se uma diferença maior entre os espectros do que quando utilizada a espectroscopia de IV, uma vez que na Figura 3a estão presentes três picos, enquanto na Figura 3b há quatro picos. Além da quantidade de picos, há diferença nos valores dos deslocamentos químicos e na altura dos sinais observados, conforme esperado pela literatura (McMURRY, 2004, BRUICE, 2006, CONSTANTINO, 2008).

Figura 3. Espectros de $\mathrm{RMN}-{ }^{1} \mathrm{H}$ para o (a) isobutirato de metila e (b) propionato de etila, ambos simulados utilizando o NMRDB.

(a)

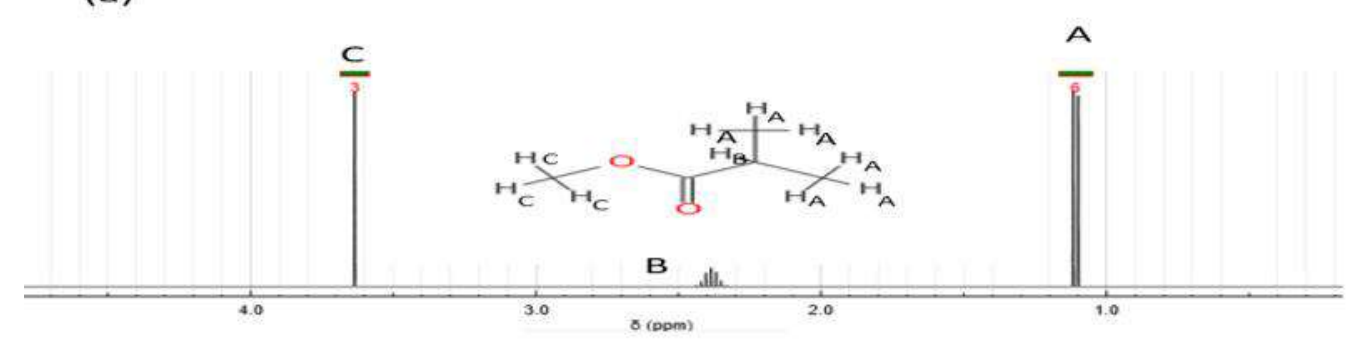

(b)

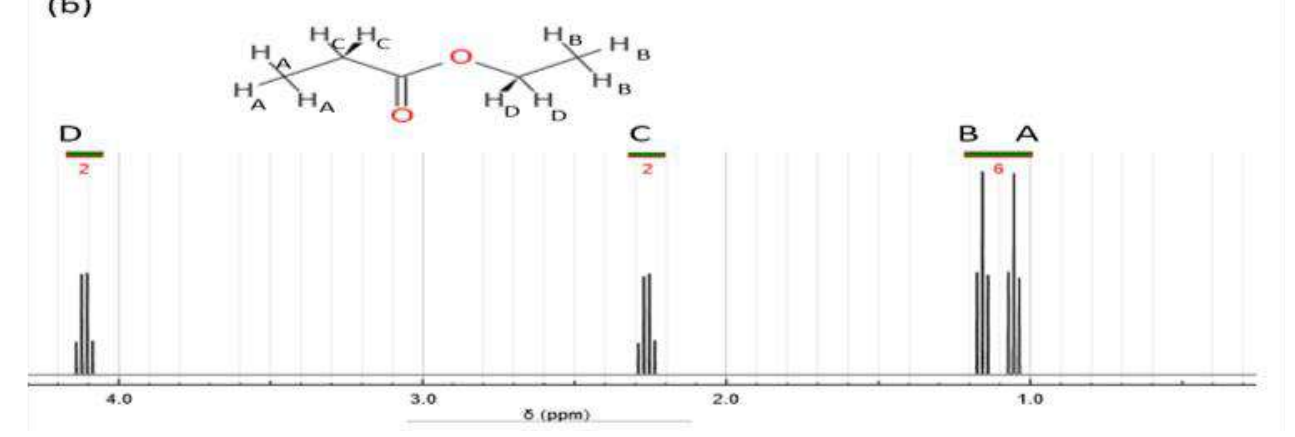

Fonte: adaptado do PubChem. 
Como citado anteriormente, uma das possibilidades na utilização do NMRDB é a correlação entre os deslocamentos químicos e os hidrogênios da molécula simulada, como exemplificado na Figura 4, a qual discrimina qual pico é relativo a qual hidrogênio para os espectros simulados, como destacado com os hidrogênios e os picos marcados nas mesmas cores. Para o isobutirato de metila (Figura 4a), por exemplo, foi observado que o deslocamento em 1,11 ppm está relacionado a 6 hidrogênios, como mostrado no espectro e evidenciado pelos prótons que estão pintados em amarelo na estrutura presente. Já para o propionato de etila (Figura 4b) é possível observar dois picos bem próximos (itens bl e bll), os quais apresentam ambientes químicos parecidos, uma vez que estão a distâncias similares do grupamento éster, o que faz com que sua blindagem seja parecida.

Lembrando que a blindagem sofrida pelo núcleo está relacionada aos elétrons que o circundam e tem relação com o campo efetivo experimentado pelo núcleo (CONSTANTINO, 2008). Outra análise que pode ser feita utilizando o simulador é relativa ao desdobramento dos sinais que aparecem nos espectros de RMN, sendo que estes desdobramentos são promovidos por prótons que estão ligados diretamente a carbonos adjacentes.

O número de picos de um sinal é conhecido como multiplicidade do sinal e o desdobramento é sempre mútuo. O cada sinal se desdobra em função do número de prótons vizinhos seguindo a regra $\mathrm{n}+1$, sendo $\mathrm{n}$ o número de prótons adjacentes. Por isso na Figura 4 (a) observamos o próton do grupo $\mathrm{C}$ dando um sinal único, porque não tem ao seu lado prótons.

No caso do grupo de prótons A (em azul), seus sinais desdobram em dois, porque o vizinho é o próton $B$. Outro aspecto a ser explorado com o simulador é a altura dos sinais. Ela está relacionada com a quantidade prótons em cada grupo (McMURRY, 2004; BRUICE, 2006), portanto, o sinal menos intenso é o B na estrutura do isobutirato de metila na Figura 4(a). 
Figura 4. Espectros de $\mathrm{RMN}^{-1} \mathrm{H}$ para o (a) isobutirato de metila) e (b) propionato de etila, ambos simulados utilizando o NMRDB. Os insets das figuras correspondem a estrutura molecular com destaque para os hidrogênios que também estão destacados no espectro.

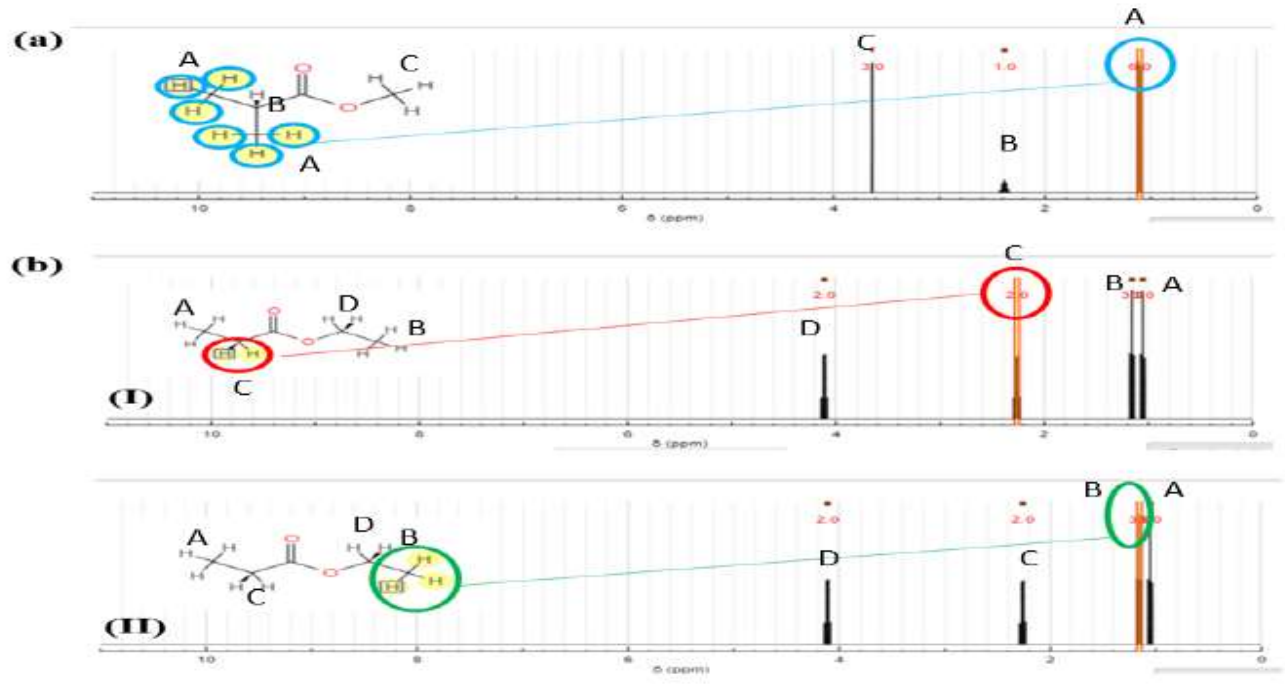

Fonte: adaptado do PubChem.

\section{INTERAÇÃO DADOS EXPERIMENTAIS VERSUS DADOS DA INTELIGÊNCIA ARTIFICIAL}

Além das simulações utilizando o NMRDB, é possível obter os dados experimentais dos espectros de $\mathrm{RMN}-{ }^{1} \mathrm{H}$ do banco de dados SDBS conforme mostrado na Figura 5.

Quando comparados os dados dos espectros simulados da Figura 3 e dos espectros obtidos experimentalmente abaixo, observa-se que há uma boa correlação entre eles, ou seja, podemos utilizar os dados simulados para fazer as discussões que foram feitas anteriormente, uma vez que os deslocamentos químicos e os picos estão de acordo em ambos os espectros, sobre as semelhanças e diferenças.

Este ponto da atividade pode ser adequado para a problematização dialógica sobre a inteligência artificial que foi treinada para pensar quimicamente, mas com limitações para reproduzir as informações que dependem das condições experimentais, por exemplo, os sinais os grupos - $\mathrm{OH}$ ou $-\mathrm{NH}$-que variam de posição no espectro em função da concentração da substância. 
Figura 5. Espectros de $\mathrm{RMN}-{ }^{1} \mathrm{H}$ do (a) isoburitato de metila e (b) propionato de etila. Fonte: adaptados do banco de dados SDBS Spectra.

(a)

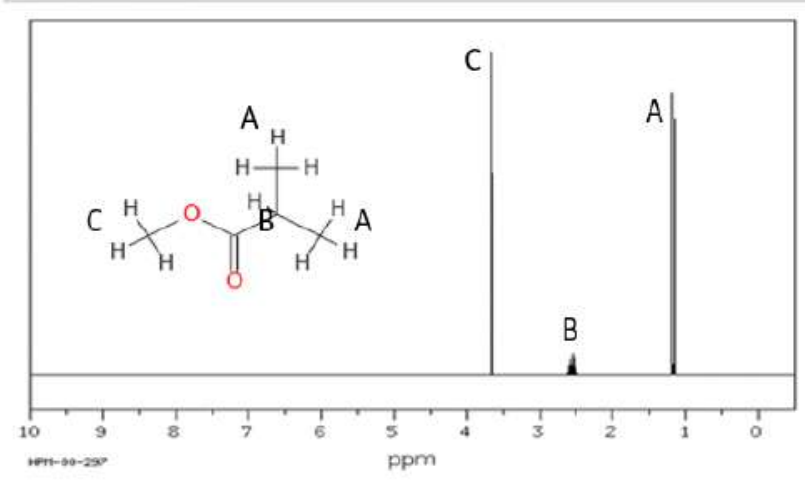

(b)

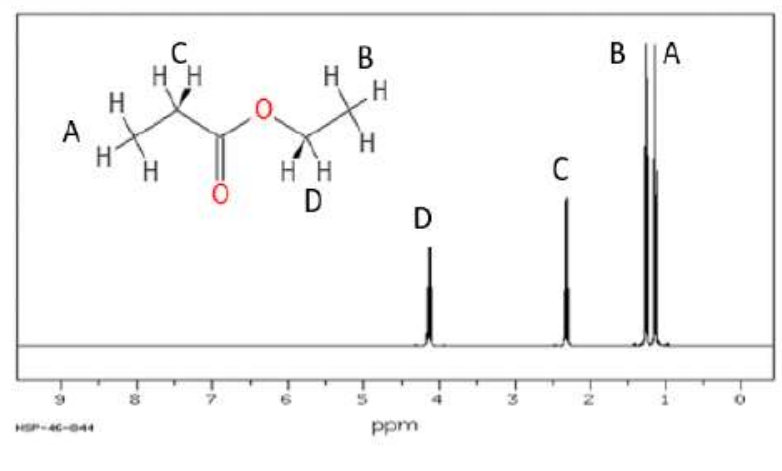

Fonte: adaptado do PubChem.

\section{IDENTIFICAÇÃO DE DIFERENÇAS ESTRUTURAIS EM SUBSTÂNCIAS RELACIONADAS COM OS ASPECTOS ÉTICOS E SOCIAIS DA QUÍMICA}

A fim de motivar as discussões sobre a relevância da identificação das estruturas químicas, o exemplo a seguir está relacionado a drogas sintéticas que possuem estruturas parecidas e que podem ser identificadas pelas técnicas espectroscópicas citadas. As anfetaminas são conhecidas como drogas sintéticas fabricadas em laboratórios e são drogas estimulantes da atividade do sistema nervoso central. Existem várias drogas sintéticas pertencentes ao grupo das anfetaminas, sendo que algumas delas podem ser comercializadas sob a forma de remédio (drogas lícitas), como por exemplo a metanfetamina, que tem como nome comercial Pervitin, embora esse remédio tenha sido retirado do mercado brasileiro (CEBRID, 2021). Já outras, como a metilenodióximetanfetamina (MDMA), também conhecida como "êxtase" são consideradas ilegais. A Figura 6 contém as estruturas da metanfetamina (Figura 6a) e do MDMA (Figura 6b), sendo possível observar que o MDMA pode ser considerado como um derivado da primeira.

Ele foi sintetizado e patenteado como um inibidor de apetite pelo laboratório alemão Merck, no entanto não se tornou comercialmente viável devido aos seus muito efeitos adversos, como por exemplo, os efeitos alucinógenos (XAVIER et al., 2008). 
Figura 6. Estrutura química e representação de bolas e varetas (a) da metanfetamina e (b) do MDMA. As bolas cinzas representam os carbonos, as brancas os hidrogênios, as azuis os nitrogênios e as vermelhas os oxigênios.

(a)
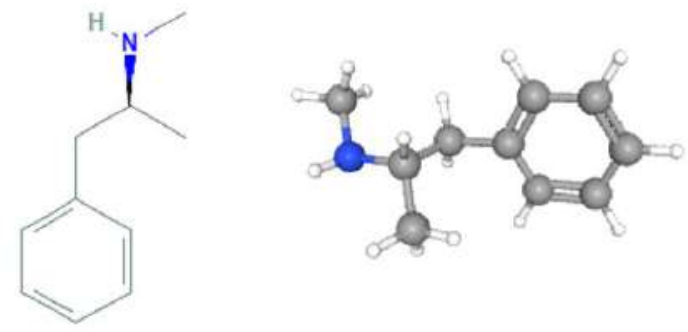

(b)

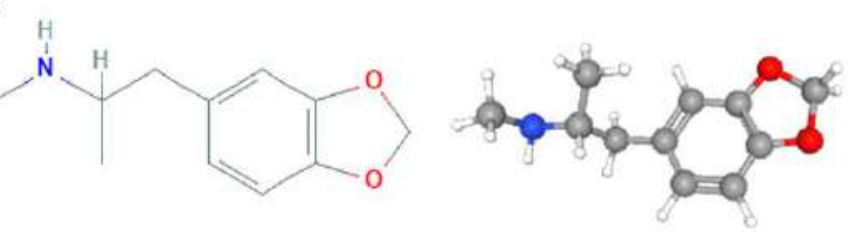

Fonte: adaptado do PubChem.

Quando analisadas as estruturas químicas da metanfetamina (Figura 6a) e a do MDMA (Figura 6b), nota-se que a diferença entre elas é a presença de um anel conjugado ao anel aromático, o qual contém dois oxigênios como heteroátomos na estrutura do MDMA, fazendo com que os espectros de $\mathrm{RMN}-{ }^{1} \mathrm{H}$ dessas moléculas (Figura 7) apresentem alguns picos parecidos devido a porção da molécula que é estruturalmente semelhante, o que faz com que os $\mathrm{H}$ possuam a mesma vizinhança e picos que os diferenciam devido a presença dos heteroátomos e do $-\mathrm{CH}_{2}$ que fecha o novo anel, os quais influenciam no ambiente químico de alguns hidrogênios.

Figura 7. Espectro de $\mathrm{RMN}^{-1} \mathrm{H}$ (a) da metanfetamina e (b) do MDMA, ambos simulados utilizando o NMRDB.

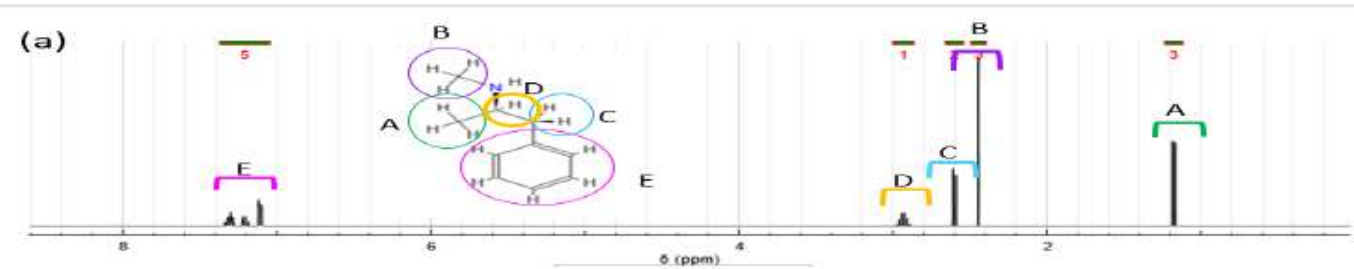

(b)

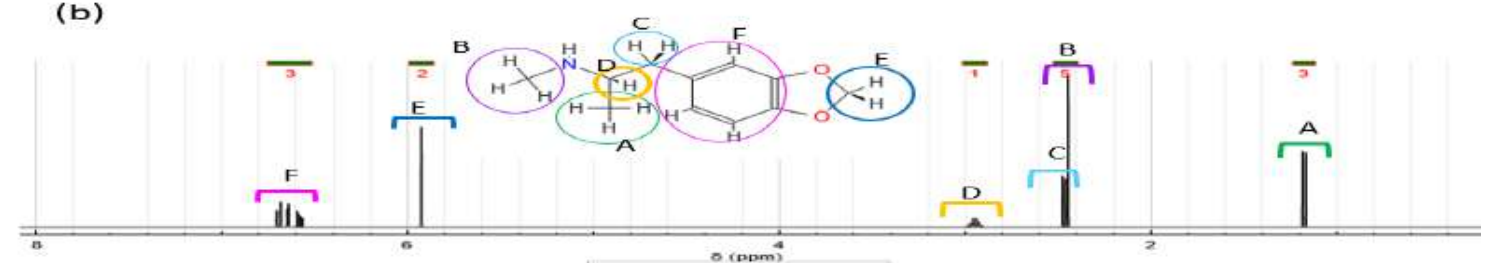

Fonte: adaptado do PubChem. 
Vale ressaltar que quando observadas as estruturas dessas moléculas notase que pequenas e simples modificações podem transformar medicamentos (drogas lícitas) em drogas ilegais, uma vez que essas alterações podem mudam completamente as propriedades do composto que será produzido. Porém, a inteligência artificial do NMRDB não consegue simular os sinais do próton do grupo$\mathrm{NH}$-, porque isto depende de informações sobre as condições experimentais. Esses fatos podem conduzir à mobilização da curiosidade, para que com a alfabetização científica sobre os fatos básicos sobre estruturas moleculares aqui discutidos, haja a problematização dialógica sobre os limites dos modelos para a leitura do mundo natural invisível da química com o tema "drogas: química, sociedade e tecnologia".

\section{CONSIDERAÇÕES FINAIS}

A aplicação dos recursos digitais PubChem - estruturas 3D, SDBS - banco de dados de espectros experimentais e NMRDB - simulador de espectros de RMN${ }^{1} \mathrm{H}$ com inteligência artificial, foi exemplificada para o desenvolvimento de atividades interativas para despertar o interesse dos alunos para a leitura do mundo atômicomolecular. Foi sugerido que a adoção de um par de isômeros de moléculas pequenas e de moléculas polêmicas como drogas e fármacos, deve ser mais adequado para o processo de ensino-aprendizagem no Ensino Médio, porque resulta em dados espectrais de fácil interpretação para não especialistas, podendo despertar a curiosidade e questionamentos sobre diferenças estruturais e de propriedades, de substâncias com a mesma composição.

Dessa forma, os recursos digitais vivenciados na elaboração dessa proposta se mostraram promissores para a elaboração de atividades interativas na formação de professores e para o Ensino Médio, visando despertar a argumentação e o pensamento científico. Além disso, essas atividades permitem aos professores discutir as diferenças básicas na interpretação dos espectros de IV e RMN- ${ }^{-1} \mathrm{H}$ e como essas técnicas podem ser úteis na identificação das substâncias, tema central para a Química e sugestivo para alfabetização científica, pois todas as substâncias químicas possuem uma estrutura que implica em suas propriedades. No contexto do pensamento de Paulo Freire (2011), a proposta da atividade interativa é para que no exercício da curiosidade sobre como as estruturas das substâncias químicas são identificadas, os professores e estudantes se apropriem dos saberes sobre $\mathrm{RMN}-{ }^{-1} \mathrm{H}$ 
com o NMRDB e visualização estrutural com o PubChem, "para convocar a imaginação, a intuição, as emoções, a capacidade de conjecturar, de comparar"... estruturas, dados espectrais e propriedades das substâncias, elaborando atividades nas quais os estudantes possam "admitir hipóteses várias em torno da origem" de um espectro de $\mathrm{RMN}-{ }^{1} \mathrm{H}$ ou de IV, para irem "eliminando algumas" até que cheguem à explicação sobre a relação estrutura-propriedade das substâncias químicas.

\section{REFERÊNCIAS}

AGUIAR, L. K. Simulações interativas no ensino de química: uma experiência dos estados de agregação da matéria. 2016. 38 f. Trabalho de Conclusão de Curso (Especialização em Educação na Cultura Digital), Universidade Federal de Santa Catarina, Florianópolis.

AIRES, J. A.; LAMBACH, M. Contextualização do ensino de química pela problematização e alfabetização científica e tecnológica: uma possibilidade para a formação continuada de professores. Revista Brasileira de Pesquisa em

Educação em Ciências, v. 10, n. 1, 2010. Disponível em:

https://periodicos.ufmg.br/index.php/rbpec/article/view/3984/2548. Acesso em: 08 set. 2021.

ANDERSEN, V. F.; ORSNO, K. B.; JORGENSEN, S.; NIELSEN, O. J.; JOHNSON, M. S. Atmospheric chemistry of ethyl propionate. Journal of Physical Chemistry, v. 116, p. 5164-5179, 2012.

ATKINS, P.; JONES, L. Princípios de Química: questionando a vida moderna e o meio ambiente. 3 ed. Porto Alegre: Bookman. 2006. 968 p.

AULER, D.; DELIZOIVOC, D. Alfabetização científico-tecnológica para quê? Revista Ensaio, v. 3, n. 2, p. 122-134, 2001.

BANFI, D.; PATINY, L. www.nmrdb.org: resurrecting and processing NMR spectra on-line. Chimia, v. 62, p. 280-21, 2008.

BNCC. Base Nacional Comum Curricular. Disponível em:

http://basenacionalcomum.mec.gov.br/images/BNCC El EF 110518 versaofinal site.pdf.

Acesso em: 20 abr. 2021.

BRUICE, P. Y. Química orgânica. Volume 1. 4 ed. São Paulo: Pearson Prentice Hall. 2006. 705 p. 
BONJOUR, J. L.; HASS, A. L.; POLLOCK, D. W.; HUEBNER, A.; FROST, J. A. Bringing NMR and IR spectroscopy to High Schools. Journal of Chemical Education, v. 94, p. 38-43, 2017.

CEBRID. Anfetaminas. Disponível em:

https://www2.unifesp.br/dpsicobio/cebrid/folhetos/anfetaminas .htm

. Acesso em 27 abr. 2021.

CHASSOT, A. Alfabetização científica: questões e desafios para a educação. 7 ed. Ijuí: Editora Unijuí, 2016.

Alfabetização científica: uma possibilidade para a inclusão social.

Revista Brasileira de Educação, n. 22, p. 89-100, 2003.

CONSTANTINO, M. Química orgânica: curso básico universitário. Volume 3. Rio de Janeiro: LTC, 2008. 521 p.

DEBSKA, B.; GUZOWSKA-SWIDER, B. Molecular structures from ${ }^{1} \mathrm{H}$ NMR spectra: education aided by internet programs. Journal of Chemical Education, v. 84, p. 556-560, 2007.

FRANCISCO JR, W. E.; FERREIRA, L. H.; HARTWIG, D. R. Experimentação problematizadora: fundamentos teóricos e práticos para a aplicação em salas de aula de ciências. Química Nova na Escola, n. 30, p. 34-41, 2008.

FREIRE, P. Pedagogia da autonomia: saberes necessários à prática educativa. 25 ed. São Paulo: Paz e Terra, 2002.

Pedagogia do oprimido. 17 ed. Rio de Janeiro: Paz e Terra, 1987. GUAITA, R. I., GONÇALVES, F. P. A Leitura em uma perspectiva progressista e o ensino de química. Química Nova na Escola, v. 37, n.1, p. 53-62, 2015.

KRASILCHIK, M. Caminhos do ensino de ciências no Brasil. Tendências na educação em ciências, v. 11, n. 55, p. 3-8, 1992.

LORENZETTI, L.; DELIZOICOV, D. Alfabetização científica no contexto das séries iniciais. Revista Ensaio, v. 3, n. 1, p. 45-61, 2001.

MACHADO, G. E. A experimentação como estratégia para o ensino de química na perspectiva de Paulo Freire. Periódico Tchê Química, v. 12, n. 24, p. 68-73, 2015.

MCMURRY, J. Química orgânica: Combo. 6 ed. São Paulo; Thomson Learning. 2004.

PENICK, J. E. Ensinando "alfabetização científica”. Educar, n. 14, p. 91-113, 1998. 
PUBCHEM. Disponível em: https://pubchem.ncbi.nlm.nih.gov/. Acesso em 21 abr. 2021.

SAITO, T.; HAYAMIZU, K.; YANAGISAWA, M.; YAMAMOTO, O. Spectral Database for Organic Compounds. Disponível em: https://sdbs.db.aist.go.jp/sdbs/cgi-

bin/direct frame top.cgi. Acesso em 21 abr 2021.

SASSERON, L. H.; CARVALHO, A. M. P. Alfabetização científica: uma revisão bibliográfica. Investigações em Ensino de Ciências, v. 16, n. 1, p. 59-77, 2011.

SILVA, W. R. Polêmica da alfabetização no Brasil de Paulo Freire. Revista Veja, Edição 2608, ano 51, n. 46, p. 74, 2018.

TALANQUER, V. Central ideas in chemistry: an alternative perspective. Journal of Chemical Education, v. 93, p. 3-8, 2016.

WAYTT, S. E.; BAXLEY, J. S.; WELLS, J. R. The hydroxyl radical reaction rate constant and products of methyl isobutyrate. International Journal of Chemical Kinetics, v. 31, p. 551-557, 1999.

XAVIER, C. D. C.; LOBO, P. L. D.; FONTELES, M. M. F.; VASCONCELOS, S. M. M.; VIANA, G. S. B.; SOUZA, F. C. F. Êxtase (MDMA): efeitos farmacológicos e tóxicos, mecanismo de ação e abordagem clínica. Revista de Psiquiatria Clínica, v. 35, p. 96-103, 2008. 


\title{
100 ANOS DE PAULO FREIRE: A RELEVÂNCIA DA AMOROSIDADE NA FORMAÇÂO DE PROFESSORES.
}

\author{
Any Carolina Ribeiro Silva, \\ Thiago Simao Gomes, \\ Marisa Catta-Preta
}

\section{RESUMO}

Este artigo tratou sobre a amorosidade na relação entre aquele que ensina e aquele que aprende no espaço escolar, com vistas a necessidade do estudo aprofundado do tema e da obra de Paulo Freire à formação inicial e à continuada dos professores. O referencial teórico adotado foi pautado no educador Paulo Freire, que enfatiza determinantes sociais, históricos e culturais da condição humana e reconhece que, no Homem, as dimensões cognitivas, sociais e afetivas são inseparáveis. A metodologia empreendida foi de abordagem qualitativa mediante aplicação de questionários, com vistas a identificar o papel da amorosidade e da obra do educador na formação dos professores. O resultado da pesquisa permitiu identificar o papel relevante da amorosidade e de Paulo Freire na formação dos professores.

Palavras-chave: Paulo Freire; afetividade; amorosidade; relação professor-aluno; formação de professores.

\section{INTRODUÇÃO}

Refletir sobre o tema instiga a compreensão da forma como a afetividade e a amorosidade estabelece novas relações no espaço escolar e proporciona um sentindo diferente à atuação e à percepção dos vínculos estabelecidos entre professores e alunos, o que enriquece a experiência e a prática. Um olhar diferenciado para essas relações estabelecidas no ambiente escolar é parte da atribuição profissional e preocupação enquanto psicólogos e educadores. Isso proporciona oportunidade para acompanhar e refletir sobre as ações utilizadas pelos professores em suas atividades pedagógicas, bem como, a relevância da temática na formação de professores.

A constituição da escola se dá em espaço essencialmente educativo. Sua função principal é mediar o conhecimento e oferecer oportunidade ao educando para acessar a reconstrução do saber. As relações estabelecidas neste espaço, entre professores e alunos, devem ser permeadas pelo diálogo e afeto, pois são elementos importantes para que as relações sejam significativas. Isso contribui para o desenvolvimento saudável do professor e discente aconteça, haja vista que tal prática impacta no processo de ensino e de aprendizagem. Concebe-se que estes dois personagens são responsáveis para o estabelecimento de clima afetivo e saudável na 
sala de aula, sendo o professor o agente que favorece tal ambiente, desde que conduza com amorosidade, respeito, consciência e seriedade sua atuação.

Contudo, sabe-se que nem sempre é simples essa tarefa. Por vezes, alunos os afetam de forma desafiadora. Nessas situações, ancorado pelo saber científico, é necessário um espaço de formação onde o docente possa entrar em contato e refletir sobre suas angústias, incertezas e dificuldades. Diante disso, ao pensar sobre a afetividade e a amorosidade em educação, vislumbra-se a possibilidade de serem estabelecidas relações mais saudáveis e justas entre educador e educandos, para estimular a visão humana que permeia o ato de educar.

Diante da complexidade sobre os diversos significados para o termo da afetividade e relevância acerca da presença do estudo da amorosidade na formação de professores, o embasamento teórico utilizado foi sobre a perspectiva do educador Paulo Freire e autores da área da educação. Utilizou-se tal referencial teórico para a análise e discussão dos resultados, pois Paulo Freire referência estudos humanistas e democráticos na área da educação, com aproximações no olhar do ser humano, que indica possíveis direções às relações estabelecidas no espaço escolar, o que torna mais saudáveis, humanos e democráticos os processos de ensino e aprendizagem. Considera-se que o referencial teórico atende as necessidades atuais, tanto dos professores, quanto dos alunos. A concepção humanista da educação é a crença de que todo processo humano precisa ser compreendido como uma unidade, diferentemente da concepção dualista ou maniqueísta e da educação bancária que visa relações verticais entre educadores e educandos que, de certa feita perdura, em alguns ambientes escolares. No presente artigo buscou-se identificar o papel da afetividade na formação dos professores.

\section{REVISÃO BIBLIOGRÁFICA}

Uma vez que a escola se configura como espaço onde as relações humanas se fazem presentes entre alunos e professores, tendo papel importante no desenvolvimento de todos que interagem no espaço, as práticas pedagógicas precisam favorecer o aprendizado por meio do respeito, da amorosidade e do diálogo, em que os sentimentos e as emoções sejam observados e valorizados, para proporcionar a reflexão, revisão das ações e favorecer, por consequência, um ambiente saudável. Entende-se que é preciso enfrentar os desafios presentes na formação dos professores e na relação professor-aluno. Enfrentar e superar esses 
desafios requer, de cada um, a percepção de sua incompletude. Segundo Freire (2016) é através da "inconclusão do ser, que se sabe como tal, que se funda a educação como processo permanente. Mulheres e homens se tornaram educáveis na medida em que se reconhecem como inacabados" (FREIRE, 2016, p. 57).

A partir das pesquisas que visam investigar as questões relativas à identidade profissional do professor mais o processo de formação, observa-se o movimento de reconceitualização da educação continuada dos docentes. As propostas visam o potencial de auto crescimento do educador, de modo a reconhecer a base das noções já adquiridas como suporte para trabalhar novos conceitos e opções (GATTI; BARRETO, 2009).

O educador Paulo Freire (2016) contribui com aspectos importantes na formação de professores a respeito da importância da reflexão crítica sobre a prática como exigência, sem a qual a prática pode vir a se tornar ativismo e a teoria somente discurso. O educador nos diz:

É preciso, sobretudo, e aí já vai um destes saberes indispensáveis, que o formando, desde o princípio mesmo de sua experiência formadora, assumindo-se como sujeito também da produção do saber, se convença definitivamente de que ensinar não é transferir conhecimento, mas criar possibilidades para a produção ou construção (FREIRE, 2016, p. 24).

Tavares (2009) refletiu sobre aspecto importante da prática pedagógica que afeta diretamente as relações entre os professores e alunos, qual seja: o papel político que os professores exercem à construção e transformação para uma sociedade mais igualitária, tendo como alicerce a formação de professores, conforme o pensamento freireano. Em um de seus trabalhos a autora escreveu:

Uma análise da prática pedagógica, a reflexão sobre o papel social da escola hoje, nos remetem a uma contribuição do pensamento freireano à formação do professor, entende-se que o educador tem um papel eminentemente político a desempenhar, educando para a transformação da sociedade atual, tendo em vista uma educação igualitária e com qualidade para todos [...] Alguns demonstrarão não acreditar nesta possibilidade, no entanto sabe-se, também que para ser possível o amanhã é somente porque, no hoje, essa possibilidade já está sendo pensada pelos educadores que vem se reeducando, juntos (TAVARES, 2009, p.109).

Paulo Freire (1996) aponta que a seriedade e o rigor científico se fazem necessários na prática pedagógica, porém, devem estar unidos com a amorosidade e afetividade: 
Essa abertura de querer bem não significa, na verdade, que, porque professor, me obrigo a querer bem a todos os alunos de maneira igual. Significa, de fato, que a afetividade não me assusta, que não tenho medo de expressá-la. Significa, esta abertura ao querer bem a maneira que tenho de autenticamente selar meu compromisso com os educandos, numa prática específica do ser humano. Na verdade, preciso descartar como falsa a separação radical entre seriedade docente e afetividade. Não é certo, sobretudo do ponto de vista democrático, que serei tão melhor professor quanto mais severo, mais frio, mais distante e "cinzento" me ponha nas minhas relações com os alunos, no trato dos objetos cognoscíveis que devo ensinar. A afetividade não se acha excluída da cognoscibilidade (FREIRE, 1996, p. 138).

Desde o final do século XIX verificam-se estudos sobre a afetividade no meio acadêmico. Parte desses trabalhos contribuiu às críticas ao modelo tradicional de educação. Tais produções acadêmicas tiverem e ainda causam impactos. Contudo, embora a temática e o acesso ao material científico publicado ainda precisem ocupar mais espaços nos cursos de formação de professores, existem trabalhos a disposição. Tassoni e Santos (2013), em 'Afetividade, ensino e aprendizagem: um estudo no GT20 da ANPED', indicaram a exigência de ajuste entre os domínios cognitivos e afetivos com o objetivo de aprofundar a discussão, tornando-a mais ampla, especialmente entre os formadores. Também, falam sobre a urgência dos trabalhos na formação inicial e continuada, para que se potencialize o conhecimento dos professores em lidar com a amorosidade numa perspectiva democrática de educação.

Freire (2016) também alertou sobre os aspectos relevantes na formação docente que contemplam e validam os aspectos afetivos inerentes ao espaço da sala de aula:

O que importa, na formação docente, não é a repetição mecânica do gesto, este ou aquele, mas a compreensão do valor dos sentimentos, das emoções, dos desejos, da insegurança a ser superada pela segurança [...] nenhuma formação docente verdadeira pode-se fazer alheada, de um lado, do exercício da criticidade que implica a promoção da curiosidade ingênua à curiosidade epistemológica, do outro, sem o reconhecimento do valor das emoções, da sensibilidade, da afetividade, da intuição ou adivinhação (FREIRE, 2016, p.46).

Em publicação recente, Tavares e Godoy (2019) afirmam que, para Freire, o modelo de educação bancária estabelece relação vertical entre educador e educando, ao que se predomina um modelo de educação opressora por parte do educador, que 
assume papel do detentor do saber, que repassa de forma homogeneizada conteúdo aos discentes. "Tornar os alunos uma massa homogênea, que não pensa, não sonha, não transforma, é leva-los a não almejar ser mais!" (TAVARES; GODOY, 2019, p.16).

Freire (2015) diferenciou a educação bancária da educação problematizadora, em que o modelo do educador é o de mestre e aprendiz. O teórico defendeu a ação pedagógica no processo de libertação através da educação problematizadora que, ao contrário da educação bancária, serve à libertação. Freire apontou um esquema dialógico e horizontal que favorece a aquisição do saber ao diluir as hierarquias e descontruir a ideia de que os educandos são meros receptores de conteúdo, respeitando-os como indivíduos dotados de conhecimentos e pertencentes ao mundo. “Na visão 'bancária' da educação, o saber é uma doação dos que se julgam mais sábios aos que se julgam nada saber. Doação que se funda numa das manifestações instrumentais da ideologia da opressão" (FREIRE, 2015, p. 81).

Segundo Dalla Vecchia (2005), em suas obras, Freire não se dispõe a fundamentar categorias de afetividade e amorosidade, porém, essas categorias se configuram como expressão da densa vivência nos textos e na prática do autor.

\begin{abstract}
A obra de Paulo Freire em algumas passagens se refere à exigência da afetividade como fundamento do processo pedagógico e social, contudo, nas entrelinhas de seu pensamento, da sua ação, inserida nos procedimentos didáticos, nas dinâmicas de grupo, nos círculos de cultura, nos processo de discussão crítica da realidade, na relação efetiva de Paulo Freire com seus educandos, está presente de forma densa e efetiva a afetividade, o amor solidário, a compaixão, a ternura, a qualificação e a crença na capacidade do oprimido, em comunhão com o outro, se libertar através de um processo pedagógico-político de conscientização e de engajamento pela mudança. (VECCHIA; 2005, p. 30).
\end{abstract}

Observa-se na obra do educador a caracterização do amor como intercomunicação entre dois sujeitos, permeados pelo respeito, pela humildade e pela esperança, afirmando que o diálogo só pode existir, se houver profundo amor pelos homens e pelo mundo.

Não há diálogo, porém, se não há um profundo amor ao mundo e aos homens. Não é possível a pronúncia do mundo, que é um ato de criação e recriação, se não há amor que a infunda. Sendo fundamento do diálogo, o amor é, também, diálogo (FREIRE, 2015, p. 110). 
De acordo com Andreolla (2000), Freire não se inspira num sentimentalismo vago, mas sim, na radicalidade de uma exigência ética. $O$ autor defende $o$ amor que liberta, sem ser dominador e, tampouco romantizado, permissivo ou sufocante. Em conformidade com Andreolla, a amorosidade em Freire deve ser observada sem desconsiderar as perspectivas da razão, da corporeidade, da ética, da inteligência e da política para a experiência tanto pessoal, como coletiva. $O$ autor ressalta a importância da afetividade na educação na perspectiva freiriana: "No que tange às emoções, reafirma a amorosidade e a afetividade, como fatores básicos da vida humana e da educação" (ANDREOLA, 2000, p. 22).

Freire (2016) apresentou reflexão sobre o encontro da disciplina e rigor intelectual com os aspectos subjetivos vinculados aos sentimentos, emoções e o querer bem dos educandos.

Como prática estritamente humana jamais pude entender a educação como uma experiência fria, sem alma, em que os sentimentos e emoções, os desejos, os sonhos devessem ser reprimidos por uma espécie de ditadura racionalista. Nem tampouco jamais compreendi a prática educativa como uma experiência a que faltasse o rigor em que se gera a necessária disciplina intelectual (FREIRE, 2016, p. 142).

Segundo o autor, ensinar é especificidade humana, sendo necessário na prática docente a competência profissional, autoridade e a generosidade nas relações com os educandos. Entende-se que a generosidade é dimensão das relações afetivas entre educador e educando.

Outra qualidade indispensável à autoridade em suas relações com os as liberdades é a generosidade. Não há nada que mais inferiorize a tarefa formadora da autoridade do que a mesquinhez com que se comporta. A arrogância farisaica, malvada, com que julga os seus. A arrogância nega a generosidade também nega a humildade, que não é virtude dos que ofendem tampouco dos que regozijam com sua humilhação. O clima de respeito que nasce das relações justas, serias, humildades, generosas, em que a autoridade docente e as liberdades dos alunos se assumem eticamente, autentica o caráter formador do espaço pedagógico (FREIRE, 2016, p. 90).

Ainda segundo o autor, o trabalho do educador é com gente, e querer bem seus educandos é inerente ao ato de educador, inerente ao ser humano. Freire (2016) afirma: 
Lido com gente e não com coisas. E porque lido com gente, não posso, por mais que, inclusive, me dê prazer, entregar-me à reflexão teórica e crítica em torno da própria prática docente e discente, recusar a minha atenção dedicada e amorosa a problemática mais pessoal deste ou daquele aluno ou aluna. Desde que não prejudique o tempo normal da docência, não posso fechar-me a seu sofrimento ou a sua inquietação porque não sou terapeuta ou assistente social. Mas sou gente. O que não posso, por uma questão de ética e de respeito profissional é pretender passar por terapeuta. Não posso negar minha condição de gente de que se alonga, pela minha aventura humana, certa dimensão terapia" (FREIRE, 2016, p. 141).

Pode-se observar, na teoria de Freire, a clareza e tranquilidade com que defende a comunhão dos aspectos humanos, científicos e cognitivos da prática. Neste caso, do educador com os aspectos subjetivos e humanos que envolvem os sentimentos e a amorosidade nas relações mediadas pelo diálogo, de modo a buscar romper a dicotomia entre a razão-emoção e o modelo bancário de educação.

Dentro desta ótica, o ato de educador não se reduz ao trabalho mecânico, puramente técnico, sendo impraticável formar pessoas dando atenção somente para os aspectos cognitivos. É necessário ser atento e sensível ao diálogo, ao respeito, ao conhecimento, aos sentimentos, emoções, desejos e interesses dos educandos.

\section{METODOLOGIA}

A metodologia desta pesquisa caracterizou-se pela pesquisa-ação, a tomar por base Franco (2005), por apresentar cunho social, haja vista relacionar-se com ação social e/ ou voltar-se à resolução de problema coletivo no qual ocorre a participação dos sujeitos envolvidos (pesquisado e pesquisadora) de forma cooperativa, com exercício ativo. O estudo teve caráter qualitativo e foi realizado inicialmente por meio de pesquisa bibliográfica apoiada nos estudos e pesquisas do educador humanista Paulo Freire (2016), além de outros autores da área da educação. Diante disso, foi elaborado instrumento de medida, com base na literatura presente no referencial teórico. O questionário elaborado contém 8 perguntas fechadas foi aplicado aos professores do ano do Ensino Fundamental II, em um Colégio no município de Santos, em 2018. De acordo com Franco (2005), pesquisa e ação podem e devem caminhar juntas quando o propósito for a transformação da prática. O estudo foi direcionado por assuntos de interesse da pesquisa. (LAKATOS; MARCONI, 2001). Foi aplicado o TCLE (Termo de Consentimento Livre e Esclarecido), aos professores que concordaram em participar. O TCLE foi devidamente aprovado pelo Comitê de Ética 
em seres humanos. Número do parecer: 3.235.018. O questionário foi respondido no primeiro semestre de 2018.

\section{DISCUSSÃO DOS RESULTADOS}

A tomar por base o referencial teórico em que se abordou a amorosidade entre aquele que ensina e aquele que aprende, com vistas a necessidade do estudo aprofundado do tema e da obra de Paulo Freire à formação inicial e à continuada dos professores buscou-se no presente artigo identificar o papel da amorosidade e da obra do educador na formação dos professores.

Para a análise, objetivo da pesquisa foi investigar, através da aplicação do questionário e, consequentemente, análise das perguntas fechadas o papel da afetividade na formação de professores. Como citado anteriormente, foi entregue o questionário junto com o TCLE (Termo de Consentimento Livre e Esclarecido) aos dez professores do nono ano do Ensino Fundamental e devolvido, devidamente autorizado.

Ao perguntarmos se a afetividade foi contemplada no percurso da formação, $60 \%$ dos professores responderam positivamente. Observa-se que a maioria dos professores foram contemplados durante formação com conceitos acerca da afetividade. A formação do professor se dá desde a sua vivência como aluno, antepõese a formação acadêmica. Freire (2016) apresentou a relevância das emoções, intuições e curiosidade durante a formação dos professores, unidos à reflexão crítica de sua atuação.

Dessa forma, a formação dos professores, independentemente de documentação, ou política pública que busca assegurar a inserção da afetividade na formação de professores, deve considerar a significância da afetividade baseada na reflexão crítica, aliada aos aspectos subjetivos, já que se trata de uma atuação humana.

Outro ponto analisado diz respeito aos $40 \%$ dos professores que não tiveram contemplada, em sua formação, a temática da afetividade. É importante salientar que a formação de professores tradicional e fragmentada, que visa puramente os aspectos cognitivos, não garante ao professor a possibilidade de refletir sobre a sua prática docente sobre um tema que envolve aspectos subjetivos presentes no ato de educar e que afetam diretamente o processo de ensino e aprendizagem e o próprio desenvolvimento do educador e de seus alunos. 
Figura 1 - A Contemplação da Afetividade na Formação do Professor

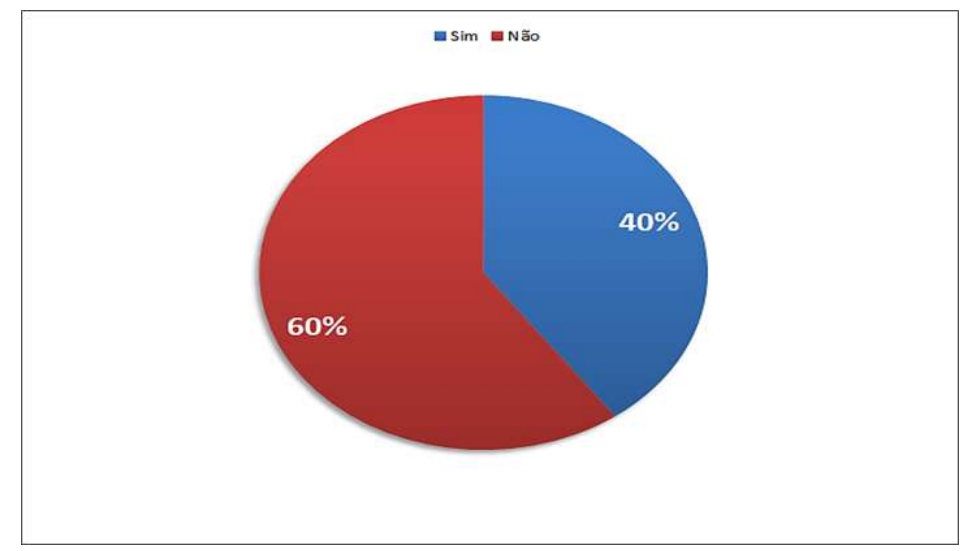

A próxima questão abordou a importância da afetividade na formação dos professores. Ao perguntar aos pesquisados sobre a importância da afetividade ser contemplada em sua formação, $90 \%$ dos professores afirmaram que é relevante 0 estudo da temática durante a graduação.

Observa-se que a maioria dos professores atribuiu importância à afetividade na sua formação. Porém, de acordo com o resultado anterior, $40 \%$ dos professores não tiveram acesso à temática. Conforme Tassoni e Leite (2013) devido à discrepância nos estudos que envolvem a cognição e estudos que abordam aspectos da afetividade, sem esquecer que, aqueles que trazem aspectos cognitivos são dominantes, pode-se supor defasagem na formação dos professores em relação aos aspectos afetivos. Ainda assim, é possível encontrar no resultado a valorização da afetividade durante a formação, o que demonstra conscientização neste grupo de pesquisados sobre a relevância e necessidade do estudo científico acerca da afetividade na formação de professores. Freire (2016) afirmou que somos seres inacabados, em constante movimento de busca.

É desta maneira que se funda o processo de educação permanente, com a tomada de consciência da "inconclusão" dos homens e mulheres que possibilita a educabilidade, não o oposto. "É na inconclusão do ser, que se sabe como tal, que se funda a educação como processo permanente. Mulheres e homens se tornaram educáveis na medida em que se reconhecem como inacabados." (FREIRE, 1996, p. 64). O educador também afirmou, sobre os aspectos relevantes na formação docente que contemplam e validam os aspectos afetivos inerentes ao espaço da sala de aula e a prática pedagógica. 
Figura 4 - A Importância da Afetividade na Formação de Professores

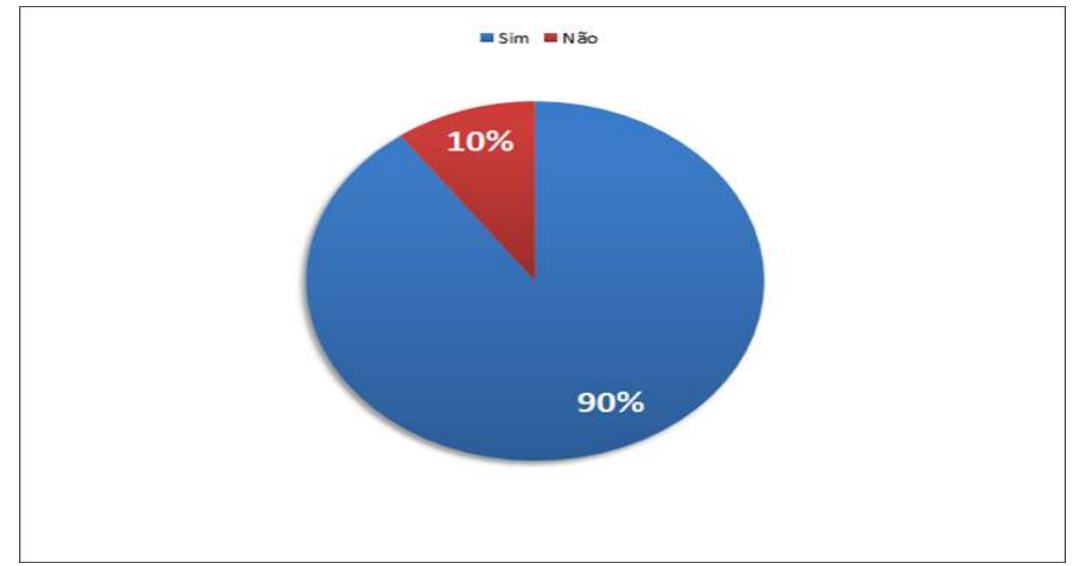

\section{CONSIDERAÇÕES FINAIS}

Compreende-se que a temática da afetividade é pouco explorada no campo científico, em comparação a outras temáticas que visam os aspectos cognitivos. Há herança do modelo bancário de educação que permeia o contexto educacional e, por se tratar de conceito que traz consigo variações no campo filosófico, psicológico e pedagógico, os resultados podem vir a sofrer variações de acordo com visão de educação e formação de professores.

Em relação ao papel da afetividade na formação de professores, ao realizar a análise das respostas dos professores, identificou-se que a maioria dos entrevistados foram contemplados em sua formação e todos consideraram importante o estudo da afetividade na relação professor-aluno. Isso demonstra um estado de conscientização, de compromisso que cada professor deve carregar dentro de si, que contempla, concomitantemente, a responsabilidade humana e sua consciência acerca da importância de refletir sobre a prática pedagógica amorosa, respeitosa, dialógica, aliada a rigorosidade científica. No decorrer do percurso da pesquisa bibliográfica, foram encontradas pesquisas que apontaram à importância da afetividade na relação docente-discente na formação de professores. Constatou-se a intensificação na produção cientifica acerca da afetividade, ainda que seja evento recente em comparação aos estudos cognitivos na área da educação. Tanto a presença, quanto a ausência desta, irá afetar o trabalho do profissional da educação e seu público alvo, os alunos. O professor, não somente no plano racional, como na dimensão afetiva, precisa romper com o modelo tradicional da própria formação, para transcender aos 
aspectos humanos inerentes nas relações, e assim auxiliar na verdadeira educação democrática e humanista de seus discentes.

Diante da análise e do que foi exposto na discussão de resultados, nota-se que os professores devem considerar a sua atribuição profissional como enquanto construtores de relações humanas saudáveis, respeitosas e democráticas. Tal perspectiva não separa a emoção da razão, o intelecto do sentimento. Antes, reconhece o ser humano como um todo, lança um olhar humanista e afetuoso para as relações.

Para que professor possa se conectar a seus alunos, ele precisa estar conectado a ele mesmo, utilizar do conhecimento científico para ser pesquisador de si, não somente para transmitir conhecimentos pedagógicos que visem resultados numéricos, como notas ou pontuação em vestibulares. Dessa forma, acredita-se em uma vinculação fundada no amor, no prazer em ensinar e ser ensinado haja visto que a afetividade se dá em sua prática pedagógica diária.

Sabe-se que essa pesquisa não é conclusiva e que muitas indagações e questões surgiram a partir das reflexões expostas, que a cada momento busca-se caminhos possíveis para que as relações entre professores e alunos se tornem afetuosas, dialógicas, pautadas na amorosidade e respeito para com as individualidades e personalidades de cada personagem presente no espaço escolar

Deseja-se ressaltar que esse caminho, esta jornada de estudar a afetividade na relação professor-aluno é inquietante e instigante. Contudo, simultaneamente, é como dizer sobre algo explícito, porém, por vezes, não falado. Portanto, tácito. É como se fosse necessário relembrar que somos seres humanos com alma e sentimentos. Somos pessoas e profissionais, com virtudes e imperfeições, inacabados e pertencentes ao mundo. Que por fazermos parte dele, somos responsáveis pela maneira como afetamos o outro. Acredita-se no compromisso humano de todos os profissionais da educação em tornarem-se, cada dia mais, conscientes dessa responsabilidade afetiva.

\section{REFERÊNCIAS BIBLIOGRÁFICAS}

ANDREOLA, Balduíno Antônio. Carta-prefácio a Paulo Freire. In: FREIRE, Paulo. Pedagogia da Indignação: cartas pedagógicas e outros escritos. São Paulo: UNESP, 2000. 
DALLA VECHIA. Educação e Afetividade em Paulo Freire: Pedagogia da Autonomia 2005.Disponível em:http://www.pensamentobiocentrico.com.br/content/ed06 .art03php. Acesso em 02 set. 2021.

FRANCO, Maria Amélia Santoro. Pedagogia da pesquisa-ação. Educação e pesquisa, v. 31, p. 483-502, 2005.

FREIRE, Paulo. Pedagogia da autonomia: saberes necessários à prática educativa. 54ํㅡ ed- Rio de Janeiro: Paz e Terra, 2016.

FREIRE. Pedagogia do Oprimido.59o ed- Rio de Janeiro: Paz e Terra, 2015.

GATTI, Bernadette; DE SÁ BARRETTO, Elba Siqueira. Professores do Brasil: impasses e desafios. Unesco Representação no Brasil, 2009. Disponível em< https://observatoriodeeducacao.institutounibanco.org.br/cedoc/detalhe/professoresdo-brasil-impasses-e-desafios,22ce829d-7087-4e73-ad49-8fdd6649a6e3> Acesso em: 02 set. 2021.

LAKATOS, E. M.; MARCONI, M. de A. Fundamentos de metodologia científica. 4.ed., São Paulo, Atlas, 2001.

TASSONI, Elvira Cristina Martins; LEITE, SA da S. A relação afeto, cognição e práticas pedagógicas. Reunião Anual da ANPED, v. 33, 2010.

TAVARES, Elisabeth dos Santos. O sistema municipal de ensino de Santos e o atendimento às demandas da educação na cidade: um estudo crítico. 2009.131f. Tese (Doutorado em Educação) - Pontifícia Universidade Católica de São Paulo, São Paulo, 2009.

TAVARES, Elisabeth dos Santos; GODOY, Malvina Suemi Ono. Pedagogia da Práxis: O olhar sobre as relações oprimido e opressor.In: TAVARES, Elisabeth dos Santos. Paulo Freire presente. $1^{\circ}$ ed- LiberArs. São Paulo, 2019 


\section{A HUMANIZAÇÃO DAS TECNOLOGIAS NO PERÍODO DE PANDEMIA}

Arnaldo H. Baptista, Thiago S. Gomes,

\section{RESUMO}

A pesquisa objetiva subsidiar maneiras diversificadas como proposta para contemplar o ensino aprendizagem para alunos público-alvo da educação especial (PAEE), e como consequência beneficiar o coletivo por meio de metodologias ativas e recursos tecnológicos. Para tanto, parte-se de uma análise dos paradigmas que envolvem a inclusão escolar, bem como os benefícios e dificuldades da adoção de recursos tecnológicos como ferramenta de ensino. Na sequência é apresentado o produto de uma experiência pedagógica com o uso destas ferramentas aliados às metodologias ativas para promover protagonismo estudantil dos alunos PAEE em uma escola pública do município de Praia Grande - SP. O trabalho delineia-se a partir da apresentação destas práticas e recursos selecionados, avaliados sob a luz da literatura.

Palavras-chave: Tecnologias digitais; Inclusão escolar; Metodologias ativas; Ensino remoto.

\section{INTRODUÇÃO}

O presente trabalho evidencia as dificuldades manifestadas no contexto educacional ao lidar com as máquinas, bem como o despreparo que permeava muitos dos atores deste cenário, ora por falta de conhecimento, ora por aversão às tecnologias, que de certa forma poderiam minimizar os efeitos negativos do ensino remoto imposto repentinamente pela pandemia.

No que tange as metodologias, apesar de alguns conceitos de aula invertida serem ocasionalmente mencionados, o contexto escolar era simultaneamente permeado por inúmeras informações que visavam sanar demandas emergenciais e pouco impactavam na transformação da prática docente, que permanecia arraigada na transmissão do conhecimento por meio de giz e lousa. Muitos eram mestres na oratória, exposições, dinâmicas, trabalhos manuais, que se davam prioritariamente em um espaço coletivo de interação presencial. Mediantes esta realidade já acomodada no cotidiano escolar, a atualização tecnológica foi protelada até o momento em que inserir os recursos tornou-se indispensável para que as tarefas mais 
básicas fossem cumpridas. Nesse contexto, a inclusão escolar dos alunos públicoalvo da educação especial torna-se ainda mais complexa. Ao atermos nossos olhares à perspectiva da escola inclusiva, a abordagem freiriana vem ao encontro da busca emancipatória e democrática, que contemple sobretudo os mais vulneráveis. Como ferramenta para viabilizar a efetivação do ensino em um contexto tão desafiador, as metodologias ativas e as tecnologias configuraram ferramentas essenciais para a criação de um novo olhar que contemple o resgate da autonomia desses estudantes.

Deste modo, objetiva-se com o presente trabalho, analisar algumas metodologias ativas em uma perspectiva interdisciplinar; compreender a implementação de recursos tecnológicos no contexto de uma escola pública durante a adesão ao ensino remoto; e elucidar a efetivação dessas práticas na aprendizagem dos alunos público-alvo da educação especial.

Mediante a imprevisibilidade do fim da pandemia, tornou-se urgente a adequação e assimilação das tecnologias no contexto escolar, para além de informações díspares e discursos inflamados que emanavam dos espaços sociais. Deste modo, repensar esta dinâmica sob a ótica da obra de Paulo Freire nos conduz a transformação da prática, não somente em termos procedimentais, mas no compromisso que se firma com uma educação emancipatória e significativa.

\section{REVISÃO BIBLIOGRÁFICA}

O contexto da pandemia evidenciou de forma ainda mais enfática, as fragilidades da educação, tanto no aspecto social quanto metodológico. Ao nos remetermos inicialmente às práticas pedagógicas Milanez (2016, E-book Kindle) salienta

O ensino perfeito é aquele no qual a necessidade do aluno é sanada através de um material criado para ele, de acordo com os objetivos de aprendizagem a serem alcançados. Nesses novos tempos, pandêmicos ou pós-pandêmicos, criar o próprio material faz com que suas aulas sejam personalizadas e que os alunos sintam o quão presente você está. Esse processo de ensino aprendizagem possibilita um melhor engajamento dos educandos e os tornam autônomos na sua aprendizagem. 
Neste sentido, o professor que parte da realidade de seus alunos para 0 desenvolvimento dos componentes curriculares, estabelecendo uma relação dialógica entre repertório acadêmico e demandas sociais experienciadas, promove um processo de ensino aprendizagem efetivo, significativo e transformador. Essa perspectiva já era contemplada pela prática de Paulo Freire, que afirma em Pedagogia da Autonomia (2016, p.116)

Na verdade, meu papel como professor, ao ensinar o conteúdo a ou b, não é apenas o de me esforçar para, com clareza máxima, descrever a substantividade do conteúdo para que o aluno o fixe. Meu papel fundamental, ao falar com clareza sobre o objeto, é incitar o aluno a fim de que ele, com os materiais que ofereço, produza a compreensão do objeto em lugar de recebê-la, na íntegra, de mim. Ele precisa se apropriar da inteligência do conteúdo para que a verdadeira relação de comunicação entre mim, como professor, e ele, como aluno se estabeleça.

Evidenciada a abordagem que se concebe no presente trabalho, o fazer docente enquanto prática de transformação social que parte sempre da realidade dos alunos, damos destaque ao advento da tecnologia, que se mostrou essencial para minimizar os efeitos do ensino remoto imposto de forma repentina pela pandemia de COVID-19.

Freire (2016, p.85) posiciona-se sobre o uso de recursos tecnológicos pela educação

Nunca fui ingênuo apreciador da tecnologia: não a divinizo, de um lado, nem a diabolizo, de outro. Por isso mesmo sempre estive em paz para lidar com ela. Não tenho dúvida nenhuma do enorme potencial de estímulos e desafios à curiosidade que a tecnologia põe a serviço das crianças e dos adolescentes das classes sociais chamadas favorecidas. [...] Ninguém melhor que meus netos e minhas netas para me falar de sua curiosidade instigada pelos computadores com os quais convivem.

Esta perspectiva dialoga intimamente com o cenário atual, uma vez que os recursos tecnológicos se mostram essenciais para a efetivação da educação no século XXI, porém insuficientes para superar as inúmeras contradições de nossos sistemas educacionais. Cabe, neste momento, destacar também que, como afirmado por Freire na citação acima, esses recursos foram até o momento privilégios de camadas sociais mais favorecidas, o que contribui para que a pandemia aprofunde ainda mais as desigualdades sociais. 
Para que a escola pós-pandemia seja capaz de aliar as conquistas tecnológicas à perspectiva exclusivamente humana da escola inclusiva, é necessário sobretudo debruçar-se neste momento no movimento de ação-reflexão-ação ilustrado por Freire (2016, p.31)

Não há ensino sem pesquisa e pesquisa sem ensino. Esses quefazeres se encontram um no corpo do outro. Enquanto ensino continuo buscando, reprocurando. Ensino porque busco, porque indaguei, porque indago e me indago. Pesquiso para constatar, constatando, intervenho, intervindo educo e me educo. Pesquiso para conhecer o que ainda não conheço e comunicar ou anunciar a novidade.

A pesquisa enquanto elemento que permeia a prática docente conduz à inovação metodológica que, aliada às inúmeras atualizações tecnológicas, agrega frescor e dinamismo ao fazer docente e discente.

Prieto, Pagnez e Gonzalez (2014, p.6) apontam

Faz-se necessário assegurar e consolidar intervenções de formação continuada para os diferentes participantes da comunidade escolar com a participação dos gestores das escolas, professores de classes comuns e de serviços de educação especial, funcionários técnicoadministrativos, [...] pois todos precisam, mais e mais, compreender o(s) seu(s) papel(éis) diante desses estudantes. Além disso, é preciso aprimorar mecanismos de monitoramento das políticas para que sejam identificadas as distorções e necessidades de aprimoramento e sejam organizadas intervenções mais específicas onde forem constatados deslocamentos de atribuições.

Deste modo, considerando o objeto de estudo proposto, faz-se necessário observar a constituição deste cenário de forma crítica, valendo-se de dados para constatação da efetividade deste modelo.

No que tange as especificidades da época atual, Bacich, Neto, Trevisani (2015, p.4) salientam

O ensino híbrido é uma abordagem pedagógica que combina atividades presenciais e atividades realizadas por meio das tecnologias digitais de informação e comunicação (TDICs). Existem diferentes propostas de como combinar essas atividades, porém, na essência, a estratégia consiste em colocar o foco do processo de aprendizagem no aluno e não mais na transmissão de informação que o professor tradicionalmente realiza. [...] O aluno estuda o material em diferentes situações e ambientes, e a sala de aula passa a ser o lugar de aprender ativamente, realizando atividades de resolução de problemas ou projeto, discussões, laboratórios, entre outros, com o apoio do professor e colaborativamente com os colegas. 
A revisão das concepções em ambas as esferas deve acontecer sincronicamente e, mediante esse novo olhar, ressignificar também suas práticas. Biesta (2017, p.486) apresenta uma distinção importante: "Enquanto a aprendizagem como aquisição consiste em obter mais e mais, a aprendizagem como resposta consiste em mostrar quem você é e em que posição está". Ao pensarmos o aluno com deficiência enquanto sujeito ativo em um contexto de sala de aula, a instauração do conceito de aprendizagem como resposta permite a todos os envolvidos na dinâmica escolar exercer protagonismo em um ambiente de transformação social efetiva e, consequentemente a consolidação prática do conceito de inclusão.

\section{METODOLOGIA}

O presente trabalho partiu de uma experiência de campo em uma escola pública da rede municipal de Praia Grande - SP durante a atuação do autor como Professor de Educação Especial, atuante em Sala de Recursos Multifuncionais. Mediante esse primeiro contato com o campo de estudos, desenvolveu-se uma revisão bibliográfica com vistas ao aprofundamento teórico e desenvolvimento de arcabouço que fundamenta as primeiras observações.

Destaca-se que o trabalho consiste em um recorte da pesquisa de Mestrado Profissional em Práticas Docentes no Ensino Fundamental em desenvolvimento na UNIMES.

\section{DISCUSSÃO DOS RESULTADOS}

Muitos são os desafios impostos à educação pública, sobretudo na época atual. $O$ presente trabalho parte de uma experiência vivenciada em uma escola pública municipal de uma região periférica de Praia Grande - SP. A Unidade atende cerca de 700 alunos da segunda etapa do ensino fundamental e conta com uma Sala de Recursos Multifuncionais para Atendimento Educacional Especializado, espaço de atuação do pesquisador. Considerando o contexto pesquisado, nos discursos que permeavam o ambiente escolar pré-pandemia, as famílias muitas vezes eram chamadas para dialogar e contribuir com uma almejada mudança, contudo, os resultados estavam muito aquém do esperado. De repente, uma pandemia faz com 
que o mundo pare e todos sem exceção embarquem em uma reflexão para sua autoconstrução e realização. O intransigente precisa se flexibilizar e o ausente precisa participar. Fez-se necessária a transformação e revisão de prioridades, reconstruir e ressignificar vínculos, tudo permeado pelo grande desafio de não deixar ninguém pra trás na promoção da equidade e efetivação de uma educação inclusiva neste novo contexto.

No trabalho específico da Educação Especial, nota-se que o desafio é ainda maior, pois o contexto da deficiência exige um olhar individualizado. Deste modo, é necessário avaliar não só a viabilidade do uso dos recursos, mas também características de aprendizagem do aluno, com vistas a tornar essa vivência significativa.

A Unidade pesquisada adotou, após profundas discussões e reflexões coletivas a plataforma Google Classroom como carro chefe da interação. Ambientes Virtuais como este configuram um espaço muito rico de interação e desenvolvimento de estratégias diferenciadas, que vai ao encontro das necessidades dos alunos. Assim, é possível nesses ambientes suprir minimamente a necessidade de contato social com feedback imediato.

A adesão inicial ao ambiente virtual pelos alunos com deficiência e suas famílias apresentou bastante resistência, considerando inclusive condições socioeconômicas e grau de instrução da comunidade. Deste modo, no contexto do Atendimento Educacional Especializado iniciou-se uma interação individualizada com a ferramenta do WhatsApp, recurso mais acessível às famílias. Estabeleceu-se uma rotina de atendimentos por chamada de vídeo, visando desenvolver habilidades, aprimorar o vínculo e fortalecer a autoestima dos discentes. Notou-se aprimoramento da relação escola-família e intensificação da parceria para a continuidade das propostas do Atendimento Educacional Especializado (AEE), no cotidiano doméstico. Cabe ressaltar que, neste espaço de interação, alunos e familiares são protagonistas da construção deste novo fazer, desta nova forma de existir do ambiente escolar, para tanto, faz-se necessário que se percorra os caminhos que têm mais sentido para esses atores. Freire (2013, p.54) destaca

Nenhuma pedagogia realmente libertadora pode ficar distante dos oprimidos, quer dizer, pode fazer deles seres desditados, objetos de um "tratamento" humanitarista, para tentar, através de exemplos 
retirados entre os opressores, modelos para a sua "promoção". Os oprimidos hão de ser o exemplo para si mesmos, na luta por sua redenção.

Deste modo, não se buscou um caminho conhecido, ou um exemplo a se seguir, mas a construção de uma história que contemplasse as características daqueles indivíduos, suas histórias, saberes e necessidades.

A partir da solidificação desta parceria, viabilizar o acesso aos novos universos tornou-se factível. Gradualmente, os alunos ambientaram-se à plataforma digital Google Sala de Aula e suas possibilidades expandiram-se. Surgiram então, as experiências de aulas coletivas, que viabilizaram a interação com os colegas, agregando significativamente ao desenvolvimento de habilidades que envolvem competência socioemocional, uma vez que a construção do conhecimento se dá de forma compartilhada e colaborativa.

A dinâmica que envolveu o trabalho foi construída por meio de metodologias ativas, técnicas de jogos diversificados e aulas práticas de origamis.

Estabeleceu-se um cronograma de encontros semanais, com interações individuais. A cada três semanas, era realizado um atendimento coletivo de maior duração em formato de Live, com participação de todos os discentes e interação organizada entre eles.

A cada atendimento notou-se o crescimento dos discentes e docente. Em uma análise qualitativa, pode-se observar que os conhecimentos foram aprofundados nessas oportunidades ao passo que eram compartilhados em ambiente virtual, transcendendo barreiras de distanciamento físico e redimensionando a própria configuração de aula.

Dentro do Google Classroom, a ferramenta mais utilizada era o Jamboard. Por meio dela, eram realizadas interações em tempo real e o aluno conseguia manusear a ferramenta junto do professor. Foram construídas nessas aulas, figuras planas de matemática que serviam como base para introdução dos conceitos de geometria espacial. A interdisciplinaridade permeava todo o contexto da aula, e podese inserir elementos de Geografia, História e Artes por meio de atividades que envolviam temáticas como Grécia, Egito e França, estabelecendo comparações entre pontos turísticos e relações com conceitos de geometria bidimensional e tridimensional. A ampliação do conhecimento de mundo expandia os horizontes dos 
discentes por meio da aprendizagem intrínseca, que despertava para a aprendizagem extrínseca e vice-versa.

As aulas ganharam corpo e intensidade, minimizando os impactos que 0 ensino remoto provocou em discentes e docentes. Deste modo, o ambiente virtual proporcionou reflexões acerca de avanços que beneficiariam o contexto de ensino e aprendizagem tanto em formato presencial, híbrido ou remoto. Pode-se afirmar que essa experiência provocou uma revisão do paradigma da tecnologia na educação, uma vez que preconceitos foram quebrados e construiu-se uma nova forma de pensar o processo pedagógico.

Como concluía Kuhn (2020, p.255)

Tudo vai bem até que os métodos legitimados pelo paradigma não conseguem enfrentar o aglomerado de anomalias; daí resultam e persistem crises até que uma nova realização redirecione a pesquisa e sirva como um novo paradigma.

Deste modo, as tecnologias passaram a contemplar um antigo anseio de atender a todos, abarcando a diversidade. Jogos convencionais foram utilizados no formato digital utilizando o Jamboard, como a forca temática em diferentes níveis de dificuldade, que resgatou lendas brasileiras no dia do folclore. Notou-se que os resultados obtidos nessas interações contagiaram também outros docentes e as práticas se expandiram para outros espaços da vida escolar dos alunos.

Cabe ressaltar que os alunos têm também acesso aos materiais impressos e material de apoio retirados na Unidade Escolar. É possível observar que este ponto garante o acesso ao conteúdo aos alunos com conexão restrita à internet, contudo também vem funcionando como um elemento de transição para tecnologias digitais para comunidades tão habituadas a um ensino mais analógico.

Todo o trabalho de observação e reflexão culminou em uma Live denominada Live das Estrelas. Neste evento, realizado via plataforma Google Meet, os alunos com deficiência exerceram todo protagonismo na apresentação de jogos, dinâmicas e atividades que envolviam conceitos acadêmicos pertinentes à sua faixa etária de forma lúdica e reorganizada. Notou-se um grande amadurecimento e desenvolvimento da autonomia e engajamento desses alunos. 
Sabe-se que a imposição do isolamento social trouxe inúmeros desafios e dificuldades. Foi, e ainda é necessário que nos reinventemos constantemente. Contudo, observou-se também um aprimoramento da dinâmica escolar para ressignificar a educação e a participação da família neste processo.

Durante todo o percurso que se deu até aqui, é claro que avaliar os alunos para a construção de um projeto consistente exige sobretudo uma revisão das práticas, expectativas e objetivos.

A tecnologia já permeava a vida de vários alunos há algum tempo, entretanto, ela assumiu neste período um novo papel tornando-se uma aliada do processo educativo. Neste sentido, presume-se que a aprendizagem criativa configura um meio de amenizar os efeitos negativos do distanciamento físico, ressignificar práticas, e congregar maiores possibilidades de autonomia, reflexão e construção de perspectivas para um novo futuro a partir da valorização das potencialidades individuais dentro do contexto coletivo.

Apesar dessa proposta destinar-se à resolução de uma situação-problema momentânea, há uma necessidade de reinvenção com foco no contexto póspandemia. Acredita-se que essa proposta diferenciada demostra potencial para transformar práticas escolares convencionais e expandir-se no cotidiano. O mundo das tecnologias é inovador e nos apresenta a cada dia, infinitas possibilidades. Esse movimento às práticas pedagógicas, até então, encarado como uma utopia, transformou muitas perspectivas e mesmo com alguns infortúnios é visível o quão essencial se tornou.

Algumas metodologias ativas diferenciadas como Matemática russa, Matemática egípcia, Matemática chinesa, Matemática babilônica, Matemática inglesa, Divisão TDAH, Torre Inteligente, Criação de Histórias Ilustradas, Tangram, Mapa Mundi (Fusos), Contação de Histórias, Bingo da Matemática, Soletrando, Videoaulas, Planificações de origamis, Histórias com Fantoches, Matemática arábica, Gamificações e outros; foram transportados de uma maneira diferenciada à ferramenta Jamboard que, em tempo real, otimizou o processo de ensino e aprendizagem, proporcionando autonomia e gerando o protagonismo estudantil para muitos alunos que foram relegados à invisibilidade no ensino presencial 


\section{CONSIDERAÇÕES FINAIS}

A presente proposta surge sobretudo do incômodo, do desejo e das reflexões que os acontecimentos impõem. Há tempos, observa-se um descompasso entre o discurso educacional que permeia os debates acadêmicos e a prática ainda tão arraigada de modelos conservadores, mecanizados, massificantes e marginalizantes. O contexto do ensino remoto imposto pela pandemia escancara as fragilidades desse sistema, e emerge com ainda mais força, a necessidade de revisão, desconstrução e reconstrução de uma escola que contemple um ideal, um projeto aberto ao acolhimento e vivência integral das diferenças.

Como afirma Mantoan (2015, p. 203)

Um novo paradigma do conhecimento está emergindo das interfaces e das novas conexões que se formam entre saberes outrora isolados e partidos e dos encontros da subjetividade humana com o cotidiano, o social, o cultural.

Sob uma perspectiva mais otimista, é possível valer-se deste momento para reduzir os contrastes e expandir o diálogo entre o conhecimento científico e os saberes e oportunidades que se desvelam no chão da escola. Mantoan (2015, p. 208) exprime as infinitas possibilidades que tal contexto nos propõe

Diante dessas novidades, a escola não pode continuar ignorando o que acontece ao seu redor, nem anulando e marginalizando as diferenças dos processos pelos quais forma e instrui os alunos. $E$ muito menos desconhecer que aprender implica ser capaz de dar significado a objetos, fatos, fenômenos, à vida. Expressar, dos mais variados modos, o que sabemos implica representar o mundo com base em nossas origens, em nossos valores e sentimentos.

Em tempos de pandemia, antes de avaliar os alunos, precisa-se estabelecer uma autoavaliação. Saber de todas as dificuldades, e com elas aprender a superar os obstáculos. Faz-se necessário desenvolver a empatia, compreensão e sensibilidade afinadas para poder enxergar os alunos. Não há avaliação se não houver público, há a necessidade de mudar as estratégias e atraí-los de alguma forma e conseguir diversificar a aprendizagem. Contudo, muitos não são abarcados e ficam sem o acesso, mas por meio de metodologias ativas há como contemplá-los.

Por fim, as experiências vivenciadas durante este processo retomam uma reflexão fundamental, que deve permear todo espaço formativo: a quais interesses o projeto pedagógico serve? Essa questão emergiu de forma ainda mais intensa durante 
este período, e foi possível reafirmar os valores da Unidade escolar, de promover a emancipação a partir da realidade dos sujeitos que constroem aquele espaço. Evidentemente, este processo se dá diariamente, conforme desvelamos a realidade escolar, contudo é fundamental que possamos sempre ponderar sobre o que propõe Freire (2013, p. 54)

A pedagogia do oprimido como pedagogia humanista e libertadora terá dois momentos distintos [...] o segundo, em que, transformada a realidade opressora, esta pedagogia deixa de ser do oprimido e passa a ser a pedagogia dos homens em processo de permanente libertação.

\section{Referências}

BACICH, Lilian; Neto, Adolfo; Trevisani, Fernando. Ensino Híbrido: Personalização e tecnologia na educação. Porto Alegre, Penso, 2015. E-book kindle

BIESTA, Gert. Para além da aprendizagem: educação democrática para um futuro humano. Belo Horizonte: Autêntica Editora, 2017.

FREIRE, Paulo. Pedagogia da autonomia: saberes necessários à prática educativa. 54.ed. Rio de Janeiro: Paz e Terra, 2016.

Pedagogia do oprimido [recurso eletrônico]. Rio de Janeiro: Paz e Terra, 2013. E-book kindle.

KUHN, Thomas. A Estrutura das revoluções científicas. 13.ed. São Paulo: Perspectiva, 2017, E-book Kindle.

MANTOAN, Maria. Inclusão Escolar: O que é? Por Quê? Como fazer? São Paulo, Summus Editorial, 2015. E-book Kindle.

MILANEZ, Carolina G. Compreender o ensino híbrido: de acordo com a necessidade do aluno. São Paulo: Amazon, 2020.E-book Kindle.

PRIETO, Rosângela G.; PAGNEZ, Karina S. M. M.; GONZALEZ, Roseli K.

Educação especial e inclusão escolar: tramas de uma política em implantação.

Educ. Real., Porto Alegre, v. 39, n. 3, p. 725-743, Set. 2014. Disponível em: Acesso em: 15 mai. 202 


\title{
A PEDAGOGIA CRÍTICA DE PAULO FREIRE NA NOVA MUSEOLOGIA
}

\author{
Cecília Régis \\ Scarlet Karen Buzzi
}

\section{RESUMO}

O presente artigo sugere reflexões acerca da influência da pedagogia crítica e da autonomia do educador Paulo Freire sobre as práticas educativas dentro da Nova Museologia. Tal abordagem foi tratada na Mesa-redonda de Santiago, em prol de uma educação decolonial como ferramenta para estimular o respeito à diversidade étnica e cultural, suscitando em uma formação integral dos estudantes para o exercício da cidadania. Promove, por conseguinte, novas estruturas sociais, transformando e construindo novas relações de poder a partir da conscientização do público em geral enquanto atores da prática cultural. Neste sentido, compreendemos a importância do diálogo entre a Educação Museal e a comunidade escolar, visando a promoção do bem cultural para a valorização do mesmo junto à sociedade.

Palavras-chave: Paulo Freire; Nova Museologia; Educação Museal; Cidadania.

\section{INTRODUÇÃO}

Os museus e demais espaços de cultura são entidades sociais que representam a memória de um povo. São espaços de produção de conhecimento e muitos como até mesmo uma oportunidade de lazer. O conteúdo de um museu, ou seja, seu acervo em exposição, favorece a construção social e uma percepção crítica da sociedade.

Nesse contexto, é importante evidenciarmos sobre o seu papel na constituição da memória social, sendo fundamental a iniciativa dos museus em seus processos educativos, do mesmo modo que, através deles novos saberes serão construídos e produzidos pelas relações que ocorrem no âmbito museal.

A construção desse texto surgiu com a necessidade de questionarmos alguns museus regionais, quanto às suas responsabilidades sociais enquanto entidades informais. A visita aos museus na região da baixada santista, instigou-nos a querer 
compreender como os espaços museológicos são aproveitados em prol de projetos educativos; dessa forma, não temos o intuito de relatar as visitas neste artigo.

Temos como objetivo fazer uma reflexão sobre a influência de Paulo Freire na Educação Museal, em relação a dialogicidade entre o Museu e a proposta freiriana, tendo em vista a valorização do território e o fortalecimento da identidade cultural.

Pretende-se, por meio da abordagem do tema sugerido, compreender o quanto a Nova Museologia coincide com a proposta do educador. Para tanto, deve-se abrir discussões também sobre o quanto os profissionais da educação compreendem acerca do tema e qual é a sua participação ativa na construção de sujeitos críticos da sociedade a que pertence.

A problemática central desse artigo surgiu a partir do questionamento: "A que ponto os museus compreendem a sua função social na educação de uma sociedade?" sob a ótica da teoria da pedagogia crítica de Paulo Freire. Em tal reflexão, atentamos para os diversos problemas enfrentados na realidade do cotidiano de um museu, os que mais refletem no insucesso na educação, são os de ordem social. Ou seja, a falta de uma equipe especializada em educação que tenha uma consciência social no desenvolvimento dos projetos ou a falta de comprometimento político com uma educação para a cidadania.

\section{REVISÃO BIBLIOGRÁFICA}

Este artigo foi desenvolvido e fundamentado a partir de diversas pesquisas, utilizando como fonte de recursos artigos, dissertações, teses e livros já publicados, com o objetivo de identificar as possibilidades para o futuro da Educação Museal no campo da museologia com responsabilidade social, dentro das instituições de memória da região. A respeito dos conceitos no campo da Nova Museologia, bem como, para ampliar as reflexões sobre temas contemporâneos, analisamos artigos do museólogo Mário Moutinho, sendo procedida a leitura flutuante de todo acervo, pela identificação dos eixos temáticos e aferidos seus respectivos núcleos de sentido.

Após a análise dos conteúdos dos artigos buscou-se estabelecer um diálogo entre a Educação Museal e suas potencialidades educativas sob a ótica das práxis freiriana no que concerne às resoluções da Nova Museologia adotada na MesaRedonda de Santiago (1972). A esse respeito, encontramos no livro escrito pelo 
educador em 1967, Educação como prática da liberdade, menção à educação com intenção de promover uma compreensão mais crítica da realidade no sentido de impulsionar consciência crítica do sujeito em sua realidade: "o papel ativo do homem em sua e com sua realidade" (FREIRE, 2020, p.142), conceitos substanciais que reitera a influência de Paulo Freire sobre a Nova Museologia, no que tange à função social e educativa dos museus.

\section{PAULO FREIRE NA NOVA MUSEOLOGIA}

O educador e filósofo brasileiro, Paulo Freire, teve forte influência sobre o documento na Mesa-Redonda, chegou a ser convidado para ser orador em Santiago, pelo então presidente do ICOM (Conselho Internacional de Museus), o museólogo francês Hugues de Varine. O Governo brasileiro da época não permitiu que Freire participasse de uma missão da UNESCO, no entanto, isso não impediu que suas teorias sobre educação conscientizadora inspirassem uma Nova Museologia, na qual todo cidadão é sujeito ativo em relação à sua realidade. Para Freire (1967/2020) a cultura é toda criação humana, o homem, afinal, no mundo e com o mundo como sujeito criador, por isso crítico. "A cultura como aquisição sistemática da experiência humana. Como uma incorporação, por isso crítica e criadora, e não como uma justaposição de informes ou prescrições "doadas"." (FREIRE, 1967/2020).

O documento de Santiago coloca o Museu a serviço da sociedade contemporânea, propõe uma melhor comunicação entre as coleções e o visitante, atuando como fator de reflexão sobre as identidades coletivas e na construção de uma consciência crítica, assumindo uma releitura da história, das relações, das lutas e da exclusão social. Que o Museu possa colaborar para o engajamento das comunidades na ação, colocando-as em um quadro histórico que permita esclarecer os problemas atuais, associando o passado ao presente, acarretando mudanças em suas realidades.

É importante ressaltarmos o cenário em que tudo isso aconteceu: infelizmente, a presença de Paulo Freire não foi verificada, pois foi cancelada pelo presidente da UNESCO por conta do momento político em que vivíamos - ditadura militar com Paulo Freire exilado. Nesse evento, Paulo Freire faria toda a interlocução dos educadores e museólogos. 
Gostaríamos de registrar que o educador Paulo Freire foi convidado para dirigir a mesa-redonda, mas não "pôde" participar. Freire não "pôde" participar porque o delegado brasileiro junto à Unesco se opôs fortemente à sua designação, "evidentemente por razões políticas", nas palavras de Hugues de Varine. E talvez exatamente pelas razões políticas, tenhamos que reconhecer que nada puderam ou quiseram fazer em seus países os participantes do encontro de

Santiago. Em grande número de países latino-americanos o contexto era de uma ditadura militar, inclusive no Chile, a partir de 1973. Até hoje, as ideias de Paulo Freire têm sido e continuam sendo tomadas para reflexão na área da educação em museus, e não somente no Brasil. (STUDART, 2004, p.42).

Museus são espaços de memória e de poder, alguns surgem apenas com o objetivo de trabalhar a memória do poder, reproduzindo o colonialismo e promovendo saberes eurocêntricos e dominadores. A Nova Museologia assume a função de reconstruir as narrativas de poderes e saberes instituídos, reescrevendo a história construída pela colonialidade, contrariando a manipulação do pensamento. Nesse sentido, é importante compreender a importância dos museus para as comunidades populares como ferramenta de conscientização e cidadania.

O homem pode ser eminentemente inferior. Sua ingerência, senão quando distorcida e acidentalmente, não lhe permite ser apenas um espectador, a quem não fosse lícito interferir sobre a realidade para modificá-la. Herdando a experiência adquirida, criando e recriando, integrando-se às condições de seu contexto, respondendo aos seus desafios objetivando-se a si próprio, discernindo, transcendendo, lança-se o homem num domínio que lhe é exclusivo - o da história e da cultura. (FREIRE, 1967/2020, p.58).

A Nova Museologia aproxima a comunidade escolar das instituições de memórias em prol de uma educação decolonial, contexto cada vez mais desigual da contemporaneidade. É indispensável que o museu assuma uma prática social mais ampla, evidenciando a formação de sujeitos críticos, capazes de construir sua própria narrativa sobre a história. Educar para a vida pensando na sociedade que desejamos formar, problematizando as ideologias dominantes e despertando para valores diversos culminando na inclusão social, bem como, múltiplas equidades.

\section{EDUCAÇÃO LIBERTÁRIA NOS MUSEUS}


A educação é um setor essencial para todo museu. Além das exposições, da preservação, da conservação e da comunicação, é através da ação educativa que os museus exercem um papel de transformação social na sociedade. Um museu precisa compreender o seu contexto social junto a uma consciência crítica e abrangente da realidade em sua volta.

A Nova Museologia propõe uma visão de museu argumentativo que propicia uma reflexão sobre a sua narrativa e que nos possibilita modificar nossa forma de pensar e de agir. Essa nova forma de pensar o museu, foi no início chamada de museu fórum, onde as questões inquietantes nascem das narrativas relacionadas às exposições. Essa visão de museu que participa amplamente das formas culturais, sociais e econômicas foi desdobrada na Mesa-Redonda de Santiago do Chile, realizada em 1972, que teve como base a Nova Museologia como já foi citado acima. Esse documento mostrou a necessidade de os setores educativos fazerem uma mediação com as escolas e com a comunidade, com programas para a dinamização do acervo com a educação. "O museu é uma instituição a serviço da sociedade, da qual é parte integrante e que possui nele mesmo os elementos que lhe permitem participar na formação da consciência das comunidades que ele serve." (Mesa Redonda de Santiago do Chile, ICOM, 1972).

Em 1958, já havia sido realizado um Seminário "A Função Educativa dos Museus", promovida pela UNESCO, no Rio de Janeiro, apontando a crescente importância da educação dentro dos museus. Na década de 50, no Brasil, o ICOM realizou um seminário no Rio de Janeiro debatendo a função educativa dos museus, gerando vários documentos sobre um movimento para a elaboração de um Programa Nacional de Educação Museal. O museu, quando assume esse papel educativo, amplia as suas ações, dinamizando as suas exposições, propondo relações com a comunidade local e com as escolas e rompendo com a visão de um museu como uma caixa monumento, que apenas deixa estática a memória em objetos e legendas, sem se preocupar com as inquietações que são vividas na sociedade.

Os programas de formação museológica devem oferecer oportunidades de formação que visem o preenchimento das necessidades imediatas e das expectativas da comunidade museológica para muni-la de uma programação proativa em vez de uma instrução reativa. (MOUTINHO, 2007, p. 425). 
Uma forma de pensar na Educação Museal é fugir da concepção do museu tradicional, levando em conta as concepções e as relações educacionais e culturais comprometidas com a comunidade. Nesse âmbito, podemos entender o quanto um espaço informal pode estar contribuindo para uma consciência mais crítica da realidade social. O diálogo e as relações que são estabelecidas entre a comunidade e a instituição oportuniza a ampliação dos conceitos relacionados.

É importante ressaltar que os museus sempre foram formados pela elite de ideologia dominante, e o compromisso da Nova Museologia é romper com esse modelo para o exercício da cidadania.

\begin{abstract}
Esta proposta de definição é mais do que um puro exercício gramatical pretende na verdade chamar atenção para toda uma vasta área de preocupações, métodos e objetivos que dão cada vez mais sentido a uma museologia cujos limites não cessam de crescer. A visão restritiva da museologia como técnica de trabalho orientada para as coleções, tem dado lugar a um novo entender e práticas museológicas orientadas para o desenvolvimento da humanidade. (MOUTINHO, 2007, p. 427).
\end{abstract}

Nesse sentido, ela compreende o sujeito como um construtor de conhecimento numa articulação ativa entre o fazer e o pensar. É um processo de conhecer o sujeito e a coletividade. Essa reflexividade busca no sujeito uma ação de respeito e conhecimento sobre si e sobre o outro. Assim, compreendemos que a Nova Museologia consiste na apropriação dialógica, crítica, afetiva e sensível do ser humano.

Quando falamos de Paulo Freire, sabemos que o seu principal intuito é de aprender a aprender e pensar criticamente, demonstrando uma preocupação constante com uma educação que proporcione liberdade de pensamento e autonomia.

Freire não concebe a educação de forma hierarquizada, onde o profissional da educação soubesse mais que o outro, muito mais do que fazer algo para o sujeito, é fazer junto com ele. Sendo assim a proposta freiriana não abre mão de desenvolver no sujeito uma consciência de sua cidadania. Dessa forma, vemos o quanto a Nova Museologia caminha com a proposta freiriana.

Vistos como espaços multiculturais e interdisciplinares, como 
ambientes de contemplação, questionamento, descoberta, ressignificação, mediação, encantamento, entretenimento, confronto e diálogo, os museus possuem grande potencial para oferecer oportunidades educacionais a pessoas de todas as idades, formações, habilidades, grupos sociais e etnias, sendo caracterizado como um espaço de educação não-formal. (FIGURELLI, 2011, p.116).

O museu se torna um espaço não formal de educação, torna-se habitual pensar na educação como um processo intrínseco ao museu, temos a historicidade e um vasto conhecimento que precisam ser compartilhados dentro do museu. Vemos essas possibilidades em ações educativas que os museus podem oferecer, porém ainda encontramos ações com algumas discussões esgotadas e muitos museus ainda não conseguiram articular essa linha tênue nas suas ações educativas, tratando muitas vezes o visitante como um "objeto de exposição" numa ação educativa.

\section{CONSIDERAÇÕES FINAIS}

A elaboração desse artigo, deu-se a partir das visitas nas instituições de memórias na região da baixada santista que, na maioria das vezes, dispõe de programas educativos desenvolvidos pelos setores de educação, mas que não passam de atividades eventuais, de forma que as ações museológicas de conservação das exposições e de pesquisa, têm sido insuficientes no sentido de estar fornecendo um suporte necessário para a construção de conhecimento da sociedade pertencente.

Nesse sentido, advém uma problematização para nosso questionamento: a que ponto os museus compreendem a sua função social na educação de uma sociedade?

As autoras deste artigo são educadoras e assim, a favor da proposta freiriana, não pensamos duas vezes em dialogar com os conceitos de uma Museologia que seja afinada com as propostas do Educador Paulo Freire. Elaboramos nossos objetivos propondo uma reflexão para do quanto Paulo Freire pode estar presente dentro das propostas de uma Educação Museal. Resolvemos iniciar nosso texto por meio de como tudo surgiu e então, percebemos que, desde o surgimento de uma nova proposição das instituições museais, Paulo Freire estava presente com as suas perspectivas educacionais corroborando para uma educação que perpassa os muros 
de dentro dos museus.

A Nova Museologia propõe romper barreiras e dentro de muitos Museus ainda ocupa lugares de pouca importância. É certo pensar numa Educação Museal como um campo de conhecimento, ainda em construção sim, com pouca autonomia, mas considerando as perspectivas contemporâneas, não vemos um modo diferente de os museus estarem delineando ou trilhando seus caminhos educacionais.

Percebemos o quanto as iniciativas da Nova Museologia permanecem esquecidas ou desconhecidas nas instituições Museais. Precisamos começar a quebrar barreiras institucionais e muitas vezes filosóficas, na busca dessa transformação Museal, que foi delineada na mesa redonda em Santiago. Sabemos que os sistemas autoritários, políticos dificultam uma iniciativa que seja mais crítica e comunitária, porém, esse documento, de certa forma, é nossa legitimação.

Paulo Freire, professor e um dos maiores pedagogos de todos os tempos, naquela época, exilado do nosso país, mesmo assim foi convidado pelos organizadores do evento pois sabiam da riqueza de sua contribuição. Não obstante a sua ausência, seus conceitos se fizeram presentes e ficaram sendo a cerne das proposições da Mesa Redonda de Santiago. "Todo educador precisa se engajar social e politicamente, e que seja comprometido com a sociedade."

Dessa forma, concluímos que a inserção das narrativas da Nova Museologia, influenciam na identidade coletiva da comunidade local, garantindo reflexões acerca de significados dos bens culturais, constituindo espaços de debate sobre temas históricos, problematizando a ideologia dominante, favorecendo o respeito à diversidade étnica e cultural, permitindo uma formação integral dos sujeitos, que passam a valer-se das memórias como ferramenta de pertencimento comunitário, ao mesmo tempo que se reconhecem como agentes construtores de sua própria realidade.

\section{REFERENCIAS}

FIGURELLI, Gabriela Ramos. Articulações entre Educação e Museologia e suas Contribuições para o desenvolvimento do ser humano. Revista do Programa de Pós-graduação em Museologia e Patrimônio PPG-PMUS Unirio/MAST- vol. 4. Rio de Janeiro, 2012.

FREIRE. Paulo. Educação como Prática da Liberdade. 46. ed. São Paulo: Editora Paz e Terra, 2020. 
Terra, 1997.

Ação Cultural para a Liberdade. 17. ed. São Paulo: Editora Paz e

INSTITUTO BRASILEIRO DE MUSEUS. Caderno da Política Nacional de

Educação Museal. IBRAM. Brasília, 2018. Disponível em:

https://www.museus.gov.br/wp-content/uploads/2018/06/Caderno-da-

PNEM.pdf. Acesso em: 15 ago. 2021.

. Mesa-Redonda de Santiago do Chile: 1972. IBRAM. Brasília,

2012. Disponível em:

https://www.revistamuseu.com.br/site/br/legislacao/museologia/3-1972-icom-mesa-

redo nda-de-santiago-do-chile.html. Acesso em: 10 ago. 2021.

MOUTINHO, Mário. Museus e sociedade: reflexões sobre a função social do museu. Cadernos de Patrimônio. Ed. Museu Etnológico. Monte Redondo, n. 5, 1989.

. Definição evolutiva de sociomuseologia.13. Atelier Internacional do MINOM. Cadernos de Sociomuseologia, v.28 n.28. Ed. Universitária Lusófona Lisboa, 2007.

. Os museus como instituições prestadoras de serviços. Revista de Humanidades e Tecnologias. Cadernos de Sociomuseologia, n.12. Ed. Universitária Lusófona. Lisboa, 2008.

PRIMO, Judite Santos; MOUTINHO, Mário. Sociomuseologia e Decolonialidade: contexto e deságios para uma releitura do Mundo. Cadernos de Sociomuseologia. Universidade Lusófona. Lisboa, 2021.

STUDART, Denise. Educação em Museus: produto ou processo? - MUSASRevista Brasileira de Museus e Museologia/Instituto do Patrimônio Histórico e Artístico Nacional, Departamento de Museus e Centros Culturais. Vol.1, n.1. Rio de Janeiro, 2004. 


\section{NÊDIA MARIA BORDIGNON DA SILVA HERNANDEZ}

\section{RESUMO}

Este trabalho, cuja prática foi realizada em 2019, fase anterior a pandemia que, hoje, assola o Brasil e o mundo, iniciou-se com a necessidade de realizar uma aula dinâmica e que apresentasse bons resultados. Para isso, na época, procura-se embasamento nas obras de teóricos, tais como: Skinner; Vygotsky; Jean Piaget; e o professor Paulo Freire, Patrono da Educação no Brasil. Realiza-se essa pesquisa bibliográfica com a intenção de encontrar subsídios para a elaboração de uma prática de ensino, para ser aplicada em um grupo de estudantes, entre 14 e 16 anos, moradores das áreas periféricas do Distrito de Vicente de Carvalho - Guarujá - SP. A atividade fez parte de um projeto, no qual os autores trabalham como voluntários, cujo objetivo é de atender aos jovens, considerados pertencentes a grupos de risco, com aulas de reforço e para concursos.

PALAVRAS-CHAVE: Freire; Ensino; Emancipadora; Metodologia; Amor.

\section{INTRODUÇÃO}

Herdando a experiência adquirida, criando e recriando, integrando-se às condições de seu contexto, respondendo a seus desafios, objetivando-se a si próprio, discernindo, transcendendo, lança-se o homem num domínio que Ihe é exclusivo - o da história e o da cultura.

Paulo Freire.

Trata-se neste Artigo, inicialmente, sobre as reflexões do professor Paulo Freire, o Patrono da Educação no Brasil, a respeito de nossa problemática historicidade geradora de alienação e acomodação, face uma possível solução, advinda das práticas de ensino, conforme será discutido no desenvolvimento deste trabalho. Considerando que essa questão somente apresentará bons resultados se norteada por um sistema de educação que priorize a autonomia do sujeito.

Para promover uma discussão fecunda sobre essa temática, os autores decidiram debruçar-se, principalmente, sobre a obra: Educação como prática da Liberdade, escrita por Freire, nos períodos em que o autor esteve preso e exilado.

A obra supracitada nos apresenta uma reflexão bastante fértil a respeito da problemática de uma educação, que clama por democracia, em um país desacostumado com a liberdade e saturado da experiência, traumatizante, da colonização predatória, na qual homens e mulheres eram tidos como objetos, enquanto o colonizador somente almejava explorar ao máximo "as gentes e a terra". 
Analisando o que é revelado por Freire, percebe-se que o contexto predatório, primevo nas relações no Brasil, impossibilitou o surgimento de uma gênesis minimamente inclinada para a verdadeira democracia. Pois, hora os homens e as mulheres, que mais contribuíram para o desenvolvimento da colônia com seu trabalho braçal, percebiam-se escravizados e completamente dominados, noutra hora estavam totalmente dependentes dos "favores" dos grandes senhores e, dessa forma, subjugados pela imposição da vontade dos poderosos. Esses, alicerçados, inicialmente, pelo poder da metrópole e, depois, pelo das classes mais abastadas, conforme denunciado por Paulo Freire.

A concepção de exploração, tanto da terra quanto dos homens e mulheres, somada as grandes distâncias entre as propriedades, obrigava os trabalhadores a procurarem a "proteção" dos grandes senhores da terra, em uma relação comparável a de servidão.

Vertente essa que fez com que surgisse uma espécie de aceitação da dominação, em que o homem brasileiro ainda se via como devedor dos favores dos grandes senhores, sentimento que acabou ficando profundamente arraigado em nosso ethos.

Deixando a problemática da colonização para trás. Na modernidade, marcada pelo momento de transição que era vivenciado no Brasil, configurava-se um período oportuno para se repensar sobre as relações de poder aqui celebradas, ocasião impar para que se tentasse modificar a sociedade brasileira pela implementação de um sistema de ensino que valorizasse a autonomia dos estudantes.

\section{Desenvolvimento}

Para alterar o cenário vivenciado desde o Brasil Colonial, fazia-se necessário que se abandonasse a mentalidade feudal e o comportamento típico de homem vencido, que se experimentou por séculos. Além disso, deveria ser abandonado o mutismo e adentrar em um sistema de ensino em que fosse celebrada a dialogação; a participação; e a responsabilidade política e social. Pois, segundo Freire (2011, p.108), somente encontraremos condições para o surgimento de uma democracia plena quando houver: "Transitividade que não nasce e nem se desenvolve a não ser 
dentro de certas condições em que o homem seja lançado ao debate, ao exame de seus problemas e dos problemas comuns".

Buscando essa concepção é que, na metodologia freiriana, discutida em: Educação como prática da Liberdade percebe-se o seguinte questionamento: como se poderia chegar a uma educação capaz de promover o homem "da transitividade ingênua à crítica", livrando-o assim da massificação? O próprio Freire (2011, pág. 141) soluciona essa questão com a seguinte proposição:

Somente um método ativo, dialogal, participante, poderia fazê-lo. E que é o diálogo? É uma relação horizontal de A com B. Nasce de uma matriz crítica e gera criticidade (Jaspers). Nutre-se do amor, da humildade, da esperança, da fé, da confiança. Por isso, só o diálogo comunica. E quando os dois polos do diálogo e ligam assim, com amor, com esperança, com fé um no outro, se fazem críticos na busca de algo. Instala-se então, uma relação de simpatia entre ambos. Só aí há comunicação.

Com base nessa perspectiva de Freire, seria possível construir uma prática, ou método de ensino, em que se alcance um estado quase mítico de afinidade entre o professor e os alunos, devendo ser ativo, dialogal e participante. Com base na reflexão sobre essas condições, foi possível, aos autores deste Artigo, concluírem que a prática ideal para alcançar todas as condições descritas por Paulo Freire coaduna, perfeitamente, com a dinâmica dos jogos de ensino.

Dessa forma, os autores deste trabalho consideraram oportuno desenvolver com os alunos um jogo de ensino inspirado no programa "passa ou repassa" e outro contemplando a dinâmica conhecida como "passa a bola". Sendo assim, foi elaborada uma atividade, ministrada para os jovens de comunidades carentes residentes nas áreas periféricas do Distrito de Vicente de Carvalho - Guarujá - SP.

\subsection{Validade das brincadeiras e das dinâmicas de ensino}

Para elaborar a atividade de prática de ensino, os autores deste Artigo partiram do pressuposto de que as dinâmicas de ensino e as brincadeiras são extremamente importantes para o desenvolvimento psicomotor e cognitivo das crianças. Considerando que, de acordo com a interpretação que Oliveira (1995. Apud. ROLIM et al., 2008, pág. 179) faz de Vygotsky: 
O desenvolvimento da pessoa está extremamente ligado a sua relação com o ambiente sociocultural e só irá vingar se tiver o contato e o suporte de outros indivíduos de sua espécie. O desenvolvimento fica impedido de ocorrer na falta de situações propícias ao aprendizado. Com isso, é possível entender que o brincar auxilia a criança nesse processo de aprendizagem.

Com base nessa concepção, advinda das teorias de Vygotsky, pode-se compreender, perfeitamente, que ao elaborar atividades em que os alunos poderão aprender brincando, o professor estará proporcionando um momento de descontração, em que os estudantes poderão aprender interagindo com os colegas e com o docente.

Dessa forma, podendo exercitar o diálogo com o outro e ampliar a habilidade de comunicação. Além de possibilitar o desenvolvimento de suas capacidades: cognitiva, motora e intelectual. Nesse sentido, Rolim et al. (2008, pág. 180) afirmam o seguinte:

\begin{abstract}
A relação entre 0 desenvolvimento, o brincar e a mediação são primordiais para a construção de novas aprendizagens. Existe uma estreita vinculação entre as atividades lúdicas e as funções psíquicas superiores, assim pode-se afirmar a sua relevância sociocognitiva para a educação infantil. As atividades lúdicas podem ser o melhor caminho de interação entre os adultos e as crianças e entre as crianças entre si para gerar novas formas de desenvolvimento e de reconstrução de conhecimento.
\end{abstract}

$\mathrm{Na}$ atividade proposta pelos autores deste trabalho, colocou-se em prática uma dinâmica de ensino, procurando confirmar o seguinte: com a possibilidade de interação entre os colegas, utilizando musica em conjunto com uma brincadeira, seria possível desenvolver nos estudantes do ensino fundamental, com idades entre $14 \mathrm{e}$ 16 anos, algumas das competências previstas nas BNCC, tais como: - Conhecimento (1); Pensamento científico, crítico e criativo (2); Repertório cultural (3); Comunicação (4); e Empatia e cooperação (9).

Capacidades e habilidades essas que, de acordo com a percepção subjetiva dos autores deste trabalho, estão diretamente relacionadas com as características necessárias para que o aluno consiga alcançar a própria autonomia, conforme a concepção proposta por Paulo Freire. Considerando-se que realizar dinâmicas de ensino são essenciais para que seja possível mitigar os séculos de atraso, causados pela sistemática da colonização e pelo descaso com os processos de educação. 
Contexto esse que mantém, ainda na atualidade, uma camada substancial da população brasileira sob a égide da alienação e da massificação, conforme pode ser comprovado face ao resultado de uma pesquisa realizada pelo IPSOS, em 37 (trinta e sete) países, sobre o Índice de Percepção Equivocada, na qual o Brasil aparece em $5^{\circ}$ lugar. Atrás da Tailândia ( $\left.1^{\circ}\right)$; do México $\left(2^{\circ}\right)$, da Turquia $\left(3^{\circ}\right)$, e da Malásia $\left(4^{\circ}\right)$.

Fonte: https://www.ipsos.com/pt-br/perigos-da-percepcao-2018

De acordo com essa pesquisa, realizada em 2018, percebe-se que as reflexões realizadas por Freire ainda podem ser consideradas bastante atuais, apesar de escritas há 55 anos. Fator esse que provoca reflexão sobre se, no ensino fundamental brasileiro, estão sendo aplicados os métodos discutidos por Paulo Freire, de acordo com a vasta e densa obra desse autor.

Sendo assim, faz-se necessário propor o seguinte questionamento, com a finalidade de provocar uma reflexão em nossos possíveis leitores: no Brasil, as metodologias de ensino propostas pelo professor Paulo Freire, podem ser aplicadas de forma eficaz? Pretendemos chegar a uma resposta para essa questão, até a conclusão deste trabalho.

\subsection{Uma metodologia baseada no amor}

Debruçando-se sobre uma metodologia de ensino que almeja ter a capacidade de iluminar a psique das crianças, jovens e adolescente, para que adquiram as condições mínimas necessárias para sair da situação de alienação e de massificação, nas quais estão sujeitados os brasileiros desde a colonização, pode-se concluir que para alcançar esse estado de graça, não se pode pensar em uma motivação maior do que a advinda de uma metodologia que se declara baseada no amor ao próximo, reconhecendo, também, a importância da fé em um Deus onipotente, conforme a seguinte assertiva de Paulo Freire (1979, pág. 90. Apud. MARTINS, 2010, pág. 92):

A palavra de Deus me convida, em última análise, a re-criar o mundo, não para dominação de meus irmãos, mas para sua libertação. (...) Isso significa que ouvir a palavra de Deus não é um ato passivo, nem um ato em que somos recipientes vazios a serem preenchidos por essa palavra que não poderia, então, ser salvadora. Essa palavra de Deus, enquanto salvadora, é uma Palavra libertadora que os homens têm que assumir historicamente. Os homens devem transformar-se em sujeitos de sua salvação e libertação. 
Pode-se perceber, nitidamente, que essa é a vertente que flui, abundantemente, da metodologia freiriana. Assinalando a intenção do autor de envolver, nos processos de ensino, a figura do Criador com a emoção mais sublime, que constitui o segundo mandamento instituído pelo próprio Cristo: - Amarás o teu próximo como a ti mesmo (BÍBLIA, Mt 22, 37-30).

Com base nesse caráter, até mesmo messiânico, de que se reveste uma concepção de ensino baseado no amor, acaba-se por perceber a importância da interação com o outro, complementando-se no aprendizado com base na experiência vicária. Dessa forma, a aquisição do conhecimento se faz, também, com base na assimilação decorrida do convívio com o grupo a que o indivíduo pertence.

Pode-se perceber que essa é uma característica marcante e bastante singular nos seres humanos, evidenciada com base na seguinte afirmação de Paulo Freire (2011,59-60): "Portanto, enquanto o animal é essencialmente um ser da acomodação e do ajustamento, o homem o é da integração".

Dessa frase de Freire, é possível perceber que uma atividade, que se pretende de ensino emancipador, deve primar pela integração do estudante com os colegas e com o corpo docente. Com base nessa assertiva, a priori, manifestou-se, nos autores deste Artigo, o desejo, de aplicar os conceitos metodológicos de Paulo Freire em uma dinâmica de ensino, considerando a seguinte assertiva de Souza (2007, pág.112-113. Apud. NICOLA, PANIZ, 2016, pág. 359):

Utilizar recursos didáticos no processo de ensino - aprendizagem é importante para que o aluno assimile o conteúdo trabalhado, desenvolvendo sua criatividade, coordenação motora e habilidade de manusear objetos diversos que poderão ser utilizados pelo professor na aplicação de suas aulas.

Certamente, essa percepção de que com jogos de ensino é possível desenvolver várias habilidades no aluno, levou os autores deste trabalho a acreditar na possibilidade de uma prática na qual, seria essencial que: os professores criassem condições para que os estudantes participassem, de forma coletiva e cooperativa, de atividades em que poderiam exercitar algumas de suas inteligências múltiplas, tais como: a espacial-visual; a verbo-linguística e a corporal-cinestésica.

Sendo assim, também para embasar a disposição dos autores de realizar uma prática, baseada em jogos de ensino, procurou-se apoio em afirmativas tais como a de Castoldi (2006, pág. 985. Apud. NICOLA, PANIZ, 2016, pág. 357): 
(...) com a utilização de recursos didático-pedagógicos, pensa-se em preencher as lacunas que o ensino tradicional geralmente deixa, e com isso, além de expor o conteúdo de uma forma diferenciada, fazer dos alunos participantes do processo de aprendizagem.

Conforme se pode perceber da assertiva acima, ciente das concepções de ensino idealizadas por Paulo Freire, é possível afirmar que, a priori, os jogos pedagógicos são ferramentas de ensino que se encaixam, perfeitamente, na ideologia de uma educação que se propõe emancipadora.

\subsection{Metodologia para uma prática de ensino que se pretende emancipadora}

Conforme já foi falado, este Artigo originou-se da práxis vivenciada no trabalho, voluntário, realizado em um projeto que oferece reforço escolar e para concursos. Esse projeto atendeu a 40 crianças e jovens, com idade entre 14 e 16 anos, moradores da periferia do Distrito de Vicente de Carvalho - Guarujá - SP.

Os procedimentos metodológicos, adotados para tornar possível uma aula envolvendo temas típicos da literatura, vislumbrando a experiência cultural e de vida do grupo que constituiu a classe atendida pelo projeto, foram os seguintes:

1. Realização de uma pesquisa bibliográfica, revisitando alguns dos teóricos da educação, tais como Skinner; Vygotsky; Jean Piaget; e Paulo Freire;

2. Elaboração da dinâmica com base nos conceitos do behaviorismo, na teoria dos estágios de desenvolvimento e no construtivismo; Além disso, procurou-se amparo, principalmente, no Método de Paulo Freire. Foi descartada a Teoria de Desenvolvimento Proximal, por se contrapor aos métodos de Piaget;

3. Procurou-se trabalhar, mais amiúde, com os conceitos disponíveis nos livros de Paulo Freire, a saber: Pedagogia do Oprimido; Pedagogia da Autonomia; e Educação como Prática da Liberdade, por se tratar de obras bastante discutidas nos Cursos de Pedagogia, acompanhando os pedagogos durante e após o (per) curso acadêmico;

4. Após a decisão sobre quais seriam os teóricos utilizados para ilustrar o trabalho, passou-se a construção da atividade em si, sendo adotadas as seguintes linhas de ação-reflexão: Confecção do Plano de Aula; e Criação do handout para ser distribuído aos alunos; 
Após a confecção da documentação, passou-se ao preparo do material que iria ser utilizado, tomando-se os seguintes procedimentos:

a. Confecção de 80 cartões, 40 redondos e 40 quadrados, divididos em 4 series de 10 (redondos), nas cores vermelho, azul, laranja e verde; e 4 séries de 10 (quadrados), nas mesmas cores;

b. Preparação de dois cartazes, um com textos não literários e outro com textos literários. Compostos, respectivamente, das seguintes temáticas: reportagem sobre a astrofísica capixaba, Marcelle Soares-Santos, intitulada: "Brasileira vence um dos maiores prêmios da ciência mundial"; e Poesia: Fanatismo, da poetisa portuguesa Florbela Espanca, apresentada, concomitantemente, com a adaptação musical homônima, composta por Raimundo Fagner;

c. Elaboração de cartões com características e exemplos de textos não literários, literários, denotação e conotação;

d. Produção de 40 cartões com textos motivacionais, a serem entregues aos alunos, juntamente com um bombom.

2.4 Atividade prática: Os jogos de ensino desenvolveram-se da seguinte forma:

2.4.1 Passa a bola - dinâmica na qual os professores reproduzem uma música em um aparelho de som, enquanto uma bola passa de mão em mão, interrompendo-se a brincadeira ao parar a música. O aluno que ficar com a bola deverá responder a uma questão, previamente elaborada. Nessa prática, a temática escolhida foi sobre os conceitos de textos literários e textos não literários.

A atividade desenvolveu-se da seguinte forma:

a. Apresentação dos professores para os alunos;

b. Explicação sobre como funcionaria à primeira dinâmica;

c. Informação de que o grupo vencedor receberia uma caixa de bombons para dividir entre os componentes da equipe;

d. Solicitação aos estudantes para que formassem um semicírculo com as carteiras;

e. Distribuição dos cartões coloridos, quadrados, para os componentes dos grupos;

f. Foram afixados, lado a lado, bem no topo da lousa e na metade direita, os cartazes com os exemplos de textos; 
g. Um dos professores ficou de costas para a turma e iniciou a audição das músicas previamente selecionadas, dando pausa em intervalos aleatórios.

O aluno que ficava com a bola, depois de ler a característica contida no cartão, respondia se era relativa a um texto literário ou não literário, sendo seu cartão colado na lousa, abaixo do cartaz, juntamente com o cartão com a característica.

Após o final da primeira etapa dos jogos, os cartazes e os textos colados pelos alunos, permaneceram na lousa.

2.4.2 Passa ou repassa - atividade elaborada com base em um programa de auditório, do tipo game show, que estreou em 1987 no SBT e continua no ar ainda hoje.

A dinâmica consiste em realizar perguntas previamente elaboradas, sendo retiradas de uma caixa de sapato, ou de um saco, que não seja transparente, para que não ocorra a suspeita de favorecimento de algum grupo e os alunos percebam que a relação entre docentes e discentes deve ser pautada no respeito e na ética, conforme aparece sendo defendida na obra de Paulo Freire (1996, p. 33).

Nessa segunda atividade prática, a temática discutida foi: conotação e denotação, desenvolvendo-se da seguinte forma:

a. Definição, com a realização de um sorteio, sobre a ordem dos grupos, que ficou assim definida: azul 1, vermelho 2, laranja 3 e verde 4;

b. Explicação aos alunos sobre como funcionaria à segunda dinâmica;

c. Solicitação aos estudantes para que liberassem espaço no centro da sala da aula e, depois, formassem 4 (quatro) colunas, uma coluna para cada grupo;

d. Nova distribuição dos cartões (redondos) para os alunos dos grupos;

e. Foram afixados, lado a lado, no topo do lado esquerdo da lousa, cartões grandes com as frases: denotação e conotação;

f. Era retirada da caixa de sapatos, por um dos professores, uma frase, previamente elaborada, que era entregue ao primeiro aluno da fila para que fosse lida e fixada abaixo do cartaz; denotação ou conotação.

Após o final da segunda etapa dos jogos, todos os cartazes e os textos colados pelos alunos, permaneceram na lousa.

Finalizando as duas dinâmicas, os professores deram alguns minutos para que os líderes de cada um dos grupos, eleitos no início da brincadeira pela maioria, 
conversassem com os componentes de sua equipe e, caso julgassem necessário, alterassem alguma resposta.

Depois disso, foi feita uma avaliação com a participação de todos os estudantes, apontando uma por uma das respostas e indagando se estava correta a escolha feita pelo colega.

Concluindo a dinâmica, os professores lançaram as pontuações da segunda atividade, no quadro de pontuação que havia sido, previamente, elaborado na lousa. Ao mesmo tempo em que corrigiam os poucos erros cometidos pelos alunos, explicando sobre porque estavam errados.

Encerrando os jogos de ensino, foi solicitada uma salva de palmas aos grupos, citados individualmente, e entregue por um dos professores, um bombom para cada aluno, juntamente com um cartão contendo uma frase motivacional.

No desenvolvimento dessa prática, foi possível provocar os alunos para que eles saíssem de si mesmos e entrassem no mundo real, o que é importante e necessário para o desenvolvimento de homens e mulheres que possam construir as condições ideais para o surgimento de um sistema verdadeiramente democrático no Brasil. Considerando que, segundo Paulo Freire (2011, pág. 55):

\begin{abstract}
As relações que o homem trava no mundo com o mundo (pessoais, impessoais, corpóreas e incorpóreas) apresentam uma ordem tal de características que as distinguem totalmente dos puros contatos, típicos de outra esfera animal. Entendemos que, para o homem, o mundo é uma realidade objetiva, independente dele, possível de ser conhecida. É fundamental, contudo, partirmos de que o homem, ser de relações e não só de contatos, não apenas está no mundo, mas com o mundo.
\end{abstract}

\title{
3. Conclusão
}

O resultado final da prática realizada com o intuito de inserir a metodologia de Paulo Freire em uma atividade emancipadora, baseada em jogos de ensino, foi bastante satisfatório, pois os estudantes alcançaram altos índices de aproveitamento, com as equipes apoiando-se mutuamente, mesmo não pertencendo ao mesmo grupo. Com isso, entre outras, desenvolveram a competência nove da Nova BNCC - Empatia e Cooperação: exercitar a empatia, o diálogo, a resolução de conflitos e a cooperação.

Além disso, os alunos puderam escolher, entre seus pares, aqueles que melhor os representariam. Sendo que, dessa forma, uma parte dos alunos puderam exercitar a capacidade de liderança dentro dos seus grupos, enquanto a maioria pode 
participar, diretamente, da indicação de quem seria mais capacitado para os liderar nas atividades práticas.

A concepção de ensino defendida por Paulo Freire, e utilizada com muito sucesso na atividade prática descrita neste Artigo, leva a acreditar que com boa vontade e muito "amor" por aquilo que se faz, os professores que se debruçam sobre a obra de Freire, no intuito de elaborar boas práticas de ensino, encontram um material muito fecundo e bastante denso. Bastando, para alcançar êxito, dar asas a imaginação e deixar que os alunos atuem como "senhores de sua própria autonomia" (FREIRE, 1996, p. 07).

\section{Referências}

BíBLIA, A. T. Provérbios. In: BÍBLIA. Sagrada Bíblia Católica: Antigo e Novo Testamentos. Tradução: José Simão. São Paulo: Sociedade Bíblica de Aparecida, 2008.

BRASIL. Ministério da Educação. Secretaria da Educação Básica. Base nacional comum curricular. Brasília, DF, 2016. Disponível em: < http://basenacionalcomum.mec.gov.br/\#/site/inicio>. Acesso em: 13 Abr 2021.

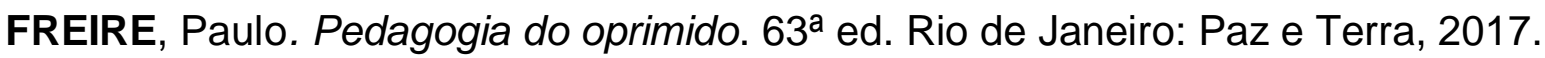
. Pedagogia da Autonomia. São Paulo: Paz e Terra, 1996.

Paz e Terra, 2011.

Educação como Prática da Liberdade. 14. ed. Rio de Janeiro: Editora

MARTINS, Eduardo Simões. Paulo Freire e a Teologia da Libertação: aproximações. Dissertação de mestrado apresentada ao PPGR, da Univ. Mackenzie. Junho 2010. Disponível em: < http://tede.mackenzie.br/jspui/handle/tede/2376 >. Acesso em: 13 Abr 2021.

NICOLA, Jéssica Anese; PANIZ, Catiane Mazocco. A importância da utilização de diferentes recursos didáticos no ensino de biologia. Infor, Inov. Form., Rev. NEaDUnesp, São Paulo, v. 2, n. 1, p.355-381, 2016. Disponível em: < https://ojs.ead.unesp.br/index.php/nead/article/view/infor2120167 >. Acesso em: 13 Abr 2021.

ROLIM, Amanda Alencar Machado; GUERRA, Siena Sales Freitas; TASSIGNY, Mônica Mota. Uma leitura de Vygotsky sobre o brincar na aprendizagem e no desenvolvimento infantil. Rev. Humanidades, Fortaleza, v. 23, n. 2, p. 176-180, jul./dez. 2008. Disponível em: < http://brincarbrincando.pbworks.com/f/brincar\%20_vygotsky.pdf > >. Acesso em: 13 Abr 2021. 
Sites visitados - favor fazer a indicação dos acessos

https://www.ipsos.com/pt-br/perigos-da-percepcao-2018

https://www.hipercultura.com/inteligencia-multipla-conheca-os-varios-tipos-deinteligencia-e-descubra-a-sua/ 


\title{
PEDAGOGIA DE PROJETOS X "EDUCAÇÃO E MUDANÇA" DA CONSCIÊNCIA MÁGICA PARA A CONSCIÊNCIA CRÍTICA.
}

\author{
Cristina Almeida da Silva \\ Mariangela Camba
}

\section{RESUMO}

Pensar no contexto da Pedagogia de Projetos em consonância com as ideias de Paulo Freire mediante perspectiva de mudança no cenário educacional requer uma reflexão acerca da realidade que a escola está inserida, tendo como desafio criar condições para uma aprendizagem que universalize as formas de aprender. É proposto nesse artigo, articular a obra de Paulo Freire - "Educação e Mudança" (1979), e o método da Pedagogia de Projetos baseado no conceito da Escola Ativa de John Dewey (1859-1952), objetivando um redimensionamento do ensino, despindo o educando de uma visão ingênua ou mágicapassiva das tratativas epistemológicas para a construção do conhecimento críticoparticipativo. Faremos um estudo bibliográfico, inicialmente dos descritos introdutórios de Moacir Gadotti da obra de Paulo Freire enaltecendo a docilidade desse grandioso educador, além da postura profissional docente, comprometida com a destituição da visão mágica para a visão crítica do educando, enfatizando o sujeito histórico em movimento no processo do coexistir transitório. Evidenciaremos ideias Freireanas em complementaridade ao método de Dewey mediado pela prática da democratização do ensino focada numa educação progressista. Traremos questionamentos posteriores como - Pode a educação operar mudanças? As tratativas não são conclusivas porque somos seres inacabados, porém, constituídos de propósitos e abertos a "projetos" de mudança objetivando fazer e pensar educação transpondo a realidade social atual.

Palavras-chaves: Pedagogia de Projetos. Educação. Mudança. Professor. Ensino.

\section{INTRODUÇÃO}

Evidenciar uma análise bibliográfica mediada por uma proposta reflexiva da obra de Paulo Freire - Educação e Mudança (1979), associada ao método da Pedagogia de Projetos criada pelo educador e filósofo John Dewey (1859-1952), nos traz à tona questões essenciais sobre o desafio dos sistemas de ensino, bem como a mais tensa realidade vivida no cotidiano escolar: estudantes sendo "envolvidos" por um currículo proposto viabilizado para atender uma pequena parcela de estudantes, tendo que se moldar ao que já está posto, trazendo consequências negativas para a formação do sujeito e sua materialidade histórica, constituindo-o como reprodutor de uma cultura ideológica classista pela qual, nem ele mesmo se apropria em sua totalidade, reduzindo a educação as práticas metodológicas pautadas por uma visão tecnicista.

No percurso dessas discussões se dá continuidade à reflexão de Moacir Gadotti, na obra supracitada que também reverencia no prefácio, a grandiosidade de Freire em escrever um livro com tamanha docilidade sobre o enfrentamento dos desafios e, essencialmente, pelos métodos inovadores de educação, e que em razão 
disso foi preso e exilado (ditadura de 1964), arruinando assim o seu trabalho, já que, foi impedido de dar continuidade aos seus projetos (questões que o moviam no cenário educacional brasileiro).

Gadotti também difundiu a ideia proposta por Freire de que a educação leva ao conhecimento e a conscientização, porém, não é somente isso que pode libertar o ser humano da sociedade classista em que vivemos.

Nesse sentido, constituindo-se de uma roupagem metodológica na arte da verdadeira aprendizagem significativa, dialoga-se conforme a base analítica desse artigo, com a proposta de Dewey, que direciona essa conscientização do ato de ensinar e aprender por meio do método da Pedagogia de Projetos, como forma de valorizar a capacidade de pensar dos alunos e de prepará-los para questionar a realidade, buscando não somente o acesso ao ensino sistematizado, mas pautandose numa pedagogia ativa, propondo assim ao educando a transposição das disciplinas segundo as diretrizes e temáticas direcionadas para a resolução de problemas reais, estruturando uma formação digna de um sujeito histórico, capaz de atuar política e socialmente para a construção de sua própria base histórico-coletiva.

Dentro dessa perspectiva, Freire $^{2}$ nos leva a refletir de que não existe nenhum ato político que não seja educacional, como também não existe nenhum ato educacional que não seja político, mostrando-nos toda a intencionalidade movida pela ação docente, onde o educador precisa estar ciente de que o ato de ensinar não é neutro.

Com isso se faz necessário que o mesmo reveja seu papel e sua forma de estar no mundo mediante suas reflexões e práticas, ao mesmo tempo em que, venha a propor por meio da prática com projetos, uma constante reconstrução da experiência e da liberdade intelectual dos seus alunos (filosofia deweyana) - fortemente estruturada como prática significativa, complementando e fazendo reverências dialéticas importantes na visão do educador Paulo Freire.

Freire salienta que o educador seja um agente de mudança, ao mesmo tempo em que Dewey ${ }^{3}$ evidencia a prática docente nos moldes libertadores da busca pelo aluno em elaborar suas próprias certezas, por meio de conteúdos apresentados pelo professor em forma de problemas, propondo desafios aos educandos na tratativa de soluções para com o meio em que vivem.

\footnotetext{
2 Obra em análise proposta na pesquisa

${ }^{3}$ Fonte: https://novaescola.org.br/conteudo/1711/john-dewey-o-pensador-que-pos-a-pratica-em-foco
} 
As análises do estudo bibliográficas aqui expostas de dois grandes educadores, além de pequenas contribuições de autores como Fernando Hernandéz e Vitor Paro irão nortear caminhos que venham a objetivar o educador a refletir e agir - (práxis) articulando ações por meio da Pedagogia de Projetos, cobertas de intencionalidade político-pedagógica.

Propõem-se, também, no decorrer desse artigo, uma revisão da literatura mediada por um breve relato da aplicabilidade da metodologia da Pedagogia de Projetos, comprovando sua eficácia e complementando as ideias temáticas com a obra de Paulo Freire articulando-as às contribuições de John Dewey, e dessa forma dialogando com as práticas e reflexões de grande como contribuição para a atuação dos educadores nos sistemas de ensino.

\section{REVISÃO DA LITERATURA}

Nas tratativas bibliográficas, foram feitas consultas na BDTD (Biblioteca Digital de Teses e Dissertações) e no Google Acadêmico, sendo estruturada como base de análise uma Dissertação e um Artigo para que possamos refletir as diretrizes do estudo aqui exposto. A primeira temática apresentada - "Currículo da Vida: Contribuições Freireanas para o Ensino da Matemática" defendida no ano de 2019 pela Universidade Federal de São Carlos, por Rogério de Morais, dimensiona uma proposta evidenciada num projeto realizado na EJA (Educação de Jovens e Adultos) com o tema "Leitores de Mundo" estruturado na disciplina de Matemática em consonância com as ideias de Paulo Freire. O pesquisador buscou ressignificar a disciplina, ou seja, conduziu os estudantes a serem construtores mediados por desafios de suas realidades sociais, na resolução de questões matemáticas contextualizadas, orientando os educandos a praticar e, sobretudo, a raciocinar a respeito das questões matemáticas de seus contextos sociais.

O autor do trabalho desempenhou como professor na pesquisa-ação uma autorreflexão, posicionando-se como agente de mudança nesse processo, isto é, além de cogitar a ideia, também integrou-se de suas práticas pedagógicas, e em meio a essas questões do distanciamento de suas estratégias para com os alunos, passou a destituir-se de uma prática repetitiva e reprodutora por meio de exercícios matemáticos mecânicos, a uma desenvoltura pautada nos estudos da realidade e da desestruturação do senso comum ao senso crítico, colocando os alunos para discutir 
a racionalização da dialética, desde a resolução das contas domésticas a questões problematizadoras sociais a que estavam submetidos no universo da Matemática. Diante do estudo aqui exposto, o autor da pesquisa faz um paralelo à obra de Freire "Educação e Mudança” sustentando o compromisso autêntico que o educador deve ter diante do seu papel, bem como, o educando também deve assimilar que "ser humano" (humanizado) é, principalmente, ação, reflexão e ação, dentro dessa dialética, é fulcral orientar crianças e jovens a dominar, a administrar o seu "papel" como agente de mudança (transformação) dentro e fora do contexto escolar. Nesse sentido, o educador-pesquisador defende em sua pesquisa a relevância do docente em esperançar na ação e, acima de tudo, (trans)formar o que está exposto, manifestar essa internalização transformadora que avançou no processo de sua pesquisa para si.

Em segunda análise, o Artigo "A Pedagogia de Projetos e Ideias Freireanas como Contributo na Prática Docente para o processo Ensino-Aprendizagem" das autorias de Zélia Maria Freitas dos Santos; Rilva José Pereira U.C.; Maria José Calado e Maria ljaci G. Correia - (2018) - tem como base a pesquisa participante, onde se afirma que a metodologia da Pedagogia de Projetos vinculada à prática docente, possibilita a construção de sujeitos autônomos e protagonistas no processo de ensino-aprendizagem. Nesse sentido, analisa duas turmas de Ensino Médio, por meio da pesquisa semiestruturada e observação participante, onde evidencia o desinteresse e falta de estímulo da primeira turma onde os conhecimentos são apresentados de forma pronta, colocando-os como sujeitos passivos da aprendizagem.

A segunda turma é direcionada para uma proposta da Pedagogia Ativa baseada no método de John Dewey - onde os estudantes atuam como seres participantes com temáticas desafiadoras escolhidas pela própria turma. Os resultados foram bem mais positivos na formação desses sujeitos, comprovando de forma efetiva a aprendizagem significativa e contextualizada na construção do conhecimento elaborada pelo educando, contribuindo com a formação plena do mesmo. Em consonância com as ideias de Paulo Freire, os autores da pesquisa reforçam que a autonomia do educador só ocorre em sala de aula, quando os mesmos se aproximam efetivamente dos seus estudantes, pautando-se na sintonia e compromisso de todos os envolvidos nesse processo, e entre reflexão e ação mútua, 
passa a constituir tanto o educador quanto o educando por meio da dialética - da visão mágica (ingênua), para a visão crítica (ativa).

O que nos elucida diante dessas duas análises, é que a Pedagogia de Projetos não somente estimula educador e educando a dar mais vida ao ensinar e aprender, mas a desnudar a realidade, estruturando uma conduta participativa no meio social de cada sujeito, tornando-o parte responsável de todo o universo que o rodeia. Nesse processo, dar voz aos estudantes por meio de um diálogo autêntico é colocar em prática uma ação libertadora, oportunizando aos educandos uma visão crítica de que nada do que está posto, pode vir a atender a todos e a escola não é a principal responsável dessa mudança social, mas sim, os agentes ali imersos que podem agir e transformar.

\section{O COMPROMISSO DO PROFISSIONAL E OS REFLEXOS DE UMA SOCIEDADE EM TRANSIÇÃO.}

Num segundo ponto de reflexão ao prefácio da obra de Freire, Gadotti nos impulsiona a reflexões essenciais, onde Freire a constrói movido não somente pela esperança de melhorar a educação, mas sobretudo de evidenciar em suas ideias à missão das instituições escolares em prol de mudanças para com uma sociedade mais humanizada e libertadora, sendo mediada por um processo de conscientização, destituindo a visão ingênua de que a educação seria uma alavanca de transformação social e política para o indivíduo, ao mesmo tempo em que Freire se opõe a ideia de que a educação é apenas válvula reprodutora de uma sociedade.

A obra supracitada, escrita num período de Ditadura Militar, se moldava contra os preceitos de uma sociedade fechada, e que ansiava por mudanças educacionais, havendo a necessidade de luta por uma sociedade mais justa, mais igualitária, ao mesmo tempo em que Freire, exilado fora do Brasil, vivencia experiências que elevam ainda mais o seu entusiasmo e a vontade de lutar pelos oprimidos, onde a educação sem dúvida seria a mola propulsora para essa transição.

Carregando o contexto histórico educacional dos reflexos dessa vivência política de décadas atrás, o panorama educacional brasileiro demonstra consequências alarmantes desse período, tendo nos dias atuais a necessidade de se fazer valer uma estrutura curricular mais humanizadora e libertadora, dentro da concepção do educador Paulo Freire, pois ainda vivemos numa sociedade fechada 
(impessoal e conformista). Portanto, para que se concretize uma prática de educação progressiva e transformadora, dar voz aos estudantes e desafiá-los ao universo da dialética, promulgado na constituição de práticas que (re) signifiquem os currículos para uma pedagogia que problematize e desnude as problemáticas da vida, do meio social, pois a educação na visão deweyana é uma constante reconstrução da experiência. ${ }^{4}$

Dentro dessa ótica, temos clareza da necessidade dos sistemas de ensino de reestruturar o currículo, levando os estudantes a serem produtores de novas culturas, como nos coloca Vitor Paro, pois:

Numa sociedade em que amplas camadas trabalhadoras são relegadas a uma posição de subalternidade em todos os campos sociais, políticos e econômicos parecem mesmo que somente as elites no poder e os grupos a elas associados têm o direito a usufruir aquilo que, no decurso da história, a humanidade criou, com o esforço precisamente dos trabalhadores de todas as gerações (PARO 2007, p. 37-38).

Diante dessa afirmação, é notório que a desigualdade social é sem dúvida, fruto histórico de uma educação focada em minorias e o processo de humanização e recondução de uma educação progressiva criada para todos, carece ser revisto e, assim, assegurar uma nova visão de sociedade mais aberta e justa.

Por conseguinte, Freire em sua essência enfatiza o verdadeiro compromisso do profissional nas relações de ensino e de aprendizagem e que, se não somos seres prontos, somos seres inacabados, portanto, a sociedade também é inacabada e não devemos aceitar como verdade uma ciência única. Nesse sentido, sempre haverá um conflito entre o que está estável e o que está mudando, sendo necessário que o educador se distancie e se perceba nesse mundo em movimento, atuando em conjunto com seus educandos de forma a direcioná-los ao processo de humanização, fazendo com que os mesmos sejam atuantes na geração de novas culturas, passando a se sentir parte responsável nesse processo de transição e mudança.

Diante do exposto, Fernando Hernandéz nos direciona ao fato de que tudo que se ensina por meio de um projeto, parte de um problema inicial e que a escola é uma instituição que se organiza com saberes historicamente acumulados, que devem

\footnotetext{
${ }^{4}$ Fonte: $\underline{\text { https://www.scielo.br/i/rbedu }}$
} 
ser resgatados e reconstruídos nesse processo da postura profissional docente na visão de Paulo Freire.

Com isso, aprende-se a apreender todos os dias e a Metodologia de Projetos pode vir a proporcionar um redimensionamento de novas culturas, pois que, por intermédio do método proposto por Dewey, conforme nos indica Hernandéz, cria-se oportunidades ao educando do desenvolvimento do olhar crítico na busca de soluções às temáticas propostas nesse método, onde a transposição entre as disciplinas se processam pelas informações analisadas, refletidas e transformadas nas práticas do fazer inteligente dos alunos. Dentro dessa perspectiva, uma sociedade em transição deve ser pautada no meio educacional por duas ferramentas essenciais de acordo com Freire, que é o Amor e a Esperança.

O amor nos faz ver o educando na perspectiva docente como seres inconclusos e devemos estar junto com os estudantes nesse processo de desenvolvimento pleno dos mesmos, ao mesmo tempo em que, é preciso ter esperança e acreditar na educação como processo de transformação social, pois nós somos seres de relações, e é por intermédio das relações com o mundo, que vamos nos constituindo e reconstituindo de ações reflexivas no ato de ensinar, de transformar o indivíduo, fortalecendo a consciência de ser e estar no mundo, transformando a si e o meio em que vive, tendo como norte essencial o panorama histórico em que vivemos, isto é, por intervenção dessa referência, possamos nos constituir no sujeito que somos hoje, sempre em transição.

\section{PODE A EDUCAÇÃO OPERAR MUDANÇAS?}

Refletir sobre educação sem se posicionar em sua própria condição é inegável, como nos coloca Freire em sua obra abordada no contexto de análise desse artigo. E qual seria a essência fundamental da condição em que o ser "homem" se encontra para com o processo educacional? O ser que reflete sobre seu lugar no mundo, percebe-se que não é acabado, portanto, constitui-se como um prospecto de cultura antropológica que não se esvai, mas se reconstrói, numa busca entre os seus por meio de consciências coletivas num projeto axiológico pautado na constância.

Dentro dessa ótica, a educação protagoniza-se num papel dessa inter-relação de educador e educando, e nesse processo, se faz necessário propor uma troca de conhecimentos e descobertas entre quem ensina e quem aprende e vice-versa, tendo 
como primordial o entendimento da não domesticação para com os estudantes, e da percepção de que tudo que se aprende, é humanizador e contextualizado nos preceitos da humildade.

Externalizar práticas com o método de projetos em sala de aula, que conduza os educandos ao processo de conscientização na resolução de problemas reais, dando voz às experiências sociais e transpondo os muros da escola para com o universo político social, evidenciando o conceito da democratização do ensino, não forma somente seres crítico-conscientes do seu papel na sociedade, mas seres que venham a refletir sobre a aplicabilidade de ser e estar no mundo, sendo conduzido por ações transformadoras.

Freire destaca o ímpeto criador dentro de nós, que nasce por conta desse processo de inconclusão, citado anteriormente, pois somos seres ontológicos. E a educação vai nos servir como mola propulsora para que se operacionalize mudanças, onde sua essencialidade não pode ser restritiva e sim criativa, sendo esse potencial criador direcionado para estratégias de ensino permeadas por ações significativas. Nesse sentido, a Pedagogia de Projetos vai de encontro ao ser que constrói e se reconstrói, que nos tira da condição mágica de passividade, para o sujeito que desenlaça seu objeto, o manipula, transforma, recria e reformula, criando nova essência do objeto de conhecimento, e não ao contrário. "Formando" cidadãos críticos capazes de reconduzir o contexto histórico de uma sociedade em transição, projetando para dentro de si novas concepções de vida.

\section{CONSIDERAÇÕES FINAIS}

Destacar a problemática de uma sociedade fechada neste momento nos remete a obra de Freire, escrita nos anos de 1970, nos expondo às suas concepções sobre os reflexos de uma sociedade também alienada. A primeira postulada numa mobilidade vertical ascendente, que reproduz condições sociais injustas, e a segunda que descontextualiza e desvaloriza nossa cultura, enfatizando valores de outras culturas, a fim de não só tentar copiá-las, como também punir quem não a alcança, por não atingir aquilo que não lhes pertence.

Vale considerar que não busco aqui nessa pesquisa, "copiar" uma ideia pautada num método de projetos no viés da grandiosidade do filósofo John Dewey, mas de compreender a sua essência, onde nós seres humanos somos levados a 
aprender pela experiência e isso é quase que universal. A intenção é maior e mais instigante que isso.

A intencionalidade aqui refletida, não é só expor a amplitude da obra de um autor humanista e progressista como Paulo Freire, mas também, denunciar toda a plenitude das suas ideias educativas que perpassa e transpõe qualquer método ou prática. Além disso, expande, incorpora e produz vida com mais ênfase às práticas com projetos porque somos seres constituídos de vida em movimento. Portanto, projetar é planejar; e planejar constantemente é se posicionar em cada momento histórico do hoje que vivemos, para poder existir em sua essencialidade na práxis do coexistir mais adiante.

E como que num movimento constante, não há o inerte na busca do entendimento e da transformação da vida. Há sim o sujeito, que se abre para o mundo a cada projeto desenvolvido, a cada ação educativa na dialética constante com seu professor, com a sociedade, com o mundo.

\section{REFERÊNCIAS}

DEWEY, John. O Pensamento Educacional Brasileiro: A Centralidade da Noção de Movimento. Disponível em: https://www.scielo.br/j/rbedu. Acesso em: 28 ago. 2021.

DEWEY, John. Pensadores da Educação. Disponível em: https://novaescola.org.br/conteudo/1711/john-dewey-o-pensador-que-pos-a-pratica-em-foco. Acesso em: 25 ago. 2021. FREIRE, Paulo. In: Educação e Mudança. São Paulo. Paz e Terra, 1979. HERNÁNDEZ, Fernando. Pedagogia de Projetos. Disponível em https://educador.brasilescola.uol.com.br/gestao-educacional/fernando-hernadez.htm. Acesso em: 29 ago. 2021. PARO, V. H. Gestão Escolar, Democracia e Qualidade do Ensino. São Paulo, Ática, 2007. 


\section{BRASIL 2021: TENSIONAMENTOS E DESAFIOS À LUZ DE PAULO FREIRE}

Eliana Nardelli de Camargo

Ana Laura Ribeiro da Silva

\section{RESUMO}

A investigação que ora se apresenta, insere-se na área temática referente à atualidade do pensamento de Paulo Freire. Para tanto, selecionou-se sua primeira obra, e por meio de pesquisas qualitativa, exploratória, básica e essencialmente bibliográfica, selecionaram-se os conceitos que foram organizados de modo a facilitar a interpretação das vivências dos brasileiros nos três últimos anos. Essas vivências foram extraídas de artigos de estudiosos do cotidiano da Educação no país. O resultado a que se chegou surpreende pela atualidade das reflexões de Paulo Freire e da advertência de que contra a intolerância flagrante na sectarização da sociedade brasileira, somente o debate crítico deve ser empregado, para que essa não se agrave.

Palavras-chave: Paulo Freire. Sociedade sectarizada. Intolerância ideológica.

\section{Introdução}

No momento em que esse estudo se desenvolve, o Brasil enfrenta um sectarismo radical provocado em grande medida pela intransigência. É possível afirmar mesmo que essa inflexibilidade se origina de uma formação acrítica e antidialógica que por muitos anos frequentou os bancos escolares.

A primeira Lei de Diretrizes e Bases da Educação Nacional - LDBEN - 4.024/61 (BRASIL, e sua sucedânea 5692/71, em vigor até a publicação da atual Lei 9394/96 (ARNONI, 2004), não previam a participação da comunidade escolar na elaboração de um projeto político pedagógico apropriado para cada realidade. Fortemente influenciada pela administração científica de Taylor (SILVA, 2004, p. 23) a educação tecnicista ministrada durante esse longo período, mesmo após a vigência da atual LDBEN - 9394/96 impregnou-se de tal modo nas escolas que acabou por gerar um considerável contingente de cidadãos politicamente ignorantes (BURKE, 2020), tamanho o silêncio que lhes foi imposto durante sua escolaridade.

Em Freire (1967) é possível resgatar esse histórico, no entanto, mais que isso, é intrigante a atualidade de suas considerações, tema sobre o qual versa esta investigação. Nesse sentido prospera esta reflexão com dois objetivos: resgatar as últimas contingências relacionadas ao Brasil registradas em periódicos e lançar mão 
do pensamento dialógico e dialético freireano para buscar uma possibilidade de entendimento da construção dessa esdrúxula realidade.

\section{Revisão bibliográfica}

Educação como prática de liberdade, publicada em 1967, foi a obra escolhida para simbolizar a grandiosa reflexão de Paulo Freire, nesse estudo. A razão dessa seleção situa-se não somente no fato de ser a primeira, mas também no de que inclui as dimensões política e social da educação, como toda a sua literatura.

Trazer a ideia de liberdade como prática, como exercício, supõe que esta não seja um hábito, mas uma prática ocasionada pela educação

Utopicamente,

uma educação como prática da liberdade só poderá se realizar plenamente numa sociedade onde existem as condições econômicas, sociais e políticas de uma existência em liberdade [...] Não basta que o povo imerso em seu silêncio secular emerja dando voz a suas reinvindicações. Ainda deve tornar-se capaz de elaborar de maneira crítica e prospectiva a sua conscientização de maneira a ultrapassar um comportamento de rebelião para uma integração responsável e ativa numa democracia. (FURTER, apud FREIRE 1967, p. iii)

Para Freire (1967), a liberdade se traduz na concretude de uma luta permanente de homens e mulheres na construção de sua história e da História. Seu pensamento proporciona tanto uma imersão em princípios ou conceitos quanto em juízos ou apreciações.

Insistimos, em todo o corpo de nosso estudo, na integração e não na acomodação, como atividade da órbita puramente humana. A integração resulta da capacidade de ajustar-se à realidade acrescida da de transformá-la a que se junta a de optar, cuja nota fundamental é a criticidade. Na medida em que o homem perde a capacidade de implicar em que, tanto a visão de si mesmo, como a do mundo, não pode absolutizar-se, fazendo-o sentir-se um ser desgarrado e suspenso ou levando-o a julgar o seu mundo algo sobre que apenas se acha. (FREIRE, 1967, p. 52)

Outro mérito desse registro de Paulo Freire (1967) consiste em favorecer a

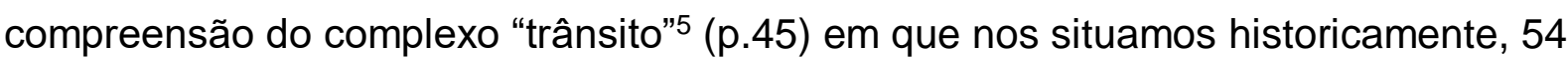
anos após a publicação do livro.

\footnotetext{
5 "Nutrindo-se de mudanças, o tempo de trânsito é mais do que simples mudança. Ele implica realmente nesta marcha acelerada que faz a sociedade à procura de novos temas e de novas tarefas".(FREIRE, 1967, p.46)
} 
De acordo com Dourado (2019), não foram poucos os movimentos e as lutas que propiciaram formação social do Brasil. Os embates envolveram movimentos sociais que provocaram ora rupturas, ora continuidades, ora renovações e provocações por forças externas.

\begin{abstract}
A temática democracia, Estado e educação é muito instigante e faz parte da agenda brasileira, sobretudo das políticas e gestão da educação. Essa tríade tem sido objeto de lutas e movimentos diversos. Se partirmos da premissa que vivemos em um cenário de mudanças que impactam a vida social, as políticas públicas e, nesse contexto, a educação, a partir de proposições, tensionamentos e desafios em escala global, nacional, local e institucional, essa discussão ganha em escala, sobretudo num contexto de grandes retrocessos e, paradoxalmente, de resistências. (DOURADO, 2019, online)
\end{abstract}

No entanto, interessa a essa confrontação, apenas o que tangencia a atualidade. Assim sendo, retoma-se, no tocante à Educação, a aprovação do PNE Plano Nacional de Educação - com vigência de 2014 a 2024, pelo Congresso Nacional sem vetos pela presidente Dilma Rousseff (Lei $n^{0}$ 13.005/2014) em cumprimento ao disposto no Art. 214 da Constituição Federal de 1988.

\begin{abstract}
A materialização das metas e estratégias do PNE15 ganhou, nesse contexto, algum aceno em 2015 e primeiro semestre de 2016, com ações e políticas direcionadas ao cumprimento do plano, tais como a aprovação pelo Conselho Nacional de Educação e homologação pelo Ministério da Educação (MEC): das diretrizes curriculares nacionais para a formação dos profissionais do magistério da educação básica, por meio da Resolução CNE/CP no 2/2015 (BRASIL, 2015); das diretrizes curriculares nacionais para a formação dos funcionários da educação básica, por meio da Resolução CNE/CES no 2/2016 (BRASIL, 2016a); aprovação pelo MEC do Decreto № 8752/2016 (BRASIL, 2016b), que dispôs sobre a Política Nacional de Formação dos Profissionais da Educação Básica, em consonância com o disposto na meta 15 do PNE e de outras medidas e políticas direcionadas à materialização do PNE.(DOURADO, 2019, on-line)
\end{abstract}

Tensões importantes entre o Congresso e o Governo Federal relativas a políticas de ajuste fiscal conservadoras culminaram no impeachment da presidente Dilma e na ascensão de Michel Temer ao poder, em 2016. Mais uma vez, os poderes Executivo e Legislativo, com o apoio dos setores dominantes, por meio de emendas à Constituição Federal, retomam a construção de um projeto de sociedade excludente que refletiu o processo da formação social brasileira e sua democratização. 
A classe trabalhadora é vitimada pela opção da política econômica conservadora que afrontou o enorme empenho para a edificação da democracia no Brasil. Um programa denominado “Uma Ponte para o Futuro”, proposto pela Fundação Ulysses Guimarães, apresentava diretrizes para as reformas fiscal e da previdência, além da vinculação constitucional, de recursos para a área social (educação e saúde), por meio de emendas, já prevendo as dificuldades para sua implantação.

Especialmente em relação à Educação,

a aprovação da Emenda Constitucional no 95/2016, que, ao alterar o Ato das Disposições Constitucionais Transitórias, institui o Novo Regime Fiscal e dá outras providências. Essa emenda, que vigorará por vinte exercícios financeiros, fixa limites individualizados para as despesas primárias dos órgãos integrantes daqueles orçamentos e estabelece, nos termos do $\S 1^{\circ}$ do art. 107, o método para sua determinação. $\mathrm{Na}$ prática, significa o congelamento das despesas primárias, acarretando grande impacto para as políticas sociais e, neste contexto, para a educação e o cumprimento do PNE. [...] a reforma do ensino médio (aprovada pela Lei ํㅜ 13.415/2017) e a aprovação da Base Nacional Comum Curricular, a partir de dicotomia da educação básica, apresentam-se como importantes retrocessos na agenda educacional, inclusive na materialização do PNE. (DOURADO, 2019, on-line)

A situação agrava-se com a eleição do presidente Bolsonaro, sob cuja gestão ultraconservadora abriga novos ajustes neoliberais e cortes nos orçamentos de instituições públicas de educação básica e federais de educação superior. Divulga intolerância à diversidade de ideias e pensamentos, desqualificando o marxismo; depreciando Paulo Freire, exaltando educação a distância na educação básica, difundindo a escola sem partido e criando o Programa Nacional das Escolas Cívico Militares, por exemplo.

Nas Escolas Cívico Militares a meritocracia aparece vinculada a disciplina. Em pesquisa realizada por Ratier (2020), que analisa o manual das Escolas Cívico Militares, a palavra mais recorrente é disciplina que aparece 127 vezes, seguida de uniforme (115), respeito (81), transferência compulsória (17) civismo (13), cabelo (12), bandeira (11), democracia (1), gênero, no caso alimentício (1), racismo (2), desigualdade, mas não social (3). As Escolas buscam criar um sistema de submissão e concorrência entre os alunos pela distribuição e retirada de pontos de acordo com o comportamento apresentado, podendo chegar à transferência compulsória (expulsão) dos alunos que não apresentem o comportamento e o aspecto físico considerados adequados. Aqui a disciplinarização dos corpos dos alunos (talvez por isso a obsessão com uniforme e cabelo) é dada como critério para o sucesso individual e passa pela anulação das identidades dos jovens e grupos de jovens das periferias. Chama a atenção que o projeto das 
escolas cívico militares esteja voltado para a militarização de escolas públicas e nunca das privadas. Partindo, como nos aponta Arroio (2019), da premissa de que jovens de periferia são violentos e que essa violência tem que ser detida pela disciplina militar. Nesse modelo educar significa treinar, disciplinar, evitar o contraditório e o questionamento como quesito para o enquadramento na vida social de forma passiva. (LOBO, 2020, p. 24)

O eixo centralizador de toda ação dos jovens é a meritocracia e o estímulo à concorrência individual. A solidariedade é banida, entendendo-se a escola como uma empresa, quer em relação à gestão, quer em relação aos conteúdos os quais devem abranger o comportamento empresarial/competitivo que naturaliza as diferenças, pouco interessando o processo de ensino/aprendizagem. Todo esforço deve ser desenvolvido em favor do empreendedorismo, ocultando-se as diferenças sociais que facilitam o sucesso das classes abastadas, diminuindo sensivelmente as oportunidades para o jovem trabalhador. Sexismo e racismo são formas de naturalização das diferenças.

Uma vez que se ignoram as diferenças sociais dos diversos sujeitos do processo educativo e se responsabiliza o indivíduo pelo sucesso ou fracasso de seu percurso, [...] qualquer escola cujo projeto político pedagógico esteja focado em uma educação inclusiva, que tenha como fundamento a pesquisa como elemento da formação intelectual dos educandos, que trabalhe a cooperação, a solidariedade e autonomia no processo educativo e, a aprendizagem como algo coletivo e não individual, estarão fadadas ao fracasso do ponto de vista do sistema estabelecido. (LOBO, 2020, p. 26, 27)

A BNCC - Base Nacional Comum Curricular - propõe que $60 \%$ do conteúdo ministrado nas escolas provenha da Base, e os $40 \%$ restantes, da cultura local, entretanto, como as escolas concorrem entre si por meio de avaliações institucionais como o PISA - Programa Internacional de Avaliação de Alunos; ENEM - Exame Nacional do Ensino Médio; ENADE - Exame Nacional de Desempenho de Estudantes; ANRESC - Avaliação Nacional do Rendimento Escolar (conhecida como Prova Brasil) etc., provavelmente, os $40 \%$ destinados à cultura local serão substituídos por conteúdos da BNCC.

A BNCC, por meio de itinerários formativos, dificulta o acesso a disciplinas que não matemática e português. Instituições públicas e particulares deverão oferecer um itinerário para uma formação profissional. O Brasil já experimentou um sistema similar, por ocasião da vigência da LDBEN 5692/71 que acabou por desqualificar o Ensino Médio. Ademais, as diferenças entre as escolas que atendem as classes 
trabalhadoras e as que atendem classes abastadas, novamente se acentuam, já que é previsível que as últimas não se afastarão das disciplinas de formação geral, o que dificilmente ocorrerá com estudantes das primeiras.

A proposta torna clara a intenção de aprofundar do ponto de vista político, ideológico e do imaginário dos jovens a concepção de que o empreendedorismo será a solução mágica e individual para todos os problemas enfrentados pela classe trabalhadora pobre do país que não será mais 'trabalhadora', mas, 'empreendedora'. Busca assim esvaziar a identidade de classe dos jovens estudantes. (LOBO, 2020, p. 28)

De acordo com Dourado (2019), a retomada da crescente conquista de direitos sociais, por meio de políticas de Estado, requer uma quebra dos movimentos sociopolíticos brasileiros que transcendam uma aparente modernização, conservadora e excludente, "visando à constituição de uma formação social brasileira democrática, com o fortalecimento e engajamento da sociedade civil na defesa da democracia como valor essencial e universal."(On-line)

Para Freire (1967) essa grande luta implica em superar os intervenientes que fazem do homem um ser acomodado ou ajustado. Trata-se da conquista de sua humanização que se vê permanentemente acuada pela opressão que por vezes revela-se disfarçada de luta por sua própria libertação. O homem brasileiro precisa desenraizar-se, incorrendo em crescente interferência nas escolas de seus filhos; em seus sindicatos; em seus locais de trabalho; em seu bairro; em sua igreja; em sua comunidade; em clubes; associações; conselhos...Enfim, aprender a democracia, vivendo a democracia.

Daí a necessidade de uma educação corajosa, que enfrentasse a discussão com o homem comum, de seu direito àquela participação. De uma educação que levasse o homem a uma nova postura diante dos problemas de seu tempo e de seu espaço. A da intimidade com eles. A da pesquisa ao invés da mera, perigosa e enfadonha repetição de trechos e de afirmações desconectadas das suas condições mesmas de vida. A educação do 'eu me maravilho' e não apenas do 'eu fabrico'. A da vitalidade ao invés daquela que insiste na transmissão do que Whitehead chama de inert ideas - 'Ideias inertes, quer dizer, ideias que a mente se limita a receber sem que as utilize, verifique ou as transforme em novas combinações. (FREIRE, 1967, p. 93)

O autor afirma não haver educação em sociedades não humanas nem homem no vazio, particularizando a sociedade brasileira, com seus atritos, seus conflitos, e contradições, em meio a um período "que se esvaziava, com seus valores, com suas 
peculiares formas de ser, e que 'pretendia' preservar-se e um outro que estava por vir, buscando configurar-se." (FREIRE, 1967, p.35) Vale dizer que ao imergir-se no conservadorismo ou projetar-se para o futuro, o homem já realiza uma opção: da permanência na subordinação a uma elite alienada, desconhecedora de seu mundo e que o coisifica, ou da aventura do futuro em "nova sociedade, que, sendo sujeito de si mesma, tenha no homem e no povo sujeitos de sua História." Ao se educarem as massas, deve-se, então, decidir "entre uma 'educação' para a 'domesticação', para a alienação, e uma educação para a liberdade. 'Educação' para o homem-objeto ou educação para o homem-sujeito." (Ibid.)

Freire (1967) afirma que o crescimento da renda nacional e a democracia não são suficientes para modificar as condições sociais dos trabalhadores. A riqueza está estreitamente relacionada aos valores políticos e ao estilo de vida da classe dominante. Quanto mais pobre a classe oprimida, tanto mais desprezada será pela dominante, no entanto, se emergem e descobrem o que pensam dela seus opressores, tendem a reagir com extremada violência. Em resposta, recebem ou violência na mesma medida ou recompensas falsamente generosas.

No caso do Brasil, seria determinante sustentar a democracia sobre um grande desenvolvimento econômico que amainasse o poder dos muito ricos sobre os muito pobres, com um projeto apropriado para a sua nação que previsse uma mudança nas mentalidades. No entanto, quanto maior a manifestação popular por direitos, tanto menor a disposição dos poderosos para abrir mão de seus privilégios, nem sempre lícitos. "E grande parte do povo, emergente, mas desorganizado, ingênuo e despreparado, com fortes índices de analfabetismo e semi-analfabetismo (sic), passa a joguete dos irracionalismos." (FREIRE, 1967, p. 87, 88)

A falta desta permeabilidade parece vir sendo dos mais sérios descompassos dos regimes democráticos atuais, pela ausência, dela decorrente, de correspondência entre o sentido da mudança, característico não só da democracia, mas da civilização tecnológica e uma certa rigidez mental do homem que, massificando-se, deixa de assumir postura conscientemente crítica diante da vida. Excluído da órbita das decisões, cada vez mais adstritas a pequenas minorias, é comandado pelos meios de publicidade, a tal ponto que, em nada confia ou acredita, se não ouviu no rádio ${ }^{6}$, na televisão ou se não leu nos jornais. Daí a sua identificação com formas míticas de explicação do seu mundo. Seu comportamento é o do homem que perde

\footnotetext{
${ }^{6}$ Grifo das autoras.
} 
dolorosamente o seu endereço. É o homem desenraizado. (Id., p.90, 91)

De acordo com Freire (1967), esta sociedade partiu-se em decorrência do choque entre os impulsos que a mantinham equilibrada. As alterações econômicas que se originaram ainda no século XIX foram as sementes dessa fenda. Se ainda não éramos uma sociedade aberta, éramos uma sociedade permanentemente em trânsito que passou a recuar, correndo riscos "de um retorno catastrófico ao fechamento" ( $p$. 48) por meio de novo golpe.

\section{Metodologia}

Quanto à abordagem, conforme se constata, trata-se de uma pesquisa qualitativa, pela subjetividade presente na livre escolha do tema; quanto à natureza, poderia ser considerada básica, face à atualidade de sua abordagem.

Em relação aos objetivos, essa investigação caracteriza-se como exploratória, na medida em que oferece possibilidades de continuidade; descritiva, pois concentrase em um período delimitado e explicativa, pois esclarece ocorrências atualíssimas, à luz das reflexões de Paulo Freire. Quanto aos procedimentos, é exclusivamente bibliográfica, posto que foi efetuada a partir de material já publicado.

\section{Discussão dos resultados}

Ao se buscar em Freire (1967) uma exegese do complexo momento que a sociedade brasileira enfrenta, encontra-se o fundamento dialético de toda a História. Sua narrativa mostra-se totalmente procedente e integralizada, apesar de concentrarse em uma única obra. A atualidade de suas considerações só surpreende o leitor por encontrarem-se os verbos no pretérito.

Dourado (2019) e Lobo (2020) contextualizam o cenário político, social e econômico, retratando privilegiadamente aspectos referentes à Educação. São apresentados documentos legais esparsos que ilustram as tomadas de decisão dos dois últimos governos do Estado brasileiro. A letra da lei não é suficiente para promover a unidade das ações representativas de uma política educacional que considere a promoção humana.

Quando se apensa o que afirmam os dois pesquisadores desta realidade às reflexões de Paulo Freire, tem-se a impressão de que o filósofo está assistindo aos 
jornais diários ou tomou conhecimento dos registros aqui explorados. No entanto, esses atores estão separados por pouco mais de meio século.

O que torna instigante o resultado dessa pesquisa é o fato de trabalhadores e parcela considerável da sociedade apoiarem incondicionalmente o poder executivo, sem se dar conta de que esse apoio só se deve à sua "exclusão da órbita das decisões, cada vez mais adstritas a pequenas minorias" (FREIRE, 1967, p. 90, 91), da qual seu ídolo, denominado, popularmente, Mito, faz parte.

O que se pode depreender dessa situação é que houve grande privação dos excluídos, de uma escola tal qual Freire idealizou. A impossibilidade de compartilhar ideias, dialogar, ouvir, ser ouvido, conviver com a diferença em ambiente de respeito e inclusão, a necessidade de competir acirradamente com colegas por prêmios ou notas melhores, ter causado ou sofrido bulling podem ter favorecido a adoção de um líder messiânico que fosse o reflexo do descontentamento, de seus seguidores.

É provável que os apoiadores do governo Bolsonaro tenham permanecido calados, habituados que estavam com o tipo de disciplina implantado desde nossa colonização. O mutismo do homem oscilava entre o senhor das terras (patrão) e o governador (capitão-mor), mediado pela ausência de vida comunitária em que se resolviam problemas comuns..

"Não será exagero falar-se de um centro de gravitação de nossa vida privada e pública, situado no poder externo, na autoridade externa dominadora; a criação de uma consciência hospedeira da opressão e não uma consciência livre e criadora, indispensável aos regimes autenticamente democráticos. (FREIRE, 1967, p. 71)

\section{Considerações finais}

É bem verdade que a dinamicidade da realidade ainda não apresentou o desfecho dessa difícil fase da História da Educação no Brasil, entretanto, acompanhála pari passu, buscando novos instrumentos de interpretação enriquecem o momento e reanimam a chama da tolerância e do respeito em relação ao diferente, em uma sociedade sectarizada.

Com essa mesma intenção, Dourado encontra em Apple (2003) uma análise do movimento conservador de direita na educação que

\footnotetext{
"é singular ao descortinar seus objetivos e pode auxiliar na compreensão desse movimento em curso no país. Segundo o autor:
} 
'Um dos objetos mais importantes da atuação direitista é mudar nosso senso comum, alterando o significado das categorias mais básicas, as palavras-chave que empregamos para compreender o mundo social e educacional e o nosso lugar nele. De muitas formas, um aspecto crucial dessa atuação diz respeito ao que tem sido chamado política de identidade. A tarefa é alterar radicalmente aquilo que pensamos ser e como nossas principais instituições devem responder a essa alteração de identidade' “. (APPLE, 2003, p.11 apud DOURADO, 2019, on-line)

Tanto em Dourado quanto em Apple, encontramos a necessidade de descaracterizar-se enquanto educador para estabelecer alguma empatia com os que adotam os pressupostos que regem a pregação de tamanha desigualdade. É difícil a convivência com a submissão à força física ou moral, e, pior que isso, compreender que há quem apoie seus defensores. Mas assim mesmo, é preciso que se tome conhecimento dos diversos pontos de vista a respeito da educação, distinguindo suas marcas diferenciais nos diversos discursos à disposição nos inúmeros meios de comunicação que inundam a sociedade.

Como bem observou, Weffort (1967) a respeito da obra de Freire,

Se é verdade que com a crise da ordem tradicional a consciência popular alcança transitivar-se, isto de modo algum quer significar, segundo o autor deste livro, que possa alcançar de imediato, sem trabalho e esforço, o estado de transitividade crítica. E a consciência transitiva ingênua, esta condição de disponibilidade sem objetivos autônomos claros, é, em verdade, a matéria prima da manipulação elitária.

Nesse sentido, é preciso estar alerta para a escolha dos novos vocábulos que participam da realidade de jovens e crianças em uma sociedade em que não somente suportes dos textos alteraram-se, mas principalmente, muitos de seus conteúdos foram proposital e equivocadamente reduzidos.

A obra estudada detalha o difundido método Paulo Freire empregado em Angicos para alfabetizar 300 trabalhadores em 40 dias. Trata-se do método silábico que toma como palavras geradoras, aquelas que interessam aos alfabetizandos. Embora nesse momento não se tenha debruçado sobre essa experiência, há que se notar que a respeito de Paulo Freire sempre haverá com o que se surpreender, o que sinaliza o início de novas pesquisas.

\section{Referências}


ARNONI, Maria. Programa de Legislação Educacional Integrada: dinâmica e tendências (ProLei Histórico, 1961-1996). Rev. Bras. Estud. Pedagog., Brasília, DF, Brasil, v. 85 n. 209-10-11, 2004.

BRASIL. Lei no 4.024, de 20 de dezembro de 1961. Fixa as Diretrizes e Bases da Educação Nacional. Brasília, 20 de dezembro de 1961. Disponível em: http://www.planalto.gov.br/ccivil 03/leis/14024.htm . Acesso em 07 set. 2021.

BRASIL. Lei no 5.692, LEI No 5.692, de 11 de agosto de 1971 Fixa Diretrizes e Bases para o ensino de $1^{\circ}$ e $2^{\circ}$ graus, e dá outras providências. Brasília, 12 de agosto de 1971, retificada em 18 de agosto de 1971. Disponível em: http://www.planalto.gov.br/ccivil 03/leis/15692.htm . Acesso em 07 set. 2021.

BRASIL. Lei no 9.394, de 20 de dezembro de 1996. Estabelece as diretrizes e bases da educação nacional. Disponível em:

http://www.planalto.gov.br/ccivil 03/leis/19394.htm . Acesso em 07 set. 2021.

BURKE, Peter. A ignorância na política: e a política da ignorância. Piauí. Tribuna da história ed. 168, set. 2020. Disponível em: www.revistapiaui.com.br . Acesso em 07 set. 2021.

DOURADO, Luiz Fernandes. Estado, educação e democracia no Brasil: retrocessos e resistências. Educ. Soc. 2019, v. 40. Disponível em:

https://www.scielo.br/j/es/a/vsCq3LjxSXYrmZDgFWwk7tG/?lang=pt\# . Acesso em: 06 set. 2021.

FREIRE, Paulo. Educação como prática de liberdade. Rio de Janeiro: Paz e Terra, 1967.

FURTER, Pierre. Paulo Freire ou o poder da palavra. In: Educação como prática de liberdade. Rio de Janeiro: Paz e Terra, 1967.

LOBO, Sônia A. Políticas para educação sob o Governo Bolsonaro e seus impactos sobre a formação de .professores. JORNAL DO SINTEF GO, 4 ed. p. 24, 23 out. 2020. Disponível em: https://sintef.org.br/wp/2020/10/23/4a-edicao-do-jornal-do-sintef-go/ . Acesso em 07 set. 2021.

SILVA, Tomaz Tadeu. Documentos de identidade: uma introdução às teorias do currículo. 2ed. Belo Horizonte: Autêntica, 2004.

WEFFORT, Francisco C. Educação e Política: reflexões sociológicas sobre uma pedagogia da liberdade. FREIRE, Paulo. Educação como prática de liberdade. Rio de Janeiro: Paz e Terra, 1967. 


\title{
A EDUCAÇÃO DE JOVENS E ADULTOS NA BAIXADA SANTISTA E A REALIDADE NA PANDEMIA - O DIÁLOGO COM OS DOCENTES
}

\author{
Maria da Graça Pimentel Carril \\ Michel da Costa \\ Elisete Gomes Natário
}

\section{RESUMO}

A história da educação brasileira apresenta experiências em relação a oferta de educação para a população que teve seus direitos educacionais negados - jovens e adultos. Na atualidade a Constituição Federal de 1988 e a Lei de Diretrizes e Base da Educação Nacional - L.D.B.9394/96 legitimaram o acesso à educação para jovens e adultos em um espaço que se redemocratizava. As redes de ensino na Baixada Santista em consonância com o que determina a L.D.B 9394/96 oferece o Ensino Fundamental na modalidade EJA. No ano de 2020, o cotidiano dessas escolas foi modificado em função do surgimento do vírus SARS-COV2. Diante das alterações nos diferentes espaços escolares, as pesquisadoras realizaram este estudo empírico referente ao público da EJA. Apresenta como objetivo investigar como se comportou a demanda do Ensino Fundamental na modalidade EJA na Baixada Santista, durante o período da pandemia da Covid 19 na percepção dos docentes a fim de conhecer como as práticas de aprendizagem se desenvolveram e seus resultados para o público da EJA. Os participantes estabeleceram um diálogo com as pesquisadoras e explanaram sua realidade como educadores da EJA. Os resultados dos diálogos foram analisados a luz dos estudos de Paulo Freire, Di Pierro, Possani, Gadotti e a legislação oficial. Espera-se que os resultados possam contribuir para a reflexão e para a aprendizagem do aluno da EJA.

Palavras-chave: Ensino Remoto, Educação de Jovens e Adultos, Paulo Freire, Aprendizagem, Ambiente Digital.

\section{INTRODUÇÃO}

A relevância para as educadoras sobre a oferta de educação para jovens e adultos ocorreu, em especial, a partir dos estudos de Carril (2006) sobre a demanda do Ensino Médio na cidade de Santos no período de 1995 a 2004 - evidenciando-se a ampliação de oferta de vagas nas escolas que ofereciam a modalidade Educação de Jovens e Adultos, o que ocorreu em função da legislação vigente (BRASIL,1996). 
Na época já havia uma demanda que buscava a conclusão de sua escolaridade pela via da Educação de Jovens e Adultos, tanto na modalidade Ensino Fundamental como Ensino Médio.

O interesse em saber como se encontra a implementação das políticas públicas para este público mobilizou as pesquisadoras a apresentarem algumas reflexões construídas em discussões acadêmicas, pois sempre houve preocupação com a educação básica, considerando que atuam em cursos de Licenciaturas, tanto na modalidade presencial como na educação a distância - EaD.

Em nossas práticas docentes entendemos como essencial o aprimoramento do direito a uma educação de qualidade que permita ao estudante a percepção da importância pela busca constante por novos saberes, assim como thes possibilitem fazer as suas escolhas em diferentes aspectos: profissional, pessoal, social e cultural, contribuindo assim para um novo formato de sociedade e para tal o processo educacional precisa considerar em suas práticas pedagógicas temas como os direitos humanos, a inclusão, a valorização da vida, da ciência e de melhores relações entre todos, assim como estejam associadas as questões humanitárias, presentes em cada um dos cidadãos.

Nossas discussões sempre constataram os desafios para oferta de Educação de Jovens e Adultos, como uma política pública de inclusão, o que acreditamos tenha se agravado com a decretação da crise de saúde pública, por conta do surgimento do vírus SARS-COV2. No começo do ano de 2020 foi detectado um vírus que causava elevado grau de contaminação e de óbitos, era a doença denominada Covid 19. Em 11 de março de 2020 a Organização Mundial da Saúde (OMS) declarou uma situação de pandemia, considerando que o vírus se espalhou por todos os países em um curto espaço de tempo, constituindo-se uma "Emergência de Saúde Pública de Importância Internacional - o alerta máximo da Organização, conforme previsto no Regulamento Sanitário Internacional" (PAMO -Organização Pan-Americana de Saúde, 2020, s/p).

Diante do cenário apresentado e de acordo com o reconhecimento do Ministério da Saúde sobre a gravidade da situação, o Ministério da Educação publicou as Portarias nํㅜ 343, 345 e 356 que permiti a adoção de aulas por meio de recursos digitais em substituição as aulas presenciais, tanto na Educação Básica como no Ensino Superior, o que foi posto em vigor por Estados e Municípios por meio da publicação de legislações especificas (BRASIL, 2020). Falar aqui de SP decreto. No Estado de São Paulo, o Decreto № 64.879, de 20 de março de 2020 determinou a suspensão 
das atividades presenciais, inclusive as escolares, com vistas a promover 0 distanciamento social e, assim, evitar a contaminação da sociedade (SÃO PAULO, 2020).

A literatura sobre a educação de jovens e adultos evidencia as dificuldades para a oferta de tal modalidade de ensino, considerando a falta de recursos, a compreensão de docentes sobre o perfil desse público, assim como os desafios desses para manter-se na escola devido a jornadas intensas de trabalho, como é o caso das mulheres e de homens que desenvolvem suas atividades laborais em períodos de turnos alternados de trabalho ou de maneira informal, sem um horário fixo e sem os benefícios trabalhistas. Com a suspensão das aulas presenciais mais um desafio se soma aos demais, o uso de recursos tecnológicos com a finalidade de aprendizagem e o distanciamento físico de professores e colegas que sempre estavam disponíveis para sanar dúvidas e mantendo-os em constante motivação para o acesso ao saber. Diante dos obstáculos já destacados, nossas preocupações se ampliaram, o que justifica o presente estudo.

Como educadores portadores de uma visão progressista, que partilham preocupações e sonhos com a educação básica, entendemos que a participação política e social é vista como instrumentos importantes para criação e a implementação de políticas públicas que possam favorecer mudanças na questão educacional e consequentemente permitam aos nossos estudantes usufruir de direitos que Ihes foram negados no passado. Diante das discussões realizadas e considerando o momento de pandemia que se instalou no mundo, apresentamos como questões norteadoras: Como a escola se organizou para continuar oferecendo a EJA? Quais os recursos pedagógicos e tecnológicos foram utilizados durante as aulas do ensino remoto? Houve participação dos educandos? Houve aprendizagem durante este período? Que ações devem ocorrer para garantir a aprendizagem, após o período de pandemia?

Sempre visando sanar e elucidar as dúvidas, as inquietações o estudo apresenta como objetivo investigar como ocorreu a oferta do Ensino Fundamental na modalidade EJA em algumas redes de ensino nos municípios da Baixada Santista, durante o período da pandemia da Covid 19 na percepção docentes, assim como conhecer como as práticas de aprendizagem se desenvolveram, e as possíveis ações para o período pós pandemia, considerando o percurso no período da pandemia. 
O processo de redemocratização garantiu por meio das políticas públicas, legitimadas na Lei de Diretrizes e Bases - 9394/96, novas possibilidades de ampliação da escolaridade de jovens e adultos, aos que não ingressaram ou não concluíram sua escolaridade na idade própria, o acesso à educação de jovens e adultos, nas modalidades fundamental e médio constitui-se em "instrumento para continuidade de estudos e a aprendizagem ao longo da vida" (BRASIL,1996).

Para Gadotti (2013), o acesso à educação não se restringe a garantir a oferta, é necessário garantir a melhor aprendizagem, por meio de uma educação em que temas como direitos humanos, a diversidade racial, ambiental e as questões de gênero estejam contemplados no currículo, garantindo qualidade social para todos os cidadãos e cidadãs.

Ainda de acordo com as afirmações de Gadotti (2013) a questão não está apenas no ato de aprender, mas no que se aprende, trata-se de garantir uma aprendizagem que possa contribuir para uma mobilização que gere transformações sociais, econômicas e culturais para o indivíduo e a sociedade. Observando a forma como a escola se organiza identificamos valores de políticas neoliberais centrada na meritocracia, na responsabilidade de cada um em gerir seu processo de aprendizagem "e encontrar estratégias mais interessantes para ele próprio, numa base individual, competitiva, em que o cidadão é visto como um consumidor e como cliente". (GADOTTI, 2013, p.19)

A adoção de uma visão neoliberal em um país como o Brasil, cujo contexto histórico educacional foi de negação a um direito básico a ser oferecido pelo estado, pode ser entendido como uma segunda situação de exclusão a que são submetidos, em que prevalece o discurso "da globalização que fala da ética, esconde, porém, que a sua é a ética do mercado e não a ética universal do ser humano, pela qual devemos lutar bravamente se optamos pela verdade, por um mundo de gente" (FREIRE, 1996, p. 144).

Para Possani (2008), a oferta de uma nova educação de jovens e adultos implica em que grupos de jovens e adultos percebam a situação de exclusão a que são submetidos e a necessidade de um processo educativo que permita aos sujeitos uma formação com capacidade para intervir no mundo de modo criativo, e que possam participar do processo de mudanças que se torna urgente

As políticas educacionais contemporâneas trazem em sua concepção aspectos identificados como neoliberais, considerando que ao público da EJA cabe a 
responsabilidade pelo seu sucesso escolar, desconsiderando todos os entraves a que estão submetidos em termos de sobrevivência no seu cotidiano, pois trata-se de pessoas que são ou foram profissionais que estão em atividades laborais intensas com baixa remuneração e que percebem o acesso à educação como uma via para a volta ou a melhoria as condições de trabalho, mas que não o eximem de possuidores de saberes e de uma educação como direito social e humano.

\section{METODOLOGIA}

Os dados que permitiram a elaboração deste artigo foram coletados com professoras que atuam nos anos finais do Ensino Fundamental na modalidade Educação de Jovens e Adultos na Baixada Santista. Sem a pretensão de ser uma pesquisa ampla, mas com informações a partir de um diálogo entre docentes, parece possível encontrar alguns espaços para acreditar que apesar dos momentos de incertezas e de receios devido ao cenário de pandemia, algumas realidades foram construídas. Dentre os professores alguns destacam -se por pensar a EJA como uma possibilidade de inclusão, são educadores, militantes sociais e políticos que acreditam "mudar é difícil, mas é possível” (FREIRE, 1996, p. 79), outros apenas como a ampliação da escolaridade.

\section{RESULTADOS E DISCUSSÕES}

Em março do ano de 2020, fomos tomados pela notícia que a escola e todos os locais em que houvesse aglomerações deveriam ser fechados como medida para evitar o contágio pelo vírus SARS-COV2.Tratava-se de uma forma de contaminação da qual pouco se sabia, a época e que ainda hoje gera medo, incertezas e desafios sob diferentes aspectos políticos, sanitários, econômicos e sociais. O campo educacional já tomado por tantos momentos de imprecisão em função das dúvidas, quanto aos caminhos que seriam definidos pelos dirigentes públicos, tínhamos agora a nossa frente uma realidade mais desconhecida. Como seguir em frente com o ano letivo?

Diante de tal cenário nossas preocupações se voltaram, também, para a continuidade da oferta de Educação de Jovens e Adultos. Para conhecer a nova realidade dessa modalidade de ensino, buscamos estabelecer um diálogo com professoras do ensino 
público da Baixada Santista e que atuam na EJA há mais de dez anos. Estas docentes atuam nos anos finais do Ensino Fundamental nos componentes curriculares Língua Portuguesa e Matemática.

Em nosso diálogo as professoras destacaram que as escolas tiveram liberdade para se organizar da melhor maneira possível e escolheram como recursos tecnológicos e pedagógicos a atividade impressa, o whatsapp e algumas lives realizadas pelo suporte da EJA sediada na Secretaria de Educação de um dos municípios envolvidos em nosso estudo. Estas lives abordavam temas diversos e os estudantes podiam interagir, havia interesse dos alunos, principalmente dos que já se destacavam em termos de participação nas aulas. É importante "discutir com os alunos a razão de ser de alguns desses saberes em relação com o ensino dos conteúdos." (FREIRE,1996, p.30).

Percebemos que todos os municípios trabalharam com as atividades impressas e o uso de whatsapp. Os alunos retiravam na escola as atividades impressas, quinzenalmente, e apresentavam a devolutiva. Os recursos pedagógicos utilizados estavam sempre em torno da leitura e da resolução de situação-problema, como uma tentativa de possibilitar relação entre o conteúdo abordado e o cotidiano do discente. As práticas envolvendo as situações de leitura, seguia o texto impresso, pois alguns estudantes não dispunham de telefonia móvel. Os que possuíam celulares em outras ocasiões eram direcionados a buscar um texto online, mas sempre com a finalidade de estabelecer um diálogo sobre os conteúdos a serem apresentados e, também, a sua aproximação com a tecnologia e o saber do estudante $O$ educador precisa ter claro que "o respeito à autonomia e à identidade do educando exige de mim uma prática em tudo coerente com este saber" (FREIRE,1996, p.61).

Estudos de Carril et al (2020) já desvelam que o contexto da pandemia fez com que o uso da tecnologia abrisse uma nova possibilidade de acesso ao saber. No cenário dessa pesquisa, os alunos do EJA, mesmo aqueles com mais idade, muitas vezes, navegam na internet, se conectam nas redes sociais, mas o fazem apenas como forma de comunicação, de troca de informações, não há muitas vezes a utilização da rede como fonte de conhecimento, acreditamos ainda na possibilidade de não terem desenvolvido competências a serem utilizadas no ambiente virtual como: pesquisar, compreender a importância de novos saberes, assim como estabelecer relação entre eles. A escola precisa propiciar ao educando oportunidade para buscar a informação com suporte nas tecnologias, como nas "aulas, no livro didático, na TV, 
no rádio, no jornal, nos vídeos, no computador, e os elementos cognitivos para analisá-la criticamente e darem a ela um significado pessoal." (LIBÂNEO, 2001, p. 2627).

Nas práticas de construção do conhecimento a partir da utilização das novas tecnologias, a presença do professor é indispensável para o estímulo ao cognitivo e de situações em que os estudantes possam entender como significativas as mensagens disponibilizadas nos meios de comunicação e de formas diversas. O valor da aprendizagem escolar está na mobilização empregada para garantir aos alunos compreensão e relevância sobre a cultura e a ciência, recorrendo as mediações cognitivas e interacionais oportunizadas pelo professor. Ao promover o saber que atenda aos interesses da sociedade de hoje, a escola se alinha com os "objetivos de uma educação básica de qualidade: formação geral, preparação para o uso da tecnologia, desenvolvimentos de capacidades cognitivas e operativas, formação para a cidadania crítica, formação ética." (LIBÂNEO, 2001 p. 28).

Em nosso diálogo com as professoras da EJA tínhamos interrogação de como seria a participação discente nas aulas durante o período da pandemia pelo recurso WhatsApp. Notamos que alguns professores mantiveram uma situação inalterada, ou seja, os estudantes assíduos e participativos no presencial continuaram no período da pandemia, já os faltosos e com pouca dedicação aos estudos, também, mantiveram-se com o comportamento anterior, mas percebemos a ação de alguns docentes que adicionaram os educandos em grupos no WhatsApp e utilizavam esse espaço tanto para esclarecer as dúvidas sobre as atividades, como para manter uma aproximação e assim evitar a evasão. Outros afirmaram que percebiam a falta de participação nas aulas via WhatsApp, assim como quanto a devolutiva das atividades na escola está associadas as dificuldades de ordem material como o acesso à internet e aos meios tecnológicos, também houve a dificuldade em manter-se no emprego ocasionada pela Pandemia, já que muitos estudantes são adultos e necessitam trabalhar, alguns de modo informal, mas também perceberam que muitos evadiram das aulas nos primeiros meses de 2020, retornando com certa insegurança no $2^{\circ}$ semestre.

Os estudos apresentados por Possani (2008) apresentam que o perfil dos estudantes da Educação de Jovens e Adultos são ou foram trabalhadores, com experiência profissional, desejosos de ingressar ou voltar ao mercado de trabalho, com uma maturidade e visão própria do mundo, ou seja, desenvolveram uma 
sociabilidade no exercício cotidiano da sua atividade profissional, ao transitar pela sociedade e, por conta disso, apresentam saberes, os quais a escola muitas vezes não valoriza. Assim, o que essa pessoa busca na escola é a oficialização desses saberes, daí sempre ocorrer seu retorno à escola.

Quanto aos efeitos da utilização do recurso WhatsApp como recurso para garantir o avanço no processo de aprendizagem, os professores dos diferentes componentes curriculares tinham período de plantão no noturno para atender aos estudantes. Para alguns docentes, a aprendizagem não ocorria e também nem todos entregavam atividade na escola e mesmo quando entregavam ficava a dúvida se haviam sido elaboradas por eles próprios. Para outros houve alguma aprendizagem, mas só será possível entender a qualidade desta quando do retorno de todos à sala de aula.

O uso do recurso WhatsApp constitui-se em uma multiplataforma que permite de forma gratuita a comunicação entre indivíduos ou em grupos entre si, por meio de mensagens, imagens, vídeos, áudios, compartilhar localização e fazer backup do conteúdo postado nos grupos. No período de pandemia tornou-se importante recurso pedagógico, mas com algumas considerações que devem ser observadas por parte dos docentes, como: conhecimento sobre as fragilidades de cada aluno, seja em relação ao domínio cognitivo ou a um comportamento social .Há alunos que são inseguros quanto a participação nas aulas, o professor precisa conhecer o momento para incentivar, respeitar, dialogar e principalmente desafiá-los, seja em sala de aula presencial ou em uma comunicação pelo Whatzapp. O Whatzapp utilizado como recurso pedagógico constitui-se em uma prática coletiva em que os saberes são construídos de forma colaborativa, a qual "pode trazer à tona o que há de melhor em você e o que sabe, fazendo o mesmo com seu parceiro, e juntos vocês podem agir de forma que talvez não estivessem disponíveis a um ou outro isoladamente" (MOREIRA; SIMÕES, 2017, p.31).

Em resposta a outra questão formulada as docentes sobre as ações a serem realizadas quando do retorno ao ensino presencial, quais ações devem ocorrer para garantir a aprendizagem dos estudantes? Aqui houve uma resposta única sobre a necessidade de uma avaliação diagnóstica com a finalidade de identificar os conteúdos a serem retomados, assim como o estabelecimento de diálogos sobre as necessidades e os desafios que todos experimentaram no período de pandemia, "preciso, agora saber ou abrir-me à realidade desses alunos com quem partilho a 
minha atividade pedagógica." (FREIRE,1996, p.137).

Nesse cenário um passo fundamental é realizar uma busca ativa para identificar estas pessoas e o nível de precariedade a que estão submetidos e que podem interferir na sua volta à escola, assim como se gostariam de iniciar e retomar seus estudos e quais as condições necessárias para isso. Com estas ações o poder público cumpre com a obrigação legal de oferecer educação para jovens e adultos a partir de um "planejamento integrado, organizar estratégias para chegar até as pessoas, conhecer sua realidade e oferecer alternativas para que se engajem na alfabetização e para que possam dar continuidade aos estudos." (UNESCO, 2008, p.56).

\section{CONSIDERAÇÕES FINAIS}

Para iniciar a elaboração deste estudo, buscamos entender por meio de um diálogo com docentes, que atuam nos anos finais do Ensino Fundamental, modalidade Educação de Jovens e Adultos como as escolas se organizaram para continuar oferecendo a EJA na Baixada Santista, envolvendo aspectos pedagógicos e tecnológicos. Para conhecer a realidade da escola optamos por uma conversa, com a finalidade de deixá-los à vontade nas manifestações de suas impressões reais. Era um diálogo entre colegas professores que atuam e pesquisadoras que já atuaram na EJA da educação básica e hoje estão envolvidas com a formação de docentes, em curso de licenciaturas.

Nossa preocupação com esta modalidade de ensino tem como origem inicialmente o momento político em que mergulhamos a partir do início do ano de 2019, em que o campo educacional se mostrou bastante fragilizado em relação a continuidade das políticas públicas educacionais principalmente as que são destinadas a população mais vulneráveis, como o público da educação de jovens e adultos. No início do ano 2020, fomos surpreendidos com o surgimento do vírus SARS-COV2, que levou a decretação de uma pandemia, então todos os locais em que pudessem haver aglomeração foram fechados. A alternativa do que fazer, veio por meio da tecnologia e a adoção do ensino remoto, mesmo que com pouco domínio e com muitas interrogações sobre tal prática, tanto por parte dos educadores, alguns com pouca familiaridade quanto aos recursos tecnológicos, como dos discentes que muitas vezes utilizavam o aparelho de telefonia móvel, mas não como um instrumento de aprendizagem. 
Nos municípios, as escolas se organizaram oferecendo ao seu público as atividades impressas a ser retirada na escola e as aulas ministradas pelo Whatzapp pelos docentes, como suporte para a elaboração das atividades.

A população que frequenta a modalidade EJA são homens e mulheres, jovens ou não tão jovens pertencentes aos grupos populacionais com maior comprometimento econômico, para esses os prejuízos foram maiores, pois alguns não possuíam um equipamento com condições para acessar as aulas remotas por meio do aplicativo WhatsApp - o qual se transformou em importante recurso pedagógico durante a pandemia, ou muitas vezes não disponham de uma conexão eficaz e assim ter acesso as explicações para a realização das atividades. Estes grupos ficaram excluídos desse processo educacional emergencial, no formato como ainda está colocado para as redes de ensino.

As docentes ressaltaram que havia o comprometimento da escola em imprimir e oferecer todo o material didático, assim como as orientações para que fossem utilizadas de forma correta. Devido a prática em atender estes estudantes sabemos que por conta de uma fragilidade afetiva em decorrência de muitas situações de exclusão sofridas, alguns deixavam de retirar as atividades ou não faziam a devolutiva, o que contribuiu para a evasão dos estudantes.

A utilização do aplicativo em alguns aspectos aproximou discentes e professores, pois quando havia a ausência de determinado estudante, este era contactado pelo WhatsApp e estimulado a continuar no grupo, participando das aulas, o que podemos identificar como um ponto positivo percebido pelos docentes, assim como se faltou algo do ponto de vista do conhecimento universal para o processo de aprendizagem, talvez possamos dizer que aproximou pessoas, permitiu alguma convivência, não sei dizer se na mesma proporção. Lembro aqui o trecho de um poema do filósofo e poeta mineiro Thiago Adão Lara "conviver é a única chance que temos para viver ricamente. Mas conviver implica compromisso, o que significa acordo, acerto prometido, em pontos fundamentais que possibilitam a vida”. (LARA, 2016, p.17).

\section{REFERÊNCIAS}

BRASIL, Ministério da Educação. Portaria № 343/2020. Dispõe sobre a substituição das aulas presenciais por aulas em meios digitais enquanto durar a situação de 
pandemia do Novo Coronavírus - COVID-19. Disponível em:

https://www.in.gov.br/en/web/dou/-/portaria-n-343-de-17-de-marco-de-2020-

248564376. Acesso em: 1 set. 2021.

BRASIL. Lei Federal nº 9394/1996. Estabelece Diretrizes e Bases da Educação

Nacional. Disponível em: http://www.planalto.gov.br/ccivil 03/LEIS/L9394.htm.

Acesso em: 20 jul. 2021.

CARRIL, Maria da Graça P. O futuro das Escolas Públicas Estaduais no Período Noturno - O comportamento da Demanda Ensino Médio 1995-2004. Dissertação de Mestrado. Pontifícia Universidade Católica de São Paulo, PUC/SP, Brasil, 2006.

CARRIL, Maria da Graça P et al. Ensino Remoto no Curso de Pedagogia Formação Interdisciplinar para a gestão educacional. REVASF, PetrolinaPernambuco -Brasil, vol. 10, n.22, p. 453-484, setembro-dezembro, 2020. Disponível em: https://www.periodicos.univasf.edu.br/index.php/revasf/article/view/1252/867. Acesso em: 30 ago. 2021.

FREIRE, Paulo. Educação como prática da liberdade. 17 ed. Rio de Janeiro: Paz e Terra, 1979.

FREIRE, Paulo. Pedagogia do Oprimido. 42 ed. Rio de Janeiro: Paz e Terra, 2005.

FREIRE, Paulo. Pedagogia da autonomia. 25 ed. São Paulo: Paz e Terra, 1996.

FREIRE, Paulo. Política e educação. São Paulo: Cortez, 1997.

GADOTTI, Moacir. Educação de adultos como direito humano. EJA em Debate. Florianópolis, n.2, 18p., jul. 2013. Disponível em: https://periodicos.ifsc.edu.br/index.php/EJA/article/view/1004/pdf. Acesso em: 3 set. 2021.

LARA, Thiago Adão. Educar? Juiz de Fora: Gryphon Edições, 2016. 
LIBÂNEO, Jose Carlos. Adeus Professor, Adeus Professora? Novas exigências educacionais e profissão docente. 13 ed. São Paulo: Cortez, 2011.

MOREIRA, Micheli L.; SIMÕES, Andenson S. M. O uso do whatsapp como ferramenta pedagógica no ensino de química. ACTIO, Curitiba, v. 2, n.3, p 21-43, out/dez. 2017.

PAMO - Organização Pan-Americana de Saúde. OMS declara emergência de saúde pública de importância internacional por surto de novo coronavírus. 2020. Disponível em: https://www.paho.org/pt/news/30-1-2020-who-declares-public-healthemergency-novel-coronavirus. Acesso em: 2 set. 2021.

POSSANI, Lourdes de Fátima P. Currículos emancipatórios para a educação de jovens e adultos na perspectiva das políticas públicas: resistências e esperanças. Doutorado em Educação e Currículo. Pontifícia Universidade Católica de São Paulo, PUC/SP, SÃO PAULO, 2008

SÃO PAULO. Decreto № 64.879, de 20 de março de 2020. Reconhece o estado de calamidade pública, decorrente da pandemia do COVID-19, que atinge o Estado de São Paulo, e dá providências correlatas. Diário Oficial do Estado de São Paulo. Disponível em: https://www.saopaulo.sp.gov.br/wpcontent/uploads/2020/03/decretos64879-e-64880.pdf. Acesso em: 2 set. 2021. (PDF não encontrado)

UNESCO. Alfabetização de jovens e adultos no Brasil: lições da prática. 2008. 211p. Disponível em: http://www.ceeja.ufscar.br/alfabetizacao. Acesso em: 6 set. 2021. 


\title{
A IMPORTÂNCIA DOS JOGOS NO ENSINO DA MATEMÁTICA
}

\author{
Flávia Gomes dos Santos \\ Thiago Simão Gomes
}

\section{RESUMO}

A matemática tem múltiplas semelhanças com os jogos, e permite ao educador atingir atividades para levar o educando à compreensão da matemática. $A$ dificuldade de socialização das crianças nas redes da escola pública reflete-se na diversidade cultural. $O$ ensino qualitativo requer uma visão da necessidade de novas experiências educativas, que tenham por base os componentes socializadores e integradores para situar a criança no espaço da escola. Neste sentido, o jogo pode ser considerado como estratégia de interação social em situações diversas para a promoção de aprendizagens orientadas, que garantam a troca entre as crianças, para que possam comunicar-se e expressar-se, demonstrando seus modos de agir, pensar e sentir, em um ambiente acolhedor e que propicie a confiança e a autoestima. Objetiva-se, estruturar uma revisão bibliográfica que justifique o uso de jogos nas escolas, bem como, qual a maneira adequada de trabalhar com eles.

Palavras-Chave: Jogos; Matemática; Interação Social; Aprendizagens.

\section{Introdução}

A educação é uma das formas mais transformadoras da sociedade; com educação de qualidade proporcionamos mudanças significativas e valiosas, contribuindo com uma incontestável socialização e humanização.

No contexto de educação diferenciada, deixando a velha educação bancária de lado e adotando alternativas que possam transformar o ensino de forma a aproximar o educando do contexto escolar, evita-se a evasão e o desinteresse. Portanto, proporcionando um ambiente acolhedor com perspectivas de crescimento, resultará em contribuição positiva refletida na sociedade.

A utilização de jogos é uma proposta, para o ensino da matemática, podendo proporcionar educação descontraída, dinâmica, criativa e poderosa. Neste aspecto, pode-se pensar em aprendizado diferenciado, provocando o interesse, o 
desenvolvimento do raciocínio crítico capaz de relacionar conceitos para o despertar da curiosidade e resolução de problemas.

A realização de jogos deve ser utilizada nas séries do ensino fundamental, desde o momento em que a criança inicia o processo de educação formal. Jogos bem elaborados permitem o aprimoramento de conteúdos e viabiliza o entendimento, possibilitando a diminuição de bloqueios à matemática.

Com a utilização de recursos que estimulem a resolução de problemas, principalmente quando o conteúdo a ser estudado não tem estreita relação com o dia a dia do aluno, objetiva-se a aprendizagem significativa.

Este artigo objetiva a utilização da revisão bibliográfica que justifique o uso de jogos nas escolas bem como, qual a maneira adequada para trabalhar com eles.

A cada nova vivência, a criança dará um salto qualitativo como sujeito na sociedade em que está inserida.

\section{Conceito de jogos}

Os jogos para as crianças não têm um fim exterior. O jogar, por si só, já basta para uma criança. A única finalidade é o da alegria, porém o grande propulsor destas atividades é o fato de que através dos jogos as crianças podem superar suas dificuldades, transcender seus limites. Mas, afinal, o que é um jogo? O que diferencia essa atividade das demais brincadeiras?

Segundo Huizinga (2007),

jogo "é uma atividade ou ocupação voluntária, exercida dentro de certos e determinados limites de tempo e espaço, segundo regras livremente consentidas, mas absolutamente obrigatórias, dotado de um fim em si mesmo, acompanhado de um sentimento de tensão e alegria e de uma consciência de ser diferente da vida cotidiana" (HUIZINGA, 2007, p. 33).

Efetuando um arrolamento das atividades mais corriqueiras desenvolvidas pelas crianças surgiram os jogos de faz-de-conta. Destacam-se tais atividades por serem uma das mais ricas que representam o espírito do jogo e suas características mais marcantes.

Por meio dos jogos de faz-de-conta, iniciados na mais tenra infância, as crianças passam a arquitetar uma realidade adicional, trocando conhecimentos entre 
as duas realidades. Ao começar um novo jogo, a criança terá a possibilidade de explorar sua imaginação e criatividade, arquitetando uma nova realidade para si e para os demais que com ela jogam, assumindo papéis diferenciados e desempenhando diferentes atividades, tudo isso com a garantia de que, ao encerrar a brincadeira, todos voltarão para sua realidade carregados de novas experiências. $A$ cada nova vivência, a criança estará dando um salto qualitativo como sujeito na sociedade em que está inserida.

Quanto mais nos esforçamos por estabelecer uma grande separação entre a forma a que chamamos "jogo" e outras formas aparentemente relacionadas a ela, mais se evidencia a absoluta independência do conceito de jogo (HUIZINGA, 2007, p. 7)

\section{Reflexos dos jogos}

Para algumas pessoas, o jogar desperta um prazer incontrolável, de tal forma que o jogo já foi estudado por muitos médicos na busca de esclarecer a dicotomia “agradável-doloroso". Mesmo tendo como objetivo final a vitória, a sensação de jogar desperto um desafio íntimo que dá prazer.

Os jogos vêm com intuito de manter o ensino mais prazeroso, despertando mecanismos diferenciados, visando manter os educandos interessados dentro do universo escolar, evitando evasão e falta de interesse, estimulando o crescimento humano e intelectual, a fim de evitar cidadãos alvos de uma sociedade desequilibrada e marginalizada.

Com intuito de esclarecer a visão de educação tradicional, e seus reflexos, Saviani aponta que:

[...] A causa da marginalidade é identificada com a ignorância, é marginalizado da nova sociedade quem não é esclarecido. A escola surge como um antídoto à ignorância, logo, um instrumento para equacionar o problema da marginalidade. Seu papel é difundir a instrução, transmitir os conhecimentos acumulados pela humanidade e sistematizados logicamente. (Saviani, 2008, p. 5)

A atividade do jogo, desperta envolvimento, acaba até por formar uma categoria de "jogadores profissionais", que dominam uma conduta especial. Como possuem regras, jogadores procuram se posicionar dentro de alguns limites no desenvolvimento 
do jogo, normalmente sabendo a hora de se retirar do mesmo e traçando estratégias com muita precisão. Entretanto, como coloca Padilla (1995, p.36) "a compulsividade é inimiga da conduta", de forma que um grande conflito se estabelece. Assim, mesmo os melhores jogadores acabam passando por momentos difíceis durante um jogo.

A análise crítica que os jogadores têm de suas jogadas, na maioria das vezes é muito clara. Mesmo dando-se conta das arriscadas jogadas, eles optam por continuar no jogo, pois ao final, mesmo perdendo, resta-Ihes o prazer de ter arriscado, de ter duvidado da capacidade de seu adversário.

Fica claro que, para o jogador, o resultado é o que menos importa, a grande emoção do jogo se encontra em seu desenvolvimento. Buscando esclarecer essa colocação, Motta (2002, p. 17) afirma que, "o jogo modifica o jogador enquanto ocorre e seu resultado é menos importante que o processo".

Em relatos coletados por Padilla (1995), alguns jogadores colocam que é na mesa de jogo que se conhece o verdadeiro caráter de uma pessoa. O sujeito que é um grande amigo ou um excelente colega de trabalho, torna-se durante o jogo, um feroz jogador, imperdoável, até mesmo agressivo.

O sujeito que brinca, provavelmente sorri, ri, apresenta-se relaxado e exibe afeto neutro ou positivo.

Para se encontrar o verdadeiro prazer de jogar, é necessário que se encontre a criança que existe dentro de cada um. Somente encarando o jogo como a criança o encara, de entrega total e de busca na superação do desafio proposto, é que se encontrará novamente o prazer no jogo. Conseguir atuar em um palco lúdico e imergir em uma nova realidade e encarar um novo desafio sem preocupações paralelas, tendo a segurança de retornar à realidade quando o jogo acabar, é o que garante emoção ao jogo. Se for possível trazer dessa realidade suplementar um novo conhecimento ou uma nova perspectiva de relacionamento, tem-se ainda um ganho maior.

Corroborando com essa ideia, Motta (2002) afirma que:

Para jogar é fundamental resgatar a criança que existe dentro de nós, pois as crianças sabem brincar, são elas que transitam entre fantasia 
e realidade, levando e trazendo elementos de um contexto a outro, refazendo a história com a liberdade de um criador. Como todos os mamíferos, as crianças já nascem sabendo brincar, mas são capazes de ir além, de se apropriar do mundo criando seus jogos dramáticos. Este potencial para o aperfeiçoamento próprio é uma peculiaridade humana que distingui o ser humano dos filhotes de animais. Mas, curiosamente, a criança não joga para evoluir; ela evolui porque joga. (Motta, 2002, p. 16-17).

Portanto, os jogos realmente não podem ser considerados como simples brincadeiras, visto que os mesmos proporcionam, além da alegria de vivenciá-lo, um crescimento para as crianças nele envolvidas. E através de um estudo mais detalhado, é possível analisar os jogos sob uma perspectiva cultural, como um artefato carregado de significados.

Os jogos, por sua vez, podem trazer um ensino problematizado, deixando de lado a mera reprodução de conceitos. Seguindo a tendência progressista, em pressupostos da aprendizagem Libâneo destaca:

A própria designação de "educação problematizadora" como correlata de educação libertadora revela a força motivadora da aprendizagem. A motivação se dá a partir da codificação de uma situação-problema, da qual se torna distância para analisa-la criticamente. "Esta Análise envolve o exercício da abstração, através da qual procuramos alcançar, por meio de representações da realidade concreta, a razão de ser dos fatos." (Libâneo, 1985, p.24)

\section{Jogos como metodologia de ensino e aprendizagem}

Os jogos apresentam além da aplicação social, a de poder ser o condutor de um conteúdo específico. Os jogos se tornam um instrumento potencial para a educação no momento em que o professor que irá fazer uso deles tiver clareza dos potenciais desse instrumento e de que tipo de aluno deseja formar.

Se o desejo desse educador for formar um educando participativo, reflexivo, independente, criativo e que domine um raciocínio lógico voltado à resolução de problemas, certamente os jogos serão um grande aliado seu. Atuando dessa forma, o educador está proporcionando que o aluno se desenvolva em um ambiente de construção do conhecimento, em que os mesmos terão significado para esse educando. 
Pensado nos professores como intelectuais transformadores, Girox aponta que:

Ao encarar os professores como intelectuais, podemos elucidar a importante ideia de que toda a atividade humana envolve alguma forma de pensamento. Nenhuma atividade, independentemente do quão rotinizada possa se tornar, pode ser abstraída do funcionamento da mente em algum nível. Este ponto é crucial, pois os argumentos que o uso da mente é uma parte geral de toda atividade humana, nós dignificamos a capacidade humana de integrar o pensamento e a prática, e assim destacamos a essência do que significa encarar os professores como profissionais reflexivos. Dentro deste discurso, os professores podem ser vistos não simplesmente como "operadores profissionalmente preparados para efetivamente atingirem quaisquer metas a eles apresentadas. Em vez disso, eles deveriam ser vistos como homens e mulheres livres, como dedicação especial dos valores do intelecto e ao fomento da capacidade crítica dos jovens." (Giroux, 1989 , p. 161)

Outro questionamento primordial para o educador é qual o objetivo que ele deseja alcançar com os jogos. Conforme já vimos anteriormente, os jogos quando bem estruturados, apresentam-se sob diferentes tipos e enfoques e essa diferença precisa estar clara para o educador.

É sempre bom lembrar que, quando se usa um jogo, é necessário atenção para quem e para que é o jogo, pois como o jogo é instrumento de poder sobre a realidade, é importante saber com que ética se usa tal recurso.

Pesquisas realizadas na área da educação mostram que as crianças, até seus oito anos, constroem seus esquemas de raciocínio, atitudes, hábitos e valores que Ihes acompanharão pelo resto de sua escolaridade. Nesta fase, suas formas de adaptação e reação frente ao desafio estarão sendo formadas, fortemente influenciadas pelas relações que estabelecem com seu educador. Sendo assim, fazse necessário trabalhar desde cedo com jogos, pois dessa forma estaremos preparando o aluno para superar e encarar desafios. Posteriormente, tal atitude será bastante valorizada, pois tal sujeito deverá se tornar um adolescente e adulto acostumado a resolver situações-problemas sem medo e com persistência, além de proporcionar a socialização.

Em relação aos mecanismos de socialização da escola, Gomez descreve: 
Os alunos/as aprendem e assimilam teorias, disposições e condutas são apenas como consequência da transmissão e intercâmbio de ideias e conhecimentos explícitos no currículo oficial, mas também principalmente como consequência das interações sociais de todo tipo que ocorrem na escola ou na aula[...] (Gomez, 2008, p. 17)

$\mathrm{Na}$ verdade, os jogos, quando bem utilizados, permitem que se realize uma dupla avaliação. O professor poderá avaliar, durante o desenvolvimento da atividade, as hipóteses, as jogadas e o raciocínio de seus alunos. Já o aluno, através dos questionamentos e orientações de seu professor, poderá avaliar suas hipóteses, jogadas e quais ações foram positivas ou negativas. Dessa forma, além de construir uma excelente avaliação da atividade, o professor estará estimulando a construção de estratégias vencedoras.

Frente a essa nova forma de encarar os jogos, os educadores passam a ter um papel fundamental. Já foi colocada a necessidade de alguns cuidados especiais ao se propor uma atividade com jogos; da mesma forma, faz-se necessário que se tenha claro o papel do professor frente a essa metodologia.

É necessário que a criança conviva em um ambiente rico de materiais e oportunidades, de modo que possa construir e elaborar seus conhecimentos. Deve-se levar em conta as etapas do desenvolvimento, quando do planejamento do ensino.

Uma área de ensino que tem desenvolvido muitos trabalhos com jogos é a matemática, porém com ênfase em materiais concretos e estruturados, utilizados como recursos didáticos.

Como ocorrem diversas formas de enfoque do uso dos jogos no ensino, a escolha do professor pelo trabalho com o jogo deve ser uma opção de ação didático-metodológica, na qual seus objetivos estejam bastante claros.

O professor, para propor um ensino diferenciado, tem que haver compromisso, e amorosidade na busca da transformação, na visão de Freire, ele contribui:

Não é possível um compromisso verdadeiro com a realidade, e com os homens concretos que nela e com eles estão, se desta realidade e destes homens se têm uma consciência ingênua. Não é possível um compromisso autêntico se, àquele que se julga comprometido, a realidade se apresenta como algo dado, estático e imutável. Se este olha e percebe a realidade enclausurada em departamentos estanques. Se não a vê e não a capta como uma totalidade, cujas partes se encontram em permanente interação. Daí sua ação não poder incidir sobre as partes isoladas, pensando que assim transforma a realidade, mas sobre a totalidade. É transformando a totalidade que se transformam as partes e não o contrário. No primeiro caso, sua ação, que estaria numa visão ingênua, meramente "focalista" da realidade, não poderia construir um compromisso. (Freire, 2007, p. 10) 
Segundo Macedo, Petty e Passos (2005), ao jogar, uma criança dá muitas informações e comunica, através da ação, sua forma de pensar, desde que o observador reconheça nas ações ou nos procedimentos os indícios que está buscando para realizar sua avaliação. Em outras palavras, deve ser capaz de transformar as informações, sempre presentes, em dados significativos.

Em síntese os autores destacam que esse recorte com jogos expressa uma das possibilidades de se coordenar pedagogia diferenciada com avaliação formativa. Pedagogia diferenciada porque permite ao professor criar e gerir situações de aprendizagem mais condizentes com as atuais condições educacionais. A avaliação formativa envolve a confirmação da aprendizagem, é muito importante para os educadores que revejam suas práticas.

E considerando a perspectiva de benefícios no ato de jogar, Moura defende:

O jogo é um material de ensino quando promove a aprendizagem. Desse modo, o jogo, passa a ter o caráter de material de ensino quando considerado promotor de aprendizagem. A criança, colocada diante de situações lúdicas, apreende a estrutura lógica da brincadeira e, deste modo, aprende também a estrutura matemática presente. (MOURA, 2000, p. 80).

Podemos demonstrar que o jogo lúdico pode ser considerado como uma estratégia de interação social em situações diversas para a promoção de aprendizagens orientadas que garantam a troca entre as crianças, de forma que possam comunicar-se e expressar-se, demonstrando seus modos de agir, de pensar e de sentir, em um ambiente acolhedor e que propicie a confiança e a autoestima.

Assim podemos considerar o que diz Smole, 2007:

O trabalho com jogos nas aulas de matemática, quando bem planejado e orientado, auxilia o desenvolvimento de habilidades como observação, análise, levantamento de hipóteses, busca de suposições, reflexão, tomada de decisão, argumentação e organização, as quais estão Comunicação Científica estreitamente relacionadas ao assim chamado raciocínio lógico (SMOLE, 2007; p.9).

Ainda para destacar a importância dos jogos na educação, Kishimoto destaca o interesse de vários autores, afirmando que o jogo recebe de teóricos como Piaget, Vigotsky, Leontiev, Elkonin, entre outros, as contribuições para o aparecimento em propostas de ensino de matemática.

Kishimoto ainda destaca que:

O jogo, como promotor da aprendizagem e do desenvolvimento, passa a ser considerado nas práticas escolares como importante aliado para o ensino, já que colocar o aluno diante de situações de jogo pode ser uma boa estratégia para aproximá-lo dos conteúdos culturais a serem veiculados na escola, além de poder estar promovendo o 
desenvolvimento de novas estruturas cognitivas. (KISHIMOTO, 2017, p.13)

Diante do exposto pelo autor, a contribuição dos jogos na educação matemática, defendida por Kishimoto, 2017 é que "o jogo se aproxima da matemática via desenvolvimento de habilidades de resolução de problemas (Moura, 1991) e mais, permite trabalhar os conteúdos culturais inerentes ao próprio jogo."

\section{Considerações finais}

A dificuldade de socialização das crianças nas redes da escola pública reflete-se na diversidade cultural, fazendo com que o trabalho pedagógico do professor se torne ainda mais complexo. O ensino qualitativo requer uma visão da necessidade de novas experiências educativas que tenham por base os componentes socializadores e integradores para situar a criança no espaço da escola. Neste sentido, o jogo lúdico pode ser considerado como uma estratégia de interação social em situações diversas para a promoção de aprendizagens orientadas que garantam a troca entre as crianças, de forma que possam comunicar-se e expressar-se, demonstrando seus modos de agir, de pensar e de sentir, em um ambiente acolhedor e que propicie a confiança e a autoestima.

Vivemos em uma sociedade desigual, na qual as crianças, embora tenham direitos garantidos pela Constituição, não possuem ensino de qualidade, e a educação segue com precariedade.

Este texto deixa evidente a aproximação dos alunos da escola pública dos conceitos matemáticos, utilizando jogos, tornando assim, o ensino mais efetivo e eficaz.

\section{Referências}

FREIRE, Paulo. O compromisso do profissional com a sociedade. In: Educação e Mudança. São Paulo. Paz e Terra, 2007.

GIROUX, Henry A. Professores como intelectuais transformadores (cap. 9). In: Os professores como intelectuais: rumo a uma pedagogia crítica da aprendizagem. Porto Alegre: Artes Médicas, 1997.

GÓMEZ, A. I. Pérez. As funções sociais da escola: da reprodução à reconstrução crítica do conhecimento e da experiência (cap. I). In: SACRISTÁN, J. Gimeno e GÓMEZ̉ A. L. Pérez. Compreender e Transformar o Ensino. Porto Alegre: Artes Médicas, 2008.

HUIZINGA, Johan. Homo ludens: o jogo como elemento da cultura. 5edição. São Paulo: Perspectiva, 2007. 
KISHIMOTO, Tizuko M. Jogo, brinquedo, brincadeira e a educação. São Paulo: Cortez, 2007.

LARA, Isabel Cristina Machado de. Jogando com a Matemática de $5^{\mathbf{a}}$ a $8^{\mathbf{a}}$ série. São Paulo: Rêspel, 2003.

LIBANEO, José Carlos. Democratização da escola pública: a pedagogia crítico-social dos conteúdos. São Paulo: Loyola, 1985.

MACEDO, Lino de. PETTY, Ana Lúcia Sícola. PASSOS, Norimar Christe, Os jogos e o Lúdico na aprendizagem escolar. Artmed, 2005.

MOTTA, Júlia M. C. Jogos: repetição ou criação? 2. ed., São Paulo: Ágora, 2002.

MOURA, Manoel Oriosvaldo de. A séria busca no jogo: do lúdico na Matemática. In:KISHIMOTO, Tizuko (Org.). Jogo, brinquedo, brincadeira e a educação. São Paulo: Cortez, 2000.

PADILLA, Ricardo. O jogo: uma paixão. Porto Alegre: Só livros, 1995.

SMOLE, Kátia Stocco; DINIZ, Maria Ignez; Milani, Estela. Jogos de matemática de 1a a 5o ano. Porto Alegre: Artmed, 2007.

SAVIANI, Demerval. Escola e Democracia. Campinas: Autores Associados, 2008. 


\title{
O Populismo e o Movimento da Educação Popular: notas sobre Educação como prática da liberdade de Paulo Freire
}

\author{
Clara Versiani \\ Marcos Rafael da Silva
}

\section{RESUMO}

A presente comunicação objetiva discutir a relação entre o populismo, enquanto regime político, e a educação popular, como movimento de acesso democrático à educação. A reflexão parte da leitura de Educação como prática da liberdade de Paulo Freire procurando situá-la no contexto histórico da sua produção. Entende que mesmo que as intenções do Estado populista na promoção da educação popular estivessem ligadas à manutenção de seu projeto de poder, as classes trabalhadoras lograram vantagens neste processo.

Palavras-chave: Paulo Freire; populismo; educação popular.

Introdução

A obra de Paulo Freire, em geral, e Educação como prática da liberdade, em particular, oferece uma análise do homem moderno, da sociedade contemporânea e, portanto, como teoria é detentora de validade universal. No entanto, sua feitura está calcada intimamente na realidade que a cerca. A realidade brasileira da primeira metade do século XX. É sobre essa realidade que a presente comunicação almeja jogar luz.

Ainda se preocupa com uma questão que, a nosso ver, é fundamental para o entendimento da obra do autor: qual seja, a relação entre o populismo e o movimento da educação popular. Sobre a manipulação populista e a proposta libertadora do educador popular. Esta questão nos foi inspirada na leitura do excelente prefácio à obra em tela feita pelo cientista político Francisco Weffort. Segue uma das muitas passagens que levanta a

A indagação sobre o interesse efetivo do populismo numa mobilização autenticamente democrática, como foi o movimento de educação popular, é mais complicada do que poderia parecer a um primeiro exame. Em todo este período histórico, no qual a ascensão popular não apenas se realiza por via institucional como é frequentemente estimulada através do Estado, a ambiguidade do regime populista entre a mobilização democrática e a manipulação aparece como uma característica central (WEFFORT, 1967, p. 20). 
Não obstante, a percepção de que a manipulação das massas tem seu limite, na medida em que ela também possui seus interesses e, em alguma medida, luta por eles; Weffort vê como caraterística central certa ambiguidade entre o projeto libertador via educação, tal como aparece em Paulo Freire, e os interesses do regime populista em estimular uma participação popular sob seu controle.

Em outra passagem, Weffort levanta o problema sob o aspecto do educador popular:

Esta indagação sobre o sentido da manipulação tem também o seu reverso. E aqui esboçamos um tema que diz respeito mais de perto à compreensão deste livro e do movimento de educação popular. Podese compreender que os populistas promovam ou permitam alguma mobilização efetivamente democrática em seu afã de manipular novas massas. Mas se podemos admitir que eles são políticos eficientes, caberia indagar se a experiência brasileira de mobilização educacional, realizada por vias institucionais, não conduziria paradoxalmente a resultados contrários dos que pretende. Ao promover a mobilização através do Estado, o educador não estaria comprometendo, através dos resultados políticos de sua ação, seu próprio projeto de criticização da consciência popular (WEFFORT, 1967, p. 22)?

Veremos, ao longo do texto, que mesmo Paulo Freire, numa retomada sempre crítica das suas ideias, vai responder a esses e outros questionamentos da sua obra. É importante frisar que nosso autor sempre recebeu e refletiu sobre as críticas recebidas, num processo de constante revisão de suas ideias provocado pela relação dialética entre teoria e prática.

No contexto do centenário de Paulo Freire, e como uma proposta de história das ideias freirianas, destaca-se aqui o Brasil que surgiu depois de 1930. A "revolução feita antes que o povo a fizesse", como queria o slogan do político reformista e um dos articuladores do movimento, Antonio Carlos Ribeiro de Andrada, foi um ponto de inflexão na história do país.

Gomes destaca que a história do período 1930 a 1964, tem início com os tiros das revoltas e das guerras, e se conclui com o golpe civil-militar. Nele teve lugar ainda uma guerra civil, a Revolução Constitucionalista de 1932 e, no contexto mais amplo, a Segunda Guerra Mundial da qual o país participou declarando guerra ao Eixo e com o envio de tropas. Além da dimensão humana implicada por essa participação, há 
"uma mudança de patamar no processo de industrialização", atrelada "a um irrestrito alinhamento com os Estados Unidos" (GOMES, 2013, p. 24).

É o período do nacionalismo, do desenvolvimentismo, do trabalhismo, do populismo, da União Nacional dos Estudantes, das Ligas Camponesas, das juventudes universitária e operária católicas, do samba exaltação, da bossa nova, do rádio, da TV e do cinema nacionais. O tempo da instauração da democracia burguesa (WEFFORT, 1978, p. 17.), e do movimento de educação popular.

A partir de 1945, "o crescimento das cidades e do proletariado lança à cidade amplos contingentes da população e o processo de absorção das massas passa a constituir uma dimensão política essencial de novo período" (WEFFORT, 1978, p. 17). No entanto, há que se atentar para o fato de que a democracia, além de burguesa, era ainda mais parcial sob outro aspecto, excluía os analfabetos.

A incorporação e participação política das massas nessa nova ordem é caracterizada como individualizada, sendo o sufrágio, mais especificamente a eleição para o executivo, sua maior forma de expressão. Ainda que tais características indiquem debilidade da atuação popular, determinavam que, a partir de 1945, qualquer um que pretendesse disputar um cargo executivo de forma mais ou menos independente deveria, "embora de maneira parcial e mistificadora, prestar contas às massas" (WEFFORT, 1979, p. 21). É dessa nova relação entre as massas e os líderes que nasce o populismo no Brasil.

O populismo brasileiro de meados do século XX foi expressão de diferentes crises e debilidades: a crise da oligarquia e do liberalismo; a debilidade dos grupos urbanos que pretenderam assumir a liderança política; e a crise sociopolítica, do ponto de vista das elites, com a incorporação das massas no jogo político. Essas últimas não estavam em cena apenas para servir à manipulação. No populismo encontraram espaço para mobilização e formas de expressar sua insatisfação (WEFFORT, 1979, pp. 61-63).

Em outra chave, Marcia D'Alessio, em sua tese de Doutoramento apresentada em novembro de 1979, e defendida em 1980, na Université de Paris I - PanthéonSorbonne, sob a orientação de Pierre Vilar, intitulada Problematique nationale et populisme dans le Brésil de Getúlio Vargas, discute a formação do Estado-nação e o surgimento do fenômeno populista no Brasil, como resultado do processo de formação histórica nacional baseado nos "poderes locais". O populismo seria também uma reação a tais "poderes". 
A autora, não obstante considere a formação étnica do país como um elemento importante para a compressão da realidade brasileira, privilegia na sua análise a questão dos "poderes locais" relacionando-a com a sua problemática central, qual seja, do surgimento do populismo no país. Para isso, numa síntese de longa duração, analisa aspectos considerados pertinentes desde o período colonial. Entendendo que a origem dos "poderes locais" teria relação com o "espírito da colonização portuguesa" e com a forma de ocupação do território "descoberto". O fato de a colônia ter sido considerada por Portugal como um prolongamento da sua própria economia, diferente do que ocorreu com as colônias inglesas, por exemplo, eliminou contradições - nos primeiros anos de colonização - entre Metrópole e Colônia. Por conseguinte, permitiu e fortaleceu a consolidação dos poderes locais (D'ALESSIO, 1979, p. 5).

Passado esse período inicial da colonização, as contradições econômicas entre Metrópole e Colônia começam a surgir. Na tese, Marcia D’Alessio não se preocupa com uma periodização desses momentos decisivos para a compreensão da mudança de postura da Metrópole. De todo modo, apresenta os fatores que fazem surgir essas contradições: 1. A decadência do comércio entre as Índias e Portugal; 2. A descoberta de minas de ouro e diamantes em Minas Gerais; 3. O monopólio que a metrópole passa a exercer sobre todas as atividades econômicas da colônia; 4. A pressão da metrópole contra o desenvolvimento econômico da colônia, que se fez sentir pela interdição de toda atividade manufatureira no Brasil (D'ALESSIO, 1979, p. 7).

Tais contradições, reforçadas pelo consequente endurecimento da autoridade metropolitana, tanto no nível econômico quanto político, encetou um processo de fortalecimento do poder público sobre o privado, produzindo um quadro que se manterá ao longo da história política do Brasil durante longo período, e que se manifestou na luta, por exemplo, entre Federalismo e Unitarismo, entre Regionalismo e Centralização nacional.

Segundo a autora, com a independência, em 1822, as contradições entre poder central e poderes locais atingiu seu ápice. Os interesses das oligarquias "hegemônicas", fortalecidas economicamente passam a visar sua expansão no âmbito político. Tais oligarquias, descontentes com a centralização política do período imperial, engendraram a instauração do regime republicano. Após dois presidentes militares, a oligarquia civil se instalou no poder e a ele estará ligada até 1930 (D’ALESSIO, 1979, p. 8). 
Logo se vê que este era um período de intensas disputas, com projetos de nação antagônicos, cuja vitória dependerá da entrada de um novo ator político no jogo, qual seja, as massas. A vitória de Vargas sobre projetos regionais de poder esteve atrelada na sua capacidade de articular interesses diversos, apaziguar tensões e neutralizar seus críticos. Deste modo, entendemos o interesse do Estado na promoção da educação popular como meio de garantir participação eleitoral. Ao mesmo tempo que defendemos que os ganhos, as conquistas das camadas populares nesse jogo de interesses também se fizeram presentes.

Ainda com Francisco Weffort, temos o destaque do movimento de educação popular como "uma das várias formas de mobilização adotadas no Brasil" a medida em que se expandiu a participação dos "de baixo" pelo voto e também através de organismos surgidos no processo de desenvolvimento social, econômico e político pós 1930 (WEFFORT in FREIRE, 1967, p. 09).

Tal desenvolvimento implicou a transformação de velhas ideias e movimentos e o surgimento de novos a exemplo da esquerda católica que trocou a "assistência" pela "transformação das estruturas sociais", a contemplação pela ação, a elaboração teórica pela práxis (DULLO, jun/2014, p. 53).

Da Juventude Universitária Católica nasceu a Ação Popular com forte atuação estudantil, também em movimentos pela sindicalização de trabalhadores rurais, sobretudo, na região nordeste do país, nos círculos populares de cultura e no Movimento de Educação de Base.

A Paulo Freire não escapou a percepção de que o Brasil vivia um momento de mudanças e que a emergência das classes populares na cena política se constituía num desafio, nem tanto para as elites, mas, sobretudo, para as massas. Eduardo Dullo, pesquisador da obra de Freire, evidencia que na tese do educador, em 1959, Educação e Realidade Brasileira, o argumento central pode ser resumido na "antinomia fundamental" entre a entrada das massas na cena pública e sua pouca "disposição mental" para a ação.

A indisposição das massas teria suas razões no caráter autoritário não só de regimes recentes, como a ditadura do Estado Novo, 1937-1945, mas no nosso passado colonial, quando o povo, na visão de Freire, não existia, havendo apenas senhores e escravos. Dessa visão decorre aquela que será a questão norteadora do trabalho de Freire: como trabalhar para emancipar um povo que não se vê, e nem é visto pelos outros, como tal (DULLO, 2014, p. 25)? 
Testemunha e sujeito da história no Brasil dos anos 50, apresentado como existencialista cristão, ou teórico pós-colonial, Freire foi influenciado por pensadores católicos engajados na ação política e defensores da democracia.

O significado do passado escravista e colonial, Freire buscou entre alguns dos que, nos anos 50, eram considerados os principais intérpretes da sociedade e história do Brasil: Gilberto Freyre, Oliveira Vianna, Caio Prado Jr, Fernando Azevedo e os intelectuais que faziam parte do Instituto Superior de Estudos Brasileiros, o ISEB (DULLO, 2014, p. 54).

Acredita-se geralmente que sou autor desse estranho vocábulo "conscientização" por ser este o conceito central de minhas ideias sobre educação. $\mathrm{Na}$ realidade foi criado por uma equipe de professores do INSTITUTO SUPERIOR DE ESTUDOS BRASILEIROS por volta de 1964. Pode-se citar entre eles o filósofo Álvaro Pinto e o professor Guerreiro. Ao ouvir pela primeira vez a palavra conscientização, percebi imediatamente a profundidade de seu significado, porque estou absolutamente convencido de que a educação, como prática da liberdade, é um ato de conhecimento, uma aproximação crítica da realidade (FREIRE, 1979, p. 15).

Com tal postura crítica, e reconhecendo mesmo os limites da atuação do Estado na promoção da democracia e da cidadania no Brasil, Freire buscou aprender e apreender a realidade nacional para transformá-la a favor dos oprimidos. Orientando-se pelas reflexões sociológicas do período, construiu seu método na prática educativa para a liberdade, na intenção de uma educação libertadora, base do movimento da educação popular.

De todo modo, Paulo Freire teve que lidar com questionamentos sobre uma posição defendida nos anos 60 , qual seja, a da aliança entre as elites e o povo. Obviamente, este não um compromisso defendido apenas por Freire, mas por todo um grupo de intelectuais que, na época, era considerado dos mais progressistas. De fato, é preciso colocar as ideias no contexto em que foram elaboradas, para daí sair uma análise crítica que forneça elementos para a superação de potenciais contradições presentes nelas (HADDAD, 2019, p. 149).

Por esta razão, vale a pena mais uma palavra sobre o movimento da Educação Popular.

\section{O Movimento da Educação Popular}


O tema da educação das classes populares, reconhecidamente oprimidas, ou do povo, perpassa e é o centro da obra de Paulo Freire. Em Pedagogia do oprimido, considerada sua obra mais importante, em diálogo com autores marxistas, como Lênin, Marcuse, Fromm, Lukács, Freire discute, em profundidade, a relação entre opressores e oprimidos, dando evidência à dimensão política da educação e contrapondo concepções educativas.

Em síntese, para Freire, a expressão educação popular designa a educação feita com o povo, com os oprimidos ou com as classes populares, a partir de uma determinada concepção de educação: a educação Libertadora, que é, ao mesmo tempo, gnosiológica, política, ética e estética. Esta educação, orientada para a transformação da sociedade, exige que se parta do contexto concreto/vivido para se chegar ao contexto teórico, o que requer curiosidade epistemológica, a problematização, a rigorosidade, a criatividade, o diálogo, a vivência da práxis e o protagonismo dos sujeitos (PALUDO, 2019, p. 172).

Essa educação com o povo, uma vez enunciada, rompe com a tradição conservadora sobre o papel da escola. E mesmo com a visão de muito autores marxistas que viam a atuação das vanguardas, ou seja, dos intelectuais à frente do povo, guiando-o rumo à revolução. Freire advogava uma educação junto com o povo. E nisso ficará fiel por toda a vida.

Nesse sentido, Carlos Rodrigues Brandão expõe a perspectiva da educação popular:

temos proclamado também a existência alternativa de um modelo, que, em diferentes contextos limitados de realização de trabalho pedagógico, tem gerado inúmeras possibilidades reais de uma prática educativa com o povo; uma educação que quer ser autônoma e produtora de autonomia de classe, dialogal, comprometida, participante, crítica, conscientizadora, livre e libertadora (BRANDÃO, 1994).

De todo modo, a derrota do movimento da educação popular duramente golpeada em 1964, encerrou um período de emergência das classes populares na arena política e, também, no acesso à educação formal. Devemos lembrar que o pacto populista, na sua relação de pressão e barganha com as camadas trabalhadoras, ofereceu condições de melhoria do padrão de vida e das oportunidades educacionais dessa classe. 
Imaginemos se, num esforço de contra história, tivéssemos tido a oportunidade de vivermos um regime democrático consolidado e sem intervalos autoritários. Possivelmente estaríamos hoje, em relação ao projeto de Paulo Freire, num patamar de autonomia e liberdade muito maiores. Devidamente livres de certo traço populista que acompanha a cultura política brasileira, e mais conscientes do papel de cada um e de todos na construção de uma sociedade democrática. Até porque a democracia como regime político, deve ser exercitada cotidianamente, e na medida que esse exercício é constante seus limites e problemas vão sendo sanados.

\section{Referências}

BRANDÃO, Carlos Rodrigues. Os caminhos cruzados: formas de pensar e realizar a educação na América Latina. In. GADOTTI, Moacir; TORRES, Carlos Alberto (orgs.). Educação Popular: utopia latino-americana. São Paulo: Edusp, 1994.

D'ALESSIO, Marcia Mansor. Problematique nationale et populisme dans le Brésil de Getúlio Vargas. Tese (Doutorado) - Université de Paris I - Panthéon-Sorbonne. Paris, França. 1980.

DULLO, Eduardo. Paulo Freire, o Testemunho e a Pedagogia Católica - A ação histórica contra o fatalismo. Revista Brasileira de Ciências Sociais, v. 29, n. 85, jun/2014.

Disponível em: https://www.scielo.br/j/rbcsoc/a/zK76dRtXQRdd9BpqL59SgbD/?lang=pt. Acesso em: 18/08/21 (pp 49-61).

DULLO, Eduardo. Paulo Freire e a produção de subjetividades democráticas: da recusa do dirigismo à promoção de autonomia. In: JEFFREY, Débora C.; SMOLKA, Ana Luiza B.; ALMEIDA, Ana Maria F. (org.) Dossiê: Paulo Freire e o Debate Educacional Contemporâneo. Revista Pro-Posições, v. 25, n.3, set/dez 2014 (pp 2343). Disponível em: https://www.scielo.br///pp/a/kLwD68zXpDarYyHDMRG49Hv/?lang=pt. Acesso em: 20/08/21.

FREIRE, Paulo. Conscientização: teoria e prática da libertação - uma introdução ao pensamento de Paulo Freire. São Paulo: Cortez \& Moraes, 1979. 
FREIRE, Paulo. Educação como prática da liberdade. Rio de Janeiro: Paz e Terra, 1967.

GOMES, Angela de Castro. As marcas do período. In: GOMES, Angela de Castro (coord.). Olhando para dentro - 1930-1964. Madrid: Fundacíon Mapfre; Rio de Janeiro: Objetiva, 2013 (col. História do Brasil Nação (1808-2010), v. 04).

HADDAD, Sérgio. O educador: um perfil de Paulo Freire. São Paulo: Todavia, 2019.

PALUDO, Conceição. Educação Popular. In. STRECK, Danilo; REDIN, Euclides; ZITKOSKI, Jaime (orgs.). Dicionário Paulo Freire. 4 ed. rev. e ampl. Belo Horizonte: Autêntica, 2019.

WEFFORT, Francisco C. Educação e Liberdade - Reflexões Sociológicas sobre uma Pedagogia da Liberdade. In: FREIRE, Paulo. Educação como Prática da Liberdade. Rio de Janeiro: Paz e Terra, 1967.

WEFFORT, Francisco C. O populismo na política brasileira. Rio de Janeiro: Paz e Terra, 1978. 


\title{
FREIRE E BRENNAND: CONSIDERAÇÕES CINQUENTA E SETE ANOS DEPOIS
}

\author{
Margarete Barbosa Nicolosi Soares \\ A alegria não chega apenas no encontro do achado, mas \\ faz parte do processo da busca. \\ E ensinar e aprender não pode dar-se fora da procura, fora \\ da boniteza e da alegria.
}

Paulo Freire

\section{CONTEXTUALIZAÇÃO: DO MOVIMENTO DE CULTURA POPULAR ÀS FICHAS DE CULTỦRA}

Refletir e escrever sobre as imagens do Apêndice do livro Educação como prática de liberdade foi um desafio que nos remeteu ao ano de 2009, na ocasião do Seminário: Ações Singulares 2, sobre a História do Ensino da Arte: Experiências, no Instituto Tomie Ohtake. Antes do evento, encontra-se o arte-educador Fernando de Azevedo, presidente da Escolinha de Arte do Recife, à época, na Avenida Paulista, em São Paulo. Ele estava entusiasmado com a palestra que daria no Seminário pela responsabilidade de resgatar o lugar e a importância dos Círculos de Cultura na história do ensino da arte no Brasil. Fernando esteve numa aula de campo no Museu Oficina Brennand, em Recife, com um grupo de professores da rede pública, cuja maioria nunca tinha ido a um museu. E qual foi a sua surpresa quando viu um conjunto de pinturas à guache, que seriam algumas das ilustrações realizadas para as fichas de cultura de Freire que haviam sido apreendidas pela ditadura.

Para Azevedo (2009, p.101) "arte e estética são dimensões da vida humana”, e complementa: "nos ajuda a interrogar e nos arranca da anestesia para vermos algo mais do que apenas a ideia de beleza."

A memória afetiva e a investigação sobre a alfabetização freireana conduzem as ideias refletidas no presente artigo.

Paulo Freire, um jovem educador no início da década de 60, atuou na alfabetização de adultos nos Círculos de Cultura do Movimento de Cultura Popular 
(MCP). Os círculos quebravam a hierarquia e rompiam com a "cultura do silêncio", como denunciava Paulo Freire quando se referia à educação bancária, onde o professor era considerado o único detentor do saber e o educando como aquele que nada sabia.

De acordo com o antropólogo Carlos Rodrigues Brandão, um dos fundamentos de Freire no processo de alfabetização no Círculo, era:

\begin{abstract}
Alfabetizar-se, educar-se (e nunca: "ser alfabetizado, "ser educado") significa algo mais do que apenas aprender a ler palavras e desenvolver certas habilidades instrumentais. Significa aprender a ler crítica e criativamente "o seu próprio mundo". Significa aprender, a partir de um processo dialógico em que importa mais o próprio acontecer partilhado e participativo do processo do que os conteúdos com que se trabalha, a tomar consciência de si mesmo (Quem de fato e de verdade sou eu?). Tomar consciência do outro (Quem são os outros com quem convivo e partilho a

vida? Em que situação e posições nós nos relacionamos? E o que isso significa?); e tomar consciência do mundo (O que é o mundo em que vivo? Como ele foi e segue sendo socialmente construído para haver-se tornado assim como é agora? O que nós podemos fazer para transformá-lo?)" (BRANDÃO, 2008, p. 78).
\end{abstract}

O processo de aprendizagem no Círculo de Cultura passava pela apreensão e apropriação significativa intrínseca ao desenvolvimento da capacidade de leitura de mundo, que não se dá solitariamente e sim em relação ao outro. Assim, arte e educação para Freire eram indissociáveis, conforme afirmou sua ex-aluna, amiga e arte-educadora Ana Mae Barbosa:

Poucos sabem que Paulo Freire esteve ligado à Arte/Educação desde os inícios de sua ação educacional. Foi presidente da Escolinha de Arte do Recife nos anos 50, e sua mulher Elza Freire pode ser considerada uma das pioneiras da integração da Arte na Escola Pública, dando ênfase às produtivas implicações do fazer artístico com a alfabetização (BARBOSA apud GADOTTI, 1996, p. 637)

Soma-se ainda o fato de que, junto de Freire, um dos fundadores do Movimento de Cultura Popular, faziam parte do movimento mais dois nordestinos defensores da arte e da cultura brasileira, que se destacavam: Francisco Brennand e Ariano Suassuna, entre outros. O Movimento criou também o Centro de Artes Plásticas e Artesanato e a Galeria de Arte do Recife (AZEVEDO:2009:102). A 
criação do Círculo de Cultura e do Centro de Artes pelo Movimento demonstra a luta pela democratização dos saberes e dos fazeres artísticos concomitantemente, ou seja, a luta pela educação e pela arte.

\section{A ESTÉTICA DA EDUCAÇÃO LIBERTÁRIA}

As experiências de Paulo Freire com o Movimento de Cultura Popular e os Círculos de Cultura culminaram com a criação do Sistema de Alfabetização na década de 60, de cunho político ideológico, que chegou a alfabetizar em Angicos, Rio Grande do Norte, 300 pessoas em 48 horas. A repercussão dessa façanha resultou na elaboração do Programa Nacional de Alfabetização sob coordenação de Paulo Freire, cujo início se deu na Baixada Fluminense, Rio de Janeiro, objetivando a alfabetização de cinco milhões de pessoas em dois anos. O programa foi brutalmente esfacelado pelo golpe de estado de 64. A Campanha do Programa de Alfabetização foi denunciada publicamente como "perigosamente subversiva" (BRANDÃO, 1981, p.19).

O sistema fazia inicialmente um levantamento do vocabulário da comunidade a ser alfabetizada, identificando seus desejos e necessidades, por meio de uma roda de conversa informal sobre a realidade em que viviam. Destas conversas extraiam-se palavras geradoras codificadas em fotografias ou desenhos que davam origem às fichas de cultura com as famílias silábicas. Os desenhos das fichas de aprendizagem da experiência de Angicos foram idealizados por um desenhista de Natal. Este fato denota a preocupação estética de Freire naquela época e ainda não compreendida por muitos setores da Educação no Brasil até os dias de hoje. Em 1963 o MEC reproduziu uma nova série de desenhos mais elaborados e editados pelo Instituto Nacional de Cinema Educativo. A terceira série de desenhos foi realizada por Francisco Brennand, pintor, desenhista, ilustrador, gravador e famoso ceramista pernambucano, conforme conta Fávero:

Paulo Freire mostrou aos mais próximos uma série de desenhos em aquarela, explicando: "Vejam o que ganhei do Brennand. Ele me disse: 'Você vai levar aqueles desenhos feios para o Ministro? Deixa que faço outros melhores."' Recentemente, Brennand afirmou que produziu as referidas fichas pela intervenção de um amigo comum, Ariano Suassuna. Esta série original foi "requisitada" pelos militares, em um dos inquéritos a que foi submetido Paulo Freire, e nunca mais localizada. Os desenhos eram reproduzidos 
em dispositivos, abrindo o "filminho" que seria usado nos círculos de cultura do Programa Nacional de Alfabetização, criado pelo MEC, no final de 1963. (FÁVERO, 2012, p. 475)

O Sistema de Alfabetização de Paulo Freire priorizava a reflexão sobre o conceito antropológico de cultura como a marca que o homem deixa no mundo em consequência do seu trabalho.

Brennand era um pesquisador da arte popular e dela se valeu para desenvolver uma estética significativa para seus interlocutores. Ele apresentou representações iconográficas do povo brasileiro. O caráter de suas imagens enaltece a natureza, o homem do campo e da floresta, e a cultura popular pela qualidade estética dando a ela o mesmo status da cultura erudita, sem hierarquização.

Mesmo com as pinturas de Brennand tendo sido cassadas, Freire não desistiu da luta pela educação em consonância com a arte. O educador convidou o artista Vicente de Abreu para ilustrar algumas situações das 17 palavras geradoras do curriculum dos Círculos de Cultura do Estado do Rio e da Guanabara para o apêndice do livro Educação como Prática da Liberdade (2017). As imagens representam as vivências existenciais que favorecem a compreensão do conceito de cultura e leitura de mundo.

Não é possível realizar uma leitura estética adequada das pinturas originais concebidas por Brennand, uma vez que observador não está diante delas materialmente. A dimensão da composição, a textura da pincelada, a tonalidade das cores, são elementos carregados de significações. As imagens disponíveis são reproduções fotográficas das pinturas acessíveis pela internet, possibilitando apenas uma leitura dos vestígios das imagens originais. A leitura parcial será realizada segundo os estágios de leitura de imagem estabelecidos por Michael Parsons no livro Compreender a Arte (1992):

1. Descrever: identificar o que se vê na imagem visual, apenas o que está em evidência.

2. Analisar: identificar na imagem elementos da composição, estabelecendo relações entre eles. 
3. Interpretar: dar sentido ao que observou na imagem, procurando identificar quais os sentidos, ideias, sentimentos e expressões intencionadas pelo artista.

4. Julgar: emitir juízo de valor sobre a imagem, se é ou não importante e se tem qualidade estética.

As imagens concebidas originalmente por Brennand para as fichas de cultura (lado esquerdo) eram coloridas e os desenhos equivalentes de Vicente de Abreu são pretos e brancos (lado direito). A obra de Freire é atemporal e nos desafia a realizar uma leitura de caráter pessoal das imagens desde o seu contexto original até os dias de hoje, apesar de não serem mais utilizadas.

Figura 1 - 0 homem no mundo e com o mundo. Natureza e cultura

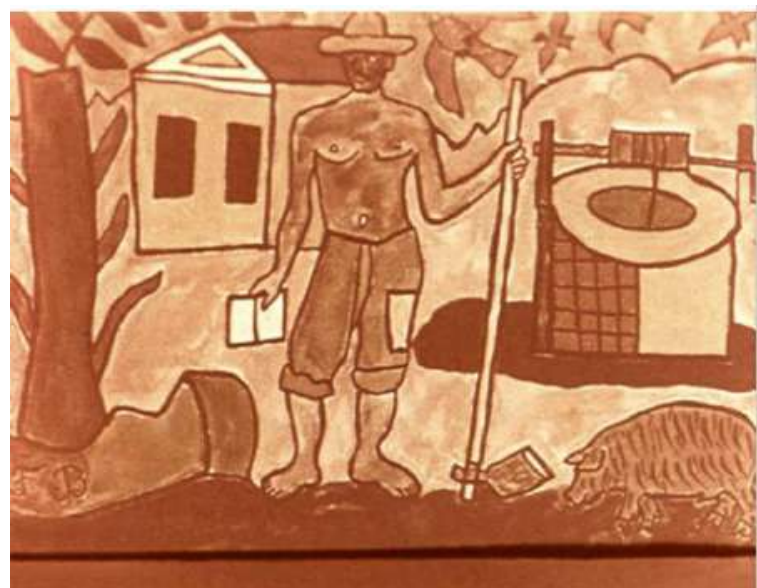

Francisco Brennand

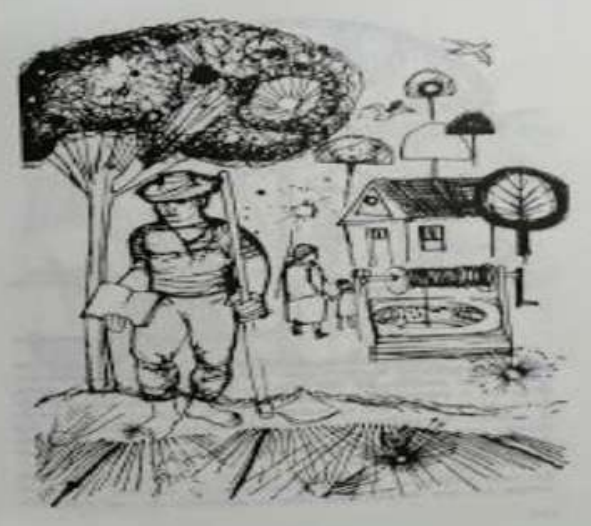

Vicente de Abreu

A composição apresenta seus elementos figurativos sobre a linha de base (terra) em torno do eixo principal homem (centro), representando suas relações com a terra, a árvore, os animais, a casa, a enxada, o poço e o livro. O poço produz a água, essencial para vida humana; o porco é criado no terreiro e alimenta a família, fornecendo a banha para cozinhar; os pássaros simbolizam a liberdade, consequência da cultura letrada (simbolizada pelo livro) e do trabalho do homem na terra (enxada). Ou seja, a imagem sugere questões sobre a necessidade que leva o homem a construir uma casa, cavar um poço, plantar e colher. A composição retrata a essência das relações entre o homem, o trabalho, a natureza e a cultura de forma igualitária e não hierarquizada. O desenho é marcado pelo contorno, mas não apresenta perspectiva e ilusão de profundidade, típico da cultura popular que 
pelas mãos dos artistas alcança o mesmo status da cultura erudita. A imagem remete a um dos conceitos que fundamenta o círculo de cultura:

Cada pessoa é uma fonte original e única de uma forma própria de saber, e qualquer que seja a qualidade deste saber, ele possui um valor em si por representar à representação de uma experiência individual de vida e de partilha na vida social. (BRANDÃO, 2008, p. 77)

Atualmente, a imagem poderia representar a luta do Movimento dos Trabalhadores Rurais sem Terra (MST) pela Reforma Agrária. Será que se o sistema educativo estético freireano não tivesse sofrido uma derrocada em 1964, estaríamos 50 anos depois tendo que lutar pelos mesmos direitos básicos?

Figura 3 - Caçador iletrado

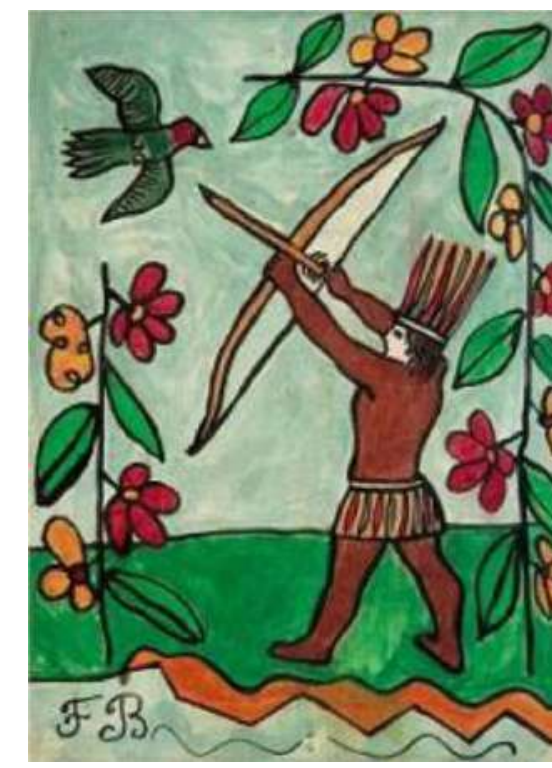

Francisco Brennand

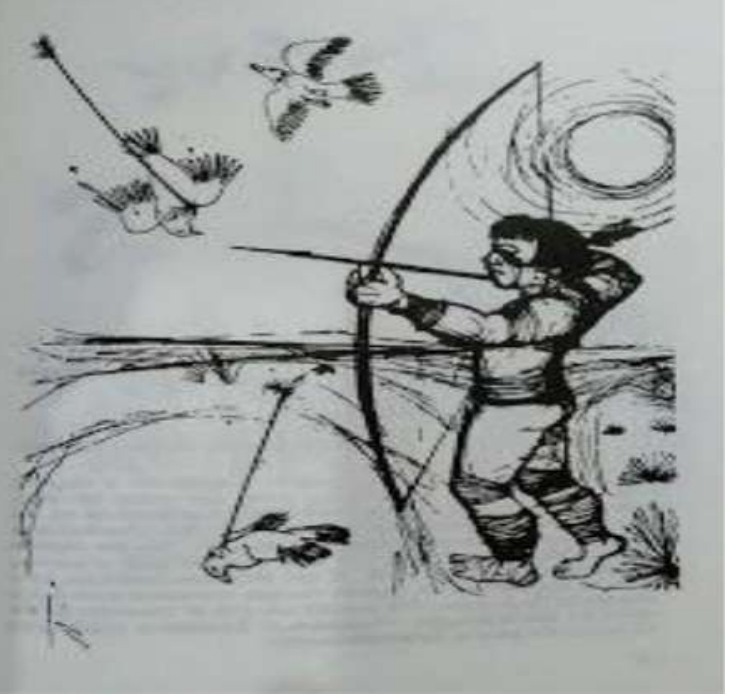

Vicente de Abreu

O homem da floresta é retratado originalmente nas cores marrom, vermelho, laranja, verde, preto e branco, o que Brennand chamou numa conversa com Ariano de "contraste inocente". O contraste das cores estabelece uma diferença imediata entre os elementos e facilita sua identificação na composição. A imagem reflete a relação do homem com a natureza, a necessidade de comer e se vestir que gerou a construção do arco e flecha para matar a presa sem tocá-la. Confeccionar o arco, a flecha, o cocar e o saiote de penas é produzir cultura. Transmitir esse saber-fazer para as gerações mais jovens é uma ação educativa. A imagem exemplifica outro fundamento do círculo: 
[...] cada cultura representa um modo de vida e uma forma original e autêntica de ser, de viver, de sentir e de pensar de uma ou várias comunidades sociais. Cada cultura só se explica de seu interior para fora, e os seus componentes "vividos e pensados" devem ser o fundamento de qualquer programa de educação ou transformação social. (Brandão, 2008, p. 77)

O povo da floresta não adentra a mata sem pedir licença, não mata qualquer pássaro sem que seja permitido, pois ele considera todos os elementos da natureza igualitariamente como partes integrantes de um mesmo universo e dele mesmo, conforme afirmou Aílton Krenak recentemente em palestra, no curso "Saberes Ancestrais e Práticas de Cura".

Figura 4 - Caçador letrado (cultura letrada)

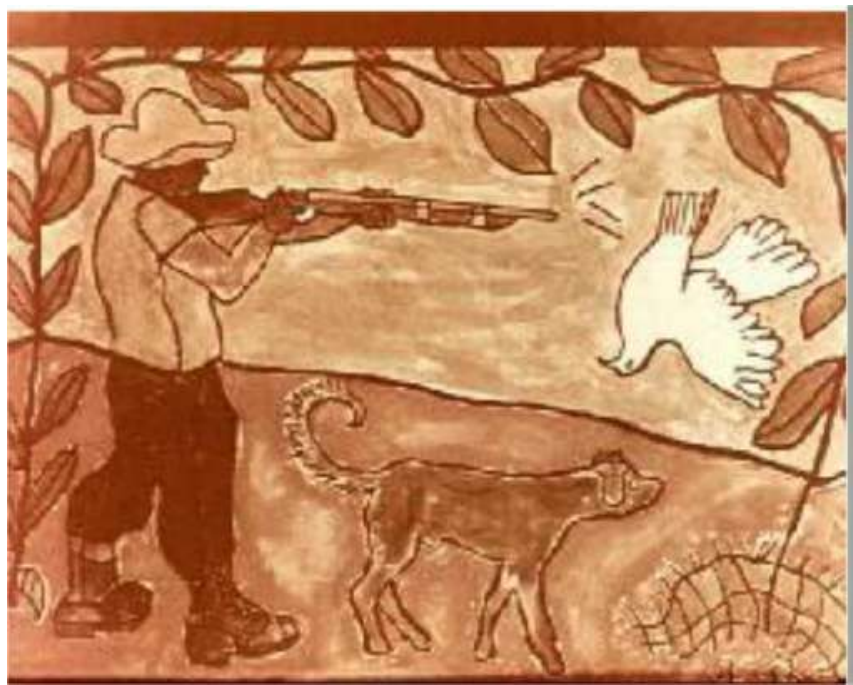

Francisco Brennand

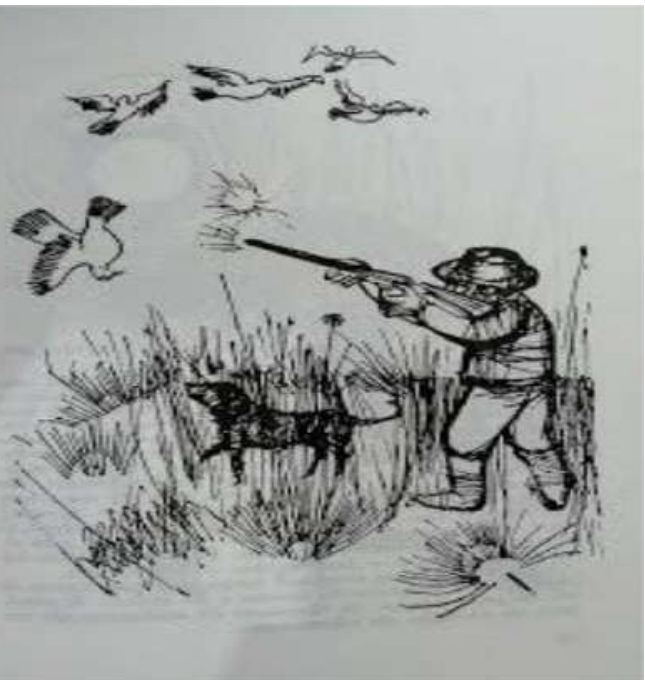

Vicente de Abreu

A composição de todas as figuras é marcada pelo contorno, para que as pessoas possam enxergar de longe (no caso de Brennand) e distinguir cada elemento do outro. No desenho de Abreu, além da queda do pássaro, nosso olhar segue os outros pássaros que voam em liberdade. A situação possibilita reconhecer o caçador como homem da cultura, mesmo que analfabeto, assim como a evolução tecnológica do arco e flecha para espingarda. Ambas as imagens favorecem a reflexão sobre a educação no desenvolvimento humano como alavanca libertadora. As discussões nos Círculos de Cultura com Paulo Freire levaram a compreensão de que o homem da floresta (fig. 3) e o caçador estão em "fases histórico-culturais" 
distintas, reconhecem a cultura e educação dos povos da floresta, e salientam a opressão vivida pelo homem iletrado, mas que com a alfabetização torna-se parte da cultura letrada e poderá dar o salto de oprimido para protagonista da própria vida. (FREIRE:1977:128)

Figura 5 - O homem transforma a matéria da natureza com seu trabalho

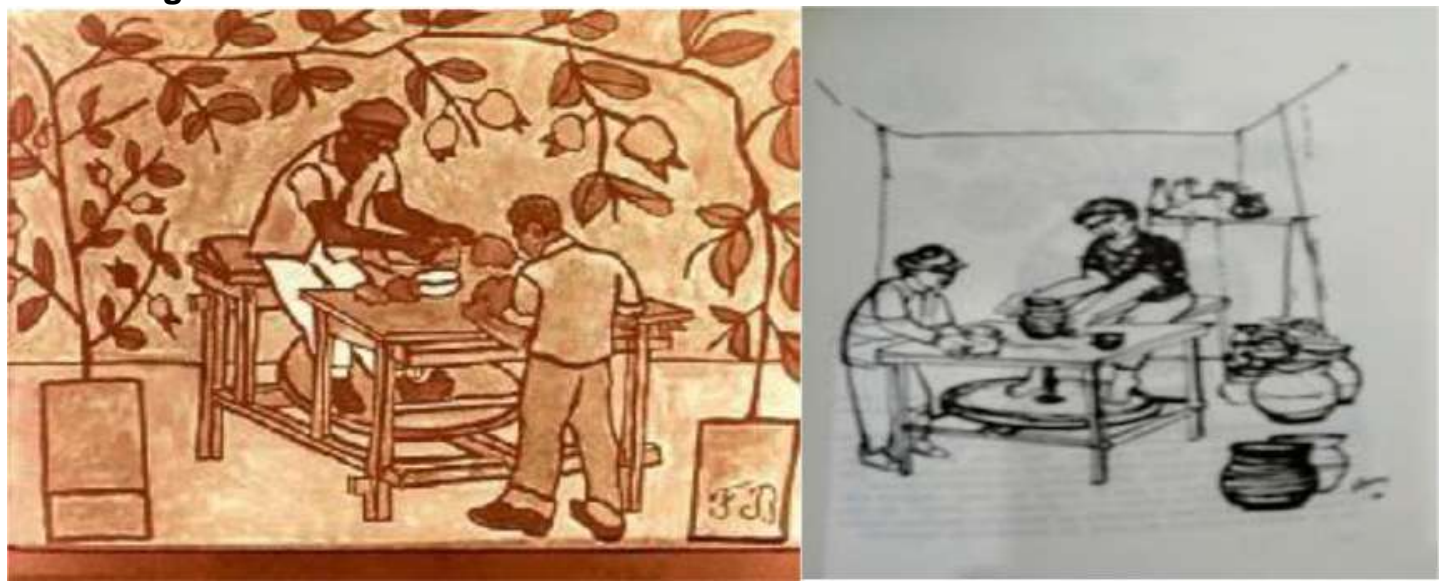

Francisco Brennand

Vicente de Abreu

A pintura de Brennand novamente está emoldurada pela natureza. Pode-se identificar a relação do homem consigo mesmo enquanto move seus pés no torno, com o barro na modelagem e com o outro dividindo a mesma bancada. Vê-se na imagem a tríade perfeita: homem, natureza e cultura. Enquanto o homem modela o barro, o barro molda o homem. Os frutos que alimentam o homem também carregam

sementes que podem germinar novos e outros projetos e ideias que favoreçam novas transformações da sociedade autoritária para democrática. A situação leva ao debate sobre o saber-fazer e ensinar como possibilidade de criar objetos da cultura: um vaso, uma quartinha ou uma panela. A imagem dignifica o homem que vive em harmonia com a terra e dela faz seus objetos estéticos e utilitários, produzindo a sua cultura.

Conclui-se assim, com uma síntese do Círculo de Cultura:

Ninguém educa ninguém, mas também ninguém se educa sozinho, embora pessoas possam aprender e se instruir em algo por conta própria. As pessoas (...) educam-se umas às outras e mutuamente se ensinam e aprendem através de um diálogo midiatizado por mundos de vivência e de cultura entre seres humanos, grupos e comunidades diferentes, mas nunca desiguais. (BRANDÃO, 2008, p. 78) 


\section{CONSIDERAÇÕES FINAIS}

Freire afirmou no livro A importância do ato de ler (1981) que "a leitura do mundo precede a leitura da palavra". O universo vocabular do homem do campo e da floresta retratado nas fichas de cultura possibilitou a identificação da pessoa iletrada com a sua vida, história e cultura, favorecendo a aprendizagem da leitura e escrita das palavras significativamente e sua consequente inserção na cultura letrada.

\footnotetext{
Educar e educar-se, na prática da liberdade, é tarefa daqueles que pouco sabem - por isto sabem que sabem algo e podem assim chegar a saber mais - em diálogo com aqueles que, quase sempre, pensam que nada sabem, para que estes, transformando seu pensar que nada sabem em saber que pouco sabem, possam igualmente saber mais. (FREIRE, 1996, p. 25)
}

Ao comemorarmos o centenário de aniversário de Paulo Freire vive-se um desmantelamento de conquistas e de retrocesso na Educação Brasileira. As imagens das fichas de cultura hoje nos fazem lembrar que, como Paulo Freire, não se pode desistir de caminhar nas trilhas da educação estética em defesa da nossa cultura, da natureza e do meio ambiente, dos animais, dos povos da floresta, das nossas raízes africanas, da dignidade humana e da nossa liberdade; que só será alcançada quando erradicarmos a miséria, o analfabetismo e todos os resquícios de exclusão humana social no Brasil.

\section{REFERÊNCIAS}

AZEVEDO, Fernando Antônio Gonçalvez de. Projetos sociais e ateliês livres: Tudo começa com o Movimento de Cultura Popular e os Círculos de Cultura? In: História do Ensino da Arte: Experiências. Seminário: Ações Singulares 2. Instituto Tomie Ohtake. São Paulo: 2009, p. 98 - 105.

BRANDÃO, Carlos Rodrigues. Paulo Freire, educar para transformar: fotobiografia. São Paulo: Mercado Cultural, 2005. 
diciembre, 2012, pp. 465-483. Universidade de Brasília.

https://periodicos.unb.br/index.php/linhascriticas/article/view/3988 disponível em 03.04.2021.

FREIRE, Paulo. Educação como prática da liberdade. $7^{\mathrm{a}}$ ed. Rio de Janeiro: Paz e Terra, 1977.

FREIRE, Paulo. A importância do ato de ler: em três artigos que se completam. São Paulo: Editora Cortez, 1981.

GADOTTI, Moacir (org.). Paulo Freire: uma bibliografia. São Paulo: Cortez: Instituto Paulo Freire; Brasília, DF: UNESCO, 1996.

PARSONS, Michael. Compreender a arte. Lisboa: Presença, 1992.

\section{REFERÊNCIAS DAS FIGURAS}

Figuras 1, 2, e, 4 e 5 de Francisco Brennand. www.acervo.paulofreire.org:8080/jspui/handle/7891/656 - disponível em 03.04 .2021

\section{Figuras 1, 2, 3, 4 e 5 de Vicente de Abreu.}

www.aristotelesberino.blogspot.com/2017/10/paulo-freire-trama-das-imagensentre-o.html - disponível em 03.04.2021. 


\title{
DIÁLOGO ENTRE A ALFABETIZAÇÃO E A MATEMÁTICA: REFLEXÃO PARA UMA PRÁTICA LIBERTADORA
}

\author{
MARIA DAS GRAÇAS BEZERRA BARRETO \\ SIRLEI IVO LEITE ZOCCAL
}

\section{RESUMO}

O artigo resulta de um estudo sobre o movimento metodológico da alfabetização, refletindo como a proposta freiriana encontra-se presente no contexto atual, tanto no ensino presencial como a distância. Destaca-se a reflexão como princípio de uma boa situação de aprendizagem, superando a utilização de quaisquer métodos de ensino. Em uma abordagem qualitativa, utilizou-se como coleta de dados a pesquisa bibliográfica e experiências das pesquisadoras na Cátedra Paulo Freire e em cursos para formação de professores. Os resultados sinalizam que a alfabetização e letramento matemático permeados pelo diálogo e a reflexão/criticidade defendidos por Freire em 1965, perpassam pelas diferentes modalidades de ensino e áreas do conhecimento.

PALAVRAS-CHAVE: Ensino e aprendizagem, ação, reflexão, situação significativa, prática libertadora.

\section{INTRODUÇÃO}

O artigo apresenta um recorte do trabalho desenvolvido em cursos para formação de professores e objetiva uma reflexão sobre o movimento metodológico da alfabetização, destacando como a proposta freiriana implícita nessa trajetória permite relacioná-la ao processo do ensino da língua materna e da matemática, no contexto atual.

A pesquisa de abordagem qualitativa teve como procedimentos metodológicos para coleta de dados a pesquisa bibliográfica e experiências das pesquisadoras em grupo de estudo da Cátedra Paulo Freire e em cursos para formação de professores, nas modalidades presencial e ensino a distância - EaD.

A alfabetização considerada como o ensino de leitura e escrita das crianças em fase inicial de escolarização tem sido uma preocupação constante das políticas públicas e despertado o interesse de muitos pesquisadores desde o século passado, promovendo o surgimento de diferentes métodos, concepções e estudos sobre a temática.

No decorrer do artigo serão expostos a trajetória de Paulo Freire e a releitura de um de seus legados - Educação como prática de liberdade -, com ênfase nos 
capítulos que abordam a massificação e conscientização, objetos centrais deste estudo. Na sequência, o artigo focaliza o embasamento teórico que fundamenta a relação entre o ensino inicial da língua materna e da matemática. Apresenta os procedimentos utilizados para descrever o relato da prática e enfatiza a importância da reflexão sobre o processo de aprendizagem e seu sistema organizacional, como também, os conceitos de alfabetização, letramento e multiletramentos. Após a análise dos dados, dá-se a finalização do trabalho com as considerações como espaço nobre de reflexão sobre as possibilidades que resultaram deste estudo.

\section{PAULO FREIRE E O MÉTODO DIALÓGICO}

Paulo Reglus Neves Freire, formado na Faculdade de Direito do Recife, passou a sua vida dedicado à educação e teve suas obras reeditadas em diferentes idiomas.

O estudo coletivo do legado de Paulo Freire permitiu uma releitura critica do livro "Educação como prática de liberdade" para compreender seus pensamentos e discuti-los frente aos desafios impostos pela atualidade sem dicotomizar teoria e prática.

O pensamento freireano, segundo define Cortella,

é novo, não é novidade. Ele é um clássico, sem ter se emoldurado num processo de engessamento. O pensamento de Freire continua animado. Paulo Freire nos anima. Quero lembrar as pessoas, se um dia virem isso mais de perto, que a palavra "animar" significa "encher de alma", de "anima", de "vida". Animar é inspirar. Paulo Freire tem um pensamento altamente inspirador (CORTELLA, 2011, p.12).

A educação propagada por Freire na década de 60 permitia ao educando uma discussão corajosa dos problemas enfrentados e desta forma se conscientizar da transitividade para ser usada criticamente e perceber as limitações de seus conhecimentos e a necessidade dos outros para ampliá-los. Propagou um agir educativo e democrático que valorizasse a cultura histórica e ideológica da humanidade e as relacionasse às condições presentes na atualidade, propiciando saberes do aprendiz que ampliassem a participação e a responsabilidade social e política. 
Freire (1965) defendia e praticava uma educação que fosse além do "discurso verboso", e que permitisse mudança constante de atitudes. Uma alfabetização que superasse o "puramente mecânico" e enfatizasse os discursos, o debate, a investigação para fortalecer o aprendiz a acreditar no seu poder em fazer, trabalhar e discutir quaisquer tipos de problemas pessoais, sociais e políticos.

Saul (2016, p. 13), que tem se dedicado a estudar Paulo Freire, assegura que sua vida e obra refletem "sua indignação contra as injustiças sociais que negam a humanização. Desde os seus primeiros escritos, esse tema esteve presente, engendrando a utopia de sua proposta político-pedagógica”.

Nesse sentido, a proposta freiriana é de uma educação como "um ato de amor e, por isso, um ato de coragem" (FREIRE, 2020, p.127).

$\mathrm{Na}$ década de 60, Freire experimentou técnicas e processos de comunicação, visando a realização de um método para uma alfabetização mais direta ligada a uma "democratização da cultura" e a "integração com a realidade" e que permitisse uma "consciência crítica". Assim, colocou em prática um "método ativo, dialogal, crítico e criticizador" que explorou um conteúdo programático adequado ao interesse dos alunos (FREIRE, 2020, p.133-140).

Ressalta-se que o processo de criação desse método originou-se no interior do Movimento de Cultura Popular - MCP do Recife, pautados nos debates ocorridos com grupos populares nos Círculos de Cultura. Para Freire (2015, p. 192) eles eram "espaços em que dialogicamente se ensinava e aprendia. Em que se conhecia em lugar de se fazer transferência de conhecimento". O conhecimento não era imposto, mas compreendido e construído.

\section{IMPORTÂNCIA DA EDUCAÇÃO E CONSCIENTIZAÇÃO}

Diante de métodos centrados no silêncio em que o aprendiz não tem o direito de opinar, apenas reproduzir o que lhe é apresentado, Freire os definia como um antidiálogo. Por isso, ressaltava que o diálogo era a comunicação entre dois polos, entre o ensinante e o aprendiz. Considerava essa interação como um ato de amor, de esperança, de acreditar um no outro e unidos pela busca de ampliar o conhecimento de forma crítica. Afinal, dialogar é muito diferente de ouvir e repetir as palavras das cartilhas, mas um mergulho na descoberta de uma dimensão humanista da cultura para o aprendizado da escrita e da leitura. Esse processo desperta o "ímpeto de criação e recriação" do analfabeto e do letrado, propiciando uma redescoberta da 
cultura como "toda criação humana". O aprender a ler e escrever não é imposto, apenas uma necessidade. Esse ato supera o "simples domínio psicológico e mecânico de técnicas" e permite apreender criticamente e entender o que se está fazendo (FREIRE, 2020, p. 141-145).

Freire (2020, p. 146) assegura que "a alfabetização não pode ser feita de cima para baixo, como doação ou uma imposição, mas de dentro para fora, pelo próprio analfabeto, com a colaboração do educador".

Nesse sentido, cabe ao docente organizar e propor atividades que sejam significativas, propiciando uma boa situação de aprendizagem, como salienta Weisz (2000, p 65-66), elas devem ser "[...] planejadas, propostas e dirigidas com a intenção de favorecer a ação do aprendiz sobre um determinado objeto de conhecimento, e essa ação está na origem de toda e qualquer aprendizagem". A autora destaca quatro princípios, envolvendo o diagnóstico sobre o saber e o pensar, a reflexão, a circulação de informações e decisões acerca do conteúdo trabalhado, que precisa ser carregado de significado social, perpassando por todos os componentes curriculares.

Assim, faz-se necessário que a escola possibilite ao aprendiz uma formação que lhe permita compreender criticamente as realidades sociais e nela agir, sabendo, para tanto, organizar a sua ação. Para isso, esse aprendiz precisa apropriar-se do conhecimento e de meios de produção e de divulgação da linguagem escrita, sobretudo no que se refere à leitura, quanto ao ensino e aprendizagem da matemática e da língua materna.

Segundo Freire, portanto, a concepção de professor autônomo e reflexivo sobre sua prática parte da própria natureza do exercício docente, uma vez que:

[...] o que há de pesquisador no professor não é uma qualidade ou uma forma de ser ou de atuar que se acrescente à de ensinar. Faz parte da natureza da prática docente a indagação, a busca, a pesquisa. O de que se precisa é que, em sua formação permanente, o professor se perceba e se assuma, porque professor, como pesquisador (FREIRE, 2003, p. 29).

As transformações resultantes de uma abordagem gerencial do trabalho pedagógico colocam em evidência a íntima inter-relação entre as políticas públicas em educação, o currículo, as práticas docentes e a formação inicial e continuada de 
professores. Na implementação de uma política pública, são criados programas com o objetivo de atender o esperado pelos proponentes com relação à alfabetização e à matemática: ler e escrever, contar e operar.

As reformas educacionais, em qualquer época, preveem melhorias em um processo evolutivo, como podemos perceber nos diferentes métodos de alfabetização e de ensino da matemática ao longo da história e na contemporaneidade. Destacamos documentos e programas que nortearam os projetos educacionais públicos e privados, tais como: os Parâmetros Curriculares Nacionais, PCN (1997), o Programa de Professores Alfabetizadores, PROFA (2001), o Plano Nacional de Alfabetização na Idade Certa, PNAIC (2007) e recentemente, o Plano Nacional de Alfabetização, PNA (2019).

Com a homologação da Base Nacional Comum Curricular - BNCC (BRASIL, 2018), documento que determina o currículo nas diferentes áreas do conhecimento durante toda a Educação Básica, deixa claro que a Matemática e a Língua Portuguesa são essenciais a todos os aprendizes e define competências necessárias à compreensão de contexto e conexão com outras áreas do conhecimento, visando a valorização da inter-relação existente entre elas.

\subsection{LER E ESCREVER NA MATEMÁTICA}

As políticas públicas têm direcionado seu foco para tentar sanar os problemas relacionados à alfabetização (ler e escrever) e à Matemática (contar e operar), demonstrando pouca preocupação com as outras áreas do conhecimento.

Para muitos há uma magnitude com relação ao ensino da Língua Portuguesa e da Matemática pelas suas diferenças, a interdependência entre elas ou a supremacia de uma sobre a outra. O discurso dos educadores tem confirmado a preponderância da língua materna quando afirmam confiantes nas formações em serviço que somente se aprende matemática quando se domina a língua materna.

Essas afirmações são refutadas pelos estudos de Machado (1998) ao assegurar que:

[...] a Matemática e a Língua Materna representam elementos fundamentais e complementares, que constituem condição de possibilidade do conhecimento, em qualquer setor, mas que não podem ser plenamente compreendidos quando considerados de maneira isolada (MACHADO, 1990, p.83). 
Percebe-se que a convicção da dependência entre esses componentes curriculares suplanta a função de complementaridade e permeia a rotina de trabalho de muitos professores dos anos iniciais escolares. A prioridade escolar está direcionada para o domínio da base alfabética - o aprender a ler e escrever -, e posteriormente, dedica-se ao ensino do contar, operar e resolver problemas. Como se esses processos fossem hierárquicos e não paralelos; distintos e não complementares.

Entretanto, trata-se de dois signos, únicos em suas construções, mas diversos em suas funções. Eles se diferenciam na representação simbólica e imagética e se assemelham na estrutura organizacional. As duas representações apresentam regras e regularidades em seus processos de composição e decomposição. Elas lidam com princípios comuns e "desenvolvem-se em ambos os sentidos, o da unidade e o da diversidade, em um permanente e indissociável processo de ir-e-vir cuja dinâmica importa cada vez mais investigar" (MACHADO, 1996, p.124). Para o autor ao ignorarse a compreensão da complementaridade entre a Matemática e a Língua Materna evita-se sanar as dificuldades de ensino que poderiam ser superadas com boas propostas de ações práticas.

Barreto (2012) salienta que na prática de sala de aula, muitos professores tolhem esse ato mágico que permite desabrochar o poder da imaginação e da criatividade, retardando ou mesmo excluindo o direito do aluno de mergulhar no universo mágico de falar, ler, produzir e interpretar tanto o código alfabético como o campo numérico. Universo que é permitido conjecturar, elaborar as próprias regras, descobrir procedimentos, refletir sobre os resultados, generalizar e abstrair. Um explorar para melhor compreensão e utilização que favoreça uma comunicação e participação mais segura, nesse mundo cultural, impregnado de imagens e linguagens que nos envolvem todos os dias. Diferentes linguagens que carecem ser descobertas, despertadas e decodificadas.

\subsection{ALFABETIZAÇÃO E LETRAMENTO}

As práticas educacionais de alfabetização têm procurado eleger um método mais adequado para ensinar a ler e a escrever. Entende-se que o método pode auxiliar, mas não é determinante, faz-se necessário favorecer que o aprendiz reflita sobre como funciona o sistema de escrita. Ferreiro (2001) considera que para 
enfrentar as mudanças propostas sobre a aquisição da base alfabética, os docentes não precisam de muitos materiais didáticos e métodos novos, mas de reflexão e compreensão sobre como ocorre o processo de ensino e de aprendizagem. A autora sustenta que o aprendiz elabora uma série de hipóteses, por meio da construção de princípios organizadores, resultados não só de vivências externas, mas de um processo interno. Assegura ainda, que o aprendiz interpreta textos escritos antes de compreender a relação entre as letras e os sons da linguagem, fazendo uso do letramento. As questões didático-pedagógicas para tratar a alfabetização e o letramento encontraram nos estudos de Ferreiro (2001) a importância de compreender para transformar a prática docente.

Em sua prática educativa Freire (1995) defendia a relevância da leitura para o exercício da cidadania, corroborando com a citação de Lobato (1932), "Um pais se faz com homens e livros". Entende-se a leitura como fio condutor no processo de alfabetização, sendo crucial para a aprendizagem do ser humano e a aquisição da base alfabética.

Nesse sentido, a leitura deve ser compreendida como parte de um processo mais amplo: o letramento, que se configura com a apropriação dos usos da leitura e da escrita nas diferentes práticas sociais. Nessa perspectiva, um leitor competente é aquele que usa a linguagem escrita - e, portanto, a leitura - efetivamente, em diferentes circunstâncias de comunicação; é aquele que se apropriou das estratégias e dos procedimentos de leitura característicos das diferentes práticas sociais das quais participa.

A concepção pedagógica central pauta-se no pressuposto de que, tanto a didática quanto a metodologia dos processos de alfabetização devem ser realizados em contextos de letramento, isto é, "estado ou condição de quem não apenas sabe ler e escrever, mas cultiva e exerce as práticas sociais que usam a escrita" (SOARES, 2001, p.47). Trata-se, portanto, de trazer para dentro da escola a escrita e a leitura que acontecem fora dela, isto é, aproximar ao máximo a "versão escolar" da "versão social”.

O letramento é compreendido por Kleiman (1995, p.19) "como um conjunto de práticas sociais que usam a escrita, como sistema simbólico e como tecnologia, em contextos específicos, para objetivos específicos". De acordo com a autora, ele envolve os gêneros textuais discursivos com as práticas sociais. Compreende-se que o letramento permeia todas as áreas do conhecimento humano. 
No contexto da alfabetização da língua materna e alfabetização matemática, destacam-se 0 ensino e aprendizado voltados às práticas de multiletramentos. 0 prefixo "multi" diz respeito à multiculturalidade das sociedades globalizadas (multiplicidade cultural das populações) e à multimodalidade dos textos que circulam nelas (multiplicidade semiótica de constituição de textos por meio dos quais ela se informa e se comunica) e que resultou definir o termo no plural. (Rojo 2012).

O ensinar e o aprender estão intrinsicamente ligados, isto é, é uma ação de construção conjunta na sala de aula e na escola. Para realizá-la o professor, segundo Weiz (2002, p.16), deve "[...] refletir enquanto age, pode tomar decisões, mudar rapidamente o rumo de sua ação, interpretar as respostas que os alunos dão, autocorrigir-se". A autora assegura ainda, que a prática pedagógica dos docentes está alicerçada na concepção e teorias em que foram alfabetizados, mesmo sem a consciência das "ideias que as orientam".

\section{RELATO DE UMA PRÁTICA LIBERTADORA}

Os problemas enfrentados na atualidade direcionaram a realização de atividades práticas com as licenciandas de Pedagogia da modalidade presencial e no ensino a distância - EaD, elaboração de Trabalho de Conclusão de Curso - TCC.

$\mathrm{Na}$ modalidade presencial considerando o contexto de 2020, ocorreu virtualmente. A proposta envolveu quatro docentes de diferentes componentes curriculares e cada uma orientou dois grupos de forma virtual.

A atividade proposta se iniciou com a leitura da obra de Paulo Freire intitulada "Professora sim, tia não: cartas a quem ousa ensinar". Os oito grupos tinham como tarefa responder de forma crítica às cartas destinadas por sorteio, entre as dez apresentadas no livro. Nas respostas, os grupos deveriam utilizar os conhecimentos adquiridos de forma interdisciplinar, realizando um roteiro escrito para as respostas e a apresentação por meio de uma produção de Podcast.

Neste estudo será destacado o trabalho realizado por dois grupos (A e B), orientados por uma das autoras deste artigo. $O$ grupo $A$ realizou a resposta à primeira carta "Ensinar - aprender. Leitura do mundo e da palavra". O grupo B respondeu a duas cartas, sendo: a quinta "Primeiro dia de aula" e a oitava "Identidade cultural e educação".

O propósito da atividade era propiciar aos estudantes entender o legado de Paulo Freire na vida e na prática e compartilhar de forma reflexiva e crítica, fazendo 
uma relação entre a teoria aprendida sobre processo de ensino e aprendizagem e o desejo de ensinar e de aprender. Esta proposta baseou-se na dimensão multiletrada de validar a teoria na prática, considerou a relação que as licenciandas poderiam estabelecer com o saber, com a sua trajetória acadêmica e com o aprender a aprender.

Na visão de Charlot,

[...] ninguém pode aprender sem uma atividade intelectual, sem uma mobilização pessoal, sem fazer uso de si. Uma aprendizagem só é possível se for imbuída do desejo (consciente ou inconsciente) e se houver um envolvimento daquele que aprende (CHARLOT, 2005, p.76).

O grupo A organizou um roteiro em forma de diálogo para a gravação do Podcast, destacando a importância de que a leitura e a escrita fossem mais estimuladas pela escola, para que houvesse menos insegurança e mais domínio para exercer as práticas de letramento.

O Grupo B que ficou com duas cartas apresentou para a primeira, uma resposta na cultura regional nordestina, literatura de cordel, considerada por Freire (2020) como um patrimônio cultural do povo brasileiro. O cordel exaltou a educação, em verso e prosa, falou sobre o saber, o educador, o conhecimento, a escola, o querer e o aprender.

Na segunda carta, o grupo utilizou um Rap como gênero textual para a resposta, demonstrando a importância de se dar voz às comunidades, aos homens simples do povo.

$\mathrm{Na}$ modalidade EaD, durante os dois semestres de 2020, os trabalhos de Conclusão de Curso - TCC propiciaram a realização de um diálogo entre a Matemática e a Língua Portuguesa na elaboração do Projeto Didático Interdisciplinar - PDI. O projeto apresentava uma situação-problema que descrevia os resultados obtidos após a avaliação diagnóstica, indicando as dificuldades dos alunos do $1^{\circ}$ aos $3^{\circ}$ anos do Ensino Fundamental, nesses dois componentes curriculares.

Os estudos realizados pelos grupos permitiram a apresentação de diferentes ações práticas explorando os hábitos e a cultura popular. A utilização da literatura infantil, da literatura de cordel, das parlendas, do movimento das feiras livres e outras 
situações típicas das diferentes regiões brasileiras deram base para as sequências de atividades interdisciplinares. Para cada ação de Língua Portuguesa foi possibilitada a percepção e a relação com os objetos do conhecimento matemático, possibilitando a construção reflexiva de um caminho que ampliasse a prática docente das licenciandas e futuras pedagogas.

Observa-se nos relatos das pesquisadoras momentos diferenciados de práticas e a oportunidade da realização de boas situações de aprendizagem, permitindo que os estudantes colocassem em ação tudo o que sabiam e pensavam sobre o assunto, tanto na modalidade presencial como na EaD,

As atividades demonstraram que no âmbito acadêmico tomam-se decisões educativas, curriculares e pedagógicas que permitem situações de aprendizagem mais dinâmicas. Para Freire (1986) esse dinamismo pode ser encontrado nos movimentos sociais, mostrando como as pessoas estão criando e recriando fora da educação formal. Esse aprendizado que não está nos livros acadêmicos permitiu aos professores e orientadores a experiência de outras perspectivas e propiciou às licenciandas um pesquisar para conhecer o que ainda não conheciam.

As formações presenciais ou EaD que valorizam a sala de aula como um ambiente privilegiado de descobertas, de outros caminhos, de teorias e práticas, propiciam momentos de vencer desafios, suplantar dificuldades e valorizar as vivências presentes nas histórias de vida pessoal e profissional dos licenciandos (BARRETO, 2011).

Segundo Zoccal (2011), "tem-se consciência de que os resultados de um trabalho se configuram como momentos de análise e reflexão sobre todo o conjunto de ideias expostas permitindo, portanto, que se chegue não às conclusões definitivas, mas abrindo caminho para outras ideias e buscas, em um reprocurar".

\section{ALGUMAS CONSIDERAÇÕES}

Neste momento, faz-se necessário retomar a parte introdutória da pesquisa, cujo trabalho vincula-se ao estudo da obra de Paulo Freire e às vivências das pesquisadoras com relação à reflexão sobre alfabetização e letramento na língua materna e na matemática. Apresentaram-se os princípios de uma boa situação de aprendizagem e as possibilidades de superar a utilização de quaisquer métodos de ensino. 
Percebeu-se a necessidade do docente, tanto na contemporaneidade, como no passado, de conhecer os saberes dos aprendizes, visando propor atividades que permitam avanços em seu conhecimento e que possam ser usadas no contexto social real de futuras práticas, exercendo-as com criticidade e cidadania defendidas por Freire.

As atividades realizadas demonstraram que o ensinar e o de aprender são ações interdependentes e complementares, que constituem o processo educacional. O desenvolvimento dinâmico e interativo que se estabelece entre tais ações requer envolvimento do educador e do educando, promovendo reflexão e elaboração de outras ações.

Nessa perspectiva, os resultados sinalizam que a alfabetização e letramento defendidas por Freire em 1965 perduram, pois o ensino e aprendizagem permeados pelo diálogo e a reflexão perpassam pelas diferentes modalidades de ensino e áreas do conhecimento. Esses processos desenvolvidos em uma abordagem investigativa e questionadora, pautados em uma relação com a vida, para além dos muros da universidade, favorecem uma formação acerca da criticidade proposta por Freire.

Ressalta-se a necessidade do estudo da língua materna e da matemática de forma interligada, permitindo ao aprendiz vivenciar situações de aprendizagem significativas que possibilitem a compreensão de sua organização, complementaridade e características compatíveis.

Dessa maneira, entende-se que para uma prática fazer sentido e ter significado na contemporaneidade, tem que incorporar a história do aluno. $O$ aprendiz alfabetizado ou letrado carrega uma história tão ou mais importante que o currículo validado e testado.

\section{REFERÊNCIAS}

BARRETO, Maria das Graças Bezerra. A formação continuada de matemática dos professores dos anos iniciais do ensino fundamental e seu impacto na prática de sala de aula. 2011. 194 f. Dissertação (Mestrado em Educação Matemática) - Universidade Bandeirante de São Paulo, UNIBAN, São Paulo, 2011.

BRASIL. Base Nacional Comum Curricular: Educação Infantil e Ensino Fundamental. Brasília: MEC/Secretaria de Educação Básica. 2018. Disponível em: 
http://basenacionalcomum.mec.gov.br/images/BNCC El EF 110518 versaofinal sit e.pdf. Acesso em: 20 fev. 2021

. Parâmetros Curriculares Nacionais. temas transversais: meio ambiente.

Secretaria de Educação Fundamental. - Brasília, 1997.

Disponível em: http://portal.mec.gov.br/seb/arquivos/pdf/meioambiente.pdf. Acesso em: 20 fev. 2021.

Ministério da Educação. Pacto Nacional pela Alfabetização na Idade

Certa - Currículo na alfabetização: concepções e princípios. Brasília: 2012.

Disponível em:

http://www.plataformadoletramento.org.br/acervo-para-aprofundar/252/pactonacional-pela-alfabetizacao-na-idade-certa-pnaic-cadernos-de-formacao.html. Acesso em: 13 de mar. 2021.

. Ministério da Educação. Secretaria de Alfabetização. PNA Política

Nacional de Alfabetização/Secretaria de Alfabetização. - Brasília : MEC, SEALF, 2019. Disponível em: http://portal.mec.gov.br/images/banners/caderno pna final.pdf. Acesso em: 13 de mar. 2021

CHARLOT, Bernard. Relação com o Saber, Formação dos Professores e Globalização. Porto Alegre, Artmed, 2005.

CORTELLA, Mário Sergio. Paulo Freire: um pensamento clássico e atual. Revista ecurriculum, São Paulo, v.7 n.3 dezembro 2011(Edição especial de aniversário de Paulo Freire). Disponível em:

https://revistas.pucsp.br/index.php/curriculum/article/view/7590/5542. Acesso em: 26 fev. 2021

FERREIRO, Emília. Alfabetização em Processo. 13aㅡ Ed. São Paulo: Cortez, 2001. Reflexões sobre a alfabetização. São Paulo: Cortez, 1992.

FREIRE, Paulo. (1967) Educação como Prática da Liberdade. 46 ed. São Paulo: Paz e Terra, 2020. 
. (1994). Cartas a Cristina: Reflexões sobre minha vida e minha práxis. 2 ed. São Paulo: Paz e Terra, 2015.

. Conscientização: teoria e prática da libertação. Uma introdução ao pensamento de Paulo Freire. São Paulo: Centauro, 2008.

Pedagogia da Autonomia - saberes necessários à prática educativa. São Paulo: Paz e Terra, 2003.

. Professora sim, tia não: cartas a quem ousa ensinar. 4 ed. São Paulo: Editora Olho d'Água, 1994, p.127.

FREIRE, Paulo.; SHOR, Ira. (1987). Medo e Ousadia - O Cotidiano do Professor. Rio de Janeiro: Paz e Terra, 2000. 224 p.

KLEIMAN, Angela B. (org.). Os significados do letramento: uma nova perspectiva sobre a prática social da escrita. Campinas: Mercado de Letras, 1995.

LERNER, Délia; trad. ROSA, Ernani. Ler e escrever na escola: o real, o possível, o necessário. Porto Alegre: Artmed, 2002.

MACHADO, Nilson José. Matemática e língua materna: análise de uma impregnação mútua. São Paulo: Cortez: Autores Associados, 1990. (Coleção educação contemporânea, 59)

ROJO, Roxane Helena Rodrigues. MOURA, Eduardo. Multiletramentos na escola. São Paulo: Parábola. 2012.

SAUL, Ana Maria. Paulo Freire na atualidade: legado e reinvenção. Revista eCurriculum, São Paulo, v.14, n.01, p. 09 - 34 jan./mar. 2016. Disponível em: 
https://revistas.pucsp.br/index.php/curriculum/article/viewFile/27365/19377. Acesso em: 26 fev. 2021

SOARES, Magda. Letramento - Um Tema Em Três Gêneros. 2 Ed. Belo Horizonte: Autêntica, 2001.

WEISZ, Telma. O diálogo entre o ensino e a aprendizagem. 2 Ed. São Paulo: Editora Ática, 2000.

TONINI, Adriana Maria. MIRANDA, Fábio Neves de. Estratégias pedagógicas utilizadas no processo de ensino aprendizagem na modalidade a distância dos cursos técnicos do e-tec cefet-mg. Disponível em:

https://www.bing.com/search?q=estrategias+pedagógicas+de+ensinoaprendizagem+

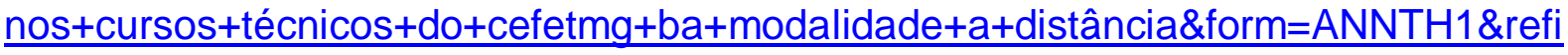
$\mathrm{g}=65 \mathrm{e} 97 \mathrm{e} 7 \mathrm{c087d4d639368b3a8d49d2c0c}$. Acesso em 10 mar.de 2021.

ZOCCAL, Sirlei Ivo Leite. A relação dos professores alfabetizadores com o saber no contexto do Programa Ler e Escrever. CDU 37 (043.3). Dissertação de Mestrado,189f. Universidade Católica de Santos. Santos - 2011. 


\title{
JOSÉ MARTÍ E PAULO FREIRE: CONTRIBUIÇÕES À PEDAGOGIA LATINO-AMERICANA
}

\author{
Maria do Carmo Luiz Caldas Leite
}

\section{RESUMO}

O presente trabalho tem como objetivo estabelecer movimentos de aproximação entre as ideias pedagógicas de José Martí e de Paulo Freire, destacando a contribuição de ambos ao ideário educativo da América Latina. São arrolados dois aspectos: a) os pensamentos autóctones que reafirmam constantemente a busca de uma legítima cultura ajustada à realidade latino-americana, não mais a uma Educação com teorias importadas da Europa e da América Anglo-Saxônica. b) a presença de uma visão crítica e a inserção das obras freiriana e martiana na história das insurgências pedagógicas de nosso continente, que radicam na capacidade de indignação diante das injustiças. Considerando a profusão textual de Martí e de Freire, a escolha voltouse à construção teórica inerente a uma pesquisa bibliográfica. Dessa forma, o trabalho discute, especialmente, os aspectos pertinentes à integração dos dois pensamentos filosófico-pedagógicos. Como conclusão, apresenta-se o imperativo de nutrir a tensão entre a relevância destes legados e a disposição para defendê-los, no bojo da radicalidade de suas ideias educativas, salientando categorias comuns, que são a esperança e a liberdade para refletir, voltadas às ações cotidianas, como variante do princípio de vinculação da teoria com a prática e da escola com a vida.

Palavras-chave: José Martí, Paulo Freire, Pedagogia latino-americana, colonialidade

\section{Introdução}

El pueblo más feliz es el que tenga mejor educados a sus hijos, en la instrucción del pensamiento, y en la dirección de los sentimientos. Un pueblo instruido ama el trabajo y sabe sacar provecho de él. Un pueblo virtuoso vivirá más feliz y más rico que otro lleno de vicios, y se defenderá mejor de todo ataque. Un pueblo de hombres educados será siempre un pueblo de hombres libres. (MARTí, 1975)

Não é possível existir sem assumir o direito e o dever de optar, decidir, lutar, fazer política. Daí a imperiosidade da prática formadora eminentemente ética. Posso ter esperança, sei que é possível intervir para melhorar o mundo. Meu "destino" não é predeterminado, ele precisa ser feito e dessa responsabilidade não posso me eximir. A História em que me faço com os outros e dela tomo parte é um tempo de possibilidades, de problematização do futuro e não de inexorabilidade (FREIRE, 2000). 
Na busca de aproximação aos legados de Paulo Freire e José Martí é significativo destacar que as similaridades entre Brasil e Cuba são muitas, quando a cultura e a educação são consideradas frutos dinâmicos e intrínsecos das dimensões produtiva e social. Há muitos elementos que permitem inferir essa identidade, incluindo a condição de ex-colônia, o extermínio das populações indígenas e a escravidão dos negros originários das mesmas famílias africanas, o que aproxima os traços físicos, fruto de misturas étnicas semelhante entre brasileiros e cubanos. Os laços entre os dois países fluíram em regime de normalidade até 1964, quando o governo brasileiro rompeu as relações diplomáticas, assinalando mudanças da política externa. Anteriormente a essa ruptura, as significativas palavras do herói nacional cubano, "Nenhum povo é dono do seu destino se antes não é dono de sua cultura" (MARTÍ, 1975, t.4, p. 93), apareceram no documento final do II Encontro Nacional de Alfabetização e Cultura Popular, realizado em Recife, no ano de 1963. Os movimentos populares brasileiros, em "oposição à recusa inflexível ao sonho e à utopia", no dizer de Freire (2000, p. 15), atingiram seu período mais significativo entre 1962 e 1964, anos marcados pela ruptura da teoria e da prática da classe dominante como única depositária da Cultura e da Educação.

As ponderações registradas nesta pesquisa de cunho bibliográfico pretendem contribuir para larguear o pensamento relacionado à educação na América Latina, que procura soluções em meio à realidade impregnada de inúmeros recuos e lentos avanços, marcados pela passividade e pela leitura fragmentada da realidade. A pedagogia problematizadora, sem constituir-se em uma simples transmissão pronta do saber, defendida por Martí e por Freire, almeja uma ruptura epistemológica e ontológica do paradigma egocêntrico, que despreza valores humanistas, gerando situações de desigualdade e injustiças próprias do discurso monológico da escola tradicional.

José Martí (1853-1895) e Paulo Freire (1921-1997) protagonizaram uma práxis radical, que deitou raízes para além de suas épocas e de seus contextos. $\mathrm{O}$ espaço do presente trabalho não comporta um estudo comparativo amplo, mas admite trazê-los em um diálogo acerca de algumas convergências identificáveis, que vão desde suas trajetórias de exilados, que os fizeram passar por vários países, proporcionando-Ihes saberes avançados para seu tempo, até a fé e a esperança no melhoramento humano. As ideias sobre a educação nas concepções martianas e 
freirianas respondem a uma compreensão do mundo em que a reflexão e a ação se insertam em uma práxis própria dos intelectuais contra hegemônicos.

Nesta análise, é possível destacar aspectos de suas obras, em que a América Latina vai se situando no mundo, como um lugar privilegiado de densa produção pedagógica, ainda que existam fronteiras culturais e educativas entre os países, pela falta de permeabilidade das pesquisas desenvolvidas e, de forma mais acentuada, pelas dificuldades de que os estudos na esfera da educação saiam da academia e cheguem às escolas de nível básico.

$\mathrm{Na}$ concepção de Pedagogia latino-americana, consideraram-se inúmeras pedagogias que se apresentam com características emancipatórias, entre elas: do oprimido, da revolução, da insurgência e da resistência, em reconhecimento à pluralidade e à diversidade de práticas educativas deste subcontinente. Em muitas delas surgem traços da obra martiana, construída no século XIX. Martí possuía um referencial teórico - que evoluiu historicamente - no qual a educação é concebida como uma estratégia para o desenvolvimento do homem. Nesse sentido, avaliou os limites estreitos da corrente positivista que adentrou na América Latina, na segunda metade do século XIX, "elaborando sua própria concepção educativa livre, integral e multifacetada que ultrapassava as fronteiras do utilitarismo e as caricaturas de cópias e ideias de outras latitudes" (CHÁVEZ RODRÍGUEZ, 1996, p.36).

Uma das aportes mais significativos das teorias pós-coloniais à reestruturação das ciências humanas foi pôr a sinalização de que o surgimento dos Estados na América, durante o século XIX, não foi um processo autônomo, porque arcam com um contrapeso estrutural: a constante ameaça do colonialismo europeu no além-mar. Posteriormente, essas questões adquiriram novas urgências diante das políticas de internacionalização na educação e das discussões sobre a decolonialidade e a recolonização (QUIJANO, 2007).

\section{A insurgência como princípio educativo em Martí}

José Martí, nascido em Havana, no ano de 1853, filho de pais espanhóis, iniciou sua participação política escrevendo a jornais separatistas. Com a prisão de seu mestre Rafael Mendive, cristalizou-se em Martí a atitude de rebeldia contra a dominação espanhola. Em 1869, foi condenado a 6 anos de trabalhos forçados, mas passou somente 6 meses na prisão, pois conseguiu permutar a pena pela deportação 
à Espanha. Dedicou-se ao estudo do Direito, obtendo, em 1874, o diploma na Universidade de Zaragoza. Entre 1881 e 1895, viveu em Nova lorque, porém foi no México, na Guatemala e na Venezuela que alcançou o mais alto grau de identificação com a autoctonia da América, até o momento desconhecido a um filho de espanhol. Em razão de seu ativismo radical, foi nomeado cônsul do Uruguai e representou os interesses desse país em Nova York. Influente na intelectualidade hispano-americana no final do século XIX, Martí percebeu que a libertação de Cuba não poderia acontecer sem a união do povo e de todos os setores da sociedade. O Partido Revolucionário Cubano, por ele fundado em 1892, assumiu essa bandeira e foi a base das ideias de unidade. Nos últimos anos de sua vida, regressou aos EUA, país estrangeiro onde mais tempo viveu, dando continuidade às suas atividades no campo cultural e jornalístico, mas, principalmente, dedicando-se à preparação do regresso à llha e da guerra de independência. Nas duas vezes em que conseguiu regressar a Cuba, julgado como conspirador, foi deportado. Em 1895, Martí partiu de Nova York a Cuba para se juntar às tropas comandadas pelo general Máximo Gómez, mas no dia 19 de maio desse mesmo ano, no vilarejo de Dios Rios (Cuba), morreu em combate, sem ver concretizado o sonho de sua vida (FERNÁNDEZ RETAMAR, 1983).

Em "Nuestra América”, escrito em 1891, no momento de reorganização das lutas contra o sistema colonialista, o "apóstolo" de Cuba apresenta suas concepções de insurgência, como princípio educativo, que mantém significativa vigência na pedagogia latino-americana, reivindicando uma história da América Latina, além da história da Europa opressora. Bastante aguerrido, Martí (1983, p. 199) denunciava que as universidades não serviam para preparar os novos governantes, uma vez que os jovens da América necessitavam "arregaçar as mangas”, colocar as mãos na massa e fazê-las crescer com a levedura de seu suor.

Como estudioso não apenas dos problemas da instrução em todos os países de continente americano, onde teve a oportunidade de viver, Martí elaborou um pensamento pedagógico, convencido de que "Patria es humanidad". A síntese de tal ideário constitui, até hoje, um paradigma:

- Escola obrigatória, universal, gratuita e laica: a educação, como direito e dever de todos, assegurava a liberdade de consciência ao professor e ao aluno. "Un pueblo de hombres educados será siempre un pueblo de hombres libres" (MARTí, 1975, t.12, p.375). 
- Educação científica e politécnica: o ensino das ciências e a educação para o trabalho constituíam princípios básicos. " $Y$ detrás de cada escuela un taller agrícola, a la lluvia y al sol, donde cada estudiante sembrase su árbol" (MARTí, 1975, t.8, p.287).

- Educação para a vida: o fim primordial da educação consistia em educar o homem para seu momento histórico. "La educación ha de ir a donde va la vida. Es insensato que la educación ocupe el único tiempo de preparación que tiene el hombre, en no prepararlo" (MARTí, 1975, t.22, p. 308).

- Conteúdo da educação - democrático e popular: fazer partícipes as massas populares dos bens da educação. Para que os povos sejam realmente livres, a educação deve refletir suas necessidades, em uma postura crítica aos modelos escolásticos e dogmáticos.

Hay un sistema de educación que consiste en convertir a los hombres en mulos, en ovejas, -en deshombrarlos, en vez de ahombrarlos más. Una buena educación, ni en corceles siquiera en cebras ha de convertirlos. Vale más un hombre rebelde que un manso (MARTí, 1975, t.21, p.142).

- Incorporação da mulher à educação: a educação da mulher anuncia os homens que dela hão de surgir, desenvolvidos no calor do lar.

Las campañas de los pueblos solo son débiles, cuando en ella no se alista el corazón de la mujer; pero cuando se estremece y ayuda, cuando la mujer, tímida y quieta de su natural, anima y aplaude, cuando la mujer culta y virtuosa unge la obra con la miel de su cariño, la obra es invencible (MARTí, 1975, t.5, p.16).

Ao diferenciar instrução de educação e destacar o processo dialético entre as categorias pedagógicas, Martí defendeu o princípio de que não há boa educação sem instrução. Era necessário orientar o pensamento, porém, ao mesmo tempo, era imprescindível dirigir os sentimentos. A obra de Martí - um dos precursores do pensamento filosófico em nosso continente - está permeada de características polifônicas, ao emprestar voz ao índio e ao afro-americano, realizando importantes críticas à herança etnocêntrica da filosofia europeia contra as possibilidades plurais identificadas na polifonia da mestiçagem presentes na América. No pensamento de 
Martí, "a inteligência americana estava no penacho indígena e quando se paralisou ao índio, se paralisou a América" (ACOSTA, 2015, p.26).

Em meio aos seus pensamentos e ações voltados à revolução independentista em Cuba, Martí analisou com clareza a dominação implícita na falsa dicotomia de seu tempo: "no hay batalla entre la civilización y la barbarie, sino entre la falsa erudición y la naturaleza" (MARTí, 1975, t. 6, p. 17).

Com o avançar do século XIX, a afirmação do positivismo contribuiu para a consolidação, falsamente técnica e naturalizada de sentido pejorativo, da ideia de latinidade, como expressão do "atraso" ou "fracasso" histórico e político-econômico. Partindo de um projeto político emancipador, o pensamento martiano adquiriu importância educativa, na relação com a sociedade, na captação de espaços de disputas e no conhecimento construído como forma de insurgência na escola e na luta: "Trincheiras de ideias valem mais que trincheiras de pedras" (MARTí, 1983, p. 194).

A derrocada das lutas contra a Espanha pela independência em Cuba ocorreu no bojo das transformações socioeconômicas de afirmação do capital monopolista no final do século XIX, que ensaiou o progressivo aumento de requisitos para a reprodução capitalista, não apenas em Cuba, mas em todo o continente americano. Em um contexto histórico marcado pela polarização entre o centro capitalista hegemônico e a periferia que lhe seguia a reboque, a llha tornou-se uma neocolônia.

No seio dos movimentos independentistas, operava-se, durante a República Mediatizada instalada em Cuba durante as primeiras seis décadas do século XX, a naturalização do imaginário dos neocolonizadores, sob várias formas, entre elas a sedução do fetichismo cultural, estimulando a forte aspiração aos valores norteamericanos por parte dos sujeitos subalternizados.

$\mathrm{Na}$ forma de colonialidade, o colonialismo chegou às raízes profundas do povo cubano e sobreviveu, apesar da descolonização ou da emancipação política da última colônia espanhola nas Américas. Não raras vezes, a própria história oficial foi grosseiramente utilizada nas exortações após a independência do colonialismo espanhol em Cuba, que conviviam com a estrutura neocolonial.

Para Quijano (2007, p. 93), nas tensões dialéticas entre a colonialidade e as resistências buscam-se alternativas à superação das intencionalidades existentes nas epistemologias tradicionais. Neste sentido, o legado emancipador de Martí, forjado na perspectiva de suplantar a colonialidade pedagógica, está impregnado pelas lutas 
contra a intervenção estrangeira dentro do campo educativo. Quijano (2005) cunhou o conceito de colonialidade como algo que transcende ao colonialismo histórico e que não desaparece com a independência ou descolonização.

A distinção entre colonialidade e colonialismo reside na existência de continuidade nas formas coloniais de dominação, mesmo após o fim das administrações coloniais. Na tentativa de entender as estratégias de poder subjacentes ao exercício da colonialidade, o sociólogo peruano desenvolveu a ideia de colonialidade do poder, como um modelo de exercício da dominação que interliga a Educação, a formação racial, o controle do trabalho, o Estado e a produção de conhecimento, em uma relação mais duradoura e estável do que aquela apresentada no colonialismo histórico.

\section{A radicalidade como princípio e prática no legado freiriano}

Nascido em Recife, em 1921, Paulo Reglus Neves Freire foi filósofo e educador, considerado um dos pensadores mais notáveis da Pedagogia Crítica. Ingressou, em 1943 na Faculdade de Direito da antiga Universidade do Recife. Nas décadas de 1950 e 1960, dedicou-se aos estudos no campo da educação de adultos em áreas proletárias, urbanas e rurais, em Pernambuco, nos quais alcançou resultados positivos. Em 1961, Freire assumiu a Diretoria do Departamento de Extensões Culturais da Universidade do Recife e, desde então, empenhou-se cada vez mais na educação das classes oprimidas. Freire empregou um modelo de alfabetização no Rio Grande do Norte, precisamente, na cidade de Angicos, em que logrou êxito em pouquíssimo tempo, conhecido por Método Paulo Freire, ampliado no Plano Nacional de Alfabetização, em 1964, pelo governo de João Goulart.

O educador pernambucano notabilizou-se pela sua proposta interdisciplinar, pelo desenvolvimento do pensamento crítico dos estudantes, para que estes pudessem intervir em suas realidades, e pela crítica ao que chamou "modelo bancário de educação". O educador presava a articulação das vivências e realidades dos educandos, de modo que a Educação lhes servisse de instrumento para a conquista de sua autonomia e de intervenção na sociedade e para o desenvolvimento de sua consciência emancipada. 


\begin{abstract}
É fundamental que, na prática da formação docente, o aprendiz de educador assuma que o indispensável pensar certo não é presente dos deuses nem se acha nos guias de professores que iluminados intelectuais escrevem desde o centro do poder, mas, pelo contrário, o pensar certo, que supera o ingênuo, tem que ser produzido pelo próprio aprendiz em comunhão com o professor formador (FREIRE, 2000, p. 43).
\end{abstract}

Ainda em 1964, foi exilado, passando por diversos países, nos quais recebeu o reconhecimento por seu método e por sua obra revolucionária. Primeiramente, Paulo Freire esteve na Bolívia, por algumas semanas, e, em seguida, no Chile, onde permaneceria até 1969. No exílio, durante o governo do democrata-cristão, Eduardo Frei, trabalhou no Movimento Chileno de Reforma Agrária. Entre 1969 e 1970, trabalhou em Harvard por dez meses e, na década seguinte, foi Consultor Especial do Departamento de Educação do Conselho Mundial das Igrejas, em Genebra (Suíça). Nesse período, assumindo missões pedagógicas, coordenou programas educacionais e ministrou cursos em muitos países europeus, africanos, asiáticos e americanos., sempre na valorização da autoctonia e da decolonialidade do saber, o que o aproxima de Martí. Retornou ao Brasil, em 1980, após o início da abertura política. Foi Secretário de Educação Municipal, entre 1989 e 1991, no Governo de Luiza Erundina. Paulo Freire morreu de um ataque cardíaco em 2 de maio de 1997, em São Paulo (GADOTTI, 2001).

\title{
Aproximações entre Martí e Freire
}

A inserção de obra martiana na história das insurgências de nosso continente radica no sabor de testemunho e na disposição de lutar frente às injustiças, fato que aproxima Paulo Freire do legado martiano. Ambos não foram apenas variantes terceiro-mundistas das teorias europeias, mas revolucionários originais, que souberam se nutrir da própria realidade latino-americana para projetar um futuro diferente ao mundo. $\mathrm{Na}$ ordem sociopolítica, as diferentes etapas de construção dos ideários dos dois educadores valorizaram processos autóctones, os quais contribuem para a vindicação do trabalho docente, em um contexto distinto dos postulados colonialistas e neocolonialistas e do pensar com "mentes importadas". Em distintas conjunturas de insurgências pedagógicas, os dois pensadores contribuíram para educar, sem reproduzir simplesmente o que germina na América Anglo-saxônica e na 
Europa, representando muito mais do que a simples recusa à herança legada à América Latina, sendo necessário contextualizá-los histórica e epistemologicamente.

Um outro ponto significativo tem a ver com a inquietação de ambos em não separar a educação do tempo em que ela se realiza. Para Martí, o fim primordial da educação consisti em educar o homem para sua circunstância histórica e para Freire um dos elementos mais deploráveis é um educando ser um exilado de sua própria época. Esta questão tem importantes desdobramentos na relação entre a educação e a instrução concebidas como perspectivas fechadas. Segundo o legado martiano: "es criminal el divórcio entre la educación que se recibe en una época y la época" (MARTí, 2001, p. 281), no âmbito da pedagogia comprometida com o mundo em transformação.

Outro destaque, que aproxima Martí e Freire, é o fato de ambos lutaram por um mundo justo e voltado aos valores humanistas. Os arcos das duas vidas, em contextos semelhantes, confirmaram a estreita relação entre os modos de ser e de atuar. As vivências no exílio, a que ambos foram condenados, Ihes serviram de favorecimento para discernir as realidades locais, dentro de um contexto cultural e político mais amplo.

Ainda que não existam em Paulo Freire referências diretas a José Martí, o legado freiriano reflete a inquietação de não repetir uma metodologia de alfabetização entre as inúmeras utilizadas. O alvo para a prática educativa deveria ser a realidade do educando. O estudo dentro do universo temático para os temas geradores, nos quais são identificadas as palavras "grávidas de mundo", compõe o processo de alfabetização, partindo do pressuposto de que o analfabeto não vive num vazio de cultura e nem num estado de ignorância absoluta, assim como nas Campanhas de Alfabetização em Cuba, que tiveram seus antecedentes na época do colonialismo, como reflexo de um pensamento autóctone, quando o exército libertador vinculou a aprendizagem da escrita e da leitura à insurreição. Em 1896, com a publicação El cubano libre, editou-se a primeira cartilha voltada ao desenvolvimento de uma consciência participativa na vida político-social, onde a ideia era partir da cultura dos camponeses e dos homens escravizados, que trabalhavam no cultivo da cana. Em suas bases, a herança de Martí desmonta o mito histórico do eurocentrismo e todo o aparato da conquista colonial, rechaçando o argumento apologético segundo o qual o colonialismo havia sido o propulsor da incorporação das Américas à História. 
Para Martí e Freire, a emancipação cultural era uma maneira de alargar e aprofundar a consciência do mundo, inserindo os sujeitos como donos de suas histórias.

Dentre as características desta perspectiva pedagógica, o ato educativo, como uma prática social e culturalmente situada, passa pelas históricas desigualdades, discriminações e exclusões. O lado irônico é que os europeus iniciaram a propagação da imagem selvagem e primitiva do índio, quando na realidade os colonizadores aproveitaram os conhecimentos da flora e da fauna na América, que haviam acumulado os aborígenes, à exploração colonial no novo mundo. Seja a história esquecida do período pré-colombiano, fato que Martí denunciava, ou os temas geradores de Paulo Freire, o fundamental é que a educação esteja enraizada na vida das pessoas de carne e osso, e não mais num mundo abstrato, característico da pedagogia aposta às metodologias dialógicas e participativas, sem os instrumentos necessários para quebrar o autoritarismo nas diversas esferas da vida social e desprovida de meios para instituir outras formas de convivência e de organização social.

Em Martí, este diálogo passa pela relação amorosa dos educadores com seus educandos. O fato de o ideário martiano, impregnado de humanismo, privilegiar os valores, tornou-se evidente em 1889, quando da publicação do primeiro número de La Edad de Oro, revista voltada à infância do continente latino-americano. Com uma ternura militante, nessa obra, escrita e editada por Martí, surge a proposta de criar na crianças Nuestra América - ameaçados pela progressiva perda de sua identidade cultural - uma consciência anticolonialista. Para Paulo Freire (1981), o diálogo como ato criador ocorre em um profundo amor ao mundo e às pessoas, em uma intensa fé nos indivíduos, na sua capacidade de fazer e de criar, no clima de confiança e na propagação da esperança.

Isto conduz a ideia subsequente de que a liberdade que se expressa de duas formas: a dos círculos fechados e a liberdade para expressar vivências. Como diria Martí (1975, t. 9, p. 453), "el mundo tiene dos campos: todos los que aborrecen la libertad, porque sólo la quieren para si, están en uno; los que aman la libertad, y la quieren para todos, están en otro".

Soma-se a isso a liberdade de pensar a própria prática. José Martí (1975, t. 9, p. 457) criticava a soberba dos intelectuais que "sofocan la persona del niño, en vez 
de facilitar la expresión de la originalidad que cada criatura trae en sí; así producen una uniformidad repugnante y estéril y una especie de librea de las inteligências".

Sobre a prática da liberdade, Freire explana que o indivíduo radical não nega o direito ao outro de optar. Não almeja infligir ao outro a sua própria escolha. Discorre sobre ela, respeitando no outro o direito de também considerar-se certo e não deprime o seu oponente. Tem o dever, apesar disso, de reagir à violência dos que ambicionam impor o silêncio aos demais. Freire fez da prática o elemento privilegiado da reflexão, reafirmando ser este um dos lócus para desconfiarmos do excesso de fé, dirigida pelo poder dos mitos, que forças sociais poderosas criam para ele, que o destroem e aniquilam. É o homem tragicamente assustado, temendo a convivência autêntica e até duvidando de sua possibilidade, ao lado do medo da solidão, que se alonga como "medo da liberdade". Em suas palavras: "É uma das condições necessárias a pensar certo é não estarmos demasiado certos de nossas certezas" (FREIRE, 1992, p. 30).

\section{Considerações finais}

As reflexões do presente estudo reconhecem que, na emergência de novas propostas políticas em diferentes países latino-americanos, termos como decolonialidade e descolonização passaram a ser utilizados indiscriminadamente, como se fossem suficientes os rótulos para alcançar um pensamento descolonizador. Por esta razão, ao tratar dos elos entre a Educação e as raízes dos ideários martiano e freiriano, buscou-se demonstrar como os conceitos estruturantes da autoctonia concebem significativos aportes no entendimento da decolonialidade. Antes de converter-se em tendência na academia, uma espécie de moda, importantes intelectuais ligados aos estudos de Martí e de Freire voltaram seus pensamentos aos projetos emancipatórios, no sentido de descolonizar a Educação.

Entretanto, de forma geral, a visibilidade de todos os grandes pensadores legados ao mundo, apresenta a tendência de ser proporcional à importância dos países a que pertencem. Muitas vezes, os latino-americanos padecem de limitações em nossas próprias terras. Provavelmente, se Martí e Freire tivessem nascido em alguma nação imperial do poder e da cultura, os seus ideários estariam revestido de outra abrangência. Apesar disso, estas considerações assinalam a vigência dos pensamentos martiano e freiriano, sempre que os movimentos contemporâneos buscam realizar o que era incipiente em épocas passadas: desprezar o significado do 
autêntico e do genuíno, para dar asas ao colonialismo e ao neocolonialismo disfarçados de universalidade.

De acordo com Ferreira Mafra e Querubim (2011), nos dados levantados sobre a presença de Paulo Freire na academia brasileira existe uma situação aparentemente ambígua. Se, por um lado, os números de produções no âmbito acadêmico, precisamente no strictu sensu, revelam uma tendência de crescimento do interesse pelos estudos freirianos nos últimos anos; por outro, tais estudos não impactaram significativamente o processo de disseminação e apropriação do referencial freiriano entre os profissionais da educação de níveis fundamentais e médios.

Da percepção imanente às lutas contra a colonialidade pedagógica, a obra de José Martí, o "apóstolo" de Cuba, de quem a maioria de pessoas no Brasil conhece nada além de frases soltas, ignorando a riqueza de sua extensa contribuição à educação, ainda pouco estudada pelos brasileiros, na perspectiva deste trabalho o legado martiano tem muito a dizer ao futuro da América Latina e ao equilíbrio do mundo, assim como o legado freiriano.

Para concluir este exercício reflexivo das leituras de Martí e de Freire cabe uma breve referência aos princípios da esperança, como formas comprometidas para a transformação do mundo. Não se deve esquecer que, para Martí e Freire estar alfabetizado é pensar por si mesmo, o que pode resultar em algo perigoso, porque pensar significa também questionar as estruturas dominantes do poder.

Neste contexto se percebe a importância da educação para a ruptura, para os avanços e para o equilíbrio ético-moral do mundo. Martí (2011, p. 305) assim se expressa:

Cuando hay muchos hombres sin decoro, hay siempre otros que tienen en sí el decoro de muchos hombres. Ésos son los que se rebelan con fuerza terrible contra los que le roban a los pueblos su libertad, que es robarles a los hombres el decoro. En esos hombres van miles de hombres, va un pueblo entero, va la dignidad humana.

Freire (1981, p. 54), nesta direção, aponta que:

Nenhuma pedagogia que seja verdadeiramente libertadora pode permanecer distante do oprimido, tratando-os como infelizes e apresentando-os aos seus modelos de emulação entre os opressores. Os oprimidos devem ser o seu próprio exemplo na luta pela sua redenção. 
O conteúdo ético da esperança, como alento utópico para a realização dos homens, frente ao compromisso do humanismo radical das pedagogias de José Martí e de Paulo Freire, é um projeto para a práxis transformadora, que reivindica a dignidade e a liberdade do ser humano. Contextualizar de forma criativa as suas ideais frente às exigências culturais e educativas do mundo é a melhor homenagem que poderemos prestar nos 100 anos de nascimento do mais querido educador brasileiro e nos 168 anos do apóstolo nacional de Cuba.

\section{REFERENCIAS}

ACOSTA, Leonardo. José Martí: el indio de Nuestra América. La Habana: Centro de Estudios Martianos, 2015.

CHÁVEZ RODRíGUEZ, Justo Alberto. Las Ideas de José Martí sobre educación. In: TURNER, Lidia et al. (org.). Martí y la educación. La Habana: Pueblo y Educación, 1996.

FERNÁNDEZ RETAMAR, Roberto. Introdução a José Martí. In: MARTÍ, José. Nuestra América: antología. São Paulo: Hucitec, 1983.

FERREIRA MAFRA, Jason; Querubin, Viviane Rosa. Paulo Freire e a Academia. EccoS Revista Científica, n. 26, p. 19 - 36, 2011. Disponível em: https://www.redalyc.org/comocitar.oa?id=71522347002. Acesso: 16 ago 2021.

Freire, Paulo. Cartas a Cristina: reflexões sobre minha vida e minha práxis. $2^{\mathrm{a}}$ ed. São Paulo: UNESP, 2003.

FREIRE, Paulo. Pedagogia da autonomia: saberes necessários à prática educativa. Rio de Janeiro: Paz e Terra, 2000.

FREIRE, Paulo. Pedagogia da esperança. São Paulo: Paz e Terra, 1992.

FREIRE, Paulo. Pedagogia do oprimido. 9. ed. Rio de Janeiro: Paz e Terra, 1981.

GADOTTI, Moacir. Um legado de esperança. São Paulo: Cortez, 2001.

MARTí, José. Obras Completas. Edición Crítica. La Habana: Centro de Estudios Martianos, 2011.

MARTÍ, José. Nossa América: antologia. São Paulo: Hucitec, 1983.

MARTí, José. Obras completas. La Habana: Ciencias Sociales, 1975. 
QUIJANO, Aníbal. Colonialidad del poder y clasificación social. In: CASTRO-GÓMEZ, S.; GROSFOGUEL, Ramon (orgs.). El giro decolonial: Reflexiones para una diversidad epistémica más allá del capitalismo global. Bogotá: Universidad JaverianaInstituto Pensar, Universidad Central-IESCO, Siglo del Hombre Editores, 2007. p. 93126.

QUIJANO, Aníbal. Colonialidad del poder, eurocentrismo y América Latina. In: LANDER, E. (org.). La colonialidad del saber: eurocentrismo y ciencias sociales. Perspectivas Latinoamericanas. Buenos Aires: CLACSO, 2005. p. 227-277. 


\title{
ENSINO DA GEOGRAFIA E PAULO FREIRE: ESTUDO DO LUGAR POR MEIO DA CARTOGRAFIA EM CURSO EAD
}

\author{
Maria Glória da Silva Castro \\ Erika Megumy Tsukada \\ Simone Rezende da Silva
}

\section{RESUMO}

O presente trabalho reflete sobre o estudo do lugar, enquanto categoria de análise geográfica, e a abordagem freiriana, com destaque para a leitura da realidade vivenciada pelos estudantes. A pesquisa foi desenvolvida por meio do componente curricular Seminários Temáticos, oferecido aos estudantes do 4ํㅗㄴ semestre do curso de Licenciatura em Geografia EAD da Universidade Metropolitana de Santos (UNIMES). Destaca-se, neste artigo, a elaboração do mapa mental, seja em papel ou por intermédio da cartografia digital no ensino da Geografia, que podem ser ferramentas de análise espacial e recursos didáticos. A metodologia aplicada foi a pesquisa bibliográfica em revistas especializadas sobre o assunto e a apresentação de um estudo de caso. Neste estudo, constatou-se que a elaboração dos mapas mentais de cada estudante, permitiu a análise de seu espaço de vivência, do seu lugar. Os estudantes trocaram impressões durante a elaboração e análise do mapa mental, compartilhando a representação de sua realidade com colegas que vivem em diferentes lugares do país.

PALAVRAS-CHAVE: Geografia. Ensino a distância. Lugar. Ensino de cartografia. Google Earth Pro.

\section{INTRODUÇÃO}

A realidade chega com o estudante na escola e a valorização do seu cotidiano incentiva os processos de aprendizagem, como o da alfabetização. O lugar é uma categoria de análise geográfica análoga ao significado de realidade na abordagem freiriana, possibilitando situações para a realização de aprendizagens significativas. No curso de Licenciatura em Geografia da Universidade Metropolitana de Santos 
(UNIMES), o componente curricular Seminários Temáticos permite o reconhecimento do lugar pela elaboração de croquis, com interpretação dos elementos escolhidos a serem representados pelos estudantes, sublinhando as relações históricas e sociais presentes no cotidiano inviabilizado pelos ritmos acelerados, especialmente nas áreas urbanas. Prestigiando os olhares freirianos no desvendamento da realidade, esta prática discente efetiva a atualidade dessa abordagem pedagógica, possibilitando aos futuros professores de Geografia a oportunidade para compreenderem a importância de desenvolver com os seus estudantes os conceitos geográficos e pedagógicos presentes em seu cotidiano.

O componente curricular possui carga horária de 80 horas, desenvolvida na plataforma Moodle, utilizando-se do módulo Wiki e contando com suas ferramentas de comunicação e realizada de maneira assíncrona. O componente favorece a interação dos graduandos em grupos pela interface Wiki e pelos fóruns de orientação com o acompanhamento do professor, sendo que este relato de experiência de ensino remoto refere-se aos estudantes do quarto semestre do curso na turma do primeiro semestre de 2021.

\section{Revisão bibliográfica}

A Geografia escolar é marcada por um passado descritivo e repetitivo, o que certamente não a tornava muito estimulante, pois era marcada por uma série de nomes a serem memorizados sem nenhuma vinculação ou criticidade com a realidade vivenciada por professores e estudantes.

Desta forma, não é de se estranhar que o educador Paulo Freire tenha, em sua obra "Pedagogia da autonomia" chamado à atenção para a possível castração da curiosidade dos estudantes diante de uma mera memorização de conteúdos como, por exemplo, países e suas capitais. Segundo o autor essa Geografia que domestica, não forma o estudante:

O educador que ensinando geografia, "castra" a curiosidade do educando em nome da eficácia da memorização mecânica do ensino dos conteúdos, tolhe a liberdade do educando, a sua capacidade de aventurar-se. Não forma, domestica (FREIRE, 2005, p.16). 
Entretanto, afortunadamente a ciência geográfica trilhou caminhos distintos em sua história e se enveredou também por caminhos que a levaram a uma criticidade acerca do mundo no qual vivemos. Passa-se, portanto, de uma Geografia Tradicional a uma Nova Geografia ou Geografia Crítica, a qual abre a possibilidade de uma análise múltipla e crítica da sociedade, sua natureza e principalmente suas classes.

A evolução epistemológica da Geografia abre caminho para uma Geografia escolar mais engajada e aberta ao conhecimento prévio do estudante, afinal este se relaciona com o espaço geográfico direta e indiretamente.

Portanto, o professor de geografia tem que saber o que os alunos pensam sobre os conceitos-chave desta ciência, como: Espaço, Região, Território, Paisagem e Lugar. Para que se possa aproveitar o que os educandos já sabem de coerente e superar o erro que eles possuem sobre tais conceitos. Sendo assim, o professor de geografia estará despertando a curiosidade de seus educandos, que através de um processo de aprendizagem passará de ingênuo para a epistemológica (FREIRE, 2005, p.14).

Neste sentido, pode-se afirmar que a pedagogia freireana auxilia a Geografia na aproximação do estudante com seu mundo e suas possibilidades. De acordo com Silva (2016) a "Pedagogia da autonomia" de Paulo Freire é uma oportunidade para o professor de Geografia engajar-se em um ensino significativo e não num ensino bancário, no qual o professor deposita seus "conhecimentos" em alunos incautos.

Ler a obra "Pedagogia da Autonomia" de Paulo Freire é uma oportunidade singular para o professor de Geografia ao escolher sua metodologia didática. Somente conseguirá obter reflexão crítica de seus discentes aquele docente que "pensa certo". A "educação bancária" foi um termo extremamente utilizado por Freire para referirse ao ensino onde informações são depositadas nos educandos, assim como dinheiro é depositado nos caixas bancários. Este ensino bancário pode ser exemplificado na Geografia Tradicional fazendo-se alusão ao Positivismo formulado pelo filósofo Auguste Comte onde não se valorizava a criticidade no estudo dos fenômenos intentandose a fenômenos humanos. O professor de Geografia democrático é aquele que aproxima seus alunos da realidade vivenciada por estes. Todos nós somos sujeitos históricos, portanto, não podemos naturalizar os fenômenos humanos. (SILVA, 2016, p.15)

A leitura da realidade possibilita a valorização do lugar de vivência do estudante no processo da alfabetização, favorecendo a criação de condições para a aprendizagem significativa. "O exercício da curiosidade convoca a imaginação, a 
intuição, as emoções, a capacidade de conjecturar, de comparar na busca da perfilização do objeto ou do achado de sua razão de ser" (FREIRE, 2001, p. 98).

Enquanto objeto de estudo, a realidade é observada e problematizada, para codificá-la, decodificá-la e recodificá-la, tendo seus significados desvendados pelos e para os estudantes e professores envolvidos na pesquisa. Na elaboração de novos conhecimentos, Freire (2001) considerava a história enquanto uma construção social, que aceita e acolha suas diversidades e defende a autonomia com responsabilidade social.

O aprender a ler e escrever em qualquer fase da vida representa compreender os significados sociais das palavras pelo estudo da realidade, que encontra no ensino da Geografia importantes colaborações. A Geografia enquanto componente curricular do ensino fundamental baseia-se em conceitos que possuem representações no dia a dia das pessoas, possibilitando que o professor valorize esse conhecimento prévio dos estudantes, analisando e elaborando a sua sistematização geográfica. (CAVALCANTE, 2003).

Segundo Freire o professor deve comprometer-se metodologicamente em promover em seus alunos uma valorização da relação entre o indivíduo e o mundo que o cerca, proporcionando-lhes concomitantemente uma reflexão crítica. Ao dialogar aos seus educandos sobre a categoria geográfica "lugar" o professor de Geografia pode perfeitamente estabelecer tal relação e promover aquilo que se conceitua por reflexão crítica. O pensamento teorético e metodológico freireano consolida bastante 0 aprendizado em Geografia explanando-se nas aulas desta disciplina sobre as categorias geográficas lugar, território, paisagem e espaço. Somente utilizando-se de conceitos freireanos como liberdade e autonomia o professor de Geografia pode obter êxito no desenvolvimento de sua prática pedagógica.

Referente à categoria lugar é importante que o professor parta da construção de um croqui do bairro do aluno e que o mesmo o compare com o mapa da cidade, enumerando aparelhos públicos, áreas de lazer, comércio e indústria (ARAÚJO; BARBOSA, 2010, p.3 APUD SILVA, 2016, p.31).

Compreender a realidade favorece o aprendizado da Geografia na educação básica, especialmente em escala local, pela leitura da paisagem, permitindo a primeira aproximação da realidade, destacando suas formas, cores, texturas, odores, sons, entre outros estímulos aos sentidos humanos, fato que pode dificultar a percepção dos processos envolvidos na sua constituição. Após a leitura da paisagem, que pode ser feita por atividade de campo ou representações, como as fotografias, torna-se 
necessária a construção coletiva da categoria lugar, por trocas de informações entre os estudantes, com apoio dos docentes, sobre as histórias daqueles que construíram o lugar em estudo, compreendendo os processos envolvidos na sua formação territorial.

Cada lugar combina variáveis de tempos diferentes. Não existe um lugar onde tudo seja novo ou onde tudo seja velho. A situação é uma combinação de elementos com idades diferentes. O arranjo de um lugar, através da aceitação ou da rejeição do novo, vai depender da ação dos fatores de organização existentes nesse lugar, quais sejam, o espaço, a política, a economia, o social, o cultural. (SANTOS, 1988, p. 98).

O estudo do lugar pode ser representado espacialmente pela elaboração de croquis, considerando a escolha dos elementos mais relevantes pelos estudantes e a adoção de símbolos e técnicas, sintetizando o processo da aprendizagem significativa pela alfabetização cartográfica.

A prática de olhar e atentar para o que constitui o lugar onde os estudantes vivem constitui uma experiência única, ampliando os caminhos para a aprendizagem escrevendo novas histórias na composição do lugar geográfico.

Buscando esta compreensão da realidade e significância da vivência e cotidiano dos estudantes, a fim de dar maior sentido aos conteúdos trabalhados no curso de Geografia por meio de uma abordagem freiriana, os Seminários Temáticos foram introduzidos na matriz curricular do curso a partir de 2019. Neste sentido, no primeiro semestre de 2021 o componente curricular focou a pesquisa em "Conhecimentos cartográficos e a importância do uso de mapas e imagens de satélites no ensino da Geografia", para atender necessidades específicas do curso. Desta forma, foi desenvolvido o tema "Decifrando os mapas e as imagens de satélites". Nesse tema, a pesquisa objetivou a compreensão da realidade do entorno do estudante desenvolvendo, não somente, a capacidade cognitiva de percepção da organização espacial, como também o entendimento do seu poder em transformá-la.

\section{Metodologia}


Nesta pesquisa utilizamos a metodologia de "Estudo de caso", pois partimos da experiência concreta vivenciada na componente curricular Seminários temáticos do curso de Geografia EAD da Universidade Metropolitana de Santos.

Existem muitos tipos de estudos de caso, pois estes se aplicam a diversas áreas do conhecimento e trata-se de metodologia em franca expansão.

De forma geral, os estudos de caso podem ser classificados como únicos (quando se restringem a um único estudo) ou múltiplos (quando abarcam dois ou mais estudos a serem analisados). Além disso, é possível classificar conforme seu objetivo, nomeados como exploratórios, descritivos ou explanatórios.

Figura 1. Esquema com tipos de estudo de caso (MEIRINHO, 2010, p. 57).

\begin{tabular}{|l|l|l|}
\cline { 2 - 3 } \multicolumn{1}{c|}{} & Únicos & Múltiplos \\
\hline Exploratórios & Exploratórios únicos & Exploratórios múltiplos \\
\hline Descritivos & Descritivos únicos & Descritivos múltiplos \\
\hline Explanatórios & Explanatórios únicos & Explanatórios múltiplos \\
\hline
\end{tabular}

Os estudos de caso exploratórios visam definir questões ou hipóteses para aprofundamento posterior, podendo até serem considerados prelúdios de investigações. Os estudos de casos descritivos, como o próprio nome indica, buscam a descrição completa de um fenômeno ou situação. Já os estudos de caso explanatórios procuram estabelecer relações de causa-efeito, ou seja, procuram explicações.

Conforme a figura acima, os estudos de caso podem ser combinados de acordo com seu número e objetivo de pesquisa.

No caso específico da presente pesquisa pode-se afirmar que se trata de um estudo de caso único e descritivo, pois limita-se a um único exemplo de componente curricular e procura descrever o transcurso desta sob uma abordagem freireana.

A componente curricular Seminários Temáticos, neste trabalho analisado, teve 23 estudantes matriculados divididos em 8 grupos, sendo 7 deles com 3 estudantes cada e um grupo com 2 estudantes. A escolha do grupo é de responsabilidade de cada estudante, sendo permitida pela Instituição de Ensino que 
este o faça até uma data preestabelecida, caso contrário o sistema o faz automaticamente.

Para cada grupo foi criado um fórum de orientação, de caráter não avaliativo, constituído por um espaço destinado a interação e participação dos estudantes no desenvolvimento das etapas de forma colaborativa e na qual visava-se a prática de olhar e atentar para o que constitui o lugar, onde os estudantes vivem e que constitui uma experiência única, visando ampliar os caminhos para a aprendizagem escrevendo novas histórias na composição do lugar geográfico.

A pesquisa foi elaborada pelo levantamento bibliográfico, baseado em textos científicos da literatura da área e a pesquisa exploratória, constituindo-se por intermédio de um estudo de caso, com abordagem qualitativa e quantitativa. Inicialmente os estudantes em grupo elaboram resumo de texto de Simielli (2012), sobre a cartografia no ensino fundamental e médio, disponível na biblioteca virtual da UNIMES. Posteriormente cada integrante do grupo elaborou um mapa mental, que devia conter o desenho do trajeto de casa ao local de trabalho, ou a escola do ensino fundamental ou médio. Desenhando as referências que tinha em mente, não se preocupando com a escala cartográfica, sendo que, cada mapa mental elaborado foi fotografado e disponibilizado na Wiki, com o objetivo de proporcionar a cada estudante a realização da leitura do trajeto proposto, por meio deste mapa representando o lugar, sendo uma forma de desenvolver a noção espacial e a representação de componentes representativos de seu cotidiano.

Na última fase da atividade, cada integrante dos grupos realizou o download do aplicativo Google Earth Pro, disponibilizado na internet, com o objetivo de aprender a utilizar este aplicativo como um recurso didático de apoio as aulas de Geografia, potencializando a análise espacial de um determinado lugar.

\section{Discussão dos resultados}

Nos cursos de licenciatura em Geografia, oferecidos em EAD ou presencial, a elaboração do mapa mental é muitas vezes a primeira etapa do estabelece de vínculos entre os colegas de sala, pelas facilidades ou dificuldades em representar graficamente um caminho repleto de significados pessoais. Quando elaborado em sala de aula presencial, as trocas de informações entre os estudantes sobre onde e como moram são percebidos pelas conversas que vão criando um momento de maior 
aproximação dos grupos pelo aspecto lúdico que a representação pode conter, já que é frequente ouvir comentários de que só desenharam na escola infantil. Nos grupos do curso EAD as manifestações são semelhantes sempre que os estudantes conseguem estabelecer vínculos de confiança com os colegas para comentar sobre as dificuldades enfrentadas para a elaboração do mapa mental. $O$ professor pode envolver os estudantes para narrar suas experiências no bairro de moradia a partir do mapa, que pode receber mais símbolos ao também representar a história da localidade, símbolos que indicam os elementos visíveis da realidade, expressando a paisagem, que revelará o lugar de vivência.

O croqui ou mapa mental a seguir exemplifica a experiência da representação gráfica do lugar geográfico, com apresentação de símbolos e legenda, considerando o percurso entre a moradia e o local de trabalho.

$\mathrm{O}$ croqui escolhido indica que o estudante mora em bairro periférico de sua cidade, devido à localização de uma garagem para ônibus de linha local. Outra referência relacionada à mobilidade urbana presente no croqui é a indicação de um terminal de ônibus em rua paralela ao percurso principal, revelando a importância desse meio de transporte para o estudante.

Figura 2. Mapa mental de estudante do grupo 2.

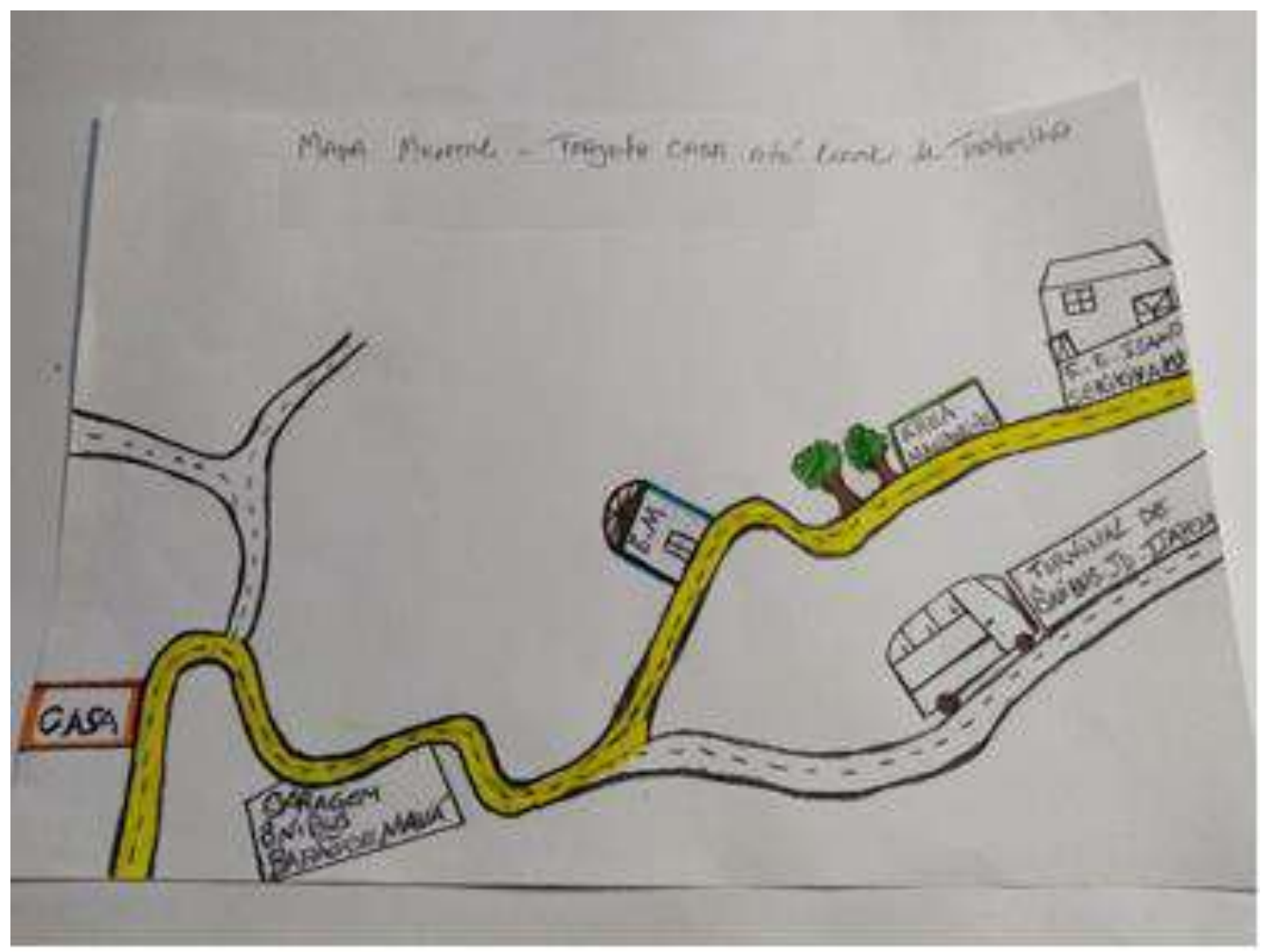


Outra referência de que o estudante mora em periferia urbana é o uso de duas árvores para representar a existência vegetação no bairro, cuja identificação como área de mananciais revela consciência e preocupação do estudante com a questão ambiental.

Como o local de destino do estudante no mapa mental é uma Escola Técnica, revela que ele já trabalha em ambiente escolar e a representação do uma escola municipal pode significar que ele também trabalha nela ou leva até esta escola crianças sob sua responsabilidade.

Na sequência da atividade, o estudante reelaborou o percurso de sua casa ao local de trabalho usando uma imagem de satélite do Google Earth Pro, possibilitando nova experiência com o lugar de vivência devido ao maior detalhamento do bairro revelado pela imagem.

Ao refazer o percurso, o estudante constatou a localização de outros componentes da paisagem, como igrejas e praças, reforçando sua experiência de representar graficamente os seus vínculos e identidade com o seu lugar de vivência.

Figura 3. Percurso desenhado pelo estudante do grupo 2 no Google Earth Pro.

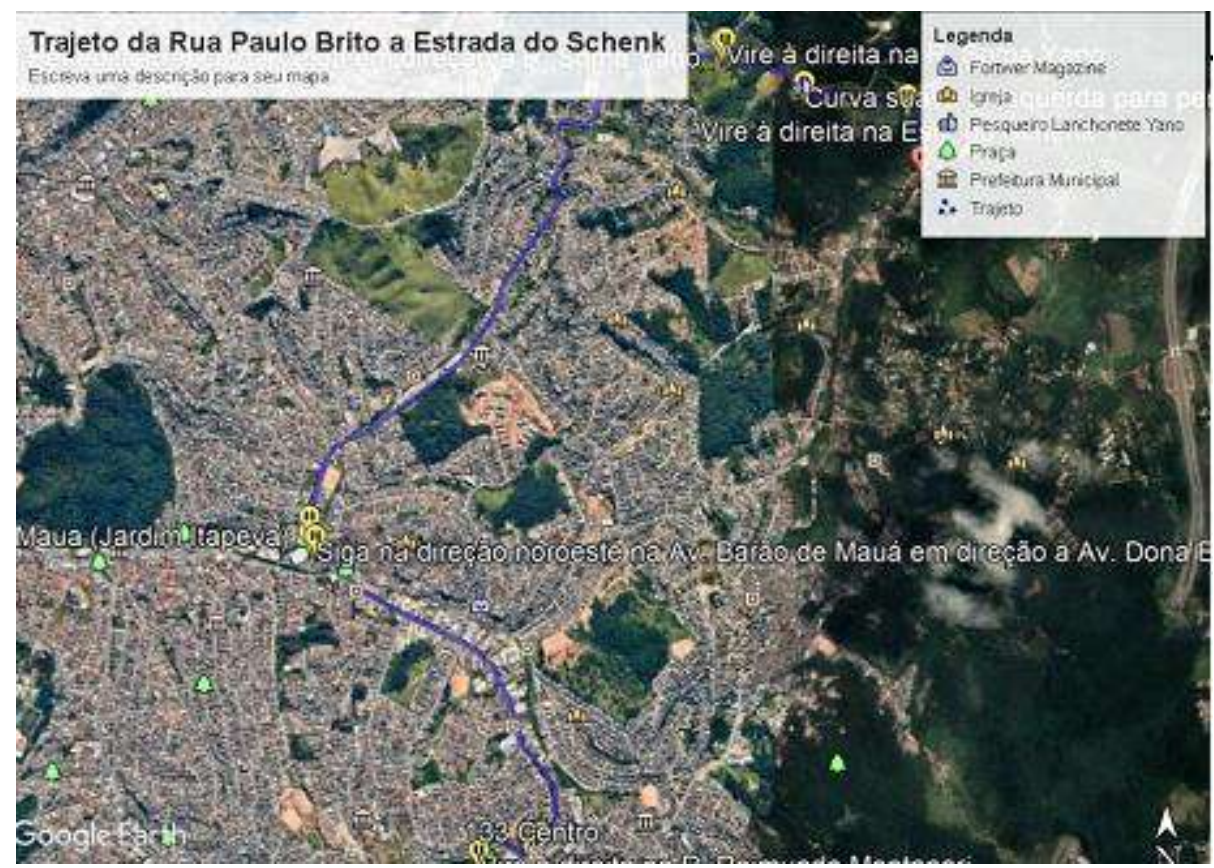

\section{Considerações finais}

Após a análise da experiência proporcionada pela componente curricular Seminários Temáticos pode-se concluir que o emprego de uma abordagem freiriana, 
ou seja, que valoriza a vivência pessoal de cada estudante o aproxima da instituição de ensino e torna o aprendizado de conceito geográficos, como o de lugar por exemplo, mais significativo.

A criação do mapa mental e posteriormente o uso do aplicativo Google Earth Pro constitui-se como importantes ferramentas de apoio ao ensino da cartografia nas aulas de Geografia, ao apresentar os mapas digitais como alternativa de análise espacial e explorando dessa forma, a leitura do seu espaço de vivência.

O lugar, enquanto conceito geográfico, possibilita ao estudante enxergar seu entorno, reconhecer a sua identidade e perceber a sociedade e o espaço em que vive e habita, sendo, portanto, um agente ativo de sua transformação.

Considerando que a realidade chega com o estudante na escola, o curso licenciatura em Geografia EAD da UNIMES busca valorizá-la durante o processo de ensino e aprendizagem, alcançando a compreensão e interpretação dos determinantes que continuamente transformam as paisagens e lugares de vivência, superando as distâncias físicas com suas interações assíncronas ou síncronas, aproximando realidades locais no ambiente de aprendizagem.

Diante do EAD, provavelmente Paulo Freire questionaria sobre a capacidade destes meios na formação de professores aptos a problematizar a realidade e construir a autonomia dos estudantes pela responsabilidade social, dentre outras preocupações. Ele também avaliaria o poder destas tecnologias na criação dos novos horizontes geográficos de ensino e aprendizagem no país, enfatizando sobre as responsabilidades sociais que essa expansão territorial envolve.

\section{REFERÊNCIAS}

CAVALCANTI, L. S. Geografia, escola e construção de conhecimentos. Campinas, SP: Papirus, 2003.

FREIRE, P. Pedagogia da Autonomia: Saberes necessários à prática educativa. São Paulo: Editora Paz e Terra, 2005. 54p

MEIRINHOS, Manuel. O estudo de caso como estratégia de investigação em educação. In: EDUSER: revista de educação, Vol 2, 2010.

SANTOS, M. Metamorfoses do espaço habitado. São Paulo: Hucitec, 1988.

SILVA, Matheus Machado. Contribuições do educador Paulo Freire para o ensino de Geografia. Frutal-MG: Editora Prospectiva. 2016. 
SIMIELLI, Maria Elena Ramos. Cartografia no ensino fundamental e médio. In: CARLOS, Ana F. A. (Org.). A Geografia na sala de aula. 9. ed. São Paulo: Contexto, 2012.

YIN, Robert. Estudo de Caso. Planejamento e Métodos. Porto Alegre: Bookman. 2010. 


\title{
CARTA AOS PROFESSORES NA PANDEMIA-COVID 19. REFLEXÕES SOBRE A QUARTA CARTA DE PAULO FREIRE
}

\author{
Maria José Marques \\ Roberto Fonseca
}

\section{RESUMO}

A pandemia-COVID 19 com a suspensão das aulas presenciais escancarou a desigualdade existente nas escolas e na sociedade brasileira, com a ausência de condições de promover uma ação orgânica capaz de assumir seu papel na sociedade por meio de uma vida digna para todos. O longo período com aulas a distância provocou a reinvenção da escola e da relação professor aluno quanto ao ensino aprendizagem. O repertório necessário para que as atividades acontecessem levaram a uma nova reflexão sobre a ação exercida pelos professores, alunos e familiares. A formação para que houvesse este desenvolvimento demandou aprendizagens aos professores e utilização de tecnologias, materiais e equipamentos ausentes para muitos envolvidos. A reorganização do "fazer pedagógico" pelos professores foi um desafio a ser enfrentado sem esmorecimento ao lidar com as aprendizagens e ensino, que implicaram em novos fazeres. Freire, na quarta carta da obra "Professora, sim; tia, não - Cartas a quem ousa ensinar", indica aos educadores predicados fundamentais e indispensáveis ao melhor desempenho de professoras e professores na prática educativa. A análise destas qualidades apontadas e como projetá-las na situação nova de "escola" apresentada seria, ou não, objeto de nova carta de Paulo Freire, voltadas aos professores como sujeitos capazes de enfrentar a complexidade de forma autônoma e emancipatória.

Palavras-chave: Aprendizagens; Professor-educador; Qualidades.

\section{INTRODUÇÃO}

A pandemia de COVID-19 que assolou o mundo e provocou período de suspensão das aulas nas escolas brasileiras no ano de 2020 e parte considerável de 2021, tornou-se marco significativo e desafiador para o funcionamento dos sistemas de ensino no Brasil em todas dimensões.

As imensas desigualdades entre as possibilidades existentes nas redes públicas com a rede privada de ensino são anteriores à crise provocada pela pandemia e já mostravam elevados índices de abandono de alunos e consequente descumprimento da escolaridade obrigatória, atingindo majoritariamente os grupos sociais com menos recursos. Este período de crise agravou significativamente a evasão de alunos, somente no estado de São Paulo, foram 670 mil alunos que deixaram de responder às atividades escolares no ano de 2020, segundo relatório do Fundo das Nações Unidas pela Infância (Unicef). 
A conectividade é apontada como a principal dificuldade e o uso de materiais impressos e aplicativos de mensagens para orientar os alunos em relação ao conteúdo ensinado também são apontados como barreiras que levam ao abandono durante a COVID-19.

O Relatório do INPE - Instituto Nacional de Estudos e Pesquisas Educacionais "Anísio Teixeira" denominado "Resposta Educacional à pandemia COVID-19 no Brasil", aplicado entre fevereiro e março de 2021 e respondido por cerca de 168739 escolas públicas e privadas, totalizando $94 \%$ das escolas brasileiras, apontou que $98 \%$ destas, adotaram estratégias não presenciais de ensino. Mostrou que os professores e escolas apoiaram-se em reuniões remotas para planejamento, monitoramento e coordenação a fim de dar continuidade ao trabalho com os alunos. O mesmo relatório informa que $80 \%$ das escolas na rede pública "treinaram" os professores para fazerem uso de materiais dos programas de ensino não presencial.

O impacto que o verbo "treinar" utilizado pelo INEP na questão que gera o relatório causa, contrasta com a afetuosidade e diálogo estabelecido por Freire na quarta carta em "Professora, sim; tia, não - Cartas a quem ousa ensinar", quando fala "das qualidades indispensáveis ao melhor desempenho de professoras e professores progressistas... predicados estes que vão sendo gerados na sua prática". (FREIRE, 1997, p. 37).

A prática do professor-educador passa fortemente pelo vínculo escola-família, que neste período teve como maior obstáculo, o suporte às famílias das crianças, já que a escola não pode ser mais usada da mesma forma, e os familiares tiveram de assumir responsabilidades e fazeres que antes eram compartilhados com o professor e a escola. Frente aos pontos levantados quanto ao momento crítico e tendo como referência a obra já citada e a quarta carta que a compõe, objetivamos analisar como as aprendizagens necessárias aos professores ocorreram na prática, destacando as qualidades essenciais para tal, apontadas por Freire(1997, p.37-43): humildade e coragem aliadas com a virtude da tolerância, sustentando com firmeza de decisão o trabalho pedagógico efetivamente democrático, com segurança, amorosidade e alegria ao desenvolver a práxis em tempos de incertezas.

Mudanças foram necessárias aos envolvidos e trabalhados à exaustão por todos, para que se efetivasse o processo de superação e conciliação do sonho que a 
vida equânime coloca no patamar principal, mesmo em momentos extremamente difíceis como este que vivemos. "Somos um conjunto de infinitas possibilidades. A única coisa que não muda é a possibilidade da mudança" (FREIRE, SHOR, 1992, p. 86).

\section{Revisão bibliográfica e percurso metodológico}

Este artigo assume como perspectiva teórico-metodológica, a análise discursiva de orientação freiriana. $O$ estudo baseia-se na análise de enunciados presentes nos diversos diálogos que sua obra propõe, quanto ao fazer pedagógico do professor-educador, qualidades e virtudes de sua formação a favor da perspectiva de transformar-se em educador libertador tendo a educação como instrumento de mudança social.

Nosso interesse é compreender as políticas em que as classes dialógicas foram impactadas e tornam iguais alunos e professores durante o período de isolamento causado pela COVID-19. Por precauções sanitárias, a chegada da pandemia impediu a realização de aulas em classes presenciais, causando 0 afastamento de professores, crianças e jovens do ambiente escolar.

O evento gerou uma profunda reviravolta na educação no mundo inteiro, provocando a paralisação das atividades presenciais que no Brasil atingiram 98\% das escolas de educação básica (INEP, 2021). Os impactos dessa nova configuração foram diversos e significativos especialmente quando demonstra o estado de proletarização dos professores, em que grande número não possuía meios para comunicação virtual que garantisse interação com os alunos.

Desponta com força a desigualdade gritante existente na sociedade brasileira quanto às condições de desenvolver o ensino virtual por meio de tecnologias sustentadas pela internet com os alunos das redes públicas e suas famílias, que garantissem o estudar isoladamente. Apontamos que muitos destes, porém, nada mais são do que o agravamento de problemas já existentes. Correlacionar esses aspectos e dialogar com a obra de Freire nos inspirou a escrever as reflexões feitas. 


\section{Metodologia}

\section{Contexto}

Em 2020, o mundo é paralisado por uma pandemia. Um vírus altamente contagioso e letal provoca uma transformação inimaginável na sociedade. Surgem pavores e pânico de diferentes formas fortalecidos pelo medo da doença, do desemprego, da falta de recursos materiais, financeiros e de atendimento à saúde, medo da fome, da violência, enfim, medo da certeza crescente de que não voltaremos a ser o que éramos. A pandemia de COVID-19 abruptamente nos faz lembrar da fragilidade humana. A situação é caótica, mas mesmo assim, ensinar é preciso e o direito à educação é soberano (Saraiva, Traversini, Lockmann, 2020).

A referência das desigualdades socioeconômicas dos alunos dá-se com a ausência da presença física e do olhar instigante na turma de alunos e professores. A falta de recursos provoca isolamento, tristeza e sensação de inoperância, especialmente com as crianças, adolescentes e jovens da educação básica sem as condições necessárias para acompanhamento do ensino remoto e das aulas síncronas que foram disponibilizadas.

Estas, por sua vez, tornaram-se o maior desafio para que os professores conseguissem aproximar-se e estabelecer relações de ensino e aprendizagem com os alunos. Para dar mínimas condições, $43 \%$ das escolas das redes públicas desenvolveram políticas e disponibilizaram equipamentos - computador, notebook, tablets e smartphones aos docentes e acesso à internet em seus domicílios. Algumas destas medidas foram expandidas em menor intensidade aos alunos das escolas públicas, que em sua maioria não dispunham de acesso à internet e que, em grande número, só tinham acesso às aulas com a chegada da família do trabalho, tendo em vista que muitas famílias possuíam apenas um celular a ser compartilhado por todos.

\section{Análise da quarta carta em contexto.}

Professor (a), aluno(a), família, ensinantes e aprendentes.

A obra de Freire (1992), "Professora, sim; tia, não - Cartas a quem ousa ensinar", foi refletida considerando que o ensinante é professor-educador, professora- 
educadora, não a figura do tio ou tia, como um parente postiço. Assim diz Freire (1997, p. 9): "a recusa, a meu ver, se deve sobretudo a duas razões principais. De um lado, evitar uma compreensão distorcida da tarefa profissional da professora, de outro, desocultar a sombra ideológica repousando manhosamente na intimidade da falsa identificação. Ser professor(a)-educador(a) tem exigências profissionais, afetivas e dialógicas com a sociedade que implicam em ousadia, coragem e também em formação permanente e na prática.

Clarificando a proposição, ouvimos a palavra de Freire sobre o tema

Professora, sim; tia, não - Cartas a quem ousa ensinar, eis o enunciado geral que temos diante de nós a exigir um primeiro empenho de compreensão. O de entender, tão bem quanto possível, não propriamente o significado em si de cada uma das palavras que compõem o enunciado geral, mas compreender o que elas ganham ou perdem, individualmente, enquanto inseridas numa trama de relações (FREIRE, 1997, p.8).

Entendendo que o ato de educador em si se dá em relações, Freire (1997, p.8), expõe sobre o escrito que justifica, "minha intenção neste texto é mostrar que a tarefa do ensinante, que é também aprendiz, sendo prazerosa é igualmente exigente. Exigente de seriedade, de preparo científico, de preparo físico, emocional, afetivo". E nesta dimensão o professor-educador necessita de importantes e significativas aprendizagens para sua formação pessoal e profissional que é fruto de composição de ensinante ao longo da vida, portanto tornando-se um eterno aprendiz.

Ainda na consideração do porquê do direcionamento da obra, afirma Freire (1997)

É impossível ensinar sem essa coragem de querer bem, sem a valentia dos que insistem mil vezes antes de uma desistência. É impossível ensinar sem a capacidade forjada, inventada, bem cuidada de amar. Daí que se diga no terceiro bloco do enunciado: Cartas a quem ousa ensinar... É preciso ousar para jamais dicotomizar o cognitivo do emocional. É preciso ousar para ficar ou permanecer ensinando por longo tempo nas condições que conhecemos, mal pagos, desrespeitados e resistindo ao risco de cair vencidos pelo cinismo (1997, p. 8,9).

E nesse sentido absorvemos a quarta carta que trata de qualidades para professores e professoras e fazemos analogia com os desafios que os assolaram no momento da Pandemia, especialmente os da rede pública. Estes, encontrando-se ou 
percebendo-se proletarizados, residindo em bairros periféricos com baixo índice ou nenhum cesso à internet, tiveram a necessidade de aprender a usar tecnologia, aplicativos interagindo a distância, apreendendo o dito "ensino híbrido" e concomitantemente demonstrando proatividade aos alunos em suas aprendizagens e nas de suas famílias, que em parte ficaram corresponsáveis por este processo.

No referente às famílias, outros problemas surgiram, como dificuldade de alimentar adequadamente seus filhos, que muitas vezes se utilizam da merenda escolar como a principal refeição do dia.

O professor Nilson José Machado, em entrevista ao programa Jornal da USP no $\operatorname{Ar} 1 \underline{\text { a Edição, }}$ analisa que o nível de ensino menos afetado pela transição à educação remota foi o da alfabetização. Provavelmente, faz esta abordagem por tratar-se de turma de alunos com menos envolvimento de convivência social na escola, sendo menor o impacto emocional, aspecto bastante afetado nos alunos. Para ele, o maior obstáculo está sendo o suporte às famílias das crianças, já que a escola não pode ser mais usada da mesma forma:

Problemas de alimentação, problemas de a família não estar bem estruturada para atender já existiam e foram amplificados. E eu não vejo problema muito especial com a alfabetização, acho que o governo faria bem em se preocupar menos com a miudeza dos processos de avaliação e mais com a condição de trabalho do professor e a condição de vida dessas famílias. Têm crianças em fase de alfabetização que estão sofrendo com isso e já estavam antes da pandemia. (MACHADO, 2021).

Um outro ponto importante foi a troca de saberes em uma nova situação apresentada referente ao conhecimento e uso dos recursos tecnológicos. Os alunos eram os que mais sabiam e muitos tiveram a oportunidade de ensinar os professores na operacionalização das aulas remotas, sugerindo nas Lives e em contato pelas redes sociais e aplicativos, medidas que poderiam ser utilizadas com mais acerto.

Destacando a humildade, apontada como uma qualidade indispensável ao professor por Freire (1997, p. 37), quando diz:

A humildade nos ajuda a reconhecer esta coisa óbvia: ninguém sabe tudo; ninguém ignora tudo. Todos sabemos algo; todos ignoramos algo. Sem humildade dificilmente ouviremos com respeito a quem consideramos demasiadamente longe de nosso nível de competência. 
Para abordar o tema humildade, temos que nos remeter à relação que esta ação tem com o conceito da palavra "didática" cujo significado é a arte de ensino e, para muitos professores que nada conhecem do seu sentido mais profundo, entendem como instruir, isto é, transmitir conhecimentos. Esse erro explica porque, assim na prática como na teoria, o vocábulo "didática" tem sido investido de uma ação que se distanciou do seu predicado precípuo e, de acordo com Freire, é a coerência do educador na sua prática educativa progressista.

Ao mesmo tempo podemos levantar uma questão a respeito deste fenômeno que vem ocorrendo na escola e mesmo na educação. Assim, este novo formato de escola que estaria nascendo a partir dessa experiência que deve permanecer, já vem criando "algo" novo que merece nossa reflexão.

Assim, certamente entre as qualidades dos ensinantes se faz necessário a amorosidade junto com a humildade, sem a qual o trabalho perde o significado de anunciar. E para que estas virtudes tenham sentido real na prática, é necessário investir-se de coragem como resposta ao medo, que é algo concreto. Freire esclarece que:

... quando pensamos em medo, somos levados a refletir sobre a necessidade de sermos muito claros a respeito de nossas opções... de sonhos, que são substantivamente políticos e adjetivamente pedagógicos, na medida em que reconheço que, enquanto educador, sou um político, também entendo melhor as razões pelas quais tenho medo e percebo o quanto temos ainda de caminhar para melhorar nossa democracia (FREIRE, 1997, p 38).

Em razão disso podemos registrar que não há medo sem a devida coragem para vencê-lo e sem o sonho para assumi-lo. Outro predicado, que sem ele não ocorre o trabalho pedagógico sério, é a tolerância.

Tolerância é virtude. Por isso mesmo se a vivo devo vivê-la como algo que assumo. Como algo que me faz coerente, primeiro, com o ser histórico, inconcluso que estou sendo, segundo, com minha opção político-democrática. Não vejo como possamos ser democráticos sem experimentar, como princípio fundamental, a tolerância, a convivência com o diferente (FREIRE, 1997, p. 39).

O diferente nos ensina sempre e essa convivência é fundamental na construção deste fazer pedagógico em que aprendemos e ensinamos com os alunos e suas 
famílias. Em que assumimos esta virtude, no momento em que decidimos ser educadores ou educadoras progressistas, na perspectiva de estarmos formando-nos permanentemente na prática social sem fugir à responsabilidade de tomar decisões com segurança, o que exige "competência científica, clareza política e integridade ética”. (FREIRE, 1997, p.40).

\section{Considerações Finais}

Vivendo os desafios de momento e transcendendo o presente, perguntamos: Paulo Freire escreveria nova carta aos professores nos tempos de Pandemia-COVID$19 ?$

Acreditamos que não, especificamente. Paulo Freire já as escreveu e as retomaria com o fazer comprometido de professores, detalhando que "o homem está no mundo e com o mundo... Isto o torna um ser capaz de relacionar-se; de sair de si; de projetar-se nos outros; de transcender" (FREIRE, 1987, p. 30). Complementando: “ o que não é possível é estar no mundo, com o mundo e com os outros, indiferentes a uma certa compreensão de por que fazemos o que fazemos, de a favor de que e de quem fazemos, de contra que e contra quem fazemos o que fazemos " (FREIRE, 2000, p. 125).

Para entender a ação que Paulo Freire espera que os professores em 2020/2021 realizem, está exposto como:

Despolitizando a educação e reduzindo-a ao treino de destrezas, a ideologia e a política neoliberais terminam por gerar uma prática educativa que contradiz ou obstaculiza uma das exigências fundamentais do próprio avanço tecnológico. A de como preparar sujeitos críticos capazes de responder com presteza e eficácia a desafios inesperados e diversificados. Na verdade, o treinamento estreito, tecnicista, habilita o educando a repetir determinados comportamentos. O de que precisamos, contudo, é algo mais do que isto... O de que precisamos é a capacidade de ir mais além de comportamentos esperados, é contar com a curiosidade crítica do sujeito sem a qual a invenção e reinvenção das coisas se dificultam (FREIRE, 2000, p.124)

Ainda diz: "Me parece importante, reconhecendo a incompletude das reflexões em torno das qualidades, discutir um pouco a alegria de viver como virtude fundamental da prática educativa democrática." (FREIRE, 1997, p. 42). 
E ainda buscando as qualidades e virtudes apontadas na quarta carta, objeto principal de nossa análise, destacamos que

é vivendo, não importa se com deslizes, com incoerências, mas disposto a superá-los, a humildade, a amorosidade, a coragem, a tolerância, a competência, a capacidade de decidir, a segurança, a eticidade, a justiça, a tensão entre a paciência e a impaciência, a parcimônia verbal, que contribui para forjar a escola feliz, a escola alegre... FREIRE (1997, p. 42)

não importando a distância física entre alunos, professores e família compartilhando e participando do processo, o que especialmente nos permite esperançar.

Esperançar nos delineia que "não há possibilidade de pensarmos o amanhã, mais próximo ou mais remoto, sem que nos achemos em processo permanente de "emersão" do hoje, "molhados" do tempo que vivemos, tocados por seus desafios, instigados por seus problemas ..." (FREIRE, 2000, p.117).

Considerando finalmente, quando Freire (2000) firmemente diz: "para mim, ao repensar nos dados concretos da realidade, sendo vivida, o pensamento profético, que é também utópico, implica a denúncia de como estamos vivendo e o anúncio de como poderíamos viver. É um pensamento esperançoso, por isso mesmo". Dessa forma nos aponta com clareza que "é neste sentido que... o pensamento profético não apenas fala do que pode vir, mas falando de como está a realidade, denunciando-a, anuncia um mundo melhor" (FREIRE, 2000, p. 119).

\section{Referências}

BRASIL, SENADO FEDERAL_Pandemia acentua déficit educacional e exige ações do poder público, 2021. Disponível em < https://www12.senado.leg.br/noticias/infomaterias/2021/07/pandemia-acentua-deficiteducacional-e-exige-acoes-do-poder-publico >. Acesso em 06_set_2021.

FREIRE, Paulo, Educação e Mudança. São Paulo, Editora Paz e Terra, 1987.

FREIRE, Paulo; SHOR, Ira. Medo e Ousadia, cotidiano do professor. Rio de Janeiro Editora Paz e Terra, 1992.

FREIRE, Paulo. Professora sim, tia não - cartas a quem ousa ensinar. São Paulo, Editora Olho d'agua, 1997. 
FREIRE, Paulo, Pedagogia da Indignação. Cartas Pedagógicas e outros escritos. São Paulo: Editora UNESP, 2000.

Jornal da USP no Ar / Jornal da USP no Ar 1 $1^{\underline{a}}$ edição / Rádio USP Atualidades < https://jornal.usp.br/?p=418460 >.24/05/2021. Acesso em 05_set_2021.

MEC / INEP- Divulgados dados sobre impacto da pandemia na educação, disponível em < https://www.gov.br/inep/pt-br/assuntos/noticias/censo-escolar/divulgadosdados-sobre-impacto-da-pandemia-na-educacao >. Acesso em 06_set_2021.

SARAIVA, Katia, TRAVERSINI, Clarice, LOCKMANN, Kamila, A educação em tempos de COVID-19: ensino remoto e exaustão docente, Praxis Educativa 2020, vol. 1515 (2020), p. 1-24, 2020 - lume.ufrgs.br, disponível em:

https://revistas2.uepg.br/index.php/praxiseducativa/article/view/16289, acesso em 07_set_2021

UNICEF, Busca ativa de estudantes é prioridade para redes municipais de educação em 2021, disponível em < https://www.unicef.org/brazil/comunicados-deimprensa/busca-ativa-de-estudantes-e-prioridade-para-redes-municipais-deeducacao-em-2021 >. Acesso em 08_set_2021. 


\section{EDUCAÇÃO PATRIMONIAL LIBERTADORA, RELAÇÃO INDIVÍDUO- SOCIEDADE: OBSERVAÇÕES DA CONCEPÇÃO E CONTRIBUIÇÃO PEDAGÓGICA DE PAULO FREIRE NA EDUCAÇÃO PATRIMONIAL NAS SÉRIES INICIAIS DO FUNDAMENTAL I.}

Maria Vitória De Moura Opasso Pequeño

Scarlet Karen Buzzi

\section{Resumo}

Está pesquisa propõe uma análise das contribuições epistemológicas da Educação Libertadora de Paulo Freire no âmbito da Educação Patrimonial. Temos a intenção de trazermos reflexões vigentes na maneira de abordar e pensar este tema de suma relevância para a educação. Não conseguimos pensar em Educação Patrimonial sendo construída sozinha dentro de uma instituição, os ideais precisam ser em conjunto, pois, são elaborados para o desenvolvimento de um todo: a instituição, gestão, coordenadores, diretores, professores e alunos. O processo de escolarização sobre a Educação Patrimonial nas séries fundamentais é um processo que influenciará os adultos do futuro, numa comprovação de quanto este assunto é pertinente em documentos curriculares educacionais da atualidade e de como essas mudanças que ocorrerão no âmbito educacional correlacionam-se com os ideais da Educação Libertadora de Paulo Freire. Está pesquisa preza sobre a importância, a repercussão e as diversas maneiras que este tema pode ser abordado na sala de aula para os alunos do fundamental dos anos iniciais, tendo em vista o fortalecimento de vínculos entre identidade, memória, cultura popular e regional junto a uma educação libertadora nas escolas brasileiras.

Palavras-chaves: Educação Patrimonial; Educação Libertadora; Paulo Freire.

\section{Introdução}

No Brasil, abordar sobre Patrimônio Cultural ou Educação Patrimonial são temas muito contemporâneos e de diversas discussões, que vem crescendo com ações educativas em museus, escolas e espaços educativos não formais. É importante reconhecer o crescimento e o fortalecimento deste termo no âmbito educacional e como método de pesquisa em diversas áreas de conhecimento das ciências humanas. Acreditamos por estas razões a necessidade da Educação Patrimonial dentro das escolas, sendo abordada desde as séries iniciais, pois as futuras gerações passam a ter uma nova visão social, histórico e econômico, 
aprendendo a fazer a leitura do mundo que o rodeia, como cidadãos conscientes da importância e da valorização do passado e da história.

Esta pesquisa traz como pauta não só reflexiva, mas também a correlação do aspecto histórico-social no âmbito da Educação Patrimonial enfatizando a Educação Libertadora de Paulo Freire. Tais análises trazem à tona indagações as quais temos como enfoque responder: qual a importância da Educação Patrimonial para os estudantes do fundamental I? O que é ser um educador libertador? A Educação Patrimonial pode ser libertadora no seu processo de ensino aprendizagem? Tais questões salientam a respondê-las para serem fundamentadas para a evolução deste tema no repertório educacional.

A pesquisa vigente tem como panorama informativo moldar este assunto com as análises da pedagogia discutida aqui, que propõe uma educação crítica pensada no serviço de transformações sociais, ideias que andam juntas com a Educação Patrimonial. Correlacionando o conceito de Educação Patrimonial com as práticas reflexivas escolares da Educação Libertadora, buscamos através dessa junção o desenvolvimento da curiosidade crítica do aluno, como ser autônomo e pensante.

Atualmente na área das ciências humanas, alguns historiadores e profissionais da área da educação que lidam com a memória como fonte de estudo, da sociedade e do passado, vêm expondo no campo de suas instituições culturais, sobretudo em museus, a elaboração de programas de Educação Patrimonial, o que já vem sendo um grande passo na trajetória da conscientização no âmbito da Educação Patrimonial na sociedade e não somente como fonte de pesquisas. Caminhando junto com a linha de pensamento deste estudo, as concepções educacionais de Paulo Freire, educador que contribuiu muito para a história da pedagogia em suas obras, enfoca em seus trabalhos na essência humana e na relação indivíduo-sociedade; essa linha de pensamento auxilia na ampliação de ideias sobre a educação libertadora correlacionada com a Educação Patrimonial.

\section{Revisão Bibliográfica}

Temos como suporte teórico o Guia Básico de Educação Patrimonial - MUSEU IMPERIAL / DEPROM - IPHAN - MINC, obras do educador Paulo Freire, focalizando na Educação Libertadora no ensino das Ciências Humanas e leituras de artigos que têm como base a Educação Patrimonial. E temos também como suporte as leituras 
das obras de educadores e pesquisas como: Isabel Alarcão, Michele Abreu Arroyo, Flávio de Lemos Carsalade, Allana Pessanha Moraes, entre tantos outros nomes que engradece o estudo no ramo educacional de práticas pedagógicas, que visa as transformações na educação e no aspecto indivíduo- sociedade.

\section{Metodologia}

A metodologia desse artigo tem cunho bibliográfico, com sua fundamentação nas análises e dizeres do autor Paulo Freire, nas pesquisas de artigos acadêmicos na área de Educação Patrimonial e nas vivências de uma das autoras durante seu estágio na Pinacoteca Benedicto Calixto. Formou-se um conjunto de ideias e procedimentos para a reflexão e a elaboração de uma Educação Patrimonial Libertadora nas séries iniciais do Fundamental I. De acordo com o objetivo desta proposta, a atividade escolar contempla discussões de temas sociais e políticos através da familiarização dos alunos com o passado, o patrimônio em ações sobre a realidade, analisando questões e fatores dos reflexos da nossa sociedade e com isso estrutura-se uma forma de atuação para que se possa transformar a realidade social e política dentro das escolas, nos ciclos do Fundamental I.

Os primeiros passos para o pertencimento e o educar patrimonial: conceituar, articular e vivenciar na sala de aula.

Desde a consciência mais antiga que se manifestou na humanidade quanto à disseminação dos bens de família, quanto aos registros nas paredes das cavernas na era pré-histórica (as artes rupestres), até os diários que se tornaram moda em toda Europa do século XVIII ao XIX, como forma de registro do momento de passagem da juventude para vida adulta e relatos do cotidiano, até o entendimento mais contemporâneo, desenvolveu-se a ideia de um Patrimônio a ser transmitido para gerações futuras. É importante ressaltar neste momento de fala que o conceito de Patrimônio é uma construção social, independente do seu tempo cronológico histórico.

Conceituar Patrimônio é muito além de explicar o significado da parte etimológica, estrutural e gramatical do termo: a junção de "patri", termo designador de "pai" com "monium", que exprime "recebido", para referir-se a "herança": (patrimonium), origem latina, que entre os antigos romanos, tudo que era de pertencimento ao pai de família. 
"O órgão governamental que se responsabiliza sobre tudo que é relacionado ao Patrimônio é o Instituto do Patrimônio Histórico e Artístico Nacional - IPHAN, criado como secretaria durante o governo Vargas, como SPHAN no ano 1934, 14 de julho." (MORAES, Allana, 2006).

Este órgão vem concretizando o processo de resgate do passado para a sociedade, abordando a importância da conscientização do Patrimônio Cultural em coletivo e não somente histórico para obter resultados na sociedade contemporânea. A maneira que esse procedimento deve ser direcionado é pelo processo de escolarização na educação inicial dos alunos e para que haja resultados em massa na sociedade.

É evidente o quão este assunto é primordial para a introdução de uma visão de mundo social. Com todas as informações da nossa contemporaneidade é pertinente notar os adjetivos que este termo recebeu ao longo do tempo (artístico, tesouro, herança, paisagístico, histórico, móvel, imóvel, intangível, imaterial etc.) que indicam uma recriação do conceito de Patrimônio sempre apropriado e também indicando as concepções de tempo, questões políticas, lugar social, autor produtivo, perspectivas teóricas e metodológicas criadas entre lembranças e esquecimentos pelos indivíduos de sua época. Ter essa visão ampla da época que foi abordado e por quem foi abordado, significa muito na hora de vivenciar e explicar essa contextualização em sala de aula para os alunos em um processo educativo.

A palavra Patrimônio é usada em vários contextos e expressões desde seu surgimento. É importante evidenciar que também depende muito do seu cenário cultural, em cada país, cidade e local terá seus significados coloquiais usados pela sociedade. Falar sobre Patrimônio "coloquial" é referir-se aos Patrimônios do dia a dia como, por exemplo, dos Patrimônios imobiliários, econômicos, que são os Patrimônios financeiros de uma empresa, de uma pessoa ou de uma família visto como herança e bens materiais. O Patrimônio também tem o sentido cultural que abrange as questões (arquitetônicos, históricos, artísticos, etnográficos, ecológicos, genéticos), que são temas de pesquisas, debates, palestras, projetos de educação Patrimonial. O foco dessa pesquisa é evidenciar no Patrimônio como cultura e construção social.

"É importante ressalvar também os chamados patrimônios intangíveis ou imateriais, de recente formulação segundo o Decreto $n \times 3.551$, de 4 de agosto de 2000, que institui o registro e cria o Programa Nacional 
do Patrimônio Imaterial, compreende o Patrimônio Cultural Imaterial brasileiro como os saberes, os ofícios, as festas, os rituais, as expressões artísticas e lúdicas, que, integrados à vida dos diferentes grupos sociais, configuram-se como referências identitárias na visão dos próprios grupos que as praticam." (CAVALCANTI; FONSECA, p. 11, 2008).

O Patrimônio tem sido cada vez mais usado, não somete em questões de pesquisas ou relacionados ao âmbito educacional, mas sim por diferentes sujeitos, grupos e instituições, o que torna nítido o quão sua repercussão foi importante nesses últimos anos do final do século $\mathrm{XX}$ e começo do século $\mathrm{XXI}$. Os contextos sociais e históricos responsáveis pelo alargamento do conceito do termo Patrimônio Cultural serão aos poucos abordados neste artigo, pois trazer a trajetória dos seus sentidos é refletir sobre as mudanças do amanhã.

O melhor método de construir qualquer tipo de mediação em torno desse assunto e dos diversos bens culturais que existem em nosso país, cidade, região ou bairro, é fazer com que esses bens culturais ganhem valor de Patrimônio representativo de alguma coletividade, seja ela nacional, regional ou até mesmo da comunidade de um bairro. Com isso, sem dúvidas, conhecendo a trajetória dos mesmos bens culturais e fazendo com que desenvolva o sentimento de pertencimento.

O intuito desta pesquisa é rever e modernizar a grade curricular brasileira, com a inserção da Educação Patrimonial para além de um plano de aula, uma sequência didática ou em projetos pedagógicos e sim em algo mais extenso, inserido na grade curricular para a sala de aula. O Patrimônio Cultural na educação seria um planejamento para um exercício de conscientização, valorização e pertencimento que sejam trabalhados desde cedo nos jovens estudantes, nas futuras gerações já habituadas e ingressadas nessa nova visão de mundo.

Com essas mudanças nas práticas educacionais, a educação terá reflexos, transformando opiniões, desconstruções em vários âmbitos.

Inserir uma "nova disciplina" na grade curricular brasileira, é um trabalho que exige muito esforço e dedicação para todo seu processo de estruturação como disciplina para sair do papel, é preciso também o suporte das secretarias de educação dos estados e municípios de cada região em parceria com os órgãos de preservação 
e instituições sociais que acolhem a causa tornando possível a universalidade do tema nas escolas brasileiras. A inserção da Educação Patrimonial não é apenas a criação de uma matéria escolar, e sim como será o desenvolvimento deste conteúdo ao decorrer dos anos letivos do fundamental para a compreensão das crianças. O tema precisa acompanhar a idade do aluno, o assunto precisa ser dominado pelo professor atuante, onde as escolas têm a obrigatoriedade de disponibilizar cursos e atividades pedagógicas que preparem o professor com a metodologia adequada sobre Educação Patrimonial adaptada para as idades de acordo com cada série.

A Educação Patrimonial pode ter seu papel reconhecido dentro do currículo escolar, através do preparo profissional da escola. Sempre que possível, a escola tem o dever de atualizar o currículo com práticas educativas que trabalhem de diferentes formas a construção do que é Patrimônio e sua importância como: leituras, palestras, vídeos, gincanas etc. Abrindo o caminho da valorização das identidades culturais, desenvolvendo práticas e habilidades do tema e canalizando-as assim, com o cotidiano do aluno.

Existem diversas maneiras que o professor(a) pode abordar o tema Patrimônio na escola. Como se tratam de crianças em fase de desenvolvimento cognitivo, motoro, sensorial e seus esquemas (estruturas mentais), não é suficiente apenas conceituar ou esclarecer dúvidas, é preciso inovar o método de ensino, abordando o assunto de forma significativa, instigando o aluno a pesquisar, sentir-se um próprio pesquisador através de conhecimentos a serem compartilhados em sala de aula com os colegas, estimular a visão dos alunos com o antigo como se fosse algo normal, jogos, brincadeiras que compõem o lúdico com o tema educacional proposto.

A Museóloga, e historiadora Maria de Lourdes Parreiras Horta ${ }^{1}$ (Guia básico de Educação Patrimonial, 1999) ${ }^{1}$, aponta a Educação Patrimonial como um processo permanente e sistemático de trabalho educacional, centrado no Patrimônio Cultural como fonte primária de conhecimento e enriquecimento individual e coletivo, seguindo a linha de raciocínio com as palavras da autora, o contato direto com as evidências da cultura proporciona um trabalho que leva os indivíduos a um processo ativo de apropriação e valorização.

A autora no Guia Básico de Educação Patrimonial afirma a importância em provocar momentos de aprendizados sobre o processo cultural durante as aulas e suas manifestações, desperta nos alunos 0 interesse de resolver questões significativas que levaram para a vida, pessoal e coletiva, tendo como resultado o 
sentimento de pertencimento, ao passado, à história como ser atuante. O Patrimônio Cultural e o meio-ambiente histórico em que está inserido oferecem oportunidades de provocar nos alunos sentimentos de surpresa e curiosidade, levando-os a querer conhecer mais sobre eles. É visível a relevância que este tema possui no processo educativo, a fim de desenvolver a sensibilidade, a consciência e o sentimento de atuação e estimulando o exercício da cidadania nos alunos.

\section{Educação Patrimonial no contexto pedagógico: O reflexionar libertador sobre o passado, intencionado no amanhã.}

Quando estimulamos o saber e o reconhecer sobre o Patrimônio durante o período escolar, estamos semeando na educação uma formação de cidadãos mais conscientes e democráticos. Esse reconhecimento é fundamental para a leitura de mundo do aluno, para que tenha em sua bagagem pessoal a conscientização do cuidado coletivo, o pertencimento, o respeito pela cultura local e do mundo afora. As gerações dos anos dois mil para cá, têm acesso à informação de maneira rápida e prática, auxiliando a educação na formação de seres pensantes que possuem informações em uma agilidade que não se tinham há três décadas. "A designação de sociedade do conhecimento e da aprendizagem traduz o reconhecimento das competências que são exigidas aos cidadãos de hoje. Importa, assim, refletir sobre novas competências." (ALARCÃO, 2011).

Estudarmos a origem das palavras usadas na língua portuguesa no âmbito pedagógico, vem com o intuito de explicar sobre como certas palavras surgiram e o que significavam; ter esta visão é refletir como os seus significados no trazem ações educativas para serem praticadas na atualidade. Analisar as contribuições de Paulo Freire para a educação brasileira é influenciar os aspectos mais íntimos do seu campo de ideias, é ter em mente que ensinar exige a ideia de que mudanças no ensino sempre será possível.

Com a ótica das contribuições da Educação Libertadora na Educação Patrimonial, será analisada a parte etimológica da palavra "Educação Libertadora":

A pedagogia elaborada como libertadora, teve em seu contexto de origem, no século vinte, mas exatamente o final da década de cinquenta e o início da década de sessenta, passando por interrupção pelo Golpe Militar de 1964, e retoma o seu desenvolvimento e seus estudos em prol de mudanças no âmbito educacional no final da década de setenta e início da década de oitenta. Desde então, não trouxe somente 
mudanças para educação e sim transformações do ensino num todo, trazendo consigo, oportunidades até então não exploradas, um olhar mais humano, estimulando nos estudantes não somente a liberdade no ato de pensar, expressar e desenvolver sua trajetória na escola, mas também "ensinando" princípios da vida, como seres atuantes na sociedade. A Educação Libertadora tem como alicerce a educação conscientizadora, na maneira que o intuito é fazer com que os alunos, busquem e tenham um olhar além de conhecer a realidade e sim procurar mecanismos na busca de transformá-la. O professor como mediador, aprende muito com os alunos, por abrir espaço entre os alunos, a sua liberdade de expressão.

Quando pensamos em fazer mudanças na educação, analisamos primordialmente o contexto em que estamos inseridos, o social e o histórico. Paulo Freire quando propôs um novo método no ato de educar, estava pensando nos futuros estudantes brasileiros e é o que tentamos através desta pesquisa, expandir as visões dos educadores para os educandos, abordando o passado de forma contemporânea, na estimulação do desenvolvimento dos valores atuais, do século vinte e um.

Paulo Freire priorizara a discussão dos conceitos fundamentais sobre Patrimônio Cultural abarcando as categorias de identidade, memória e cultura. $\mathrm{Na}$ concepção freiriana de "leitura do mundo", a valorização das culturas locais e do contexto social perpassa pelo reconhecimento dos bens culturais, sejam eles patrimônios consagrados ou não consagrados.

A partir do estudo da Pedagogia Libertadora de Paulo Freire, foi construído o entendimento de que essa proposta freiriana, focaliza no campo da Educação Libertadora e este conceito pedagógico possui um direcionamento para as transformações sociais na educação, na forma de ensinar, visualizando novos significados para as práticas educativas, para aprender, resplandecendo o modelo de educação proposto por Paulo Freire, pois se diferencia da educação tradicional, trazendo a liberdade e autonomia ao aluno, tendo como enfoque a visão negativa de elementos da dependência dominadora.

Ao analisar o estudo teórico utilizado por Paulo Freire sobre o que é uma Educação Libertadora, tivemos o intuito de abordar nesta pesquisa sobre como esse conceito está articulado dentro de uma Educação Patrimonial nas escolas. A constituição de uma educação libertadora depende muito do professor presente e da instituição de ensino, pois ambas trabalham juntas, para que possam colher frutos dentro da sala de aula, incentivando além da autonomia nos estudantes, a consciência 
que nos permite compreender, da importância da educação libertadora dentro da Educação Patrimonial em uma história educacional dentro de uma sociedade opressora produzida pelo ser humano, principalmente no meio educacional. "É por isso que transformar a experiência educativa em puro treinamento técnico é amesquinhar o que há de fundamentalmente humano no exercício educativo: o seu caráter formador." (FREIRE, 2020).

A Educação Patrimonial na escola tem a função de ser o momento em que o aluno possa ter a liberdade de desenvolvimento da curiosidade crítica, através de suas perguntas, ideais, transmitir sua visão para ajudar a compor a aula, pois falar sobre Patrimônio Cultural, é falar sobre os indivíduos que nele habitam, falar sobre o passado, é visualizar opiniões, costumes e crenças que uma determinada sociedade viveu e possuíam em um período. Aulas que possibilitam a criação, reflexão crítica e visões amplas de mundo, pois tais atos transformam experiências educativas.

O autor Paulo Freire nos motiva a mudar nossa conduta como educador, e essa pesquisa foi pensada numa articulação que pratique a liberdade da educação progressista: "Como professor preciso me mover com clareza na minha prática. Preciso conhecer as diferentes dimensões que caracterizam a essência da prática, 0 que me pode tornar mais seguro ao meu próprio desempenho." (FREIRE, 2020).

\section{Considerações Finais}

As contribuições do Ensino Patrimonial como disciplina libertadora, são vastas e com o estudo dos variados documentos nacionais educativos, pesquisas, estudos das obras de Paulo Freire, percebemos o quanto este tema agregará muito para tornar as escolas brasileiras como espaços mais reflexivos e mais sociais. A Educação Patrimonial vai muito além do exercício de cidadania, ela ultrapassa barreiras, visando o desenvolvimento da curiosidade crítica e a autonomia e sensibilidades cognitivas adquiridos por meio desta prática docente desde o início dos anos iniciais do fundamental I. O ensino sobre Patrimônio é um assunto que está sendo criticamente pensado a sua prática de hoje, de ontem ou de uma década atrás. Por essas questões discutidas e salientadas, esta pesquisa nos mostra que se pode melhorar as próximas práticas de um mesmo assunto, interligando pensadores, revendo as práticas antigas, estigando a criatividade do educador e pensando no desenvolvimento social das gerações de alunos do amanhã. 
O autor Paulo Freire nos pontua que ensinar exige reflexão crítica sobre a prática, o aperfeiçoamento é com o tempo e as práticas passaram a serem outras e assim que a educação evolui a cada década.

Refletir sobre a importância e os resultados dos valores e conhecimentos que a Educação Patrimonial agregará na formação social e cultural das futuras gerações, é aprender a estudar cada dia a mais que a construção da consciência histórica contemporânea devem ser trabalhadas pela educação.

As séries iniciais são o período ideal para o desenvolvimento dessa amplificação de visões de mundo, conceituando-as de acordo com o cotidiano do estudante, vivenciando e amplificando essas questões junto ao lúdico e ao decorrer das séries fundamentais fazendo com que o desenvolvimento desse conceito se torne algo agradável e de simples compreensão para os alunos.

Através desta pesquisa, temos o princípio de levar o leitor a refletir não somente da importância da Educação Patrimonial Libertadora já pontuados em pesquisas, documentos curriculares, mas sim em pensar: Por que ainda não se tornou um componente curricular? A Educação Patrimonial Libertadora é um exercício de modernização educacional do século vinte um, quebrando paradigmas a serem trabalhados nas gerações da atualidade? $O$ ato de educar sobre o passado já não é uma prática da liberdade no âmbito individuo-sociedade? As ideias esclarecem as dúvidas e questões que possam ter sobre o tema abordado, mas ao finalizar a leitura deste artigo, é instigante e possível que professores, educadores e especialistas da área trabalhem juntos para desenvolver não só a Educação Patrimonial como um tema a ser desenvolvido em algum projeto interdisciplinar, mas sim como uma área de conhecimento, quem sabe, em algum dia transformando-a num componente Curricular.

\section{Referências bibliográficas}

ALARCÃO, Isabel. A Sociedade em que vivemos. In: Professores Reflexivos em uma Escola Reflexiva. vol. 8, ed. 8, São Paulo: Cortez Editora, 2011, p. 17-18 
ARROYO, Michele Abreu. Educação Patrimonial e a cidade como espaço educativo. (PREFEITURA DE SANTOS. Secretaria de Educação, Documento Currículo Santista, p. 400, 21 de agosto de 2019).

CARSALADE, Flávio de Lemos. Educação e Patrimônio Cultural. In: GRUPO Gestor do Projeto de Educação Patrimonial. Reflexões e contribuições para a Educação Patrimonial.

Cristina A. R. Barletta, PREFEITURA DE SANTOS Secretaria de Educação, Documento Currículo Santista. p. 3, 21 de agosto de 2019.

FREIRE, Paulo. Ensinar não é só transferir conhecimento. In: Pedagogia da autonomia: saberes necessários à prática educativa. $63^{2} E d$. Rio de Janeiro/ São Paulo: Editora Paz e Terra, p. 67 - 74, 2020

FREIRE, Paulo. Prática Docente: Primeira Reflexão. In: Pedagogia da Autonomia: saberes necessários à prática educativa. $63^{\mathrm{a}} \mathrm{Ed}$. Rio de Janeiro/ São Paulo: Editora Paz e Terra, p. 34, 2020.

PREFEITURA DE SANTOS Secretaria de Educação, Documento Currículo Santista. p. 15, 21 de agosto de 2019.

SOUSA, Antônio Oziêlton; PIO, Paulo Martins. A Constituição de uma Concepção de Educação Libertadora em Paulo Freire. Ceará: Universidade Estadual do Ceará - UECE, p. 1.

MENEZES, Ebenezer Takuno de. Verbete pedagogia libertadora. Dicionário Interativo da Educação Brasileira - EducaBrasil. São Paulo: Midiamix Editora, 2001. Disponível em <https://www.educabrasil.com.br/pedagogia-libertadora/>. Acesso em 10 ago 2021.

MORAES, Allana Pessanha. Educação Patrimonial nas escolas: aprendendo a resgatar o patrimônio cultural. Rio de Janeiro: Centro de Ciências do Homem, Universidade Estadual do Norte Fluminense Darcy Ribeiro, p. 1-15, 2006.

Outras Fontes - Necessário acrescentar elementos as fontes utilizadas para melhor identificá-las, de modo a serem inseridas nas referências. 
BRASIL. Ministério da Educação. Base Nacional Comum Curricular. p.11, 2018.

O patrimônio cultural brasileiro: novos instrumentos de preservação. Brasília: MinC: IPHAN:DID, 2002.

Curso de extensão online Competências Profissionais, Emocionais e Tecnológicas para Tempos de Mudança: com os professores Leandro Karnal e Luiza Helena Trajano - 2020. Pontifícia Universidade Católica do Rio Grande do Sul- PUCRS.

Curso de Extensão Universitária na modalidade de Difusão: Discussões e Incursões sobre o Patrimônio. República Federativa do Brasil Universidade de São Paulo Ruínas Engenho São Jorge dos Erasmos -2018.

Enap- Curso Acessibilidade em Museus-2020.

Enap- Curso Conservação Preventiva para Acervos Museológicos - 2020

Formação de Mediadores de Educação para Patrimônio- Curso 4 FUNDAÇÃO DEMÓCRITO ROCHA | UNIVERSIDADE ABERTA DO NORDESTE.

IPHAN - Guia Básico de Educação Patrimonial. 


\title{
O PENSAR ESPERANÇOSO NA LEITURA DE IMAGENS \\ E REFLEXÕES SOCIOAMBIENTAIS DA BAIXADA SANTISTA
}

\author{
Mariana de Paula Caetano \\ Renata Barrocas \\ Gerson Tenório dos Santos
}

\section{RESUMO}

O presente estudo bibliográfico resgata a obra Pedagogia da esperança: um reencontro com a pedagogia do oprimido, de Paulo Freire, e a relaciona com a importância do trabalho com a leitura de imagens. Referenciando-se em alguns autores que investigam o tema a partir de diferentes abordagens, é apresentada uma proposta de sequência didática interdisciplinar. A sequência propõe analisar imagens sobre questões socioambientais da Baixada Santista, permitindo que a leitura parta de temas locais. São apresentados alguns componentes curriculares e habilidades a serem desenvolvidas em turmas de $3^{\circ}$ Ano do Ensino Fundamental. O estudo avança também em reflexões sobre a alfabetização visual como forma de se aprender e ensinar a leitura de imagens. Levanta-se a hipótese de como esta alfabetização pode despertar nas crianças o interesse pela busca do conhecimento. Por fim, aponta que novas elaborações teóricas e práticas sobre a leitura de imagens e a alfabetização visual devem ser seguidas.

Palavras-chave: Pedagogia da esperança; Leitura de imagens; socio ambientalismo; Baixada Santista; Alfabetização visual.

\section{Introdução}

A história de Greta Thuberg, jovem ativista ambiental, que despertou para a questão ecológica motivada por professores no ensino fundamental, nos serviu de inspiração para desenvolver este trabalho. Com 8 anos de idade, seus professores trabalharam com a turma imagens de florestas desmatadas, plásticos nos oceanos e ursos polares famintos. Em 2019, ela se juntou a 15 ativistas (de 8 a 17 anos), que apresentaram uma denúncia ao Comitê dos Direitos da Criança da ONU (Organização das Nações Unidas). Pediram a criação de medidas que protejam as crianças dos efeitos da crise climática. Este movimento tem levado à organização coletiva de milhares de crianças e adolescentes pelo planeta, incluindo o Brasil.

Em nosso país, muitos de nós, professores e professoras, andamos desesperançados com a Educação e com os problemas socioambientais que enfrentamos. Mas quando vemos ações de jovens ativistas ambientais, projetamos nossos estudantes neles e sentimos que vale a pena seguir nos dedicando a nossa profissão. Assim, a busca por estratégias didáticas a partir da realidade socioambiental das nossas crianças, por exemplo, pode ser fundamental. Neste 
sentido, o trabalho com leituras de imagens deve ser um instrumento para despertar nas crianças a paixão pela busca do conhecimento e por inspirações para o futuro de suas vidas.

Apoiando-nos na obra de Paulo Freire (2014), Pedagogia da esperança: um reencontro com a pedagogia do oprimido, procuramos relacionar o pensamento pedagógico e as práticas educativas do autor com uma pesquisa qualitativa em estudos bibliográficos de Lucia Santaella (2002, 2012, 2017), Paulo Cesar Gomes (2017), Marina Martins (2008), Sandra Ramalho (2014), dentre outros materiais. Assim, buscaremos encontrar novas possibilidades de encarar os desafios do presente e transformar a esperança em práticas concretas.

Apresentaremos imagens do Brasil e da Baixada Santista que despertam atenção para questões socioambientais. O objetivo é preparar uma sequência didática que possa ser utilizada em aulas sob uma perspectiva interdisciplinar para crianças com cerca de 8 anos do $3^{\circ}$ ano do Ensino Fundamental. Os componentes e objetos do conhecimento da BNCC que desenvolveremos serão os de Língua Portuguesa (Compreensão em leitura e o tema/assunto do texto), História (A cidade, seus espaços públicos e privados e suas áreas de conservação ambiental), Geografia (Princípios de análise da paisagem: distinção e classificação dos seus elementos), Ciências da Natureza (Meio Ambiente) e Arte (Patrimônio Cultural).

Analisaremos imagens da região do fotógrafo da natureza Araquém Alcântara e do pintor caiçara Benedito Calixto. Trabalharemos também com um mapa e imagens de materiais jornalísticos de Santos, São Vicente e Praia Grande.

\section{Questões socioambientais através da leitura de imagens: uma proposta de sequência didática}

Nos últimos anos as queimadas de nossas riquezas naturais têm sido intensificadas. Araquém Alcântara escolhe utilizar sua câmera fotográfica como instrumento de denúncia da matança e também de registros da luta pela sobrevivência das espécies, incluindo a humana. Fotografar é um ato de escolha, conforme afirma Lúcia Santaella:

O que congelar para sempre? Para onde dirigir o olho da câmera? A que distância, em que posição e sob qual ângulo se colocar em relação ao motivo a ser fotografado? Que lugar ocupa o fotógrafo diante do espetáculo do mundo, vasto mundo? Como enquadrar? O que fica 
dentro e o que fica fora da inevitável moldura da foto? Tudo isso porque, depois do clique, depois do gatilho, do corte ao vivo de uma fatia única e singular de espaço e tempo, não há mais como mudar o instante que se congelou para sempre (SANTAELLA, 2012, p. 72).

Apoiando-nos na pedagogia de Paulo Freire, propomos, a seguir, uma sequência didática para o trabalho das questões socioambientais através da leitura de imagens para estudantes de $3^{\circ}$ ano do Ensino Fundamental. Partiremos da leitura de mundo das crianças, pois "o educando se torna realmente educando quando e na medida em que conhece, ou vai conhecendo os conteúdos, os objetos cognoscíveis, e não na medida em que o educador vai depositando nele a descrição dos objetos, ou dos conteúdos". (FREIRE, 2014, p. 46, grifos do autor)

Na aula 1 serão exploradas a leitura das Figuras 1 e 2, fotos de animais que lutam para sobreviver às queimadas na região do Pantanal e na região Amazônica.

Figura 1 - Quati procura comida perto do corpo de um jacaré morto nos incêndios que devastam o Pantanal.

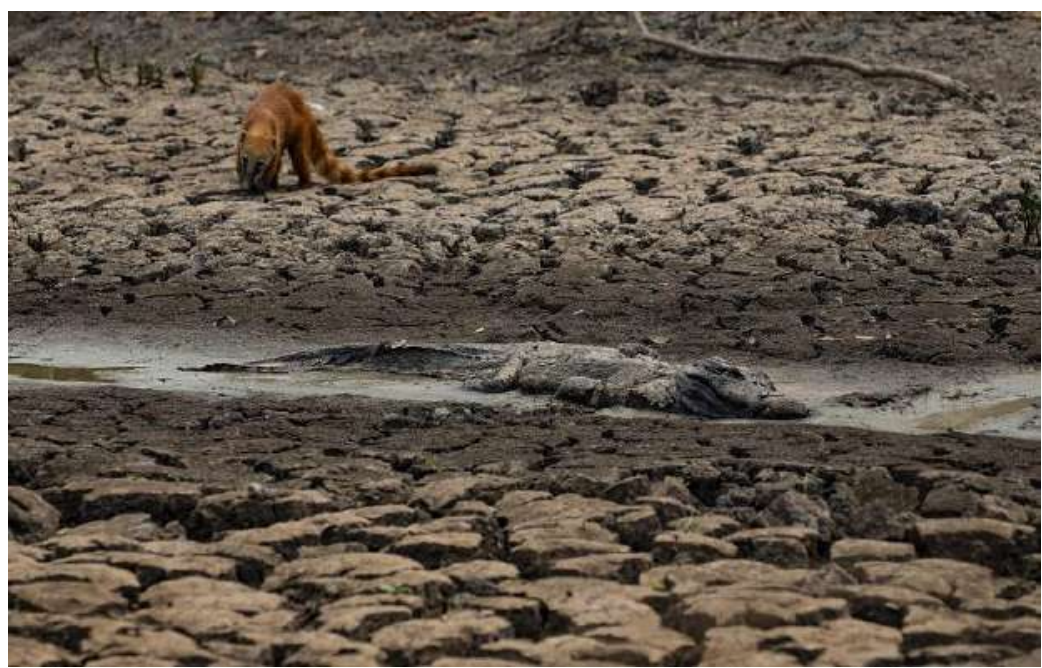

Fonte: A Tribuna, Foto de Araquém Alcântara /Divulgação Setembro, 20207

\footnotetext{
${ }^{7}$ Disponível em:

https://www.atribuna.com.br/variedades/atrevista/araqu\%C3\%A9m-alc\%C3\%A2ntara-celebra-50-anos-defotografia-veja-imagens-in\%C3\%A9ditas-feitas-por-ele-no-pantanal-1.120171. Acesso em: 27 mar. 2021
} 
Figura 2 - Amazônia, o desespero do tamanduá-mirim cego ao fugir da queimada

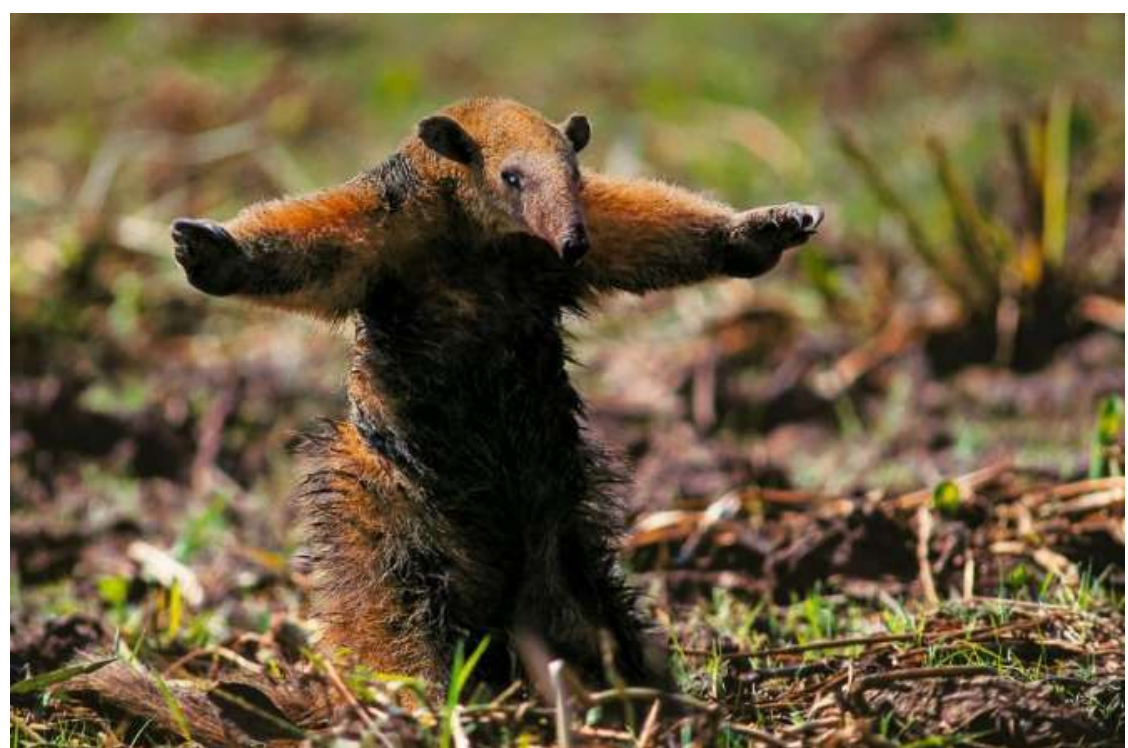

Fonte: A Tribuna, Foto: Acervo Araquém Alcântara, $2005^{8}$

Após o trabalho de exploração das imagens serão lidos dois textos jornalísticos retratando dados recentes de animais ameaçados de extinção encontrados sem vida em praias da Baixada Santista. Os alunos debaterão as causas das mortes trazidas pelos jornais e relatarão situações vividas por eles ao se depararem com casos semelhantes nas praias. Eles deverão buscar fotos de tartarugas e toninhas encontradas na região. Ao buscarmos partir da realidade dos educandos, buscamos romper com o ensino conteudista tão criticado por Paulo Freire em que há um esvaziamento do sujeito cognoscente.

Em Pedagogia do oprimido, Paulo Freire relata um caso que mostra a importância de romper com a consciência alienada:

Uma das educadoras do Full Circle, de Nova York, instituição que realiza um trabalho educativo de real valor, nos relatou o seguinte caso: ao problematizar uma situação codificada a um dos grupos das áreas pobres de Nova York que mostrava, na esquina de uma rua - a rua mesma em que se fazia a reunião - uma grande quantidade de lixo, disse imediatamente um dos participantes: "Vejo uma rua da África ou da América Latina". "E por que não de Nova York?", perguntou a educadora. "Porque, afirmou, somos os Estados Unidos e aqui não pode haver isto". Indubitavelmente, este homem e alguns de seus companheiros, que com ele concordavam, com uma indiscutível "manha da consciência", fugiam a uma realidade que os

\footnotetext{
8 Disponível em:

https://www.atribuna.com.br/variedades/atrevista/araqu\%C3\%A9m-alc\%C3\%A2ntara-celebra-50-anos-defotografia-veja-imagens-in\%C3\%A9ditas-feitas-por-ele-no-pantanal-1.120171. Acesso em: 27 mar. 2021
} 
ofendia, e cujo reconhecimento até os ameaçava. (FREIRE, 1987, p. 89)

$\mathrm{Na}$ aula 2 serão apresentadas imagens trazidas por alunos e analisadas as Figuras 3 e 4 .

Figura 3 - Toninha encontrada morta ao lado de filhote em praia de Santos/SP

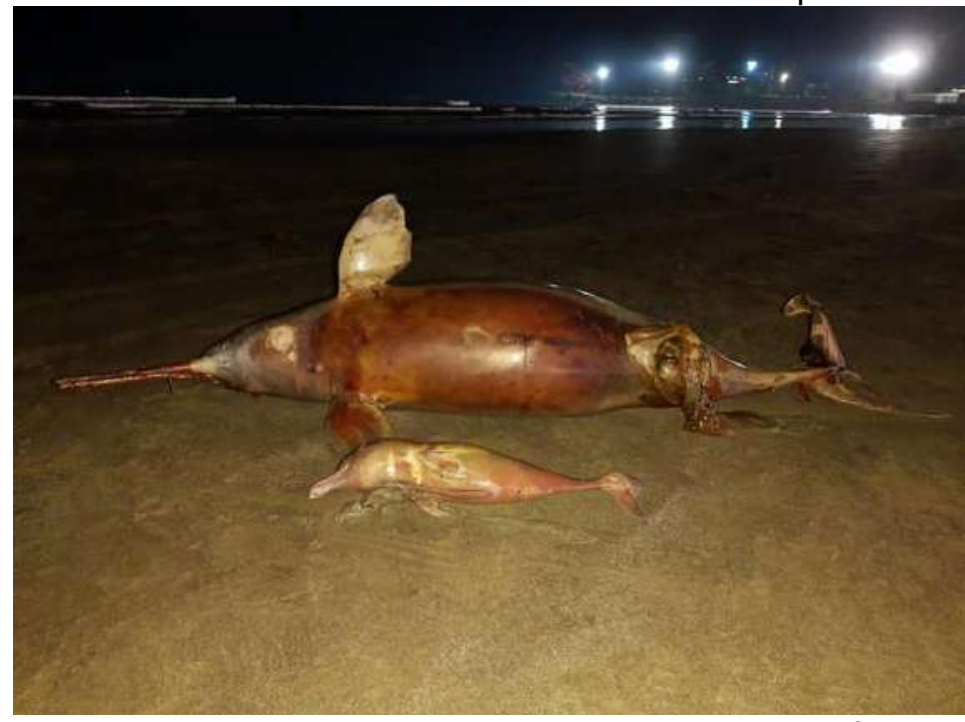

Fonte: G1, Foto: Divulgação/Instituto Gremar $2020^{9}$

Figura 4 - Tartaruga cabeçuda encontrada por moradores de Praia Grande/SP em estado de decomposição na orla

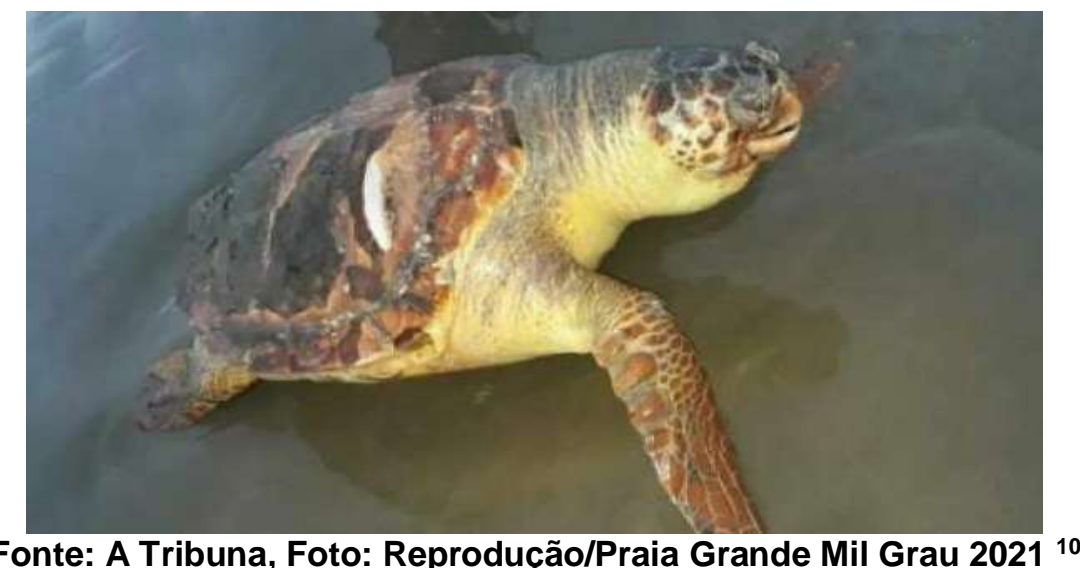

\footnotetext{
${ }^{9}$ Disponível em:

https://g1.globo.com/sp/santos-regiao/noticia/2020/08/11/toninha-e-encontrada-morta-ao-lado-defilhote-em-praia-de-sp.ghtml. Acesso em: 27 maio 2021.

${ }^{10}$ Disponível em:

https://www.atribuna.com.br/cidades/praiagrande/moradores-de-praia-grande-encontram-tartarugacabecuda-em-estado-de-decomposicao-na-orla. Acesso em: 17 jun. 2021.
} 
A maioria das imagens de animais encontrados mortos nas praias são registradas por banhistas em vídeos e fotografias amadoras. Apesar de não possuírem toda a qualidade técnica desejada, devem ser contextualizadas e utilizadas em sala de aula. Lucia Santaella, analisando a eloquência de vídeos de educação ambiental relata

Entretanto, por pior que seja a qualidade do vídeo (que se tenha em vista a lição que $O$ lixo nos deu!), sua importância e relevância se mantêm. Ficarmos expostos às pulsações da Terra viva em oposição às imagens da paisagem degradada pela ignorância, egoísmo, brutalidade e ambição dos seres humanos já contém em si uma eloquência própria e um gérmen educativo que cumpre ser explorado. O vídeo não pode realizar sozinho a tarefa educativa e emancipadora, pois, para isso, ele deve ser contextualizado com sabedoria. Há nesses vídeos, entretanto, um bom começo para a descoberta de que a natureza não é apenas nossa mãe, mas deve ser também nossa filha. (SANTAELLA, 2005, p. 134)

Após a análise das fotografias será apresentada na Figura 5 uma paisagem de uma área de conservação ambiental da Baixada Santista onde várias espécies terrestres e aquáticas buscam se proteger. Perguntaremos às crianças se sabem onde fica o lugar e se gostariam de conhecê-lo. Analisaremos a paisagem sob a ótica turística e lhes apresentaremos este Parque, que é visto todos os dias por eles e cuja uma das comunidades do seu entorno é a da escola.

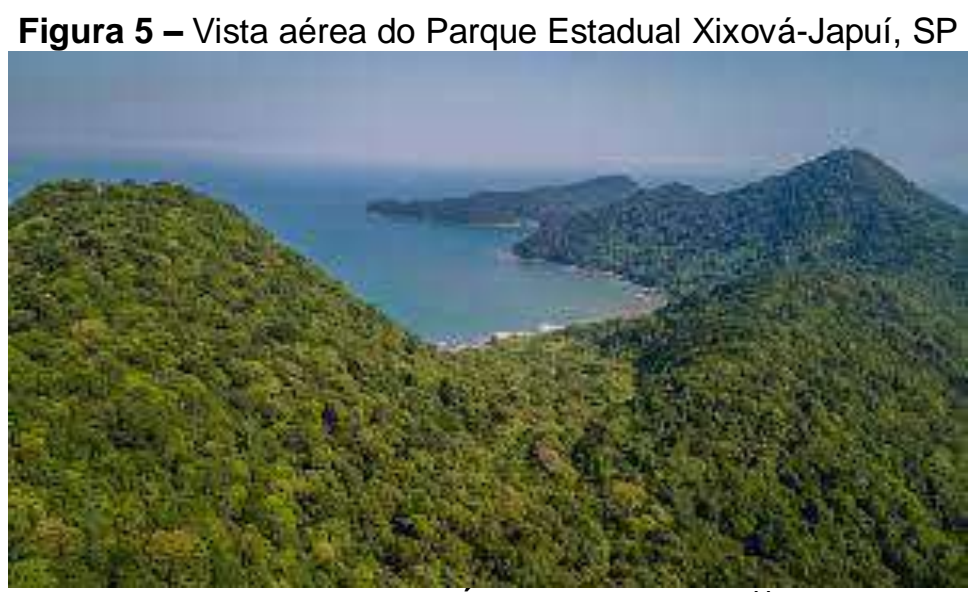

Fonte: Guia de Areas Protegidas ${ }^{11}$

$\mathrm{Na}$ aula 3 , será proposta uma caminhada pelo bairro e a observação da paisagem vista ao longo da Avenida Ecológica, que delimita o Parque Estadual

\footnotetext{
${ }^{11}$ Disponível em: https://guiadeareasprotegidas.sp.gov.br/ap/parque-estadual-xixova-japui/. Acesso em: 14 jun. 2021.
} 
Xixová-Japuí com o bairro Canto do Forte, na Praia Grande. Buscaremos dar enfoque às questões sociais e ambientais da região. Como nos lembra, Maria Cañas Martins:

Paisagem é um termo muito utilizado por diferentes disciplinas, como a geografia, a arquitetura, o urbanismo, a ecologia, a história, a arte, as ciências políticas e a arqueologia, para citar algumas. Mesmo se tratando de um mesmo tema, cada uma dessas áreas confere à paisagem significados diferentes, o que a torna bastante polissêmica. É importante ressaltar que a adoção de qualquer concepção de paisagem pode levar o trabalho a rumos distintos, mesmo em se tratando de um mesmo espaço. (MARTINS, 2008, p.9)

Na volta da caminhada os alunos desenharão o trajeto percorrido e os aspectos socioambientais observados para montar um mural em sala de aula. Direcionaremos o enfoque da paisagem à presença indígena no Parque e vamos propor uma visita a Aldeia Paranapuã. Importante destacar, na perspectiva freiriana, que toda educação é diretiva, não neutra e passa necessariamente pelas opções do educador, mas isso não implica interferir na capacidade criadora, formuladora, indagadora do educando, o que seria manipulação e autoritarismo.

Sobre o chamado ideal de neutralidade do educador, Paulo Freire argumenta:

Respeitar os educandos, porém, não significa mentir a eles sobre meus sonhos, dizer-Ihes com palavras ou gestos ou práticas que o espaço da escola é um lugar "sagrado" onde apenas se estuda e estudar não tem nada que ver com o que se passa no mundo lá fora; esconder deles minhas opções, como se fosse "pecado" preferir, optar, romper, decidir, sonhar. Respeitá-los significa, de um lado, testemunhar a eles a minha escolha, defendendo-a; de outro, mostrarIhes outras possibilidades de opção, enquanto ensino, não importa o quê... (FREIRE, 2014, p.78)

Na aula 4 será analisado um mapa do trajeto da escola até a Aldeia Paranapuã, que permitirá visualizar também a área do Parque na Figura 6. Trabalharemos ainda com uma atividade para que relatem como imaginam esta aldeia. 
Figura 6 - Mapa do trajeto entre EM Estina Campi Baptista e Aldeia Paranapuã, em São Vicente, SP

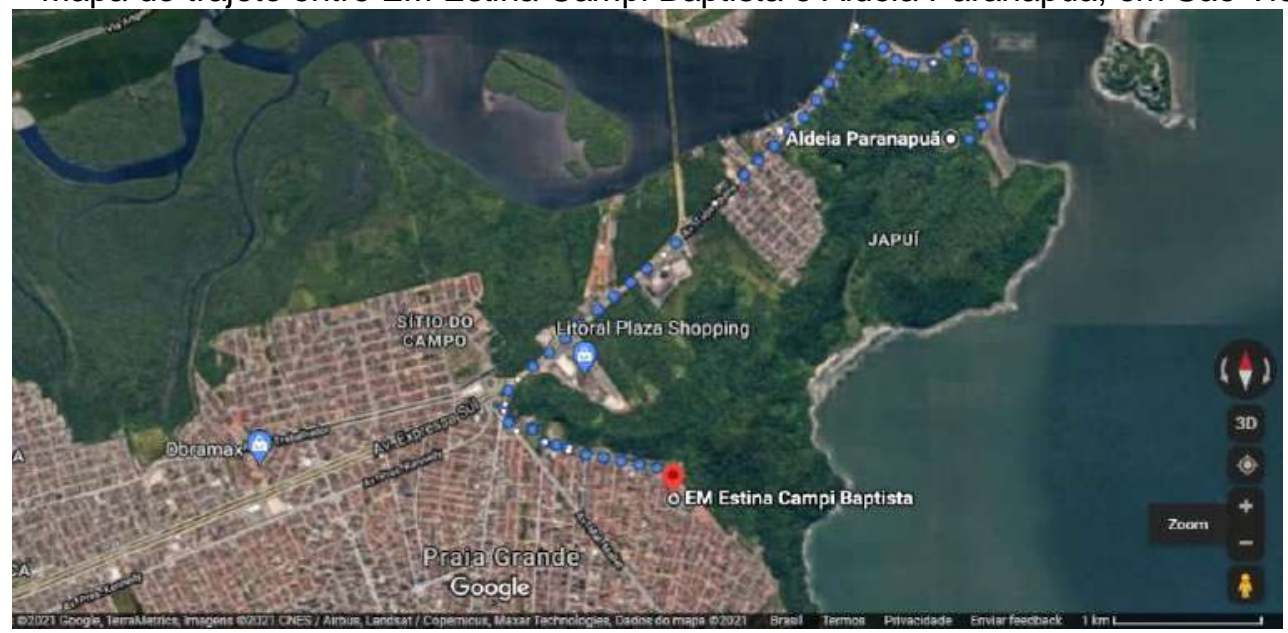

Fonte: Google Maps, CAETANO (2021)

Introduziremos a figura 7 com a reflexão fundamental proposta por Paulo Cesar Gomes:

Quando falamos em imagens, em quadros, estamos falando de algo que é fruto de escolhas, do arbítrio daquele que os constrói. [...] isso nos impede de tratar um mapa, e também uma pintura, um romance, ou mesmo uma foto, como um documento que representaria a realidade de um lugar ou de uma época. Essas imagens são elementos de significação e devem ser analisadas enquanto tal. A pergunta fundamental assim é: O que aquela imagem nos faz ver? (GOMES, 2017, p.138-139)

Figura 7 - Aldeia Paranapuã, no Parque Estadual Xixová-Japuí, em São Vicente, SP

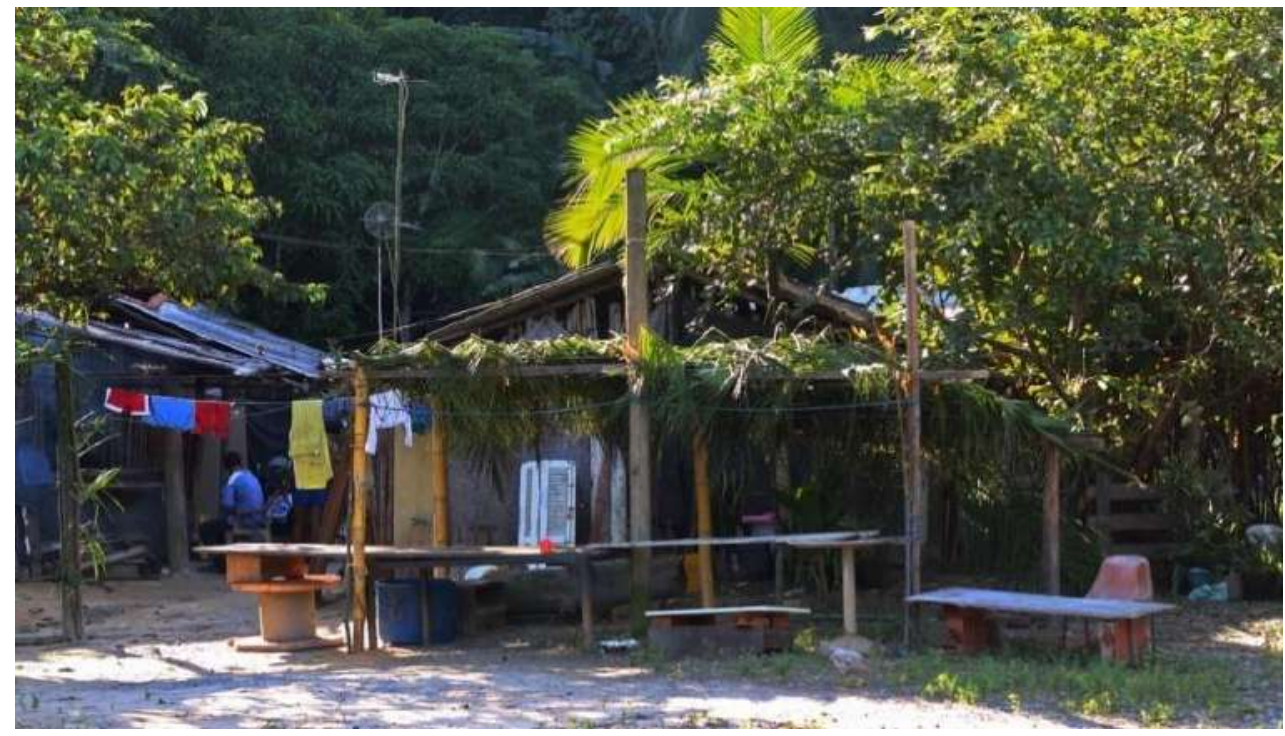

Fonte: G1, Foto: Paulo Victor Natário, $2018^{12}$

12 Disponível em: https:/g1.globo.com/sp/santos-regiao/noticia/indigenas-lutam-pelo-direito-de-viver-naprimeira-cidade-do-brasil.ghtml. Acesso em: 27 maio 2021. 
Após a análise da fotografia, apresentaremos a situação atual da aldeia com vídeos e prepararemos uma entrevista a ser feita com líderes da aldeia indígena.

$\mathrm{Na}$ aula 5, terminaremos nossa sequência didática de leitura de imagens, após a visita à aldeia. Iremos debater a polêmica sobre a permanência da comunidade indígena no Parque Estadual Xixová Japuí. Com a análise da Figura 8 iniciaremos 0 debate.

Figura 8 - Fundação de São Vicente (1900)

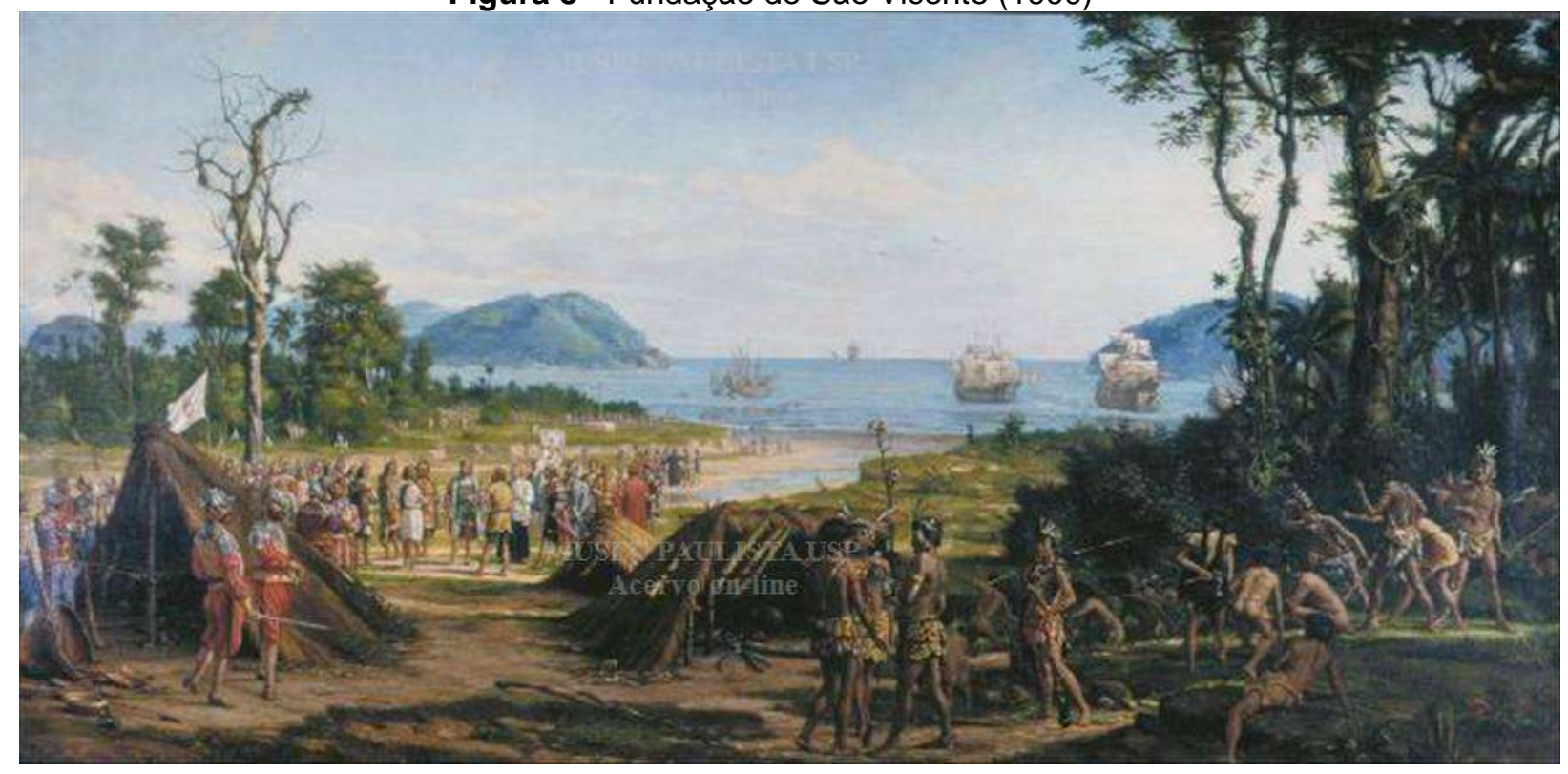

Óleo sobre tela

Coleção Benedito Calixto de Jesus

Fonte: Acervo on-line do Museu Paulista da USP (São Paulo) ${ }^{13}$

Para se fazer uma análise de uma obra de arte é necessário compreender os tempos históricos presentes dos espaços refletidos nela. Lúcia Santaella, aprofunda o desafio inclusive da definição de arte:

Poucos fenômenos são tão difíceis de definir quanto a arte. Uma das razões dessa dificuldade provém do fato de que a arte é uma produção histórica. Isso significa que não existe uma definição universal que dê conta de todas as variações da criação artística no tempo e no espaço. A arte varia de acordo com os instrumentos, meios e técnicas de que historicamente dispõe; varia, também, de acordo com as funções sociais a que se destina e que não são as mesmas em todas as sociedades; varia, ainda, de acordo com os valores humanos que expressa. Enfim, embora não se possa negar que a arte é uma esfera de produção constitutiva da condição humana, mesmo quando sua

${ }^{13}$ Disponível em: http://acervo.mp.usp.br/Storage/EspacoDomestico/MPACERVO_ICONO//1-19216-00000000-01_880x0.jpg. Acesso em: 14 jun. 2021. 
finalidade não é estritamente estética, mas religiosa, como objeto de culto, por exemplo, não é possível encontrar uma definição capaz de abraçar toda a riqueza de suas manifestações. (SANTAELLA, 2012, p. 23)

A análise de uma pintura de arte nos anos iniciais do Ensino Fundamental exigirá uma grande preparação para a contextualização do pintor em uma linguagem acessível. Aproveitaremos para resgatar a obra de Benedito Calixto de Jesus sobre a Baixada Santista.

\section{Leituras de Imagens numa perspectiva interdisciplinar}

Observa-se através da prática em sala de aula que as imagens dos livros didáticos de $3^{\circ}$ ano, pouco se relacionam com a realidade ou o cotidiano das crianças de 8 anos de idade. Assim, propomos trabalhar com imagens ou produzidas por artistas que viveram na região ou imagens da Baixada Santista em si, partindo de situações e lugares conhecidos pelas crianças.

A Base Nacional Curricular Comum (BNCC) prevê que uma das competências gerais da Educação Básica a serem desenvolvidas nos estudantes deve ser a de:

Argumentar com base em fatos, dados e informações confiáveis, para formular, negociar e defender ideias, pontos de vista e decisões comuns que respeitem e promovam os direitos humanos, a consciência socioambiental e o consumo responsável em âmbito local, regional e global, com posicionamento ético em relação ao cuidado de si mesmo, dos outros e do planeta. (BRASIL, 2018, p.9)

A leitura de imagem pode contribuir muito como ferramenta para o desenvolvimento desta competência geral. E a ela relacionaremos alguns dos componentes curriculares e objetos de conhecimento que serão trabalhados ao longo de duas semanas e sistematizados a seguir.

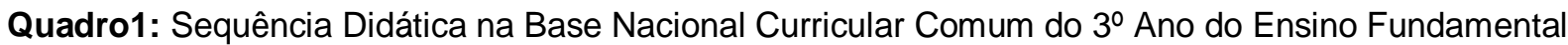

\begin{tabular}{|l|l|}
\hline HABILIDADE & $\begin{array}{l}\text { COMPONENTE CURRICULAR } \\
\text { Objeto de conhecimento }\end{array}$ \\
\hline $\begin{array}{l}\text { (EF03LP18) Ler e compreender, com } \\
\text { autonomia, cartas dirigidas a veículos da mídia } \\
\text { impressa ou digital (cartas de leitor e de } \\
\text { reclamação a jornais, revistas) e notícias, } \\
\text { dentre outros gêneros do campo jornalístico, }\end{array}$ & $\begin{array}{l}\text { Compreensão em leitura e o } \\
\text { tema/assunto do texto }\end{array}$ \\
\hline
\end{tabular}




\begin{tabular}{|c|c|}
\hline $\begin{array}{l}\text { de acordo com as convenções do gênero carta } \\
\text { e considerando a situação comunicativa }\end{array}$ & \\
\hline $\begin{array}{l}\text { (EF03HI10) Identificar as diferenças entre o } \\
\text { espaço doméstico, os espaços públicos e as } \\
\text { áreas de conservação ambiental, } \\
\text { compreendendo a importância dessa distinção. }\end{array}$ & $\begin{array}{l}\text { HISTÓRIA } \\
\text { A cidade, seus espaços públicos } \\
\text { e privados e suas áreas de } \\
\text { conservação ambiental }\end{array}$ \\
\hline $\begin{array}{l}\text { (EF03GE04) Explicar como os processos naturais e } \\
\text { históricos atuam na produção e na mudança das } \\
\text { paisagens naturais e antrópicas nos seus lugares de } \\
\text { vivência, comparando-os a outros lugares. }\end{array}$ & $\begin{array}{l}\text { GEOGRAFIA } \\
\text { Princípios de análise da } \\
\text { paisagem: distinção } \\
\text { classificação dos seus elementos }\end{array}$ \\
\hline $\begin{array}{l}\text { (EF03CI03PG) Conhecer e respeitar a relação } \\
\text { entre o homem e o ambiente, visando à sua } \\
\text { preservação e à própria saúde. }\end{array}$ & $\begin{array}{l}\text { CIÊNCIAS } \\
\text { Meio Ambiente }\end{array}$ \\
\hline $\begin{array}{l}\text { (EF15AR25) Conhecer e valorizar o patrimônio } \\
\text { cultural, material e imaterial, de culturas } \\
\text { diversas, em especial a brasileira, incluindo-se } \\
\text { suas matrizes indígenas, africanas e europeias, } \\
\text { de diferentes épocas, favorecendo a construção } \\
\text { de vocabulário e repertório relativos às } \\
\text { diferentes linguagens artísticas. }\end{array}$ & $\begin{array}{l}\text { ARTE } \\
\text { Patrimônio Cultural }\end{array}$ \\
\hline
\end{tabular}

Fonte: Organizado por CAETANO (2021) baseado na BNCC (2018)

As imagens escolhidas serão trabalhadas sob a forma de sequência didática numa perspectiva interdisciplinar. Assim os conteúdos poderão ser explorados por distintos enfoques disciplinares e permitirão aos estudantes terem uma visão do conjunto das questões socioambientais que as envolvem.

O trabalho com as leituras de imagens exige tempo de preparação do professor para a exploração e técnicas distintas para cada tipo de imagem a ser analisada, sejam fotografias, pinturas, mapas, entre outras. As imagens não devem ser usadas apenas como meios para se chegar a determinados objetivos; elas podem ser lidas a partir de distintos objetivos. Segundo Sandra Regina Ramalho,

Como se percebe, cada ciência usa as imagens como um meio, às vezes auxiliar, para atingir seu objeto de estudo específico; como as que mais se interessam por imagens são as ciências humanas, observa-se que todas visam compreender o ser humano, mas cada uma delas sob seu ponto de vista particular.

Eis aí uma grande diferença entre as ciências que usam as imagens como meio e a semiótica, que tem na linguagem, inclusive na linguagem visual, o objeto mesmo de seus estudos. (RAMALHO, 2014, p. 7)

\section{A alfabetização visual desde o Ensino Fundamental}


A cada dia vivemos mais rodeados de imagens, porém estamos ainda muito amarrados aos textos verbais como prioritários para a construção de conhecimento. Necessitamos dar a devida importância à leitura de imagens para o avanço dos processos de ensino aprendizagem. A alfabetização visual é fundamental para isso. De acordo com Lúcia Santaella, ela tem o significado de:

[...] aprender a ler imagens, desenvolver a observação de seus aspectos e traços constitutivos, detectar o que se produz no interior da própria imagem, sem fugir para outros pensamentos que nada têm a ver com ela. Ou seja, significa adquirir os conhecimentos correspondentes e desenvolver a sensibilidade necessária para saber como as imagens se apresentam, como indicam o que querem indicar, qual é o seu contexto de referência, como as imagens significam, como elas pensam, quais são seus modos específicos de representar a realidade. (SANTAELLA, 2012, p.10)

Para avançarmos no sentido da alfabetização visual das crianças desde o Ensino Fundamental devem ser dadas as condições para que nós, professores, também desenvolvamos estes conhecimentos apresentados pela autora, ou seja, sejamos alfabetizados visualmente também.

Assim, com nossa alfabetização visual, poderemos desenvolver nos estudantes a percepção crítica das imagens e as sensibilidades para a compreensão das mesmas e suas maneiras específicas de representar a realidade ou comentá-la. Importante não desconsiderarmos que também a leitura das imagens à exemplo da leitura das palavras não podem prescindir da leitura do mundo, da realidade que nos cerca. Paulo Freire argumenta sobre a importância também da leitura de mundo,

A leitura e a escrita das palavras, contudo, passa pela leitura do mundo. Ler o mundo é um ato anterior à leitura da palavra. O ensino da leitura e da escrita da palavra a que falte o exercício crítico da leitura e da releitura do mundo é, científica, política e pedagogicamente, capenga. (FREIRE, 2014, p.79)

A exemplo do que nos fala Paulo Freire sobre a leitura das palavras, a alfabetização visual pode despertar nas crianças o interesse pela busca do conhecimento. Este conhecimento será visto como algo significativo, a partir do momento que for usado para a compreensão da sua realidade local. Nosso objetivo mais geral é que a partir daí a criança possa chegar a uma visão mais ampla e crítica do mundo. Neste sentido a alfabetização visual pode nos ajudar a abrir a visão da 
criança para os desafios da humanidade, como a consciência socioambiental e a inclusão social e escolar.

O trabalho com imagens pode também ajudar a alfabetização visual das crianças com Transtorno do Espectro Autista como no caso de Greta Thunberg. Ela era uma criança com dificuldade de interação e comunicação, mas que, por outro lado, tinha características de querer saber tudo sobre coisas específicas, o que a levou a focar suas pesquisas sobre a crise climática. Não foi a fala da professora ou dos colegas, nem os textos lidos, mas justamente as imagens que despertaram nela a dedicação aos estudos sobre a questão climática e sua atitude diante da causa ambiental. "As imagens não saiam da minha cabeça” (WINTER, 2020, p. 21).

A gravidade da questão socioambiental exige mudanças de atitudes muito mais de nós professores do que das nossas crianças. $O$ trabalho com a leitura de imagens e a alfabetização visual desde o Ensino Fundamental é uma obrigação, se quisermos recuperar o tempo perdido. Conforme o discurso de Greta Thunberg no Fórum Mundial Econômico, na Suíça, "Não quero que tenham esperança. Quero que entrem em pânico. Quero que sintam o medo que eu sinto todos os dias... Quero que ajam como se sua casa estivesse pegando fogo. Porque ela está" (WINTER, 2020, p. 33). A despeito do tom ante esperançoso do discurso emocional de Greta Thunberg, construído para nos alertar sobre o perigo iminente de nossas ações contra o meio ambiente, não podemos, como educadores, dispensá-la em nome de uma visão racional e técnica de educação nem tampouco achar, acrítica e ingenuamente, que ela sozinha dará conta da transformação da realidade. A esse respeito, a pedagogia de Paulo Freire coloca a esperança na relação tanto com a necessidade de conscientização e formação crítica quanto na necessidade de uma ação sobre o mundo, que à luz dessa conscientização, realize as devidas transformações para a construção de um mundo melhor para todas as pessoas:

Pensar que a esperança sozinha transforma o mundo e atuar movido por tal ingenuidade é um modo excelente de tombar na desesperança, no pessimismo, no fatalismo. Mas prescindir da esperança na luta para melhorar o mundo, como se a luta se pudesse reduzir a atos calculados apenas, à pura cientificidade, é frívola ilusão. Prescindir da esperança que se funda também na verdade como na qualidade ética da luta é negar a ela um dos seus suportes fundamentais. O essencial, como digo mais adiante no corpo desta Pedagogia da esperança, é que ela, enquanto necessidade ontológica, precisa de ancorar-se na prática. Enquanto necessidade ontológica, a esperança precisa da 
prática para tornar-se concretude histórica. É por isso que não há esperança na pura espera, nem tampouco se alcança o que se espera na espera pura, que vira, assim, espera vã. (FREIRE, 2014, p.10-11)

\section{Considerações Finais}

Esperamos - do verbo esperançar e não de esperar - que os educadores, especialmente os das séries iniciais, dediquem-se, como ocorre com a leitura da palavra, a elaborações teóricas e práticas sobre a leitura de imagens e a alfabetização visual desde o início do Ensino Fundamental devido à sua importância para a ampliação de uma visão crítica sobre a realidade que nos cerca.

$O$ acesso que temos a imagens atualmente nos permite abordar distintas temáticas. A sequência didática sugerida é apenas um exemplo de como podemos utilizar não apenas as imagens dos livros didáticos, mas também o que a realidade local produz como imagem.

$\mathrm{Se}$ as crianças forem alfabetizadas visualmente poderão desenvolver a sensibilidade crítica para analisarem sua realidade numa perspectiva interdisciplinar. Se a leitura de imagem passar a ser trabalhada desde o início do Ensino Fundamental teremos melhores condições para superar as dificuldades que enfrentamos em nossas salas de aula ao aproximar o ensino de suas vivências e práticas cotidianas, permitindo-Ihe uma aprendizagem criadora, formuladora e indagadora da realidade, como nos ensina Paulo Freire na Pedagogia da esperança.

Devemos, ainda, em nossos estudos e práticas pedagógicas buscar evidenciar como o trabalho com imagens também pode auxiliar a inclusão escolar de crianças com Transtorno do Espectro Autista, como ocorreu com Greta Thunberg, para despertar nelas a paixão pela busca do conhecimento e por inspirações para o futuro de suas vidas. E assim elas poderão mudar seus olhares e nunca mais serem as mesmas.

\section{Referências}

BRASIL, Ministério da Educação. Base Nacional Comum Curricular. Brasília, 2018. Disponível em: 
http://basenacionalcomum.mec.gov.br/images/BNCC_El_EF_110518_versaofinal_sit e.pdf. Acesso em: 14 jun. 2021.

FREIRE, Paulo. Pedagogia do oprimido. 17. ed. Rio de Janeiro: Paz e Terra, 1987. $107 \mathrm{p}$.

FREIRE, Paulo. Pedagogia da esperança: um reencontro com a pedagogia do oprimido. 3. ed. Rio de Janeiro: Paz e Terra, 1994.

GOMES, Paulo Cesar da Costa. Imagem, imaginários: quadros para a imaginação geográfica. In: Quadros geográficos. Uma forma de ver, uma forma de pensar. Rio de Janeiro: Bertrand Brasil, 2017. p. 131-142.

MARTINS, Marina Canãs. Os significados da paisagem: fundamentação teórica. In: Paisagem em circulação: o Imaginário e o patrimônio paisagístico de São Francisco do Sul em cartões postais (1900-1930). Dissertação de Mestrado, UFRS, Faculdade de Arquitetura, 2008, p. 9-35.

RAMALHO, Sandra Regina. Leituras de Imagem no Ensino da Arte. Revista Ciclos, Florianópolis, V. 1, n. 2, , Ano 1, p.4-13, fev. 2014. Disponível em: https://www.revistas.udesc.br/index.php/ciclos/article/view/3941/3001. Acesso em: 14 maio 2021.

SANTAELLA, Lucia. Semiótica aplicada. São Paulo: Pioneira Thomson Learning, 2005. $186 \mathrm{p}$.

SANTAELLA, Lucia. Leitura de imagens. São Paulo: Melhoramentos, 2012 (Edição Kindle). $180 \mathrm{p}$.

SÃO PAULO (Estado). Secretaria do Meio Ambiente. Parque Estadual Xixová Japuí - Plano de Manejo. São Paulo: Fundação Florestal do Estado de São Paulo, 2010. 544p. Disponível em:

http://arquivos.ambiente.sp.gov.br/fundacaoflorestal/2012/01/PE_XIXOVAJAPUI/PEXJ-Principal.pdf. Acesso em: 14 jun. 2021.

WINTER, Jeanette. Ninguém é pequeno demais para fazer a diferença: $O$ chamado de Greta Thunberg para salvar o planeta. São Paulo: Companhia das Letrinhas, 2020, $40 \mathrm{p}$. 


\section{PASSOS E DESCOMPASSOS NO PROCESSO DE CONSTRUÇÃO DA ALFABETIZAÇÃO DE ADULTOS A DISTÂNCIA: REFLEXÕES DOS ESTUDANTES DE LICENCIATURA DA UNIMES}

Gabriel Freitas dos Santos

Maria Lúcia Gomes Barbosa

Paolo Civita

\section{Resumo}

O presente texto procura refletir e avaliar as ações realizadas no grupo de pesquisa sobre currículo e alfabetização de adultos a distância no contexto da pandemia de Covid -19. Para isso, utilizou-se dos registros feitos nos encontros entre estudantes, professores dos cursos e educandos atendidos pelo projeto, uma vez que este diário de bordo continha registros de momentos importantes de todo o processo formativo do grupo. A fundamentação teórica trata do diálogo dos escritos de Freire com outros autores que versam sobre educação popular. Perante ao observado, foi constatado que o arcabouço teórico de Freire continua mais vivo e atual como nunca e que se faz urgente e necessário a implementação de projetos de educação popular visando alfabetizar adultos e jovens. Para estudantes e professores dos cursos de licenciaturas da UNIMES a experiência tem sido válida para estudo, análise e reflexão sobre a prática freiriana nos contextos atuais

Palavras-chave: Alfabetização de adultos a distância; Práticas pedagógicas; Tecnologias digitais; Covid -19; Paulo Freire

\section{INTRODUÇÃO}

Um dos mais importantes intelectuais do Brasil, Paulo Freire completaria 100 anos em 2021. É um ano que temos que comemorar, agradecer e tornar ainda mais vivo o legado intelectual desse educador de reputação internacional.

Em 40 horas, Paulo Freire mostrou ao Brasil e ao mundo que poderia alfabetizar jovens e adultos e, sobretudo, tornar essa experiência respeitosa, democrática e crítica. Isso aconteceu em Angicos, no Rio Grande do Norte, e, com esse modelo de educação popular, passou a ser conhecido no mundo todo.

Inspirados por Freire e atentos aos problemas antigos que insistem em permanecer nos dias atuais, o Grupo de Pesquisa em Currículo e Alfabetização de Adultos decidiu, audaciosamente, enfrentar o desafio de auxiliar jovens e adultos no processo de alfabetização e letramento. Com a coordenação da Profa. Me. Janaína

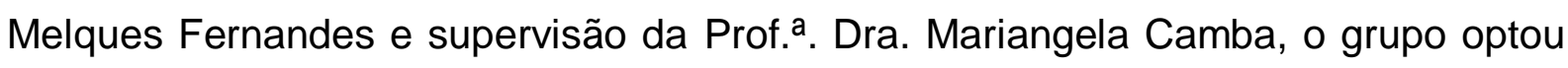
por aprofundar os estudos no método Paulo Freire e também compreender se era possível fazê-lo com o uso de tecnologias educacionais. 
O projeto de alfabetização iniciou-se no segundo semestre de 2020 junto aos professores e estudantes ainda em tempos pandêmicos da Covid-19 nos desafiando a refletir sobre o processo de aprendizagem. Propusemos, em diversas reuniões, discutirmos sobre a práxis freiriana nos novos tempos tecnológicos objetivando o letramento.

Em nossas reuniões realizadas semanalmente, possibilitou-nos enxergar em suas obras, que é possível trazermos seu legado em novos tempos, considerando os recursos digitais mediante ao novo contexto em que vivemos no distanciamento social.

Atualmente, são aproximadamente 11 milhões de brasileiros que não sabem ler e escrever, o que nos estimulou pôr em prática seu método de alfabetização mediante as experiências vivenciadas de cada educando. A linguagem e o diálogo como ponto de partida dinamizado na interação coletiva: o fazer e refazer como proposta pedagógica freireana. As falas trazidas dentro da realidade de cada educando como o termômetro para decodificar as palavras escritas com a compreensão do mundo.

Paulo Freire era defensor do conceito de alfabetização para além da decodificação dos códigos linguísticos, ou seja, não basta apenas saber ler e escrever, mas fazer uso social e político desse conhecimento do cotidiano de cada um.

Diante do descrito, este artigo tem como objetivo refletir e avaliar as ações realizadas no grupo de pesquisa e experimentações em currículo e alfabetização de jovens e adultos dos estudantes dos cursos de licenciatura da UNIMES, utilizando-se como fundamentação teórica e inspiração as obras de Freire. Nesse sentido, o texto foi dividido em três partes, além da introdução, considerações finais e referências. $\mathrm{Na}$ primeira, apresenta-se uma breve revisão bibliográfica; na segunda, a metodologia e na terceira parte, a discussão e os resultados.

\section{REVISÃO BIBLIOGRÁFICA}

O que afligia Freire, obviamente, não era apenas a enorme taxa de analfabetismo que havia na época, uma vez que, se assim fosse, bastava utilizar-se de uma cartilha para alfabetizar adultos e jovens. Sua preocupação ia além e revelava a emergência por parte dos programas educacionais de uma postura libertadora no sentido amplo da palavra. 
De acordo com ele, a liberdade é a matriz que atribui sentido a uma prática educativa que só alcança a efetividade e eficácia na medida da participação livre e crítica dos educandos (FREIRE, 1967, p. 4). Buscou-se então procurar esse sentido de liberdade nas práticas pedagógicas do grupo e refletir sobre elas.

Um dos princípios essenciais de sua pedagogia era o "círculo de cultura", um lugar que substitui a "escola" tradicional com o sentido autoritário. Nesse lugar, a peça fundamental na educação popular era reunir um coordenador e algumas dezenas de homens do povo para a conquista da linguagem (FREIRE, 1967, p. 4). Desse modo, a ideia era a de, na condição de colaboradores, articular os diálogos para promover a alfabetização e jamais impor ou influenciar. Círculo cultural é um termo cunhado por Freire, que representa um espaço dinâmico de aprendizagem e troca de conhecimentos.

Segundo Paulo Freire (1991), o círculo cultural é baseado em uma sugestão de ensino cujo caráter radical democrático e emancipatório propõe um método de aprendizagem completo que rompe com a situação fragmentada e exige posicionarse sobre os problemas encontrados em um determinado ambiente. O círculo cultural sistematizado por Freire pode estruturar o ensino e investigar o mundo do vocabulário e dele extrair palavras geradoras. Esse tipo de mergulho permite que o educador interaja no processo, ajudando-o a determinar seu ponto de partida e articulando ideias interdisciplinares.

Na visão de Brandão (2010, p. 69), nos círculos culturais, o diálogo não é mais uma simples metodologia ou uma técnica de ação, mas um guia para a experiência docente. Vivemos e interagimos em uma cultura que criamos objetivamente. Somos, subjetivamente, a internalização da prática cultural, das regras de comportamento, do sentido do sistema de vida e do mundo em que vivemos (BRANDÃO, 2010, p.100).

Os Círculos de Cultura são espaços em que dialogicamente se ensina e se aprende em que se conhece ao invés de se fazer transferência de conhecimento. Em que se produz conhecimento em lugar da justaposição ou da superposição de conhecimentos feitos pelo educador(a) ou sobre o educando e constrói novas hipóteses de leitura do mundo. Ou seja, é um lugar onde todos têm a palavra, onde todos leem e escrevem o mundo. É um espaço de trabalho, pesquisa, exposição de prática, dinâmicas e vivências que possibilitam a construção coletiva do conhecimento. 
A questão do levantamento vocabular dos partícipes do projeto, também esteve presente nos estudos do grupo e na práxis a distância. A questão remota não permitiu que alguns educandos e educadores pudessem se conhecer pessoalmente, sendo crucial esses diálogos preliminares, assim como em sua teoria, procuramos o máximo de interferência dos educandos na estrutura do nosso trabalho. Para Freire:

Ao educador cabe apenas registrar fielmente este vocabulário e selecionar algumas palavras básicas em termos de sua frequência, relevância como significação vivida e tipo de complexidade fonêmica que apresentam. Estas palavras, de uso comum na linguagem do povo e carregadas de experiência vivida, são decisivas, pois a partir delas o alfabetizando irá descobrir as sílabas, as letras e as dificuldades silábicas específicas de seu idioma, além de que servirão de material inicial para descoberta de novas palavras (FREIRE,1967, p. 4).

O que significa dizer que, após fazer o levantamento vocabular dos educandos, procurou-se discutir, em grupo, as melhores formas de intervir para a realização de um trabalho consistente e, ao mesmo tempo, consciente. A partir daí, criou-se as palavras geradoras, com as quais tinha-se a intenção de promover a conscientização, pois, como afirma, a alfabetização e a conscientização jamais se separam (FREIRE, 1967, p.5).

Já Brandão (2006) menciona que o educador tem uma responsabilidade em si mesmo que vai além de simples práticas de letramento, devendo proporcionar condições favoráveis para o despertar da mudança e da transformação.

Palavras geradas são ferramentas, durante o trabalho Alfabetização, conduzindo os debates que cada um deles sugeriu na compreensão do mundo (BRANDÃO, 1982, p. 39)

$\mathrm{Na}$ metodologia freireana, se propõe a identificar palavras-chave do vocabulário dos alunos, as chamadas palavras geradoras, propor situações de vida comuns e significativas para os membros da comunidade em que trabalham.

\section{METODOLOGIA}

Neste estudo, utilizou-se como enfoque a pesquisa qualitativa em educação, a qual buscou-se "compreender e aprofundar os fenômenos, que são explorados a partir da perspectiva dos participantes em um ambiente natural e em relação ao contexto" (HERNÁNDEZ 
SAMPIERI; FERNÁNDEZ COLLADO; BAPTISTA LUCIO, 2013, p. 376), a fim de entender a realidade que se apresenta. Para o tratamento e análise das informações optou-se por utilizar a técnica da análise de conteúdo com base nos registros de encontros do próprio grupo. Ao término de cada reunião virtual, ou seja, por meio de videochamada na plataforma Google Meet, os integrantes do grupo de pesquisa, encabeçados pela Prof. ${ }^{a}$ Me. Janaína Melques, registrou-se as impressões, sentimentos e inquietações num arquivo de trabalho colaborativo.

A utilização da plataforma possibilitou a discussão de ideias e acesso a todos os registros, tornando o processo de construção das propostas mais adequado aos objetivos que se pretendiam alcançar.

Para a discussão foi realizada uma pesquisa bibliográfica de autores que fundamentaram o nosso trabalho, que corroboravam com as ideias de Paulo Freire e, sobretudo, que puderam nos indicar caminhos possíveis para auxiliar no trabalho que vínhamos desenvolvendo.

O documento em nuvem foi organizado da seguinte forma: número do encontro, data, tema, planejamento e registro. O objetivo dessa organização foi o de não perdermos nenhum momento importante da pesquisa que estávamos realizando. Nesse sentido, informações como data, o número do encontro e o planejamento do que se pretendia realizar contribuíram para muitas de nossas reflexões. A análise que faremos aqui utilizou como fundamentação os escritos no campo "registro" e levou em consideração aspectos como facilidades, dificuldades, semelhanças, diferenças, avanços, retrocessos e, sobretudo, relações que consideramos importantes para a formação dos estudantes de pedagogia, professores, educandos envolvidos no processo e com a educação popular tão defendida por Freire.

\section{DISCUSSÃO E RESULTADOS}

Nesta parte, propomos uma discussão e análise do processo, bem como resultados da alfabetização dos educandos que, além de ressaltar todo percurso, manifesta todo o cuidadoso planejamento de intervenção proposto, a começar pelo diálogo e aproximação. Aqui, visando a privação de imagens, iremos nos referir aos educandos da seguinte forma: Educando 1, educando 2, educando 3, e assim por diante. 
A partir de reuniões de forma remota, por meio de videochamadas via plataforma Google Meet, optou-se pela utilização da sistemática freiriana, tal como: universo vocabular, codificação e decodificação, círculo de cultura, e palavras geradoras. $\mathrm{O}$ intuito era $\mathrm{o}$ de beber da fonte teórica de Freire para possibilitar a aproximação de educadores e educandos, entendendo o cotidiano deste e transformando-o em protagonista, em que o mesmo constrói sua caminhada libertadora a partir de um espaço de diálogo e conhecimento com seu respectivo educador.

Sendo assim, passamos a manter contato com nossos educandos, criando separadamente um grupo através do aplicativo de mensagens WhatsApp composto por uma dupla de educadores (alunos dos cursos de licenciatura Unimes) para um educando, a fim de criar interação, edificar vínculos a partir de conexões interpessoais, além de ser um espaço de ensino-aprendizagem, de modo que daremos prioridade a transmissão das atividades por áudios, vídeos e ligações de videochamada.

O primeiro ponto que destacamos é a importância do respeito, aproximação e diálogo, além da abordagem para participação no projeto, em que todo o contato com essas pessoas precisou ser milimetricamente calculado. Todos sabiam que dentro de cada um deles havia uma história difícil; acreditávamos que essas pessoas não estavam tentando ler o mundo ou serem alfabetizadas pela primeira vez.

De acordo com os escritos do grupo, num primeiro encontro os educadores aproveitaram para o conhecimento e compartilhamento de histórias e vivências de ambas as partes, principalmente da Educanda 01, que por diversas vezes, segundo ela, fora ofuscada e silenciada pela sociedade opressora por não saber ler e escrever. De acordo com seus relatos, tornou-se prisioneira daquilo que ela deveria fazer parte, mas que por diversos fatores, não pôde ter acesso à educação ou teve a responsabilidade da vida adulta cedo demais; sendo assim, não soube como criar uma intervenção e superar todos esses anos apagados.

É nesse momento que podemos estudar e diagnosticar melhor a realidade do educando, criar um ambiente confortável onde a educanda se sente livre para ser o que de fato ela é. O processo de aproximação é importante para dar ao educando não só a autoconfiança, mas também a confiança em quem a está educando. De tal modo, a relação dialógica, em si: 
Nutre-se do amor, da humildade, da esperança, da fé, da confiança. Por isso, só o diálogo comunica. E quando os dois polos do diálogo se ligam assim, com amor, com esperança, com fé um no outro, se fazem críticos na busca de algo. Instala-se, então, uma relação de simpatia entre ambos. Só aí há comunicação (FREIRE, 1967, p. 107).

Após a apresentação das educadoras com a Educanda 1, observou-se que esse contato não perdurou por muito tempo. Nesse sentido, fez-se necessário uma reunião entre as educadoras para entender a melhor forma de reaproximação com a educanda, logo fora definido que cada educadora enviaria uma mensagem de voz para ela com intuito de indagá-la sobre como passou seus últimos dias e manter essa relação. O grupo relata que não obteve resposta e após diversas tentativas de contato periodicamente, para a surpresa de todos, a Educanda 1 realizou, via aplicativo de mensagens, o envio de uma música. Em reunião, o grupo partilhou da felicidade em receber essa resposta; para nós, cada educando era importante e portanto, cada resposta era um incentivo para continuarmos tentando estreitar os laços e construir relações edificantes para posterior trabalho com o letramento. Aliás, as opções pedagógicas que estávamos fazendo já sinalizavam para esse trabalho com a alfabetização. Ficou entendido que ela gostava dessa música, do estilo musical e um pouco de sua forma de ser e agir no mundo.

Os questionamentos que perduraram para o grupo no processo de ensino e aprendizagem são: como melhorar o diálogo, manter o interesse e foco do educando? Como podemos manter uma relação de total entrega? Ou melhor, como podemos nos aproximar de alguém ou nos reaproximar? Essas perguntas têm respostas, e fazem parte do processo da Comunicação Não-Violenta (CNV), uma contribuição de Marshall B. Rosenberg.

De modo geral, o processo da CNV é composto por quatro componentes, e são eles: 1. Observação; 2. Sentimento; 3. Necessidades; 4. Pedido. E assim demos continuidade ao diálogo. No primeiro passo, observamos o que está acontecendo em uma dada situação sem apresentar juízo de valor; em segundo, analisamos nossos sentimentos em relação ao que fora observado - o sentimento apresentado pelas educadoras, foi de respeito em relação ao tempo da sua alfabetizanda; no terceiro passo, nossa necessidade em relação à ação que observamos: como podemos dialogar com a educanda, mostrando a ela nossa necessidade de sua presença e de suas respostas? E é sobre isso que se refere o quarto passo, o pedido. 
Por meio de mensagens de áudios, uma de suas educadoras a questionou sobre curiosidades, bem como: "Quantos anos você tinha quando a música que você mandou foi lançada? ", "Quais novelas se passavam na sua época? ", "Você se lembra de alguma delas?". Após algumas horas, obtivemos resposta: ela replicou as perguntas realizadas, houve a troca de informações, não só em relação às perguntas, mas com todo o processo da CNV. Fazendo proveito da oportunidade e da motivação da Educanda 1, todas marcaram uma data para que houvesse uma aula por meio de videochamada com 45 minutos de duração, e também foi explicado o que seria abordado em tal encontro.

O segundo aspecto que queremos destacar é com relação ao Educando 2 e diz respeito à importância do olhar atento e da avaliação criteriosa para nossos educandos no processo de ensino, inclusive popular. Num primeiro momento, observou-se a necessidade de fazer uma espécie de sondagem com o educando e descobrir o que ele reconhece e quais são suas dificuldades. Informações sobre seu universo vocabular foram recolhidas, assuntos que fazem parte do seu cotidiano, e percebeu-se que o alfabetizando tinha um apego por jogos de videogame, e em específico, jogos de futebol e de guerras. Baseado nisso, os educadores mantiveram uma relação de aproximação e construção de vínculo, bem como também de confiança de modo que, as conversas fossem relacionadas aos jogos da rotina do alfabetizando.

Destaca-se esse momento, pois como aponta Brandão (1989, p.26), o vivido e o pensado que existem vivos na fala de todos, todo ele é importante: palavras, frases, provérbios, modos peculiares de dizer, de versejar, ou de cantar o mundo e traduzir a vida; exortamos o alfabetizando partindo de suas vivências e sua realidade, evitando o sistema tradicional, conhecido por utilizar a cartilha. Vamos ao encontro com o que Freire defendia, pois, parte do pressuposto da estruturação de diálogos sem a utilização de materiais prontos, mas sim ter as partes de ambos, educador e educando, que façam parte do mesmo comunitário, como afirma, a cartilha é um saber abstrato, pré-fabricado e imposto. É uma espécie de roupa de tamanho único que serve para todo mundo e para ninguém (FREIRE, 1967, p.10).

De acordo com relatos dos educadores nos encontros e registros do grupo, entendeu-se que as atividades dadas anteriormente não deram conta de perceber que o educando poderia estar consultando algum material ou até mesmo um site de busca 
para realizá-las. Nas propostas, as educadoras notavam que o Educando 2 sempre respondia após um tempo considerável e de forma correta. Abateu-se sobre elas um desânimo e a sensação de que fizeram algo errado, no entanto, na exposição com o grupo, tratamos de sinalizar que não só esse comportamento era esperado como devemos valorizar isso. O fato do Educando 2 saber que existe um local que possa tirar suas dúvidas e procurar possíveis soluções para os desafios que enfrenta, feznos refletir sobre o adulto em fase de alfabetização e o processo de letramento como um todo, pois afinal, estamos utilizando das tecnologias para a comunicação e também com o intuito de favorecer o processo de alfabetização.

Talvez por inexperiência ou empolgação, posteriormente aos envios das atividades do Educando 2, as educadoras começaram a ter compreensão dos detalhes, nos quais, o alfabetizando não estava aprendendo, mas sim apenas copiando tudo o que lhe era enviado. Em virtude desse detalhe, uma situação muito delicada permeia dentro do processo de sua alfabetização. Qual caminho tomar? Qual caminho não tomar? Como evitar? O que evitar? Podemos seguir caminhos para vias que favoreçam todas as partes. Habitualmente, partimos do princípio do diálogo, primeiramente entre educadores, por meio de reuniões via plataforma Google Meet, fora discutido quais abordagens tomar para evitar a cópia do Educando 2. Logo, estabeleceu-se que voltariam à estaca zero, uma vez que não houve progresso na primeira caminhada.

Outra dificuldade que torna a interromper o desenvolvimento da alfabetização do Educando 2, é a sua falta de acesso à internet. Em virtude do Covod-19, como dito anteriormente, o projeto se consolidava integralmente à distância, contudo, o caso se agrava ainda mais com a falta de acesso à internet, uma vez que temos ela como principal fonte de comunicação dentro desse contexto. A única saída possível era esperar o alfabetizando tornar a ter acesso à internet, já que a fase vermelha (período em que o governo estadual restringiu a aglomeração em espaços públicos visando evitar a proliferação do vírus) ainda estava instaurada.

Depois de alguns dias sem internet, o Educando 2 manifestou-se no grupo e imediatamente marcou-se uma videochamada a fim de realizar uma atividade. Ficou decidido em reunião com os demais educadores que o certo a se fazer era uma atividade de sondagem, para que se entendesse em qual estágio ele se encontrava. No encontro despretensioso, após colocarmos a conversa em dia falando de fatos do 
cotidiano e assuntos pessoais, mostramos as letras do alfabeto e perguntamos quais letras ele conhecia. O Educando 2 respondeu que sabia quais eram a letra $A B$ e $E$, mas que não sabe quais são as letras do seu nome. Também se notou que ele sabe contar, mas até o número 4. Além do reconhecimento das letras e números, é relatado que o educando decorou algumas funções tecnológicas por conta do seu apego com videogame. Com todas essas grandiosas e valiosas informações, notamos a importância do vínculo. Com sua paixão por jogos de videogame e futebol, ficou decidido que iríamos utilizar as palavras que estão inseridas nesse contexto. Surge daí a manifestação das palavras geradoras bem como temas geradores e do universo vocabular, conceitos da metodologia freiriana, que estão inseridas no vocabulário do educando, como por exemplo a palavra BOLA, fazendo proveito de seu conhecimento em relação a letra $B$ e dos jogos de futebol, que fazem parte de seu universo vocabular.

Com o método de Paulo Freire, os alfabetizados partem de algumas poucas palavras que lhes servem para gerar seu universo vocabular. Antes, porém, conscientizam o poder criador dessas palavras: são elas que geram o seu mundo. São significações que se constituem em comportamentos seus; portanto, significações do mundo, mas sua também (FREIRE, 1987, p. 13).

Um terceiro aspecto observado e que merece destaque diz respeito às inúmeras tentativas que esses adultos enfrentam na intenção de serem alfabetizados. A escola com seus moldes entende que todos precisam se encaixar para caber naquele espaço e circunstância; como efeito, observa-se o afastamento de muitos que, por alguma razão, não se adequaram aparentemente naqueles padrões.

Após muitas tentativas, a Educanda 3 decidiu fazer parte do projeto, porém como todos, apresentou uma rotina corrida de trabalho, bem como os seus afazeres domésticos. Dentre as atividades principais, destaca-se o trabalho com seu nome. Percebeu-se que a educanda conhecia as letras do alfabeto quase em sua totalidade e as nomeava, então priorizou-se o ensino com o as letras do seu nome e a família silábica do M. Seu desempenho nas atividades estava satisfatório até começar, após um período curto de tempo, a se confundir com as sílabas. De acordo com suas palavras, ela até conhece as letras, "mas é difícil juntar", então enviou mensagem para o seu grupo de educadoras dizendo que pretendia parar com as atividades do projeto. 
O que aconteceu com a Educanda 3 é comum quando se trata de adultos em processo de alfabetização, haja vista os números de evasão com relação ao ingresso na educação de jovens e adultos no Brasil. Por algum motivo, ao se depararem com um desafio muito grande ou que acreditam que não irão superar, alguns desmotivados com toda situação e com as sucessivas vezes em que tentaram e não conseguiram decidem desistir. No entanto, é preciso continuar acreditando e, mesmo respeitando as decisões, manifestar apoio e desejo de retorno, como fizeram as suas educadoras.

\section{CONSIDERAÇÕES FINAIS}

A experiência no desenvolvimento desse projeto nos mostra o quanto precisamos avançar com relação aos níveis de alfabetização no Brasil. Escolas, projetos sociais, organizações sem fins lucrativos e demais interessados na sociedade precisam compreender que enquanto tivermos adultos ou jovens à margem desses processos nosso país não avançará.

A Universidade Metropolitana de Santos, por meio de seus professores e alunos acredita que pode contribuir com a inserção desses educandos no mundo letrado e sempre apoiou projetos nesse sentido.

Os escritos de Freire nos mostram que estão mais atuais do que nunca, uma vez que, municiados de seus feitos teóricos e práticos, fomos a campo, em meio a pandemia, e conseguimos feitos significativos. Investigar o universo vocabular de cada educando, trabalhar sob a perspectiva do círculo de cultura a distância e não perder o foco na alfabetização para a tão sonhada liberdade nos tornaram seres melhores no âmbito pessoal e profissional.

Apontamos aqui algumas dificuldades e etapas do processo, bem como, um pouco das nossas frustrações e discussões para superá-las. No aspecto quantitativo, é possível afirmar que não foi possível atingir grandes feitos como alfabetizar uma quantidade grande de educandos, no entanto, com relação ao aspecto qualitativo, houve uma mudança crucial em todos os alunos do curso de licenciatura participantes do projeto, bem como também em seus professores: em todos eles reforçou-se a crença de nossa responsabilidade social com relação ao trabalho enquanto educadores e a crença em torno da busca por uma educação verdadeiramente libertadora . 


\section{REFERÊNCIAS BIBLIOGRÁFICAS}

BRANDÃO, C. R. O que é método Paulo Freire. 34를 reimpressão. São Paulo: Brasiliense, 2013.

BRANDÃO, Carlos, Rodrigues. Círculo de Cultura. In: STRECK, R, Danilo; REDIN, Euclides; ZITKOSKI, J, Jaime (orgs). Dicionário Paulo Freire. 2. ed.Belo Horizonte: Autêntica Editora, 2010. P. 69-70.

BRANDÃO, Z. O saber escolar e as contradições de vida das camadas populares in:conferência brasileira da educação: anais, São Paulo, 1982, pp. 275-291.

Método Paulo Freire de alfabetização. Andragogia Brasil. Disponível em: https://andragogiabrasil.com.br/metodo-paulo-freire-de-alfabetizacao/> Acesso em 22 de ago. 2021.

FREIRE, Paulo. Educação Como Prática da Liberdade. Rio de Janeiro: Paz e Terra, 1967.

Disponível em: http://www.gestaoescolar.diaadia.pr.gov.br/arquivos/File/otp/livros/educacao pratica liberdade.pdf acesso em 19 de agosto de 2021.

FREIRE, Paulo. Pedagogia do Oprimido, 17ª . ed. Rio de Janeiro: Paz e Terra, 1987. Disponível em: https://cpers.com.br/wp-content/uploads/2019/10/Pedagogia-doOprimido-Paulo-Freire.pdf

HERNÁNDEZ SAMPIERI, Roberto; FERNÁNDEZ COLLADO, Carlos; BAPTISTA LUCIO, Maria del Pilar. Metodologia de pesquisa. Tradução Daisy Vaz de Moraes. 5. ed. Porto Alegre: Penso, 2013.

ROSENBERG, Marshall B. Comunicação não-violenta. Técnicas para aprimorar relacionamentos pessoais e profissionais. 4. ed. São Paulo: Ágora, 2006. 


\title{
DOCENTE CRÍTICA E A MEDIAÇÃO DE CONFLITOS EM UM NÚCLEO DE JORNADA AMPLIADA.
}

\author{
Rogerio Oliveira Manzano \\ Elisabeth dos Santos Tavares \\ Lilian de Oliveira Batista
}

\section{RESUMO}

Os entraves de adaptação e integração, diante da redefinição da equipe de educadores em um período curto de tempo na escola, interferiram na ambiência escolar, com reações comportamentais dos alunos, tais como: bullying, agressões físicas e morais, conflitos familiares, entre outros. Esta pesquisa apresenta a caracterização do maior núcleo de Jornada Ampliada no município de Santos e os desafios encontrados pela equipe de educadores na sua prática com os alunos. A metodologia utilizada foi pesquisa bibliográfica inicialmente nas obras de Freire e autores como: Alarcão, Gadotti, Vale e Vygotsky, que embasam as ações educativas desenvolvidas pelo grupo de educadores, promovendo uma prática docente crítica para a promoção da cultura, do ensino e da construção identitária de todos que partilham deste ambiente escolar. Concluiu-se que reuniões de equipe, focadas na reflexão sobre a prática docente crítica, propostas de atividades voltadas para a dinâmica de acolhimento diário, assembleias para escuta ativa dos estudantes promoveram a reflexão dos educadores, alunos e, por consequência, a mediação e solução dos conflitos.

Palavras-chave: Educação Integral; Paulo Freire; Jornada Ampliada; prática docente crítica; mediação de conflitos.

\section{Introdução}

As instituições escolares são espaços de convivência e aprendizado constituídos por pessoas que exercem diferentes papéis sociais, sejam alunos, professores, equipe técnica e de apoio operacional, em contextos de formações e experiências de vida diversas, com o objetivo comum de ensinar conteúdos que serão indispensáveis para o convívio social e o exercício da cidadania.

Freire (1996, p. 79) destaca em sua obra que não existe neutralidade no processo da educação, portanto toda a educação é um ato político. Freire (2020, p.46) 
apresenta, ainda, que "Há uma pluralidade nas relações do homem com o mundo, na medida em que responde à ampla variedade de seus desafios".

As instituições escolares são locus privilegiados para o exercício da convivência entre pessoas com origens socioculturais diversas que, presentes no ambiente escolar, constituem um espaço privilegiado para a discussão de concepções diferentes sobre temáticas variadas e, diante destas diferenças, ocasionam situações potenciais para conflitos, o que exige da equipe gestora uma postura capaz de mediação, buscando soluções por meio de mecanismos democráticos. Diante deste cenário, como mediar conflitos interiorizados no ambiente escolar?

Esta pesquisa teve como objetivo refletir sobre as práticas desenvolvidas em um núcleo de Jornada Ampliada no município de Santos, analisando como a prática docente crítica, pautada na reflexão sobre a ação, pode mediar os conflitos e buscar soluções na integração do grupo docente e discente.

Para tanto, o artigo foi estruturado em três tópicos, o primeiro tem como objetivo caracterizar como ocorreu a implantação do Programa Escola Total - Jornada Ampliada no município de Santos, o segundo tem como objetivo descrever as demandas de atendimento do maior núcleo de jornada ampliada do município de Santos e o terceiro tópico tem como objetivo refletir sobre os aspectos da rotina dos alunos, das práticas dos educadores e as ações para mediação de conflitos.

A metodologia adotada foi a pesquisa qualitativa, de caráter exploratório e revisão bibliográfica, no pensamento das obras de Freire e demais autores como Alarcão, Gadotti, Valle e Vygotsky, mediando à busca pelo conhecimento que servirá como base para esclarecer como a prática reflexiva pode ser utilizada na mediação de conflitos no cotidiano escolar.

Freire, em suas obras, salienta a prática docente crítica, criativa, transformadora e libertadora perante os desafios que a própria sociedade apresenta, como fundamental para o desenvolvimento profissional dos envolvidos no universo da educação, diante da reflexão e leitura do mundo.

\section{Processo de implantação do Programa Escola Total - Jornada Ampliada e a constituição da Educação Integral no município de Santos.}


"Ensinar não é transferir conhecimento, mas criar as possibilidades para a sua própria produção ou a sua construção" (Paulo Freire)

No município de Santos, em 2006, foi implementado pela Secretaria de Educação (SEDUC), o Programa Escola Total - Jornada Ampliada, que nasce a partir do Programa Santos Criança, parceria entre as secretarias de Esporte e Cultura, voltado para o desenvolvimento da primeira infância.

A cidade passou a oferecer a Educação Integral por meio da ampliação da jornada em duas modalidades, para as 37 escolas de ensino fundamental da rede municipal. Em cinco delas, a estrutura física é compatível com o atendimento e os alunos permanecem na escola em período integral. Nas outras 32 escolas, a ampliação da jornada se dá no contra turno escolar, e em doze espaços da cidade. A proposta de Educação Integral e ampliação da jornada, destinada ao atendimento dos alunos, objetiva minimizar a exposição das crianças e jovens às situações de vulnerabilidade e também promover a inclusão social e educacional, acesso à cultura, à arte, ao esporte e à preparação para o trabalho.

Assim, os alunos matriculados na rede municipal de ensino e inscritos no Programa Escola Total - Jornada Ampliada participam no contra turno do ensino regular, das atividades oferecidas nas escolas e nos chamados núcleos ${ }^{14}$, o que oportuniza a aproximação das famílias dos estudantes, percepção de suas potencialidades, por meio de uma metodologia de oficinas, elaboradas e executadas por educadores de diversos segmentos e formações.

"Ensinar não é transferir conhecimento, mas criar as possibilidades para a sua própria produção ou a sua construção." (FREIRE, 1996, p. 47). Corroborando o pensamento do autor, a metodologia de oficinas diz respeito a uma dinâmica democrática, participativa e reflexiva, onde a troca de saberes se faz na horizontalidade e prevê a formação coletiva.

\footnotetext{
${ }^{14}$ Espaços da cidade que são fruto de parcerias com universidades, sociedades do bairro, sindicatos, igrejas, clubes, áreas de cultura e esporte.
} 
O Programa Escola Total - Jornada Ampliada é uma política pública consolidada, atualmente no município de Santos. A oferta da Educação Integral ocorre por meio da ampliação de jornada em escolas e em sete núcleos educativos, sendo que um deles se encontra na área continental do município, sete unidades municipais de educação em tempo integral para o Ensino Fundamental, e três escolas de atendimento híbrido. Nessas escolas, apenas parte dos alunos das unidades participam da ampliação da jornada e parte estuda em período parcial.

Neste programa, observa-se a potencialidade de interação em suas oficinas, onde o aluno é o sujeito que interage e se forma no convívio social, relaciona-se, descobre e aprende no espaço em que está inserido.

Como afirma Vygotsky, o comportamento do homem é formado por peculiaridades e condições biológicas e sociais do seu crescimento (2001, p.63). O autor afirma que o sujeito precisa do "outro" para ser, pensar, agir, colaborar no meio em que vive; faz-se necessário, a interação e intervenção para aprender. Este contexto dinâmico, oportunizado pelos núcleos de jornada ampliada, proporciona um ambiente favorável à aprendizagem para a diversidade.

As atividades são oferecidas em formato de oficinas pedagógicas e estão divididas por eixos: esportes e movimento, artes e orientação pedagógica. Como características gerais, as atividades são desenvolvidas sob o formato de oficinas lúdicas com os alunos, em complemento aos parâmetros do ensino regular.

Os alunos são organizados em grupos multisseriados, compreendendo os seguintes níveis: nível 1 : alunos de $1^{\circ}$ ao $3^{\circ}$ ano; nível 2: alunos de $4^{\circ}$ e $5^{\circ}$ ano e nível 3: alunos de $6^{\circ}$ ao $9^{\circ}$ ano, caracterizando-se, assim, a competência do aprender a conviver.

Diante da abordagem na Pedagogia de Projetos, o educador trabalha de forma contextualizada, direcionando os objetivos das oficinas para o despertar da criatividade, desafio e criticidade dos alunos.

Segundo Freire "não haveria a criatividade sem curiosidade, que nos move e que nos põe pacientemente, impaciente diante do mundo que não fizemos, acrescentando a ele algo que fizemos." (FREIRE, 1996, p. 35). 
Essas ações pedagógicas nas atividades permitem ao aluno a releitura do protagonismo de sua vida como sujeito histórico. Este trabalho pedagógico na jornada ampliada permite ainda aos participantes, um olhar diferenciado para o seu entorno e para o mundo.

\title{
3. A educação integral em um núcleo de Jornada Ampliada do município de Santos.
}

\author{
"Quem ensina aprende ao ensinar e quem \\ aprende ensina ao aprender" (Paulo Freire)
}

O Núcleo, local da pesquisa deste artigo, localiza-se no bairro da Vila Mathias, em Santos e possui uma ampla estrutura física, bem como cinquenta educadores atuantes para o atendimento da demanda de setecentos alunos, em período complementar de atividades, oriundos de escolas e regiões distintas do município, com idades entre sete e quatorze anos.

O quadro de funcionários conta com um professor articulador, estatutário da Prefeitura de Santos e representante da SEDUC, responsável por todo o processo de desenvolvimento pedagógico do programa no local, assim como a supervisão de seis colaboradores responsáveis pela manutenção e limpeza do prédio, além de quarenta e três educadores, contratados por uma Organização Social (OSC) na modalidade de prestadores de serviço para a Secretaria Municipal de Educação (SEDUC).

Este Núcleo, por atender, especificamente, alunos oriundos de nove Unidades Municipais de Ensino (UMEs), localizadas em diversos zoneamentos na parte insular do município de Santos, torna-se um núcleo de referência, com o maior número de demandas e atendimentos.

Em sua demanda de atendimento, cerca de setecentos alunos de idade entre sete e quatorze anos, estudantes do primeiro ao nono ano do ensino fundamental, são acolhidos por dia, conforme o calendário escolar do município, de segunda à sexta-feira. São organizados em trezentos e cinquenta alunos, no período matutino, o que compreende o horário das oito ao meio dia; trezentos e cinquenta alunos no período vespertino, no horário das treze às dezessete horas. Os alunos deslocam-se diariamente das suas escolas de origem para o núcleo, em ônibus fretado pela 
SEDUC, com a monitoração de dois educadores contratados por uma Organização Social (OSC), na modalidade de prestadores de serviço para a Secretaria Municipal de Educação (SEDUC).

A diversidade de perfil das unidades de ensino atendidas referente a diferentes regiões do município, as características de alunos por idade e a multiplicidade de cultura e comportamentos, reunidos em um único local, originam variadas demandas de intercorrência no espaço, integração entre pessoas, organização e logística, necessárias para a execução de todo o processo pedagógico proposto. Neste processo, Freire destaca que: "A prática docente crítica, implicante do pensar certo, envolve um movimento dinâmico, dialético entre o fazer e o pensar sobre o fazer." (FREIRE, 1996, p. 43)

No mês de agosto de 2019, houve um significativo processo de transição no Núcleo, marcado pela chegada de um professor articulador, funcionário de carreira responsável pela execução das diretrizes pedagógicas da Secretaria de Educação de Santos e uma equipe de educadores, recém-contratados por meio da OSC. Essa transição se deu diante de um grupo de alunos, que já participavam das atividades deste local desde o mês de fevereiro do decorrente ano, já ambientados com a equipe de profissionais, que lá atuava. As inúmeras mudanças em um pequeno período de tempo ocasionaram uma série de desafios para a equipe docente.

Esta quebra e troca abrupta de alguns educadores, bem com a saída da equipe técnica anterior, rompeu o vínculo com os alunos, causando impacto direto, interferindo consideravelmente na ambiência educativa Tais consequências, foram determinantes para o novo processo de integração, com a reformulação desta equipe de educadores.

Os desafios diagnosticados foram a integração do professor articulador com a equipe de educadores que já atuavam, a integração dos novos profissionais com o local, os alunos e as demandas já existentes. A constante reclamação dos pais e responsáveis, tanto na SEDUC, quanto nas UMEs e presencialmente no núcleo.

Esta nova reestruturação de equipe, gerava divergências e conflitos constantes entre os alunos, principalmente os de faixa etária entre doze e quatorze anos, 
ocasionando relatórios de ocorrência, objeto este também de diversos questionamentos presenciais dos pais e responsáveis.

Em destaque, também, para esta nova reformulação em relação aos fatores disciplinares, evidenciou-se a incidência de casos de bullying, em alguns casos pontuais de aplicação, especialmente no trajeto onde os alunos embarcam e desembarcam entre a escola de origem até o núcleo, ainda que monitorados por um grupo de educadores que os acompanhava. Também, eram constantemente relatadas agressões de forma verbal, com palavras de baixo calão proferidas entre os alunos, manuseio indevido de materiais e bolsas não pertencentes aos alunos, e extravio de objetos pertencentes aos educadores.

Os desafios impactaram o trabalho da equipe de higienização e manutenção predial, com o foco em se manter os sanitários devidamente organizados e higienizados, uma vez que alguns alunos persistiam em não os manter higienizados, utilizando-os de formas inadequadas.

No espaço para alimentação, a equipe observou o desperdício de alimentos, a desorganização das mesas e cadeiras, a sujeira proveniente do derramamento de sucos e alimentos no chão, o descarte inadequado de alimentos, entre outros procedimentos de menor relevância. A incidência de brigas e discussões na hora dos intervalos eram constantes e de consideráveis proporções.

Para uma melhor contextualização sobre as consequências na troca abrupta de uma parte da equipe pedagógica que participava da execução de atividades e sobre a importância no processo da prática reflexiva, apresentada por Gadotti:

"Todavia não existe nenhuma teoria da educação que não defenda expressamente a necessidade da reflexão na prática do professor. Por isso, falar de "professor reflexivo" pode ser considerado como redundância. Para o educador não basta ser reflexivo. É preciso que ele dê sentido a reflexão" (GADOTTI, 2003, p. 39) 
As ações construídas de forma consciente, coletiva e participativa, envolvendo alunos, educadores, equipes de apoio e equipe técnica, consolidaram os resultados de pertencimento e valorização do espaço coletivo, de convivência e aprendizagem.

\section{A prática reflexiva coletiva no processo de tomada de decisões, na redução de danos e mediação de situações de conflito.}

"Ensinar e aprender não podem dar-se fora da
procura, fora da boniteza e da alegria" (Paulo
Freire)

O processo de tomada de decisões coletivas, consonante com o sentimento de pertencimento, partiu de observações no mês de agosto de 2019. Verificou-se como principais desafios, a organização no quesito do processo educativo, a segurança, o cuidado próprio e com o outro, a higiene do local, a conservação do patrimônio físico, o cuidado com o material identitário e coletivo, protagonistas necessários para uma estratégia dinâmica de acolhimento diário destes educadores e educandos.

As ações práticas para a reflexão que conseguisse melhoria aos desafios diagnosticados nas ocorrências diárias foram propostas pelo professor articulador, em ocasião das reuniões integradas com a equipe, como caminhos que pudessem amenizar as principais ocorrências e sem perder a referência do principal foco da educação de jornada ampliada. Assunto de visualização desafiadora, uma vez que a maior parte dos profissionais, possuía um pouco mais de um mês de atuação no local. As discussões acaloradas iniciais, procurando-se a justificativa ou o culpado de tal situação, evoluiu para a análise e apresentou o caminho de conscientização. O grupo passou da reflexão coletiva para a ação individual nas práticas educativas, diante dos desafios instaurados neste núcleo.

"É pensando criticamente a prática de hoje ou de ontem que se pode melhorar a próxima prática. O próprio discurso teórico, necessário a reflexão crítica, tem de ser de tal modo concreto que quase se confunda com a prática" (FREIRE, 1996, pag. 44)

Diante do desencadeamento nas reuniões entre os educadores, após inúmeras reflexões, a equipe chegou ao consenso de uma nova proposta, a de acolhimento dos alunos logo na chegada para o início das atividades no núcleo, 
instaurando o sentimento de aproximação, acolhimento e pertencimento dos alunos em relação a todos os profissionais no local.

A partir dos educadores de música, foi proposta uma atividade especial, onde todos os alunos deveriam, ao chegar no local, sentar-se na área de recreação, relaxar e ouvir uma música de boas-vindas. Toda a equipe técnica, educadores e a equipe de limpeza e manutenção estavam nesta recepção especial.

A esta dinâmica, observou-se certa "estranheza" por parte dos alunos, porém, ao encaminhar os grupos para as salas das oficinas, ficou determinado que todo o grupo refletiria sobre o momento daquele acolhimento. Para a satisfação inicial da equipe de educadores, uma parte dos alunos respondeu que era uma novidade, e que poderia se repetir.

"Há uma pluralidade nas relações do homem com o mundo, na medida em que responde à ampla variedade de seus desafios. Em que não se esgota num tipo padronizado de resposta. A sua pluralidade não é só em face dos diferentes desafios que partem do seu contexto, mas em face de um mesmo desafio. No jogo constante de suas respostas, altera-se no próprio ato de responder. Organiza-se. Escolhe a melhor resposta. Testa-se. Age. Faz tudo isso com a certeza de quem usa uma ferramenta, com a consciência de quem está diante de algo que o desafia" (FREIRE, 2020, p. 56).

Identificado um primeiro caminho de acolhimento aos alunos, por ação integrada de todos, com possibilidades de melhoria contínua, integração e bem estar, as ações do dia seguinte foram definidas para que os educadores de esportes definissem o acolhimento inicial, aplicando-se as atividades de alongamento e relaxamento com um diferencial: nos últimos trinta minutos finais do período, todos os alunos se reuniriam novamente no pátio. Então, o professor articulador, junto com a equipe de educadores e todos os profissionais do local perguntaram aos alunos: "Como foi o dia de atividades?" Poucas respostas, rasas e uníssonas foram devolvidas, porém, ao retornarem para a escola de origem, uma parte das crianças e de jovens nos ônibus dirigiram-se aos educadores com: "Amanhã terá mais atividades com todo mundo?". Os educadores questionaram o motivo, e de forma satisfatória, a devolutiva foi de que o dia tinha "sido legal". 
$\mathrm{Na}$ reflexão proposta em se evidenciar o núcleo como um local de atividades complementares e lúdicas, com sentido de aprendizagem para a praticidade da vida, ao final da primeira semana, os educadores se revezaram neste processo de acolhimento, com as boas-vindas e atividades direcionadas coletivamente. Ao final do dia, sempre ocorria a reflexão coletiva sobre como o dia tinha sido. E surgiam impressões motivadoras por parte da equipe dos educadores.

Neste processo de transição, as ações iniciais de acolhimento referenciam-se no pensamento de Freire, a respeito da tomada coletiva de decisões e da busca por melhorias coletivas no ambiente escolar. Desta forma:

"o difícil ou a dificuldade está sempre em relação com a capacidade de resposta do sujeito que, em face do difícil e da avaliação de si mesmo quanto à capacidade de resposta, terá mais ou menos medo ou nenhum medo ou medo infundado ou, reconhecendo que o desafio ultrapassa os limites do medo se afunda no pânico" (FREIRE, 2012. p. 76).

No decorrer de duas semanas, a equipe observou que, timidamente, parte dos alunos apresentava uma sensação de "leve conforto" com o acolhimento verificado, tanto as crianças como os jovens.

A sensação de pertencimento, embora ainda não alterasse todos os desafios identificados e a criação da nova rotina permitiram o acesso à reflexão e avaliação nas reuniões de equipe. Foi unânime a percepção da necessidade de se questionar os alunos, sobre quais as dificuldades que estavam enfrentando e sobre a necessidade de todos se conscientizarem para zelar de um espaço coletivo, no sentido do cuidado com o eu e com o próximo.

Neste caminho entre reflexão e ação, com as reuniões semanais de equipe e o processo de acolhimento dos alunos, com a reflexão final de "como foi o seu dia de atividades", identificou-se de forma integrada a possibilidade da criação de possíveis propostas com as temáticas de pertencimento coletivo, autonomia e cidadania e respeito às diferenças.

Segundo Alarcão (2010, p.54) "a reflexão sobre a ação pressupõe um distanciamento da ação. Reconstruímos mentalmente a ação para tentar analisá-la retrospectivamente" 
Ao cotidiano nas atividades do núcleo, uma das necessidades apresentadas foi a de se abrir diariamente, sob a forma de assembleias, oportunidade em que os alunos fossem à frente no momento inicial e final das atividades, com todos presentes, para apresentarem as suas ideias, em relação aos fatos ocorridos no núcleo e que desfavoreciam a harmonia e o clima local. Em uma das ocasiões, pela ocorrência do uso indevido dos sanitários masculino e feminino, por parte dos alunos, a equipe de manutenção e limpeza expôs a necessidade da ajuda de todos, e os alunos que participaram da plenária foram duramente criticados por outros alunos.

No decorrer dos meses, como eixo de orientação complementar, foi trabalhado com a equipe integrada aos alunos, de que forma as oficinas de que todos participavam na jornada ampliada poderiam contribuir para a melhoria do clima escolar, organização do local e a identidade de pertencimento coletivo de todos no local.

Um dos maiores destaques, em relação ao resultado da melhoria do clima, participação e pertencimento, foi a ornamentação e caracterização das salas de atividades e pintura das áreas comuns, nas quais os educadores, em suas respectivas oficinas, envolveram todos os alunos, direcionando esta melhoria para atividades lúdicas.

\section{Considerações Finais}

Esta pesquisa teve como objetivo refletir sobre as práticas desenvolvidas em um núcleo de jornada ampliada no município de Santos, analisando como a prática docente crítica pode contribuir na mediação de conflitos e buscar soluções na integração do grupo docente e discente.

Primeiramente foi abordada a implementação do Programa Escola Total de Jornada Ampliada no município de Santos, um marco que descreve o funcionamento da Educação Integral nos núcleos de jornada ampliada e que orienta o trabalho dos educadores. 
Em um segundo momento, foi caracterizado o maior núcleo de Jornada Ampliada do município de Santos com uma demanda de atendimento de setecentos alunos com faixa etária de sete a quatorze anos, provenientes de nove unidades municipais, com localização em diferentes zoneamentos do município e atendidos por cinquenta educadores no contraturno do ensino regular.

E, no terceiro momento, apresentou-se o processo de ruptura de vínculos causado pela troca da equipe gestora e de boa parte dos educadores, no início do segundo semestre do ano letivo, sendo que o grupo de alunos já participava das atividades neste local, desde o início do ano letivo, já integrados com a equipe de profissionais que lá atuava.

Apresentou-se, em seguida, como a equipe gestora, no coletivo, mediados pelo estudo de autores como Freire, Alarcão, Gadotti, Valle e Vygotsky e dedicaram-se a estudar os processos reflexivos, a prática docente crítica diante de desafios, tendo como objetivo a práxis criativa e transformadora com a participação coletiva dos alunos, promovendo o espaço de cidadania.

A rotina de reuniões semanais, discutindo os desafios enfrentados pelos educadores, e a proposta de práticas como dinâmicas de acolhimento diário, assembleias para escuta ativa dos estudantes, a ornamentação e caracterização das salas de atividades, com pintura das áreas comuns, agregando o processo de reflexão e ação, promoveram a transformação no clima escolar, levando à reflexão dos educadores e alunos, e por consequência, à mediação dos conflitos.

Conclui-se que o exercício da prática crítica e reflexiva dos educadores e alunos foi capaz de transformar a ambiência escolar, inicialmente rejeitada pela mudança abrupta do corpo docente, inicialmente rejeitada, em um ambiente acolhedor, que viabilizou a criação de vínculos e o sentimento de pertencimento coletivo neste núcleo.

\section{Referências}

ALARCÃO, I. Professores reflexivos em uma escola reflexiva. São Paulo: Cortez 2010. 
FREIRE, P. Pedagogia da autonomia: saberes necessários à prática educativa. São Paulo: Paz e Terra, 1996. - (Coleção Leitura)

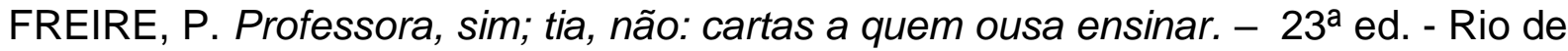
Janeiro: Civilização Brasileira, 2012.

FREIRE, P. Educação como prática da liberdade. - 48aㅗ ed. - São Paulo: Paz e Terra, 2020.

GADOTTI, M. Boniteza de um sonho: ensinar e aprender com sentido. Novo Hamburgo: FEEVALE, 2003.

VALE, M. J. Paulo Freire, educar para transformar: almanaque histórico / Maria José Vale, Sonia Maria Gonçalves Jorge, Sandra Benedetti. São Paulo: Mercado Cultural, 2005.

VYGOTSKY, L. S. Psicologia pedagógica. São Paulo: Martins Fontes, 2001. 
O ADOLESCENTE NA EJA - ASSEMBLEIA DE CLASSE COMO MOMENTO DE ESCUTA

Rosalina de Fatima Valadão Rodrigues Vellozo, Elisete Gomes Natario

\section{RESUMO}

Este estudo apresenta reflexões sobre a problemática da juvenilização da Educação de Jovens e Adultos. A base teórica foi construída por meio da literatura freireana de forma a delinear as reflexões dialógicas sobre o ingresso de adolescentes de 15 anos para EJA. Assim, algumas discussões são apresentadas tendo como referência Brunel (2004), Siqueira e Haddad (2015) e outros autores que tratam do tema. O objetivo do estudo é apresentar a assembleia de classe como uma prática educativa que possibilita aos estudantes inseridos nesta modalidade de ensino refletir sobre as razões que os colocaram como educandos da EJA, uma vez que uma das hipóteses é a indisciplina escolar. Para tanto a proposição da assembleia de classe é parte de observar a dialogicidade freireana na atualidade.

Palavras-chave: Paulo Freire; Educação de Jovens e Adultos; Juvenilização; Assembleia de Classe.

\section{Introdução}

Esta pesquisa tem abordagem qualitativa. Dessa maneira, busca-se na literatura refletir sobre a juvenilização na Educação de Jovens e Adultos (EJA). Logo, esta pesquisa bibliográfica é um recurso de investigação que visa levantar hipóteses para o ingresso desta população juvenil na EJA relacionadas aos anos iniciais e finais.

A produção do estudo justifica-se à medida que a pesquisa bibliográfica ajuda na reflexão crítica sobre a problemática em torno da juvenilização da EJA e do papel que os educadores e gestores públicos que atuam no ensino regular têm nesta demanda.

Neste contexto, a experiência de uma das autoras como docente nos anos iniciais da EJA - alfabetização - em uma rede pública de ensino municipal conduziu a escolha do tema, assim o estudo é também um diálogo sobre como a educação de pode ajudar a transformar a vida dos indivíduos que dela participa.

Logo, a literatura Freireana (1979, 1996, 1997, 1980) embasa as reflexões realizadas e busca nos autores pesquisados, caso de Araújo (2008), Brunel (2004), Siqueira e Haddad (2015) e outros, ressaltar a importância da educação como prática de liberdade e de atuação cidadã, considerando que estes jovens tiveram seus direitos 
negados e que à juvenilização da EJA conectam-se indicadores de falhas pedagógicas e de acolhimento no ensino regular.

Nesta perspectiva, o objetivo do estudo é apresentar a assembleia de classe como uma prática educativa que possibilita os estudantes inseridos nesta modalidade de ensino refletir sobre as razões que os colocaram como educandos da EJA, visto que a cada dia aumenta o número de matrículas de adolescentes entre 14 e 18 anos nesta modalidade de ensino, quando o esperado seria a conclusão do ensino fundamental ( $9^{\circ}$ ano do ensino fundamental) aos 14 ou 15 anos de idade (BRASILPNE, 2011-2020).

\subsection{Educação desde a primeira infância - direito de todos}

De acordo com a legislação educacional brasileira, Lei de Diretrizes e Bases da Educação - LDBEN, 9394/965 (BRASIL, 1996), até concluir a Educação básica o estudante deve passar por modalidades: educação infantil, ensino fundamental e ensino médio.

Nesta perspectiva, a criança chegará ao Ensino Fundamental passando pelos anos iniciais ( $1^{\circ}$ ao $5^{\circ}$ ano) e finais ( $6^{\circ}$ ao $9^{\circ}$ ano), caso não tenha retenção ou abandono escolar concluirá os estudos, desta etapa, após três anos no ensino médio. No entanto, muitos estudantes iniciam na Educação de Jovens e Adultos, ao completarem 15 anos de idade e, em sua maioria, são oriundos do ensino regular. Logo, uma pergunta se faz pertinente: Por que isso ocorre se a escola é para todos e sua obrigatoriedade inicia aos 4 anos de idade? Segundo Haddad,

A repetência e a evasão ainda são problemas para a permanência do alunado na escola, fazendo com que muitas crianças desistam antes de completar o ensino fundamental. Mais de 1 milhão de jovens entre 15 e 17 anos estão fora da escola. É esta situação que alimenta a composição do enorme contingente de pessoas que, mesmo tendo passado pela escola, não consegue se alfabetizar com qualidade para que se mantenha autônomo no uso da escrita e da leitura. Apesar do aumento na oferta de vagas no ensino fundamental regular, e a melhoria na promoção do alunado ao longo das últimas décadas, o atraso acumulado na escolaridade cria uma demanda potencial significativa por políticas de educação de jovens e adultos (EJA) (SIQUEIRA; HADDAD, 2015, p. 99).

Assim, embora a legislação brasileira pontue a obrigatoriedade do ingresso na educação básica aos quatro anos de idade, como parte de possibilitar aos estudantes um maior tempo de escolaridade e aproveitamento dos estudos, existem muitos 
adolescentes que são encaminhados para a EJA e sua caminhada se dá porque o ensino regular não supriu as necessidades deste educando.

Neste caso, uma reflexão se faz importante: "[...] O cenário ideal, entretanto, seria aquele em que todos os alunos pudessem concluir o ensino fundamental aos 14/15 anos e o ensino médio aos 17/18 anos frequentando uma escola regular e de preferência no turno diurno [...]" (INEP, 2019, p. 28).

Nesse viés de idealização, uma das metas do Plano Nacional de Educação é: "[...] universalizar o ensino fundamental de nove anos para toda população de 6 a 14 anos. Para tanto, tem como uma das possíveis estratégias a criação de: "[...] mecanismos para o acompanhamento individual de cada estudante do ensino fundamental". No referido documento encontra-se metas e estratégias que se efetivadas concretamente no sistema educacional brasileiro a juvenilização na EJA não ocorreria.

Assim, percebe-se que exista uma distância entre o que se pretende na teoria e o que de fato ocorre no chão da escola, uma vez que o Parecer (23/2008, p.9) ressalta,

Tal situação é fruto de uma espécie de migração perversa de jovens entre 15 (quinze) e 18 (dezoito) anos que não encontram o devido acolhimento junto aos estabelecimentos do ensino sequencial regular da idade própria. Não é incomum se perceber que a população escolarizável de jovens com mais de 15 (quinze) anos seja vista como "invasora" da modalidade regular da idade própria. E assim são induzidos a buscar a EJA, não como uma modalidade que tem sua identidade, mas como uma espécie de "lavagem das mãos" sem que outras oportunidades lhes sejam propiciadas. (BRASIL, PARECER № 23/2008, p. 9)

Em que pese, as particularidades de cada região quanto a desigualdade social e econômica, é preciso observar que a citação descreve como perversa a juvenilização da EJA e, compreende-se que é necessário analisar desinteresse dos estudantes pela escola, assim como refletir sobre os motivos que levam gestores a encaminhar jovens de 15 anos para esta modalidade de ensino.

O encaminhamento do adolescente para a EJA, conforme relata Brunel (2004, p. 10), "[...] muitos destes alunos apresentam problemas de indisciplina no ambiente escolar [...]". Sobre isso Vellozo e Natário (2021) apresentam:

Sendo a sala de aula um espaço com características próprias de uma habitação voltada para a educação formal, composta por culturas 
diferentes, ela encontra-se permeada por metodologias que estão ligadas à formação acadêmica do professor que observa o estudante como um objeto a ser preenchido com os saberes dos docentes e, dependendo da abordagem, os conflitos se iniciam, dando origem ao que comumente se chama de indisciplina escolar. (VELLOZO; NATÁRIO, 2021, p. 45)

Ao propor alternativas para o trabalho com a indisciplina escolar na sala de aula, a autora enfatiza a importância do diálogo como parte do fazer pedagógico no $5^{\circ}$ ano do ensino fundamental, última etapa dos anos iniciais. Logo, se a indisciplina está presente na vida destes estudantes que são encaminhados para a EJA, o certo seria compreender porque tais situações se apresentam em sala de aula e quais as possibilidades de intervir ainda no ensino regular para que este jovem possa concretizar seus estudos com 14 ou 15 anos de idade.

Conforme Freire (1997, p. 35), "[...] a pesquisa, como ato do conhecimento, tem como sujeitos cognoscentes, de um lado, os pesquisadores profissionais; de outro, os grupos populares e, como objeto a ser desvelado, a realidade concreta [...]". Sendo assim, investigar as razões pelas quais estes estudantes iniciam cada vez mais cedo na EJA é parte de refletir sobre as estratégias pedagógicas que são ofertadas no ensino regular diurno e de como estes educandos e educadores dialogam neste espaço chamado sala de aula.

Neste contexto, as práticas educativas do educador precisam prever a "realidade concreta" que estão presentes na sala de aula e, em um diálogo contínuo buscar novas formas de atender aqueles e aquelas que têm dificuldades para compreender os conteúdos abordados, assim como as regras escolares que possibilitam o aprendizado. Portanto, as falhas no ensino regular se apresenta como uma possível resposta para esta "juvenilização" da EJA.

Reconhecendo que a entrada na EJA destes adolescentes decorre das dificuldades que eles e elas encontraram no ensino regular, o que se deve buscar é "[...]uma reflexão sobre o homem e de uma análise do meio de vida concreto do homem concreto a quem queremos educar, ou melhor dito: a quem queremos ajudar a educar-se [...]". (FREIRE, 1980, p. 33-34).

Desta feita, uma reflexão sobre este jovem que inicia na EJA com pouca escolarização é parte de motivar a construção de políticas públicas direcionadas a compreender o fenômeno da indisciplina escolar no ensino regular, a retenção do estudante e as dificuldades em proporcionar uma educação que no "[...] ato de ensinar 
[...] exige [...] o conhecimento e a assunção da identidade cultural" (FREIRE, 1996, p. 46) deste cidadão atendido no ensino regular e na EJA.

Nesta perspectiva, a exclusão do adolescente do ensino regular preserva a desigualdade social, a marginalização do educando e educanda adolescente que, muitas vezes, não se adapta à modalidade e tende a abandonar os estudos ou terminá-lo sem ter condições de aprendizagem que o ajude a aumentar suas chances de efetivar-se no campo profissional, social e político. Brunel (2004, p.33-34) apresenta as seguintes questões para reflexão,

\begin{abstract}
Por que estes jovens desistiram ou abandonaram a escola regular? Quais são os projetos e os serviços oferecidos pelo sistema público, no que se refere à educação de jovens e adultos? Qual é o peso da reprovação nesse fenômeno? Quais foram os principais fatores que interferiram no momento da escolha por essa modalidade de ensino? Os fatores econômicos são os mais determinantes? Os fatores cognitivos são os que mais interferem? Recuperar o tempo perdido é fundamental neste contexto? Existe realmente um desencanto dos jovens pela escola regular?
\end{abstract}

Problematizar tais questões nas formações pedagógicas dos professores, gestores, governantes é um dos caminhos para respondê-las. A máxima "[...] ensinar não é transferir conhecimento [...]" (FREIRE, 1996, p. 47) deve ser efetivada, não apenas apregoada em cartazes formativos, precisa fazer parte da prática da sala de aula, do diálogo que compõe as singularidades da sala de aula, da dinâmica educativa entre professor e aluno, pois, assim poderão efetivar os acordos entre os pares para que se tenha um aprendizado que faça diferença na vida dos estudantes, de modo que sua passagem pela escola tenha continuidade, seja no tempo próprio.

Em síntese, é trazer as ideias de diálogo e educação que liberta para a atualidade, oportunizando aos educandos adolescentes, jovens e adultos um olhar para si e para o outro, compreendendo o importante papel que a educação tem para toda comunidade.

É nesse sentido, pois, que de um modo ou de outro, as questões levantadas por Brunel (2004) estão conectadas com a própria aceitação deste estudante por seus professores quando em sala de aula no ensino regular. Tal aceitação que muitas vezes vem travestida do olhar desaprovador quando tem uma atitude considerada indisciplinada, quando se recusa a fazer tais atividades proposta, sem apresentar o porquê da recusa. 
Observações recentes na literatura acenam que o comportamento está ligado à falta de entendimento sobre os objetivos do que foi proposto pelo educador, ou pela inabilidade em lidar com as regras escolares e até transitar entre os conteúdos pedagógicos. Assim, conforme apresenta Freire:

\begin{abstract}
A primeira condição para que um ser possa assumir um ato comprometido está em ser capaz de agir e refletir. Se a possibilidade de reflexão sobre si, sobre seu estar no mundo, associada indissoluvelmente à sua ação sobre o mundo, não existe no ser, seu estar no mundo se reduz a um não poder transpor os limites que the são impostos pelo próprio mundo, do que resulta que este ser não é capaz de compromisso (FREIRE, 1997, p. 16).
\end{abstract}

Vale ressaltar que neste ato de comprometimento a educação não marginaliza, não exclui, não encaminha adolescentes para EJA por falha institucional. Tal compromisso reside em políticas públicas que atendam educadores, educandos e gestores, que possibilitem reflexão crítica da sociedade sobre os fazeres escolares que oportunizam muito mais que o ingresso nesta modalidade de ensino. Há que se discutir que esta chegada à EJA seja efetiva e, isso, significa ir além das práticas educativas com as quais estes adolescentes conviviam no ensino regular.

\title{
1.2 Assembleia de Classe na EJA - diálogo e reflexão
}

Compreendendo que o perfil do estudante da Educação de Jovens e Adultos não é o mesmo da década de 30 ou 90 - pedreiros, costureiras, operários, donas de casa, pescadores etc.-, homens e mulheres, em sua maioria, negros, excluídos do processo educacional desde a infância, é necessário refletir sobre como estes sujeitos adolescentes, jovens e adultos poderão atuar no mesmo espaço, sala de aula, de modo que o aprendizado ocorra e tenham momentos de fala, podendo expressar suas realidades e conhecimentos prévios sobre este estar no mundo e dele fazer parte como cidadão transformador.

Neste sentido, "[...] a EJA necessita ser pensada como um modelo pedagógico próprio a fim de criar situações pedagógicas e satisfazer necessidades de aprendizagem de jovens e adultos [...]" (BRASIL, 2000, p. 8). Uma fala expressa no Parecer CNE/CEB 11/2000 que definiu as Diretrizes Curriculares Nacionais para a Educação de Jovens e Adultos, apresentando três funções para esta modalidade: 
reparadora (restaurar direitos não atendidos), equalizadora (homens e mulheres) e qualificadora (ofertar o conhecimento necessário).

A proposição de fazer uso da assembleia de classe em turmas da EJA faz parte de transitar entres as funções trazidas pelo Parecer 11/2000, de modo a alinhar as diferentes faixas etárias por meio do diálogo sobre o que é ser e estar da EJA. Para Araújo (2008, p.119),

O modelo das assembleias é o da democracia participativa que tenta trazer para o espaço coletivo a reflexão sobre os fatos cotidianos, incentivando o protagonismo das pessoas e a coparticipação do grupo na busca de encaminhamentos para os temas abordados, respeitando e naturalizando as diferenças inerentes aos valores, crenças e desejos de todos os membros que dela participam. Com isso, nem sempre o objetivo é de se obter consenso e acordo, e sim, o de explicitar as diferenças, defender posturas e ideias muitas vezes opostas e mesmo assim levar as pessoas a conviver num mesmo espaço coletivo.

Nota-se na fala do autor que por meio das assembleias as diferenças, por exemplo, entre adolescentes e adultos, com o coletivo expressando suas ideias e, assim trocarem conhecimentos no percurso das aulas.

Vellozo e Natário (2021, p. 149) ressaltam que: "[...] Ela manifesta o compromisso destas pessoas, deste grupo de sala de aula, em que as possibilidades de interação se encontram ofuscadas pelo individualismo de cada um".

Em face disso para Araújo (2008, p.118), o trabalho com assembleias: "[...] permite a construção psicológica, social, cultural e moral do próprio sujeito, em um movimento dialético em que o coletivo transforma e constitui cada um de nós [...]". Transpondo a fala de Araújo para a literatura freireana conclui-se

O fato de me perceber no mundo, com o mundo e com os outros me põe numa posição em face do mundo que não é de quem nada tem a ver como ele. Afinal, minha presença no mundo não é a de quem a ele se adapta, mas de quem nele se insere. É posição de quem luta para não ser apenas objeto, mas sujeito também da História. (FREIRE, 1996, p. 60)

Ao dar voz aos estudantes, a assembleia torna-se instrumento de luta, de aprendizagem, de trocas de experiências, de possibilidades de o adolescente aprender com o adulto que ali se encontra, seja ele o professor ou um colega de sala trabalhador ou trabalhadora. É válido dizer, portanto, que a assembleia é uma prática 
educativa que pode ser vivenciada na modalidade da EJA, para estruturar as relações interpessoais entre adolescentes, jovens e adultos, ao mesmo tempo, que os ajudam a refletir sobre as razões sociais, políticas e econômicas que os colocaram juntos.

Por conseguinte, todos têm na assembleia um papel reflexivo-crítico sobre este estar na escola, educadores e educandos apresentam sua condição de sujeito ativo, capaz de problematizar toda e qualquer exclusão que tenham vivenciado no ensino regular e, assim poderão encontrar novas possibilidades de aprendizagem, de interagir socialmente durante o processo escolar, pois segundo Araújo (2012, p. 85): "[...] a educação deve visar o desenvolvimento de competências para lidar com a diversidade e o conflito de ideias, com as influências da cultura e com os sentimentos e emoções presentes nas relações do sujeito consigo mesmo e com o mundo à sua volta.

Freire (1996, p.23), destaca: "[...] não há docência sem discência, as duas se explicam e seus sujeitos, apesar das diferenças que os conotam, não se reduzem a condição de objeto, um do outro. Quem ensina aprende ao ensinar e quem aprende ensina ao aprender". Assim, a assembleia dá voz aos educandos, dá-lhes poder para não serem enganados, ajudam-nos a emanciparem e compreender que seus conhecimentos prévios são tão importantes, quanto aqueles apresentados nas escolas.

\section{Metodologia}

Este estudo compreende a pesquisa bibliográfica, tal como afirma Boccato (2006, p. 266), tem como um de seus focos a "[...] resolução de um problema (hipótese) por meio de referenciais teóricos publicados, analisando e discutindo as várias contribuições científicas". O tratamento da literatura estudada foi na abordagem qualitativa, visto que a mesma é cabível quando se requer visão ampla do objeto de estudo e suas inter-relações no que se refere aos aspectos sociais, políticos e culturais (BRITO, OLIVEIRA; SILVA, 2021).

\section{Considerações finais}


No que tange as vivências como professora alfabetizadora na Educação de Jovens e Adultos destaca-se as falas dos autores sobre a importância dos educadores e educandos refletirem criticamente sobre as razões para esta demanda juvenil na EJA. É certo que a desigualdade econômica e social aumenta as chances dos estudantes abandonarem os estudos, porém o que se percebe nas questões levantadas na literatura é que estes educandos não são atendidos no ensino regular. Assim é preciso refletir de modo a construir novas formas de atender estes estudantes adolescentes. Logo, em que pese a resistência dos educandos adolescentes quanto as formas de interação no espaço da sala de aula no ensino regular, o seu encaminhamento para a EJA é o reconhecimento de que a escola tem desafios e precisa transformar-se em um espaço que atenda esta população.

O estudo teórico revela que é por meio da reflexão-crítica que se pode compreender a juvenilização da EJA. Ouvir estes participantes, oportunizar momentos de fala se faz urgente, seja no ensino regular ou na EJA, pois se compreende que o ingresso destes adolescentes na EJA não pode ser a revelia de seus próprios interesses, não pode ser apenas para minimizar situações de conflitos ou mascarar a marginalização destes educandos e educandas no ensino regular.

Diante do exposto, a proposição de fazer uso da assembleia de classe constitui o enriquecimento do fazer pedagógico que acolhe, constrói ações educativas com base nos saberes dos educandos e educadas, sejam estes adolescentes, jovens ou adultos. No âmbito das ideias de Paulo Freire, a Assembleia torna-se uma oportunidade de reconhecer as dificuldades de aprendizagem, as ideias e necessidades da comunidade escolar e, solidificar o poder de voz de cada participante inserido no espaço escolar.

\section{Referências}

ARAÚJO, Ulisses Resolução de conflitos e assembleias escolares - Cadernos de Educação | FaE/PPGE/UFPel | Pelotas [31]: 115 - 131, julho/dezembro 2008Disponível em: http://www2.ufpel.edu.br/fae/caduc/downloads/n31/06.pdf. Acesso em: 10 ago. 2021.

. O processo de construção de escolas democráticas. Educação e

Linguagens, Campo Mourão, v. 1, no 1, p. 78-86, Ago./ Dez. 2012. 
BOCCATO, Vera Regina C. Metodologia da pesquisa bibliográfica na área odontológica e o artigo científico como forma de comunicação. Rev. Odontol. Univ. São Paulo, São Paulo, SP, v. 18, n. 3, p. 265-274, 2006.

BRASIL. Lei Federal no 9394/1996. Estabelece Diretrizes e Bases da Educação Nacional. Disponível em: http://www.planalto.gov.br/ccivil 03/LEIS/L9394.htm. Acesso em: 20 jul. 2021.

BRASIL. Parecer CNE/CEB № 23/2008. Aprovado em 8/10/2008. Brasília; MEC: 2008.

Parecer CNE/CEB no 11/2000, de 10 de maio de 2000. Dispõe sobre as Diretrizes Curriculares Nacionais para a Educação de Jovens e Adultos. Brasília: Ministério da Educação/ Conselho Nacional de Educação/Câmara de Educação Básica, 2000.

, Ministério da Educação. Plano Nacional de Educação para o decênio 2011-2020- PNE 2011-2020, de 15 de dezembro de 2010. Disponível em: http://portal.mec.gov.br/index.php?option=com_docman\&view=download\&alias=7116 -pl-pne-2011-2020\&ltemid=30192 Acesso em: 6 set. 2021.

. Ministério da Educação Instituto Nacional de Estudos e Pesquisas Educacionais Anísio Teixeira (INEP). Censo Escolar 2020- Divulgação dos Resultados-Diretoria de Estatísticas Educacionais Brasília, 29 de janeiro de 2021. Disponível em:

https://download.inep.gov.br/censo_escolar/resultados/2020/apresentacao_coletiva.p df. Acesso: 10 ago. 2021.

BRITO, Ana Paula G.; OLIVEIRA, Guilherme S.; SILVA, Brunna A. A importância da pesquisa bibliográfica no desenvolvimento de pesquisas qualitativas na área de educação. Cadernos da Fucamp, v.20, n.44, p.1-15, 2021. Disponível em: file://C:/Users/carol/AppData/Local/Temp/2354-8496-1-PB.pd. Acesso em: 06 set. 2021.

BRUNEL, Carmem. Jovens cada vez mais jovens na Educação de Jovens e Adultos. Porto Alegre: Mediação, 2004.

FREIRE, Paulo. Educação como prática da liberdade. 17.ed. Rio de Janeiro: Paz e Terra, 1979.

. Conscientização: teoria e prática da libertação: uma introdução ao pensamento de Paulo Freire. São Paulo: Moraes, 1980.

. Pedagogia da autonomia. São Paulo: Paz e Terra, 1996.

. Política e educação. São Paulo: Cortez, 1997.

SIQUEIRA, Filomena; HADDAD, Sergio. Analfabetismo entre jovens e adultos no Brasil. Revista Brasileira de Alfabetização - ABAlf | ISSN: 2446-8576 / e-ISSN: 2446- 
8584 Vitória, ES | v. 1 | n. 2 | p. 88-110 | jul./dez. 2015. Disponível em: https://revistaabalf.com.br/index.html/index.php/rabalf/article/view/81/64. Acesso: 10 ago. 2021.

VELLOZO, Rosalina F. V. R.; NATÁRIO, Elisete G. Conviver, debater e aprender na perspectiva da assembleia de classe. Universidade Metropolitana de Santos UNIMES. 2021. Disponível em:

https://educapes.capes.gov.br/handle/capes/601314. Acesso: 10 ago. 2021. 


\title{
O método de ensino na prática docente: considerações freirianas
}

\author{
Israel Batista de Oliveira \\ Valéria Santana de Oliveira \\ Abigail Malavasi
}

\section{RESUMO}

O presente trabalho traz um olhar sobre a questão do processo de ensino e de suas metodologias a partir das discussões colocadas por Paulo Freire, buscando um diálogo com outros educadores, como Zeichner e Alarcão, a fim de compreendermos que importantes papéis desempenham o ensino e seus métodos em uma prática docente imersa na realidade dos educandos, problematizadora e comprometida com a transformação social de todos os seus atores. Buscamos, na perspectiva freiriana, refletir a respeito da educação que consiste em pensar o ser humano, pois nele reside o fundamento do processo educativo. E nesta premissa está inserida a concepção de educar que, em síntese, é, também, promover, nos sujeitos, a capacidade de interpretação dos diferentes contextos em que estão inseridos, bem como, qualificá-los e "instrumentalizá-los" para a ação. Isto implica que, numa prática educativa libertadora, não há métodos prontos, conteúdos aprioristicamente definidos, sujeitos formais e abstratos apreensíveis por certas leis cognitivas ou comportamentais.

Palavras chave: Prática docente; Educação Libertadora; Processos de ensino

\section{INTRODUÇÃO}

É de fundamental importância que o professor da atualidade seja reflexivo e pesquisador. $O$ ensino tradicional e tecnicista vem saindo de cena e dando a oportunidade a novos métodos de ensino.

Um professor reflexivo deve elucidar a carência da formação continuada e encaminhar suas práxis aos interesses e às necessidades dos alunos e que essa consciência reflexiva possa estimular um caminho afincado de melhorias na educação.

Dewey (1979, p. 24), nos diz que "a necessidade da solução de uma dúvida é o fator básico e orientador em todo o mecanismo da reflexão". Freire (1997) atribui relevância ao constante movimento de procura, na inquietação, na curiosidade ingênua, na crítica, no posicionamento ético e da responsabilidade na prática docente.

Freire (1983, p.78) defende a educação como "Prática de Liberdade", problematizadora, antagônica à educação bancária. A concepção freiriana se opõe a processos meramente depositários de conteúdo, de valores que são transmitidos aos educandos, que devem memorizar as informações recebidas que servem aos 
objetivos de dominação. Esse processo nega a dialogicidade como essência da educação.

Defendemos nesta discussão, os fundamentos da educação libertadora pautada na dialogicidade. A prática problematizadora considera que não é possível haver conhecimento quando o aluno não é convidado a conhecer o objeto cognoscível, quando ao aluno cabe somente memorizar o que está sendo transmitido pelo professor. O docente problematizador refaz constantemente o processo de ensino, pois sua prática busca proporcionar a reflexão num constante ato de desvelamento da realidade. Para Freire (1983) quanto mais os alunos são desafiados, mais se comprometerão a responder aos desafios.

A presente discussão traz um olhar sobre a questão do processo de ensino e de suas metodologias a partir destas discussões colocadas por Paulo Freire, buscando um diálogo com outros educadores, como Zeichner e Alarcão, a fim de compreendermos que importantes papeis desempenham o ensino e seus métodos em uma prática docente imersa na realidade dos educandos, problematizadora e comprometida com a transformação social de todos os seus atores.

\section{O que é ensinar?}

Para Freire (2003), ensinar é criar possibilidades para os alunos produzirem ou construírem o conhecimento, numa propositura em que o professor e o aluno não se reduzem à condição de objeto um do outro. Freire ressalta ainda que "[...] ensinar não é transferir conhecimento, mas criar as possibilidades para sua própria produção ou a sua construção" (FREIRE, 1996, p. 25) e que o conhecimento precisa ser vivido e testemunhado pelo agente pedagógico.

Ensinar exige comprometimento, conhecimento e generosidade para que o educador tenha competência, autoridade e liberdade (FREIRE, 1996), sendo necessário que haja aproximação entre os nossos discursos e nossas ações.

Nesse confronto é possível construir conhecimento e, ainda neste contexto, para Freire (1997), o ser consciente de seu inacabamento está em constante movimento de busca. "Como professor devo saber que sem a curiosidade que me move, que me inquieta, que me insere na busca, não aprendo, nem ensino" (FREIRE, 1997, p.44). 
Para Freire, a prática pedagógica deve estar fundamentada no conhecimento, no exercício contínuo da reflexão crítica diante dos fatos. Para o educador, o saber ser e o saber fazer são elementos que permitem pela via do conhecimento, da reflexão constante, tomarmos consciência que não devemos aceitar o determinismo, pois a história é tempo de possibilidades, de problematizações e das possibilidades de mudanças.

Cabe ao educador propiciar a capacidade crítica do educando, sua curiosidade, sua insubmissão. Nesse processo é tarefa do educador trabalhar com os educandos a rigorosidade metódica que possibilitará a estes se "aproximarem" dos objetos cognoscíveis (Freire 1997, p.28). O educador ensina não só o conteúdo pedagógico, mas também a prática crítica, dinâmica, dialética, o pensar sobre o que se faz. Aprender criticamente é possível por parte dos educandos que vão se transformando em reais sujeitos da construção e reconstrução do saber ensinado, ao lado do educador, igualmente sujeito do processo.

\section{Como ensinar?}

Para Freire (1997), não há ensino sem pesquisa. Pesquisa-se para conhecer o que ainda não se sabe e comunicar ou anunciar o novo. É necessário ao educador/a compreender a clareza de sua prática, pois o ato de ensinar exige comprometimento. Tal clareza exige que saibamos que ensinar não é transferir conhecimento, é criar condições para que o educando produza suas reflexões e construa seus conhecimentos. Por esta razão, é necessário o respeito à sua autonomia, utilizando o bom senso e valores éticos como fundamentos da prática educativa. Para Freire (1997), o professor que desrespeita a curiosidade do educando, sua linguagem, inquietude transgride os princípios fundamentais da ética humana.

A busca da autonomia vai se constituindo na experiência de inúmeras decisões, que vão sendo tomadas ao longo do tempo. "A autonomia, enquanto amadurecimento do ser para si, é um processo, é vir a ser" (FREIRE, 1997, 121). Tem de estar centrada em experiências estimuladoras da decisão, da responsabilidade e principalmente da liberdade.

A compreensão de que somos seres históricos, sociais, éticos, capazes de comparar, valorizar, intervir, escolher, decidir, romper, não permite transformar a 
experiência educativa em racionalidade técnica, pois se o fizermos estaremos a negar o que há de fundamentalmente humano no exercício educativo, que é o seu caráter formador e transformador.

Nesse contexto, a formação dos educadores e educadoras deve insistir na construção do saber necessário e dos fatores ideológicos, da importância do contorno ecológico, social e econômico em que vivemos.

Em seu livro $A$ formação reflexiva de professores: ideias e práticas, Zeichner (1993) busca fazer uma investigação centrada na maneira como os professores aprendem a ensinar visando contribuir para a formação docente e sua atuação responsável nas escolas. Surgem por meio da observação e experiência do autor, propostas com o intuito de ajudar a todos os professores em adquirir desde a sua formação atitudes, saberes e capacidades essenciais para junto de uma população educacional variada, desenvolver um trabalho eficiente.

Para que o processo de ensino e aprendizagem na escola aconteça é preciso valorizar seus atores. "A razão de ser dos professores é a existência do aluno e este, na sua qualidade de aluno - não necessariamente de aprendente - não existe sem aquele" (ALARCÃO, 1996, p.08). Mas, ressalta Alarcão, em consonância com o pensamento de Paulo Freire, que atuação docente passa necessariamente pela reflexão, que:

baseia-se na vontade, no pensamento, em atitudes de questionamento e curiosidade, na busca da verdade e da justiça. Sendo um processo simultaneamente lógico e psicológico, combina a racionalidade lógica investigativa com a racionalidade inerente à intuição e à paixão do sujeito pensante: une cognição e afectividade num acto específico, próprio do ser humano. (ALARCÃO, 1996, p. 03)

Antes de se pensar em propor métodos que levem ao ensino é preciso ter claro o que se quer ensinar, sua intencionalidade e objetivo, mas também as condições sociais, econômicas, políticas e ideológicas que determinam o que ensinar, como ensinar, a quem ensinar e onde ensinar.

Estudos sobre o processo de ensino são fundamentais e ainda se fazem necessárias muitas pesquisas acerca dos diferentes métodos pedagógicos. Muitas formas e movimentos educacionais aconteceram ao longo do tempo até que se 
percebesse "a necessidade de investigar como o conhecimento em si se processa" (LACANALLO et. al., 2007, p. 12). Mas é importante destacar que todo ato de investigação está relacionado a práticas sociais e ideológicas que se imiscuem no próprio ato de investigação, uma das questões centrais implicadas no ato de reflexão, como vêm sendo destacados por Nóvoa, Alarcão, Zeichner, Pimenta e vários outros pesquisadores do conceito de professor reflexivo. Nesta perspectiva, nos diz Zeichner que "para além do saber na acção que vamos acumulando ao longo do tempo, quando pensamos no ensino quotidiano, também estamos continuamente a criar saber" (ZEICHNER, 1993, p.21).

Alarcão (1996) contribui para esta reflexão ao levar-nos a pensar que para "ser professor implica saber quem sou, as razões pelas quais faço o que faço e consciencializar-se do lugar que ocupo na sociedade" (ALARCÃO, 1996, p. 05).

Nesta perspectiva, cabe ao professor reflexivo não só conhecer sobre a estrutura do objeto a ser ensinado, ter em mira conteúdos específicos valorizados por uma sociedade abstrata e independente do contexto, é necessário conhecer e tematizar a realidade de nossos educandos, os vieses ideológicos que atravessam nossas práticas e nossas concepções sobre essas mesmas práticas, as astúcias de nossos educandos para adequarem os conhecimentos escolares à sua visão de mundo.

A exemplo disso, podemos refletir sobre os processos de alfabetização. Para Telma Weisz (2001), uma estudiosa dos processos cognitivos utilizados pela criança para aquisição da escrita, o processo de aprendizagem da língua escrita não ocorre como se fosse uma cópia do mundo externo, uma simples adequação da estrutura da mente à estrutura do mundo externo, mas por meio de aproximações ao objeto do conhecimento a partir de sua visão de mundo, das práticas sociais nas quais está imerso:

$$
\begin{aligned}
& \text { Enquanto não encontra respostas satisfatórias para as duas } \\
& \text { perguntas fundamentais: "o que a escrita representa?" e "qual a } \\
& \text { estrutura do modo de representação da escrita?", a criança } \\
& \text { continua pensando e tentando adequar suas hipóteses às } \\
& \text { informações que recebe do mundo (WEISZ, 2001, p. 03). }
\end{aligned}
$$

Façamos um paralelo entre a criança a quem Weisz (2001) busca conhecer enquanto processo de aprendizagem e o homem deste final de século, a quem 
Alarcão (1996) se refere como inquieto e questionador (ALARCÃO, 1996, p. 03). Compreender o processo de construção do conhecimento, a aquisição de novos conceitos, as práticas sociais em que educador e educando se inserem e ter por intencionalidade proporcionar novas aprendizagens é uma prática do professor reflexivo. Magda Soares (2012, p. 06) defende que o aprendiz, sujeito ativo no processo da alfabetização, é quem define seus problemas e, ávido por respostas, descobre as possíveis soluções.

\section{Qual o melhor método?}

A palavra Método vem do latim, < Gr. méthodos, que methodu significa caminho para chegar a um fim; conjunto de procedimentos técnicos e científicos; ordem pedagógica na educação; sistema educativo ou conjunto de processos didáticos. (LACANALLO et al., 2007, p. 2).

Para compreender a influência dos métodos de ensino e de aprendizagem é preciso contextualizar a organização da sociedade em cada situação histórica. Basicamente defendia-se a inserção de novos métodos, criticando o modelo anterior.

Elaborado pela Companhia de Jesus por volta de 1551, o primeiro método de ensino teve por base a repetição, com o objetivo de atender aos interesses da burguesia e manter os jovens fiéis à igreja. As instituições de ensino eram organizadas pelas ordens religiosas, interessadas no processo de evangelização e expansão da cultura europeia (LACANALLO et. al., 2007, p. 03).

Com Comenius (1593 a 1670), considerado o pai da didática moderna, os métodos passam a levar em conta a capacidade das crianças, a vida e a natureza. Ao comparar o professor com o jardineiro e o desenvolvimento com a natureza, Comenius mudou a forma de ver a educação. Partindo da ideia de natureza, criou um método que, segundo ele, seria capaz de ensinar tudo a todos para alcançar a totalidade do saber. Nessa didática, o professor é o centro do ensino, controlador e transmissor absoluto do conhecimento e parte de uma educação de sentidos que tem início no conhecido e na valorização de experiências. Assim como Comenius, a Influência de Rousseau foi enorme na educação, especialmente na educação infantil, em virtude 
de ver a criança como criança, com capacidades e especificidades diferentes do adulto (LACANALLO et. al., 2007, p. 07).

A partir do século XVIII, com a Revolução Industrial, houve a necessidade dos operários aprenderem a ler, escrever e contar despertando os ideais da Escola Nova. Para Dewey, a tarefa do professor seria promover o ato de pensar, respeitando a curiosidade e o tempo dos alunos, colocando-se no lugar do aprendiz (LACANALLO et. al., 2007, p. 09).

Skinner (1904-1990), influente psicólogo do século XX, estabeleceu bases metodológicas num modelo de ensino chamado análise experimental do comportamento. Este modelo persistente até a década de 80 esteve presente na prática docente ao final dos anos 60 e início dos anos 70 atendendo à perspectiva tecnicista. Os alunos eram agrupados segundo o nível de conhecimento. O processo de ensino deveria ser reforçado a cada tarefa, conferindo o acerto ou erro da resposta dada.

\begin{abstract}
Passou-se a ter maior rigor no planejamento tanto em relação à forma como aos objetivos e metas; a produção de livros didáticos foi estimulada; a utilização crescente de recursos audiovisuais; a preponderância na avaliação quantitativa, dentre outros aspectos ganhou destaque nas escolas, tudo para se que (sic) garantisse um controle do processo de ensino e da aprendizagem com total eficácia e eficiência (LACANALLO et. al., 2007, p. 10).
\end{abstract}

As críticas a este método desencadearam novos movimentos educacionais justificando que a forma tecnicista e mecânica atribuída ao trabalho didático necessitava de um olhar para o processo do ensino e da aprendizagem atendendo às necessidades vigentes.

Paulo Freire, crítico ferrenho dos métodos tradicionais e tecnicistas, como o de Skinner, irá propor uma nova abordagem sobre o os processos de ensinar e a aprender com base na realidade do educando e na compreensão do papel político da educação e seu compromisso com a luta dos trabalhadores oprimidos.

Para Freire (1997), é a inconclusão do ser humano o fundamento da educação como processo permanente. "Mulheres e homens se tornaram educáveis na medida em que se reconheceram inacabados. Não foi a educação que fez mulheres e homens educáveis, mas a consciência de sua inconclusão é que gerou sua educabilidade" (FREIRE, 1997, p. 64). 
Numa postura progressista, como assevera Paulo Freire, é necessário que educadores possam contribuir significativamente para que o educando torne-se sujeito de sua própria formação, o que significa, no caso de crianças, que devemos estar atentos à difícil passagem da heteronomia para a autonomia, e no caso de adultos, que devemos estar atento ao que o nosso "trabalho possa significar como estímulo ou não à ruptura necessária com algo defeituosamente assentado e à espera de superação" (FREIRE, 1997, 78).

Ou seja, na perspectiva do educador progressista, nosso compromisso é com um sujeito em construção, autor de sua própria história, questionador e crítico. Isto implica que, numa prática educativa libertadora, não há métodos prontos, conteúdos aprioristicamente definidos, sujeitos formais e abstratos apreensíveis por certas leis cognitivas ou comportamentais, mas uma intensa relação dialética entre educador e aprendente mediatizados por situações-limites, práticas sociais tensas e conflitantes à espera de um inédito-viável.

Creio poder afirmar, na altura destas considerações, que toda prática educativa demanda a existência de sujeitos, um que, ensinando, aprende, outro que, aprendendo, ensina, daí o seu cunho gnosiológico; a existência de objetos, conteúdos a serem ensinados e aprendidos; envolve o uso de métodos, de técnicas, de materiais; implica, em função de seu caráter diretivo, objetivo, sonhos, utopias, ideais. Daí sua policiticidade, qualidade que tem a prática educativa de ser política, de não poder ser neutra. (FREIRE, 1997, p. 77-78, grifos do autor)

\section{Considerações finais}

A pedagogia de Freire apresenta elementos constitutivos da compreensão da prática docente enquanto dimensão social da formação humana. É uma pedagogia que não se reduz a aspectos estritamente pedagógicos e atravessados pelo caráter político de sua ação. É uma pedagogia alicerçada nos Direitos Humanos e na construção de uma escola democrática fundamentada nas relações horizontais, lugar em que ocorrem as relações professor/aluno e as trocas de saberes e experiências que propiciam as aprendizagens. Essa pedagogia exige uma educação que seja praticada na perspectiva crítica, autônoma, com o compromisso para a formação de sujeitos capazes de transformar suas realidades políticas e sociais. Para Freire (1997), é preciso haver coerência entre "o saber-fazer e o saber ser-pedagógicos". 
Isso implica nos colocarmos contrários a todas as práticas de desumanização, traduzidas na educação bancária, na falta de compromisso com as nãoaprendizagens, no fracasso escolar, no conformismo com os desmandos do jogo político a serviço do neoliberalismo que impõem um modelo educacional pautado na racionalidade técnica, e ainda, em tempos atuais, no processo de patologização da educação, entre outros problemas que afetam a comunidade, o aluno, o professor, a escola, criando entraves para a transformação das realidades locais e, no sentido mais amplo, das sociais.

O saber-fazer da autorreflexão crítica e os saberes exercitados permanentemente na direção de princípios adotados coletivamente nos mais diversos espaços educativos defendidos por Freire tem como finalidade a emancipação do sujeito como ser histórico e para tanto o processo educacional deve se desdobrar de maneiras específicas, conforme o espaço social em que atua, instrumentalizando os educandos para atuarem a partir das relações estabelecidas nos acordos sociais, ora concordando com as mesmas, ora propondo reformulações ao longo do seu amadurecimento ou, ainda, por meios legitimamente constituídos, encaminhando formas de superação de seu desenvolvimento.

A pedagogia freiriana é dialógica, problematizadora da realidade concreta dos educandos e tem como finalidade o desenvolvimento da dimensão humana, ética dos seres humanos, bem como da instrumentalização dos sujeitos para tornarem-se profissionais comprometidos com a mudança social. Nesse sentido, ao pensarmos, enquanto docentes, na seleção de metodologias de ensino, essa seleção exige de nós um posicionamento frente à política educacional que assumimos.

Temos que necessariamente nos posicionar e responder que tipo de sociedade queremos, que modelo de ensino propomos e para quem propomos. Se nosso compromisso for na direção contrária a da educação como reprodução das desigualdades sociais, do formalismo distanciado da crítica da própria sociedade, da conscientização sobre a ideologia em sentido restrito, da crítica da inculcação de determinismos - que, embora não naturais e não legítimos, são assumidos como verdadeiros, norteando a vida escolar e controlando o seu desdobramento por meio dos jogos das políticas públicas educacionais, que controlam, silenciam, desvalorizam a reflexão - , nossas escolhas certamente irão na direção da reflexão sobre a realidade e de reunião de todos os esforços na direção concreta da garantia 
da educação como direito de todos em sentido pleno, da democracia na sociedade como condição para a existência de uma escola democrática e da justiça social como manifestação efetiva no combate a qualquer tipo de perversidade que desqualifica e coisifica o homem como objeto manipulável do capital.

Nesta direção, Paulo Freire enfatiza que a "[...] existência humana, não pode ser muda, silenciosa, [...]. Existir, humanamente, é pronunciar o mundo, é modificá-lo. [...]. Não é no silêncio que os homens se fazem, mas na palavra, no trabalho, na açãoreflexão" (FREIRE, 1983, p. 92). Então, nossas escolhas metodológicas nos definem enquanto docentes comprometidos com a educação como prática da liberdade, que tem compromisso com a conscientização e emancipação dos sujeitos e de suas consciências.

\section{Referências bibliográficas}

ALARCÃO, Isabel. Ser professor reflexivo. In: Formação reflexiva de professores: estratégias de supervisão. Editora Porto. Porto, Portugal, 1996.

ARAÚJO. Laura Ribeiro. O legado acadêmico. In: Letra A, O jornal do alfabetizador. Ano 8. Edição Especial. Belo Horizonte, Nov/Dez 2012. Disponível em:

<http://www.ceale.fae.ufmg.br/app/webroot/files/uploads/JLA/2012 JLAesp.pdf> Acesso em: 03 Maio 2021.

DEWEY, John. Como pensamos: como se relaciona o pensamento reflexivo com o processo educativo, uma reexposição. São Paulo: Editora Nacional,1979.

FREIRE, Paulo. Pedagogia da autonomia: saberes necessários à prática educativa. São Paulo: Paz e Terra, 1997 (Coleção Leitura).

Pedagogia do Oprimido. 12 ed. Rio de Janeiro: Paz e Terra, 1983.

LACANALLO, Luciana Figueiredo; SILVA, Sandra Salete de Camargo; OLIVEIRA, Diene Eire de Mello Bortotti de; GASPARIN, João Luiz; TERUYA,Teresa Kazuko. Métodos de ensino e de aprendizagem: uma análise histórica e educacional do trabalho didático. VII Jornada do Histedbr: O trabalho didático na história da educação. Atas do Evento, Campo Grande, 2007, p. 580-587. Disponível em: $<$ https://scholar.google.com/citations?view op=view citation\&hl=ptBR\&user $=2$ QB1 C7gAAAAJ\&citation for view $=2$ QB1C7gAAAAJ:8k81 kl-MbHgC $>$ Acesso em: 03 maio 2021.

SAVIANI, Dermeval. Educação socialista, pedagogia histórico-crítica e os desafios da sociedade de classes. In: LOMBARDI, José Claudinei; SAVIANI, Dermeval (Orgs.) 
Marxismo e Educação: debates contemporâneos. Campinas: Autores Associados, 2005.

WEISZ, Telma. Como se aprende a ler e escrever ou, prontidão, um problema mal colocado. Programa de Formação de Professores Alfabetizadores. MEC. 2001. Disponível em: <http://www.colegiojohnkennedy.com.br/downloads/2015/AnaLucia25-04/TEXTO\%20TELMA\%20WEISZ.pdf> Acesso em 03 maio 2021.

ZEICHNER, K. A Formação reflexiva de Professores: ideias e práticas. Lisboa: Educa, 1993. 


\title{
O SMARTPHONE COMO FACILITADOR E MOTIVADOR NO PROCESSO DE ENSINO APRENDIZAGEM DA LÍNGUA INGLESA NAS ESCOLAS PÚBLICA DE ENSINO FUNDAMENTAL
}

\author{
Vanessa dos Santos Neiva \\ Thiago Simão Gomes \\ Gerson Tenório dos Santos
}

\begin{abstract}
RESUMO
Já faz alguns anos que os smartphones têm sido uma presença constante em sala de aula. Hoje, praticamente todos os alunos têm um aparelho em mãos e, que acaba levando para todo lugar, principalmente para a escola. Este aparelho, muitas vezes dispersa os alunos do foco das aulas. Há algum tempo as escolas vêm tentado banir arduamente o uso do celular pelos estudantes durante as aulas, porém será que esse é mesmo o caminho correto? $\mathrm{Na}$ maioria das vezes, quando proibimos o adolescente de algo, com isso ele torna-se resistente fazendo o que Ihe foi proibido. Pensando assim, a escola poderia utilizar o smartphone como um aliado no processo de ensino-aprendizagem? Será que ela não deveria acompanhar os avanços da tecnologia para não ficar com uma metodologia ultrapassada, monótona e entediante? O aluno precisa estar motivado para aprender. Nessa perspectiva, este estudo tem como objetivo discutir e apontar como os smartphones podem proporcionar uma aprendizagem mais atrativa, e contextualizada no ensino da língua inglesa, e para tanto fazer uso do aplicativo Duolingo como um recurso tecnológico em sala de aula. Busca-se em Moran (2015) e Mattar (2017) e outros pesquisadores da tecnologia como ferramenta de aprendizagem o suporte para as reflexões do estudo.
\end{abstract}

Palavras-chave: Ensino de língua inglesa; Smartphone; Facilitador; Motivador.

\section{INTRODUÇÃO}

É de conhecimento geral sabermos que nos últimos anos não podemos mais imaginar nossas vidas sem a intervenção dos recursos tecnológicos, principalmente por aqueles que são nativos digitais (PRENSKY, 2002).

Os dispositivos móveis, como o telefone celular, hoje mais conhecido como smartphone, estão por todo lugar e fazem parte de nossas vidas, parece até que é uma parte de nosso corpo. Com ele, podemos fazer tudo que se pode imaginar como, conversar, pesquisar, pagar contas, trabalhar, estudar entre outras coisas. Nesse contexto, o uso desses aparelhos atravessa a rotina escolar e, por muitas vezes, os educadores não sabem como lidar com essa situação se colocando contra o uso deste dispositivo, e assim acarretando conflitos desnecessários neste ambiente. No entanto, os alunos utilizam essa tecnologia em aula, na maioria das vezes, para 
ouvirem música, utilizar as redes sociais, tirar fotos e produzirem vídeos, sem autorização do professor, e com isso acabam impossibilitando o andamento das aulas, e, consequentemente, seu aprendizado e de seus colegas de classe.

Nessa perspectiva, em diferentes disciplinas, o estudante acaba por preferir utilizar o smartphone a prestar atenção ou participar das aulas, pelo fato dessas aulas não se utilizar de recursos tecnológicos que hoje, é o que faz sentido na vida desses estudantes. Ou seja, esse aparelho tornou-se para os jovens mais interessante do que uma aula totalmente expositiva onde ele fica somente ouvindo o professor explicar o conteúdo. Em face do cenário atual, proibir o uso do smartphone em sala de aula talvez não seja a melhor saída, mas sim fazer deste aparelho um aliado no processo de ensino e aprendizagem nas aulas de língua inglesa.

Neste contexto, compreende-se que é com um aprendizado que faça sentido para o educando que ele terá mais oportunidades de transformar a sociedade e fazer uso deste conhecimento em sua vida profissional e cultural no futuro. Nessa perspectiva, após observar as dificuldades dos estudantes em relação à aprendizagem da língua inglesa nas escolas públicas em que lecionei e (olhar informal), sabendo que essa geração atual tem facilidade em utilizar os recursos tecnológicos (uso dos smartphone e aplicativos) a proposta para este estudo encontra na tecnologia sua aliada.

Nesse sentido, Costa (2014) defende que a tecnologia sozinha não potencializa a aprendizagem se não for aliada à prática pedagógica do professor e, portanto, o uso do smartphone como facilitador no processo de ensino-aprendizagem da língua inglesa é uma proposta interessante do ponto de vista da aprendizagem significativa (AUSUBEL, 2002), já que a utilização de recursos tecnológicos deixam as aulas mais atrativas e interessante para os estudantes que podem, articular os conhecimentos prévios com os novos conhecimentos por meio de pesquisas na internet, por exemplo.

Dessa maneira, tal proposta coaduna com os argumentos de Freire (1996) quando o autor propõe a aprendizagem baseada na autonomia e nos conhecimentos prévios dos estudantes, visto que cada indivíduo traz consigo conhecimentos que devem ser valorizados. 
É justamente a partir desse contexto que, o ensino de língua inglesa nas escolas públicas, vem perdendo espaço a cada ano que passa, uma vez que, a carga horária não é favorável, e isso acaba impossibilitando e não permitindo dar atenção igual, e, que envolva as quatro habilidades linguísticas - ouvir, falar, ler e escrever em língua Inglesa. É por essa razão que os PCNs (Brasil, 1999) recomenda que a ênfase seja dada ao desenvolvimento da habilidade de leitura. Então, é por isso que, o smartphone poderá completar as lacunas que ficam no ensino desta língua, pois ele pode proporcionar para o aluno as habilidades, cujo, não é dado tanta ênfase na escola devido a diversos fatores e, principalmente, ao tempo limitado.

Visto que, com esta tecnologia o aluno consegue desenvolver todas essas habilidades, uma vez que, com este recurso ele poderá aprender onde e quando quiser, não se limitando somente às poucas aulas semanais na escola pública. Para a aprendizagem da língua inglesa, é fundamental que seja trabalhada e desenvolvida as quatro habilidades citadas anteriormente. $E$ atentando para o fato de que "mesmo a classe média que normalmente frequenta cursos particulares de inglês durante 5/7 anos geralmente perde a fluência alcançada no curso depois que termina seus estudos" (Moita Lopes, 1996, 131).

Nesse sentido, o smartphone possui excelentes recursos que ajudará o professor a trabalhar essas habilidades, e ao mesmo tempo permitir a interação e troca de experiências possibilitando a motivação para o ensino e aprendizagem em língua inglesa dentro ou fora da sala de aula.

Assim, busca-se em Ausubel (2002), Costa (2014), Moran (2015), Mattar (2017), BNCC (2017), Freire (2007), entre outros autores a fundamentação teórica para este estudo e sua justificativa se dá à medida que a escola precisa adequar-se as mudanças que ocorrem na sociedade. Logo, aprender uma língua estrangeira a partir dessa ferramenta, será mais motivador para o estudante, uma vez que este recurso permite contextualizar a aprendizagem pelos estudantes sendo mediada pelo educador.

\section{REVISÃO BIBLIOGRAFICA}

A Base Nacional Comum Curricular (BNCC) defende o uso de tecnologias para se comunicar, acessar e disseminar informações produzir conhecimentos, resolver 
problemas e exercer protagonismo e autonomia na vida pessoal e coletiva. Nesta perspectiva, é relevante "[..] Compreender, utilizar e criar tecnologias digitais de informação e comunicação de forma crítica, significativa, reflexiva e ética nas diversas práticas sociais (incluindo as escolares)" (BASE NACIONAL COMUM CURRICULAR, 2018, p. 9). Nesse sentido, o uso do smartphone em sala de aula poderá contribuir para resgatar o interesse dos estudantes para o aprendizado da língua inglesa, por exemplo.

Camargo e Daros (2018) afirma que os alunos reclamam do fato de terem de ficar horas ouvindo aulas expositivas, da rigidez dos horários, do distanciamento do conteúdo proposto com a vida pessoal e profissional, e dos recursos pedagógicos pouco atraentes. Contudo, de acordo com os estudos de Carbonell (2002, p.19), a inovação educacional trata-se de

[...] um conjunto de intervenções, decisões e processos, com certo grau de intencionalidade e sistematização, que tratam de modificar atitudes, ideias, culturas, conteúdos, modelos e práticas pedagógicas. $\mathrm{E}$, por sua vez, introduzir, em uma linha renovadora, novos projetos e programas, materiais curriculares, estratégias de ensinoaprendizagem, modelos didáticos e outra forma de organizar e gerir o currículo, a escola e a dinâmica da classe.

Nessa perspectiva, de acordo com Camargo e Daros (2018) inovar acarreta uma nova prática educacional com finalidade bem estabelecida, mas é necessário que essas mudanças partam de questionamento das finalidades da própria experiência educacional como aspecto promotor da reflexão-ação docente, ou seja, a inovação como um processo, e não como um fim em si mesma.

Conforme essa afirmação, pode-se compreender que o processo de inovar não é um fim em si mesmo, mas um meio para alcançar e dar efetividade a determinado objetivo. Ainda no sentido de Carmo e Daros, para que se garanta o processo de inovação com uso de recursos tecnológicos deve-se

[..] contar com novos recursos tecnológicos, nova estrutura que possibilite a interação, um novo modelo de formação docente e, principalmente, a incorporação de novos saberes, sem desconsiderar o conhecimento científico clássico. É preciso considerar que a inovação não ocorre apenas no plano pedagógico, mas também no epistemológico. (CARMO \& DAROS, 2018, p.7)

Observa-se que os autores colocam como principal espaço para a realização do processo de ensino e aprendizagem para certas realidades da escola pública, a 
sala de aula, mas que estas devem contar com os recursos tecnológicos. Nesse sentido, Lima (2009) coloca que as horas na sala de aula precisam ser usadas de forma a despertar no aprendiz o desejo de ultrapassar os limites de tempo e espaço da sala de aula, em busca de novas experiências com a língua. Segundo Moran:

Todos nós que estamos envolvidos em educação, precisamos conversar, planejar e executar ações pedagógicas inovadoras, com a devida cautela, aos poucos, mas firmes e sinalizando mudanças. Sempre haverá professores que não querem mudar, mas uma grande parte deles está esperando novos caminhos, o que vale a pena fazer. Se não os experimentamos, como vamos aprender. (MORAN, 2004, p.355)

Diante do exposto, defende-se que o uso do smartphone nas aulas de língua inglesa poderá despertar no aluno o interesse por essa língua estrangeira, fazendo com que ele não limite sua aprendizagem somente no ambiente escolar, mas fora dele também, que, é onde ele pode fazer uso do conhecimento, ou seja, o uso desse aparelho nas aulas, com mediação do professor, fará com que o aluno, fora deste ambiente, também busque o conhecimento desta língua estrangeira.

Em referência ao uso dos jogos digitais como recurso pedagógico, Mattar (2009) faz a seguinte colocação: “[...]. Devemos levar em consideração novos estilos de aprendizagem. [...] E o DGBL não serve apenas para atividades de revisão, mas para o aprendizado efetivo de diversos temas. Nesse contexto, a aprendizagem significativa (AUSUBEL,2002) ocorre a partir do interesse que os jogos digitais e uso de aplicativos voltados a aprendizagem da língua inglesa despertariam nos estudantes.

Como o uso do smartphone é algo corriqueiro na vida dos discentes, é possível explorar esta ferramenta nas aulas de língua inglesa. Conforme relata Kenski:

[...] é preciso que conhecimentos, valores, hábitos, atitudes e comportamentos do grupo sejam ensinados e aprendidos, ou seja, que se utilize a educação para ensinar sobre as tecnologias que estão na base da identidade e da ação do grupo e que se faça uso delas para ensinar as bases da educação. (KENSKI, 2007, p. 43).

Fazer uso do smartphone em sala de aula é, assim, mediar um conhecimento que o estudante já possui para que ele possa construir saberes. Moran (2017, p.23) ao falar sobre metodologias ativas diz que ela: "[..] há inúmeros caminhos de aprendizagem pessoais e grupais, que concorrem e interagem simultânea e 
profundamente com os formais e, que questionam a rigidez dos planejamentos pedagógicos educacionais.

Portanto, é fundamental que as aulas sejam mais dinâmicas e contextualizadas, sendo o smartphone uma ferramenta possível para construir a aprendizagem da língua inglesa por meio dos recursos digitais como o youtube, que é uma ferramenta muito utilizada para exibição de vídeos. No entanto, é necessário filtrar aquilo que realmente será útil e agregador para a formação e desenvolvimento do aluno. Alguns jogos online como Sim City e aplicativos como o Duolingo e kahoot também são ótimos recursos tecnológicos para o aprendizado desta língua estrangeira.

Para esse estudo o aplicativo escolhido foi o Duolingo, pelo fato de ser uma ferramenta digital de fácil acesso e bem conhecida pela maioria dos estudantes.

\section{METODOLOGIA}

Este estudo é descritivo TRIVIÑOS (1987) e utiliza pesquisa bibliográfica. $\mathrm{Na}$ primeira etapa apresenta a fundamentação da tecnologia para construir um diálogo sobre a importância de utilizar a tecnologia por meio do smartphone em sala de aula para a aprendizagem da língua inglesa.

Assim, é um estudo que pertence ao campo das metodologias ativas como parte das práticas educativas em sala de aula. Na segunda etapa, disserta sobre o aplicativo DUOLINGO (figura 1) que pode ser baixado no smartphone e mediado pelo professor em sala de aula, e, principalmente, fora do ambiente escolar, que é onde o aluno tem muito mais tempo para essa interação.

Nesse sentido, falar no smartphone como facilitador no processo de ensino aprendizagem da língua inglesa é ir além das exposições gramaticais em sala de aula, de modo que o estudante se interesse e alcance uma aprendizagem significativa e o professor seja um mediador e não o detentor de conhecimentos prontos (FREIRE,1996).

Em face disso, o Duolingo é um aplicativo de download que pode ser utilizado em dispositivos conectados à internet, como, o smartphone. Segundo o site (Techtudo, 2016) ele é uma plataforma colaborativa que: 
"[...] permite o aprendizado de línguas estrangeiras. Com um simples cadastro, o serviço libera ferramentas didáticas e exercícios para aprender idiomas como inglês, francês, alemão e espanhol, tudo gratuitamente. Além da versão online, está disponível em formato de app para os celulares com Android, iOS (iPhone) e Windows Phone. Também possui extensão para o Chrome.

Nessa perspectiva, o seu uso se dá de forma interativa com o usuário, inclusive fazendo as correções da fluência do idioma em tempo real, algo que, muitas vezes, as aulas expositivas não possibilitam. Sua utilização também permite escolher o nível que gostaria de fazer - Básico, Intermediário ou Avançado. Ou seja, é possível que o estudante o utilize a partir dos conhecimentos prévios que ele já tem sobre a língua, pois não é uma atividade focada no conteúdo por séries, mas sim em níveis que o sujeito que irá "jogar" entende como sendo o correto para ele.

O Duolingo é formado por diversos módulos, quando se conclui um, outros mais complexos surgem e vão sendo apresentados ao usuário para que ele interaja virtualmente. Ao mesmo tempo a própria imagem deste recurso tecnológico já é um facilitador da aprendizagem à medida que possui cores que chamam atenção e um designer interessante para os jovens, como se observa abaixo:

Figura 1 - Aplicativo Duolingo

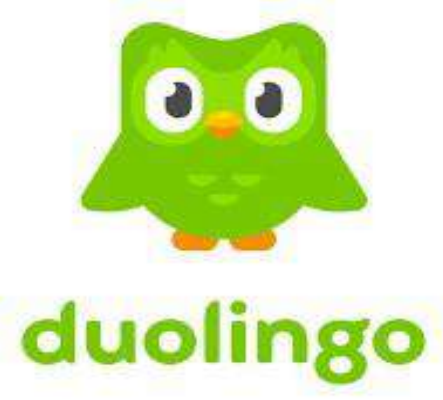

Fonte: play.google.br

O funcionamento deste site pode se dar por meio do aplicativo instalado em um smartphone, que tenha disponível os sistemas Android ou IOS. São oferecidos diversos temas para aprender língua inglesa, como por exemplo: animais, comidas, cores, roupas etc., como demonstrado na interface da figura abaixo: 


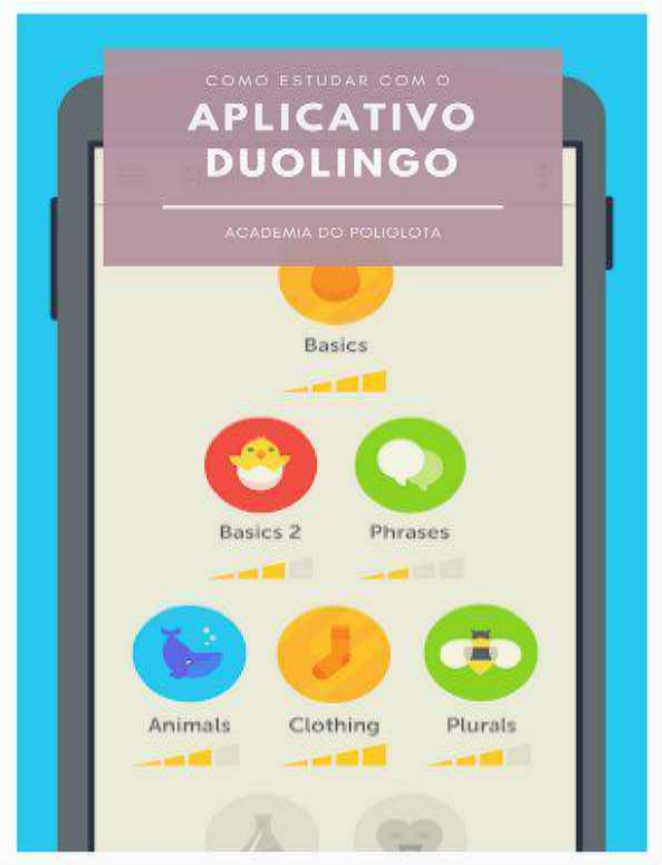

Fonte: play.google.br

A figura 2 traz a versão básica para iniciantes, ao tocar na imagem abre-se uma nova janela, com atividades relacionadas a oralidade e contextualização do seu uso na sociedade. Assim, ao utilizar o smartphone como facilitador da aprendizagem da língua inglesa por meio deste aplicativo, por pesquisas feitas na internet, e, até mesmo pelo Google tradutor, o estudante torna-se autônomo, não ficando à mercê do momento em que o professor possa-Ihe tirar suas dúvidas, sendo que, ele mesmo poderá sanar por meio deste recurso tão imprescindível na vida das pessoas atualmente, o smartphone.

Cabe ao professor mediar a utilização do aplicativo e suas possibilidades de aprender com ele e, nesse caso, como bem relata Moran (2017, s/p), ao falar de metodologias ativas: "[...] O que faz a diferença não são os aplicativos, mas estarem nas mãos de educadores, gestores (e estudantes) com uma mente aberta e criativa, capaz de encantar, de fazer sonhar, de inspirar.

Moran demonstra que os aplicativos são excelentes recursos, mas as mediações dos professores oportunizam o uso voltado a aprendizagem quando se 
estabelece em uma sala de aula a utilização de aplicativos, como é o caso do Duolingo.

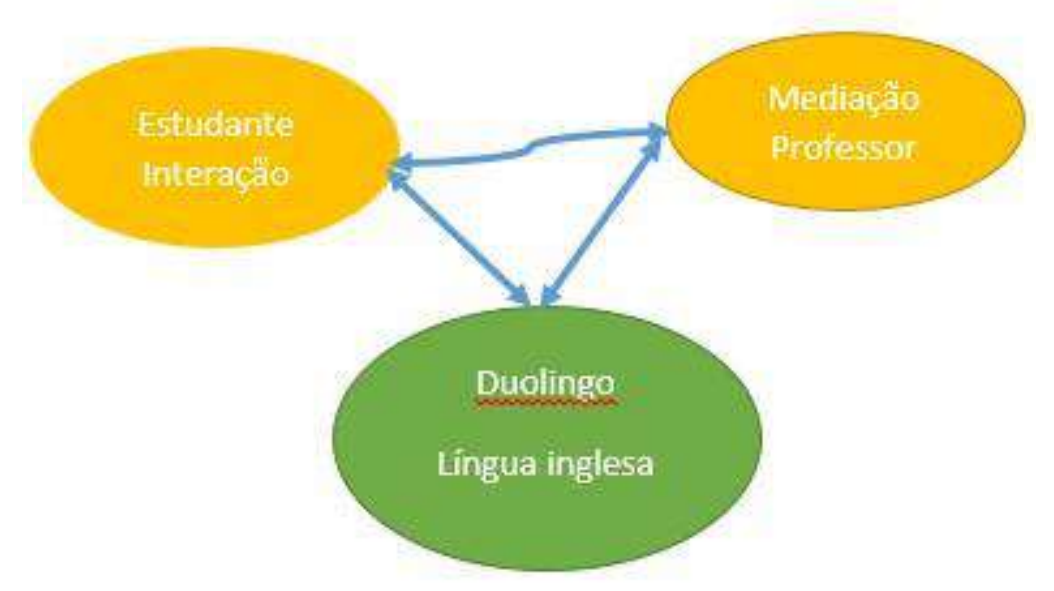

Essa tríade interativa faz do professor o mediador no processo de aprendizagem por meio do smartphone e confere ao estudante a participação autônoma. Educar os estudantes para fazer uso do smartphone como ferramenta de aprendizagem e este aplicativo para aprender uma outra língua, é assim ajudá-los a compreender que este recurso vai além do lazer. Nesse sentido, a BNCC defende que

o estímulo ao pensamento criativo, lógico e crítico, por meio da construção e do fortalecimento da capacidade de fazer perguntas e de avaliar respostas, de argumentar, de interagir com diversas produções culturais, de fazer uso de tecnologias de informação e comunicação, possibilita aos alunos ampliar sua compreensão de si mesmos, do mundo natural e social, das relações dos seres humanos entre si e com a natureza. (BASE NACIONAL COMUM CURRICULAR, 2018, p. 58).

Logo, o Duolingo é um aliado do processo de ensino-aprendizagem e, portanto, o smartphone permite que ambos se organizem para que aprender e ensinar seja algo, além de explicações orais e, muitas vezes, descontextualizadas com a realidade. Nesse sentido, esse aplicativo consegue desenvolver as quatro habilidades necessárias para se aprender qualquer língua estrangeira. No entanto, "Se a educação sozinha não transforma a sociedade, sem ela tampouco a sociedade muda." (FREIRE, 1996) 


\section{CONSIDERAÇÕES FINAIS}

É sabido que as tecnologias digitais móveis não vão salvar o ensino de língua inglesa nas escolas públicas, mas podem ser um suporte extremamente favorável às práticas docentes. Visto que, a BNCC foi criada para a introdução de novas políticas educacionais, e, partindo do ponto de que seu foco está voltado para o desenvolvimento das competências e habilidades, e nas escolas públicas, o foco no ensino da língua inglesa é somente em leitura, ficando então de lado as outras três habilidades que são as de ouvir, falar e escrever, sendo assim torna-se cada vez mais distante uma aprendizagem contextualizada desta língua, já que é praticamente impossível se aprender qualquer língua se não for trabalhado um pouco de cada uma dessas habilidades.

Nesse sentido, a BNCC criou seis competências específicas de língua inglesa para o ensino fundamental. Ela também transformou as habilidades linguísticas desta língua em eixos, que são eles: eixo oralidade, eixo escrita, eixo conhecimentos linguísticos e o eixo dimensão intercultural. Nesses eixos são propostas diversas habilidades as quais devem ser desenvolvidas pelos alunos.

Sendo assim, o objetivo é avaliar as possibilidades que os smartphones e, também, podem oferecer para facilitar a vida dos aprendizes (nativos digitais) e dos ensinantes (imigrantes digitais) em um mundo cada vez mais digital. $O$ duolingo não é o único, mas sim um entre as inúmeras possibilidades que os docentes têm para mediar o ensino-aprendizagem, e ao mesmo tempo despertar o interesse desta língua pelos alunos, uma vez que esse dispositivo móvel é muito atrativo, principalmente, para os adolescentes.

Nessa perspectiva, nós professores, precisamos mostrar o caminho para esses jovens, porque mesmo eles sendo nativos digitais, isso não significa que eles saibam fazer bom uso dessa tecnologia. Uma vez que para eles os smartphones servem para ouvir músicas, utilizar as redes sociais, tirar fotos, pedir comida e fazer compras. Então cabe a nós, docentes, orientar esses alunos para que este recurso possa ser utilizado para a construção de seu conhecimento e de sua autonomia, e assim, apontar-Ihes os caminhos para que eles possam alcançar a aprendizagem da língua inglesa de forma mais atrativa e contextualizada. 


\section{Referências}

AUSUBEL, D.P. A aprendizagem significativa: a teoria de David Ausubel. São Paulo: Moraes, 1982.

AUSUBEL, D. P. Aquisição e retenção de conhecimentos: Uma perspectiva cognitiva. Lisboa: Editora Plátano, 2003.

BASE NACIONAL COMUM CURRICULAR. Educação de base. Disponível em: <http://basenacionalcomum.mec.gov.br/images/BNCC EI EF 110518 versaofinal site.pdf $>$. Acesso em: 15 Jun.2020

BRASIL. Parâmetros Curriculares Nacionais (PCN. Língua Estrangeira). Brasília: MEC/SEF, 1998.

FAUSTO CAMARGO, THUINIE DAROS. A sala de aula inovadora: estratégias pedagógicas para fomentar o aprendizado ativo. Porto Alegre: Penso, 2018.

CARBONELL,J. A aventura de inovar: a mudança na escola. São Paulo: Artes Médicas, 2002

COSTA, IVANILSON. Novas tecnologias e aprendizagem. Rio de janeiro: Editora Wak, 2014

De MATTAR. Digital Game-Based Learning. Disponível em:

$<$ http://joaomattar.com/blog/2009/01/24/digital-game-based-learning/ > Acesso em: 23. Jun2020

DE LIMA, D,C. (org) Ensino aprendizagem de língua inglesa: conversas com especialistas. (Estrátegias de Ensino). São Paulo: Parábora Editorial, 2009.

DUOLINGO. Diaponível em: <https://www.techtudo.com.br/tudosobre/duolingo.html> Acesso em: 21. Jun2020

FREIRE, P. Pedagogia da autonomia: saberes necessários à prática educativa. São Paulo: Editora Paz e Terra, 1996.

KENSKI, V. M. Educação e tecnologias: o novo ritmo da informação. 1. Ed. Campinas: Papiros, 2007.

MOITA LOPES, L, P. da . A função da aprendizagem de línguas estrangeiras na escola pública, in Oficina de linguística aplicada - a natureza social e educacionaldos processos de ensini/aprendizagem de línguas. Campinas: Mercado de Letras, 1996.

MORAN, J. M. A contribuição das tecnologias para uma educação inovadora. Revista Contrapontos - volume 4 - n. 2 - p. 347-356 - Itajaí, maio/ago. 2004.

MORAN, J. M. Mudando a educação com metodologias ativas. In Convergências Midiáticas, Educação e Cidadania: aproximações jovens. Coleção Mídias Contemporâneas. 2015 Disponível em:

$<$ http://www2.eca.usp.br/moran/wpcontent/uploads/2013/12/mudando moran.pdf>

MORAN, J. M. Atualização do texto Tecnologias no Ensino e Aprendizagem Inovadoras do meu livro A Educação que Desejamos: novos desafios e como 
chegar lá. Papirus, 5a ed, cap. 4. Disponível em: www2.eca.usp.br > 2017/11 > tecnologias_moran

PRENSKY, Marc. Digital game-based learning: practical ideas for the application of digital game-based learning. St. Paul, MN: Paragon House, 2007. Resenha de João Mattar.

TRIVIÑOS, Augusto. Introdução à pesquisa em ciências sociais: a pesquisa qualitativa em educação. São Paulo: Atlas, 1987 


\title{
PAULO FREIRE: EXÍLIO, (R)EXISTÊNCIA E ESPERANÇA
}

\author{
Juliana Janaína Tavares Nóbrega \\ Mariza Galvão \\ Vanice Ribeiro
}

\section{RESUMO}

Tendo como principal ação transformadora seu método de alfabetização que promoveu trabalhadores a eleitores; consciência ingênua e mágica à consciência crítica, Paulo Freire, produziu inúmeras obras para além de uma fundamentação teórica, mas com propostas práticas de uma pedagogia libertadora, da pergunta e da esperança. Com a valorização do diálogo e de uma visão politizada do mundo, sua vida e experiência de exílio são reflexos diretos da realidade vivida não só no Brasil, mas em outros países. Como os presentes diálogos com Antonio Faundez no exílio político que sofreram em Genebra presentes na obra "Pedagogia da pergunta". Desta forma, podemos pensar: de que forma a vida e obra de Freire nos aponta para uma Filosofia da linguagem? Que diálogos possíveis podemos trazer desta interpretação filosófica? Qual o papel da linguagem no processo de exílio e resistência perante tempos de silenciamento? Trata-se de uma pesquisa bibliográfica que busca refletir tais relações da linguagem neste contexto freireano de vida e obra, tendo como fundamentações teóricas Freire (1967,1985); Prado Jr. (2004) e Wittgenstein (2009). A figura do exilado, seja Faundez com seu ensino da Filosofia ou Freire com a questão da alfabetização, são cruciais para uma reflexão profunda da linguagem que está refletida em suas obras e sua preocupação com o conhecer e com o saber, mas também com o transformar.

Palavras-chave: Linguagem; Exílio; Resistência.

\section{Introdução}

Em comemoração aos cem anos do nascimento de Paulo Freire, aos trinta e seis anos do livro Por uma pedagogia da pergunta (1985) e seu diálogo profundo com a realidade e sua transformação, propomos um olhar filosófico da linguagem em sua experiência de vida, exílio e ação pedagógica.

Freire transitou sobre o terreno da educação pautado num modo novo de uso da linguagem, que culmina num método de prática educacional do qual é referência internacional, mesmo que diante de duras críticas na atualidade, justamente pelo cunho político de sua proposta. Talvez mais que dizer que a prática educacional de Freire tem um método, é importante ressaltar que Freire não propôs um método, mas um modo de pensar a vida e, por meio de pensar a vida, se apropriar de um pensar que leva a um saber conhecer. Essa ação de pensar a vida que leva a um saber conhecer passa, inevitavelmente, por uma nova experiência da linguagem e é por essa direção que nossa reflexão se orienta. 
Tomando a linguagem como referência, a obra freiriana permite articular questões próprias da filosofia da linguagem, tais como aquelas referentes ao relativismo linguístico. Com essa reflexão podemos expor a extensão e a amplitude da produção de Freire, que se mostra capaz de alcançar problemas genuinamente filosóficos, o que favorece seu estudo numa dimensão maior e mais abrangente. Para propor a reflexão, tomaremos como referência o exílio de Freire, que constitui sua formação enquanto intelectual e professor. $\mathrm{Na}$ figura do exilado, podemos compreender a ambiguidade que intensifica o caráter existencial e não relativista de seu pensamento.

A vasta obra de Freire remete o leitor a pensar o cotidiano dando direção a uma pedagogia crítica, uma pedagogia especialmente social que derivou na obra $\mathbf{A}$ Pedagogia do Oprimido (1974). As 40 horas de Angicos, em 1963, foram as 40 horas mais expressivas para se pensar a aprendizagem, no âmbito da esperança de que todos podem almejar, mas para almejar, precisa experienciar. Angicos foi uma grande experiência de alfabetização de adultos no Sertão do Rio Grande do Norte que, em 40 horas, trezentos adultos foram alfabetizados. Estes alunos eram trabalhadores rurais e urbanos. Palavras faladas passaram a ser palavras apreendidas: "DEUS, PROMESSA, ESMOLA, CHUVA, BRANCO, PRETO, TRISTE, ALVOROÇO, MEDO, CORAGEM, CONFORMAÇÃO E INVERNO"15.

Palavras que a princípio expressam o cotidiano religioso, da natureza, dos sentimentos, passaram ser expressões de preocupação para aqueles que queriam a permanência do analfabetismo, já que o analfabetismo ou a cegueira da ignorância mantém um sistema que explora sem manifestações de esclarecimentos. Alfabetizar em Angicos se tornou um ato perigoso, pois Freire possibilitava que as pessoas passassem a atuar politicamente, o que não quer dizer que passassem a ter partido político. Atuar politicamente é entender sua própria condição no mundo e, para isso, faz-se necessário aprender a ler o mundo pelas coisas do mundo.

Entender o mundo recorrendo às coisas do mundo e da nomeação de cada coisa é entender com o auxílio da linguagem, da oralidade, do significado de cada coisa. A oralidade e o livro falado, que é o livro com estilo de diálogo, são contribuições

\footnotetext{
${ }^{15}$ Cf. Angicos: as 40 horas que mudaram vidas. Disponível em: $<$ http://www.ihu.unisinos.br/noticias/518872-angicos-as-40-horas-que-mudaram-vidas >. Acesso em: 06 set. 2021.
} 
para a educação política de Freire e se contextualizam na pedagogia da existência. Uma pedagogia que se insere no cotidiano do aprender a entender por meio de entender o sentido das coisas. A educação dialógica se insere no momento em que se percebe o mundo e lança sobre ele perguntas sem burocratizar o ato de perguntar. O educador participa do processo instigando o aluno a fazer novas perguntas e delas conseguir chegar a possíveis respostas, uma maiêutica.

O livro falado e o modo dialógico são o estilo literário do livro Por uma pedagogia da pergunta (1985). Neste livro, Paulo Freire e o chileno Antonio Faundez travam um diálogo no exílio político que sofreram em Genebra. Eles trataram sobre temas comuns a ambos, como: o próprio exílio; o cotidiano; a experiência intelectual; a experiência docente; o aprender a perguntar e a resistência popular.

A proposta do livro falado se deu pelos diálogos nos encontros de Freire e Faundez. Eles concluíram que os diálogos não deveriam ser apenas entre um e outro. Lembrou Faundez o que disse Freire "Antonio, deveríamos gravar tudo isso, porque este diálogo não deve ser um diálogo exclusivamente entre mim e você; deveríamos fazer com que dele participassem outros intelectuais e não-intelectuais que dialogariam conosco através de nosso diálogo" (FREIRE, 1985, p.07). O primeiro fio a ser puxado por Freire era sobre o transplante enraizante do qual viviam. Freire se referia ao exílio. A resposta de Faundez detalha este transplante.

Paulo, o que você está me pedindo é para eu contar toda a minha vida e todas as minhas experiências vitais, intelectuais e emocionais, porque o exílio, como você afirma, é uma ruptura, e ruptura é uma negação à qual devemos contrapor outra negação para alcançar o positivo, como dizia Hegel. Este o desafio que nós, intelectuais, enfrentamos: superação do negativo para chegar a um nível no qual o exílio se torne efetivamente algo positivo, tanto para o nosso trabalho como para o que pode ajudar a transformar a realidade. Portanto, não se poderia obter uma compreensão do meu exílio sem falar do Chile. Nesse sentido, eu não poderia deixar de dizer que meu trabalho no Chile, por exemplo, é um trabalho que se faz fundamentalmente no nível das ideias, da filosofia. (FREIRE, 1985, p.07).

A fala de Faundez é marcada pela memória da resiliência, superar os desafios para que deles brotem o positivo, particularmente, como uma pedagogia da esperança e, se apoiando na esperança como uma necessidade ontológica, já que o trabalho de Faundez era ensinar filosofia na Universidade de Concepción no Chile. O ensino de filosofia de Faundez se dava de modo prático, possibilitando que os grandes sistemas 
filosóficos não ficassem apenas nas ideias, mas se tornassem possíveis na atuação das pessoas, que as pessoas além de interpretar a realidade conseguissem transformá-las. Um espaço de ensino filosófico que não promove o pensar é um espaço de letras mortas ou de uma filosofia do papel.

Freire acreditava que a experiência intelectual de Faundez poderia ser mais explanada, para que outros jovens filósofos tivessem conhecimento que o ensino filosófico de seu amigo chileno era uma filosofia concreta porque tinha Gramsci como referência, além da experiência universitária na Europa. A experiência de Faundez não era uma experiência individual, mas geracional, de uma geração que vivenciou as lutas de classes sociais. O contexto libertário de Faundez ultrapassava a América Latina. Era um contexto marcado pelos "[...] movimentos internacionais, como a libertação da África, a luta dos argelinos contra a colonização francesa, a revolução cubana e todas essas experiências latino-americanas que convidam a transformar a realidade." (FREIRE, 1985, p.09). A filosofia era um motor que impulsionava a dignidade, pois é papel da filosofia promover uma capacidade de criticidade para que os alunos consigam compreender a realidade.

Claro que não basta apenas bons professores de filosofia ou a própria filosofia e seu contexto, é necessário abertura por parte dos alunos para que se faça verdadeiramente uma leitura transformadora de mundo. E, dessa leitura, o engajamento de atitudes sociais. Tudo isto é muito perigoso. Enquanto Freire em Angicos ensinou um grupo de professoras a ensinar a ler, Faundez ensinava a pensar, a proposta freiriana de leitura era uma proposta que também mobilizava a pensar, pois as palavras já citadas anteriormente, algumas como: ALVOROÇO, MEDO, CORAGEM e CONFORMAÇÃO são palavras de identidades políticas que necessitam de reflexão. Entender concretamente tais palavras é entender uma condição filosófica, uma condição política O militar Humberto de Alencar Castelo Branco acreditou que a proposta de Freire poderia ser perigosa para sua estratégia política e fez apenas um pronunciamento de bastidores, disse que Freire estava "engordando cascavéis" 16 .

Um ano após a formatura dos alunos de Angicos, Castelo Branco passou a ser o presidente da República e com o golpe de 64 o projeto de Paulo Freire foi desarticulado. Freire e o coordenador do projeto Marcos Guerra foram presos, o que

\footnotetext{
${ }^{16}$ Cf. Angicos: as 40 horas que mudaram vidas. Disponível em: <http://www.ihu.unisinos.br/noticias/518872angicos-as-40-horas-que-mudaram-vidas>. Acesso em: 06 set. 2021.
} 
impediu a expansão do projeto. O contexto político (1963) no qual Freire criou o projeto de alfabetização era favorável ao projeto, pois era um momento que havia movimentos de resistências. Com a renúncia de Jânio Quadros (1961), houve um clima de mudanças políticas e estruturais com a reforma agrária e reformas universitárias. $\mathrm{O}$ trabalho de Paulo Freire não era isolado, ele culminava com tais mudanças do período. Uma situação importante do momento é que o analfabeto não votava, o que tornava o projeto de Freire mais necessário diante das possiblidades de mudança. Não tem como não negar que esta era uma conquista popular, mas também um afronto ao político que já tinha como conhecido seus eleitores. Quem eram estes novos trezentos eleitores?

A expressão de Castelo Branco sobre Freire "engordar cascavéis" deriva desta preocupação, já que estes trezentos eleitores não eram pessoas que tinham aprendido apenas a escrever o próprio nome, mas pessoas que tinham aprendido a ler o mundo e as coisas do mundo. ALVOROÇO, MEDO, CORAGEM e CONFORMAÇÃO tinham muitos significados neste contexto. As palavras não eram escolhas aleatórias, eram escolhas intrinsecamente ligadas ao contexto de cada um que promovia o repertório de corpo semântico na aprendizagem dos trabalhadores de Angicos. Essa prática da linguagem admite a possibilidade de uma diversidade de significados para as palavras, permitindo usos diferentes, ligados a diferentes contextos.

Trata-se aqui de assumir uma diversidade linguística associada a uma experiência de vida, o que podemos relacionar a certa visão de mundo. Aqui, num primeiro momento, se pode apontar para uma perspectiva relativista da linguagem, o que traria certo risco para o pensamento de Freire, já que o relativismo, apesar de possibilitar uma diversidade, impõe certo determinismo. Isto é, cairíamos na armadilha de que os diferentes contextos, ou experiências de vida, determinariam radicalmente toda e qualquer visão de mundo e, portanto, todo e qualquer uso da linguagem, e seria possível afirmar que todo uso é relativo ao contexto em que está inserido. Isso traria consequências desastrosas para uma educação libertadora. Veremos adiante como a estratégia de Freire não está vinculada a esse relativismo.

A vida de um trabalhador analfabeto na década de 60 era uma vida de subserviência, de silêncio, e romper as barreiras do silêncio se dava por meio da estratégia do entendimento da palavra cultura, onde cada um passava a entender o 
seu fazer e a necessidade do seu fazer para a sociedade. Esta ação era um despertar da consciência ingênua para a consciência crítica. Para entendermos melhor tal dinâmica, Freire, em Educação como prática de liberdade (1967) comenta que a consciência crítica é "[...] a representação das coisas e dos fatos como se dão na existência empírica. Nas suas correlações causais e circunstanciais" (1967, p.105). Já a consciência ingênua se dá de outro modo, ela acredita entender, mas se distancia da realidade e a julga conforme bem entender. Além dessas duas consciências, Freire também apresenta a consciência mágica.

A consciência mágica, por outro lado, não chega a acreditar-se "superior aos fatos, dominando-os de fora, nem "se julga livre para entendê-los como melhor the agradar". Simplesmente os capta, emprestando-Ihes um poder superior, que a domina de fora e a que tem, por isso mesmo, de submeter-se com docilidade. É próprio desta consciência o fatalismo, que leva ao cruzamento dos braços, à impossibilidade de fazer algo diante do poder dos fatos, sob os quais fica vencido o homem. (FREIRE, 1967, p.105).

Era necessária uma educação que fosse capaz de orientar e colaborar com um pensamento reflexivo que propusesse uma organização do pensar para poder pensar bem, tornando possível às pessoas a diferenciar as circunstâncias de sua própria consciência e se distanciar de uma consciência ingênua ou mágica em prol de uma consciência evidentemente crítica.

Freire e Faundez, cada um ao seu modo, possibilitou que seus alunos saíssem do exílio da ignorância. Ironicamente, os dois foram exilados e o crime político foi ensinar a pensar. Certamente que o entendimento mais concreto de exílio é de Freire e Faundez, porque eles sabem que a liberdade se dá por meio do pensar e pensar bem. Por outro lado, o exílio é um aprendizado da ambiguidade, que resulta na resistência.

Conviver com esta ambiguidade é um aprendizado difícil que o exilado tem de fazer. Ele tem de aprender a "transar" a tensão da ruptura que o exílio provoca. Seu papel não é o de aprofundar a ruptura. Se o exilado aprende a viver esta tensão - sem negar, de um lado, o seu contexto, como se fosse possível decretar que já não tem nada que ver com ele, como se, zangado porque obrigado a deixá-lo, tentasse puni-la, dizendo: "já não me lembro de ti", e, de outro, sem repudiar o contexto de empréstimo -, aí então o seu tempo de espera, no exílio, espera na ação, se faz um tempo de esperanças (FREIRE, 1985, p.11). 
$\mathrm{Na}$ figura do exilado se expõe a própria experiência da linguagem em Paulo Freire. A ambiguidade assumida pela experiência do exílio é a de afirmar uma nova realidade sem negar o que se deixou para trás. Essa tensão, como diz a citação acima, não é aprofundar a ruptura, mas viver em ajuste com ela. Aprofundar a ruptura seria justamente relativizar as visões de mundo, cindidas em nós. Ou seja, aquele que cinde suas diferentes perspectivas divide sua compreensão da realidade, sendo obrigado a escolher entre uma e outra - negar uma e afirmar a outra, rivalizando-as - impedindo no caso de Freire, uma ação de resistência.

É nesse aspecto que a experiência da linguagem em seu método não pressupõe relativismo de diferentes realidades ou de diferentes significados, mas uma abertura que possibilita novos usos e novas experiências. Claro que essa abertura não se trata de um "vale tudo" sem critérios. É a prática, ou o que podemos chamar de "vida", que baliza o critério. Assim, no processo de alfabetização dos trabalhadores, as palavras ganham novos significados porque implicam vidas. Não está em jogo aqui uma regra pré-estabelecida do uso da linguagem para que tal uso seja possível. Não é necessário admitir uma regra que transcenda à linguagem para que possamos usála. A vida é que permite seu uso. E por isso há nessa abertura uma fluidez que faz com que a linguagem se transforme e consinta outras vozes e falas.

Para não sucumbir no exílio é necessário aprendermos a lidar com as tensões e as rupturas. Supera-se negatividade com positividade. Não se apreende esperança do nada, ela se constitui por meio das ações, como se as ações e suas oposições fossem o combustível. A esperança aparece quando aprendemos a resistir.

\section{Revisão Bibliográfica}

Tomando como referência o texto de Paulo Freire Educação como prática de liberdade (1967) e de Freire em coautoria com Antonio Faundez, Por uma pedagogia da pergunta (1985), faremos uma reflexão, a partir da figura do exilado, sobre a experiência da linguagem em Freire. Essa reflexão revela o pensamento freireano como uma prática de caráter existencial e não relativista sob o ponto de vista da linguagem, o que traz elementos para se propor uma educação libertadora. Com isso conseguimos destacar também o quanto sua produção abrange também alguns problemas filosóficos da linguagem, tais como o problema do relativismo e do determinismo linguísticos. À luz das Investigações filosóficas (2009) de Ludwig 
Wittgenstein tornaremos aparente algumas considerações que se referem ao uso da linguagem associado às formas de vida e à mutabilidade. Importante ressaltar que não é o intuito aqui interpretar Freire por meio da obra de Wittgenstein ou de encontrar elementos da filosofia de Wittgenstein em Freire, mas sim servir de base para mostrar certas questões de natureza filosófica da linguagem. Para abordagem acerca do relativismo a referência é o ensaio de Bento Prado Jr., O Relativismo como contraponto.

\section{Metodologia}

Para uma análise mais ampla e crítica do contexto da pesquisa, e devido a suas características, trata-se de uma pesquisa de natureza qualitativa com recorte espaçotemporal de um fenômeno elegido pelas pesquisadoras, em que a preocupação com o processo é maior de que com o produto e o "significado" que as pessoas dão às coisas e à sua vida são focos de atenção especial pelo pesquisador. (LUDKE; ANDRÉ, 2003).

Fundamentada essencialmente em uma pesquisa bibliográfica, partimos de literaturas que fundamentem os conceitos e leituras bases que permearam as investigações e reflexões acerca da filosofia da linguagem presente na vida e obra de exílio de Freire.

\section{Discussão dos resultados - Considerações}

A reflexão aqui realizada mostra o pensamento freireano como uma prática de caráter existencial e não relativista sob o ponto de vista da linguagem, o que traz elementos para se propor uma educação libertadora. Com isso conseguimos destacar também, apresentando como pano de fundo suas aulas em Angicos e sua vida de exilado, o quanto sua produção abrange também alguns problemas filosóficos da linguagem, tais como o problema do relativismo linguístico.

\section{Referências}

FREIRE, Paulo. Educação como prática de liberdade. Rio de janeiro: Paz e Terra, 1967. 
.; FAUNDEZ, Antonio. Por uma pedagogia da pergunta. Rio de Janeiro: Paz e Terra, 1985.

LÜDKE, Menga; ANDRÉ, Marli. Pesquisa em educação: abordagens qualitativas. São Paulo: EPU, 1986 (6ª . Reimpressão, 2003).

PRADO Jr., Bento. O Relativismo como contraponto. In: Erro, ilusão, loucura. São Paulo: 34, 2004.

WITTGENSTEIN, Ludwig. Investigações filosóficas. Tradução de Emmanuel Carneiro Leão. 6. ed. Petrópolis: Vozes, 2009. 


\section{RESUMOS EXPANDIDOS E RELATOS DE EXPERIÊNCIA}

\section{A GEOGRAFIA TRABALHANDO PARA RECONHECER O HOMEM NO MUNDO E COM O MUNDO}

Cristiane Fernandes de Oliveira

\section{Introdução}

A Geografia tem buscado, nas últimas décadas, o engajamento político em suas ações e no ensino do conhecimento pertinente a esta ciência. É neste sentido que este trabalho busca discutir algumas ações práticas que, ao nosso ver, estão afinadas com o pensamento de Paulo Freire, quando ele reconhece a necessidade de ações que possibilitam ao educando notar que o homem não somente pertence ao mundo, mas deve estar ciente de suas ações em relação ao mundo (FREIRE, 1991, p. 124).

É importante que se destaque que as ações humanas promovem transformação e esta, por sua vez, é também o resultado da cultura que se impõe sobre um ambiente natural ou previamente transformado. Deste modo, há de se considerar ainda, a questão da dominação e, ou imposição, que, segundo Paulo Freire (1991, p.124) deveria ser objeto de crítica, já que o autor defende um mundo mais mediatizado pela comunicação, pelo diálogo. A humanização do Homem nestes parâmetros seria o objetivo de uma educação libertadora e em prol do desenvolvimento da sociedade.

É com base nestes princípios que propomos aqui, discutir algumas práticas na disciplina do curso de Licenciatura de Geografia a distância, que buscam nos aproximar desta educação libertadora.

Palavras-chave: Ação; Ensino de Geografia; Educação.

\section{Metodologia}

Segundo a obra de Paulo Freire (1991, p.124), a natureza e a cultura fazem parte dos temas que devem ser considerados como situações existenciais que podem se constituir como embasamento para que o Homem possa se reconhecer no mundo como um ser que trabalha e que produz e, por meio deste trabalho se relacionar com a natureza, transformando-a de acordo com sua cultura. 
Neste sentido, dentro da Geografia se procura, em grande parte de suas disciplinas, apontar como se dão estas relações de trabalho e de transformação da natureza, mas também, e principalmente se procura auxiliar o aluno a compreender o espaço geográfico como diverso, complexo, contrastante e, também, contraditório, desenvolvendo o espírito crítico.

Buscamos assim, neste trabalho, apontar por meio de algumas atividades desenvolvidas com os educandos, o vislumbre de possibilidades de ensino e aprendizagem libertárias, com base no diálogo e dentro de uma perspectiva de ações construtivas na realidade do educando.

A relação prática-teoria é uma busca permanente nas disciplinas da Geografia, mesmo no ensino a distância. Deste modo, tomamos como objeto de análise, neste trabalho, as atividades desenvolvidas no curso de Licenciatura em Geografia da Universidade Metropolitana de Santos, no que diz respeito ao desenvolvimento do espírito crítico e do incentivo ao engajamento político dos estudantes, em prol do alcance de uma educação libertadora.

Estas atividades analisadas dizem respeito aos Fóruns, às aulas online e, também, às propostas de atividades no Laboratório Virtual.

No aspecto teórico, alguns autores da Geografia nos fornecem subsídios para compreender melhor os entraves e dificuldades da tarefa de se alcançar esta educação libertadora. Entre estes autores, é possível citar, Milton Santos (2007) e Nídia N. Pontushka (2001), sendo que o primeiro nos ajuda a compreender claramente as contradições do espaço geográfico e a segunda, as dificuldades e caminhos do ensino de Geografia nos moldes apregoados por Paulo Freire.

\section{Resultados}

A revisão das atividades desenvolvidas com os estudantes de Geografia nas disciplinas de Formação da Ciência Geográfica (estudantes ingressantes) e de Teoria da Região e Regionalização desenvolvidas nos Fóruns e em aulas online, nos permite inferir que a teoria é mais bem compreendida a partir da reflexão sobre a vivência prática por parte do estudante. Neste sentido, as atividades que buscam a reflexão dos estudantes sobre como era o contexto de sua região, ou do ensino de Geografia vivido por ele no ensino médio, auxiliam sua compreensão da teoria. As leituras 
indicadas passam então, a fazer, mais sentido por não estarem mais descoladas de sua realidade de vida.

Outra questão é a do desenvolvimento do espírito crítico, que passa a ser mais bem aplicado, auxiliando no amadurecimento acadêmico do estudante e em possibilidades de um maior engajamento na busca de transformação da educação futura.

Além destas atividades dos Fóruns e das aulas online, também foram propostas atividades de contato com o meio, no laboratório virtual de Geografia. No caso desta atividade, não houve retorno por parte dos alunos, sendo que há ainda pequeno acesso dos alunos a este laboratório, apesar da existência de muitas atividades.

Buscou-se nesta última atividade, alcançar o ensino interdisciplinar, buscando estimular o estudante a desvendar a complexidade de um determinado espaço, possibilitando ainda, o despertar para a pesquisa, a partir de sua vivência e descobertas, relacionando a teoria à prática. A paisagem poderia suscitar questionamentos, que poderiam levar ao desenvolvimento de um estudo ou pesquisa sobre o assunto questionado.

\section{Discussão}

Considerando o desenvolvimento da ciência Geográfica e suas práticas de ensino, pesquisa e aprendizagem dentro de um contexto da educação libertadora, é possível reconhecer autores que também se aproximam bastante do pensamento de Paulo Freire (1991), e da necessidade de desenvolvimento de uma educação engajada politicamente. Dentre estes autores pode-se citar Milton Santos (2007) quando este discute o "Espaço do Cidadão", ou Eliseu Savério Sposito (2004, p.70) ao abordar a forma como se desenvolvem as atividades didáticas em sala, lembrando que "o conhecimento geográfico está comprometido com as formas de ação e de pensamento oriundas das estruturas sociais".

É importante lembrar, que nem sempre foi assim no processo de desenvolvimento da ciência geográfica. No início do século XIX, o pensamento geográfico não caminhava lado a lado com o pensamento crítico, mas estava aliado aos interesses coloniais e neocoloniais, em busca da exploração da natureza e de seus recursos. Neste contexto, para a Geografia só interessava o reconhecimento de novos espaços e a descrição das riquezas exploráveis. 
Mas, os tempos mudaram. A Geografia passou por um longo período de transformações e, a partir da década de 1960 o pensamento crítico começou a se fazer presente, buscando compreender a lógica moderna do trabalho humano e a transformação da natureza resultando em uma combinação que apresenta como resultado a produção da sociedade em que vivemos.

É interessante lembrar que esta sociedade que nos referimos em tempos hodiernos, é repleta de contradições e contrastes, típicas de uma sociedade capitalista. Neste modelo, nem sempre o avanço do país está vinculado à equidade social ou econômica e, por vezes, sequer faz jus aos direitos individuais, mas, certamente se ampara pela perspectiva de ampliação do consumo e não no exercício da cidadania.

Deste modo, uma das práticas que podemos citar como fortalecedora do espírito crítico, é o de apontar a visão de diferentes autores tratados em diferentes disciplinas da Geografia, apresentando aos educandos diversas possibilidades de leituras do mundo na qual o senso crítico e a ação podem se estabelecer.

Quando se discute a questão da liberdade e a questão da cidadania na Geografia, lembramos sempre das palavras de Milton Santos (2007, p.102)

(...) a meta da liberdade começa no espírito do homem e a condição de liberdade é a imersão do indivíduo renovado numa sociedade onde o homem é o sujeito e não o objeto. É fundamental, todavia, ultrapassar a reconstrução solidária do indivíduo e transformá-la em ação solidária. A individualidade somente se realiza no grupo (SANTOS, 2007, p.102).

Para Nídia N. Pontuschka (2001, p.112) ainda há grandes entraves para que possamos alcançar o ideal de ensino, na qual possamos contribuir plenamente para a construção da cidadania. Isto por que a autora questiona em primeiro lugar como poderíamos conceituar cidadania em uma sociedade tão desigual? Como construir a cidadania em uma escola pública tão numerosa e tão heterogênea (do ponto de vista escolar e sociocultural)? (PONTUSCHKA, 2001, p.112).

Ainda, para a mesma autora é importante que se reconheça no universo de conhecimento tratado pela universidade, as especificidades, diferenças e essências do público específico de alunos, além das condições culturais e econômicas (PONTUSCHKA, 2001, p.132). 
No ensino a distância, estas diferenças se ampliam, devido ao fato de que os estudantes nem sempre são oriundos da mesma região, trazendo com eles diferenças socioeconômicas, políticas e regionais bastante distintas.

Deste modo, os desafios ao ensino em geral, e especificamente em relação à própria Geografia são maiores.

Um primeiro conselho, tentando superar estes desafios, deixado na obra de Nídia N. Pontuschka (2001) é buscar conhecer os educandos, suas especificidades. A riqueza de sua cultura pode e deve ser reconhecida e, porventura, explorada nas atividades de sala.

Neste sentido, na disciplina de Teoria da Região e Regionalização, temos procurado explorar estas especificidades de vivência do aluno, seu local de cotidiano, a partir de sua região.

Quando questionado sobre a região de origem do estudante, sobre os aspectos que mais gostam nesta região, sobre sua economia, sobre aspectos culturais, sobre aspectos físicos, etc. estes estudantes têm participado mais, demonstrando mais interesse e trocando informações com os colegas nos Fóruns. Esta atividade busca aproximar a teoria da prática, impulsionando a troca de experiências e ajudando no reconhecimento da diversidade cultural e social dos participantes e das diferenças regionais existentes.

Do mesmo modo, na disciplina de Formação da Ciência Geográfica foi possível se questionar sobre como era o ensino de Geografia que os estudantes tiveram no ensino médio? Quais fatos positivos e negativos eles poderiam relatar? A partir das respostas é possível reconhecer as várias correntes da Geografia, desenvolvidas pelos respectivos professores neste passado próximo, e trazer o contexto histórico e metodológico do desenvolvimento histórico da Geografia, possibilitando aos estudantes se reconhecer dentro de cada corrente da Geografia e se posicionar frente a ela.

\section{Considerações Finais}

A prática de ensino baseada em situações existenciais, ou seja, na qual o indivíduo pode analisar os contextos propostos e ou debater determinado tema à luz de sua própria experiência enriquece seu processo de aprendizado, já que ele pode refletir, 
como exposto por Paulo Freire (1991, p.106), sobre sua "ontológica vocação de ser sujeito".

É, neste sentido, que buscamos propor em algumas atividades do curso de Licenciatura em Geografia, o método denominado "ativo" (FREIRE, 1991, p.106), de modo que, por meio de debates ou de situações desafiadoras, que também pudessem ser existenciais para os estudantes, é possível superar erros de uma educação alienada (FREIRE, 1991, p.107).

Ainda, segundo o mesmo autor, só o diálogo comunica, só ele gera criticidade, só ele gera empatia, confiança e conscientização (FREIRE, 1991, p.107).

Em um mundo que se apresenta tão dividido e com tantos contrastes, sua compreensão só pode ocorrer por meio desta forma de comunicação dialogada e, também por meio do respeito às diferenças. Esta não é só uma receita para ensinar, mas também, para aprender. O professor deve estar atento a esta tarefa perpétua de aprendizado. À medida que ensinamos, estamos sempre aprendendo.

A complexidade do espaço geográfico na atualidade, no período da globalização, exige cada vez mais um esforço de compreensão do outro, de aceitação das diferenças, mas, também, exige o reconhecimento das desigualdades e das injustiças e dos agentes e modelos produtores destas.

No Ensino de Geografia, busca-se desenvolver no estudante, o espírito crítico não somente para buscar a equidade e a justiça, mas, principalmente para perceber a Educação como uma ação que promove o diálogo e o engajamento no sentido de transformar o espaço geográfico em um espaço mais humanizado, mais solidário.

Ainda, ao mesmo tempo que se ensina a ser solidário, se ensina a respeitar a diversidade de nosso mundo, se está, também, tornando-se cidadão, ou seja, tornando-se um "homem no mundo e com o mundo", como nos apontou Paulo Freire (1991, p.124).

\section{Referências}

FREIRE, Paulo. Educação como prática da Liberdade. Rio de Janeiro: Paz e Terra, 1991.

PONTUSCHKA, Nídia Nacib. A Geografia: Pesquisa e Ensino. In: CARLOS, A.F.A.

(Org.) Novos Caminhos da Geografia. São Paulo: Contexto, 2001, p.111-142. 
SANTOS, Milton. O espaço do cidadão. 7 ed. São Paulo: Editora da Universidade de São Paulo, 2007.

SPOSITO, Eliseu Savério. Geografia e filosofia: Contribuição para o ensino do pensamento geográfico. São Paulo: Editora da Unesp, 2004. 


\section{PAULO FREIRE VIVE!}

Elisabeth dos Santos Tavares

Vanessa Laja

Refletir sobre a obra de Paulo Freire é falar da sua obstinação, escrever sobre seu sonho da utopia democrática e se tem a percepção clara de que cabe a nós educadores, uma parte desta tarefa de transformação da nossa sociedade. É relevante destacar que adiante essa utopia se caracteriza como um modo de estar sendo-no-mundo, que exige conhecimento da realidade. É projetar-se, lançar-se adiante, buscar. Essa utopia não é algo irrealizável, é um compromisso histórico de seguir em frente, do buscar.

Para Freire, a educação está sempre carregada de uma politicidade e a prática educativa exige a reflexão sobre essa prática: são atos políticos de escolha, de decisão, de luta entre contrários, de conquista de cidadania negada. Para o educador não há como se separar o político do educativo, cada qual com as respectivas especificidades e que, portanto, como processo de conhecimento, formação política, manifestação ética, a educação é prática indispensável aos seres humanos e deles específica na história como movimento.

No entanto, é importante salientar que diferentes concepções de conhecimento, educação e pessoa humana influenciam a ação docente, assim também o modo como se entende como o conhecimento se constrói, como se planeja, como se avalia interferem em como se ensina. A opção do que ensinar, porque ensinar e com que objetivo é permeado por uma visão de mundo que privilegia um determinado conjunto de saberes que necessariamente expressam um conjunto de crenças e valores revelando uma escolha política.

Assim, para Freire, não há neutralidade na educação e toda prática de ensino está carregada de ideologia, mais do que isso, aquela que se diz neutra, essa sim é carregada de ideologia. Todo conteúdo está carregado de ideologia, de forma explícita ou de forma oculta. Esse discurso da neutralidade esconde uma escolha política a favor da permanência, um empenho deliberado para manter um determinado sistema de conhecimento e, por conseguinte, um determinado sistema social. 
Logo, educação sendo um ato político e um ato de conhecimento revela que, ao se pensar a educação dessa forma, pode-se destacar alguns elementos que perpassam a sua concepção humanista, como a valorização da cultura do outro, a necessidade de ouvir o que o outro conhece, a certeza da incompletude do ser humano, a conscientização, a democracia e o diálogo.

Assim, também como processo de conhecimento, formação política, manifestação ética, procura da boniteza, capacitação científica e técnica, a educação é prática indispensável aos seres humanos e deles específica na história como movimento, como luta. Enquanto o objetivo da "educação bancária" é eliminar a capacidade crítica dos alunos e acomodá-los à realidade, a "educação problematizadora" quer despertar a consciência dos oprimidos, inquietálos e levá-los à ação de libertação.

Dessa forma, aprender é um ato revolucionário, por meio da educação, e de maneira coletiva, o indivíduo toma consciência de sua condição histórica, assume o controle de sua trajetória e conhece sua capacidade de transformar o mundo.

Isso significa que, em relação às parcelas desfavorecidas da sociedade é leválas a entender sua situação de oprimidas e agir em favor da própria libertação. Ao propor uma prática de sala de aula que pudesse desenvolver a criticidade dos alunos, Freire condenava o ensino oferecido pela ampla maioria das escolas (isto é, as "escolas burguesas"), que ele qualificou de educação bancária. Nela, segundo Freire, o professor age como quem deposita conhecimento num aluno apenas receptivo, dócil.

Nesse contexto SER PROFESSOR se reveste de singularidades. Para Freire, a docência se constrói não somente de uma habitação legal, mas, sobretudo, envolve a consciência da sua condição em ação, ou seja, nos tornamos professores por meio da nossa ação. Isso não significa desconsiderar a teoria e a reflexão, mas "a responsabilidade ética, política e profissional do ensinante lhe coloca o dever de se preparar, de se capacitar, de se formar antes mesmo de iniciar sua atividade docente" (FREIRE, 1995, p.28).

Vai além, esse processo em ação conduz o professor a uma condição de aprendente, já que enquanto ensina, aprende também. "O educador já não é o que apenas educa, mas o que, enquanto educa, é educado em diálogo com o educando que ao ser educado, também educa (FREIRE, 1987ª p.68)". 
Dessa forma, ambos, educador e educando se tornam sujeitos no processo vivido, crescendo juntos, como sujeitos em diálogo.

Essa compreensão nos conduz a refletir sobre a responsabilidade da formação inicial do professor, como em continuidade de forma permanente. Mais ainda, ao se considerar que no Brasil, a população em idade escolar da Educação Básica, especialmente do Ensino Fundamental, está majoritariamente matriculada em escolas da rede pública, exige de nós uma mobilização em favor das classes menos favorecidas economicamente presente nas escolas públicas.

O censo da educação básica de 2020 revela que:

Ao avaliar a distribuição das matrículas por dependência administrativa, percebe-se uma maior dominância da rede municipal, que detém 48,4\% das matrículas na educação básica, 0,3 ponto percentual (p.p.) a mais do que em 2019. A rede estadual, responsável por 32,1\% das matrículas da educação básica em 2020, é a segunda maior. A rede privada obtém $18,6 \%$, e a federal tem uma participação inferior a $1 \%$ do total de matrículas (INEP, 2020).

Assim, mais de $80 \%$ das crianças e adolescentes matriculadas na Educação Básica estão nas escolas públicas.

No Ensino Fundamental em 2020, foram registrados 26,7 milhões de matrículas no ensino fundamental. Vale destacar que esse valor é 3,5\% menor do que o registrado para 2016. Segundo o INEP, a queda no número de matrículas foi ligeiramente maior nos anos iniciais $(4,2 \%)$ em relação ao observado nos anos finais $(2,6 \%)$ do ensino fundamental.

Nos anos iniciais do ensino fundamental, a rede municipal apresenta a maior participação, com $68,1 \%$ das matrículas, seguida pelas redes privada (composta por 18,3\% da não conveniada e $0,7 \%$ da conveniada) e estadual (12,8\%). (INEP, 2020).

Mais uma vez, o que se revela é a predominância das matrículas em mais de $80 \%$ na rede pública de ensino.

Nessa perspectiva, a presença desse educador na rede pública ganha uma relevância maior, se acentua sua condição de cidadania e sua visão de mundo 
acompanhando a cultura e o contexto de seus alunos, o que se contrapõe à educação bancária e promove a educação problematizadora. Enquanto a primeira se desenvolve como memorização, mecânica de conteúdos, negando a concepção de "ser mais" humanizadora a educação problematizadora promove a dialogicidade entre educador e educando mediada pelo mundo.

$\mathrm{Na}$ educação problematizadora, a pergunta se constituiu como centro e parte da curiosidade sem a qual não pode haver produção do conhecimento, mas sim, está associada a uma dimensão ontológica.

A proposta pedagógica de Freire (1997, p. 26) encontra fundamentação na concretude da existência humana, e entende que "cada homem é um ser no mundo, com o mundo, e com os outros". Mas para que o educador viva essa constatação, é preciso que ele reconheça, nos outros, o direito de dizer a sua palavra, pois se os outros têm o direito de falar, o nosso dever é de escutá-los, não com malícia, pensando em receber algo em troca, mas como quem cumpre um dever. Nessa troca, escutá-los corresponde ao direito de falar a eles que, na verdade, é falar com eles, enquanto que apenas falar a eles seria uma forma de não os ouvir (ANDREOLA, 1993).

Alguns aspectos filosóficos no processo de investigação dos temas geradores e da relação desconstrução e reconstrução proposta por Paulo Freire são destacados por Andreola (1993):

\footnotetext{
a investigação-conscientização - a investigação do universo temático não é feita apenas pelo educador. O grupo envolvido naquela realidade faz parte do processo desde o início. Os alunos não são objetos de estudos, mas sujeitos. O conhecimento, sim, é objeto de investigação, portanto, desde o começo do processo de educação conscientizadora, os sujeitos se manifestam envolvendo-se e comprometendo-se com as atividades.
}

Em relação à objetividade da pesquisa, a participação do povo na pesquisa é fundamental em oposição ao pensamento positivista, segundo o qual quem pesquisa é o pesquisador, e o povo é excluído e tratado como objeto, porque é considerado ignorante e incapaz para agir junto com os "entendidos". Essa importância se dá em 
razão de que a participação do povo é fortalecida, pois os temas de investigação são parte da realidade e são tão históricos quando os sujeitos dessa realidade.

"simplesmente, não posso pensar pelos outros nem para os outros, nem sem os outros. A investigação do pensar do povo não pode ser feita sem o povo, mas com ele, como sujeito de seu pensar" (FREIRE, 1988, p. 118).

Em relação à pesquisa conscientizante, trabalha com grupos militantes da comunidade alvo da pesquisa e com animadores convidados para dar o apoio metodológico.

Os resultados da pesquisa são difundidos no conjunto da população e não são reservados ao pesquisador e seu tutor como na pesquisa informativa, nem tampouco aos pesquisadores e às suas amostras como na pesquisa participante (Andreola, 1993).

Nos parece óbvio que os demais educadores atuantes na rede privada de ensino não estão "dispensados" da presente reflexão, todos os educadores estão presentes nesta reflexão, no entanto, por considerarmos a matrícula de alunos na educação básica e no ensino fundamental apresentada na rede pública de ensino, se torna premente a reversão na formação dos professores.

Essa reversão na formação do professor tornará possível uma escola cidadã, o que para Freire significa pensar a escola como "um centro de direitos e deveres", de democratização da gestão, à democratização de conteúdos curriculares, de diálogo permanente, onde os diferentes são reconhecidos, um espaço de valorização da inclusão, da liberdade de expressão e da cidadania possível de ser vivida.

Se hoje, ainda não temos essa escola, já se sabe também que uma escola coerente com essas premissas exige uma transformação dos professores.

É preciso tornar os professores atores e autores da transformação que se deseja! Paulo Freire VIVE!!!

\section{Referências}

ALTHUSSER, Louis. Aparelhos ideológicos de estado. 6. ed. Rio Janeiro: Graal, 1992. 
ANDREOLA, Balduino A. O processo do conhecimento em Paulo Freire. Revista Educação e Realidade. Porto Alegre: UFRGS, Vol. 18, oㅡ 01, Jan/jun. 1993.

FREIRE, Paulo, SCHOR, Ira. Medo e ousadia - o cotidiano do professor. Rio de Janeiro: Paz e Terra, 1986.

INSTITUTO NACIONAL DE ESTUDOS E PESQUISAS EDUCACIONAIS ANÍSIO TEIXEIRA (INEP). Censo Escolar, 2020. Brasília: MEC. Disponível em https://download.inep.gov.br/publicacoes/institucionais/estatisticas e indicadores/res umo tecnico censo escolar 2020.pdf, acessado em 23/08/2021.

TAVARES, Elisabeth dos Santos, CAMBA, Mariângela, FEITOSA, Neuza Maria S. Política e Educação em Freire. Clube de Autores, 2016. 


\section{O PROFESSOR, A PRÁTICA E A NECESSIDADE DE REFLEXÃO- A ATIVIDADE DOCENTE DO PROFESSOR DE EDUCAÇÃO FÍSICA}

Igor de Carvalho Cunha

\section{Resumo}

O presente trabalho propõe uma reflexão sobre algumas práticas docentes do professor de educação física pautadas em modelos pedagógicos que não se articulam às necessidades da escola. Esses modelos acabam afetando a vida escolar do aluno, inclusive alunos da graduação, pois estes apresentam lacunas em sua formação. Isto posto, cabe destacar a importância do profissional da educação física refletir acerca dos documentos oficiais, das teorias educacionais e de sua prática docente no intento de buscar subsídios para que a prática pedagógica esteja apoiada na criticidade. Por meio de pesquisas bibliográficas e documentais, bem como das reflexões sobre a trajetória discente, profissional e autoavaliação. Frente às diferentes abordagens da educação física e às lacunas deixadas pela formação profissional, é patente a necessidade de o professor de educação física ser reflexivo e romper com as aulas reprodutivistas e excludentes.

Palavras-chave: Educação física; Teorias da educação; Professor Reflexivo.

\section{Introdução}

Frente às mudanças ocorridas no seio pedagógico da educação física ao final do último século, pudemos presenciar diferentes abordagens da educação física tanto como alunos, e, posteriormente, como docentes. Tendo em vista os documentos oficiais brasileiros, os quais apontam para uma educação física de caráter mais holístico e crítico, constatamos que as práticas estão distantes tanto dos documentos oficiais, quanto das teorias críticas, levando-nos a nos indagar sobre a importância do professor de educação física ser reflexivo e pensar nas lacunas de sua formação e as dificuldades encontradas para sua atuação durante a vida profissional.

Para iniciar o processo, é preciso analisar as abordagens teóricas utilizadas pelos professores de educação física a partir da literatura que tem sido publicada como, por exemplo, por autores como Darido (2008), Coletivo de autores (1992), Freire (1997), e tendo como referência os documentos oficiais do Brasil, articulados com a prática docente vivenciada e os estudos de Libâneo (2003), Freire (1987; 2007), Giroux (1997), Goméz (1998), Sacristán (2008), Alarcão (2011) e Pimenta (2012) no que se refere à escola e ao professor reflexivo.

\section{Do primeiro contato à graduação em educação física}


Iniciei meus estudos na escola regular na década de 1990.O Brasil passava por um processo de redemocratização desde a década de 1980, culminando no campo educacional em teorias críticas, que vieram a influenciar fortemente as atuais abordagens na educação física.

Nos meus primeiros anos do ensino fundamental, lembro de aulas extremamente prazerosas, com jogos, brincadeiras e atividades lúdicas. Com o passar dos anos, as aulas foram progressivamente se tornando mais pragmáticas, com foco no esporte, culminando na "rola a bola", aquela aula em que o professor deixa a cargo dos alunos escolherem o esporte -normalmente futebol- e tornava a participação discente facultativa.

Enquanto aluno, esta situação era até desejada por nós meninos, eram duas aulas semanais tidas como lazer puro. Acontece que nem sempre conseguíamos jogar nosso futebolzinho, pois a não diretividade da aula causava autoexclusão por grande parte discente, principalmente das meninas, tornando a aula de educação física algumas vezes uma aula-vaga, no sentido stricto e no sentido lato também.

Esta prática da "rola a bola" poderia bem ser compreendida no que Libâneo (1989) critica e intitula de "Tendência liberal renovada não-diretiva". Parafraseando Rogers, o autor aponta como objetivo desta tendência o autodesenvolvimento em detrimento à "procedimentos didáticos, a competência na matéria, as aulas, livros" (LIBANEO, 1989, s/p). Acontece que o que meus professores propunham (ou deixavam de propor) em aula, nada, ou pouco tinha relação com alguma teoria. Era uma falta de compromisso com a sociedade, compromisso este que Freire (1979 educação e mudança) aponta como ação e reflexão condicionadas pela realidade do homem.

$\mathrm{Na}$ graduação, ingressei com o intuito de trabalhar com esporte de alto rendimento, porém, os três primeiros anos eram voltados à licenciatura, período que me proporcionou contato com o núcleo mais "pedagógico" do curso, trazendo-me uma série de reflexões acerca da escola regular, sendo fisgado por esta corrente. Acontece que também tínhamos um núcleo de professores esportivistas, os quais desenvolviam suas aulas pautadas na técnica.

A minha crítica a estas aulas do núcleo esportivista, era justamente elas estarem distantes da realidade da escola. Isto foi em meados de 2010 , momento que 
os Parâmetros Curriculares Nacionais (Brasil, 1997) estavam em vigência, que segundo Darido (2008, p.23), são ecléticos e apontam no "sentido de abarcar as diferentes possibilidades da Educação física na escola, ou seja, a saúde, o lazer e a reflexão crítica dos problemas envolvidos na cultura corporal de movimento".

Alguns dos citados professores do grupo esportivista desenvolveram suas carreiras como atletas e exerceram o cargo de técnico desportivo em grandes clubes. Neste sentido, o referencial de esporte na escola que eu tive na graduação, foi muitas vezes o de reprodução. Cabe relatar o vivido em uma determinada aula de voleibol, quando eu questionei o professor sobre a metodologia empregada e que não condizia com a necessidade dos alunos, pois era desmotivadora para os discentes dos primeiros anos do ensino fundamental. A resposta do professor revelou um posicionamento que desvela a falta de reflexão e certo acomodamento. Ele disse que tinha ministrado aula em várias escolinhas esportivas, e que sua metodologia sempre fora um sucesso, inclusive com os mais novos, portanto não haveria de mudar o que dava certo. Analisando sua resposta, podemos enquadrar sua pedagogia, no que Gómez (2008) denomina como enfoque tradicional, que se centra mais nos conteúdos disciplinares do que nas habilidades ou nos interesses dos alunos/as (grifo nosso).

Devemos atentar para o período de formação/atuação profissional do citado grupo de professores. São pessoas que prosperaram esportivamente durante o período em que houve uma ditadura militar no Brasil, quando, segundo Darido (2008), o esporte foi utilizado como ferramenta de propaganda do governo em questão, fomentando principalmente o esporte competitivo no seio escolar.

As práticas aqui citadas vão de encontro com Alarcão, a qual discorre que o entendimento de professor reflexivo "baseia-se na consciência da capacidade de pensamento e reflexão que caracteriza o ser humano como criativo e não como mero reprodutor de ideias e práticas que Ihe são exteriores" (2011, p.44).

A discussão sobre a formação profissional dos professores é tecida por Giroux (1997, p.160) de maneira crítica. O autor cita uma pedagogia instrumental que visa técnicas em "como fazer", e "o que funciona" de modo desarticulado de reflexões acerca dos princípios que subjazem a vida e prática escolar, negando o pensamento crítico do professor. 


\section{Enfrentando a realidade docente}

Essas reflexões postas têm sido aprofundadas ao longo de minha formação e início de minha atividade docente. Ao ingressar no ensino público como professor adjunto, tais ponderações foram muito importantes frente as dificuldades da docência, porém, as lacunas na formação profissional, não proporcionaram respostas às adversidades, pelo contrário, foram motivo de desmotivação.

Como professor adjunto, trabalhei e acompanhei diferentes profissionais, nos mais diferentes anos escolares de educação física, desde o ano de 2015, quando eu ainda não possuía sede fixa, tampouco aulas atribuídas. Neste ínterim, constatei que cada professor tinha uma abordagem pedagógica diferente, influenciados pelas suas diferentes formações, mais pessoais que profissionais pedagógicas. Eu, pessoalmente, também não posso me furtar desta falta de identidade no início da carreira. Procurava me espelhar no professor que eu substituía, e de certa forma reproduzir o tipo de aula que era ministrada antes de mim, quase sempre uma aula excludente, a despeito do contato e simpatia com as teorias críticas da educação durante a graduação. "É que, quase sempre, [..], os oprimidos, em lugar de buscar a libertação, na luta e por ela, tendem a ser opressores também, ou sub opressores" (FREIRE, 1987, p.17).

Minha atuação docente no início da carreira foi reprodutivista. Ocorre que muitas vezes, mesmo sem concordar com as aulas, eu as ministrava, o que me incomodava muito. Libâneo (2011) comenta sobre o tipo de professor que fui:

Uma boa parte dos professores, provavelmente a maioria, baseia sua prática em prescrições pedagógicas que viraram senso comum, incorporadas quando de sua passagem pela escola ou transmitidas pelos colegas mais velhos; entretanto, essa prática contém pressupostos teóricos implícitos. Por outro lado, há professores interessados num trabalho docente mais consequente, professores capazes de perceber o sentido mais amplo de sua prática e de explicitar suas convicções (LIBÂNEO, 2011, s/p).

É necessário contextualizar as condições de trabalho do professor de educação física. Com relação à infraestrutura, é preciso mencionar que não são todas as escolas que apresentam o espaço necessário para o desenvolvimento das atividades e que fornecem o material necessário para o desempenho pleno da atividade docente para a realização das aulas de educação física. 
Posso mencionar que a infraestrutura não era ideal, mas preciso reconhecer que eu reproduzia práticas até certo ponto opressoras, conforme explica Freire (1987), uma hospedagem do opressor, ou ainda uma passividade em relação ao falho sistema educacional. Esse reconhecimento, feito a partir de uma dolorosa reflexão e um ponto de inflexão, foi a razão maior para que eu procurasse umas práxis libertadora.

A reflexão sobre a necessidade de superação das dificuldades, medos e lacunas é parte do processo e não precisa ser uma barreira.

Se se faz indispensável aos oprimidos, para a luta por sua libertação, que a realidade concreta de opressão já não seja para eles uma espécie de "mundo fechado" (em que se gera o seu medo da liberdade) do qual não pudessem sair, mas uma situação que apenas os limita e que eles podem transformar, é fundamental, então, que, ao reconhecerem o limite que a realidade opressora lhes impõe, tenham, neste reconhecimento, o motor de sua ação libertadora. (FREIRE, 1987, p. 19)

Em consonância com a minha inquietação, e com as mudanças na carreira, no ano de 2018, a rede municipal em que eu trabalho ofereceu um curso com duração de dois anos, com objetivo de melhorar as práticas docentes. Não foi um simples programa de treinamento técnico, tampouco um cansativo ensino teórico. Tratou-se de uma grande interação entre os profissionais, dialogando com teoria e prática. Proporcionou uma grande reflexão acerca do que estudamos, e como é possível essa implementação na escola pública atendendo tanto aos documentos oficiais, quanto às teorias educacionais que propõe uma sociedade mais justa e humana.

O curso oferecido produziu efeitos positivos, pois percebi haver um aumento da motivação tanto pessoal, quanto coletiva, no sentido de nos tornarmos melhores profissionais e propiciarmos situações significativas para os alunos.

As reflexões acerca de minha prática docente permitiram que eu buscasse modificá-la.

\section{Refletindo a história e as teorias da educação}

As teorias da educação têm profunda influência na formação docente, proporcionando capacidade de análise e compreensão ao professor, "[...] o saber docente não é formado apenas na prática, sendo também nutrido pelas teorias da educação. Dessa forma, a teoria tem importância fundamental na formação dos docentes" (PIMENTA, 2000 apud PIMENTA 2012, p.28) 
Até o final da década de 1970, Darido (2008) revela e critica uma predominante vertente tecnicista, esportivista e biologista na educação física. Tratouse da reprodução da opressão em que a sociedade vivia (e vive), excluindo grande parte dos alunos com um verniz meritocrático, pelo qual somente as pessoas biologicamente preparadas e esforçadas poderiam alcançar o sucesso. Mesmo que os conteúdos da ginástica, esporte e higiene e saúde ainda se façam presentes na educação física, este componente curricular não pode encerrar sua prática numa concepção procedimental e de exclusão como antes era feito. Logo, é preciso refletir sobre a libertação desta tendência opressora.

Isto posto, além de corpo e mente, o professor reflexivo na educação física deve levar em conta os aspectos socioculturais dos conteúdos, o todo em que estão inseridos.

Não se trata apenas de como ensinar, mas o que ensinar e, como esses conhecimentos são adquiridos. Devemos contextualizar os fatos mediante um resgate histórico. Neste sentido, Coletivo de Autores (1992) elaboram uma pedagogia "que busca responder a determinados interesses de classe" (p.14) denominada críticosuperadora. Isto posto, os mesmos autores defendem uma perspectiva na educação física sobre a cultura corporal, uma reflexão sobre formas de representação do mundo por meio da "expressão corporal: Jogos, danças, lutas, exercícios ginásticos, esporte, malabarismo, contorcionismo, mímica e outros, que podem ser identificados como formas de representação simbólica de realidades vividas pelo homem, historicamente criadas e culturalmente desenvolvidas" (COLETIVO DE AUTORES, 1992, p.26).

A referida ampliação da importância dos conteúdos na educação física encontra apoio em Sacristán (2008, p.120). O autor denota o valor dos conteúdos e expõe a fragilidade de um ensino pautado em técnicas de ensino.

Os PCN (Brasil, 1997) elencam temas transversais a permear os diferentes componentes curriculares (Saúde, Meio Ambiente, Ética, pluralidade cultural, orientação sexual e Trabalho e Consumo), e sintetizam diferentes concepções pedagógicas da educação física. Primam pela utilização das diferentes linguagens, inclusive a corporal, como "meio para produzir, expressar e comunicar suas ideias, interpretar e usufruir das produções culturais, em contextos públicos e privados, atendendo a diferentes intenções e situações de comunicação" (BRASIL, 1997, n.p.). 
Cabe destacar dois aspectos dos PCN (Brasil, 1997) que demonstram ser essenciais para prática docente do professor de educação física: a) O princípio da inclusão e b) as dimensões do conteúdo.

A) O princípio da inclusão propõe que todos os alunos devem participar da aula, não havendo mais espaço para exclusão por gênero, nível técnico ou de pessoas com deficiência.

B) Os conteúdos devem ser abordados nas dimensões procedimentais, atitudinais e conceituais. Devem proporcionar aos alunos, respectivamente, o aprender a fazer, como relacionar-se neste fazer e o porquê estar fazendo.

A educação física escolar passa a ter uma ação libertadora, a qual parte da cultura dos próprios alunos e da sociedade na qual estão inseridos (Brasil, 1997) e ruma em comparação crítica com as práticas corporais hegemônicas, enfrentando “ [...] culturalmente, a cultura da dominação" (FREIRE, 1987, p. 46).

Os saberes das aulas agora devem ser construídos com os alunos, tendo o professor uma atitude do que Freire (1987) chama de educador-educando. Ainda segundo o autor, as aulas devem ter o caráter "[...]dialógico e problematizador [...]", e ao contrário da educação bancária, deve ser uma “ [...] revolução organizada, sistematizada e acrescentada ao povo, daqueles elementos que este lhe entregou de forma desestruturada" (Idem, p. 47).

Diante das contribuições das abordagens pedagógicas aqui apresentadas, é certo que o professor reflexivo na educação física não pode tender à neutralidade. Deve refletir, atuar e acima de tudo assumir um compromisso com o homem e com o mundo. "O compromisso, próprio da existência humana, só existe no engajamento com a realidade, de cujas 'águas' os homens verdadeiramente comprometidos ficam "molhados", ensopados. Somente assim o compromisso é verdadeiro" (FREIRE, $2007, \mathrm{~s} / \mathrm{p})$.

\section{Considerações Finais}

A reflexão acerca da prática docente proporciona um rico levantamento das dificuldades, possibilidades e críticas a padrões indesejados. Discutimos assim a necessidade de que o professor de educação física seja reflexivo, a fim de que este profissional busque compreender melhor os processos relacionados ao seu trabalho desde as necessidades de sua escola às necessidades colocadas pelo mundo. 
Frente às diferentes abordagens da educação física e às lacunas deixadas pela formação profissional, é patente a necessidade de o professor de educação física ser reflexivo e romper com as aulas reprodutivistas e excludentes. Deve-se analisar criticamente sua realidade, libertar-se de modelos de aulas ultrapassadas e incompatíveis com a escola contemporânea e se apropriar de referenciais teóricos que transformem suas práxis visando a formação do cidadão crítico.

Acreditamos contribuir desta maneira à discussão do professor reflexivo na educação física, tecendo subsídio para futuras pesquisas sobre a temática, bem como de colaboração embrionária ao professor de educação física que almeja mudar sua prática docente.

\section{Referências}

ALARCÃO, I A formação do professor reflexivo. In: em uma escola reflexiva. $8^{\underline{a}}$ ed. São Paulo: Cortez, 2011. Professores reflexivos

BRASIL. Secretaria de Educação Fundamental MEC. Parâmetros Curriculares Nacionais de 1aa a $4^{a}$ séries (PCNs): Educação Física, vol.07. Brasília:

MEC/SEF,1997. Disponível em: <http://www.mec.gov.br>. Acesso em 02 out. 2020. Não paginado.

COLETIVO DE AUTORES. Metodologia do Ensino de Educação Física. São Paulo: Cortez, 1992.

DARIDO, S.C. Educação Física na escola: questões e reflexões. Rio de Janeiro. Ed. Guanabara Koogan, 2008

FREIRE, P. Educação e Mudança. 12 ed. Rio de Janeiro: Paz e Terra, 2007. Pedagogia do Oprimido. 17. Ed. Rio de Janeiro: Paz e Terra, 1987.

GIROUX, H. Professores como intelectuais transformadores. In: . Os professores como intelectuais: rumo a uma pedagogia crítica da aprendizagem. Trad. Daniel Bueno. Porto Alegre: Artes Médicas, 1997.

GÓMEZ, A.L.P. Ensino para compreensão. In: SACRISTÁN, J. G. e GÓMEZ A. L. P. Compreender e Transformar o Ensino. Porto Alegre: Artes Médicas, 2008.

LIBÂNEO, J. C. Democratização da escola pública: A pedagogia crítico-social dos conteúdos. 19ª ed. São Paulo: Edições Loyola, 2003. 
PIMENTA, S. G.; GHEDIN, E (orgs.). Professor reflexivo: construindo uma crítica. In: . Professor reflexivo no Brasil: gênese e escrita de um conceito. $7^{a}$ Ed. São Paulo: Cortez, 2012.

SACRISTÁN, J.G. O currículo: os conteúdos do ensino ou uma análise prática?. In: SACRISTÁN, J. G. e GÓMEZ A. L. P. Compreender e Transformar o Ensino. Porto Alegre: Artes Médicas, 2008 


\title{
O QUE APRENDO QUANDO ENSINO? AS VOZES DAS ESTUDANTES DE LICENCIATURA SOBRE A EXPERIÊNCIA DE ALFABETIZAÇÃO DE ADULTOS NO CONTEXTO DE DISTANCIAMENTO SOCIAL.
}

\author{
Janaina Melques Fernandes \\ Ilma Cantuária Alves \\ Isabella Mendonça de Aragão
}

\section{RESUMO}

A comunicação apresenta as vozes dos estudantes do curso de pedagogia e demais licenciaturas da Unimes que participaram, ao longo do ano de 2020 e no primeiro semestre de 2021, das experiências de letramento e alfabetização de adultos no contexto de distanciamento social. Tais práticas fazem parte de um estudo que busca ressignificar a metodologia freireana de alfabetização de adultos, levando em consideração as condições objetivas contemporâneas. A partir da questão geradora "o que aprendo quando ensino?" foram levantadas reflexões sobre potência da práxis e da dodiscência no processo de formação inicial docente dos estudantes, proporcionada pela interação virtual com educandos voluntários. A potência da experiência, narrada nas vozes dos estudantes das licenciaturas, reafirma o comprometimento ético da profissão docente e anuncia a relevância da formação crítica para o processo de conscientização dos sujeitos, sejam educadores ou educandos.

Palavras-chave: Alfabetização de adultos; Paulo Freire; Práxis; Dodiscência.

\section{Introdução}

A comunicação apresenta as vozes dos estudantes do curso de Pedagogia e demais licenciaturas da UNIMES que participaram, ao longo do ano de 2020 e no primeiro semestre de 2021, das experiências de letramento e alfabetização de adultos no contexto de distanciamento social. Tais práticas fazem parte de um estudo que busca ressignificar a metodologia freireana levando em consideração as condições objetivas contemporâneas, entre elas, o maior acesso às tecnologias digitais e o elevado número de pessoas analfabetas que ainda não tiveram a garantia do seu direito à continuidade ao estudo.

De acordo a pesquisa do IBGE (2019), no Brasil, 11 milhões de pessoas com 15 anos ou mais se encontram ainda em situação de analfabetismo. O resultado 
representa uma taxa de $6,6 \%$ da população do país e expressam o quão longe 0 Estado está da consolidação de uma política que possa garantir o direito constitucional descrito no artigo 208 (BRASIL, 1988) e nos artigos 4ํe 37 da LDB/1996, no qual, é dever do Estado, garantir oferta gratuita ao ensino fundamental a todos os que não tiveram acesso na idade própria. Vale ressaltar que o Plano Nacional de Educação (PNE 2014-2024) tem como uma das metas, erradicar o analfabetismo até 2024.

Diante do contexto pandêmico, instaurado em março de 2020, as desigualdades sociais e educacionais têm se mostrado ainda mais aparentes. $O$ cenário suscitou um levante de discussões e ideias sobre o papel dos estudantes das licenciaturas, bem como os desafios da aprendizagem para os diferentes grupos sociais, em especial os adultos. Reconhecendo a urgência de repensar práticas pedagógicas e políticas educacionais que garantam os direitos sociais e inspirados na práxis pedagógica Freireana, professores e estudantes de Pedagogia iniciaram um grupo de estudos e estenderam o convite para as licenciaturas, a fim de fortalecer a execução de investigações teóricas e práticas, todas realizadas virtualmente, de maneira a garantir o distanciamento social e a segurança de todos os participantes. Os estudos teóricos envolvem os princípios e procedimentos da pedagogia freireana, mais especificamente o trabalho de alfabetização, para fundamentar as práticas de letramento e alfabetização com os educandos voluntários. As práticas se realizam a partir da interação entre uma dupla de educadores para cada educando, por meio de conversas e videoconferências no whatsapp.

A superação da tradicional segmentação entre teoria e prática, a partir da experiência com a práxis, proporcionada pela interação com os educandos voluntários, mobilizou compreensões, sensações significativas e com potencial transformador na formação dos estudantes das licenciaturas envolvidos.

Apesar dos grandes desafios ao criar estratégias de alfabetização e letramento pelo celular, os primeiros efeitos da experiência se mostraram promissores. Destacam-se, nesta comunicação, os relatos de estudantes das licenciaturas sobre a experiência, como educadores, buscando responder à pergunta geradora: o que aprendo quando ensino?

O questionamento trouxe à tona a discussão sobre assuntos valorizados na pedagogia freireana: a docência, a discência e a práxis. A primeira corresponde à importância de aprender ensinando, em que o educador e educando apresentam seu 
conhecimento de mundo, suas realidades e saberes, contribuindo para um processo de ensino e aprendizagem que promove a reflexão, a curiosidade e a problematização acerca do ambiente à sua volta. Nessa relação ambos aprendem um com o outro, construindo um vínculo de confiança e respeito. É com a consciência do que aprendemos quando ensinamos que podemos caminhar para uma educação emancipadora fundada na práxis. Segundo Freire, "A teoria sem a prática vira 'verbalismo', assim como a prática sem teoria, vira ativismo. No entanto, quando se une a prática com a teoria tem-se a práxis, a ação criadora e modificadora da realidade." (FREIRE, 1996, p.25). A segunda, portanto, corresponde a uma atividade criadora, em que o sujeito produz e transforma a si mesmo a realidade à sua volta, numa dinâmica de interação entre a teoria e a prática, entre a ação e a reflexão.

É a partir dessa perspectiva que esta comunicação expressa a voz dos estudantes de licenciatura, apresentando os novos saberes da rica interação entre educador e educando. A força da práxis e da dodiscência se fazem presentes na narrativa.

\section{Revisão bibliográfica}

O arcabouço legal do Brasil configura a garantia dos direitos sociais, pois explicita tanto na Constituição Federal (1988), n o artigo 208, quanto na LDBEN(1996), artigos $4^{\circ}$ e 37 , o dever do Estado em garantir oferta gratuita do ensino fundamental a todos que não tiveram na idade própria. Dito isso, é importante destacar que a lei não se reduz à oferta, consolidada com a abertura de classes. O parágrafo $1^{\circ}$, do artigo 37, da LDB, expressa que os sistemas de ensino deverão assegurar aos jovens e aos adultos, que não puderam efetuar os estudos na idade regular, oportunidades educacionais apropriadas, considerando as características dos estudantes, seus interesses, condições de vida e de trabalho.

Levar em conta as características dos educandos, reconhecer seus saberes e territórios, consistem também em ações da pedagogia Freireana que, aliadas a um processo de conscientização, materializam a mudança radical em aspectos fundamentais da vida: na leitura de mundo, na conquista do direito de ler a palavra, na jornada para a emancipação (individual e coletiva). Portanto, a metodologia de alfabetização de adultos de Freire é a principal referência para a elaboração e realização das experiências de letramento e alfabetização de adultos deste estudo. 
Procedimentos como levantamento vocabular, problematização, elaboração de ficha de descoberta, processos de codificação e decodificação, bem como os círculos de cultura, orientaram o planejamento e processo de concepção das ações pedagógicas.

A formação docente para atuar na modalidade EJA ocorre no curso de Licenciatura, porém em sua maioria, sem uma abordagem sobre os conhecimentos teóricos e práticos referente à modalidade de ensino. A qualidade da educação oferecida está fortemente aliada à melhor formação dos professores, consolidada por meio da formação inicial e continuada. "A problematização da formação de professores (as) para atuar na Educação de Jovens e Adultos tem revelado não terem os profissionais [...], habilitação específica para tal, trazendo em suas práticas a marca da precarização[...] (CAPUCHO,2012, p.65)

Dessa maneira, a práxis e a dodiscência se apresentam como elementos mobilizadores da formação crítica docente. Reconhecer o que se aprende quando se ensina, faz parte do processo de conscientização que deve orientar toda educação progressista (FREIRE, 1996).

\section{Metodologia}

A investigação, de natureza qualitativa, utiliza como técnica de coleta de dados, um questionário aberto, com 4 questões diretivas cuja finalidade é apresentar diferentes pontos de vistas e compreensões acerca da pergunta geradora apresentada já no título da comunicação: o que aprendo quando ensino? Participam do questionário sete estudantes das licenciaturas que colaboram e já colaboraram com o estudo.

Para o tratamento e análise das informações, emprega-se a técnica da análise de conteúdo, a fim de compreender os sentidos e identificar os significados expressos nas vozes dos estudantes, principalmente os que se articulam com a dodiscência e a práxis na perspectiva Freireana. Para tanto, a análise foi precedida de revisão bibliográfica e o questionário previamente testado, de forma a avaliar sua aplicação em direção aos objetivos do estudo.

As análises dos resultados baseiam-se no agrupamento das respostas similares dos estudantes e na articulação com a fundamentação teórica. 


\section{Discussão dos resultados;}

Como a proposta desta comunicação é apresentar as vozes dos estudantes de licenciatura sobre a experiência de letramento e alfabetização de adultos, a discussão se desenvolve a partir da comparação e análise de cada pergunta proposta aos participantes.

A primeira questão "Por que escolhi participar do grupo de estudos?" busca identificar as motivações e interesses que envolveram a decisão de aceitar o convite para atuar na experiência. Os participantes revelam, de modo geral, dois grandes motivos para o envolvimento no estudo. O primeiro está relacionado a um processo de conscientização, que se associa a dois enfoques: a consciência das opressões sofridas e dos direitos negados de parte da população e a conscientização da responsabilidade ética, política e profissional do educador. Outro motivo está atrelado ao fato de a proposta ser conduzida com a experiência prática educativa, trazendo um movimento que rompe com a estrutura tradicional acadêmica, cujo caráter livresco não fomenta um estudo crítico e criador, inspirado na dodiscência e na práxis.

A segunda questão "O que aprendi com meus parceiros de estudos e no processo de alfabetização com os educandos?" procura refletir e observar quais aprendizagens emergiram dos procedimentos da investigação. Destacaram os relatos sobre aprender a dar e receber ajuda, repercutindo numa narrativa unânime sobre a importância do trabalho em equipe. Outro ponto abordado foi a dodiscência como guia da relação educador-educando, proporcionando ao educador uma escuta atenta à fala do educando, para aprender com seu universo, seus medos e vitórias. "Não existe docência sem discência." (FREIRE, 1996)

A terceira questão busca identificar quais os desafios encarados ao participar do projeto e se os participantes conseguiram superar os mesmos. Os educadores responderam que construir uma relação dialógica de forma on-line, assim como realizar e acompanhar as atividades e a avaliação dos progressos dos educandos consistiu numa tarefa mais complexa do que imaginada anteriormente. Como exemplo, uma resposta destaca que "até as expressões faciais precisam ser observadas". O contexto do distanciamento social também se apresentou como um grande desafio, sendo necessários muita persistência e convencimento para que os 
educandos não desistissem. Outro desafio apontado foi sobre dar e receber as devolutivas do processo de forma construtiva, mantendo a motivação do grupo. Também foram apontados os problemas com a utilização dos recursos tecnológicos e sobre a insegurança de falar em frente às câmeras.

Com relação à superação dos desafios, todas as respostas apresentam exemplos de superação. Destaca-se a presença, a atenção e a postura acessível de todos os educadores para os educandos; a utilização de recursos como músicas, imagens, mensagens, fotos, áudios e vídeos intencionavam ampliar a conexão e diálogo entre educadores e educandos, mostrando-se oportuno para despertar conexões e manter o interesse dos educandos. Também foi apontado que a disciplina e organização dos educadores, assim como o carinho e a afetividade constituíram elementos fundamentais para o processo de ensino e aprendizagem.

Quando questionados sobre a visão do projeto para os próximos anos, os educadores responderam que conseguem enxergar os educandos atuais lendo e escrevendo, que imaginam o crescimento do grupo com voluntários de diversos lugares e um alcance cada vez maior de pessoas conscientes. Acreditam que o projeto será ampliado, como uma atividade de extensão acadêmica e, até mesmo uma especialização, propiciando formação crítica para novos educadores e educandos. Os educadores também entendem que o projeto se consolida com estudo, prática e experimentação, percebem, sobretudo, que os educandos de hoje podem ser os porta-vozes para encorajar os educandos de amanhã e que o projeto provê mudança e valorização em cada vida, seja do educador ou do educando.

\section{Considerações finais}

A comunicação, ao apresentar as vozes dos estudantes a partir da pergunta geradora: o que aprendo quando ensino? revela a potência da práxis e da dodiscência no processo de formação inicial docente dos estudantes.

O título da comunicação é um convite para refletir sobre as aprendizagens do processo de ensino durante a formação inicial, valorizando a práxis e a dodiscência, dois princípios da pedagogia Freireana que se apresentaram muito significativos ao longo do processo deste estudo, a partir das vozes de quem se abriu para experimentar os desafios de uma formação docente crítica e, portanto, inclusiva e ao longo da vida. 
A fundamentação Freireana orientou todo o movimento do estudo, sobretudo ao tratar da metodologia de alfabetização de adultos. Procedimentos como levantamento vocabular, problematização, elaboração de ficha de descoberta, processos de codificação e decodificação, bem como os círculos de cultura puderam ser ressignificados a partir da experiência práxica e das tecnologias digitais.

A potência da experiência, apresentada pelas vozes dos estudantes das licenciaturas, reafirmam o comprometimento ético da profissão docente e anunciam a relevância da formação crítica para o processo de conscientização dos sujeitos, sejam educadores ou educandos. Em outras palavras, para a formação de educadores comprometidos com uma educação libertadora, é premissa viver o constante e dialético processo de conscientização.

\section{Referências}

BRANDÃO, C. R. O que é método Paulo Freire. São Paulo: Brasiliense, 2013. BRAGA, A. C; MAZZEU, F. J. C. O analfabetismo no brasil: lições da história. Revista on-line de Política e Gestão Educacional, Araraquara/SP, v.21,01, p. 2446, 2017

BRASIL. Constituição Federal do Brasil, de 05 de outubro de 1988.Diário Oficial da União, Brasília, DF, 5 out. 1988. Disponível em:

http://www.planalto.gov.br/ccivil_03/Constituicao/Constituicao.htm. Acesso em: 09/07/2021.

\section{Ministério da Educação. Lei de Diretrizes e Bases da Educação}

Nacional. Lei n. 9.394/96. Disponível em: http://www.planalto.gov.br/ccivil_03/Leis/L9394.htm. Acesso 10 /07 2021.

CAPUCHO, V. Educação de Jovens e Adultos-prática pedagógica e fortalecimento da cidadania. São Paulo. Ed. Cortez. 2012

CARVALHO, V. V. M. As imagens no "Método Paulo Freire" na experiência de Angicos (RN) - 1963. Revista Educação em Questão, Natal, v. 21, n. 7, p. 98-115, set./dez. 2004. disponível em:

https://periodicos.ufrn.br/educacaoemquestao/article/view/8383. Acesso em: 02/03/2021.

FREIRE, P. Educação como prática de liberdade. 5a ed., Rio de Janeiro, Paz e Terra, 1955.

Pedagogia da autonomia: Saberes necessários à prática educativa. São Paulo: Paz e Terra, 1996.

GADOTTI, M. Lições de Freire. Revista da Faculdade de Educação [online]. v. 23, n. 1-2, 1997 Disponível em: <https://doi.org/10.1590/S0102-25551997000100002>. Acesso em: 17/07/ 2021. 
IBGE, Pesquisa Nacional por Amostra de Domicílios (PNAD) 2019.Disponível em: <https://biblioteca.ibge.gov.br/visualizacao/livros/liv101736_informativo.pdf. Acesso em: 17/07/2021.

M, P. Paulo Freire e Antonio Gramsci: a filosofia da práxis na ação pedagógica e na educação de educadores. Revista HISTEDBR, Campinas- SP, set. 2011. Disponível em:

https://periodicos.sbu.unicamp.br/ojs/index.php/histedbr/article/view/8639926/7489. Acesso em: 16 ago. 2021.

NORONHA, O. M. PRAXIS E EDUCAÇÃO. Revista HISTEDBR, Campinas- SP, ed. 20, p. 86-93, dez. 2005. Disponível em:

http://www.gestaoescolar.diaadia.pr.gov.br/arquivos/File/sem_pedagogica/fev_2010/ praxis_educacao.pdf. Acesso em: 26 ago. 2021. 


\title{
PROJETO INTEGRADO À LUZ DE PAULO FREIRE EM UM CURSO DE TECNOLOGIA EM GASTRONOMIA
}

\author{
José Anael Neves \\ Luciana Marchetti da Silva \\ Simone dos Anjos Caivano
}

\section{RESUMO}

A educação a distância vem vivenciando transformações e aperfeiçoamentos no decorrer dos anos. Cada curso exige adequações e metodologias ativas específicas para que o discente atinja o perfil desejado e exigido pelo mercado de trabalho. Este trabalho tem o objetivo de refletir sobre a aprendizagem baseada em projetos, no curso de Tecnologia em Gastronomia na modalidade a distância, sob o ponto de vista da pedagogia de Paulo Freire. Trata-se de uma pesquisa documental, baseada no desenho metodológico dos Projetos Integrados propostos aos estudantes matriculados no $2^{\circ}, 3^{\circ}$ e $4^{\circ}$ semestres deste curso na Universidade Metropolitana de Santos, aliada à pesquisa bibliográfica. Identificou-se que os Projetos Integrados estão direcionados para assumir uma perspectiva da educação popular baseada no pensamento de Paulo Freire, com ênfase na dialogicidade e na autonomia do sujeito, contrapondo-se aos métodos tradicionais, a fim de promover uma prática reflexiva. A dialogicidade em Paulo Freire envolve a participação do educando no processo educativo como sujeito de conhecimento, por isso, a execução dos Projetos Integrados não direciona o ensino do professor para a educando, e sim o ensino é realizado em diálogo com o educando e entre os educandos. Este ensaio tem caráter inovador por tratar-se de uma discussão inédita no campo da formação em Gastronomia. Sugere-se que novos estudos e práticas sejam realizadas e orientadas à luz de Paulo Freire.

Palavras-chave: Educação a Distância; Tecnologia em Gastronomia; Dialogicidade.

\section{INTRODUÇÃO}

A Educação a Distância (EaD) possui uma característica contemporânea e promove a democratização do ensino com a possibilidade de formação superior, sobretudo para este modelo atual de vida moderna totalmente acelerada. Embora esta modalidade ocorra num certo distanciamento geográfico e atemporal entre educadores e educandos, a mediação feita pela tecnologia proporciona informação em novos espaços e possibilidades (GOMES et al., 2019).

A EaD vem vivenciando transformações e aperfeiçoamentos no decorrer dos anos. Cada curso exige adequações e metodologias ativas específicas para que 0 discente atinja o perfil desejado e exigido pelo mercado de trabalho (NEVES et al., 2019). 
Especialmente, o egresso do curso de Gastronomia deve estar capacitado a elaborar produções culinárias com criatividade e técnicas adequadas; a desenvolver competências gerenciais para elaborar projetos gastronômicos e atuar em consultoria; a planejar, organizar e implementar eventos gastronômicos; gerenciar cozinhas e empresas de alimentação, além de dimensionar cardápios dentro dos padrões da etiqueta formal; a aplicar protocolos de higiene pessoal, ambiental e de utensílios na manipulação de alimentos. Diante disso, o principal desafio do curso é desenvolver atividades a distância que propiciem o aprendizado prático e sua avaliação (CAIVANO et al., 2020; NEVES \&SILVA, 2020).

A ideia que de que o professor deve transmitir conhecimentos ao aluno e que este deve memorizá-los, internalizá-los e repeti-los mecanicamente, denominada "concepção bancária”, é contrária a proposta de Freire (2005), o autor preconiza a estratégia da ação-reflexão-ação, utilizando como ferramentas o estímulo à curiosidade, à postura ativa e à experimentação do aluno, fomentando a análise crítica da realidade durante a formação. A partir desta reflexão, os docentes e gestores do curso de Tecnologia em Gastronomia da Universidade Metropolitana de Santos (UNIMES) desenvolveram os componentes curriculares denominados Projetos Integrados I, II e III, atividades em que os alunos podem se perceber como agentes ativos e interativos do processo de aprendizagem e aplicar, na prática, os conteúdos estudados durante os diferentes semestres (NEVES et al., 2019).

Sendo assim, este trabalho tem o objetivo de refletir sobre a aprendizagem baseada em projetos, no curso Tecnológico de Gastronomia na modalidade a distância, sob o ponto de vista da pedagogia de Paulo Freire.

\section{REVISÃO BIBLIOGRÁFICA}

\section{A DIALOGICIDADE DE PAULO FREIRE NA RELAÇÃO EDUCATIVA}

De acordo com os preceitos de Paulo Freire, o processo educativo parte do educando, num sentido de dentro pra fora, em que o educador oferece a sua colaboração. Desta forma, o método educativo não é somente do educador, mas é também do educando, com característica ativa, dialógica e crítica (FREIRE, 1986). A educação não é transferência de conhecimento, esta deve ser centrada na comunicação e no diálogo. Como seres de autonomia, pelo diálogo, os indivíduos são estimulados a pensar e a repensar o pensamento do outro na construção do 
conhecimento. "O diálogo pertence à natureza do ser humano, enquanto ser de comunicação. O diálogo sela o ato de aprender, que nunca é individual, embora tenha uma dimensão individual" (FREIRE, 1986, p.14).

As experiências do educador são fundamentais, no entanto, ele precisa ter sensibilidade para esse diálogo a fim de que não se crie uma relação em que o educador que sabe, distanciando-o do educando Freire (2005, p.67) diz: "Ninguém é sujeito da autonomia de ninguém", ela é resultado de um esforço individual que gera o próprio amadurecimento e se constrói nas relações entre seres humanos e, somente nestas interações, ela se consolida. (FREIRE, 2005). Em suma, a educação freireana pauta-se no educador tornando o educando o sujeito da relação (FREIRE, 1986).

\section{TECNOLOGIA PROMOVENDO INTERAÇÃO ENTRE EDUCADORES E}

\section{EDUCANDOS}

A Tecnologia da Informação e Comunicação (TIC) quando inserida na educação, agrega muitas vantagens no processo de ensino-aprendizagem a partir do uso de ferramentas que proporcionem a oportunidade de diálogos entre educadores e educandos, bem como a realização de atividades em grupo (SEIXAS \& MANCINI, 2020). Conforme Freire (2002, p. 36), "ninguém nos ensina a fazer essas coisas, mas também não aprendemos a fazê-las sozinhos. Aprendemos a fazê-las interagindo com os outros".

O método pedagógico desenvolvido por Paulo Freire não é rígido ou estanque, estrutura-se no processo de ensino-aprendizagem, propõe trabalhar com conteúdos presentes no dia a dia dos alunos, associando dois objetivos interligados: a instrumentalização teórico-prática dos alunos, que buscam a apropriação do conhecimento, assim como um posicionamento progressivamente crítico e questionador (CARVALHO, 2006).

Dentro do universo da modalidade a distância, para que os princípios de Paulo Freire possam ser colocados em prática, a TIC deve garantir a interatividade entre os envolvidos. Há diversos recursos, entre eles, a ferramenta Wiki, que possibilita a construção de material conjunto entre os educandos, acompanhada pelo educador. Toda a produção textual é cooperativa e colaborativa: os educandos utilizam uma mesma plataforma para construir e modificar textos, quadros, tabelas, gráficos e imagens, mediados pelo educador (CARRIL \& ZOCCAL, 2020). 


\section{PROJETOS INTEGRADOS}

Os Projetos Integrados abordam a metodologia ativa que consiste na aprendizagem baseada em projeto, que tem o objetivo de "contribuir para o desenvolvimento da capacidade científica, crítico-reflexiva e criativa do aluno, articulando seu processo formativo" (UNIMES, 2017, p.27), a partir do desenvolvimento e apresentação de projeto integrando outros componentes curriculares e seus conteúdos.

O Projeto Integrado I tem a proposta de ser realizado em grupo e tem como objetivo proporcionar a possibilidade de reprodução de receitas saborosas e saudáveis, que envolvam a reflexão sobre elementos que contemplem as cozinhas regionais brasileiras, os significados e aspectos culturais da alimentação, os aspectos higiênico-sanitários, costumes locais e desenvolvimento sustentável. Sua proposta é integrar os diferentes componentes curriculares do segundo semestre em um único produto (NEVES et al., 2019).

Também com proposta de realização em grupos, o Projeto Integrado II sugere a reflexão, a produção de um cardápio e a reprodução de pratos clássicos da gastronomia internacional, por meio da articulação de conhecimentos construídos no segundo semestre do curso de Tecnologia em Gastronomia, enquanto no Projeto Integrado III, os estudantes se debruçam sobre a criação de preparações inovadoras em panificação e confeitaria a partir de todas técnicas culinárias aprendidas durante o curso (NEVES et al., 2019).

Os alunos são orientados a pesquisar, ler, construir textos, discutir, criar ou replicar receitas e experiências que relacionem temas dos diferentes componentes curriculares do semestre. Os trabalhos devem ser realizados em formato de relatórios cientificamente organizados, de acordo com as normas da ABNT - Associação Brasileira de Normas Técnicas. Tudo isso construído em três etapas, as quais têm diferentes objetivos e são disponibilizadas em conformidade com a agenda pedagógica (CAIVANO et al., 2020).

\section{MÉTODO}

O método do presente estudo é a pesquisa documental, baseada no desenho metodológico dos Projetos Integrados propostos aos estudantes matriculados no $2^{\circ}$, $3^{\circ}$ e $4^{\circ}$ semestres do curso de Tecnologia em Gastronomia da UNIMES (UNIMES, 
2017), aliada à pesquisa bibliográfica em educação alimentar e nutricional, que tem em Paulo Freire, um dos seus principais referenciais.

Vale ressaltar que a Educação Alimentar e Nutricional é um campo correlato à Gastronomia que trata do conhecimento e da prática contínua e permanente, transdisciplinar e multiprofissional que visa promover a prática autônoma e voluntária de hábitos alimentares saudáveis. A prática da Educação Alimentar e Nutricional deve fazer uso de abordagens e recursos educacionais problematizadores e ativos que favoreçam o diálogo junto a indivíduos e grupos populacionais (BRASIL, 2012, p. 23). Por tratar-se de um campo de conhecimento e de prática predominantemente brasileiro, a pesquisa bibliográfica foi orientada pela utilização das seguintes palavraschaves na Scielo - Brasil: Educação Alimentar e Nutricional, Gastronomia, Paulo Freire, Autonomia, Dialogicidade e Metodologias Ativas.

\section{DISCUSSÃO DOS RESULTADOS}

Do ponto de vista teórico-metodológico, os Projetos Integrados do curso de Tecnologia em Gastronomia da UNIMES estão direcionados para assumir uma perspectiva da educação popular baseada no pensamento de Paulo Freire, com ênfase na dialogicidade e na autonomia do sujeito, contrapondo-se aos métodos tradicionais, a fim de promover uma prática reflexiva dos sujeitos sobre si (SANTOS, 2012). A dialogicidade em Paulo Freire envolve a participação do educando no processo educativo como sujeito de conhecimento, por isso, a execução dos Projetos Integrados na perspectiva freireana não direciona o ensino do professor para o educando, e sim o ensino é realizado em diálogo com o educando e entre os educandos (OLIVEIRA, 2017).

Inspirados em Paulo Freire, os Projetos Integrados optam pela técnica de grupos de discussão centrados em temas geradores, que são temáticas de significativa relevância prática para a área da Gastronomia. O diálogo é considerado fundamental na comunicação entre educador e educandos, devendo ocorrer de forma horizontal sob a coordenação do educador (FREIRE, 2008).

Os projetos integrados são espaços de socialização e de construção de saberes coletivos, uma vez que propõem traços de uma educação não formal, com características da Pedagogia freiriana, já que contraria a ideia da educação bancária, 
em que o educador vê o educando como um "depósito" de todos os seus conhecimentos, detentor de todos os saberes e de verdades absolutas. No desenho dos projetos integrados têm-se a oportunidade de construir conhecimentos sobre as cozinhas regionais brasileiras, cozinhas internacionais e panificação e confeitaria, em paralelo à realidade dos estudantes em suas múltiplas realidades, convidando-os para um debate crítico e dinâmico, levantando assuntos inovadores tais como o papel do gastrônomo frente à difusão da sustentabilidade ambiental, e a importância e valorização da Gastronomia regional.

A Pedagogia libertadora e dialógica de Paulo Freire tem como princípio viabilizador de um processo de ensino-aprendizagem crítico a aproximação das vivências da realidade do educando e uma educação acima de tudo problematizadora, conforme destacam Tomaz \& Tomasi (2021). Esses princípios orientam o desenho dos projetos Integrados.

[...] o educador já não é o que apenas educa, mas o que, enquanto educa, é educado, em diálogo com o educando que, ao ser educado, também educa. Ambos, assim, se tornam sujeitos do processo em que crescem juntos e em que os "argumentos de autoridade" já não valem. Em que, para ser-se, funcionalmente, autoridade, se necessita de estar sendo com as liberdades e não contra elas (Freire, 2005, p. 33).

\section{CONSIDERAÇÕES FINAIS}

O referencial de Paulo Freire já é bastante reconhecido no campo da Educação Alimentar e Nutricional, e recente sua inserção no contexto da formação em Gastronomia (Neves \& Silva, 2020). A potencialização do diálogo é um desafio constante da execução Projetos Integrados. Espera-se que os referenciais de Paulo freire reflitam nas práticas cotidianas de formação dos profissionais de Tecnologia em Gastronomia. Mais uma vez, referenciando Paulo Freire, no livro Pedagogia da Autonomia: "de nada adianta o discurso competente se a ação pedagógica é impermeável a mudanças", este é um desafio que nos impulsiona a pensar.

Finalmente, este ensaio tem caráter inovador por tratar-se de uma discussão inédita no campo de formação de profissionais da Gastronomia. Sugere-se que novos estudos e práticas sejam realizadas e orientadas à luz de Paulo Freire, para que seja 
possível uma formação em Gastronomia ainda mais horizontal e comprometida com a construção popular de saberes.

\section{Referências}

BRASIL. Ministério do Desenvolvimento Social e Combate à Fome. Secretaria Nacional de Segurança Alimentar e Nutricional. Marco de Referência de Educação Alimentar e Nutricional para as Políticas Públicas. Brasília-DF: Ministério da Saúde, 2012.

CAIVANO, S.A.; SILVA, L.M.; ALVARES, R.A.;NEVES, J. A. O perfil do aluno de um curso de Tecnologia em Gastronomia na modalidade a distância. Revista Educação a Distância, v. 10, p. 137-151, 2020.

CARRIL, M. G. P.; ZOCAL, S. I. L. A avaliação e a ferramenta wiki: uma contribuição para a formação docente na educação a distância. In: Elisabeth dos Santos Tavares; Gisele da Silva Esteves Camargo Prado. (Org.). Educação a Distância - Desafios de uma trajetória. 1ed.São Paulo: LiberArs, 2020, v. 3, p. 143-151.

CARVALHO, Ana Verena et al. EAD e Paulo Freire: uma relação possível. SEMOCSemana de Mobilização Científica-EAD e Paulo Freire: uma relação possível, 2006. FREIRE, P. Educação como Prática da Liberdade. 17.ed. Rio de Janeiro: Paz e Terra, 1986.

FREIRE, P. Educação e mudança. 31. ed. Tradução Moacir Gadotti e Lilian Lopes Martin. Rio de Janeiro: Paz e Terra, 2008.

FREIRE, P. Pedagogia da autonomia: saberes necessários à prática educativa. 25. ed. São Paulo: Paz e Terra, 2002.

FREIRE, Paulo. Pedagogia do Oprimido. Rio de Janeiro: Paz e Terra, 2005.

GOMES, A. N.; BIAZON, D. M.; BEZERRA, K. M.; SILVA, T. C. Educação a distância? Nem tão a distância assim! Elisabeth dos Santos Tavares; Neuza Maria de Souza Feitosa. (Org.). Educação a Distância - Desafios de uma trajetória. 1.ed.São Paulo: LiberArs, 2019, v. 1, p. 11-18.

NEVES, J. A.; MARCHETTI, L.; CAIVANO, S. Metodologias Ativas por meio da aprendizagem baseada em projeto: experiência exitosa no curso de gastronomia na modalidade a distância. In: Elisabeth dos Santos Tavares; Neuza Maria de Souza Feitosa. (Org.). Educação a Distância - Desafios de uma trajetória. 1.ed.São Paulo: LiberArs, 2019, v. 1, p. 57-64. 
NEVES, J. A.; SILVA, L.M. Avaliação em Gastronomia: uma análise do conteúdo das provas específicas do ENADE dos anos de 2009, 2015 e 2018. In: Elisabeth dos Santos Tavares; Gisele da Silva Esteves Camargo Prado. (Org.). Educação a Distância - Desafios de uma trajetória. 1.ed.São Paulo: LiberArs, 2020, v. 3, p. 7988.

OLIVEIRA, I.A. A dialogicidade na Educação de Paulo Freire e na Prática do ensino de Filosofia com Crianças. Movimento-Revista de Educação, Niterói, ano 4, n.7, p.228-253, jul./dez. 2017.

SANTOS, L.A.S. O fazer educação alimentar e nutricional: algumas contribuições para reflexão. Ciência \& Saúde Coletiva, 17(2):453-462, 2012.

SEIXAS, D. S.; MANCINI, K. Wiki - O uso desta ferramenta interativa no processo de avaliação. In: Elisabeth dos Santos Tavares; Gisele da Silva Esteves Camargo Prado. (Org.). Educação a Distância - Desafios de uma trajetória. 1.ed.São Paulo: LiberArs, 2020, v. 3, p. 153-161.

TOMAZ, H.S.C.; TOMASI, A.R.G. Formação em gastronomia: sustentabilidade e extensão como pressupostos para o desenvolvimento local, Revista Contribuciones a las Ciencias Sociales, v. 1, o 3, p.13-32, 2021.

UNIMES. Faculdade de Educação e Ciências Humanas. Projeto Político Pedagógico do Curso Tecnológico a Distância em Gastronomia. Santos, 2017. 


\section{A DEMOCRACIA EM PAULO FREIRE}

Maurício Nunes Lobo

Ana Kalassa El Banat

\section{RESUMO}

A trajetória de Paulo Freire é repleta de lições de vida, de esperança, de amor a educação e aos educandos. Nesta proposta visamos mencionar a relação de Paulo Freire com a democracia e a autonomia, seja através de seus livros, seja no seu engajamento político. A relação entre teoria e prática sempre foi muita cara para Freire. Desde os seus primeiros escritos, a prática pedagógica e o engajamento político estavam associados. Seja passando pelos momentos de repressão política, em que foi obrigado a deixar o país, seja nos momentos democráticos, antes e depois da ditadura civil-militar, no primeiro a frente do Ministério da Educação de João Goulart e depois a frente da Secretaria de Educação da Prefeitura de São Paulo no governo de Luiza Erundina, a educação em Freire é sempre um ato político.

\section{Palavras Chave: Democracia, Autonomia, Paulo Freire}

\section{Introdução}

Paulo Freire foi um destes intelectuais que "não se faz mais" ou "que não encontramos com facilidade" nos dias de hoje. Além de possuir um pensamento contundente e alinhado com a defesa da escola, da educação crítica de qualidade, da diminuição das desigualdades sociais e econômicas e da luta pela democracia que se constrói coletivamente, era um homem de práxis que atuou seja como um educador progressista seja como gestor na construção de políticas e métodos que buscaram transformar sua teoria em realidade.

(...) a sua obra e vida testemunham sempre a sua clara opção política contra qualquer tipo de autoritarismo, desrespeito, injustiça, desigualdade, etc. A filosofia de Freire, ao contrário, se posiciona a favor da liberdade, da justiça, da ética e da autonomia do ser humano, da escola, da sociedade. Mais ainda, Freire percebe que a democracia não acontece de uma hora para outra, por decreto, por uma concessão de uma autoridade que se autointitula democrática, ou apenas quando a sociedade deixar de ser capitalista. (GASPARELLO, 2002, p.1)

A teoria e a prática de Freire valorizaram, entre outros, a democracia que é fruto do fazer em conjunto com os próprios agentes para o qual a política ou a ação são desenvolvidos, num movimento de luta para conquista de direitos. 
Ele entende que a democracia, a liberdade, a autonomia, é um processo. Mas não é um processo de cima para baixo, e sim uma conquista conjunta, coletiva, que exige respeito, diálogo e poder de decisão a todos que participam dessa caminhada. (GASPARELLO, 2002, p.1)

\section{Revisão bibliográfica}

A democracia ou forma de concebê-la é, contudo, bem diferente do modelo de democracia institucionalizado por governos desde a Revolução Francesa e que tem como referência o conhecido exemplo grego antigo na pólis de Atenas. Fazendo um rápido retrospecto podemos entender o porquê.

A palavra democracia, como bem conhecemos, é de origem grega e sabemos mais seu significado do que seu uso no auge do período em que esteve em vigor na Atenas clássica. "Demos" significa povo e "cracia" governo ou governar, temos a democracia como o governo do povo. Mas quem era o povo na Atenas clássica do século $\mathrm{V}$ a.C.?

A cidade-Estado de Atenas ao final do século VI a.C. enfrentou uma série de manifestações sociais de grupos insatisfeitos com a desigualdade e os privilégios políticos da Aristocracia e de sua forma de governo. Os demiurgos, comerciantes que enriqueceram com o comércio entre as colônias do sul da Itália e da Sicília, bem como do litoral da Ásia Menor, atual Turquia e a grande pólis ateniense reivindicavam reformas que garantissem sua participação nas decisões do sistema político.

Até este momento apenas os homens livres nascidos nas famílias mais importantes é que participavam da vida política. "Aristói" em grego significa, os melhores", portanto a Aristocracia como o "governo dos melhores" excluía a maior parte da população das decisões.

Isso começou a mudar um pouco antes com as reformas promovidas pelo legislador Sólon, em 594 a.C., que extinguiu a escravidão por dívidas, criou a divisão censitária de acordo com a renda (permitindo ascensão dos demiurgos), e consolidou as instituições políticas com a criação da "Bulé", Conselho dos 400, participando cidadãos de todas as regiões de Atenas, "Eclésia", Assembleia popular eleita pela Bulé e que votava as leis preparadas na Bulé, e "Helieu ou Heliéa", tribunal de justiça em que todos os cidadãos podiam participar. 
As reformas de Sólon apesar de acalmarem os insatisfeitos por algum tempo, foram insuficientes para conter as manifestações de vez. Depois de um período de tirania, em 510 a. C., Clístenes, mais um legislador importante, liderou uma rebelião contra o último tirano de Atenas, ampliando as reformas que culminaram na implantação da Democracia. Ainda, promoveu a ampliação da Bulé para 500 membros de todas as tribos da pólis, bem como o crescimento da Eclésia para 60 mil cidadãos e a institucionalização do Ostracismo, exílio de 10 anos para todo aquele que ameaçasse a Democracia.

Mas não podemos esquecer que a Democracia grega se alicerçava no regime escravista e mesmo com reformas ainda excluía as mulheres, os estrangeiros e os escravos da política. Apesar das suas desigualdades o regime democrático foi um modelo na busca pela maior participação nas decisões e na construção dos direitos políticos dos cidadãos.

Demorou mais de dois milênios para que a Democracia retornar como um regime de governo. Somente após a Revolução Francesa de 1789 é que a Democracia voltou como forma de governo, mas na era moderna ela passou a ser representativa e não direta como foi na antiguidade clássica. Uma definição interessante sobre a diferença entre a democracia antiga e a moderna é de Renato Janine Ribeiro:

Uma imagem que nos vem da Antiguidade é a da nau do Estado. A pólis, na Grécia, ou a civitas, em Roma, se compara a um navio. O governante é o piloto. Mas Paul Veyne, o melhor historiador atual da Roma Antiga, lembra que a nau do Estado, antiga, não leva passageiros. Ela tem piloto e tripulantes: ninguém embarca pagando só passagem. Nós, modernos, somos passageiros da nau do Estado. Pagamos impostos, obedecemos às leis, como bons clientes que quitam o valor cobrado - mas não nos chamem para mexer no cordame, ajeitar a vela! Se nos pedem isso protestamos. E dizemos que o Estado não cumpre sua tarefa (porque não acreditamos, nem nas democracias, que o Estado somos nós). (...) a democracia antiga é vista, geralmente, como superior à moderna. Invejamos os atenienses. Perdemos muito da dimensão pública. Acabou a democracia direta, começou a representação. Mas entremos na democracia moderna pelo que ela tem de melhor. Porque ela não é uma degradação da antiga: traz uma novidade importante - os direitos humanos. (2001, p.14-5) 
A Democracia moderna, burguesa ou liberal passou de um "governo do povo" e tornou-se cada vez mais um "governo para o povo". Tal democracia não é capaz de oferecer uma alternativa as desigualdades presentes na sociedade moderna e acabam reproduzindo a exclusão de classe, de etnia, de gênero, de diferenças religiosas, entre outros. Nada mais contrário a ideia de democracia de Paulo Freire:

\begin{abstract}
Um desses sonhos para que lutar, sonho possível mas cuja concretização demanda coerência, valor, tenacidade, senso de justiça, força para brigar, de todas e de todos os que a ele se entreguem, é o sonho por um mundo menos feio, em que as desigualdades diminuam, em que as discriminações de raça, de sexo, de classe sejam sinais de vergonha e não de afirmação orgulhosa ou de lamentação puramente cavilosa. No fundo, é um sonho sem cuja realização a democracia de que tanto falamos, sobretudo hoje, é uma farsa. (2001, p.25)
\end{abstract}

Desta forma não basta o governo se auto intitular democrático pela existência da sociedade de direto "à liberdade", ao voto universal, etc.

A democracia para ele é um ato político que deve estar presente em todas as instâncias sociais e não apenas na instância de governo. A participação e as decisões devem ocorrer de baixo para cima para romper com a opressão.

O respeito à autonomia e a dignidade de cada um é um imperativo ético e não um favor que podemos ou não conceder uns aos outros. (...) É nesse sentido também que a dialogicidade verdadeira, em que os sujeitos dialógicos aprendem e crescem na diferença, sobretudo, no respeito a ela, é a forma de estar sendo coerentemente exigida por seres que, inacabados, assumindo-se como tais, se tornam radicalmente éticos (...) O que quero dizer é o seguinte: que alguém se torne machista, racista, classista, sei lá o quê, mas se assuma como transgressor da natureza humana. Não me venha com justificativas genéticas, sociológicas ou históricas ou filosóficas para explicar a superioridade da branquitude sobre a negritude, dos homens sobre as mulheres, dos patrões sobre os empregados. Qualquer discriminação é imoral e lutar contra ela é um dever por mais que se reconheça a força dos condicionamentos a enfrentar. (FREIRE, 1996, p.66-7)

Para ele a democratização da sociedade passa pelo reconhecimento das "minorias" enquanto "maiorias", ou melhor, dos oprimidos ocupando e se reconhecendo nos espaços de decisão. É no esforço para romper com as desigualdades econômicas, sociais e políticas o caminho para a democratização da sociedade. 
Para nós, a participação não pode ser reduzida a uma pura colaboração que setores populacionais devessem e pudessem dar à administração pública. Participação ou colaboração, por exemplo, através dos chamados mutirões por meio dos quais se reparam escolas, creches, ou se limpam ruas ou praças. A participação, para nós, sem negar este tipo de colaboração, vai mais além. Implica, por parte das classes populares, um "estar presente na história e não simplesmente estar nela representadas”. Implica a participação política das classes populares através de suas representações no nível das opções, das decisões e não só do fazer o já programado. Por isso é que uma compreensão autoritária da participação a reduz, obviamente, a uma presença concedida das classes populares a certos momentos da administração. Para nós, também, é que os conselhos de escola têm uma real importância enquanto verdadeira instância de poder na criação de uma escola diferente. Participação popular para nós não é um slogan mas a expressão e, ao mesmo tempo, o caminho da realização democrática. (FREIRE, 2000, p. 75)

Paulo Freire é um dos poucos intelectuais em que a teoria e a prática estão sempre juntas.

Um dos momentos em que isso se evidencia é no período de 1989 a 1991 em que ele esteve a frente da Secretaria de Educação Municipal de São Paulo.

Neste verdadeiro processo de democratização da gestão da educação foram criados e incentivados os Conselhos de Escola, Conselhos Regionais de Escola, Grêmios Estudantis, o Regimento Comum das Escolas Municipais, e os ciclos de aprendizagem na construção coletiva do currículo.

Democratizando as várias instâncias da gestão da educação municipal num processo de circulação de informação e compartilhamento das decisões que aconteceu verdadeiramente "de baixo para cima", um governo do povo onde o papel do professor teve destaque como dizia ele "O educador é o sujeito de sua prática, cumprindo a ele, criá-la e recriá-la". (FREIRE, 2000, p.80)

Desta forma fica evidente que o pensamento e a prática de Paulo Freire são uma lição de luta para construção de uma sociedade e uma escola mais justa, ética e democrática.

\section{Referências Bibliográficas}

FRANCO, Dalva de Souza. A gestão de Paulo Freire à frente da Secretaria Municipal de Educação de São Paulo (1989 - 1991) e suas consequências. Pro-Posições [online]. 2014, vol.25, n.3, pp.103-121. ISSN 1980-6248. http://dx.doi.org/10.1590/0103-7307201407506. 
FREIRE, Paulo. Pedagogia do Oprimido. 10ª ed. Rio de Janeiro: Paz e Terra, 1981. . Pedagogia da Esperança: Um reencontro com a Pedagogia do oprimido. $3^{\text {a }}$ ed. Rio de Janeiro: Paz e Terra. 1994. . Pedagogia da Autonomia: Saberes Necessários à Prática Educativa. $2^{\mathrm{a}}$ ed. São Paulo: Paz e Terra (Coleção Leitura), 1996. . A Educação na Cidade. 4.ed. São Paulo: Cortez, 2000.

GASPARELLO, Vania Medeiros. "A Pedagogia da Democracia de Paulo Freire". 25르 Reunião da ANPED. Caxambu: MG, 2002. Disponível em: 25reuniao.anped.org.br/vaniamedeirosgasparellot05.rtf. RIBEIRO, Renato Janine. A democracia. São Paulo: Publifolha, 2001. 


\section{POÉTICAS DO DESENHO E O PRESENTE NÃO POÉTICO}

Rubens de Souza

É a segurança que se expressa na firmeza com que atua, com que decide, com que respeita as liberdades, com que discute suas próprias posições, com que aceita rever-se.

Paulo Freire

\section{INTRODUÇÃO}

Paulo Freire sempre reflete sobre a prática pedagógica progressiva, autonomia e fortalecimento democrático na educação.

No segundo semestre do ano de 2018, o Curso de Licenciatura em Artes Visuais ofereceu a seus estudantes a atividade de extensão universitária, denominado Poéticas do Desenho. A partir do recurso do streaming, o curso atendeu a alunos de diferentes regiões do país conectados na Internet, portanto, a distância. Houve quatro encontros virtuais que objetivaram práticas artísticas para elaboração de desenhos.

Os resultados dessa ação pedagógica foram satisfatórios e os alunos vivenciaram o fazer artístico, na modalidade de educação a distância, tais iniciativas são escassas via de regra.

Paralelo a isso, docentes, principalmente da Educação Básica assistem de forma dócil e passiva, e muitas vezes sem entender, o esfacelamento do Sistema Público de Ensino, seu rebaixamento e qualidade, ainda a redução do financiamento público para a educação, a pauperização da Escola Pública, a ampliação dos processos de privatização e a ausência de aumento salarial.

Indiferentes à reforma da Educação Básica e à Base Nacional Comum Curricular - BNCC é homologada, no mesmo momento em que surgem comentários falaciosos sobre Paulo Freire classificando-o como o grande mentor da ideologia "comunista" na aprendizagem, tanto na Educação Básica, quanto no Ensino Superior e a tentativa de desqualificá-lo e retirá-lo como Patrono da Educação Brasileira.

Justifica-se o tema e se faz necessário analisar algumas teorias freirianas, as recentes políticas educacionais brasileira, por reduzir de maneira significativa, conteúdos e práticas frequentes ao ensino da arte. Ainda, por enfatizar que processos democráticos, são escamoteados, a partir de uma espécie de fundamentalismo 
econômico ultraliberal engendrado nos governos de Michel Temer e Jair Bolsonaro. Certamente, recorre-se a Paulo Freire por ser o maior defensor da educação brasileira.

A vivência da Oficina de desenho e de ações pedagógicas eminentemente práticas, tornam-se relevantes, por explorar aspecto da criatividade e da criticidade, que vão contra a lógica imposta na estrutura da educação brasileira e a favor do pensamento freireano, que será analisado a seguir. Enfatizou-se que tais reflexões são fundamentais na formação docente, para legitimar seu protagonismo.

Nesse artigo, objetivamos identificar a importância do ensino e aprendizagem do desenho na educação básica e identificar a escassez dessa mesma prática na BNCC, para o Ensino Fundamental anos finais e para o Ensino Médio. Outro aspecto relevante é precisamente a palavra "poética", que aparece apenas oito vezes nesse documento.

A pesquisa se estrutura em procedimentos metodológicos bibliográficos. Será importante revisitar a obra: Pedagogia do Oprimido de Freire, por criticar a denominada "educação bancária", ao identificar processos de ensino e aprendizagem, nos quais o estudante se torna passivo, e há uma automatização dos conteúdos escolares, que propiciam pouco fazer artístico. O livro: Pedagogia da Autonomia, no capítulo: Ensinar exige disponibilidade para o diálogo, prevê novos olhares para o cotidiano do estudante, a partir da prática artística.

O processo de padronização dos currículos da educação básica, assim como os mecanismos de controle sobre o trabalho docente é antigo e crescente. A Lei de Diretrizes e Bases da Educação Nacional, Lei no 9.394/96 confirmam essa sistematização restringindo cada vez mais a autonomia das escolas e de seus docentes em métodos homogeneizadores. Destaca-se na Lei o Inciso IV do artigo 9o sobre a "formação básica comum" (Brasil, 1996), a partir das diretrizes curriculares em toda a educação básica.

Nesse sentido, identifica-se na obra Pedagogia da Autonomia de Freire importantes fundamentos, que insere professor e aluno em seu protagonismo.

O ensino tradicional estabelece que o educador seja autoritário e conservador. Atualmente, essa postura é muito recorrente e ganha espaço como boa prática pedagógica. Os docentes adeptos dessa postura, por vezes anulam a curiosidade e 
solicitam total subserviência dos alunos, em sala de aula. Freire alerta, que todos somos seres inacabados e a curiosidade nos remete a novas investigações diante do fenômeno social, cultural e científico. Nesse sentido o diálogo será fundamental estratégia para propiciar autonomia aos estudantes. Um incansável exercício de escuta de todos os protagonistas, estudantes e docentes. Ao contextualizar fatos políticos e sociais, da atualidade, percebe-se que o pensamento mais conservador e tradicional, entre os docentes da educação básica, se amplia principalmente nas escolas públicas. O método freireano considera, também, o movimento dialético do processo histórico,

[...] Freire não inventou o homem; apenas pensa e pratica um método pedagógico que procura dar ao homem a oportunidade de redescobrir-se através da tomada reflexiva do próprio processo em que ele vai se descobrindo, manifestado e configurando - método de conscientização. (FREIRE, 2017, p. 20)

Nesse sentido, sua obra enfatiza sobre ações pedagógicas fundamentais e capazes de codificar e descodificar o contexto social que vivenciamos, a partir de palavras geradoras que propiciem novas reflexões. Esse método iniciou na alfabetização, porém é oportuno em qualquer processo de ensino.

Contrário a isso, a Lei de Diretrizes Curriculares se consolidou como práticas obrigatórias e orientadoras do trabalho docente, dividindo em duas partes: a de conhecimento comum e a diversificada. Freire alertava "O educador democrático não pode negar-se o dever de, na sua prática docente, reforçar a capacidade crítica do educando, sua curiosidade, sua insubmissão", (FREIRE, 2018). Portanto, Freire reafirma a necessidade do método esse, por sua vez não deve vincular o discurso "bancário". Assim, a necessidade da investigação, contextualização que pressupõe conhecer e interagir no mundo. Certamente, a padronização curricular define as áreas de ensino da educação básica, como adequados para sua qualidade.

Vale destacar os Parâmetros Curriculares Nacionais de 1997, PCN, que orientam cada componente curricular que resultaram em diferentes matérias e principalmente, o livro didático, que alimentaria essa indústria rentável. Não somente isso, mas ao sistema nacional de avaliação, como forma de aferir a qualidade do ensino brasileiro. Décadas se passaram e os resultados ainda não são satisfatórios.

Os PCNs reforçam a necessidade das relações interdisciplinar e transdisciplinar. Freire afirma que o ato de ensinar exige pesquisa. São fundamentos 
distintos e distantes. O princípio epistemológico insere docente e estudante na necessidade natural que se tem sobre o conhecimento.

Essa homogeneização resultou na Base Nacional Comum Curricular - BNCC, que se vincula aos documentos legais, anteriores: Lei de Diretrizes e Bases de 1996, a Resolução do Conselho Nacional de Educação e Câmara de Educação Básica, 2012 e ao Plano Nacional de Educação de 2014 para uma base comum nacional.

A BNCC imediatamente encontrou os defensores de sua iniciativa, a partir de fundações e organizações não governamentais vinculadas a bancos, empresas, conglomerados do capital estrangeiro e nacional e gestores de diferentes segmentos. Com o argumento de defesa da educação pública e sua qualidade, quando na realidade verifica-se o campo rentável de negócios.

Especificamente, para o componente curricular Artes, na educação básica condiciona aos docentes a polivalência, ou seja, administrar aula de dança, teatro, música e visuais, ao mesmo tempo, seu caráter tecnicista.

\section{A POÉTICA E O DESENHO}

A oficina de desenho, denominada Poéticas do Desenho, destinada aos alunos do curso de Artes Visuais da Universidade Metropolitana de Santos cumpre o propósito de propiciar atividades práticas ao curso de Artes na modalidade a distância, além de explorar aspectos estéticos, contextualização da arte e o fazer artístico. Sabese que a elaboração dos currículos estabelecidos nas aulas de arte, para a educação básica, ainda enfatiza seu caráter estético como simples adorno, e muitas vezes conteúdos vagos sem explicitar dimensões de conhecimentos fundamentais na educação. A proposta de leitura, interpretação e contextualização da obra de arte encontra fortes similaridades com o método freireano, por despertar no estudante novas percepções sobre seu contexto social, cultural e por vezes, político.

Nosso papel não é falar ao povo sobre a nossa visão do mundo, ou tentar impô-la a ele, mas dialogar com ele sobre a sua e a nossa. Temos de estar convencidos de que a visão do mundo, que se manifesta de várias formas de sua ação, reflete na situação no mundo, em que se constitui. A ação educativa e política não pode prescindir do conhecimento crítico dessa situação, sob pena de se fazer "bancária" ou de pregar no deserto (FREIRE, 2017, p. 120). 
A abordagem triangular, estabelecida pela Dr. ํㅡ Ana Mae Barbosa, prevê estratégias metodológicas suficientes para se constituir processos dialéticos. Vale destacar, que Ana Mae é docente e pesquisadora, além de ser uma das principais referências brasileiras em arte-educação. Influenciada diretamente por Paulo Freire, criou a Abordagem Triangular para o ensino de Artes. Essa concepção sustenta ações para a contextualização da obra, sua apreciação e o fazer artístico. Portanto, as ações pedagógicas desenvolvidas na oficina de desenho previam as concepções freirianas, e estava ancorado na abordagem triangular. "O próprio discurso teórico, necessário à reflexão crítica, tem de ser de tal modo concreto que se confunda com a prática" (FREIRE, 2015, p. 40). Desta forma, as atividades práticas presentes no ensino de Artes, articuladas no âmbito sensível e cognitivo permitem aos estudantes novos olhares sobre o mundo, sobre a cultura. Ou seja, a partir de conteúdos que favoreçam, a compreensão da arte como cultura, da valorização das diferentes manifestações artísticas em suas diversas localidades e conteúdo que propiciem os três eixos da aprendizagem no ensino da arte, cunhados pela Prof. a Ana Mae. A metodologia é eficiente e estabelece percursos contrários às políticas públicas educacionais, tanto na redução de conteúdo, quanto na valorização da ética, a partir do diálogo, como menciona Freire:

Viver abertura respeitosa aos outros e, de quando em vez, de acordo com o momento, tomar a prática de abertura ao outro como objeto da reflexão crítica deveria fazer parte da aventura docente. A razão ética da abertura, seu fundamento político, sua referência pedagógica; a boniteza que há nela como viabilidade do diálogo (FREIRE, 2015, p. 133).

Esse pressuposto fundamentado na metodologia triangular interliga o fazer artístico, história da arte e análise da obra de arte, necessariamente vinculará a disponibilidade para o diálogo. Desta forma, a abordagem de Ana Mae tangencia harmoniosamente com a dialogicidade ${ }^{17}$ definida por Freire evidencia a necessidade do indivíduo, e principalmente o docente se abrir para os fenômenos sociais e juntos: professor, professora e estudantes se relacionarem, a partir do diálogo. Essa relação resulta em novas inquietações, curiosidades e inconclusões. Esta, por sua vez gera novas proposições e dinâmicas motivadoras para as aulas. Freire descreve muito mais, como na obra Pedagogia do Oprimido, afirma que o diálogo da educação é

\footnotetext{
${ }^{17}$ Refere-se à importante proposta humanizadora e libertadora. Pautada por Freire, no livro Pedagogia do oprimido, que estabelece o diálogo como categoria fundamental para um projeto crítico.
} 
uma prática libertadora. Ou seja, o assunto ou conjunto de temas geradores propicia percepção, análise, reflexões e mudança de condutas.

Assim, a investigação como método de observação, se aproxima da leitura da manifestação artística, estabelecida na metodologia triangular. Esta, por sua vez, vincula a contextualização da arte e pôr fim ao fazer artístico. Não existe uma ordem cronológica para a elaboração das ações na abordagem triangular.

A contextualização sendo a condição epistemológica básica de nosso
momento histórico, como a maioria dos teóricos contemporâneos da
educação comprovam, não poderia ser vista apenas como um dos
lados dos processos de aprendizagem. O fazer arte exige
contextualização, a qual é a conscientização do que foi feito, assim
como também a leitura. Qualquer leitura como processo de
significação exige a contextualização para ultrapassar a mera
apreensão do objeto. Quando falo de contextualização não me refiro
à mania vulgar de falar da vida do artista. Esta interessa apenas
quando interfere na obra. (BARBOSA. 2009. p. 32)

Na contemporaneidade, o conceito de arte mais explorado aborda a reflexão, a crítica e a arte como conhecimento. Vale destacar que há diferentes concepções metodológicas, porém, as tendências tecnicistas e reprodutivistas conflitam com a Abordagem Triangular. O desenvolvimento cognitivo vincula aspectos da mente, ao contrário do que muitos defendem, somente ao processo emocional. Evidentemente, que os fatores emocionais inseridos a interação e ao diálogo são distintos e necessários. Freire, salienta

O desrespeito à educação, aos educandos, aos educadores e às educadoras corrói ou deteriora em nós, de um lado, a sensibilidade ou a abertura ao bem-querer da própria prática educativa, de outro, a alegria necessária ao quefazer docente. É digna de nota a capacidade que tem a capacidade que tem a experiência pedagógica para despertar, estimular e desenvolver em nós o gosto de querer bem e o gosto de alegria, sem a qual a prática educativa perde o sentido (FREIRE, 2015, p. 139).

Não é possível desconsiderar que a cultura e a educação brasileira sempre foram alvos dos golpes de Estado, e, que desinvestimentos, censuras, suspensão de verbas, fragilização, inverdades entre outros, foram estratégias para a precarização da educação. Isso ocorreu com a suspensão do Plano Nacional de Educação - (PNE) em 1962, na Ditadura Militar. O Golpe Militar que colocou Temer no poder, houve o congelamento de gastos durante 20 anos, a partir da Emenda Constitucional 95. Atualmente, o ministro da educação impôs o contingenciamento de verbas, 
principalmente para as instituições federais públicas de ensino superior. Essa sequência de eventos da atualidade afeta diretamente os protagonistas da educação brasileira. Ou seja, a comunicação crítica e reflexiva sobre os fenômenos do mundo abre espaço para o retorno da educação bancária ${ }^{18}$ e aulas menos propositivas. Freire sempre propôs aos docentes que a elaboração de novos saberes, em situações dialógicas, a partir de temas geradores será escamoteado em recentes políticas públicas para a educação com a precarização do trabalho docente. Segundo Freire (1993, p.87)

[...] uma metodologia que não pode contradizer a dialogicidade da educação libertadora. Daí que seja igualmente dialógica. Daí que conscientizadora também proporcione, ao mesmo tempo, a apreensão dos "temas geradores" e a tomada de consciência dos indivíduos em tornos dos mesmos.

A proposta de Freire defende em toda sua obra um projeto de educação que pretende ser libertador, que envolva a cultura, investimentos para a escola e cidadania plena e não com o esfacelamento do sistema público de ensino. Ou seja, tais medidas promoverão o rebaixamento da formação escolar para os mais pobres. Do mesmo modo, o componente curricular: Arte sentirá os efeitos das recentes políticas públicas para a educação brasileira, que restringe a tudo que Freire afirma. Sem materiais artísticos para as aulas de artes, proximidade com a cultura e com espaços das artes, os docentes ficam impelidos a repetir a famigerada educação bancária. investimento em educação, na realidade se reduz, em diferentes setores, como no atendimento aos jovens residentes da Fundação Casa, por exemplo. Países como Inglaterra, Portugal, EUA, e outros defendem a arte na educação, pois identificaram as reais vantagens para o processo de aprendizagem de seus estudantes.

O que nos parece indiscutível é que, se pretendemos a libertação dos homens, não podemos começar por aliená-los ou mantê-los alienados, A libertação autêntica, que é a humanização em processo, não é uma coisa que se deposita nos homens. Não é uma palavra oca, mitificante. É práxis, que implica em ação e a reflexão dos homens sobre o mundo para transformá-lo (FREIRE, 1997, p. 93).

\footnotetext{
${ }^{18}$ Freire expõe a ideia de libertar os oprimidos, não com o modelo de educação protagonizado pela elite. Assim, classificam de educação bancária, modelos contrários que promovem a opressão da classe trabalhadora e não permite a consciência e a reflexão, a partir de processos educativos problematizadores.
} 
Será precisamente a práxis $^{19}$, para as aulas de artes capazes de explorar vivências e experiências, com os estudantes, na abordagem triangular em investigações não somente sobre arte, mas a partir dela conhecer nossa realidade social.

Em concomitância, verifica-se a desvalorização dos docentes, inicialmente no questionamento das suas ações pedagógicas, a partir do Fake News sobre "escola sem partido 20“", uma constituição absoluta do pensamento conservador, como única possibilidade verdadeira, maior controle sobre o trabalho educativo, baixos salários com ampliação de horas de atividades pedagógicas dentro da unidade escolar, negação da autonomia docente, a partir de controles burocráticos e tecnicistas de resultados em suas ações pedagógicas, a partir do estabelecimento de metas, avaliações sistemáticas sobre rendimento escolar, entre outros. Ou seja, a ação pedagógica foi reduzida e neutralizada, onde muitos professores e professoras não percebem o cenário atual que vivenciam.

Os pais dos estudantes, em sua maioria, bem como, alguns docentes não compreenderam as estratégias de caráter eminentemente neoliberalista, ao acreditar e apoiar nova postura política, desdenhando ódio e repúdio aos programas sociais, como: Bolsa Família ${ }^{21}$, Benefícios de Prestação Continuada - BPC ${ }^{22}$, entre outros direitos sociais. A crença na privatização do serviço público como resposta plausível ao gasto público. Exatamente nesse momento a educação deixa de ser percebida

\footnotetext{
${ }^{19}$ A obra de Freire estabelece a "práxis" como ações que promovem a reflexão sobre sua própria experiência e sua relação com os fenômenos sociais. Idem. Freire, Paulo. Educação como prática de liberdade: e outros escritos, 1976; Educação e mudança, 1979.

20 Surgiu em 2004, através da iniciativa do então procurador do Estado de São Paulo, Miguel Nagib. 0 projeto surgiu como uma reação a um suposto fenômeno de instrumentalização do ensino para fins político ideológicos, partidários e eleitorais, que em seu ponto de vista representam doutrinação e cerceamento da liberdade do estudante em aprender.

Cf. Disponível: https://www.escolasempartido.org/. Acesso: 08 dez 2020.
}

${ }^{21}$ O Programa Bolsa Família, criado pela Lei no 10.836/04, é um programa de transferência direta de renda que beneficia famílias em situação de pobreza e de extrema pobreza em todo o País. Foi utilizado um limite de renda para definir essas duas situações. Assim, podem fazer parte do Programa: Todas as famílias com renda por pessoa de até $\mathrm{R} \$ 89,00$ mensais (famílias em situação de extrema pobreza)

Disponível: http://www.sedes.df.gov.br/bolsa-familia/. Acesso: 08 dez 2020.

${ }^{22}$ São pagamentos de um salário mínimo para pessoas com deficiência ou com mais de 65 anos de idade que não possuam nenhum meio de sustento. Disponível: https://www.gov.br/ptbr/categorias/assistencia-social/programas-sociais. Acesso: 08 dez 2020. 
como investimento. O docente do serviço público perde seu valor como profissional, aos que compartilham dessa visão. A meritocracia e a competitividade surgem como única e verdadeira resposta para os problemas da educação básica. Os professores e as professoras se rendem às tensões do cotidiano sem refletir e analisar ao que foram submetidos. Vale destacar Freire

[...] a necessidade de assumirmos uma postura vigilante contra as práticas de desumanização. Para tal, o saber - fazer da autorreflexão crítica e o saber - ser da sabedoria exercitado, permanentemente, podem nos ajudar a fazer a necessária crítica das verdadeiras causas da degradação humana [...] (FREIRE, 2018).

\section{O PRESENTE NÃO POÉTICO}

Nas reflexões apontadas, conclui-se que a padronização curricular para a educação básica, estabelecida pela BNCC conduzirá, inevitavelmente para homogeneização da formação docente. A condução atual das Políticas Públicas voltadas para a educação prevê estabilidade e processos de avaliação como principal recurso de garantia da qualidade. Tais avaliações sistêmicas promovem somente o ranqueamento das instituições da educação básica e ensino superior, além de viabilizar negócios dos insumos voltados para a educação. Os resultados de 2018 do Programa Internacional de Avaliação dos Alunos - PISA apresentam que os estudantes da educação básica apresentam deficiências para as competências leitoras e cálculos matemáticos. A BNCC evidencia tal padronização e principalmente para o componente curricular Arte, impõe a polivalência e o caráter tecnicista. As políticas públicas voltadas para a educação brasileira não consideram equidade diante das assimetrias sociais e econômicas, com tais regulações. As diversidades não são respeitadas ou amplamente atendidas, a partir de sua normatização.

A partir da Abordagem Triangular, Ana Mae Barbosa propõe e repercute "as culturas", pois seu método contempla distintas especificidades locais, regionais, nacionais e internacionais, para o processo de ensino e aprendizagem da arte. Seu método não impõe a polivalência, pois seria necessária uma formação nas quatro expressões artísticas, na música, teatro, dança e artes visuais. Ao mesmo tempo, não se questiona o vínculo entre as diferentes manifestações. Destaca-se a concepção dialógica necessária na ação e interação entre o docente e seus estudantes. A leitura de imagem, sua contextualização e o próprio fazer artístico contribuem para as 
competências leitoras e escritoras do alunado, além de explorar análises conjunturais de nossa sociedade.

A educação crítica cunhada por Freire promove diferentes saberes e demanda do educador e alunos o exercício permanente pela busca do conhecimento. Não é sem razão que a BNCC não menciona seus textos e sua abordagem e o mesmo acontece com a Abordagem Triangular. O professor, a professora e seus estudantes necessitam assumir-se como sujeitos sócio-histórico-culturais, rever a história da formação brasileira, contextualizar o tempo presente para tangenciarmos novas estéticas de respeito, dignidade e autonomia.

\section{Referências}

BARBOSA, A. M. Teoria e prática da educação artística. São Paulo, Cultrix, 1995.

BARBOSA, A. M. A imagem no ensino da arte: anos 1980 e novos tempos. $1^{\underline{a}}$ reimp. da 7 ed. São Paulo: Perspectiva, 2009.

BRASIL. Diretrizes Curriculares - Educação Básica. Brasilia, 2001. Disponível: http://portal.mec.gov.br/expansao-da-rede-federal/323-secretarias112877938/orgaos-vinculados-82187207/12992-diretrizes-para-a-educacao-basica. Acesso: 08 de novembro de 2020.

BRASIL. Lei no 9.394/96, de 20 de dezembro de 1996. Estabelece as Diretrizes e Bases da Educação Nacional. Diário Oficial da União, Brasília, 20 de dezembro de 2020.

BRASIL. Parâmetros Curriculares Nacionais. Brasília: Ministério da Educação, 1998.

FREIRE, Paulo. Pedagogia da Autonomia. São Paulo: Paz e Terra, 2015.

FREIRE, Paulo. Pedagogia do Oprimido. 63 ed. São Paulo: Paz e Terra, 2017.

FREIRE, Paulo. Educação e mudança. 36 ed. São Paulo: Paz e Terra, 2014. 


\title{
ALFABETIZAÇÃO E LETRAMENTO NA PERSPECTIVA DOS NOVOS ESTUDOS SOBRE LETRAMENTO (NEL): A CONTRIBUIÇÃO DE PAULO FREIRE
}

\author{
Salma Itália Nascimento dos Santos \\ Gerson Tenório Santos
}

\section{INTRODUÇÃO}

O Brasil contemporâneo ainda enfrenta muitos problemas relacionados à escolarização dos indivíduos. Constatou-se, por meio do Inaf (Indicador de Analfabetismo Funcional), que o Brasil ainda possui uma população de $29 \%$ de analfabetos, dos quais $8 \%$ são analfabetos absolutos, que ainda não adquiriram plena capacidade de ler palavras, frases ou números telefônicos, e $21 \%$ são analfabetos rudimentares, que apresentam dificuldades em interpretar textos, ironias, informações (LOURENÇO, 2020).

Muitas políticas públicas têm sido adotadas para minimizar a situação, como o Programa Nacional de Alfabetização (PNA, 2019), o Programa Tempo de Aprender (2020) e o Conta Pra Mim (2020), além da Base Nacional Comum Curricular (BNCC, 2017). No entanto, os resultados não estão sendo suficientes.

Os conceitos sobre uma mudança na alfabetização vêm sendo construídos, refletidos e amplamente difundidos. No entanto, é necessária uma prática de ensino que não só contemple a aquisição da base alfabética, mas que se fundamenta em práticas sociais contextualizadas e significativas baseadas naquilo que Brian Street chama de letramento ideológico (STREET, 2020). O conceito de letramento ideológico está intimamente vinculado a algumas ideias fundamentais de Paulo Freire como a não neutralidade da educação e à ideia de que a leitura de mundo antecede a leitura da palavra.

O legado que deixou Paulo Freire é amplo e até hoje inspira os profissionais da alfabetização, do letramento e da pedagogia crítica, favorecendo as concepções e as idealizações de uma pedagogia da transformação emancipatória, significativa e expressiva, com uma conexão entre a reflexão e ação.

Bartlett e Macedo (2015, p. 228) destacam a colaboração de Paulo Freire para a abordagem social das concepções de letramento e alfabetização, "ao defender a inseparabilidade entre o aprendizado da leitura da palavra (linguagem) e a leitura do mundo (relações sociais)". 
Analisar as palavras de Paulo Freire no que tange a relação entre a leitura da palavra e a leitura de mundo é buscar contribuições para a pedagogia do letramento, ou seja, a necessidade do aprendiz ler e escrever a partir de práticas sociais contextuais, a partir de seu ser e estar no mundo como sujeito de sua própria aprendizagem. É neste sentido que buscamos destacar neste trabalho, a contribuição de Paulo Freire para a compreensão do processo de alfabetização e letramento numa perspectiva ideológica, destacando o quão é importante a reflexão dos professores em suas práticas escolares de alfabetização e letramento no que concerne a relação entre alfabetização e os Novos Estudos sobre Letramento (NEL), a fim de serem levados em consideração os contextos reais de significação e o conhecimento de mundo do educando nas práticas de leitura e escrita para o uma educação crítica e emancipatória.

\section{METODOLOGIA}

Trata-se de uma pesquisa de cunho bibliográfico em que se ressalta a contribuição do pensamento de Paulo Freire para se pensar o papel que os Novos Estudos sobre Letramento (NEL), tal como destacado por Brian Street, tem para uma alfabetização que leve efetivamente em consideração os contextos sociais e a leitura de mundo dos educandos para uma educação emancipadora.

\section{RESULTADOS}

Brian Street, em sua obra Letramentos sociais: abordagens críticas do letramento no desenvolvimento, na etnografia e na educação (2020), propõe um novo modelo de letramento, chamado por ele de ideológico, em oposição a outros tipos de letramentos voltados para um conjunto de capacidades cognitivas que podem ser medidas e chamados por ele de autônomos. Para Street, "as relações estruturadas de língua falada e escrita devem ser explicadas em termos de contexto social de oralidade e letramento em diferentes tradições letradas, em vez de exigências cognitivas de produção de linguagem ou aspectos estruturais isolados (universais) das modalidades faladas e escritas (STREET, 2020, p. 24 e 25). Ou seja, é no contexto social, com suas diferentes modalidades e atravessado pela cultura e por diversas relações de 
poder (ideologia) que podemos compreender como se tecem as relações entre leitura, escrita e a constituição do sujeito. Embora Paulo Freire não use o termo letramento, toda sua pedagogia está imersa no dialogismo, no uso da palavra como práxis. Dirá ele na Pedagogia do oprimido: "Não há palavra verdadeira que não seja práxis. Daí que dizer a palavra verdadeira seja transformar o mundo" (FREIRE, 1983, p. 91). Ou seja, não há aprendizagem da palavra que não seja crítica, reflexiva, imersa no cotidiano daqueles que a aprendem. Por isso, também, que Paulo Freire é contrário a qualquer educação bancária, feita de palavras vazias que não revelem o mundo do educando. A indissociabilidade entre palavra e mundo, expressa no neologismo palavramundo, citada por ele em $A$ importância do ato de ler, se revela por inteiro em suas palavras iniciais do artigo inicial do livro citado: "A leitura do mundo precede a leitura da palavra, daí que a posterior leitura desta não possa prescindir da continuidade da leitura daquele. Linguagem e realidade se prendem dinamicamente" (FREIRE, 1989, p. 9). Na perspectiva de Paulo Freire, a palavra não se dicotomiza entre fala e escrita, nem entre signo e referente, nem entre estrutura e função social, ou seja, aqueles traços que compõem o modelo autônomo de letramento, como chamado por Brian Street, mas forma um todo indissociável entre texto/contexto, língua falada/língua escrita, palavra e mundo, o que configura, nas palavras de Street, o modelo ideológico de letramento (cf. STREET, 2020, p.140-141).

\section{DISCUSSÃO}

O processo de alfabetização não é apenas decodificar códigos, levando a aquisição do alfabeto; e escrever não é somente juntar as letras, é necessário adquirir a habilidade de codificar a língua oral; é preciso haver um contexto para a leitura da palavra, uma relação entre alfabetização e letramento, que, para Magda Soares (2020), constitui-se no saber ler e escrever relacionado à capacidade de fazer uso da leitura e da escrita como práticas sociais.

É nesta perspectiva que podemos alinhar o modelo de letramento ideológico, tal como discutido por Street, com a perspectiva freiriana de alfabetização. Para Paulo Freire, 
aprender a ler, a escrever, alfabetizar-se é, antes de mais nada, aprender a ler o mundo, compreender o seu contexto, não numa manipulação mecânica de palavras, mas numa relação dinâmica que vincula linguagem e realidade (FREIRE, 1989, p. 8).

Para Freire (1989, p.11), como já ressaltamos, a leitura de mundo precede a leitura da palavra, temas relativos à cultura local, questões relativas dos alfabetizandos. É preciso ainda, salientar nas palavras de Paulo Freire que linguagem e realidade se prendem, dinamicamente. A compreensão de texto a ser alcançada por sua leitura crítica implica a percepção das relações entre o texto e o contexto (FREIRE, 1989, p.11).

Segundo diz Magda Soares em seu livro Alfabetização e Letramento (2020), Paulo Freire não criou um método de alfabetização, como fora dito em muitos noticiários após sua morte.

Mas Paulo Freire criou, e criou muito além de um método: criou uma concepção de alfabetização, no quadro de uma também nova concepção de educação. Não apenas uma concepção de educação como diálogo, que disso realmente, não foi o inventor (terá sido Sócrates?), mas uma concepção de educação como prática da liberdade, educação como conscientização; e disso, realmente, ele foi o inventor. (SOARES, 2020, p. 179, grifos da autora).

Assim, a perspectiva freiriana de alfabetização e letramento, ao enfatizar a prática da liberdade e o processo de conscientização, pode ser relida à luz dos Novos Estudos sobre o Letramento propostos por Street ao problematizar os pressupostos e práticas do modelo de letramento autônomo, que trata a alfabetização como "tecnologia", uma "variável autônoma" "independente do contexto", cujas "consequências para a sociedade e a cognição podem ser derivadas de seu caráter intrínseco" (STREET apud BARTLETT e MACEDO, 2015, p. 229). Como afirmam Bartlett e Macedo (2015), é possível situar a perspectiva de letramento de Paulo Freire numa relação de proximidade com o modelo ideológico proposto por Street, para quem o letramento é "uma prática sociocultural permeada por relações de poder. Um processo 'inextricavelmente ligado às estruturas culturais e de poder na sociedade"' (BARTLETT e MACEDO, 2015, p 229).

\section{CONSIDERAÇÕES FINAIS}


Desde 1984, Brian Street tem tecido críticas profundas ao modelo de letramento autônomo, cujo foco recai sobre os efeitos cognitivos do letramento, que podem ser medidos, sobre a visão dicotômica entre fala e escrita, bem como sobre a desconsideração dos contextos sociais na produção de significados. Com base nesse modelo tem-se propalado, especialmente em concursos, avaliações nacionais e internacionais, políticas públicas de desenvolvimento de leitura, traços que definem o suposto letramento de um indivíduo, tais como "grau de letramento", "nível de letramento", "baixo letramento", o que revela o aspecto ideológico que tem caracterizado tais tentativas de neutralizar o trabalho com o letramento. Os Novos Estudos sobre Letramento (NEL) defendido por Street têm proposto, ao invés dessa perspectiva, justamente um modelo ideológico de letramento que sustenta o caráter ideológico, as relações de poder, as relações iminentemente sociais entre leitura e escritura que têm posto em xeque, a primazia do modelo autônomo. Isso traz inúmeras consequências para se pensar por exemplo, a relação entre alfabetização e letramento em nosso país, e os ecos da proposta de Street estão presentes nas abordagens de Magda Soares. Mas, fundamentalmente, é o pensamento de Paulo Freire que desde a publicação da Pedagogia do Oprimido e suas inúmeras traduções para várias línguas do mundo que tem sido o esteio dessa nova abordagem do letramento. Sua visão de que a leitura do mundo precede a leitura da palavra, de que a palavra autêntica liberta o sujeito da opressão, de que a alfabetização só tem sentido na relação entre palavra e realidade, de que o oprimido ao libertar-se, liberta o opressor tem sido o fermento de uma desconstrução de um olhar fechado, ditado de fora para dentro tanto pela direita quanto pela esquerda sobre os processos de leitura e escrita do povo, especialmente os pobres e oprimidos. Paulo Freire sempre revelou que o povo conhece, tem "manhas" e é de dentro deste conhecimento que outro se constrói e se reconstrói na medida em que é tencionado e tenciona os conhecimentos oficiais, a lógica do modelo autônomo de letramento.

\section{Referências}

BARTLETT, L.; MACEDO, M. do S. A. N. Aproximações entre a concepção de alfabetização de Paulo Freire e os novos estudos sobre letramento. Revista Brasileira de Alfabetização, Vitória, ES, v. 1., n. 1, jan/jun 2015, p. 227-236. 
Acessível em http://revistaabalf.com.br/index.html/index.php/rabalf/article/view/46. Acessado em 05/09/2021.

FREIRE, Paulo. A importância do ato de ler. In: A importância do ato de ler: em três artigos que se completam. 23. ed. São Paulo: Cortez, 1989.

FREIRE, Paulo. Pedagogia do oprimido. 12. ed. São Paulo: Paz e Terra, 1983.

LOURENÇO, T. Escolas brasileiras ainda formam analfabetos funcionais. Jornal da USP, 13/11/20. Acessível em https://jornal.usp.br/atualidades/escolas-brasileirasainda-formam-analfabetos-funcionais/. Acessado em 05/09/21.

SOARES, Magda. Alfabetização e letramento. 7. ed. São Paulo: Contexto, 2020.

STREET, Brian V. Letramentos sociais: abordagens críticas do letramento no desenvolvimento, na etnografia e na educação. Trad. Marcos Bagno. São Paulo: Parábola, 2020. 


\title{
A IMPORTÂNCIA DO TRABALHO COLETIVO: SEMINÁRIOS TEMÁTICOS I E II AUXILIAM NA PREPARAÇÃO PARA O TRABALHO DE CONCLUSÃO DE CURSO NA UNIMES?
}

\author{
Adriana Feliciano Alves Duran \\ Lais Helena Teixeira Merlin de Andrade
}

\begin{abstract}
RESUMO
O artigo apresentado tem por objetivo discutir e ressaltar a importância do desenvolvimento de atividades colaborativas no processo de formação de docentes. As autoras correlacionaram o resultado das suas práticas, nas disciplinas Seminários Temáticos e Trabalho de Conclusão de Curso (TCC), com uma revisão da literatura específica. Esses resultados, alinhados aos objetivos gerais propostos para o curso de Licenciatura em Ciências Biológicas da Universidade Metropolitana de Santos (UNIMES), demonstraram que as disciplinas ofertadas pelo curso e as atividades desenvolvidas pelos docentes, em especial na disciplina Seminários Temáticos, possibilita aos estudantes, a aquisição de conhecimento, o estabelecimento de interações, o trabalho coletivo e colaborativo e o desenvolvimento de novas habilidades, fornecendo assim uma base sólida para a realização do Trabalho de Conclusão de Curso. As atividades e o curso favorecem, dessa forma, a formação de um profissional autônomo e crítico, promovendo condições e estimulando ações para que o mesmo reflita sobre o que the é apresentado e que esse seja integrado à sociedade para exercer a sua cidadania, trabalhando coletivamente na compreensão e resolução de situações-problema.
\end{abstract}

Palavras-chave: Trabalho coletivo; Trabalho colaborativo; Seminários Temáticos; TCC.

\section{Introdução}

No início de 2020, fomos surpreendidos com a pandemia desencadeada pelo novo coronavírus que assombra o mundo até os dias atuais. Sendo assim, a Organização Mundial da Saúde (ORGANIZAÇÃO MUNDIAL DA SAÚDE, 2020) declarou que o surto causado por este vírus "...constitui uma emergência de saúde pública de importância internacional...", devido a sua disseminação global.

Este terrível cenário, que vem adoecendo a humanidade com a Covid-19, em momentos parece que será modificado e a pandemia será controlada, em outros nos amedronta com o surgimento de novas cepas variantes virais com maior poder de transmissão devido ao rápido espalhamento.

As comunidades médicas e científicas têm se esforçado ao máximo para pesquisar, estudar e desvendar os mistérios deste vírus, visando conhecimento e entendimento sobre os mecanismos de transmissão, ação e desencadeamento da doença, e têm incentivado nossos governantes, nossos pares, sobre as diferentes 
maneiras para frear a disseminação viral e salvar a população, como a incansável divulgação sobre a importância da vacinação.

Diante do que estamos vivenciando nestes últimos anos, diversos setores da sociedade foram afetados, dentre eles a educação; do ensino infantil ao ensino superior, seja ele da rede pública ou da particular, todas as instituições incluindo seus atores foram obrigados a se adaptarem às práticas pedagógicas utilizando estratégias de Tecnologias de Informação e Comunicação (TIC) e suas ferramentas na tentativa de promover o sucesso no processo de ensino e aprendizagem de modo interativo e mais intimista, aproximando discentes e docentes (ARAÚJO, et al., 2020; ROCHA; Lima, 2021).

Apesar da pandemia ter forçado o ensino remoto, o ensino superior na modalidade a distância (EaD) vem crescendo no Brasil nos últimos anos, como apontou o Censo da Educação do Ensino Superior 2019 (MINISTÉRIO DA EDUCAÇÃO, 2020). Esta modalidade, onde alunos e professores estão distantes fisicamente, se caracteriza por promover a autonomia do educando, a flexibilidade de horários para os estudos, a dedicação, a organização, o planejamento das atividades, e habilidades para utilizar as TIC que são oferecidas nas plataformas digitais de aprendizagem (MORAN, 2009 apud ALVES, 211).

Neste contexto, a Universidade Metropolitana de Santos (UNIMES) oferece diferentes cursos na modalidade a distância, e dentre as licenciaturas, está o curso de Ciências Biológicas, que pode ser completado em até seis semestres. Esta modalidade de ensino utiliza a plataforma Moodle personalizada, idealizada como um sistema integrado e seguro, repleta de ferramentas interativas que promovem discussão e construção coletiva de conhecimentos entre os pares. Entretanto, além deste curso promover a interação entre licenciandos e docentes por meio de fóruns de orientações e discussões temáticas, ele oferece componentes curriculares para a elaboração coletiva de atividades, intercâmbio de conhecimentos e experiências, como Seminários Temáticos I e II, e Trabalho de Conclusão de Curso (TCC).

O trabalho em grupos não é uma situação estranha ou desconhecida, pois desde pequenos somos incentivados a realizar atividades coletivas, se tornando algo indissociável da convivência em sociedade. Podemos verificar que em muitas situações cotidianas, estamos constantemente realizando atividades dessa natureza, seja na escola, no trabalho, em reuniões com a família ou com os amigos, na igreja, 
no futebol, entre outros. Isso reforça que para que essas atividades sejam efetivas, é importantíssima a cooperação e o respeito entre os envolvidos. Freire (1996) em sua obra descreve que ensinar, aprender e pesquisar são processos inseparáveis, sendo práticas necessárias para a produção do conhecimento. Coll (2002), por sua vez, indica que as aprendizagens provenientes de experiências cooperativas favorecem as interações, o que resulta em produtividade maior, se comparadas com experiências individuais ou competitivas. As atividades em grupo potencializam a aprendizagem e o desenvolvimento intelectual favorecendo o desenvolvimento do raciocínio lógico e a aquisição de conteúdo, sendo esses processos resultantes da reorganização cognitiva e de interiorização, mediante as diferentes opiniões e pontos de vista do coletivo.

Para que o trabalho coletivo ocorra de forma satisfatória, faz-se necessário um ambiente adequado para tal finalidade, onde prevaleça o respeito e a confiança. Segundo Contreras (1999) e Zabala (1998), um ambiente favorável contribui para a formação de comportamentos e atitudes que promovem a "formação de autoconceito" que leva o estudante a desenvolver a empatia, colocando-se no lugar e enxergando com os olhos de outra pessoa. Isso favorece, ainda, a segurança de expor suas dúvidas e opiniões acerca de um determinado assunto. Ao elaborarmos atividades que sejam significativas para os alunos, juntamente com um ambiente adequado possibilitamos que os estudantes passem a se expressar melhor, o que, por sua vez, favorece o debate de opiniões e permite o estabelecimento de relações entre os conteúdos prévios e as experiências uns dos outros (ZABALA, 1998; HELDMAN, 2003). Além de um ambiente propício, propor atividades significativas pode gerar motivação e essa, segundo Contreras (1999) os movimenta, os impulsiona em direção a um objetivo, o que acaba exigindo uma ação do aluno. Esta motivação produz entusiasmo, o que pode contribuir para gerar criatividade na solução de problemas.

O professor possui um papel fundamental em todo o processo. Segundo Zabala (1998), o professor deve criar condições para promover que a comunicação ocorra de forma clara e eficiente, evitando possíveis mal-entendidos e incompreensões. Ele deve conduzir o processo de forma construtiva, evidenciando o progresso do grupo conforme se desenvolvem as discussões e debates causados pela troca de informações, experiências e conhecimento, provenientes das pesquisas prévias que constituem a base do trabalho.

Diante do apresentado, a elaboração deste artigo teve como intuito principal: 
- Ressaltar como os licenciandos são estimulados ao trabalho coletivo destacando a importância da interação entre pares;

- Enfatizar parte integrante da preparação dos licenciandos para a finalização do curso de licenciatura em Ciências Biológicas, ao cursarem os componentes curriculares Seminários Temáticos e TCC.

Portanto, foi realizada uma pesquisa exploratória na literatura específica acerca de temáticas escolhidas, onde artigos/publicações foram selecionados e analisados visando auxílio na construção textual; e, foram mencionadas experiências vivenciadas pelas docentes deste curso de licenciatura, atuantes nos componentes curriculares Seminários Temáticos e Trabalho de Conclusão de Curso, nos últimos dois semestres (segundo de 2020 e primeiro de 2021), e que são autoras deste artigo.

\section{Componentes curriculares que estimulam os trabalhos coletivos}

O curso de Licenciatura em Ciências Biológicas da Universidade Metropolitana de Santos, modalidade EaD, prepara os alunos para ensinarem Ciências e Biologia no Ensino Fundamental e Médio, além da possibilidade de atuarem em outras áreas relacionadas. No decorrer do curso, são promovidas atividades colaborativas que permitem ao aluno o desenvolvimento de habilidades e a aquisição de conhecimento. A seguir, descrevemos duas disciplinas onde esses conceitos são aplicados:

\subsection{Seminários Temáticos I e II}

É comum e frequente o uso do termo seminário como uma atividade escolar, que ocorre em diferentes níveis no ensino, incluindo o Ensino Superior. O seminário é classificado, de forma geral, como uma técnica de estudo e um momento de aprendizagem, cuja finalidade é orientar o estudante a pesquisar informações e analisar dados, além de promover situações que estimulem o raciocínio crítico, a reflexão, a elaboração de textos e apresentação da sua pesquisa. Os seminários abordam problemas ou situações atuais e relevantes, que precisam ser discutidas no universo acadêmico e trabalhadas em diferentes esferas do conhecimento. Por isso, é fundamental que o estudante participe das dinâmicas e processos previstos, seja para conhecer novos conceitos, quanto para escutar outros pontos de vista diferentes. Lakatos e Marconi (2005) afirmam que o seminário é uma técnica de estudo que inclui pesquisa, discussão e debate: "(...) desenvolve não só a capacidade de pesquisa, de 
análise sistemática de fatos, mas o hábito do raciocínio, da reflexão, possibilitando ao estudante a elaboração clara e objetiva de trabalhos científicos".

Neste curso de licenciatura em Ciências, o componente curricular Seminários Temáticos possibilita aos estudantes, o trabalho coletivo e colaborativo, a pesquisa e o preparo para a realização do seu Trabalho de Conclusão de Curso, colaborando na formação de um profissional diferenciado, que está apto a atuar no mercado de trabalho. Por meio do componente são promovidas vivências e experiências diferenciadas, que aliadas aos objetivos previstos para o curso, aprimoram o desenvolvimento do estudante, promovendo uma nova visão sobre determinado tema de seu interesse, permitindo ainda que o aluno identifique oportunidades e discuta formas para solucionar um determinado problema. Assim, ao estar em contato com ideias e pontos de vista de outras pessoas, é possível ampliar os conhecimentos. Ao ouvir opiniões diferentes e compartilhar as suas ideias, defendendo o seu ponto de vista, favorece o desenvolvimento de novas habilidades. Dessa forma, a interação no mundo acadêmico é de extrema importância.

\subsection{Trabalho de Conclusão de Curso (TCC)}

O TCC, disponibilizado na licenciatura em Ciências Biológicas, como o próprio nome sugere, marca a finalização do curso ofertado pela UNIMES, na modalidade de Ensino a Distância (EaD). Para a grande maioria dos alunos, significa a conclusão de uma importante etapa da vida acadêmica, a graduação, e o ingresso à docência do ensino básico, seja na rede pública ou na rede particular.

Neste curso, o TCC está inserido na matriz curricular do último semestre letivo, como componente curricular obrigatório e indispensável para a conclusão desta licenciatura, e deve ser elaborado de modo coletivo e colaborativo utilizando ferramentas tecnológicas, como Fóruns e Wiki, disponíveis no Ambiente Virtual de Aprendizagem (AVA) que utiliza a plataforma Moodle. Geralmente são formados grupos com cinco graduandos, que têm a possibilidade de escolher o grupo de colegas que deseja trabalhar ao longo da elaboração do trabalho. Dessa forma, a faculdade estimula a cooperação por meio da construção coletiva do conhecimento acerca da temática do TCC e promove a interação entre os pares que se aproximam por meios tecnológicos de comunicação. 
De acordo com Pereira e Silva (2011) apud Yamanari e Moraes (2013), mesmo que os graduandos tenham escolhido a temática para o desenvolvimento do TCC, precisam estar seduzidos, felizes e confiantes com a escolha, dessa forma, terão mais segurança ao buscar, pesquisar e estudar o tema para que consigam finalizar com sucesso o trabalho, sem a sensação de perda de tempo e sem a necessidade de mudanças ao longo do percurso, uma vez que na maioria das graduações, o TCC é solicitado para a finalização do curso.

Entretanto, para se obter sucesso na elaboração do TCC coletivo, este deve ser construído por todos os componentes do grupo que devem sincronizar e organizar o trabalho de modo que se auxiliem e complementem a pesquisa do colega. Segundo Corrêa, Vasconcelos e Souza (2018), a construção textual do TCC deve ser pautada pelos conhecimentos obtidos por meio de pesquisas, leituras e estudos ao longo do curso, sendo fundamental na formação do estudante, pois “(...) proporciona a oportunidade de resolver, de forma rigorosa e criativa, problemas teóricos e empíricos detectados no cotidiano assistencial e/ou gerencial."

\section{Diagnóstico da experienciação docente}

\subsection{Relato da experiência docente: Seminários Temáticos I e II}

A pandemia de Covid-19 nos trouxe uma série de desafios, especialmente na educação. Embora seja um assunto muito significativo, trabalhar outros temas faz-se necessário para ampliar as experiências e conhecimentos dos estudantes e futuros docentes. Nesse sentido, foi selecionado um tema atual e impactante, para ser trabalhado nos períodos mencionados: Os Efeitos das Queimadas e do Desmatamento. A proposta foi, em geral, conduzir a pesquisa sobre o assunto e levantar questões importantes como as consequências a curto e a longo prazo, para ecossistemas, populações e para o planeta. Reflexões acerca da participação de determinados setores, como a gestão pública, e o papel de cada cidadão nesse processo foram promovidas, o que resultou em artigos de natureza crítica e com aplicabilidade em salas de aula ou outras atividades de caráter informativo.

\subsection{Relato da experiência docente: TCC}

No último ano, diante do enfrentamento da pandemia, o ensino precisou passar por reformulações em um curto espaço de tempo, e os professores precisaram se 
adaptar ao uso de tecnologias para preparação e realização de suas aulas remotas. Sendo assim, os licenciandos ao finalizarem o curso e iniciarem a carreira docente, principalmente neste período, fatalmente se depararão com novas abordagens de ensino, como o ensino remoto e o híbrido. Por esta razão, foi proposta a elaboração de trabalhos de conclusão de curso visando a elaboração de Sequências Didáticas tendo como foco o ensino de Ciências para alunos do Ensino Fundamental ou, o ensino de Biologia para alunos do Ensino Médio utilizando-se de ferramentas tecnológicas na proposição de atividades pedagógicas. Diante deste desafio, os alunos escolheram diferentes assuntos relacionados com cinco grandes áreas temáticas que se relacionam com nosso cotidiano e com propostas inseridas na Base Nacional Comum Curricular (BNCC) de Ciências da Natureza. Dentre os temas destacam-se: Microbiologia, Imunologia e Saúde; Parasitologia e Saúde; Paleontologia e Geologia; Biotecnologia (técnicas moleculares); e bioética.

Estes trabalhos promoveram reflexões nos graduandos resultando em proposições de práticas pedagógicas interessantes, repletas de conteúdos e informações relevantes, voltadas ao ensino remoto ou híbrido e, com caráter de aplicabilidade.

\section{Conclusões e contribuição tecnológica/social}

elaboração deste artigo teve como objetivos relatar as experiências docentes vivenciadas com os licenciandos acerca do desenvolvimento de trabalhos coletivos e colaborativos visando prepará-los para a finalização do curso de licenciatura em Ciências Biológicas. Neste sentido, merece destaque o papel fundamental do professor como mediador/orientador do processo de ensino-aprendizagem, na estimulação e no incentivo dos licenciandos pela busca do conhecimento acerca de temáticas diversas, incluindo as que fazem parte do cotidiano, visando a correlação dos assuntos abordados ao longo do curso na proposição de atividades que podem se tornar práticas docentes futuras.

Durante esta licenciatura, o aluno é estimulado de diversas maneiras a desenvolver atividades interativas com seus pares tendo como aliada a plataforma Moodle e suas diferentes ferramentas tecnológicas. A interação do aluno durante a participação nos Seminários Temáticos e na elaboração do TCC acontece por meio do uso das ferramentas Fórum e Wiki: alunos discutem as temáticas e decidem juntos 
sobre as etapas dos trabalhos coletivos propostos e elaboram a parte textual de modo complementar e colaborativo, respectivamente.

Com base nos relatos de experiências docentes, evidencia-se que a participação dos alunos nos componentes curriculares mencionados pode ajudá-los na conclusão da licenciatura e na preparação para etapas subsequentes após a conclusão da graduação, tanto na vivência de práticas pedagógicas ao ingressarem na docência do ensino básico na modalidade de ensino remoto e híbrido, utilizando as diversas TIC, quanto na vida acadêmica, ao estimulá-los na busca pelo aprimoramento profissional tendo seu possível começo ao ingressar em programas de iniciação científica tanto na área da educação quanto nas áreas oferecidas pelas Ciências Biológicas.

\section{Referências}

ALVES, L. Educação a distância: conceitos e história no Brasil e no mundo. Vol. 10. RBAAD, 2011. Disponível em:

http://www.abed.org.br/revistacientifica/revista_pdf_doc/2011/artigo_07.pdf. Acesso em: 17 ago. 2021.

ARAÚJO, R.M., et al. COVID-19, Mudanças em práticas educacionais e a percepção de estresse por docentes do ensino superior no Brasil. Revista brasileira de informática na Educação: 28: 864-891, 2020.

COLL, C. Aprendizagem escolar e construção de conhecimentos. Porto Alegre: Artmed, 2002.

CONTRERAS, J.M. Como Trabalhar em Grupo, São Paulo, Paulus Editora, 1999. CORREAA, E.J.; VASCONCELOS, M.; SOUZA, M.S.L. Iniciação à metodologia:

Trabalho de Conclusão de Curso. Belo Horizonte: NESCON UFMG, 2018.

Disponível em: https://ares.unasus.gov.br/acervo/. Acesso em: 08 set. 2021. FREIRE, P. Pedagogia da autonomia: saberes necessários à prática educativa. São Paulo: Paz e Terra, 1996.

HELDMAN, K. Desenvolvimento da Equipe do Projeto. In: HELDMAN, K Gerência de Projetos. Rio de Janeiro, Campus Editora 2003. p. 234-263.

LAKATOS, E. M.; MARCONI, M. Fundamentos da metodologia científica 6. ed. São Paulo: Atlas, 2005.

MINISTÉRIO DA EDUCAÇÃO. Ensino à distância se confirma como tendência. 2020. Disponível em: https://www.gov.br/inep/pt-br/assuntos/noticias/censo-da- 
educacao-superior/ensino-a-distancia-se-confirma-como-tendencia. Acesso em: 07 set. 2021.

ORGANIZAÇÃO MUNDIAL DA SAÚDE. Folha informativa sobre COVID-19 (doença causada pelo novo coronavírus). 2020. Disponível em:

https://www.paho.org/pt/covid19. Acesso em: 17 ago. 2021.

ROCHA, E.M.; LIMA, J.M.S. Impactos e desafios do ensino on-line decorrentes da pandemia COVID-19. Revista Ibero-Americana de Estudos em Educação: 16(2): 377-390, 2021.

YAMARANI, T.T.; MORAES, D.A.F. O papel do TCC na formação de estudantes universitários. II Jornada de Didática e I Seminário de Pesquisa do CEMAD.

Docência na educação superior: caminhos para uma práxis transformadora. Set. 2013. Disponível em:

http://www.uel.br/eventos/jornadadidatica/pages/arquivos/l\%20Jornada\%20de\%20D idatica\%20e\%201\%20Seminario\%20de\%20Pesquisa\%20do\%20CEMAD\%20\%20Docencia\%20na\%20educacao\%20Superior\%20caminhos\%20para\%20uma\%20 praxis\%20transformadora/O\%20PAPEL\%20DO\%20TCC\%20NA\%20FORMACAO\% 20DE\%20ESTUDANTES\%20UNIVERSITARIOS.pdf. Acesso em: 08 set. 2021. ZABALA, A. As relações interpessoais em sala de aula: o papel dos professores e dos alunos In: ZABALA, A. A prática educativa, como ensinar. Porto Alegre: ArtMed editora, 1998. p.89-110.

ZABALA, A. A organização social da classe In: ZABALA, A. A prática educativa, como ensinar. Porto Alegre: ArtMed editora, 1998. p. 110-137. 


\title{
O ENSINAR-APRENDER FREIREANO DIANTE DA ATUALIDADE DA PANDEMIA EM UMA ATIVIDADE PRÁTICA INCLUSIVA NA EDUCAÇÃO A DISTÂNCIA
}

\author{
Cristiane Ramon Sampaio \\ Érika Coelho D'Anton Reipert
}

\begin{abstract}
RESUMO
O novo coronavírus trouxe mudanças para a vida de todos e nas questões que envolvem o processo-ensino aprendizagem mostrou uma desigualdade de condições de ensino no sistema educacional, onde a todo o momento professores foram desafiados a como ensinar criando possibilidades para que o ensino pudesse de fato ser concretizado. Este estudo tem por objetivo mostrar adaptações feitas durante a pandemia no primeiro semestre de $2021 \mathrm{em}$ uma atividade de prática experimental cumprida por discentes do curso de Licenciatura em Química na modalidade a distância $(\mathrm{EaD})$ da Universidade Metropolitana de Santos, UNIMES Virtual. A metodologia utilizada foi a revisão bibliográfica e também a documental, através da análise da participação dos alunos em uma atividade de experimentação científica adaptada devido à pandemia. Os resultados mostram que se pode fazer educação emancipatória favorecendo os menos favorecidos, trabalhando metodologias que correspondam à vida em particular de cada aluno incluindo o ser no saber ler o mundo.
\end{abstract}

Palavras-chave: Saber Científico; Licenciatura em Química; Paulo Freire.

\section{Introdução}

"Ensinar não é transferir conhecimento, mas criar as possibilidades para a sua própria produção ou à sua construção" (FREIRE, 2010, p.47). O novo coronavírus trouxe mudanças para a vida de todos e nas questões que envolvem o processoensino aprendizagem mostrou uma desigualdade de condições de ensino no sistema educacional, onde a todo o momento professores foram desafiados a como ensinar criando possibilidades para que o ensino pudesse de fato ser concretizado, ficando evidenciado: "Quem ensina aprende ao ensinar e quem aprende ensina ao aprender" (FREIRE, 1987, p.40). Isso porque foi um grande desafio fazer educação com o que se tem, adaptar o que se tem, aprender a usar o que se tem, pensar no que o aluno tem e no que ele não tem para a sua construção do saber. Indo de encontro ao pensamento Freireano "Quê? Por quê? Como? Para quê? Por quem? Para quem? Contra quem? A favor de quem? A favor de quê?" (GADOTTI et al. 2005, p.36).

Nesse caso em especial a construção do saber científico químico em uma disciplina de Licenciatura em Química.

A disciplina de Química pode ser um instrumento de formação humana que amplia os horizontes culturais e a autonomia no exercício da 
cidadania, se o conhecimento químico for promovido como um dos meios de interpretar o mundo e intervir na realidade, se for apresentado como ciência, com seus conceitos, métodos e linguagens próprios e como construção histórica, relacionada ao desenvolvimento tecnológico e aos muitos aspectos da vida em sociedade (BRASIL, 2002, p.109).

Conforme INEP (2019) as escolas brasileiras não possuem em sua totalidade de recursos pedagógicos como internet e laboratório de ciências, sendo um dado negativo, pois cada instituição educacional deve estar apta a construir quem vai transformar o mundo fazendo cultura e história (FREIRE, 1980).

Diante do exposto, este estudo tem por objetivo mostrar adaptações feitas durante a pandemia no primeiro semestre de 2021 em uma atividade prática experimental cumprida por discentes do curso de Licenciatura em Química na modalidade a distância $(\mathrm{EaD})$ da Universidade Metropolitana de Santos, UNIMES Virtual.

\section{Metodologia}

Foi feita a revisão bibliográfica e também a documental, através da análise da participação dos alunos em uma atividade de experimentação científica adaptada devido à pandemia.

\section{Resultados}

A atividade em questão neste trabalho é realizada como parte da proposta do Trabalho de Conclusão de Curso da Licenciatura em Química da UNIMES Virtual e, portanto, consta no último semestre da matriz curricular do curso. É desenvolvida em grupos com até 5 integrantes, sendo construída de maneira colaborativa na ferramenta wiki ofertada no ambiente virtual de aprendizagem para a modalidade EaD. Após formação dos grupos os integrantes optam por uma linha de pesquisa fundamentando a importância da prática experimental para o Ensino de Química com a realização de uma prática em escola.

Sugere-se para os alunos que apenas um dos componentes do grupo precisa realizar a prática e que a escola deve ser, preferencialmente, onde estão cumprindo o estágio, com acompanhamento do professor titular da disciplina neste caso. Todo o processo ocorre em 3 etapas, onde na primeira etapa se desenvolve a Fundamentação Teórica, Referências e Roteiro de Aula Prática. 
Na segunda etapa Introdução, Fundamentação Teórica, Desenvolvimento da atividade prática (com descrição, análise e discussão) e Referências. Na terceira etapa Introdução, Fundamentação teórica, Desenvolvimento da atividade prática, Considerações finais e Referências. A cada etapa o trabalho vai sendo aprimorado e complementado, até se tornar o trabalho completo na terceira etapa.

No decorrer destas etapas o professor orientador faz as orientações e correções necessárias e, após a última correção na wiki, um integrante do grupo posta a versão final do trabalho em extensão doc. com a devida formatação ABNT para trabalhos acadêmicos.

Por se tratar de um curso EaD os integrantes de cada grupo, independente da pandemia, podem ser moradores de qualquer região do país, estando fisicamente longe um do outro. Por estarem em localizações distintas podem assim ter realidades diferentes em relação às condições das escolas que poderiam vir a realizar a sua prática experimental. Porém, devido ao momento atual de pandemia, a prática experimental foi desenvolvida em suas casas.

Um dos grupos do primeiro semestre de 2021 optou pela temática de separação de misturas e intitulou sua prática experimental como "Separação de misturas que ocorre no dia a dia em residências".

O destaque dado a este grupo no presente trabalho se deu pelo fato de conseguirem correlacionar de forma simples a Química com nosso cotidiano de acordo com os Parâmetros Curriculares Nacionais para o Ensino Médio e com Paulo Freire, pois se quem ensina alfabetiza, neste caso o ensinar traz o alfabetismo científico (conhecimento científico) com materiais e procedimentos passíveis de execuções caseiras, de forma a incluir o oprimido (BRASIL, 2002; GADOTTI et al, 2005).

Os cinco integrantes do referido grupo desenvolveram toda a atividade de forma conjunta, incluindo também a prática, o que não é uma exigência da disciplina, pois apenas um integrante poderia realizá-la, ficando aqui caracterizado o protagonismo da construção do saber por cada integrante e de maneira colaborativa, como pode ser visto abaixo nas Figuras 1, 2, 3, 4 e 5 que apresentam fotos tiradas pelos alunos durante a realização da atividade prática. 
Figura 1. Peneiração da tapioca (Integrante 1)

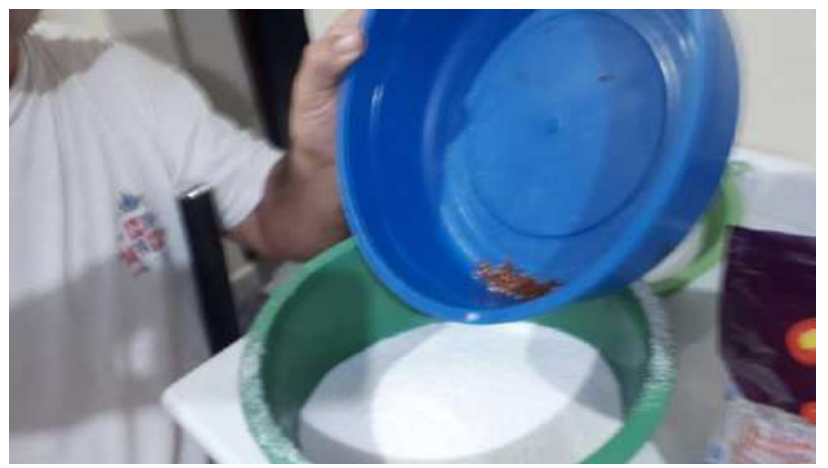

Figura 3. Catação no feijão (Integrante 3)

Figura 4. Catação no arroz (Integrante 4)

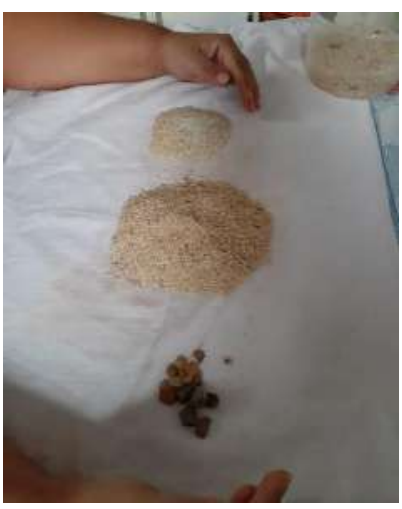

Figura 2. Peneiração da farinha (Integrante 2)

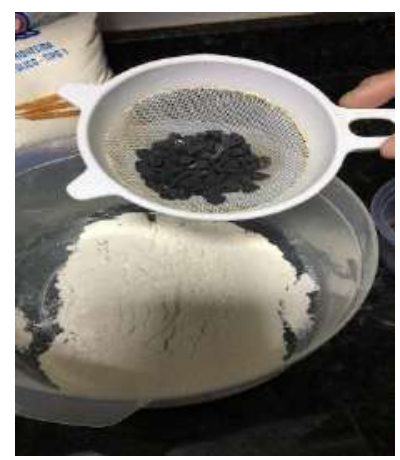

Figura 5. Catação feijão e milho (Integrante 5)

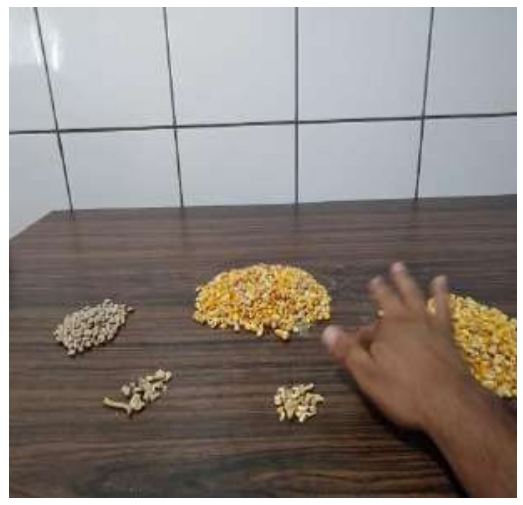

No que diz respeito a criar possibilidades e de se ensinar aprendendo conforme Freire (2010 e 1987), diante da atualidade vivenciada pelas escolas muitas delas optaram pela criação de grupos no WhatsApp, aplicativo de comunicação (NUVENS, 2018) visando o processo comunicativo entre todos os envolvidos no processo educacional. Um dos alunos do grupo do Trabalho de Conclusão citado acima, por já ter concluído uma graduação anteriormente, informou através do Fórum de Orientação, fazer parte de um grupo no Whatsapp que servia de comunicação entre ele e seus alunos da educação básica.

Tendo em vista a simplicidade da atividade prática usada no TCC, ele propôs a seus alunos do Ensino Médio, via Whatsapp, a realização dos mesmos experimentos realizados por seu grupo da graduação, cujas fotos foram apresentadas acima. A Figura 6 mostra a troca de mensagens por tal grupo de Whatsapp acerca da experimentação realizada. Além de agregar qualidade ao trabalho desenvolvido pelos 
graduandos, houve possibilidade de oferecimento de aulas práticas experimentais aos alunos da educação básica, pois: "Ninguém educa ninguém, ninguém se educa sozinho, os homens de educam em comunhão mediatizados pelo mundo" (GADOTTI et al 2005, p.36).

A prática foi realizada no mundo particular de cada um, em suas casas.

Figura 6. Print de tela das conversas via WhatsApp
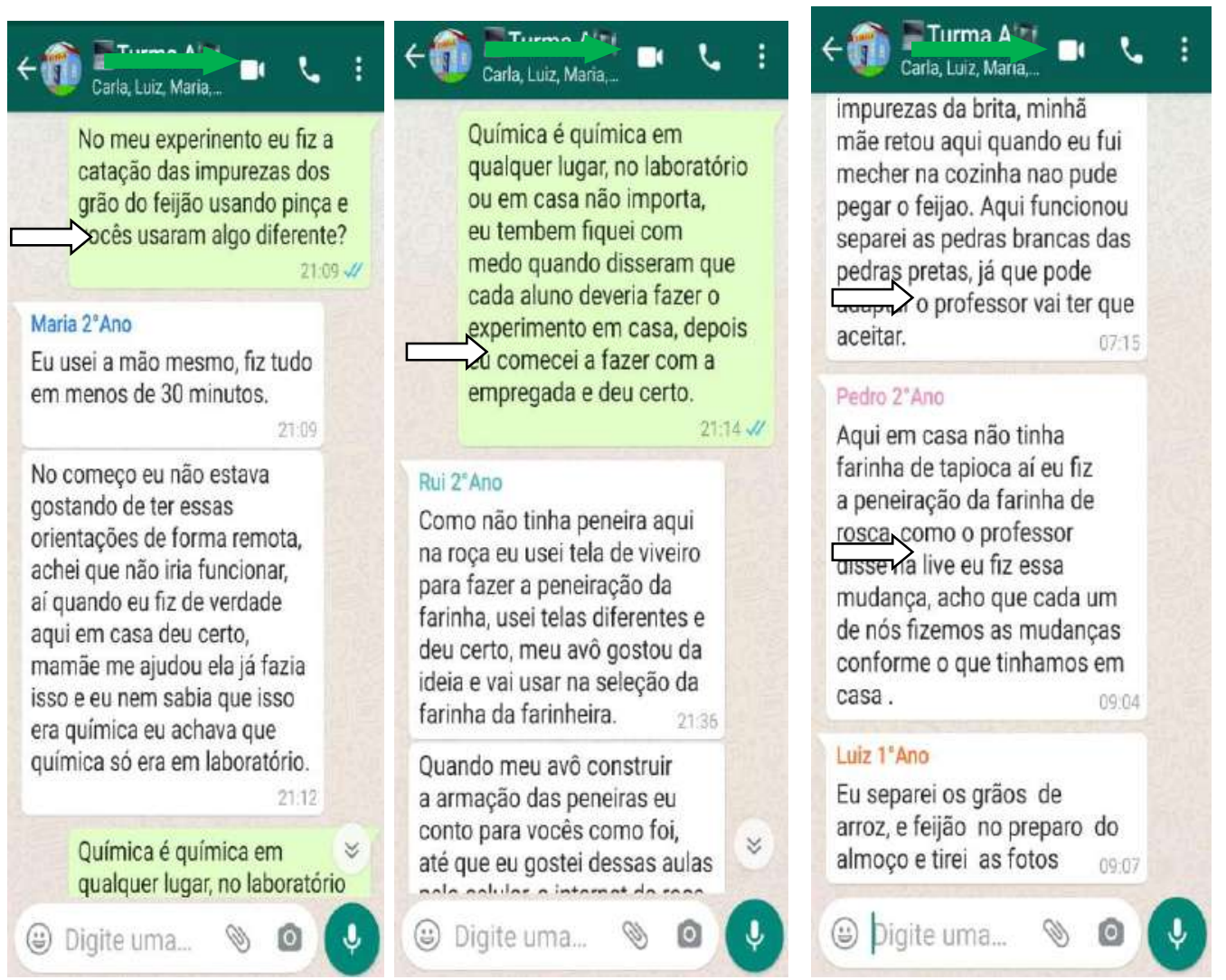

\section{Discussão}

A falta de recursos apontadas pelo INEP em 2018 e pelos meios de comunicação em tempos de pandemia evidenciou as desigualdades enfrentadas por estudantes e as necessidades mais do que nunca do docente em aprender a ensinar, não só por suas limitações do momento vivido, mas pelas limitações enfrentadas pelos seus alunos. Não há docência sem discência em qualquer etapa do ensino.

A prática apresentada neste estudo foi relacionada diretamente com a vida real do aluno atendendo os Parâmetros Curriculares Nacionais para o Ensino Médio e relacionando seu conhecimento com o mundo. Não sendo uma metodologia bancária "que tem por finalidade manter a divisão entre os que sabem e os que não sabem, 
entre os oprimidos e opressores "(FREIRE, 1987 p. 57-60). E sim educando na ação e reflexão entre educador e educando, problematizando a investigação e a interação levando ao questionamento (TAVARES e GODOY 2019).

\begin{abstract}
As atividades práticas não devem se restringir a procedimentos experimentais, mas promover momentos de discussão, interpretação e explicação das situações experimentais, desenvolvendo nos alunos compreensão dos processos químicos e sua relação com o meio cultural e natural, de maneira a desenvolver competências e habilidades para o exercício da cidadania e do trabalho (BRASIL, 1999).
\end{abstract}

Atividades práticas como está são práticas educacionais emancipadoras. A falta de recursos para o processo ensino aprendizagem das diversas disciplinas deixa lacunas imensas no saber do aluno, inovar e adaptar para ministrar os conteúdos é sempre necessário. Sabemos que o momento atual evidenciou isso, porém não podemos deixar de usar todos os recursos pedagógicos possíveis alternativos ou não para se fazer educação emancipatória, principalmente para aqueles alunos que, mais do que nunca, precisam da educação libertadora. O sistema educativo deve ser centralizado na inclusão (SILVA e SOUZA, 2019).

A partir das figuras relacionadas anteriormente (1 a 6) foi possível constatar que na segurança da casa de cada integrante do grupo do Trabalho de Conclusão de Curso destacado neste trabalho, foi possível realizar a prática de separação de misturas de maneira simples e dinâmica, viabilizando a construção do conhecimento prático e teórico que o conteúdo pede. A mesma prática poderia ser realizada em ambiente escolar com laboratório ou não, porém para que o conteúdo seja efetivamente aprendido a teoria é fundamental e toda a reflexão de maneira investigativa a atividade realizada deve ser contextualizada. Conforme Medeiros e Lobato (2010, p.66), "a contextualização do ensino tem relação com a motivação do aluno, por dar sentido àquilo que ele aprende, fazendo com que relacione o que está sendo ensinado com sua experiência cotidiana".

Indo contra o sistema bancário de ensino, no Quadro 1 estão descritas as conversas da figura 6 , que mostra que a atividade solicitada em nosso ambiente virtual para os licenciados foi repassada para alunos da educação básica. Através dos registros feitos por eles verifica-se o prazer em aprender: 
Quadro 1: Conversas dos alunos da educação básica (Ensino Médio) referente a prática experimental

"No meu experimento eu fiz a catação das impurezas dos grãos do feijão usando pinça e vocês algo diferente?"

"Eu usei a mão mesmo, fiz tudo em menos de 30 minutos".

"No começo eu não estava gostando de forma remota, achei que não iria funciona, ai quando eu fiz de verdade aqui em casa deu certo, mamãe me ajudou ela já fazia isso e eu nem sabia que isso era química eu achava que química só era em laboratório".

"Química é química em qualquer lugar, no laboratório ou em casa não importa, eu também fiquei com medo quando disseram que cada aluno deveria fazer o experimento em casa, depois eu comecei a fazer com a empregada e deu certo".

"Como não tinha peneira aqui na roça eu usei tela de viveiro para fazer a peneiração da farinha, usei telas diferentes e deu certo, meu avô gostou da ideia e vai usar na seleção da farinha da farinheira. Quando meu avô construir a armação das peneiras eu conto para vocês como foi, até que eu gostei dessas aulas".

“....impurezas da brita, minha mãe retou aqui quando eu fui mexer na cozinha não pude pegar o feijão. Aqui funcionou separei as pedras brancas das pedras pretas, já que pode adaptar o professor vai ter que aceitar".

"Aqui em casa não tinha farinha de tapioca aí eu fiz a peneiração da farinha de rosca, como o professor disse na live eu fiz essa mudança, acho que cada um de nós fizemos as mudanças conforme o que tínhamos em casa".

"Eu separei os grãos de arroz, e feijão no preparo do almoço e tirei as fotos.

Fica nítido que o ensino é facilitado quando se parte do que o aluno conhece (FREIRE, 2017). Ou seja, "educar antes de tudo é mobilizar o aluno para que se torne um aprendiz" (PERRENOUD, 2000, p75). Libertar através da educação se repensando em metodologias alternativas para suprir o que não se tem para minimizar os impactos causados por falta de recursos pedagógicos incluir este aluno menos favorecido com aulas emancipadoras a partir do mundo particular de cada um, "apreensão crítica do conhecimento" lendo o mundo com o aluno (FREIRE, 1995, p.83).

Também se identifica que os alunos, a partir da proposta inicial, encontraram seus próprios caminhos para chegar ao mesmo resultado no processo de aprendizagem, confirmando Freire (1967) 
Daí que o papel do educador seja fundamentalmente dialogar com o analfabeto, sobre situações concretas, oferecendo-lhe simplesmente os instrumentos com que ele se alfabetiza. Por isso, a alfabetização não pode ser feita de cima para baixo, como uma doação ou uma imposição, mas de dentro para fora, pelo próprio analfabeto, apenas com a colaboração do educador.

Uma inquietação diante da troca entre docente e discente em torno do conteúdo (FREIRE, 2017). "A gente se forma como educador, permanentemente, na prática e na reflexão sobre a prática" (GADOTTI et al, 2005, p.53).

\section{Considerações finais}

Práticas com materiais alternativos são práticas educacionais emancipadoras. Práticas como estas são realizadas no decorrer do curso de Licenciatura em Química EaD da UNIMES para que nosso discente possa estar preparado da melhor maneira possível a ministrar suas aulas na educação básica, utilizando o que terá disponível e adaptando o que não se tem, trabalhando de forma contextualizada fazendo uso de aulas práticas e teóricas relacionado a química com o cotidiano da sociedade e incluindo o ser no saber ler o mundo.

\section{Referências}

BRASIL. Secretaria da Educação Média e Tecnológica - Ministério da Educação e Cultura. Parâmetros Curriculares Nacionais - Ensino Médio: Ciências da Natureza, Matemática e suas Tecnologias. Brasília: MEC/SEMTEC, vol. 3, 1999. Tecnológica (Semtec). PCN + Ensino Médio: Ciências da Natureza, Matemática e suas Tecnologias. Brasília, DF: MEC/SEMTEC. 2002. Disponível em: http://portal.mec.gov.br/seb/arquivos/pdf/book_volume_02_internet.pdf Acesso em: 07 fev 2019.

COLEÇÃO MEMÓRIA DA PEDAGOGIA, n.4. Paulo Freire: a Utopia do Saber/ editor Manuel da Costa Pinto; [colaboradores Moacir Gadotti. et al.] Rio de Janeiro:Ediouro; São Paulo: Segmento Duetto, 2005.

FREIRE, P. Conscientização - teoria e prática da liberdade. São Paulo: Moraes, 1980.

Educação como Prática da Liberdade. Rio de Janeiro: Paz e Terra, 1967.

Pedagogia da Autonomia: Saberes Necessários a Prática Educativa.

São Paulo: Ed. Paz e Terra, 1995. 
Pedagogia da Autonomia: saberes necessários à prática educativa. 41 ed. São Paulo: Paz e Terra, 2010.

Pedagogia do Oprimido. 17.ed. Rio de Janeiro: Paz e Terra, 1987.

Pedagogia do Oprimido. 63.ed. São Paulo: Paz e Terra, 2017.

INEP, Instituto Nacional de Estudos e Pesquisas Educacionais Anísio Teixeira. Dados do censo escolar 2018. Disponível em: http://portal.inep.gov.br/artigo//asset_publisher/B4AQV9zFY7Bv/content/dados-do-censo-escolar-noventa-e-cincopor-cento-das-escolas-de-ensino-medio-tem-acesso-a-internet-mas-apenas-44-temlaboratorio-de-ciencias/21206. Acesso em 11 jul. 2021.

MACHADO AH, Moura ALA. Linguagem em Química. Química Nova na Escola. 1995. n. 2: 27-30.

MEDEIROS, M., LOBATO, A. Contextualizando a abordagem de radiações no ensino de química. Revista Ensaio, v.12, n.03, p. 65-84, 2010.

NUVENS, E. WhatsApp: história, dicas e tudo que você precisa saber sobre o app. 2018. Disponível em: https://olhardigital.com.br/2018/12/20/noticias/whatsapphistoria-dicas-e-tudo-que-voce-precisa-saber-sobre-o-app/. Acesso em 08 set. 2021.

PERRENOUD, P. Pedagogia diferenciada: das intenções a ação. Porto Alegre: Artmed, 2000.

SILVA, A.K.N; SOUZA, R. Encontros e desencontros entre a teoria de Freire e a BNCC. Paulo Freire presente! / organizado por Elisabeth dos Santos Tavares. - São Paulo: Liber Ars, 2019.

TAVARES, E.S..; GODOY, M.S.O. Encontros e desencontros entre a teoria de Freire e a BNCC. Paulo Freire presente! / organizado por Elisabeth dos Santos Tavares. São Paulo: Liber Ars, 2019. 


\title{
AULAS SÍNCRONAS NO ENSINO À DISTÂNCIA: ANÁLISE E PROPOSTA DE AVALIAÇÃO
}

\author{
Priscila Granado \\ Juliana Gonçalves Carvalho
}

\section{RESUMO}

A pandemia de COVID-19 trouxe consigo muitas modificações na rotina das pessoas e na educação não foi diferente. Nesse novo contexto, educadores e instituições de ensino superior precisaram modificar estratégias educacionais para garantir a qualidade do processo ensinoaprendizagem e manter a proximidade com os estudantes. Nesse sentido, iniciou-se a proposta de aulas síncronas no curso de Licenciatura em Ciências Biológicas da Universidade Metropolitana de Santos. Esta proposta consiste em agendar aulas que abordam temas das disciplinas de forma mais aprofundada, discussões de atualidades relacionadas aos temas abordados nas disciplinas e questões de exames e concursos. A iniciativa tem se mostrado uma estratégia interessante, pois os estudantes têm comparecido ou assistido as aulas posteriormente, uma vez que os docentes gravam e disponibilizam a gravação no ambiente virtual de aprendizagem (AVA). Nesse sentido, se faz necessária a avaliação dos alunos para esta proposta, para que, assim, possamos estruturar e aprimorar as estratégias de ensino que permitam o ensino aprendizagem mais dinâmico e afetuoso.

Palavras-chave: aulas síncronas; ensino-aprendizagem; avaliação

\section{Introdução}

O mundo foi surpreendido pela pandemia de COVID-19 no início do ano de 2020 e que permanece até o presente momento (Organização Mundial da Saúde, 2020). Esse fato tem modificado comportamentos, formas de se relacionar, de trabalhar e estudar (Almeida et al. 2020; Lima et al. 2020). A educação, assim como outros setores da sociedade, foi profundamente afetada neste contexto (Araújo et al. 2020). Instituições de ensino e educadores se depararam com a necessidade de explorar estratégias das atuais Tecnologias de Informação e Comunicação (TIC) (Rocha \& Lima, 2021) para a garantia do processo de ensino e aprendizagem efetivo e mais afetuoso, aproximando estudantes e professores (Araújo et al. 2020).

O ensino superior à distância tem crescido exponencialmente no Brasil como demonstra o censo de 2019 que indica que mais de 50\% dos estudantes que ingressaram no ensino superior privado optaram por essa modalidade (Ministério da educação, 2020). No entanto, o Ensino à Distância (EaD), também apresentou os impactos da pandemia (Rocha \& Lima, 2021) e, nesse contexto, surgiu a necessidade de repensar as práticas pedagógicas adotadas no ensino à distância em nosso curso, o que nos levou à proposta das aulas síncronas. Essa prática consiste em agendar dia e horário para a realização de aulas remotas (ao vivo) por meio do uso de plataformas específicas, com a presença do professor e dos estudantes. Além disso, também demanda um planejamento dos temas e preparo prévio da aula que será 
transmitida. Segundo Araújo et al. (2020), essa prática necessita também de estratégias diferenciadas para que a aula seja mais atrativa, de forma a garantir a proximidade entre os estudantes e o professor, garantindo a construção do conhecimento.

Por se tratar de uma prática nova em nosso curso, acreditamos ser importante o relato desta experiência, visando possíveis readequações nas estratégias de ensino e/ou efetivação do modelo de aulas síncronas como estratégia curricular, pois o EaD se caracteriza pela versatilidade de tempo, espaço e organização curricular, no intuito de flexibilizar o modelo tradicional de ensino, promovendo a democratização do conhecimento e a adaptação ao cotidiano do estudante (Vianney \& Paranhos, 2021; Mill, 2015).

Nesse contexto, o Decreto 9.057/2017, em seu Artigo 1ํ, que regulamenta a Educação à Distância, estabelece que:

Para os fins deste Decreto, considera-se educação a distância a modalidade educacional na qual a mediação didático-pedagógica nos processos de ensino e aprendizagem ocorra com a utilização de meios e tecnologias de informação e comunicação, com pessoal qualificado, com políticas de acesso, com acompanhamento e avaliação compatíveis, entre outros, e desenvolva atividades educativas por estudantes e profissionais da educação que estejam em lugares e tempos diversos. (Brasil, 2017)

Diante do exposto, nosso objetivo é relatar a experiência sobre a proposta das aulas síncronas (ao vivo) no curso de Licenciatura em Ciências Biológicas no EaD, no sentido de promover uma reflexão sobre as estratégias metodológicas utilizadas nas aulas síncronas, sua efetividade no processo de ensino e aprendizagem, bem como propor um método avaliativo sobre a percepção dos alunos em relação às aulas síncronas.

\section{Contexto e realidade investigada}

Iniciamos as aulas síncronas no mês de março de 2021, a partir do momento que foi decretado o lockdown devido a pandemia, no intuito de promover a aproximação entre docentes e discentes e uma efetividade no processo de ensino aprendizagem.

As aulas que acontecem de maneira síncrona são agendadas previamente com dias e horários definidos e os convites são enviados aos alunos matriculados nas diferentes disciplinas do curso. Os conteúdos abordados nas aulas, pensados 
anteriormente pelos professores, são temas da atualidade e que se relacionam com o conteúdo programático, temas que precisam de um aprofundamento ou ainda conteúdos exigidos em exames nacionais e concursos. Todas essas análises e propostas temáticas são realizadas em consonância com o exigido pelo Parecer CNE/CES no 1.301/2001, de 6 de novembro de 2001, que aprova as Diretrizes Curriculares Nacionais do curso de graduação em Ciências Biológicas (Licenciatura e Bacharelado).

As aulas remotas síncronas sempre acontecem no período noturno, pois foi elaborado para atender ao maior número de alunos possível. A ferramenta utilizada para as aulas síncronas foi o Zoom e os recursos didáticos consistem, na sua maioria, em apresentações em Power Point intercalados com vídeos disponíveis na plataforma do YouTube e divulgação de sites.

\section{Diagnóstico da situação-problema}

Observamos que essa prática tem se mostrado satisfatória quando consideramos as especificidades do ensino à distância e o perfil dos estudantes do curso de Ciências Biológicas. Os estudantes têm comparecido aos momentos síncronos ou então assistem à aula posteriormente, já que os docentes gravam as aulas e posteriormente disponibilizam no ambiente virtual de aprendizagem (AVA) da disciplina, pois alguns alunos não podem estar presentes no horário estabelecido, em sua maioria devido ao horário de trabalho.

\section{Análise da situação-problema e propostas de inovação ou intervenção ou recomendação}

Com o início do segundo semestre do curso, pensamos na possibilidade de estruturar um método avaliativo das aulas síncronas, no intuito de identificar pontos positivos e negativos da estratégia utilizada, abarcando assim, o processo açãoreflexão-ação que constitui a práxis docente. Em seu livro Pedagogia da Autonomia, Paulo Freire (2001) faz considerações importantes sobre o processo dialético entre o fazer e o pensar:

A prática docente crítica, implicante do pensar certo, envolve o movimento dinâmico, dialético, entre o fazer e o pensar sobre o fazer. [...] O que se precisa é possibilitar, que, voltando-se sobre si mesma, através da reflexão sobre a prática, a curiosidade ingênua, percebendose como tal, se vá tornando crítica. [...] A prática docente crítica, 
implicante do pensar certo, envolve o movimento dinâmico, dialético, entre o fazer e o pensar sobre o fazer (FREIRE, 2001, p. 42-43).

Dessa forma, acreditamos que um método avaliativo, apresentará os pontos positivos e negativos apontados pelos alunos e dessa forma poderemos estruturar de maneira mais assertiva as estratégias de ensino que consolidem o fazer docente, bem como tornem o ensino aprendizagem mais dinâmico e significativo aos nossos alunos.

\section{Conclusões e contribuição tecnológica/social}

Para atender essa necessidade, utilizaremos a ferramenta Google Forms que é um aplicativo disponibilizado gratuitamente pela Google e que permite a elaboração de documentos que possibilitam a coleta e análise de informações. Estruturaremos um questionário exploratório de abordagem qualitativa, com questões abertas e fechadas que permitirá a avaliação sobre a percepção dos discentes sobre as aulas síncronas, seu desempenho na disciplina, relevância dos temas abordados etc. $O$ questionário será enviado por meio de link aos alunos. Após a coleta, faremos a análise e tabulação dos dados com posterior discussão entre o grupo de docentes e coordenador do curso visando à melhora no fazer docente, bem como a relevância e efetividade das aulas síncronas.

\section{Referências}

Almeida, W. S.; Szwarcwald, C. L.; Malta, D. C.; Barros, M. B. A.; Júnior, P. R. B. S.; Azevedo, L. O. et al. 2020. Mudanças nas condições socioeconômicas e de saúde dos brasileiros durante a pandemia de COVID-19. Revista Brasileira de epidemiologia: 23: 1-14.

Araujo, R. M.; Eliseo, M. A.; Amato, C. A. H.; Silveira, I. F.; Martins, V. F. 2020. COVID19 , Mudanças em práticas educacionais e a percepção de estresse por docentes do ensino superior no Brasil. Revista brasileira de informática na Educação: 28: 864-891.

Brasil. Decreto-lei n.o 9.057 de 25 de maio de 2017. Regulamenta o Art. 80 da Lei 9394 de 20 de dezembro de 1996, que estabelece as diretrizes e bases da Educação Nacional. Disponível em: <http://www.planalto.gov.br/ccivil 03/ ato20152018/2017/decreto/d9057.htm> Acesso em: 17 Ago 2021.

Freire, P. Pedagogia da autonomia: saberes necessários à prática educativa. 20 ed. São Paulo: Paz e Terra, 2001.

Lima, N. T.; Buss, P. M.; Paes-Sousa, R. 2020 A pandemia de COVID-19: uma crise sanitária e humanitária. Caderno de Saúde Pública: 36 (7): 1-4.

Mill, D. Gestão estratégica de sistemas de educação a distância no Brasil e em Portugal. Educ. Soc., Campinas, v. 36, nº. 131, p. 407-426, abr.-jun., 2015. Disponível 
em:

<https://www.scielo.br/j/es/a/bzKxvBxsqZ6DDPXsQRTtXQQ/?lang=pt\&format=pdf>. Acesso em: 17 Ago 2021.

Ministério da Educação. Conselho Nacional de Educação. Parecer CNE/CES no 1.301/2001, aprovado em 6 de novembro de 2001. Diretrizes Curriculares Nacionais para os Cursos de Ciências Biológicas - Licenciatura e Bacharelado. Disponível em: <http://portal.mec.gov.br/cne/arquivos/pdf/CES1301.pdf>. Acesso em: 17 Ago 2021.

Ministério da educação. Ensino à distância se confirma como tendência. 2020. Disponível em: < https://www.gov.br/inep/pt-br/assuntos/noticias/censo-da-educacaosuperior/ensino-a-distancia-se-confirma-como-tendencia> Acesso em 07 de ago. de 2021.

Organização mundial da saúde. Folha informativa - COVID-19 (doença causada pelo novo coronavírus). 2020. Disponível em: < https://www.paho.org/pt/covid19> Acesso em 07 de ago. de 2021.

Rocha, E. M.; Lima, J. M. S. 2021. Impactos e desafios do ensino on-line decorrentes da pandemia COVID-19. Revista Ibero-Americana de Estudos em Educação: 16(2): 377-390.

Vianney, J.; Paranhos, M. C. As diferenças entre ensino conectado e a Educação à Distância na pandemia. Associação Brasileira de Educação à Distância - ABED, 2021.

Disponível

em:

$<$ http://www.abed.org.br/site/pt/midiateca/textos ead/2014/2021/05/as diferencas entre en sino conectado e a educacao a distancia na pandemia>. Acesso em: 17 Ago 2021. 


\title{
A RELAÇÃO ENTRE A TRAJETÓRIA E A PRÁTICA DO PROFESSOR NA ALFABETIZAÇÃO DE ALUNOS COM DEFICIÊNCIA
}

\author{
Rosângela Ferreira de ALCÂNTARA \\ Irene da Silva COELHO
}

\section{RESUMO}

Como professora alfabetizadora, percebo que as dificuldades encontradas por professores para alfabetizar alunos com deficiências é grande por desconhecerem como devem ser essas práticas e também por se depararem com diversos problemas. A inclusão ainda é um tema que provoca angústia em muitos professores. Por isso, esta pesquisa apresenta reflexões sobre a inclusão na escola pública e busca caminhos para o letramento e alfabetização de alunos com deficiência intelectual, assim como, contribuir para que o professor alfabetizador supere as barreiras em sala de aula e construa com o aluno DI uma aprendizagem efetivamente inclusiva. $O$ objetivo é ressaltar a importância de um olhar inclusivo para o desenvolvimento do trabalho realizado pelo professor alfabetizador, levando em consideração a realidade dos alunos. Fundamentada nos pressupostos de alfabetização e de letramento de Soares (2003), Kleiman (1995), Freire (2014) que pensam nesses processos articulados à função social da leitura e da escrita.

Palavras-chave: Prática docente, Alfabetização, Deficiência Intelectual.

\section{INTRODUÇÃO}

Minha prática está relacionada a minha trajetória de vida e o processo inicial de profissionalização: alguém que sai de um curso técnico, vai para uma escola particular, sem didática nenhuma para dar aulas de informática e se apaixona pelo ambiente escolar, pelos alunos da Educação Infantil, e a partir desse encontro decide iniciar o curso de Magistério.

Terminei o Magistério em 1997. Em 1999, fiz o processo seletivo para a Educação Infantil tendo trabalhado até 2001. Em 2002, após ter concluído o curso de Pedagogia, iniciei o trabalho como alfabetizadora de crianças de 7 anos ou mais no Ensino Fundamental I.

Durante o curso de Pedagogia constantemente me perguntava... Se o que estou fazendo era suficiente. Quais eram as dificuldades dos alunos e também daqueles que apresentavam alguma deficiência. Buscava respostas para qual era o meu papel como professora frente às necessidades de todos os alunos. 
Não sabia muito bem o que fazer, mas como havia trabalhado com jogos, brincadeiras e músicas na El, procurei envolver também os alunos de inclusão e fui estabelecendo estratégias neste sentido.

Já em 2002, em sala de aula, passei a buscar ajuda com os meus pares mais experientes, buscando aprender como se dá o processo de alfabetização dos alunos, principalmente os alunos com alguma deficiência, já que optei por ser professora alfabetizadora.

Desde o início de minha trajetória como professora, tive em minhas turmas alunos com deficiência e dificuldades de aprendizagem, pois os professores mais antigos se recusavam a ter classes com inclusões e os professores que estavam iniciando ficavam com essas turmas, era tudo planejado internamente. Foi necessário me aperfeiçoar, buscar e criar caminhos para poder trabalhar cada vez melhor com essas turmas heterogêneas e com os alunos de inclusão.

Após o curso de Pedagogia fiz pós graduação em Psicopedagogia Institucional e em Deficiência Intelectual. Ainda hoje me sinto desafiada em sala de aula, enfrento questões que precisam ser resolvidas, pesquisadas, compreendidas em relação aos alunos de inclusão. Faz-se necessário não somente colocar o aluno com deficiência na sala de aula e sim, dar todas as condições para que ele tenha o seu direito à aprendizagem respeitado e se desenvolva avançando em seu ensino.

Ao longo desse caminho, fui adquirindo conhecimento, fui trocando com meus pares que também se preocupavam, como eu, com a aprendizagem e alfabetização dos alunos, principalmente de inclusão.

Alguns colegas, no entanto, diziam: é só socialização que o aluno de inclusão precisa; porém minha prática me revelou que não, era possível fazer mais, cada aluno aprendia em seu ritmo, mas havia aprendizagem e desenvolvimento, porém era preciso um trabalho árduo, dedicado, fazer e muitas vezes refazer para poder obter resultados, todos os alunos possuíam um jeito próprio de aprender, mas esses resultados vinham, muitos alunos meus de inclusão terminavam o $2^{\circ}$ Ano alfabetizados ou bem encaminhados para isso, em processo, mesmo alunos mais velhos de 11 e 12 anos se desenvolviam.

No decorrer do meu trabalho também fui buscar teorias que me elucidassem a respeito do desenvolvimento infantil e da alfabetização em Emília Ferreiro, Ana Teberoski, Piaget, Kleiman, Magda Soares e Paulo Freire. 
Freire foi fundamental para minha formação, pois me identifiquei com sua visão. Principalmente por compartilhar suas reflexões e o olhar: vejo meus alunos como sujeitos de mudança e transformação de suas vidas e da sociedade como um todo.

De acordo com Freire (2007, p. 07), "para que um ser possa assumir um ato comprometido necessita ser capaz de agir e refletir, ou seja, é preciso capacidade de, estando no mundo, saber-se nele".

Essa visão revela a necessidade de o professor conhecer seu aluno, refletir sobre sua realidade e a realidade do entorno para dialogar e tomar decisões em conjunto.

Para Freire (1997), "O professor que pensa certo deixa transparecer aos educandos que uma das bonitezas de nossa maneira de estar no mundo e com o mundo, como seres históricos, é a capacidade de intervindo no mundo, conhecer o mundo".

Assumi assim o compromisso de um ensinar e aprender solidário, alegre, que inclui e não exclui, que reflete sobre o seu fazer pedagógico, que propõe práticas diversificadas, com uso de recursos tecnológicos ou não, mas que busca despertar no aluno a curiosidade, o raciocínio, a troca de saberes e o fazer coletivo. É nesse contexto de solidariedade, que todos os alunos participam, que o meu trabalho de alfabetização acontece.

Gomez (1998, p.08) corrobora a ideia de Freire, afirmando que na escola, "como em qualquer instituição social marcada por contradições e interesses conflitantes, há espaços de relativa autonomia que são capazes de desequilibrar a clara tendência à reprodução do status quo".

O papel do professor é utilizar esses espaços com intencionalidade, provocar, refletir, fazer o aluno pensar sua própria realidade, ir além da simples reprodução e fomentar a pluralidade.

Ainda segundo Gomez (1998, p.15), é: "vivendo de forma democrática na escola que o aluno aprende a viver e sentir democraticamente na sociedade, construindo e respeitando o delicado equilíbrio entre os interesses e necessidades individuais e as exigências da coletividade."

Essas exigências revelam a necessidade de compreender o que envolve a alfabetização e o letramento. Em Soares (1998), Kleiman (1995), Tfouni (1995), 
encontra-se a relação do letramento ao conjunto de práticas sociais orais e escritas de uma sociedade.

Para Soares (2003, p.3):

se alfabetizar significa orientar a própria criança para o domínio da tecnologia da escrita, letrar significa levá-la ao exercício das práticas sociais de leitura e escrita. Uma criança alfabetizada é uma criança que sabe ler e escrever, uma criança letrada [...] é uma criança que tem o hábito, as habilidades e até mesmo o prazer da leitura e da escrita de diferentes gêneros de textos, em diferentes suportes ou portadores, em diferentes contextos e circunstâncias. [...] Alfabetizar letrando significa orientar a criança para que aprenda a ler e a escrever levando-a a conviver com práticas reais de leitura e de escrita.

Fica claro que alfabetizar não é apenas ensinar a codificar e decodificar letras e sons; vai além e envolve a compreensão que nos é dada por Paulo Freire: leitura e escrita são consequência de quem tem a experiência do mundo e por estar em contato com o mundo tem condições de mudá-lo. Já o letramento, pressupõe uma intimidade relacionada tanto aos discursos que são elaborados em diferentes instituições, bem como as práticas sociais orais e escritas, aos objetos, procedimentos, atitudes, como formas sociais de expressão, entre elas a expressão em língua escrita.

o processo de alfabetização válido [...] é aquele que não se satisfaz apenas [...] com a leitura da palavra, mas que se dedica também a estabelecer uma relação dialética entre a leitura da palavra e a leitura do mundo, a leitura da realidade. A prática de alfabetização tem que partir exatamente dos níveis de leitura do mundo, de como os alfabetizandos estão lendo sua realidade, porque toda leitura do mundo está grávida de um certo saber. Não há leitura do mundo que não emprenhada pelo saber, por certo saber (FREIRE, 2014, p. 164).

\section{A PRÁTICA PENSADA PARA A NÃO EXCLUSÃo}

Dessa forma, como professora alfabetizadora, que trabalha com alunos que estão na sala de aula que não apresentam dificuldades e com alunos que são considerados de inclusão, percebo como é importante que as práticas de alfabetização e letramento sejam pensadas tendo em consideração a realidade dos alunos e suas condições de aprendizagem. 
Para o trabalho com alunos de inclusão, é importante um pensar coletivo, um trabalho colaborativo e práticas de letramento e multiletramentos que permitam a participação de todos e se tornem fundamentais para uma aprendizagem significativa dos alunos e, no caso, da experiência adquirida com alunos com deficiência intelectual, esse pensar e essa atitude são essenciais.

Para Rojo e Moura (2012), o letramento tende a se tornar multiletramentos quando "são necessárias novas ferramentas - além das da escrita manual (papel, pena, lápis, caneta, giz e lousa) e impressora (tipografia, imprensa) - de áudio, vídeo, tratamento de imagem, edição e diagramação" (p. 21). Logo, esses recursos e mídias possibilitam a aprendizagem e podem e devem ser utilizados em sala de aula.

Segundo Rojo (2009, p. 90) é preciso que a linguagem utilizada dê:

conta das demandas da vida, da cidadania e do trabalho numa sociedade globalizada e de alta circulação de comunicação e informação, sem perda da ética plural e democrática, por meio do fortalecimento das identidades e da tolerância às diferenças. Para tal, são requeridas uma visão situada de língua em uso, linguagem e texto e práticas didáticas plurais e multimodais, que as diferentes teorias de texto e de gêneros favorecem e possibilitam.

Há assim a necessidade de o professor pensar e lançar um olhar personalizado, a fim de atender as necessidades do aluno com deficiência e desenvolver suas habilidades, em um contexto onde todos participam, respeitam as diferenças e aprendem de acordo com seus ritmos e características próprias, apesar de todas as dificuldades que enfrentamos.

Em plena pandemia, através dos recursos tecnológicos, faz-se aulas on-line, jogos, vídeo aulas, interações via WhatsApp. O professor precisa utilizar com os alunos que estão em plena alfabetização, principalmente de inclusão, todos os recursos possíveis, assim, o professor tem o papel de incentivar, mediar e problematizar o ensino/aprendizagem, por meio da educação a distância; ultimamente no ensino híbrido, o papel do professor é dar direcionamento aos estudos, conduzindo o aluno a um aprendizado ativo e construindo passo a passo uma maior autonomia de estudos.

Para melhorar minha prática, precisei aprender sobre a inclusão. Mantoan (2003) afirma que incluir implica uma mudança de perspectiva educacional, pois não 
se atinge apenas alunos com deficiência, mas todos para que obtenham sucesso na corrente educativa geral.

Tal reflexão exige mais do professor sobre o assunto, pois inclusão é acolher a todos, atingindo não somente os alunos com deficiência, mas todos que correm o risco de fracassar em sua aprendizagem. É olhar a todos, mas com um olhar atento às subjetividades de cada um, suas singularidades, sem fixar rótulos, sem preconceitos, porém, na escola atual ainda há muitas barreiras para essa discussão principalmente sobre a exclusão digital.

O meu trabalho tem se voltado para essa desconstrução de olhar na escola, uma vez que trabalho com a diversidade. É preciso que todos aprendam de acordo com seus ritmos e diferenças, por meio do compartilhamento de saberes penso que é possível sim, formar um cidadão global.

Carvalho (2010) afirma que "o valor da equidade associado ao da igualdade de direitos, permite-nos, sem prejuízo da qualidade, diversificar as respostas educativas das escolas, em respeito às diferenças individuais".

Nessa perspectiva "não excludente" que o letramento e multiletramentos são fundamentais para o professor alfabetizador ressignificar suas práticas, sair do lugar comum, articulando os letramentos que acontecem no ambiente escolar com aqueles relacionados à vida, nas múltiplas linguagens e múltiplas culturas, colaborando assim para uma aprendizagem significativa, que inclua todos.

No meu fazer pedagógico, percebo o envolvimento e a motivação da maioria dos alunos nas práticas de alfabetização e letramento, multiletramentos, principalmente o aluno DI - consigo trabalhar suas dificuldades e desenvolver suas habilidades, de acordo com seu ritmo, é um trabalho dedicado, nada fácil e que os resultados muitas vezes só serão vistos no ano posterior que o aluno irá cursar, se o professor do ano seguinte der continuidade ao meu trabalho.

É preciso um fazer coletivo da/na escola, dos professores, porém, para alguns dos meus colegas ainda é difícil esse olhar e essa troca, possuem barreiras, poucos conhecimentos e não conseguem trabalhar nessa perspectiva. Além da nossa formação continuada ainda ser precária, havendo pouco ou quase nenhum investimento, acabamos, como agora em plena pandemia, tendo que usar recursos próprios tecnológicos para efetivar as aulas on-line na escola pública e dar conta de tamanha demanda, tendo a preocupação e cuidado de não deixar de fora os alunos 
de inclusão, os que não possuem internet, as famílias com apenas um celular para ser usado pelo aluno somente no final do dia e que ainda precisa dividir com os irmãos, entre outras dificuldades.

Portanto, é preciso um olhar diferenciado do professor alfabetizador, para que o aluno de inclusão desenvolva suas habilidades de leitura e escrita e que esteja inserido em todas as atividades da turma, participando ativamente da construção dos seus conhecimentos. É nesse sentido que a atenção do professor deve ser redobrada, para que não caia em uma atitude de exclusão, da não participação ativa do aluno DI.

Mantoan (2003) também deixa claro que as condições de que dispomos hoje, para transformar a escola nos autorizam a propor uma escola única e para todos, em que a cooperação substituirá a competição, pois o que se pretende é que as diferenças se articulem e se componham e que os talentos de cada um sobressaiam.

Meu trabalho, então, baseia-se em práticas personalizadas, que favoreçam essa aprendizagem desconstruída, adequada às diferenças, onde todos são convocados a participarem como indivíduos singulares, com seus afetos e valores, num ambiente de troca onde todos aprendem com todos e são importantes nesse processo. Tais práticas foram desenvolvidas ao longo da minha carreira, por meio das experiências vividas nas diversas escolas que lecionei, desde a Educação Infantil até agora, por meio do conhecimento teórico que fui buscar para desenvolver o meu trabalho, as barreiras que tive que transpor em diversas frentes e, também, na relação com meus pares - muitos me auxiliaram com suas experiências.

\section{CONCLUSÃO}

Quando se fala em prática pedagógica, estamos falando dos saberes docentes que estão interligados às demais dimensões do trabalho dos professores, como formação, desenvolvimento profissional, identidade, carreira, condições de trabalho, tensões e questões socioeducativas que marcam a profissão, características das instituições escolares em que trabalham os professores, também o conteúdo dos programas. Logo, os saberes estão integrados às práticas docentes e que são determinadas por questões normativas, éticas e políticas (TARDIF, 2011).

De acordo com Mantoan (2003) é inegável que as ferramentas estão disponíveis para que as mudanças aconteçam e para que reinventemos a escola, 
"desconstruindo" a máquina obsoleta que a dinamiza, os conceitos sobre os quais ela se fundamenta, os pilares teórico-metodológicos em que ela se sustenta.

Confirma-se, ainda, mais uma razão de ser da inclusão, um motivo a mais para que a educação se atualize, para que os professores aperfeiçoem as suas práticas e para que escolas públicas e particulares se obriguem a um esforço de modernização e de reestruturação de suas condições atuais.

Muito ainda temos que fazer para a efetivação de uma escola realmente inclusiva, mas há possibilidades se começarmos já essa desconstrução, experimentando, propondo, e tomando como medida a nossa própria realidade cotidiana, não há receitas prontas, mas já existem caminhos para serem compartilhados em busca de uma educação inclusiva.

\section{REFERÊNCIAS}

CARVALHO, R. E. Educação inclusiva: com os pingos nos is. 7. ed. Porto Alegre: Mediação, 2010.

FREIRE, P. Pedagogia da Autonomia: saberes necessários à prática educativa. 33. ed. São Paulo: Paz e terra, 1997.

FREIRE, P. O compromisso do profissional com a sociedade. In: . Educação e Mudança. São Paulo. Paz e Terra, 2007.

FREIRE, P. (2014). Pedagogia dos sonhos possíveis 1. ed. Rio de Janeiro: Paz \& Terra.

GOMÉZ, A. I. P. As funções sociais da escola: da reprodução à reconstrução crítica do conhecimento e da experiência. In: SACRISTÁN, J. Gimeno e GÓMEZ A. I. Pérez. Compreender e Transformar o Ensino. Porto Alegre, Artmed, 1998.

KLEIMAN, A. Modelos de letramento e as práticas de alfabetização na escola. In: KLEIMAN, A. (Org.). Os significados do letramento: uma nova perspectiva sobre a prática social da escrita. Campinas: Mercado de Letras, 1995. 
MANTOAN, Maria Teresa Eglér. Inclusão escolar: 0 que é? Por quê? Como fazer? São Paulo: Moderna, 2003.

ROJO, R. H. R. Letramentos Múltiplos: escola e inclusão social. São Paulo: Parábola, 2009.

ROJO, Roxane; MOURA, Eduardo. Multiletramentos na escola. São Paulo: Parábola Editorial, 2012.

SOARES, M. As condições sociais da leitura: uma reflexão em contraponto, In Zilberman, R. \& Silva, E.T. Perspectivas Interdisciplinares, São Paulo: Ática, 1988.

SOARES, M. B. Letramento: um tema em três gêneros. Belo Horizonte: Autêntica, 2003.

TARDIF, M. Os saberes dos professores. In: OLIVEIRA, D. A.; DUARTE, A. M. C.; VIEIRA, L. M. F. Dicionário: trabalho, profissão e condição docente. Belo Horizonte: UFMG/Faculdade de Educação, 2010. CDROM.

TARDIF, M. Saberes docentes e formação profissional. 12. ed. Petrópolis, RJ: Vozes, 2011.

TFOUNI, Leda Verdiani. Letramento e Alfabetização. São Paulo: Cortez, 1995. 


\title{
REFLETIR A BASE NACIONAL COMUM CURRICULAR E O ENSINO DA ARTE: IMPACTOS PARA O ENSINO MÉDIO E FORMAÇÃO DOCENTE
}

Rubens de Souza

\begin{abstract}
Convém alertar que nossa existência dialógica dar-se-á no âmbito da tensão dramática entre o passado silencioso e o futuro comunicativo, entre criar condições existenciais melhores e não criar, entre dizer a palavra verdadeira para nós e o silêncio castrador que nos oprime, entre a esperança do vir a ser e o desespero do sem porvir, entre ser mais e quase não ser no mundo vivido.
\end{abstract}

FREIRE, 1993

\section{INTRODUÇÃO}

Em 2017, homologou-se a Base Nacional Comum Curricular (BNCC), com o firme propósito de regular um conjunto de orientações para os currículos da educação básica brasileira. O processo ocorreu a partir de três versões do documento e a última finalizou, com a análise do Ministério da Educação e do Conselho Nacional de Educação (CNE), conforme a previsão da Lei de Diretrizes e Bases da Educação (LDB), promulgada em 1996.

\begin{abstract}
A BNCC expressa o compromisso do Estado Brasileiro com a promoção de uma educação integral voltada ao acolhimento, reconhecimento e desenvolvimento pleno de todos os estudantes, com respeito às diferenças e enfrentamento à discriminação e ao preconceito. Assim, para cada uma das redes de ensino e das instituições escolares, este será um documento valioso tanto para adequar ou construir seus currículos como para reafirmar o compromisso de todos com a redução das desigualdades educacionais no Brasil e a promoção da equidade e da qualidade das aprendizagens dos estudantes brasileiros (BRASIL, 2017, p. 5).
\end{abstract}

Sua implantação se iniciou em 2019 com a Educação Infantil e Ensino Fundamental, e em 2020 para o Ensino Médio, com diversas discussões, reflexões e críticas sobre as alterações do Sistema Educacional Brasileiro e seus desdobramentos. Vale destacar sobre a relevância da Base Nacional e que seus objetivos deveriam tangenciar o Plano Nacional de Educação (PNE), estabelecido pela Lei 13.005 de junho de 2014, no entanto, há pontos passíveis de crítica. Percebem-se a aproximação e a influência de grupos empresariais e as 
características voltadas para a privatização da educação básica, a usurpação da autonomia docente, caráter mais conservador, entre outros atributos. Logo, o artigo enfatizará as mudanças ocorridas para o Ensino Médio, e para o componente curricular Arte, prevista pela Base Nacional Comum Curricular (BNCC).

A proposta neste artigo é justamente a de analisar as condições do ensino de Arte para o Novo Ensino Médio, frente às várias matrizes curriculares possíveis e previstas pela Base Nacional Comum Curricular (BNCC). Ainda, identificar as teorias freirianas diante da complexa mudança da educação brasileira.

Justifica-se o tema ao analisar algumas teorias freirianas e as atuais políticas públicas voltadas para a educação básica, em especial o Novo Ensino Médio, que muda os currículos em forma, organização e período de permanência na unidade escolar, de 800 horas para 1000 horas anuais.

A pesquisa investiga os documentos oficiais da Educação Básica Brasileira e seus protagonistas, nesse sentido, será importante mencionar sobre o Fundo de Manutenção e Desenvolvimento da Educação Básica (FUNDEB), instituído pela Emenda Constitucional no 53, de 2006, MP no 339 e Lei no 11.494, Decretos no 6.253 e 6.278 de 2007, respectivamente e que financia ações de manutenção e desenvolvimento da educação básica e pública, conforme estabelecido nos $\S 20$ e $\S$ $3^{\circ}$ do Art. 211 da Constituição. Vale o destaque, pois o Fundo de Manutenção e Desenvolvimento da Educação Básica (FUNDEB) foi o grande responsável pela sustentabilidade da implantação da Base Nacional Comum Curricular (BNCC).

Em 2017, a Lei no 13.145 que instituiu a reforma do Ensino Médio foi aprovada, com alguns pontos de grande polêmica. O Novo Ensino Médio, homologado pelo então Ministro da Educação, Rossieli Soares, no qual os estados poderão administrar até $30 \%$ da carga horária na modalidade educação a distância (EAD) e admissibilidade de profissionais sem licenciatura, apenas com o "notório saber" para as áreas de formação técnica profissional. A implementação do ensino em tempo integral, com a ampliação de 1.400 horas, basicamente sete horas diárias. Para tanto, contará com um repasse financeiro de $\mathrm{R} \$ 1,5$ bilhão até 2024 , por um prazo de dez anos. Os conteúdos determinados pela Base Nacional Comum Curricular (BNCC) são de 1.800 horas do total da carga horária. Os componentes curriculares: Matemática e 
Português são obrigatórios. O artigo 35 da Lei Diretrizes e Bases (LDB) fundamenta o Parecer CNE/CP nำ 15/2017

IV - a compreensão dos fundamentos científico-tecnológicos dos processos produtivos, relacionando a teoria com a prática, no ensino de cada disciplina."; CONSIDERANDO que o art. 35-A da LDB, incluído pela Lei no 13.415/2017, define que "a Base Nacional Comum Curricular definirá direitos e objetivos de aprendizagem do ensino médio, conforme diretrizes do Conselho Nacional de Educação, nas seguintes áreas do conhecimento: linguagens e suas tecnologias; matemática e suas tecnologias; ciências da natureza e suas tecnologias; ciências humanas e sociais aplicadas", a qual deve ser complementada, nos termos do $\S 1^{\circ}$ desse mesmo artigo, por uma parte diversificada, a ser definida em cada sistema de ensino e que "deverá estar harmonizada à Base Nacional Comum Curricular e ser articulada a partir do contexto histórico, econômico, social, ambiental e cultural” (CNE/CES, № 15, 2017).

O documento informa que os currículos do Ensino Médio devem apresentar indissociavelmente a formação geral básica e os itinerários formativos, identificados na Resolução CNE/CEB n 3/2018. Ou seja, haverá arranjos curriculares, a partir da necessidade regional e as possibilidades de sistemas de ensino, como: Matemática e suas Tecnologias, Ciências da Natureza e suas Tecnologias, Linguagens e suas Tecnologias, Ciências Humanas e Sociais Aplicadas, e Formação Técnica e Profissional.

Diante das análises preliminares, organiza-se o artigo, inicialmente, com os fundamentos de Saviani (1998) sobre a educação profissional técnica e tecnológica e suas consequências. Paralelamente, tangenciam-se as teorias de Freire, sobre as recentes Políticas Públicas adotadas na Educação Básica.

Entre as críticas do autor, destacam-se a implementação de Políticas Públicas de estado mínimo, vocação para as privatizações, a partir de parcerias com institutos, objetivos claramente definidos para interesses empresariais, entre outros aspectos. $A$ segunda parte denominada Itinerários explora as tendências metodológicas frente às possibilidades curriculares preconizadas pela Base Nacional Comum Curricular (BNCC). Nota-se as teorias freirianas e seu caráter crítico, diante de propostas tecnicistas que pretendem a formação de estudantes para o mercado de trabalho, identificadas nos itinerários formativos para alunos do Ensino Médio. A última parte intitulada: Saberes da Arte apresentará a atividade prática adotada no Estágio 
Curricular Supervisionado de estudantes da Universidade Metropolitana de Santos do curso de Licenciatura em Artes Visuais, sobre o conhecimento e reconhecimento da Base Nacional Comum Curricular, o Novo Ensino Médio e suas metodologias voltadas para as aulas de artes.

\section{BASE CURRICULAR OU HEGEMONIZAR?}

As recentes Políticas Educacionais distanciam-se de seu caráter sociodemocrático e progressista e percorrem estratégias conservadoras e neoliberais, a partir da crise econômica mundial oriunda da globalização. Esse fenômeno se repete em muitos países, onde processos de privatização adquirem estratégias, para sustentar o negócio, comprometendo assim o entendimento de sociedade, como anuncia Saviani:

[...] o significado correntemente atribuído ao conceito neoliberal, a saber, valorização dos mecanismos de mercado, apelo à iniciativa privada e às organizações não governamentais em detrimento do lugar e ao papel do Estado e das inciativas do setor público, com consequente redução das ações de investimentos público [...] (SAVIANI, 1998, p.194).

As considerações justificam as análises feitas por Saviani (1998) que convergem para os fundamentos de Paulo Freire. Assim, a Educação Pública Brasileira, que atende em sua maioria a indivíduos de classe social menos favorecida, volta-se para a educação profissional. Não se trata de uma simples formação técnica profissional, mas o desenvolvimento de competências rígidas e determinadas desconsiderando ou reduzindo outros saberes, ao impor "conhecimentos mínimos" previstos na Base Nacional Comum Curricular (BNCC).

A educação profissional pode ser articulada com o Ensino Médio e há exemplos de sucesso, no entanto, evidencia-se a redução curricular da base geral. O esvaziamento de conteúdo humanístico, em detrimento do conhecimento técnico impõe riscos aos alunos, pela escassez de informações necessárias para a vida humana, bem como à formação técnica. Ou seja, os apoucamentos parecem não ser tangíveis aos propósitos estabelecidos: ensino de qualidade para todos, redução dos índices de repetência e evasão escolar. As afirmações são evidenciadas nos livros didáticos ofertados, que explicam o complexo percurso dos itinerários formativos 
previstos na Base, em que o eixo tecnológico pode ser entendido como a linha central do curso, com exigências pedagógicas a partir de seu caráter normativo que define “...o conjunto orgânico e progressivo de aprendizagens essenciais que todos os alunos devem desenvolver ao longo das etapas e modalidades da educação básica. (BNCC, 2017).

[...] enquanto prevalecer na política educacional a orientação de caráter neoliberal, a estratégia de resistência ativa será a nossa arma de luta. Com ela nos empenharemos em construir uma nova relação hegemônica que viabilize as transformações indispensáveis para adequar a educação às necessidades e aspirações da população brasileira (SAVIANI, 2018, p. 238).

Não é sem razão que Freire alerta para a "roupagem alienada e alienante" ou "educação para domesticação", ao escrever em sua obra: Educação como prática da liberdade, 1965, durante seu exílio. Nessa obra, Freire enfatizou a necessidade da autorreflexão e de reflexão sobre seu tempo e espaço. A partir da concepção gnosiológica, ele aponta para a importância da produção do conhecimento, onde a cultura e o envolvimento do humano são elementos essenciais de formação permanente, (professores, professoras e estudantes). Assim, as interações socioculturais, que ocorrem em contextos do espaço e do tempo, propõem ao humano a condição de inconclusivo, diante da dinâmica do conhecimento. Em várias de suas obras, aborda-se a necessidade da compreensão das transformações históricas, ou naturais, ou teorias formuladas pelo humano e o papel de cada indivíduo como protagonista. Ou seja, o autor analisou a implementação de ações pedagógicas voltadas para a alfabetização de jovens e adultos, considerando no processo ensino e aprendizagem os saberes contidos no estudante e o caminho de "um ser mais", a partir da tomada de consciência e do pertencimento de cada indivíduo no processo histórico.

Esta visão ontológica destaca a vocação do indivíduo como sujeito e não a manutenção de sua alienação.

[...] o homem pode ser eminentemente interferidor. Sua ingerência, senão quando distorcida e acidentalmente, não lhe permite ser um simples espectador, a quem não fosse lícito interferir sobre a realidade para modificá-la. Herdando a experiência adquirida, criando e 
recriando, integrando-se às condições de seu contexto, respondendo a seus desafios, objetivando-se a si próprio, discernindo, transcendendo, lança-se o homem num domínio que lhe é exclusivo o da história e o da cultura. (FREIRE, 2019, p. 58)

Freire afirma que o humano é o ser da integração, e seu grande desafio está precisamente em negar fatores que o torne acomodado e/ou ajustado. Sua humanização não dialoga com a opressão, e sim com dinamização, a partir da criação e recriação possíveis em seus atos. Fica evidente que as teorias freirianas transcendem a educação de jovens e adultos e convergem para as análises abordadas aqui sobre a Base Nacional Comum Curricular (BNCC).

\section{ITINERÁRIOS}

A ampliação da carga horária para o ensino médio desconsidera que muitos jovens ingressam ao mercado de trabalho, (formal, informal ou autônomo) para ajudar na renda familiar. A Base Nacional Comum Curricular (BNCC) informa sobre a oferta de diferentes currículos, a partir dos itinerários formativos, com ênfase nas áreas de conhecimento e na formação técnica profissional. Para o ensino médio, os componentes se integram às áreas do conhecimento, elas, por sua vez, são amparadas por dez competências gerais e outras específicas que se vinculam aos objetos do conhecimento, que são os conteúdos que o docente deve abordar.

O currículo possui explicitamente tendência tecnicista. Freire, (2018) considera relevantes o interesse e a experiência dos alunos, não se trata de negar o conhecimento técnico e profissional, mas de entender as tradições e os conflitos, a partir da dialética e o conceito da práxis. A saber, a práxis na visão freiriana, define saberes e um conjunto de práticas capazes de alterar a realidade e a produção da história dos protagonistas.

Ensinar com criticidade prevê uma pedagogia para a educação transformadora que vislumbra a não neutralidade, diante de fatos opressores. Nessa perspectiva, suas teorias ensinam sobre a educação alienada, a necessidade de diálogo, método ativo e participação.

Certamente, Saviani (2012) reafirma o caráter democrático da escola, ao proporcionar acesso à cultura letrada. Ainda, de nada valeria ter acesso à escola com 
esvaziamento de seus conteúdos específicos, com o saber sistematizado, seria o mesmo, que, segundo o dito popular, "dar com uma mão e tirar com a outra". Há um ponto em comum entre Freire e Saviani, que são suas preocupações sobre o processo de ensino e aprendizagem, em que o valor e a atitude são diligências intelectuais, sociais, éticas e afetivas. O desenvolvimento pessoal relaciona-se às manifestações das sensações, sentimentos, análises, reflexões e críticas.

Freire, (2019) aborda sobre os déficits quantitativos e qualitativos da educação, o analfabetismo e os impactos sobre a democratização do ensino. Ao atualizar os dados para o ensino médio verifica-se que a evasão se ampliou na gestão de Jair Bolsonaro.

Tabela 1 - Censo Escolar 2020

\begin{tabular}{|l|r|r|}
\cline { 2 - 3 } \multicolumn{1}{c|}{} & \multicolumn{2}{c|}{ Médio } \\
\hline BRASIL & \multicolumn{2}{c|}{ Parcial } \\
\cline { 2 - 3 } \multicolumn{1}{c|}{ Integral } \\
\hline Estadual Urbana & 5.124 .719 & 759.621 \\
\hline Estadual Rural & 297.496 & 35.290 \\
\hline Municipal Urbana & 33.894 & 1.479 \\
\hline Municipal Rural & 3.328 & 469 \\
\hline Estadual e Municipal & 5.459 .437 & 796.859 \\
\hline
\end{tabular}

Fonte: INEP (BRASIL, 2020)

Os resultados referem-se à matrícula inicial do Ensino Médio (incluindo o médio integrado e normal magistério), das redes estaduais e municipais, urbanas e rurais em tempo parcial e integral e o total de matrículas nessas redes de ensino (BRASIL, 2020a).

O IBGE apresenta os seguintes dados

Evolução das matrículas no ensino médio por dependência administrativa - Brasil 2016-2020: 89,2\% da população de 15 a 17 anos frequentam escola; em 2020, foram registradas 7,55 milhões de matrículas no ensino médio. O total de matrículas apresentou uma leve elevação ( $1,1 \%$ no último ano), interrompendo assim tendência de queda observada nos últimos anos (queda de 8,2\% de 2016 a 2019); $83,3 \%$ dos alunos do ensino médio estudam no turno diurno; 1,3 milhão (16,7\%) de alunos estudam no período noturno; $94,8 \%$ dos alunos frequentam escolas urbanas; A rede privada, que possui cerca 
de 926 mil alunos, tem uma participação de 12,3\% na matrícula de ensino médio; Com 6,3 milhões de alunos, a rede estadual tem uma participação de $84,1 \%$ no total de matrículas e concentra $95,9 \%$ dos alunos da rede pública (IBGE, 2019).

Assim, se Freire defendeu a alfabetização vinculada à democratização da cultura, será importante analisar o tempo presente, o currículo do ensino médio e seus desdobramentos.

\section{SABERES DA ARTE}

Ana Mae Barbosa, que conviveu por um período com Paulo Freire, contribui de forma importantíssima para a Educação Brasileira, com a Abordagem Triangular. Trata-se do desenvolvimento do olhar ativo, a partir de ação pedagógica vinculada à leitura da obra de arte, análise crítica articulada às suas circunstâncias.

Ainda, o fazer artístico e características procedentes da arte. Assim, a proposta considera o estudante como leitor, intérprete e criador. Ou seja, a partir da leitura crítica, da contextualização, da produção realizada e do diálogo entre o professor e o aluno surgem várias possibilidades criativas e investigativas. Por tais considerações, a Abordagem Triangular conquista características epistemológicas e não somente como uma metodologia para o ensino da arte. Essa abordagem caminha com a mesma ideia de Paulo Freire sobre "Pedagogia problematizadora", portanto se baseia em estratégias mais flexíveis para a resolução de problemas, a partir da realidade social e ambiental do estudante.

As pesquisas de Mae fazem parte do Parâmetro Curricular Nacional para Arte (PCN/Arte) e culminou em teorias sobre a Cultura Visual. Tais teorias, como a própria Abordagem Triangular, não foram consagradas na Base Nacional Comum Curricular (BNCC), no caderno Ensino Médio - Arte. O documento não apresenta o conceito de Cultura Visual. Vale destacar que Arte é uma área de conhecimento que envolve quatro componentes curriculares, e requer docentes formados em licenciaturas distintas, porém, a Base Nacional Comum Curricular (BNCC), impõe a polivalência, em que o licenciado ministrará conteúdos de outras manifestações artísticas. 
Os componentes curriculares Artes Visuais, Dança, Música e Teatro, compondo a área de Arte, permitem aos estudantes conhecer, produzir e elaborar leituras de mundo e compreensões críticas da arte e da sociedade, resguardando as especificidades de cada conhecimento artístico. O ensino de Arte, reconhecido como forma de conhecimento (Parecer CNE/CEB no 22 de 4/10/2005) e compreendendo os quatro componentes curriculares, possibilita a construção de conhecimentos estético culturais, tendo como premissa a formação humana, humanizada e integral na sociedade (FAEB, 2015, p. 3).

As áreas de conhecimento da Arte são fundamentais para a compreensão sobre Cultura Visual em contexto de uma pedagogia crítica. Em 1991, na Secretaria Municipal de Educação de São Paulo (SME-SP), durante a gestão de Paulo Freire, a Abordagem Triangular foi implementada no campo da dança, com resultados positivos na rede pública da cidade de São Paulo.

Na compreensão da história como possibilidade, o amanhã é problemático. Para que ele venha é preciso que o construamos mediante a transformação do hoje. Há possibilidades para diferentes amanhãs. A luta já não se reduz a retardar o que virá ou a assegurar sua chegada; é preciso reinventar o mundo. A educação é indispensável nessa reinvenção. Assumirmo-nos como sujeitos e objetos da história nos torna seres da decisão, da ruptura. Seres éticos (FREIRE, 2000, p. 40).

Os diálogos entre as teorias de Ana Mae e os temas geradores de Freire nortearam propostas consistentes para o ensino da dança.

Atualmente, a arte está inserida na área de conhecimento: Linguagens, com objetos de conhecimentos definidos e permeados por habilidades e competências, conforme verifica-se na Base Nacional Comum Curricular (BNCC).

\section{PROJETO}

Durante o ano de 2020, a pandemia ocasionada pelo novo Coronavírus impôs o isolamento social, e o Parecer n 5/2020 regulamentou as atividades acadêmicas, eminentemente presenciais, para a modalidade a distância e/ou remota. O documento informa:

o conjunto do aprendizado do curso não permite, neste período excepcional de pandemia, aulas ou atividades presenciais, é de se esperar que as atividades de estágio, práticas laboratoriais e 
avaliações de desempenho de aprendizado possam ser cumpridas também de forma não presencial (BRASIL, 2020b).

Desta forma, novas atividades foram elaboradas com o objetivo de atender às medidas sanitárias de isolamento social, como por exemplo, o Estágio Curricular Supervisionado, Atividades Complementares, Avaliação Presencial passaram a ser não presencial. As ações pedagógicas priorizaram Investigações da Base Nacional Comum Curricular (BNCC), com o propósito de verificar se o aluno concluinte, do curso Licenciatura em Artes Visuais da Universidade Metropolitana de Santos possuía conhecimentos sobre a Base Nacional Comum Curricular (BNCC) - Arte. O levantamento de dados apresentará alunos do 6올 semestre de 2020 pertencentes à matriz de seis semestres.

Objetiva-se consolidar e fazer avançar os conhecimentos construídos no curso, desenvolvendo a pesquisa e articulando teoria/prática com o posicionamento crítico do Estágio Supervisionado para uma atuação profissional compromissada e coerente com a realidade social, cultural e econômica do seu ambiente de trabalho.

O componente Estágio Curricular Supervisionado desenvolve-se de acordo com o regulamento estabelecido pela UNIMES Virtual. As atividades desenvolvidas pelos alunos envolvem observação e regência. Excepcionalmente, considerando as normas emanadas pelas autoridades da área da saúde e da educação as atividades presenciais poderão ser realizadas de forma remota.

Adotaram-se metodologias ativas plausíveis, para que o estudante desenvolvesse práticas e a partir de vídeos gravados de caráter instrucional para sanar dúvidas e abordar fundamentos elencados durante o semestre.

Formas de avaliação: atividade dissertativa; identificação de itens da BNCC; elaboração de um projeto de curso, a partir dos critérios contidos na BNCC.

A pesquisa qualitativa, analisou três atividades online, amparadas pelo Parecer № 5/2020, e contou com sessenta alunos do curso: Licenciatura em Artes Visuais, do componente Estágio Supervisionado. Na primeira etapa solicitou um release de um artigo que explora o pensamento freireano e o paradigma curricular crítico e emancipatório. 
Dez por cento dos alunos não obtiveram notas. Os aspectos positivos, além de explorar as competências escritoras nos estudantes foram o conhecimento e reconhecimento sobre o pensamento de Paulo Freire e a importância do currículo para a escola. Na sequência, a atividade exploratória de itens da BNCC, a partir de uma proposição, na qual cada estudante identificou os Códigos Alfanuméricos que informam: Etapa da Educação Básica, (Ensino Médio); Quais habilidades descritas para o Componente Curricular, (Arte); Competências específicas relacionadas com as habilidades e objetos de conhecimento. Para esta tarefa, sete alunos não concluíram ou não obtiveram acerto na atividade, e cinco conquistaram notas parciais. Por fim, os estudantes elaboraram um projeto de curso amparado nos documentos legais, em especial na Base Nacional Comum Curricular (BNCC). Oito alunos não obtiveram nota e três conquistaram notas parciais. As atividades foram plausíveis por proporcionar aos estudantes vivências e investigações com o documento da Base Nacional Comum Curricular (BNCC), no entanto, não houve análise crítica, por parte dos alunos, sobre as respostas conquistadas. É possível interpelar que o novo e complexo documento dificulte análises mais criteriosas de seu desenvolvimento.

\section{CONSIDERAÇÕES FINAIS}

Analisar a Base Nacional Comum Curricular (BNCC) é importante, pois remete à formação dos estudantes da educação básica, bem como à capacitação docente. Suas características epistemológicas se estruturam no conhecimento de caráter tecnicista para implantação dos itinerários formativos. O documento considera aprendizagem criativa, capacidade de inovação e autonomia do protagonismo juvenil. Verifica-se que o protagonismo implica fundamentalmente em entender o tempo e o espaço presentes e a necessidade de considerações de um "porvir", contidos nos pressupostos gnosiológicos freireanos, e não ao que está circunscrito, somente em metodologias ao caráter técnico e profissional. Assim, as habilidades apresentadas na Base Nacional Comum Curricular (BNCC) se constituem por objetos do conhecimento gerados por códigos alfa numéricos organizados por unidades temáticas e não ao ensino dialógico e problematizador.

Vale destacar que a organização da Base Nacional Comum Curricular (BNCC) para o Ensino Médio, orientará os currículos para fundamentar em habilidades 
diversificadas comuns em meios produtivos existentes. As áreas do conhecimento assumem outros patamares e recebem nova organização: "Linguagens e suas Tecnologias; Matemática e suas Tecnologias; Ciências da Natureza e suas Tecnologias; Ciências Humanas e Sociais Aplicadas" (BRASIL, p. 35, 2017).

Linguagens e suas Tecnologias definidas para a área de conhecimento, em que se encontra o componente Arte e obriga o docente a dominar o ensino de todas as manifestações artísticas com redução de conteúdo, e multiplicidade de processos metodológicos, a partir de eventuais projetos norteados pelos Itinerários. As respostas desse artigo não podem ser consideradas resultados finalizados, e sim proposições para novos questionamentos e análise teóricas de autores como Paulo Freire e Ana Mae Barbosa, mesmo antes de pensar a qualificação para o trabalho, e assim priorizar o pleno desenvolvimento do humano para a vida e a para a cidadania.

\section{Referências}

ADRIÃO, Theresa M. F.; GUARANHA, Teise O; BORGHI, Raquel F.; BERTAGNA, Regiane $H$.; XIMINES, Salomão Barros. GRUPOS EMPRESARIAIS NA EDUCAÇÃO BÁSICA PÚBLICA BRASILEIRA: LIMITES À EFETIVAÇÃO DO DIREITO À EDUCAÇÃO. Disponível: https://www.scielo.br/pdf/es/v37n134/16784626-es-37-134-00113.pdf Acesso: 21 nov. 2020.

BRASIL. Constituição da República Federativa do Brasil de 1988. Brasília: Casa Civil. Disponível em: Acesso em: 25 de nov. de 2018.

BRASIL. Lei Federal 13.005, de 25 de junho de 2014. Aprova o Plano Nacional de Educação - PNE e dá outras providências. Brasília, DF, 25. Jun. 2014. Disponível em: http://www.planalto.gov.br/ccivil_03/_ato2011-2014/2014/lei//13005.htm. Acesso em: 10 de maio de 2019.

BRASIL. Ministério da Educação. Lei no. 9.394, de 20 de dezembro de 1996. Lei de Diretrizes e Bases da Educação Nacional. Brasília, 1996.

BRASIL. Parâmetros Curriculares Nacionais para o Ensino Fundamental. Brasília: MEC/SEF, 1998 (a).

BRASIL. INEP. Indicadores Escolares. 2020a Disponível: https://www.gov.br/inep/ptbr/areas-de-atuacao/pesquisas-estatisticas-e-indicadores/censo-escolar/resultados Acesso: 30 mar 2021.

BRASIL. Ministério da Educação. Parecer № 5/2020. 2020b. Disponível: http://portal.mec.gov.br/pec-g/33371-cne-conselho-nacional-de-educacao/85201parecer-cp-2020 Acesso: 30 mar 2021. 
CONSELHO NACIONAL DE EDUCAÇÃO RESOLUÇÃO № 4, DE 17 DE DEZEMBRO DE 2018. Disponível em:

https://s5.static.brasilescola.uol.com.br/be/arquivos/bncc.pdf Acesso: 26 mar 2021.

FAEB. Ofício no 06/2015/FAEB. Ponta Grossa, 30 de novembro de 2015. Disponível em https://faeb.com.br/admin/shared/midias/1468022712.pdf. Acesso em: 20 mar. 2021.

FREIRE, P. Ação Cultural para a Liberdade. São Paulo: Paz e Terra, 2002.

FREIRE, P. Educação como prática da Liberdade. Editora Paz e Terra Ltda, 1967.

FREIRE, P. Pedagogia do Oprimido. Editora Paz e Terra Ltda, 23 edição, 1970.

IBGE. Pesquisa Nacional por Amostra de Domicílios Contínua 2019. Disponível: https://www.gov.br/inep/pt-br/areas-de-atuacao/pesquisas-estatisticas-eindicadores/censo-escolar/resultados Acesso: 30 mar 2021.

SANTOS, Lucíola Licínio C. P. Tentativas de padronização do currículo e da formação de professores no Brasil. Disponível:

https://www.scielo.br/pdf/ccedes/v36n100/1678-7110-ccedes-36-100-00281.pdf Acesso: 20 nov 2020.

SAVIANI, Dermeval. A nova leia da educação: trajetórias, limites e perspectivas. 4 ed. Campinas: Autores Associados, 1998.

SAVIANI, Dermeval, Escola e Democracia (42 ed.). Campinas: Autores Associados, 2012. 


\section{EDUCAÇÃO HISTÓRICA E DEMOCRÁTICA NA FORMAÇÃO DE PROFESSORES EM EDUCAÇÃO A DISTÂNCIA (EAD)}

Tathianni Cristini da Silva

\section{RESUMO}

O conhecimento histórico é fundamental para compreensão de quem somos e para análise das maneiras como vivemos, sentimos e pensamos. A História é uma ciência do presente que busca no passado questões para responder angústias da atualidade, conforme Marc Bloch. Nesta perspectiva, é realizada a pesquisa e a criação de jogos educativos em História pelos alunos do componente curricular de Seminários Temáticos II do curso de Licenciatura em História na Educação a Distância (EAD) da Universidade Metropolitana de Santos, alvo deste relato. A proposta do componente está baseada na educação histórica, democrática e ativa para formação de sujeitos sociais críticos. O texto tem por objetivo analisar a prática da educação histórica e democrática no Ambiente Virtual de Aprendizagem (AVA) para a formação dos futuros professores.

PALAVRAS-CHAVE: Educação histórica; Democracia; Autonomia; Educação a Distância.

\section{INTRODUÇÃO}

A educação histórica ocorre na escola, mas não só. Ela habita as brincadeiras que buscam na memória e em práticas cotidianas relações com o passado. Acontece também quando se lê um romance histórico, no momento de assistir uma série que dialoga com outros tempos. Portanto, a educação histórica é parte do dia a dia das pessoas.

Já, o ensino da História era ministrado, tradicionalmente, por meio de aulas expositivas nas quais os professores proferiam palestras sobre períodos chaves da cronologia humana. $\mathrm{Na}$ atualidade, as aulas seguem uma nova proposta com a atuação de professores que suscitam questões problemas partindo do presente tendo sua compreensão embasada no presente-passado-presente. Essa mudança na prática docente tem sua origem no novo entendimento do que seja a disciplina teoricamente, bem como, nas transformações do conceito de ensino de história.

Neste relato será tratada a educação histórica em seu sentido amplo e como através dela, o docente em formação pode produzir e utilizar ferramentas (jogos, vídeos, livros...) em benefício do ensino e aprendizagem seu e de seus alunos.

O estudo de caso será o componente curricular Seminários Temáticos II do curso de Licenciatura em História EAD da Universidade Metropolitana de Santos 
(UNIMES). Diferentemente dos demais componentes, neste, todas as atividades são desenvolvidas por grupos de alunos que desenvolvem pesquisa histórica e criação de jogos para uso em sala de aula e fora dela. Todo o processo de formação dos grupos até a escrita da pesquisa e desenvolvimento do jogo ocorre de forma democrática com diálogo efetivo entre grupos e professora como será relatado a seguir.

O objetivo do trabalho é analisar como ocorre a educação histórica e democrática no Ambiente Virtual de Aprendizagem (AVA) na formação dos licenciandos.

\section{EDUCAÇÃO HISTÓRICA E DEMOCRÁTICA}

O componente curricular Seminários Temáticos II é oferecido no quinto semestre do curso de Licenciatura em História do Núcleo de Educação a Distância da Universidade Metropolitana de Santos. Todas as atividades são realizadas em grupo de cinco alunos formados por escolha dos discentes nas primeiras semanas do semestre letivo. Há uma ferramenta para formação de grupos no AVA em que o aluno escolhe seu grupo.

É disponibilizado no AVA um Plano de Atividades, com a linha de pesquisa proposta para o semestre, os passos de como ocorrerá cada uma das três etapas do trabalho e a bibliografia indicada. Além do plano com as informações, a professora grava vídeos explicativos sobre o andamento do semestre e as três etapas do trabalho. No plano de atividades, há a explicação sobre o eixo norteador do componente:

O componente curricular de Seminários Temáticos II busca construir junto dos alunos um projeto de História e Cidadania a ser aplicado na educação formal ou não-formal que tenha como objeto central a História (um evento, um patrimônio etc.). A História será o veículo para promoção e entendimento da cidadania enquanto elemento central na formação da identidade dos indivíduos e a adoção de ações éticas. A proposta se enquadra na linha de pesquisa Trabalho e cidadania do curso de História/EaD/UNIMES e visa a investigação e desenvolvimento de práticas cidadãs pelos futuros professores/historiadores (Plano de atividades, História/EaD/UNIMES, 2021/2).

No curso de Licenciatura em História estão determinadas 3 (três) linhas de pesquisa, Diversidades Étnicas e de Gênero, Patrimônio Cultural e Memória, 
Cidadania e Direitos Humanos. A linha escolhida para o semestre analisado foi "Cidadania e Direitos Humanos".

Os licenciandos estudam o tema com base em bibliografias previamente escolhidas pela professora e outros materiais trazidos por eles em suas pesquisas. A proposta do componente é que o aluno desenvolva a pesquisa própria do trabalho do professor e crie ferramentas para sua atuação docente. A função de pesquisador aqui é compreendida como algo inerente ao trabalho do professor, conforme Paulo Freire.

Fala-se hoje, com insistência, no professor pesquisador. No meu entender o que há de pesquisador no professor não é uma qualidade ou uma forma de ser ou de atuar que se acrescente à de ensinar. Faz parte da natureza da prática docente a indagação, a busca, a pesquisa. O que se precisa é que, em sua formação permanente, o professor se perceba e se assuma, porque professor, como pesquisador (FREIRE, 2018, p. 32).

No plano de atividades, é disponibilizada a bibliografia digital indicada de acordo com a linha de pesquisa. Os discentes leem os textos base e escolherem outros artigos que julgam pertinentes para o início dos estudos de acordo com as investigações desenvolvidas.

A discussão das ideias ocorre em Fóruns separados por grupos, nos quais também é realizada a discussão das leituras efetuadas, demais questionamentos dos discentes, trocas de materiais de pesquisa e orientações. Após a leitura dos textos base os grupos escolhem um objeto histórico (evento, patrimônio, indivíduo...) para estudo. Geralmente, em meio aos debates, os exemplos são indicativos de temas de interesse e que poderão ser abordados pelo grupo.

$\mathrm{Na}$ ferramenta wiki ocorre a escrita do trabalho de pesquisa com a seguinte estrutura: título, introdução, objetivo, estudo de caso do objeto escolhido, proposta de jogo, metodologia de construção do jogo, regras para o jogo, considerações finais, referências e jogo em si.

As três etapas de trabalho são as seguintes:

- 1 à Etapa: apresentação do grupo no fórum; leitura e discussão dos textos iniciais; escolha do objeto de estudo; pesquisa sobre o objeto escolhido; escrita do título, introdução e objetivo da pesquisa. 
- 2a Etapa: escrita do estudo de caso com continuação da pesquisa; definição do tipo de jogo a ser desenvolvido; escrita das referências utilizadas nesta etapa.

- 3a Etapa: escrita da metodologia de criação do jogo; escritas das regras do jogo; criação do jogo; aplicação do jogo; escrita das considerações finais.

Na medida em que a pesquisa e escrita do trabalho acontecem, a professora acompanha os grupos e realiza as orientações, adaptações e correções necessárias. Portanto, embora o trabalho seja dividido em três etapas para entrega dos resultados, o processo é permeado pelo diálogo constante. Durante a escrita da pesquisa na wiki, é necessário que se retome a conversa no fórum para mudanças que o grupo julgue importantes, em alguns casos, há inclusive a troca do objeto de estudo.

Esse momento talvez seja o "ponto alto" dos licenciandos para compreensão da sua autonomia, quando tomam consciência de que são os responsáveis pelas escolhas efetuadas. Muitos alunos ficam assustados e solicitam à docente que ela determine as decisões para o grupo, no entanto, isso não acontece. Novamente, nesta situação todos retornam para o fórum com a professora e buscam tomar decisões conjuntas. Como bem nos diz Paulo Freire "é impossível ensinar participação sem participação".

O educador responsável tem que ser, pelo menos, seis pessoas: um
professor, liderando como professor e aprendendo como aluno,
criando um clima aberto em muitos sentidos, mas nunca, repito, nunca,
um clima de laissez-faire, laissez-aller, mas, pelo contrário, um clima
democrático sim. Assim, ao fazer isto, os estudantes começam a
aprender de forma diferente. Eles realmente aprendem a participar.
Mas o que é impossível é ensinar participação sem participação! E
impossível só falar em participação sem experimentá-la. Não podemos
aprender a nadar nesta sala. Temos de ir até a água. Democracia é a
mesma coisa: aprende-se democracia fazendo democracia, mas com
limites (SHOR; FREIRE, 1986).

Para se fazer democracia é preciso conhecer a História, inclusive para a luta pela permanência do estado democrático. Momento em que o conhecimento histórico é revestido de aspectos práticos.

A compreensão da História como conhecimento prático e pertencente a cada indivíduo não é tarefa fácil. O senso comum e algumas práticas no ensino de história associaram a História a um passado dado como morto e sepultado e que pouco pode alterar a atualidade. Essa visão equivocada do componente precisa ser revista 
urgentemente; para auxiliar essa mudança, propomos algumas atividades práticas a serem desenvolvidas na escola como subsídio da sua relevância para construção de visões democráticas e críticas pelos agentes envolvidos no processo de ensinoaprendizagem.

Na terceira etapa do trabalho, os grupos desenvolvem seus jogos e procedem com sua aplicação em um público convidado para verificação dos resultados obtidos. É importante salientar que a construção dos jogos costumeiramente é iniciada com o pensamento de sua aplicação escolar, no entanto, à medida que o grupo o materializa o jogo e faz seu teste para utilização, ocorre a expansão do público-alvo. Esse alargamento do acesso ao jogo acontece com a percepção do grupo de que aquele conteúdo apresentado é importante não só para os alunos, mas para qualquer pessoa disposta a conhecer História.

Na dinâmica de construção do trabalho, os discentes possuem autonomia para tomarem suas decisões, a professora atua como mediadora. Assim, as etapas de trabalho são executadas democraticamente com mudanças de posicionamento por todos os envolvidos durante o processo e muitas descobertas pelo caminho. 0 posicionamento de respeito às diferenças e aprendizado constante dos envolvidos nas atividades sem certezas puritanas é um dos aprendizados da obra freiriana.

Só, na verdade, quem pensa certo, mesmo que, às vezes, pensa errado, é quem pode ensinar a pensar certo. E uma das condições necessárias a pensar certo é não estarmos demasiado certos de nossas certezas. Por isso é que o pensar certo, ao lado sempre da pureza e necessariamente distante do puritanismo, rigorosamente ético e gerador de boniteza, que me parece inconciliável com a desvergonha da arrogância de quem se acha cheia ou cheio de si mesmo.

O professor que pensar certo deixa transparecer aos educandos que uma das bonitezas de nossa maneira de estar no mundo e com o mundo, como seres históricos, é a capacidade de intervindo no mundo, conhecer o mundo. Mas, histórico como nós, o nosso conhecimento do mundo tem historicidade. Ao ser produzido, o conhecimento novo supera outro antes que foi novo e se fez velho e se "dispõe" a ser ultrapassado por outro amanhã. Daí que seja tão fundamental conhecer o conhecimento existente quanto saber que estamos abertos e aptos à produção do conhecimento ainda não existente. Ensinar, aprender e pesquisar lidam com esses dois momentos do ciclo gnosiológico: o em que se ensina e se aprende o conhecimento já existente e o em que se trabalha a produção do conhecimento ainda não existente. A "dodiscência" - docênciadiscência - e a pesquisa, indicotomizáveis, são assim práticas requeridas por estes momentos do ciclo gnosiológico (FREIRE, 2015, p. 29-30). 
Assim, "o em que se ensina e se aprende o conhecimento já existente e o em que se trabalha a produção do conhecimento ainda não existente" (FREIRE, 2015, p. 30) permeia as atividades desenvolvidas no componente curricular Seminários Temáticos II.

Após a entrega dos trabalhos, os grupos recebem anotações escritas e orais sobre o desenvolvimento do semestre com considerações sobre o resultado apresentado e quando são pontuadas as superações enfrentadas.

\section{CONSIDERAÇÕES FINAIS}

A educação histórica experimentada no componente curricular Seminários Temáticos II do curso de Licenciatura em História do Núcleo de Educação a Distância da Universidade Metropolitana de Santos busca, conforme apresentada, a compreensão de todos os envolvidos de que somos sujeitos históricos em constante construção.

\section{Referências}

FREIRE, Paulo. Pedagogia da autonomia. 52 ed. Rio de Janeiro: Paz e Terra, 2015. SHOR, Ira; FREIRE, Paulo. Medo e Ousadia. O Cotidiano do Professor. Tradução de Adriana Lopez; revisão técnica de Lólio Lourenço de Oliveira. Rio de Janeiro: Paz e Terra, 1986. (Coleção Educação e Comunicação, v. 18). 